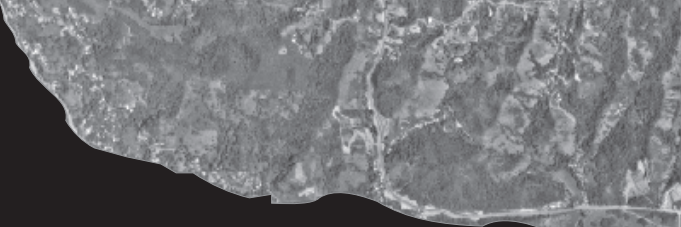

Assessment of the Habitats, Biota, Sediments, and Water Quality Near the Discharge of Primary-Treated Effluent from the Mayagüez Regional Wastewater Treatment Plant, Bahía de Añasco, Puerto Rico

Prepared in cooperation with the PUERTO RICO AQUEDUCT AND SEWER AUTHORITY

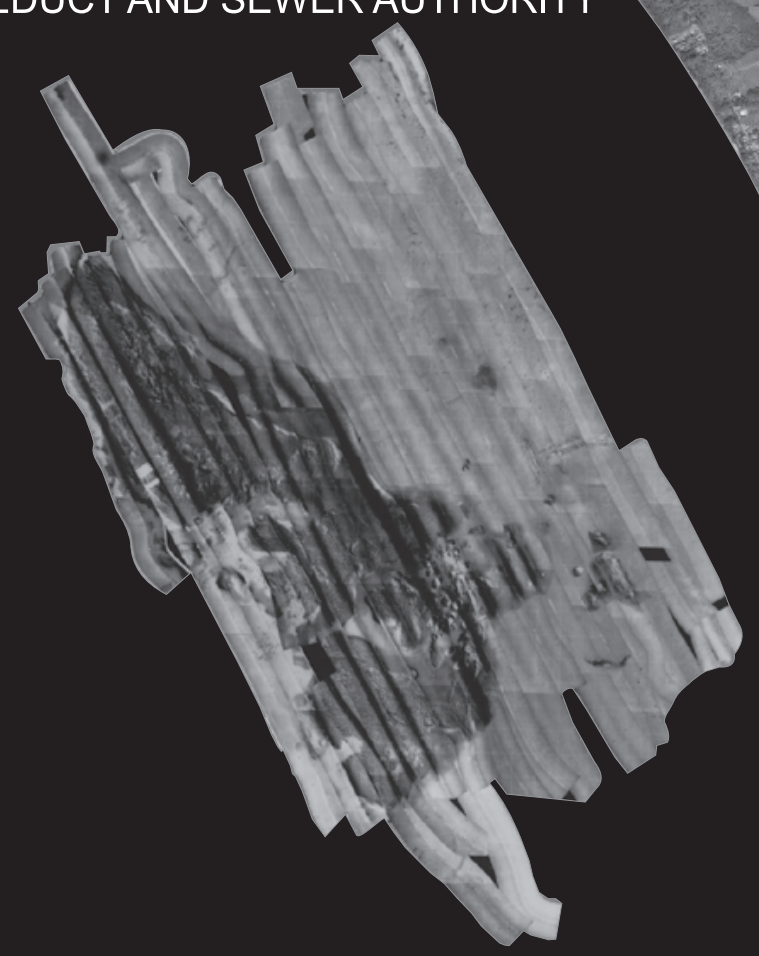

Water-Resources Investigations Report 99-4141

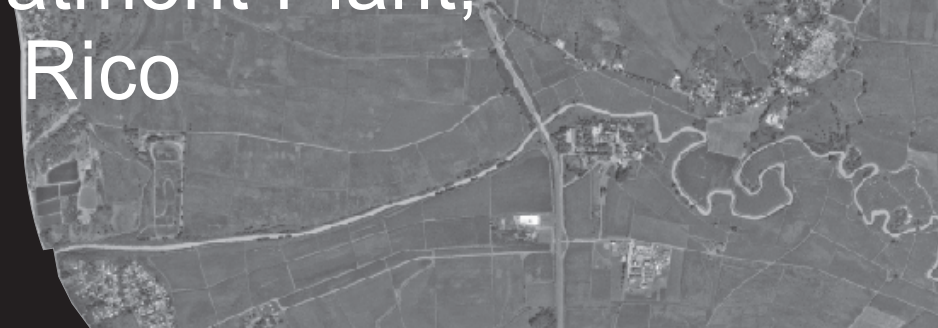




\section{Cover}

Vertical image of western Puerto Rico, the Bahía de Añasco and the Bahía de Mayagüez. The terrestrial portion is a mosaic of digital orthophotoquads (note the differences in tone along the quad margins). The side-scan-sonar image west of the coast depicts the Manchas Interiores-Manchas Exteriores reef complex (dark, textured area), and the muddy bottom surrounding the outfall (light gray tones). The trenched ocean floor around the outfall is visible east of the reef complex, 1.7 kilometers west of the coast. The cover image is about 15 kilometers from north to south. 


\section{Assessment of the Habitats, Biota, Sediments, and Water Quality Near the Discharge of Primary-Treated Effluent from the Mayagüez Regional Wastewater Treatment Plant, Bahía de Añasco, Puerto Rico}

By Richard M.T. Webb, Paul D. Collar, William C. Schwab, Carlos Goenaga, Jorge R. García, and Roberto Castro

Water-Resources Investigations Report 99-4141

In cooperation with the

PUERTO RICO AQUEDUCT AND SEWER AUTHORITY 


\section{CONTENTS}

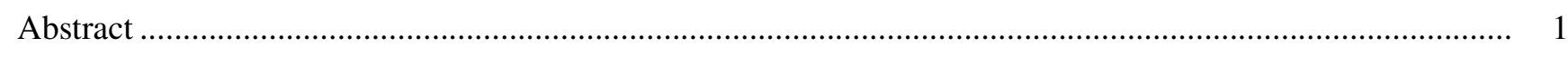

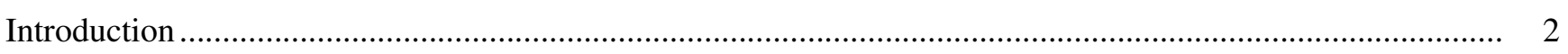

Potential impacts of wastewater on biological communities .......................................................... 3

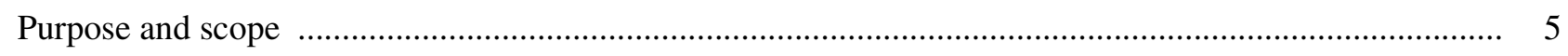

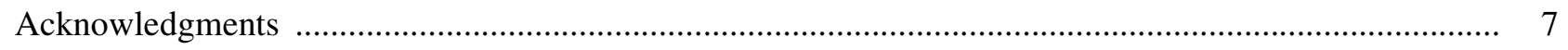

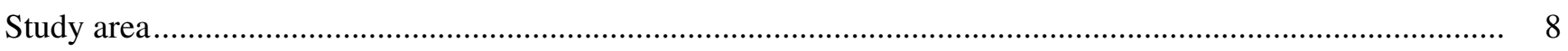

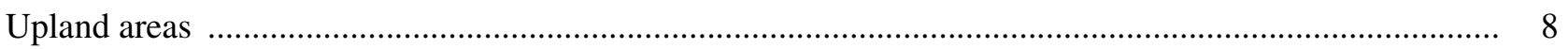

Coastal morphology, tides, ocean currents, and wave climate ...................................................... 10

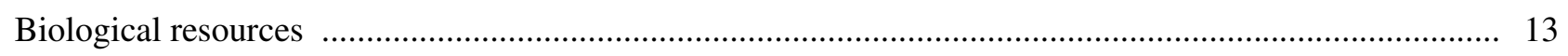

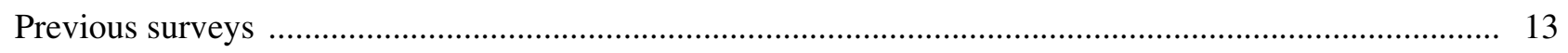

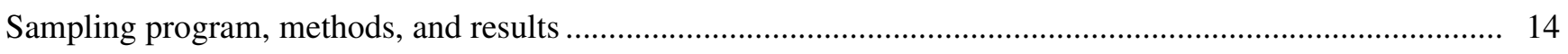

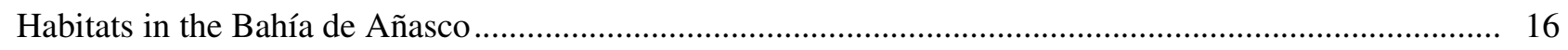

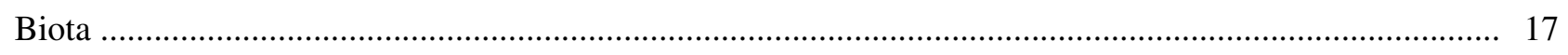

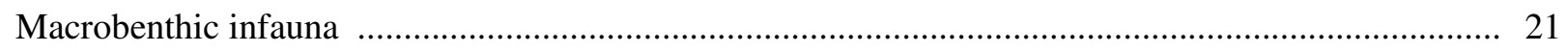

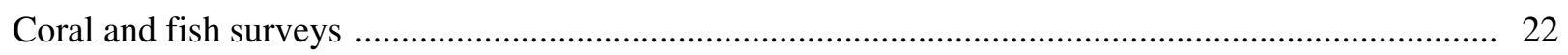

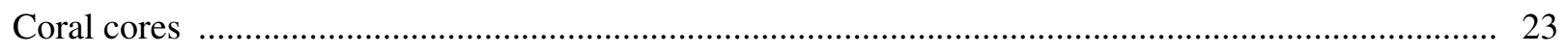

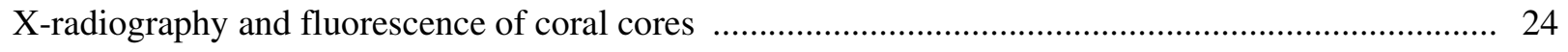

Analysis of carbon and oxygen isotopes in annual coral bands .................................................... 24

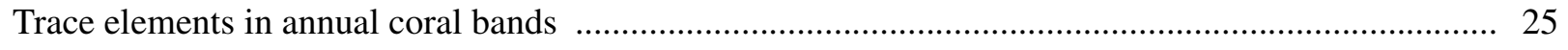

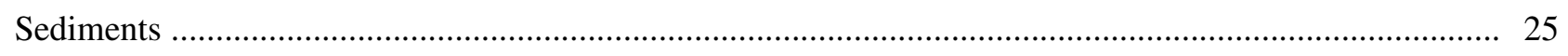

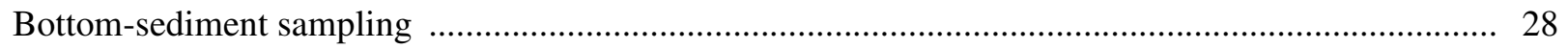

Bottom-sediment cores and sedimentation rates .................................................................. 28

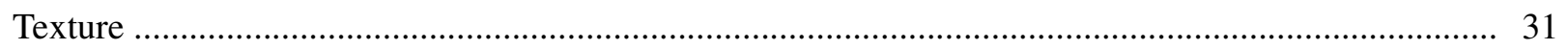

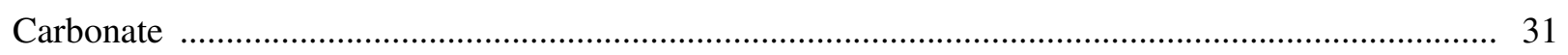

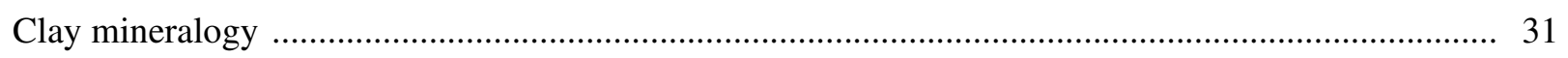

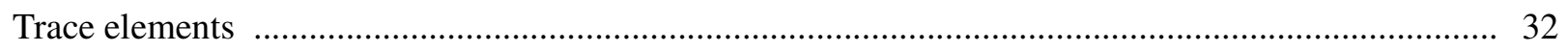

Multivariate analysis of sediment chemistry ........................................................................ 32

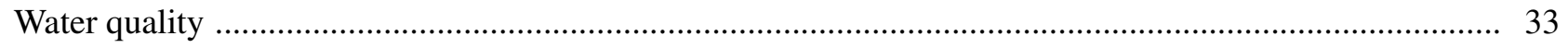

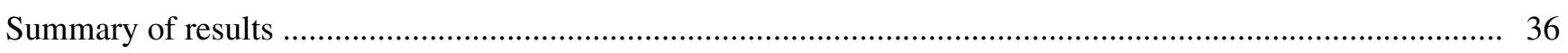

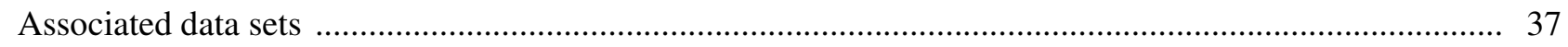

Habitats and sedimentation patterns observed in sidescan-sonar mosaic and seismic

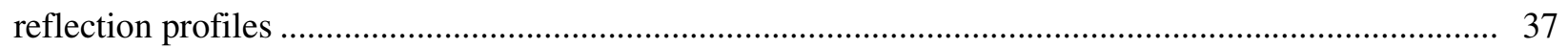

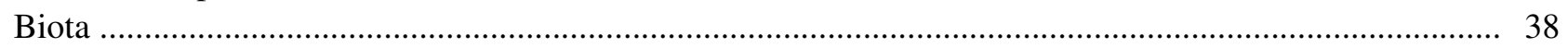

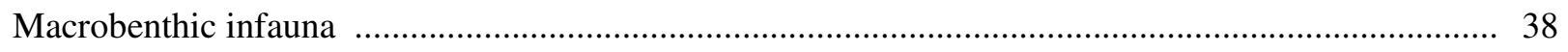


Fish and coral surveys

MSG-1 (Manchas Exteriores: 18²14'39.3" N., 67²12'32.5" W., depth 8-9 m) ............................ 46

MSG-2 (Manchas Interiores: 18¹4'13.0" N., 67²12'3.3" W., depth 7-8 m) .............................. 47

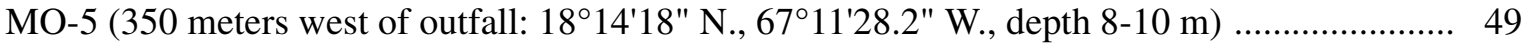

MO-4 (Escollo Negro reef: 189'55" N., 67¹5'39" W., depth 8-9 m) .................................... 49

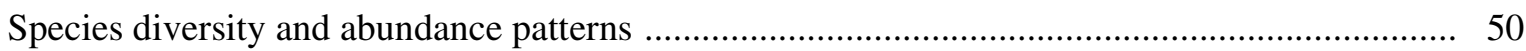

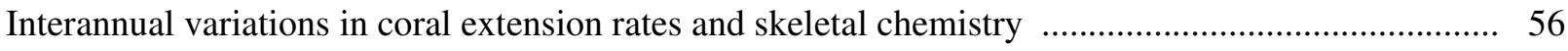

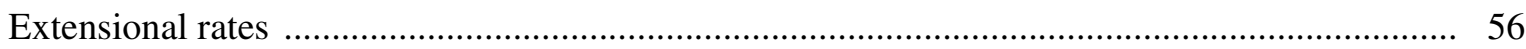

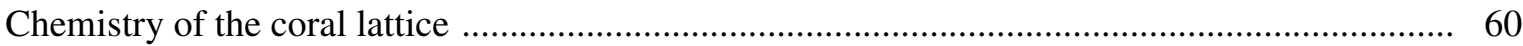

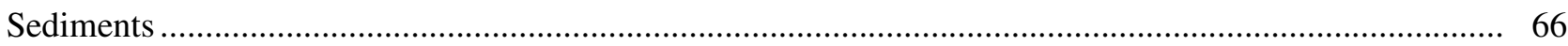

Texture and carbonate content of bottom sediments ................................................................ 66

Texture and cesium-137 analytical results for discrete depth intervals of core samples ..................... 66

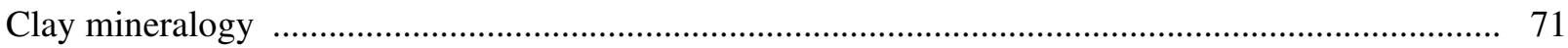

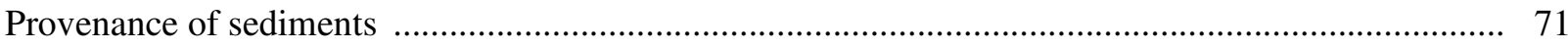

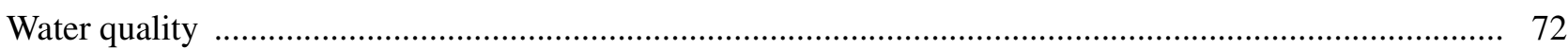

Historical water quality of the Río Grande de Añasco, the Río Yagüez, and the Río Guanajibo ......... 78

Receiving water quality, January 1991 ................................................................................ 78

Dissolved nutrients, chlorophyll, and bacteria in the surface waters ...................................... 80

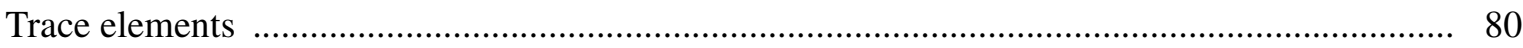

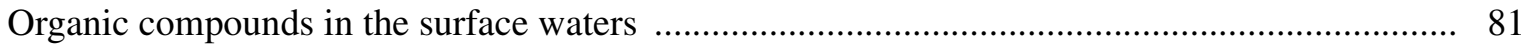

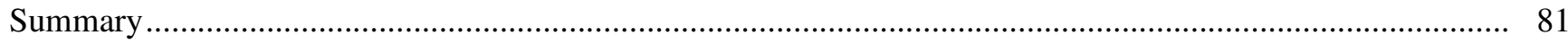

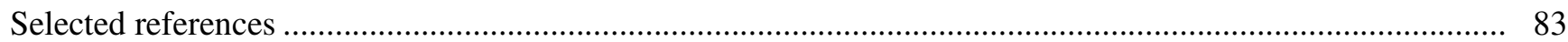

Appendix A. Macrobenthic infauna identified at stations B1 through B8, December 15, 1990, in the Bahía de Añasco and the Bahía de Mayagüez, Puerto Rico

Appendix B. Biological census data for fish and sessile benthos at stations MSG-1, MSG-2, MO-5, and MO-4, December 13-17, 1990, in the Bahía de Añasco and at the Escollo Negro reef complex, Puerto Rico

Appendix C. Elemental and isotopic composition of annual coral bands of Montastrea annularis sampled from cores C1 and C2, recovered at station MO-1 near the outfall, December 14, 1990, and cores C7 and C9, sampled at station MO-3 in the Escollo Negro, Puerto Rico, December 17, 1990.

Appendix D. Texture, elemental composition, percent carbonate, cesium-137 activity, and clay mineralogy for bottom sediments and core samples collected from December 15, 1990, through January 27, 1991, in the Bahía de Añasco and in the Escollo Negro, Puerto Rico

Appendix E. General water quality with depth and general water quality, bacteria, volatile organic compounds, semivolatile organic compounds, pesticides, PCB's, herbicides, total metals and trace elements, general inorganics, and radiochemistry by sample at 10 water-quality sampling sites in the Bahía de Añasco and near Rincón, Puerto Rico, at two sites sampled in the Río Grande de Añasco and the Río Yagüez, and at the influent and effluent of the Mayagüez Regional Wastewater Treatment Plant, January 25-30, 1991. 


\section{FIGURES}

1. Map showing location of drainage-basin boundaries, localities, and USGS streamflow and water-quality monitoring stations for west coast rivers discharging to the Bahía de Añasco and the Bahía de Mayagüez, Puerto Rico .....

2. Map showing locations of study area and remote sampling stations outside of the study area, used as control stations, Mona Passage, Puerto Rico

3. Graph showing monthly average streamflow for the Río Grande de Añasco, the Río Guanajibo, and the Río Rosario, and suspended-sediment concentrations and loads for the Río Rosario, Puerto Rico (1970-97).

4. Graph showing discharge for the period December 1, 1990, through January 31, 1991, for the Río Grande de Añasco, the Río Guanajibo, and the Río Rosario, Puerto Rico

5.-11. Map showing:

5. Site localities and nearshore bathymetry in the Bahía de Añasco and the Bahía de Mayagüez, Puerto Rico

6. Locations of sampling stations, superimposed on the sidescan-sonar mosaic, Bahía de Añasco and the Bahía de Mayagüez, Puerto Rico

7. Sampling sites for macrobenthic infauna, coral and fish census, and for coral coring in the Bahía de Añasco and the Bahía de Mayagüez, Puerto Rico.

8. Locations of 38 bottom-sediment sampling with descriptions of laboratory analyses performed on samples collected from the Bahía de Añasco and the Bahía de Mayaguiez, Puerto Rico.

9. Locations of sediment coring stations: VCA, at the Río Grande de Añasco delta; VCO, 160 meters southeast of the outfall; VCC, in a sand channel in the Manchas Interiores; and VCY, at the Río Yagüez delta, Puerto Rico.

10. Water-quality stations at the boundary of the final mixing zone, QW-2 and QW-7, and in the far field, QW-1 and QW-8, Bahía de Añasco, Puerto Rico.

11. Enlargement of figure 10, detailing the initial and final mixing zones and locations of water-quality sampling stations, QW-1 to QW-8, Bahía de Añasco, Puerto Rico

12. Graphs showing species-area curves for macrobenthic infauna measured in January 1985 and

December 1990 at stations B1-B8, Bahía de Añasco and the Bahía de Mayagüez, Puerto Rico.

13. Number of taxa, density of individuals, diversity, evenness, and dominance observed for macrobenthic infauna census stations B1-B8 in January and May 1985, and December 1990 in the Bahía de Añasco and the Bahía de Mayagüez, Puerto Rico.....

14. Graphs showing matrices of interstation comparisons of diversity and similarity for macrobenthic infauna identified for stations B1-B8, December 1990, Bahía de Añasco and the Bahía de Mayagüez, Puerto Rico

15. Ordination graph with percentages of the five most common macrobenthic infauna species, total opportunistic species, and other species identified in samples collected at stations B1-B8, December 1990 in the Bahía de Añasco and the Bahía de Mayagüez, Puerto Rico. 
16. Graphs showing diversity and percentage of opportunistic species versus distance from the outfall and distance from shore, stations B1 to B8, in the Bahía de Añasco and the Bahía de Mayaguiez, Puerto Rico

17. Graphs showing two-dimensional ordination showing the abundance of major taxa and opportunistic species for macrobenthic infauna survey stations B1 to B8, sampled December 1990 in the Bahía de Añasco and the Bahía de Mayagüez, Puerto Rico .....

18. Abundance, number of species, and diversity of scleractinea, porifera, gorgonacea, and icthyofauna at stations MSG-1, MSG-2, and MO-5 in the Bahía de Añasco and at station MO-4 in the Escollo Negro, Puerto Rico, December 1990

19. Graphs showing fish abundance and diversity versus relief for stations MSG-1, MSG-2, MO-5 in the Manchas Interiores-Manchas Exteriores, and for station MO-4 in the Escollo Negro, Puerto Rico, December 1990.

20. Graphs showing relation of fish abundance and diversity versus relief for a composite plots of data from stations MSG-1 and MSG-2 in the Manchas Interiores-Manchas Exteriores coral reef complex, and for station MO-4 in the Escollo Negro, Puerto Rico, December 1990.

21. Linear coverage of scleractinea and porifera, and number of gorgonacea and icthyofauna observed per transect at stations MSG-1 and MSG-2, May 1985 and December 1990 in the Manchas Interiores-Manchas Exteriores coral reef complex, Puerto Rico

22. Fluorescence of four samples of Montastrea annularis at station MO-1, 610 meters southeast of the outfall, and at station MO-3 in the Escollo Negro, Puerto Rico

23. X-radiographs of four samples of Montastrea annularis cored at station MO-1, 610 meters southeast of the outfall, and at station MO-3 in the Escollo Negro, Puerto Rico

24.-30. Graph showing:

24. Annual extensional rates for variable time periods between 1941 and 1990 in X-radiographs of four samples of Montastrea annularis cored at station MO-1 in the Bahía de Añasco, and at station MO-3 in the Escollo Negro, Puerto Rico

25. Relation of $\delta^{13} \mathrm{C}$ to $\delta^{18} \mathrm{O}$ for annual bands deposited by Montastrea annularis at station MO-1 near the outfall, and at station MO-3 in the Escollo Negro, Puerto Rico.

26. Three-period moving average of correlation coefficients between carbon and oxygen values for the period 1941-1986, measured in the lattice of coral core C2, growing at station MO-5 near the outfall in the Bahía de Añasco, Puerto Rico

27. Extensional rates and $\delta^{13} \mathrm{C}$ to $\delta^{18} \mathrm{O}$ values for the period 1938-90 measured in core $\mathrm{C} 2$, growing at station MO-5 near the outfall in the Bahía de Añasco, Puerto Rico

28. Average enrichment of coral lattice-bound elements relative to average concentrations in seawater for coral cores $\mathrm{C} 1$ and $\mathrm{C} 2$, growing at station MO-1 near the outfall, and cores $\mathrm{C} 7$ and $\mathrm{C}$, growing at station MO-3 in the Escollo Negro, Puerto Rico

29. Manganese/calcium and cadmium/calcium ratios, and $\delta^{18} \mathrm{O}$ and $\delta^{13} \mathrm{C}$ values for the period 1938-90 measured in core C2, growing at station MO-1 in the Bahía de Añasco, Puerto Rico

30. Time series of scores for river, oceanic, and calm factors for the period 1985-90, calculated from trace metals measured in cores $\mathrm{C} 1$ and $\mathrm{C} 2$, growing at station MO-1 near the outfall, and in cores C7 and C9, growing at station MO-3 in the Escollo Negro, Puerto Rico 
31. Map showing texture of sediment samples from 31 stations in the Bahía de Añasco and the Bahía de Mayagüez, Puerto Rico

32. Contour map of percentage calcium carbonate measured in sediments sampled in the Bahía de Añasco and the Bahía de Mayagüez, Puerto Rico

33. Elemental compositions of observed and idealized endmembers that describe unique sources for sediment deposited in the Bahía de Añasco and the Bahía de Mayagüez, Puerto Rico

34. Map showing relative percentages of source material for bottom sediments sampled from 16 stations in the Bahía de Añasco and in and around the Manchas Interiores-Manchas Exteriores coral reef complex, Puerto Rico

35. Contour maps showing the percentage of sediment composition accounted for by the geochemical endmembers representing sediment sources identified as Añasco, carbonate, and Yagüez, using extended Q-mode factor analysis

36.-38. Graph showing:

36. Variations in percentages of geochemical endmembers representing sediments from the Río Grande de Añasco, biogenic carbonates, and sediments from the Río Yagüez and the Río Guanajibo, documented for the cored sites VCO, VCA, VCY, and VCC

37. Yearly mean discharges for Río Grande de Añasco, the Río Guanajibo, and the Río Rosario, and sediment concentrations and loads measured at the Río Rosario station

38. Specific-conductivity values and dissolved-oxygen concentrations measured at five west coast water-quality monitoring stations for the period 1970-97. 


\section{TABLES}

1. Biological census and coring site locations, dates, and water depths ............................................ 14

2. Sediment-sample locations, dates, and water depths .............................................................. 15

3. Water-quality sampling locations, dates, water depths, and distance from outfall ............................. 16

4. Variability in stable-isotopes ratios measured in different parts of the same annual band, and that measured in fine and coarse fractions of coral core samples of annual growth bands deposited by colonies of Montastrea annularis growing at station MO-1 and station MO-3.

5. Trace metals measured in a laboratory standard, sample replicates, and intra-annual replicates from samples of annual growth bands deposited by colonies of Montastrea annularis growing at station MO-1 and station MO-3

6. Average abundances of selected elements in seawater.

7. Differences in the diversity of macrobenthic infauna measured at stations B1-B6 and B8, January 1985 and December 1990.

8. Percent of benthic infauna represented by various opportunistic taxa at stations B1-B8, December 1990. 42

9. Substrate relief index measure at biological census stations ..... 46

10. Differences in cover and density among stations in this study 55

11. Differences in cover and density at station MSG-1 for the 1985 and 1990 surveys 55

12. Differences in cover and density at station MSG-2 for the 1985 and 1990 surveys

13. Mean concentrations of lattice-bound trace metals measured in corals growing at station MO-1 near the ocean outfall, and at station MO-3 in the Escollo Negro reef complex

14. Factor loadings and communalities for river, oceanic, and calm factors, derived from a principal-component analysis of lattice-bound trace-metal/calcium ratios measured in coral cores $\mathrm{C} 1$ and $\mathrm{C} 2$, and cores $\mathrm{C} 7$ and $\mathrm{C} 9$

15. Communalities explaining percent of variability measured in geochemical composition of sediment samples that can be accounted for as a mixture of the three idealized endmember compositions detailed in figure 33 .....

16. Summary of criteria and water quality, January 1991 


\begin{tabular}{|c|c|c|}
\hline Multiply & By & To obtain \\
\hline \multicolumn{3}{|c|}{ Length } \\
\hline millimeter (mm) & 0.03937 & inch \\
\hline centimeter $(\mathrm{cm})$ & 0.032808 & foot \\
\hline meter $(\mathrm{m})$ & 3.2808 & foot \\
\hline kilometer $(\mathrm{km})$ & 0.62137 & mile \\
\hline \multicolumn{3}{|c|}{ Area } \\
\hline square meter $\left(\mathrm{m}^{2}\right)$ & 10.764 & square foot \\
\hline square kilometer $\left(\mathrm{km}^{2}\right)$ & 0.3861 & square mile \\
\hline square kilometer $\left(\mathrm{km}^{2}\right)$ & 247.11 & acre \\
\hline \multicolumn{3}{|c|}{ Volume } \\
\hline cubic meter $\left(\mathrm{m}^{3}\right)$ & 35.315 & cubic foot \\
\hline million cubic meters $\left(\mathrm{Mm}^{3}\right)$ & 810.7 & acre-foot \\
\hline cubic meter $\left(\mathrm{m}^{3}\right)$ & 0.0008107 & acre-foot \\
\hline \multicolumn{3}{|c|}{ Volume per unit time (includes flow) } \\
\hline cubic meter per second $\left(\mathrm{m}^{3} / \mathrm{s}\right)$ & 35.315 & cubic foot per second \\
\hline cubic meter per second $\left(\mathrm{m}^{3} / \mathrm{s}\right)$ & 15,850 & gallon per minute \\
\hline cubic meter per second $\left(\mathrm{m}^{3} / \mathrm{s}\right)$ & 22.826 & million gallons per day \\
\hline \multicolumn{3}{|c|}{ Density } \\
\hline gram per cubic centimeter $\left(\mathrm{g} / \mathrm{cm}^{3}\right)$ & 62.428 & pound per cubic foot \\
\hline \multicolumn{3}{|c|}{ Mass per area (includes sediment yield) } \\
\hline $\begin{array}{r}\text { megagram per square kilometer per year } \\
\qquad\left(\mathrm{Mg} / \mathrm{km}^{2} / \mathrm{yr}\right)\end{array}$ & 2.855 & ton per square mile per year \\
\hline
\end{tabular}

Shannon-Weaver diversity index $\left(\mathrm{H}^{\prime}\right)$

\begin{tabular}{rlll}
\hline Multiply & By & To obtain \\
\hline $\mathrm{H}^{\prime}$ & calculated using $\ln$ & 1.443 & $\mathrm{H}^{\prime}$ calculated using $\log _{2}$ \\
$\mathrm{H}^{\prime}$ & calculated using $\mathrm{ln}$ & 0.434 & $\mathrm{H}^{\prime}$ calculated using $\log _{10}$ \\
\hline
\end{tabular}


Acronyms used in this report:

$\begin{array}{ll}\text { AAS } & \text { Atomic-absorption spectrophotometry } \\ \text { BOD } & \text { Biological oxygen demand } \\ \text { BIP } & \text { Balanced indigenous population } \\ \text { CFR } & \text { Code of Federal Regulations } \\ \text { DPW } & \text { Department of Public Works } \\ \text { EPA } & \text { U.S. Environmental Protection Agency } \\ \text { LOI } & \text { Loss on ignition } \\ \text { MRWTP } & \text { Mayagüez Regional Wastewater Treatment Plant } \\ \text { NPDES } & \text { National Pollutant Discharge Elimination System } \\ \text { NRCS } & \text { National Resource Conservation Service } \\ \text { OOM } & \text { Other organic matter } \\ \text { PRASA } & \text { Puerto Rico Aqueduct and Sewer Authority } \\ \text { PREQB } & \text { Puerto Rico Environmental Quality Board } \\ \text { STP } & \text { Sewage Treatment Plant } \\ \text { TOC } & \text { Total organic carbon } \\ \text { USGS } & \text { U.S. Geological Survey }\end{array}$

\section{Translations}

$\begin{array}{ll}\text { Bahía } & \text { Bay } \\ \text { de } & \text { of } \\ \text { Escollo } & \text { Shoal } \\ \text { Punta } & \text { Point } \\ \text { Río } & \text { River }\end{array}$




\title{
Assessment of the Habitats, Biota, Sediments, and Water Quality Near the Discharge of Primary-Treated Effluent from the Mayagüez Regional Wastewater Treatment Plant, Bahía de Añasco, Puerto Rico
}

\author{
By Richard M.T. Webb, Paul D. Collar, William C. Schwab, Carlos Goenaga, Jorge R. García, \\ and Roberto Castro
}

\section{Abstract}

A multidisciplinary study was carried out during December 1990 and January 1991 to assess the effects of wastewater discharges from the ocean outfall of the Mayaguiez Regional Wastewater Treatment Plant on natural resources in the Bahía de Añasco, Puerto Rico. In 1987, the Mayagüez Regional Wastewater Treatment Plant began discharging primary-treated effluent through the ocean outfall, located 1.7 kilometers off the west coast, in an area of strong currents with good dilutional capacity. The receiving waters are home to a diverse community of biota that has adapted to living in the silt-laden waters that receive the runoff from the largest rivers on the west coast. No causal relationship could be established between the ocean outfall and adverse impacts on the biota, sediments, and water quality of the Bahía de Añasco.

The variability observed in the biological communities in the Bahía de Añasco and the offshore reef complex can be explained as adaptations to natural conditions. Patch reefs growing in the Bahía de Añasco have been smothered by a naturally prograding delta. Coral colonies present in the Manchas InterioresManchas Exteriores coral reef complex consist predominantly of species that are adapted to high levels of siltation and turbidity. Algal species form an integral part of the community, utilizing nutrients discharged from the rivers, released by bacterial degradation of organic material in the sediments, and produced by poriferans. The mixing and dilution occurring at the present discharge site appears to be effective. The macrobenthic infauna, icthyofauna, and sessile benthos, observed in the Bahía de Añasco in 1985, were similar to those observed in 1990 , after three years of outfall operation. The diversity and community composition of macrobenthic infauna sampled in the Bahía de Añasco vary both through time and between stations. Diversity measurements correlated with percent opportunistic species; both values decreased with distance from the shore, whereas no relationship was detected with distance from the outfall. The extensional rates of colonies of the star coral, Montastrea annularis, sampled only 650 meters from the outfall, have not decreased since the outfall became operational. Ratios of carbon and oxygen isotopes and trace elements measured in the aragonitic lattice of the Montastrea annularis colonies suggest that corals growing both in the Bahía de Añasco and in the Escollo Negro are affected by three main factors: river runoff, shifting oceanic circulation, and fluxes of metals and organic material from the sediments. 
The Río Yagüez and the Río Guanajibo discharge sediments eroded from serpentinite deposits rich in magnesium, nickel, chromium, cobalt, and copper. Sediments discharged from the Río Grande de Añasco are deposited in the Bahía de Añasco, occasionally reaching the Bahía de Mayagüez, but only rarely affecting the reefs in the western part of the Manchas Interiores. Bacterial mediation of organic matter in the sediments for long periods of time is evidenced by dark staining on carbonate grains.

Receiving waters sampled at the limit of the mixing zone at the outfall site at the end of January 1991 met all water-quality standards and criteria. Total coliform bacteria, present at a concentration of 29,000 colonies per 100 milliliters in the homogenized effluent sample (collected at the treatment plant), averaged 315 colonies per 100 milliliters for the two sites sampled at the limit of the zone of initial diffusion. Carbon tetrachloride concentrations exceeded 8.0 micrograms per liter in the effluent, but were below the detection limit at all marine and freshwater stations. Ammonia concentrations exceeded 20 milligrams per liter in the effluent, but was less than 0.7 milligram per liter in the zone of initial diffusion in the bay. Total phosphorous concentrations, present at 6.1 milligrams per liter in the effluent, were less than the detection level of 0.05 milligram per liter at all but one station in the bay, far from the outfall.

\section{INTRODUCTION}

The Mayagüez Regional Wastewater Treatment Plant (MRWTP) is one of 10 large regional facilities built by the Puerto Rico Aqueduct and Sewer Authority (PRASA) to accept and treat large volumes of point-source discharges. The plant was designed to treat a maximum of 0.92 cubic meters per second $\left(\mathrm{m}^{3} / \mathrm{s}\right)$ (21 million gallons per day) of wastewater before discharging it into the Bahía de Añasco through an outfall located 1,700 meters (m) offshore from Barrio Maní. The PRASA applied for a waiver of secondary-treatment requirements for discharges in marine waters under section 301(h) of the Clean Water Act (33 U.S.C. $§ 1311(h))$.

The U.S. Environmental Protection Agency (EPA) issued its final National Pollutant Discharge Elimination System (NPDES) permit for the Mayagüez plant in September 1987, specifying secondary-treatment levels for the discharge. In order to comply with the biological oxygen demand (BOD) load limitations for secondary treatment, the discharge of the primary-treatment plant, with its inherently lower BOD removal rates, is limited to approximately $0.39 \mathrm{~m}^{3} / \mathrm{s}$ ( 9 million gallons per day). The plant began discharging primary-treated wastewater through the present ocean outfall at the end of 1987.

Wastewater received by the MRWTP contains sediments, inorganic and organic compounds, including toxins, nutrients, and pathogens. The MRWTP is a primary-treatment plant that removes the majority of the solid material and adds chlorine to kill pathogens before discharging the effluent into Bahía de Añasco through an ocean outfall 1.7 kilometers $(\mathrm{km})$ west of the town of Maní. The effluent from the plant contains significant amounts of particulate matter, metals (trace elements), organic compounds, and a certain amount of pathogens. Most contaminant concentrations drop below detectable values as the effluent turbulently mixes with the receiving waters. However, depending on the composition of the effluent, the design of the diffuser, and the physical and chemical conditions present in the receiving waters, the discharge can have adverse impacts on the environment. Therefore, applicants for waivers from secondary-treatment requirements must carry out monitoring programs to evaluate the impact of the discharge on marine biological communities, to demonstrate compliance with applicable water-quality standards or criteria, and to monitor the effectiveness of urban pretreatment and toxics-control programs.

A properly designed monitoring program is an integrated study that describes the water quality of the influent, effluent, and receiving waters, in addition to spatial and temporal variability of biological communities in the area of the discharge. Also, bioaccumulation determinations and sediment sampling should be used to indicate the potential for adverse effects on human health, especially in areas of recreational activities or with active fisheries. 
A key condition for granting a waiver from secondary-treatment requirements is that the receiving waters must support a balanced indigenous population (BIP) of shellfish, fish, and wildlife. A BIP is defined in Section 301(h) regulations [40 CFR Part 125.58(f)] as "an ecological community that: (1) exhibits characteristics similar to those of nearby, healthy communities existing under comparable but unpolluted environmental conditions; or (2) may reasonably be expected to become re-established in the polluted water body segment from adjacent waters if sources of pollution were removed." The presence of a BIP in the zone of initial dilution, by definition [40 CFR Part 125.58(z)], indicates that the receiving waters are not "stressed."

\section{Potential Impacts of Wastewater on Biological Communities}

Wastewater discharged through an ocean outfall can affect biological communities in the following ways [40 CFR Part 125.62(c)]:

- Modifications to the structure of benthic communities (bottom-dwelling/feeding fishes and invertebrates) caused by accumulation of discharged solids on the seabed;

- increases in phytoplankton or macroalgal growth due to turbidity inputs;

- reductions in dissolved oxygen due to phytoplankton blooms and subsequent die-offs, leading to mass mortalities of fish or invertebrates;

- bioaccumulation of toxic substances in marine organisms due to direct contact with sediment, ingestion of sediment, direct uptake from effluent, or ingestion of contaminated organisms; and

- induction of diseases in marine organisms caused by contact with contaminated sediments, ingestion of contaminated organisms, or exposure to effluent.

If the wastewater discharged through the MRWTP ocean outfall is producing these effects, expected shifts in the community structure of biota living nearby should be observable. Because of the importance of coral reefs to the ecosystem of the Bahía de Añasco, a detailed discussion of potential impacts on this community is warranted.

Sewage discharge into coastal waters may affect coral reef communities (reviewed in Hatcher and others, 1989, and in Goenaga, 1991) by (1) causing nutrient enrichment and enhancing the growth of algae at the expense of corals (Marszalek, 1981), (2) depressing oxygen levels (Wade and others, 1972), and (3) by introducing toxic substances such as chlorine (Campbell, 1977; Best and others, 1982; Muchmore and Eepel, 1973). Coral morbidity and mortality under experimental conditions apparently results from competition for space with algae, and does not appear to be directly related to effluent toxicity (Marszalek, 1981). Large inputs of nutrients from sewage outfalls can produce blooms of planktonic and benthic algae which may displace other organisms, including corals (Banner, 1974; Smith and others, 1981; Walker and Ormond, 1982). Sewage pollution to coral reefs can take the form of dissolved inorganic nutrients, dissolved organic materials and/or particulate organic material (Pastorok and Bilyard, 1985; Marszalek, 1987). Coral reefs develop in oligotrophic waters. The introduction of additional nutrients is likely to affect them, although the effect is not always linear. For example, Tomascik and Sander (1985) found that coral growth rate correlated positively with slight increases in nutrient concentrations and other factors (for example, turbidity, sedimentation, toxicity and bacterial production), but at higher nutrient levels coral growth and diversity declined.

In Puerto Rico, coral reefs growing close to sanitary discharges, as they are, for example, off Ponce, show proliferations of green algae, namely Ulva lactuca, Enteromorpha sp. and Dyctyosphaeria $s p$. (V.P. Vicente and C. Goenaga, personal observations). These algae tend to colonize corals from their bases, eventually overgrowing them. Smith and others (1981) reported similar extensive macroalgal blooms in Kaneohe Bay, Hawaii, and concluded that the predominant source of nitrogen was in the form of particulate organics rather than in dissolved forms. The source of the nitrogen was a 
sewage outfall that discharged into the bay. Kaneohe Bay has a parallel in the earlier discharges of raw sewage into the Bahía de Mayagüez, which also has a poor dilutional capacity. Similarly, the Kaneohe Bay outfall was relocated to a nearby oceanic site with greater dilutional capacity, as was done when the Mayagüez outfall was relocated to its present site west of Maní. After a period of slow initial recovery (Smith and others, 1981; Russo, 1982; Evans and others, 1986), the now clear waters of Kaneohe Bay once again host thriving coral communities (Eric De Carlo, University of Hawaii, oral commun., 1998).

Tropical marine organisms live in waters that are usually oligotrophic or with generally low nutrient concentrations. It has been suggested that the predominance of symbiotic relationships in coral reefs, such as that between microalgae (for example, zooxanthellae) and corals (Muscatine and Porter, 1977; Taylor, 1981), and between sponges and corals (Corredor and others, 1988), has evolved in response to low nutrient concentrations. This symbiosis has resulted in an efficient recycling of nutrients between host and symbiont. Under eutrophic conditions (high nutrient concentration in the water column), organisms with faster growth rates and that are capable of rapid transformation of nutrients into biomass, such as fleshy and filamentous algae, will usually outcompete or displace the slower growing corals (Johannes, 1975). High nutrient concentration in the water column is also known to stimulate bioerosion (for example, the biochemical erosion by boring sponges, boring annelids, and sipunculids of the vertical calcium/carbonate $\left(\mathrm{CaCO}_{3}\right)$ structure produced by corals) (Highsmith, 1981). The dynamic interplay between $\mathrm{CaCO}_{3}$ accretion (for example, by coral growth) and destruction (for example, by bioerosion) of coral reefs is, therefore, strongly influenced by nutrient availability. Examples illustrating this relationship are known from the fossil record (Hallock, 1988). In addition, cnidarian larval settlement, including those of corals, is precluded where the substrate is covered by dense algal growth (Sammarco, 1980). Coral planulae need clean substrates that are free of algae to develop. The most probable outcome in eutrophic areas, as observed elsewhere around Puerto Rico (for example, Ponce; C. Goenaga and V.P. Vicente, personal observations) and in the Caribbean, is a relict reef in which the vertical $\mathrm{CaCO}_{3}$ structure may, for some time, be preserved, but in which the main reef building organisms, namely corals, become an inconspicuous element of the new community. This new community, dominated by fleshy and filamentous algae, is incapable of producing the structure necessary to maintain reef growth.

Tropical shallow-water communities are subject to many of the same anthropogenic stresses as communities from high latitudes (Hatcher and others, 1989), but the relative importance of these differ, and attempts to extrapolate the results of studies from higher latitudes to the tropics have been unsuccessful. The use of temperate marine species employed in existing procedures for bioassays may not be representative of the responses of tropical species subjected to similar testing (Gelabert and Singh, 1992). For example, dissolved-nutrient concentrations are usually much lower in tropical surface waters than in temperate waters. The elevation of phosphate concentrations by 0.023 milligram per liter $(\mathrm{mg} / \mathrm{L})$ (phosphate as P), in New England waters would result on the average in doubling of the phosphate concentration there, whereas in the eastern Caribbean it would constitute an approximately 40 -fold increase (Hatcher and others, 1989). In this context it is worth mentioning that it is well documented that phosphate suppresses calcium mineralization in coral reef organisms (Kinsey and Davies, 1979).

Substrate variables, such as the taxonomic composition of benthic biota (Bakus, 1966; Risk, 1972) and physical habitat complexity (Luckhurst and Luckhurst, 1978; Roberts and Ormond, 1987) have been shown to influence the diversity and abundance of reef fishes on microspatial scales. On the temporal scale, the marked seasonality of the discharge of large rivers and the associated sediment and nutrient loadings imposed by rainfall have potentially important implications to the reef communities of Bahía de Añasco. Therefore, an assessment of natural variability, both in temporal (seasonal) and spatial scales, is critically needed as a background to discuss any possible impacts of the PRASA's sewage treatment plant operations upon ichthyofaunal community structure in the reefs of the Bahía de Añasco. 
The marine communities in the Bahía de Añasco, and in the Caribbean in general, have been vulnerable to regional impacts of undetermined cause over the past decades, previous to the existence of the Mayagüez plant. Over the last decade, both a massive sea urchin die-off (Vicente and Goenaga, 1984) and widespread coral bleaching (Williams and others, 1987) have been documented in the western Atlantic. Previously healthy colonies of the elkhorn coral Acropora palmata have disappeared from the reefs in the Bahía de Añasco during the last 20 years (Morelock and others, 1983). The reefs in the Bahía de Añasco are vulnerable to the sediments and contaminants discharged by the Río Grande de Añasco and the Río Yagüez, sediments and contaminants discharged through the outfall, and those resuspended by wave action. Any natural or anthropogenic shift in loadings of nutrients, particulate organic matter, sediments, or in siltation can result in changes in habitat (Banner, 1974; Johannes, 1975; Kinsey and Davies, 1979; Pastorok and Bilyard, 1985; Marszalek, 1987). Site-specific data are essential to determine the degree of potential impact of sewage discharge on the surrounding community.

A multidisciplinary sampling expedition was carried out by the U.S. Geological Survey (USGS) in cooperation with the PRASA, during December 1990 and January 1991 to provide data needed to evaluate the effects of wastewater discharges from the ocean outfall on natural resources in the Bahía de Añasco, Puerto Rico. In December 1990, an image of the ocean floor surrounding the ocean outfall was created and used to select sites for more detailed analyses of the biota and sediments in the bay. In January 1991, water quality was analyzed for the MRWTP waste stream, the Río Grande de Añasco, the Río Yagüez, and the marine waters off the west coast (fig. 1). This report presents the results along with additional historical and recent data to provide decision makers with a more complete picture of observed or potential impacts of the MRWTP ocean outfall discharge on the marine environment.

\section{Purpose and Scope}

This report documents temporal and spatial variations in the habitats, biota, sediments, and water quality at and around the ocean outfall of the MRWTP where it discharges into the Bahía de Añasco. Specific objectives of the sampling program and the approaches that were used include the following.

- Define the precise extent and location of sea-floor habitats capable of supporting coral communities that may be especially vulnerable to impact from the outfall. Marine geophysical equipment including sidescan sonar and reflection seismic equipment were used to map approximately 10 square kilometers $\left(\mathrm{km}^{2}\right)$ of the ocean floor in the Bahía de Añasco, including the Manchas Interiores-Manchas Exteriores coral reef complex. The sidescansonar mosaic and seismic-reflection data were used to describe sea-floor habitats, sediment deposition patterns and to locate sampling stations in the Bahía de Añasco.

- Describe the macrobenthic infauna at eight stations previously surveyed in 1985 (PRASA, 1985). Compare the makeup and diversity of these communities with those observed in 1985. Grab samples of macrobenthic infauna were collected and identified to the lowest possible taxon. Community statistics and comparison of variance with time and both within and between sampling sites are presented.

- Describe the sessile benthos and fish at two stations previously surveyed in 1985 (Center for Energy and Environment Research, 1985), at a station with a hard-bottom substrate near the outfall identified in the sidescan-sonar mosaic, and at a control site in the Escollo Negro. Compare the communities observed in 1990-91 with those observed in 1985. The sessile benthos and fish communities were censused by visual identification along linear transects. Community statistics and comparison of variance with time and both within and between sampling sites are presented. 


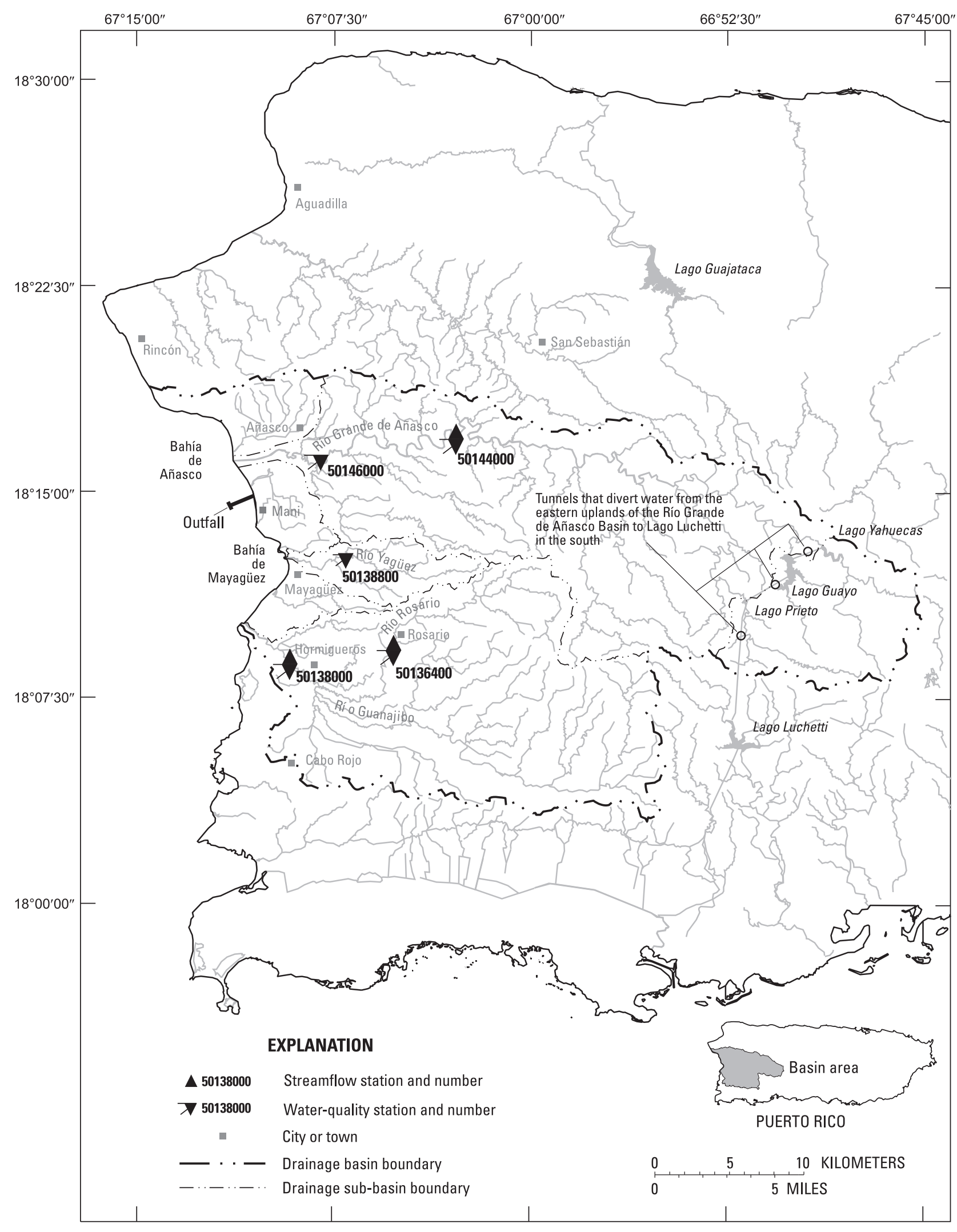

Figure 1. Location of drainage-basin boundaries, localities, and USGS streamflow and water-quality monitoring stations for west coast rivers discharging to the Bahía de Añasco and Bahía de Mayagüez, Puerto Rico.

6 Assessment of the Habitats, Biota, Sediments, and Water Quality Near the Discharge of Primary-Treated Effluent from the Mayagüez Regional Wastewater Treatment Plant, Bahía de Añasco, Puerto Rico 
- Document interannual changes of extensional rates, fluorescence, trace metal content, and the ratios of stable isotopes of carbon and oxygen, for the star coral Montastrea annularis, at a site located near the outfall, and at a control site located away from the influence of the rivers and the outfall. For four coral core samples, the extensional rates, fluorescence, elemental and isotopic composition of annual samples representing the years 1984-90 are presented, as are those for seventeen 3-year composites (1938-89) from one of the cores sampled at the station nearest the outfall.

- Describe sediment transport and deposition patterns in the Bahía de Añasco and the Manchas Interiores-Manchas Exteriores coral reef complex. Bottom-sediments in the study area and at distant control stations were sampled. In addition, sediment cores were recovered from near the outfall, in the deltas of the Río Grande de Añasco and the Río Yagüez, and in a sand channel located in the coral reefs. Results of core-sample analyses of grain size, percent $\mathrm{CaCO}_{3}$, clay mineralogy, total organic material, trace elements, and cesium-137 activity, are presented and interpreted to describe recent and historical sedimentation patterns in the study area.

- Describe the water quality in the Río Grande de Añasco, the Río Yagüez, and the Río Guanajibo, and the plant influent and effluent, in the initial mixing zone, the far field, and at reference stations far removed from the outfall. The rivers, the plant influent and effluent, and the receiving waters, were sampled and analyzed for the full array of priority pollutants, total metals, general inorganics, radionuclides, and non-conservative properties. In addition, acute and chronic bioassays were conducted on whole effluent. The results are compared with water-quality criteria established by the Puerto Rico Environmental Quality Board (PREQB) and the EPA. Supplementary data are presented to describe observations of water quality in west coast rivers for the period 1970-97.

The results are synthesized with ancillary data describing the upland watershed and active oceanic processes to evaluate the possible role of wastewater discharged through the outfall as a causal factor in the observed variations in habitat, biota, sediments and water quality in the Bahía de Añasco.

\section{Acknowledgments}

The authors would like to thank the following people and organizations: The Puerto Rico Department of Natural and Environmental Resources (DNER), for making the Research Vessel Jean A available on short notice; Captain Richy PaulRodríguez and mate Henry Colón-Vazquez, for their patience and seamanship; John Schlee, for providing additional seismic data for the area around Punta Algorrobo; Rafael Rodríguez, for support, equipment, and the use of his parents' house for deployment of a navigation transponder; radio station WOLE, for allowing us to locate our other transponder at their Atalaya site; the personnel of the DNER lab, for aiding in the sediment analysis; the Puerto Rico Ports Authority, for the use of their docks; Glen Shen, at the University of Washington, for help with the trace metals in the coral; and Ted McConnaughey, who offered key insight on stable isotopes in corals.

Analyses of stable isotopes of carbon and oxygen were done by K.C. Lohmann at the University of Michigan. Bob Halley provided expertise and the use of his facilities at the USGS Center for Coastal Geology in St. Petersburg. Art Horowitz analyzed the sediments for total metals. Sherwood McIntyre helped both in the field and in the lab by analyzing the cesium-137 activity in the sediments. Roy Armstrong at the University of Puerto Rico, supplied the Airborne Ocean Color Image of the study area. John Neil identified the minerals, using X-ray diffraction. Rafael Andreu, Wanda Alvarez, and Luis Montezuma at the PRASA, assisted greatly both in the field and in the laboratory. Luis Soler and Miguel Rodríguez were indispensable during the water-quality sampling. Luis Menoyo assisted in diving operations and creating presentations. Ruth Guzmán and Francisco Maldonado prepared the report for publication. Finally, we thank Marilyn tenBrink, José Rivera, Eric De Carlo, Briant Kimball, Vance Vicente, Bruce Taggart, Joe Troester, and Hans Perl, for their critical reviews of the manuscript. 


\section{STUDY AREA}

Puerto Rico is the easternmost of the four islands making up the Greater Antilles. The roughly rectangular island is bounded to the north by the Atlantic Ocean, to the east by the broad, shallow Puerto Rico-Virgin Islands Platform, to the south by the Caribbean Sea, and to the west by the Mona Passage. The width of the insular platform of Puerto Rico varies from less than a kilometer along much of the north and southeast coasts, to more than $20 \mathrm{~km}$ off the east and southwest coasts. The broad carbonate platform off the southwest coast narrows to the west and north of Mayaguiez (fig. 2). The main shipping channel into the Bahía de Mayagüez passes through a narrow gap between two reefs, Manchas Grandes and Manchas Interiores. Manchas Interiores is the name for the southern part of the shoal that lies on the insular shelf break west of Maní and west of the outfall; the northern part of the shoal is known as Manchas Exteriores. In this report Manchas Interiores and Manchas Exteriores may be referred to separately or together as the Manchas Interiores-Manchas Exteriores coral reef complex. The reefs act as barriers to normal wave energy, allowing muds to settle on the floor of the Bahía de Mayagüez and the Bahía de Añasco. The sediments in the Bahía de Mayagüez and the Bahía de Añasco contain varying amounts of autochthonous biogenic carbonate, but are predominantly composed of sediments discharged from the three rivers that drain the upland area.

\section{Upland Areas}

The geology of the uplands draining into the Bahía de Añasco is distinct from that draining into the Bahía de Mayagüez. The southwestern volcanicplutonic subprovince (Cox and Briggs, 1973) contains large bodies of serpentinite that provide a bedrock source for laterite deposits containing nickel, iron, and cobalt. The greenish metal-rich serpentinite deposits, known as the Bermeja complex (Mattson, 1960), are unique to southwestern Puerto Rico, which is formed from thick marine deposits scraped off a descending oceanic crust long ago. Studies of the serpentinite sampled from deep drill holes in the outcrops southwest of Mayagüez were used to better understand the now globally accepted theory of plate tectonics (Burk, 1964).

The diverse geology results in equally diverse soils. Detailed descriptions of the soils in the watersheds draining into the study area are presented by Gierbolini (1975). The main soil associations in the western watersheds are Coloso-Toa, Descalabrado, Consumo-Humatas, Humatas-Maricao-Los Guineos, Caguabo-Múcara, all formed above volcanic rock or metamorphosed marine deposits, and Nipe-Rosario, formed on the serpentinite terrain (National Resources Conservation Service, 1998). More than 99 percent of the areal coverage of Nipe-Rosario is within the Río Yagüez and the Río Guanajibo basins, and less than one percent in the Río Grande de Añasco basin (National Resources Conservation Service, 1998). The metal-rich soils of the Nipe-Rosario thus provide a key geochemical tracer to distinguish the sediments discharged to the Bahía de Mayaguiez from those discharged to the Bahía de Añasco.

Independent of their composition, sediments eroded from the uplands impact ecosystems and have deleterious effects on water quality and water supply. Average annual soil loss (for the period 1938-47) on experimental slopes (40-60 percent gradients) in the Mayagüez area ranged from 500 megagrams per square kilometer per year $\left(\mathrm{Mg} / \mathrm{km}^{2} / \mathrm{yr}\right)(1,400$ tons per square mile per year) for pasture to $35,000 \mathrm{Mg} / \mathrm{km}^{2} / \mathrm{yr}$ $(100,000$ tons per square mile per year) for fallow desurfaced slopes (Smith and Abruña, 1955). Of the 12 municipalities that share parts of the watersheds discharging into the study area, only two, Cabo Rojo and Hormigueros, are not included in the zones dedicated to coffee production. Approximately 120 $\mathrm{km}^{2}$ of the upland areas is dedicated to coffee production, resulting in almost 200,000 tons of soil loss from the upland basins every year (National Resources Conservation Service, 1998). The most significant point and nonpoint sources identified in the basins draining into the Bahía de Añasco and the Bahía de Mayaguiez are agricultural activities, urban runoff, sand extraction sites, rural and isolated community wastewaters, industrial discharges, municipal wastewater discharges, and coffee processing plants (National Resources Conservation Service, 1998). The relative loadings from each of these sources depends on the intensity of activity and prevailing weather conditions. 


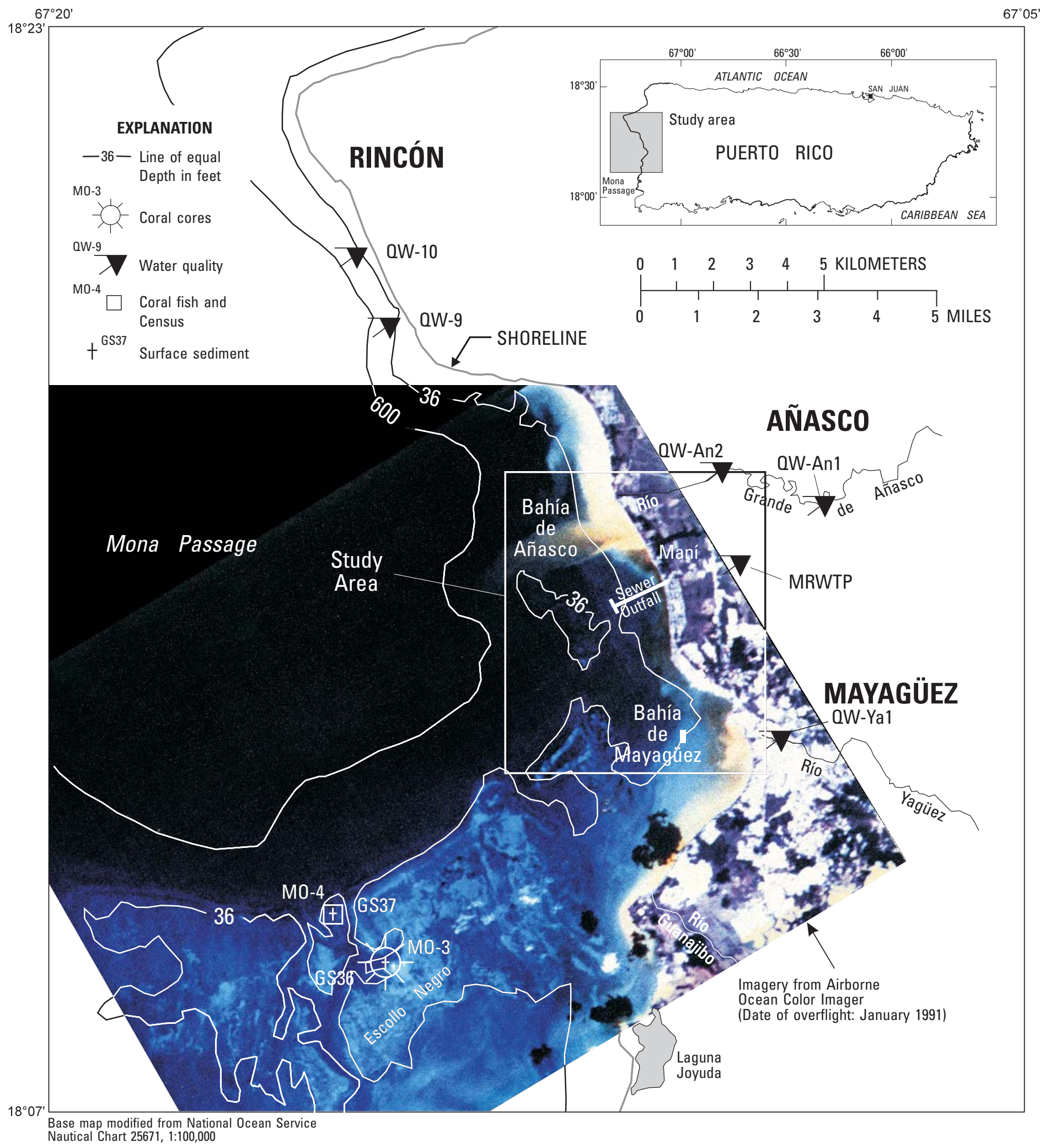

Figure 2. Locations of study area and remote sampling stations outside of the study area, used as control stations, Mona Passage, Puerto Rico. 
During a typical year, streamflow in the Río Grande de Añasco is lowest during February and March, increases with May rains, decreases during June and early July, is highest from August through November, and declines through December and January. Seasonal trends in the streamflow and sediment-discharge records for data collected from three streamflow monitoring stations in western Puerto Rico over the period 1970-97 are shown in figure 3.

Rivers and marine waters were sampled in December 1990 and January 1991, during generally declining base flows for the western rivers (fig. 4). The western rivers drain into the Bahía de Añasco and the Bahía de Mayaguiez, where they mix with the marine waters.

\section{Coastal Morphology, Tides, Ocean Currents, and Wave Climate}

Currents in the Bahía de Añasco (fig. 5) as a whole respond predominantly to the daily sea breezes and tidal fluctuations (Department of Public Works, 1971, 1974; Morelock and others, 1983). Definite vertical velocity gradients exist. Bottom waters in the Bahía de Mayagüez and the Bahía de Añasco commonly flow towards shore, replacing surface waters that are driven away from shore by the prevailing northeast Trade Winds. General upwelling of deeper waters onto the insular shelf was documented in 1971 (Department of Public Works, 1971), and again in 1983 (Morelock and others, 1983). At the outfall site, the net transport direction of the water column is clearly to the north-northwest, although currents to the east and west have been documented to persist for up to 6 hours (PRASA, 1985). In the afternoons, the occurrence of sea breeze is common as localized low pressure cells form over the hot terrain in western Puerto Rico. The sea breeze can push the surface waters towards the coast, effectively trapping the discharge of the rivers in the near vicinity of the coastline. Coast-parallel currents are observed in aerial photographs and remote sensing imagery to converge near Maní and travel away from shore, carrying sediments into deeper waters, where they settle out (fig. 2). Northerly currents may be expected to accelerate through the restricted channel between shore and the reefs in the area of the outfall. This would also enhance good dispersion of the effluent.

Currents west of the Manchas InterioresManchas Exteriores coral reef complex are generally to the north (Department of Public Works, 1971). Current intensity changes throughout the year in response to the position and intensity of the North Atlantic Equatorial Current. Landward of the reefs, the net transport is to the northwest, though rotary tidal currents can produce flows in any direction for limited periods of time.

Depending on the prevailing wave climate, the littoral currents at the coastline can travel either to the north or south. The percentage of dark minerals and igneous rock fragments in beach sands is greatest near the outlet of the Río Guanajibo, and decreases northward along the coast throughout the Bahía de Mayaguiez and to the mouth of the Río Grande de Añasco (Morelock, 1987). This indicates a net northerly transport of coastal sediments from the Río Guanajibo to the Río Grande de Añasco. However, in the nearshore region of the mouth of the Río Grande de Añasco, wave energy arrives predominantly from the north, setting up a southerly littoral drift (Morelock and others, 1983) that can travel along the coast until it meets the northerly littoral current traveling from the Bahía de Mayagüez. When they meet, rip currents will form, and carry the water and its mixed constituents into the Bahía de Añasco (fig. 2).

The coastal morphology and marine currents are major factors in determining the fate of the effluent discharged from the ocean outfall, and also in determining the makeup and distribution of biotic communities in the waters off western Puerto Rico. Both the position of the shoreline and the behavior of marine currents respond to sea-level changes. During the last million years, sea level has risen and fallen repeatedly in response to the advance and retreat of the polar ice caps. The last of the great glacial advances ceased only around 16,000 years ago, when the sea stood at least $80 \mathrm{~m}$ below its present level (Dillon and Oldale, 1978). 


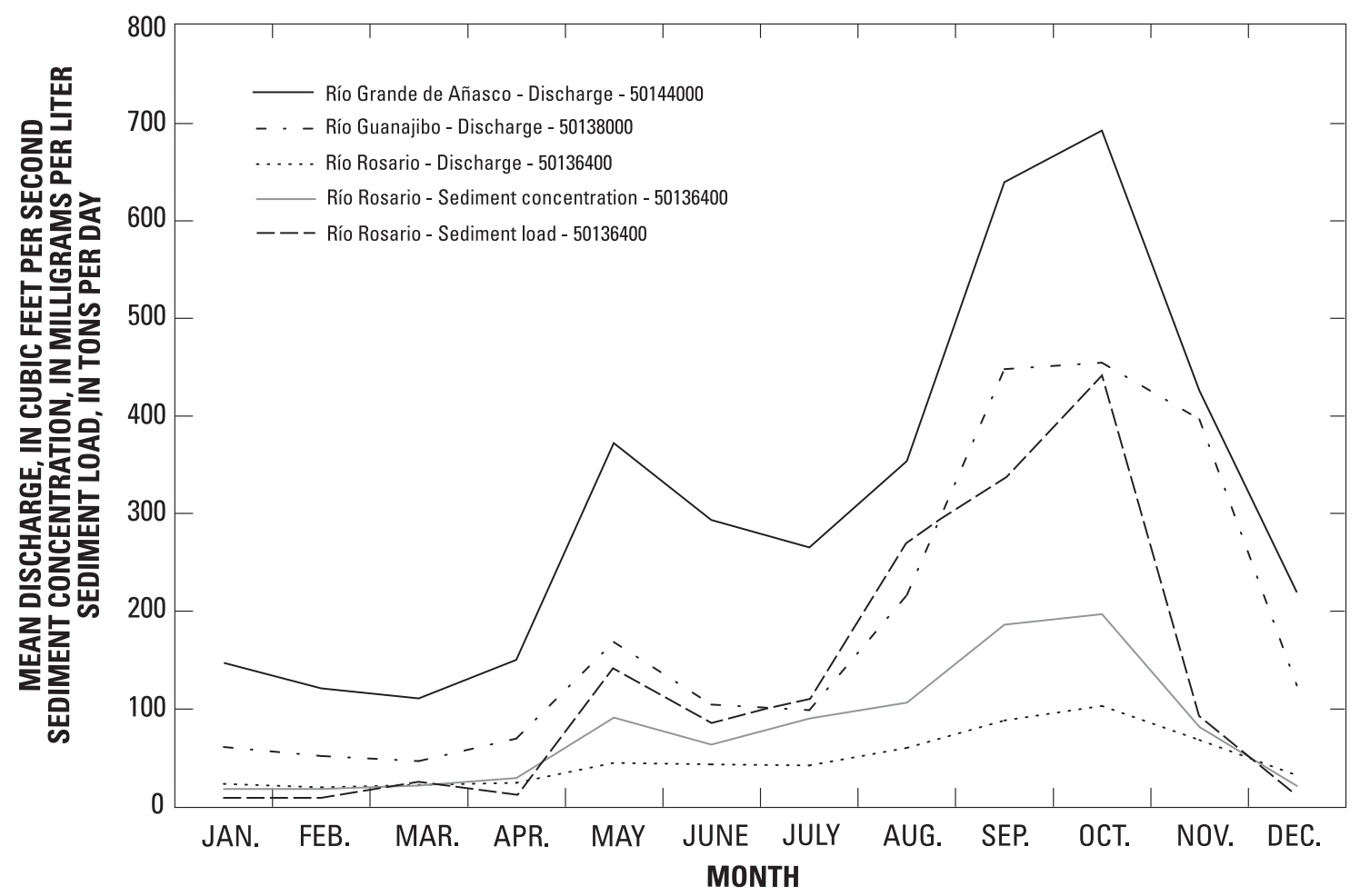

Figure 3. Monthly average streamflow for the Río Grande de Añasco, the Río Guanajibo, and the Río Rosario, and suspended-sediment concentrations and loads for the Río Rosario, Puerto Rico (1970-97).

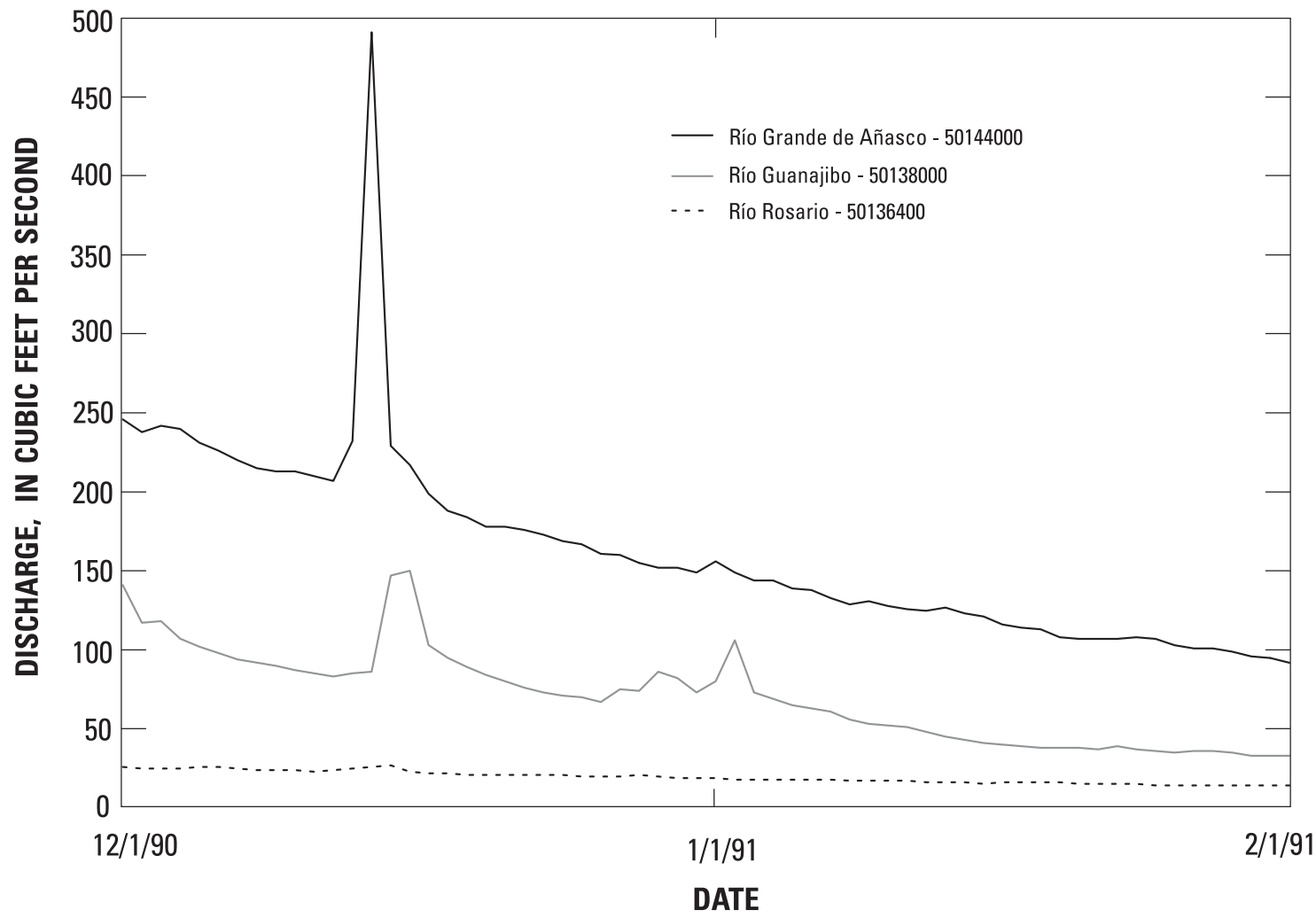

Figure 4. Discharge for the period December 1, 1990, through January 31, 1991, for the Río Grande de Añasco, the Río Guanajibo, and the Río Rosario, Puerto Rico. 


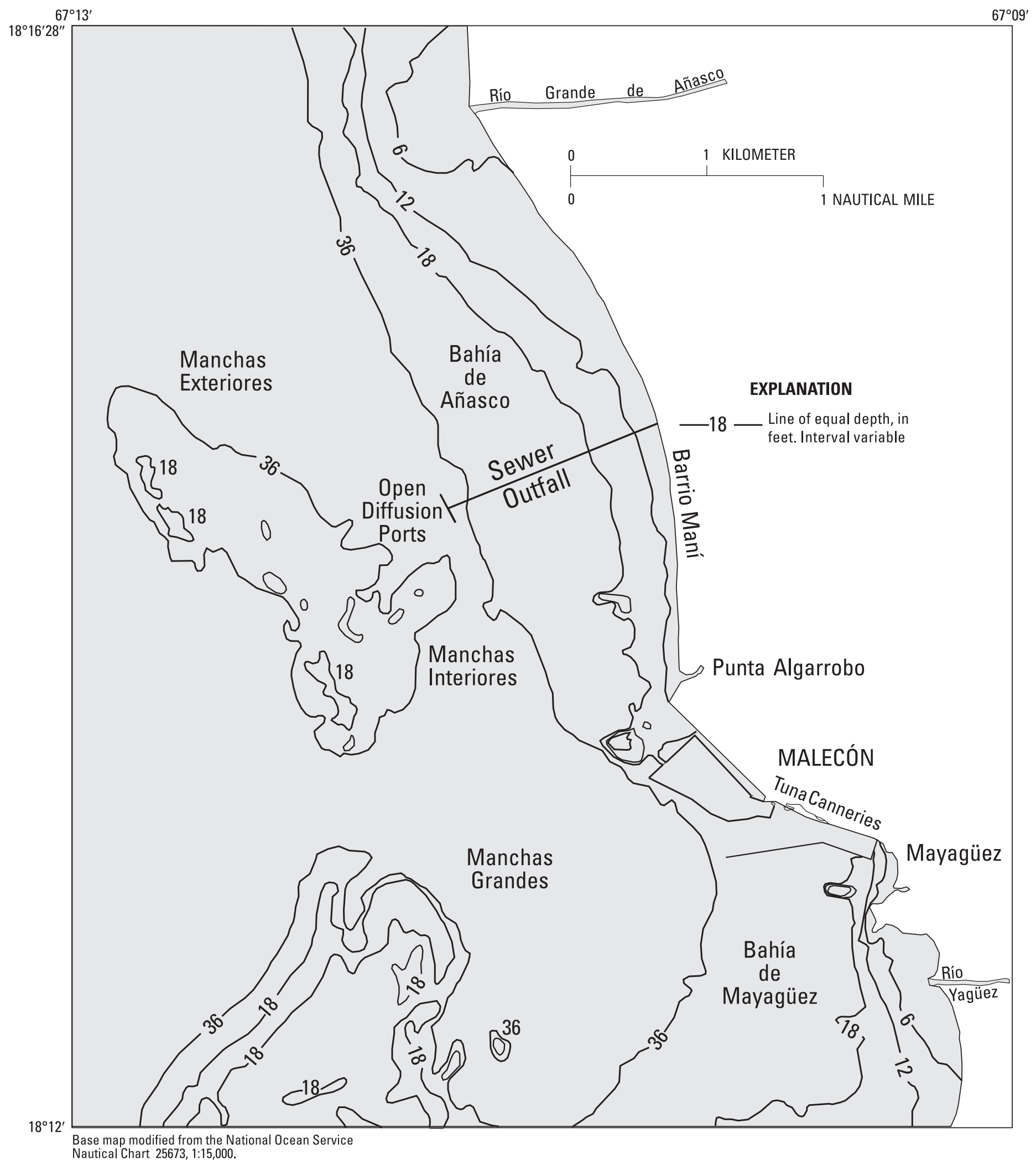

Figure 5. Site localities and nearshore bathymetry in the Bahía de Añasco and the Bahía de Mayagüez, Puerto Rico.

12 Assessment of the Habitats, Biota, Sediments, and Water Quality Near the Discharge of Primary-Treated Effluent from the Mayagüez Regional Wastewater Treatment Plant, Bahía de Añasco, Puerto Rico 


\section{Biological Resources}

Sea level around Puerto Rico has risen more than $80 \mathrm{~m}$ during the last 16,000 years. A wave-cut terrace lies submerged under $80 \mathrm{~m}$ of water off the western flank of the Manchas Exteriores (Macintyre, 1972). Relict assemblages of the foraminifer Amphistegina collected from the submerged terrace are similar to those found at similar depths on the slopes bounding Manchas Grandes and Escollo Negro (Seiglie, 1968). The abundance of living Amphistegina assemblages sampled at the three reefs was lowest at Manchas Exteriores, most likely as a result of the influence of muds discharged from the Bahía de Añasco. Seiglie (1971a) also documented shifts in the microfauna resulting from intense loading of organic matter near the docks in the Bahía de Mayagüez.

Previous observations of submerged reefs in the Bahía de Añasco documented a marked shore-normal gradient of coral health. Coral communities that are healthy and diverse offshore in the Manchas Interiores are found to be increasingly degraded with proximity to Punta Algorrobo, a fringing reef in the northern part of the Bahía de Mayaguiez (García, 1990b). The Punta Algorrobo reefs are colonized by algae and encrusting marine fauna other than live corals, but are still important fish habitats. In terms of reef fish community structure, the fundamental problem of scleractinian coral degradation is that the physical habitat will not grow to maintain its structure against the continuous marine erosion process. Thereby, a reduction of habitat space for fish populations may result. In addition, important alterations in fish community structure can result as coral polyps, consumed as the main diet of many species, disappear.

The reefs of the Bahía de Añasco represent an invaluable habitat for reef fishes and invertebrates, some of which are commercially important. The combination of different habitats present in the Bahía de Añasco, such as coral reefs, sea grass beds, mud bottoms, river mouths, and the estuarine-open water spectrum of water quality, promote high heterogeneity, and, thereby, high diversity of species. The Bahía de Añasco is, therefore, a highly complex and heterogeneous environment which serves as an important reservoir of marine life.

\section{Previous Surveys}

Benthic surveys carried out at the turn of the century found pauperate benthic communities in the southern part of the Bahía de Mayagüez, whereas healthy and diverse communities were found in the northern part of the bay (Evermann, 1900). This may represent a natural background gradient resulting from the high concentrations of nickel, cobalt, copper and chromium drained from the Río Yagüez and the Río Guanajibo drainage basins, as mentioned previously. Circulation and dilution in the Bahía de Mayagüez is poor. By 1963, discharge of sewage and organic matter into the Río Yagüez and the Bahía de Mayagüez by public and private entities resulted in pathogen-rich, oxygen-depleted conditions in the eastern and northern parts of the Bahía de Mayagüez (PRASA, 1963). The organic contamination in the Bahía de Mayaguiez resulted in shifts in the community structure of foraminifers living in the sediments (Seiglie, 1971a), and the near extermination of corals in the Punta Algarrobo reef, in the northern part of the Bahía de Mayagüez (Morelock and others, 1983). Reconnaissance surveys of the Bahía de Añasco as an alternative disposal site were completed in June 1971 (Department of Public Works, 1971). High current velocities favoring good mixing and rapid dispersion were documented, as well as the occurrence of upwelling of deep ocean waters onto the shallow insular shelf. The Bahía de Añasco was investigated further by the Puerto Rico Department of Public Works (1974) with similar results. Rotary currents with dominant northwest transport at the site were confirmed by Guzmán and Associates (1974).

Sediments and biota in the Bahía de Añasco and the Manchas Interiores-Manchas Exteriores coral reef complex were found to be under the influence of sediments discharged by west-coast rivers (Goenaga and Cintrón, 1979; Morelock and others, 1983), though the role of anthropogenic stressors could not be separated from the stress of natural deltaic progradation.

Previous to the start of MRWTP operations in 1987, baseline studies characterizing the community of fishes in the vicinity of the plant's discharge were performed (Center for Energy and Environment Research, 1985). After the plant began operations, another survey of the icthyofauna in the Manchas Interiores was prepared as baseline to the potential 
impact of the proposed Cogentrix power plant (García, 1990b). The data presented in these previous studies are only descriptive of the taxonomic composition and abundance of fishes at a given point in space and time. These stations were revisited during this study to see if they have been adversely affected by the outfall. These and other studies are presented in the application materials submitted by PRASA with their 301(h) application for the MRWTP (PRASA, 1979; Metcalf \& Eddy, Inc., 1985c, 1987b). The application materials present detailed data and discussion of the area to be served, the water quality, oceanographic conditions, and biological communities, in addition to the engineering studies describing the plant and ocean outfall design. The outfall design includes the initial and final mixing zone dimensions. Mixing of the effluent with the receiving waters within the zone of initial dilution should be such that all applicable waterquality standards are met by the time the mixed water parcels reach the boundary of the final mixing zone.

\section{SAMPLING PROGRAM, METHODS, AND RESULTS}

The sampling program was designed to provide the data needed to describe natural variations in the biota, sediments, and water quality in the Bahía de Añasco, and to determine if a causal relationship exists between the outfall and adverse impacts on the surrounding biological community.

The first step to understanding the processes active in the bay was to map the ocean floor. The mapping involved sub-bottom profiling using high resolution single-channel seismic reflection equipment run simultaneously with high-frequency sidescansonar data acquisition. Using the image, stations were then selected for biological surveys (table 1) and sediment sampling (table 2). Water-quality was measured for samples collected from the influent and effluent at the MRWTP for three river samples, and for samples collected in the receiving waters at varying distances from the outfall (table 3).

Table 1. Biological census and coring site locations, dates, and water depths

[Puerto Rico Coordinate system (equivalent to the local implementation of the North American Datum of 1927). Ten coral cores, $\mathrm{C} 1$ through $\mathrm{C} 10$, were recovered from stations MO-1 and MO-3. Abbreviations: $\mathrm{m}$, meters; --, no remarks]

\begin{tabular}{|c|c|c|c|c|c|c|c|c|c|}
\hline \multirow{2}{*}{ Station } & \multirow{2}{*}{$\begin{array}{l}\text { Date of } \\
\text { sampling }\end{array}$} & \multicolumn{3}{|c|}{ Latitude } & \multicolumn{3}{|c|}{ Longitude } & \multirow{2}{*}{$\begin{array}{c}\text { Water } \\
\text { depth } \\
\text { (m) }\end{array}$} & \multirow{2}{*}{ Remarks } \\
\hline & & Degrees & Minutes & Seconds & Degrees & Minutes & Seconds & & \\
\hline \multicolumn{10}{|c|}{ Macrobenthic Infauna Census } \\
\hline B1 & $12-15-90$ & 18 & 15 & 24.6 & 67 & 12 & 0.0 & 15 & -- \\
\hline B2 & $12-15-90$ & 18 & 14 & 51.6 & 67 & 12 & 1.5 & 15 & -- \\
\hline B3 & $12-15-90$ & 18 & 14 & 49.9 & 67 & 11 & 45.9 & 12 & -- \\
\hline B4 & $12-15-90$ & 18 & 14 & 35.1 & 67 & 11 & 26.1 & 11 & $\begin{array}{l}\text { Inside of initial } \\
\text { mixing zone }\end{array}$ \\
\hline B5 & $12-15-90$ & 18 & 14 & 42.2 & 67 & 10 & 59.9 & 6 & -- \\
\hline B6 & $12-15-90$ & 18 & 14 & 17.9 & 67 & 11 & 6.1 & 8 & -- \\
\hline B7 & $12-15-90$ & 18 & 13 & 35.1 & 67 & 11 & 37.0 & 20 & Bahía de Mayagüez \\
\hline B8 & $12-15-90$ & 18 & 13 & 10.7 & 67 & 11 & 6.8 & 17 & Bahía de Mayagüez \\
\hline \multicolumn{10}{|c|}{ Coral and Fish Census } \\
\hline MSG-1 & $12-13-90$ & 18 & 14 & 39.3 & 67 & 12 & 32.5 & 9 & $1,970 \mathrm{~m}$ from outfall \\
\hline MSG-2 & $12-14-90$ & 18 & 14 & 13.0 & 67 & 12 & 3.3 & 8 & $1,290 \mathrm{~m}$ from outfall \\
\hline MO-5 & $12-18-90$ & 18 & 14 & 18.0 & 67 & 11 & 28.2 & 8 & $350 \mathrm{~m}$ from outfall \\
\hline MO-4 & $12-17-90$ & 18 & 9 & 55.0 & 67 & 15 & 39.0 & 9 & El Negro reef \\
\hline \multicolumn{10}{|c|}{ Coral cores } \\
\hline MO-1 & $12-14-90$ & 18 & 14 & 11.9 & 67 & 11 & 9.0 & 5 & $\begin{array}{l}610 \mathrm{~m} \text { from outfall } \\
\text { (C1-C6) }\end{array}$ \\
\hline MO-3 & $12-17-90$ & 18 & 9 & 12.0 & 67 & 14 & 50.0 & 9 & $\begin{array}{l}\text { El Negro reef } \\
(\mathrm{C} 7-\mathrm{C} 10)\end{array}$ \\
\hline
\end{tabular}

14 Assessment of the Habitats, Biota, Sediments, and Water Quality Near the Discharge of Primary-Treated Effluent from the Mayagüez Regional Wastewater Treatment Plant, Bahía de Añasco, Puerto Rico 
Table 2. Sediment-sample locations, dates, and water depths

[Puerto Rico Coordinate system (Equivalent to the local implementation of the North American Datum of 1927). Abbreviations: m, meters; ,-- no depth measurement or no remarks]

\begin{tabular}{|c|c|c|c|c|c|c|c|c|c|}
\hline \multirow{2}{*}{ Station } & \multirow{2}{*}{$\begin{array}{l}\text { Date of } \\
\text { sampling }\end{array}$} & \multicolumn{3}{|c|}{ Latitude } & \multicolumn{3}{|c|}{ Longitude } & \multirow{2}{*}{$\begin{array}{l}\text { Water } \\
\text { depth } \\
(\mathrm{m})\end{array}$} & \multirow{2}{*}{ Remarks } \\
\hline & & Degrees & Minutes & Seconds & Degrees & Minutes & Seconds & & \\
\hline \multicolumn{10}{|c|}{ Surface Sediments } \\
\hline GS1 & $12-15-90$ & 18 & 15 & 29.1 & 67 & 11 & 55.7 & -- & -- \\
\hline GS2 & $12-15-90$ & 18 & 15 & 33.2 & 67 & 11 & 48.5 & 8 & -- \\
\hline GS3 & $12-15-90$ & 18 & 15 & 11.3 & 67 & 12 & 22.4 & 27 & -- \\
\hline GS4 & $12-15-90$ & 18 & 15 & 17.4 & 67 & 12 & 10.9 & 30 & -- \\
\hline GS5 & $12-15-90$ & 18 & 15 & 2.0 & 67 & 12 & 39.6 & 28 & -- \\
\hline GS6 & $12-15-90$ & 18 & 15 & 5.2 & 67 & 11 & 34.0 & -- & -- \\
\hline GS7 & $12-15-90$ & 18 & 15 & 1.1 & 67 & 11 & 47.3 & 12 & -- \\
\hline GS8 & $12-15-90$ & 18 & 14 & 52.2 & 67 & 12 & 3.1 & 15 & -- \\
\hline GS9 & $12-15-90$ & 18 & 14 & 45.8 & 67 & 12 & 21.9 & 9 & Hard bottom \\
\hline GS10 & $12-15-90$ & 18 & 14 & 50.1 & 67 & 11 & 21.9 & -- & -- \\
\hline GS11 & $12-15-90$ & 18 & 14 & 34.9 & 67 & 11 & 33.8 & 11 & -- \\
\hline GS12 & $12-15-90$ & 18 & 14 & 37.9 & 67 & 11 & 45.9 & 7 & -- \\
\hline GS13 & $12-15-90$ & 18 & 14 & 34.1 & 67 & 11 & 55.7 & 14 & -- \\
\hline GS14 & $12-15-90$ & 18 & 14 & 0.4 & 67 & 12 & 3.3 & 10 & Hard bottom \\
\hline GS15 & $12-15-90$ & 18 & 14 & 25.2 & 67 & 11 & 5.3 & 8 & -- \\
\hline GS16 & $12-15-90$ & 18 & 14 & 22.1 & 67 & 11 & 11.0 & 9 & -- \\
\hline GS17 & $12-15-90$ & 18 & 14 & 12.5 & 67 & 11 & 27.0 & 7 & Hard bottom \\
\hline GS18 & $12-16-90$ & 18 & 14 & 2.8 & 67 & 10 & 58.5 & 9 & -- \\
\hline GS19 & $12-16-90$ & 18 & 13 & 53.0 & 67 & 11 & 18.7 & 15 & -- \\
\hline GS20 & $12-16-90$ & 18 & 13 & 43.0 & 67 & 11 & 27.0 & 16 & -- \\
\hline GS21 & $12-16-90$ & 18 & 14 & 1.2 & 67 & 11 & 26.1 & 14 & -- \\
\hline GS22 & $12-16-90$ & 18 & 13 & 32.5 & 67 & 11 & 34.7 & 20 & -- \\
\hline GS23 & $12-16-90$ & 18 & 13 & 26.7 & 67 & 11 & 40.1 & 27 & -- \\
\hline GS24 & $12-16-90$ & 18 & 13 & 37.0 & 67 & 12 & 1.1 & 34 & -- \\
\hline GS25 & $12-16-90$ & 18 & 13 & 51.1 & 67 & 12 & 15.4 & 48 & -- \\
\hline GS26 & $12-16-90$ & 18 & 14 & 2.0 & 67 & 12 & 18.8 & 49 & -- \\
\hline GS27 & $12-16-90$ & 18 & 14 & 1.8 & 67 & 11 & 55.0 & 15 & -- \\
\hline GS28 & $12-16-90$ & 18 & 13 & 52.9 & 67 & 11 & 42.6 & 9 & -- \\
\hline GS29 & $12-16-90$ & 18 & 14 & 20.1 & 67 & 12 & 10.3 & 21 & -- \\
\hline GS30 & $12-16-90$ & 18 & 14 & 20.4 & 67 & 12 & 16.8 & 20 & -- \\
\hline GS31 & $12-16-90$ & 18 & 14 & 14.7 & 67 & 12 & 19.8 & 38 & -- \\
\hline GS32 & $12-16-90$ & 18 & 14 & 49.6 & 67 & 12 & 58.8 & 50 & -- \\
\hline GS33 & $12-16-90$ & 18 & 14 & 38.6 & 67 & 12 & 4.7 & 12 & -- \\
\hline GS34 & $12-13-90$ & 18 & 14 & 12.0 & 67 & 11 & 25.8 & 7 & -- \\
\hline GS35 & $12-13-90$ & 18 & 14 & 11.9 & 67 & 11 & 9.0 & 5 & -- \\
\hline GS36 & $12-17-90$ & 18 & 9 & 12.0 & 67 & 14 & 50.0 & 9 & -- \\
\hline GS37 & $12-17-90$ & 18 & 9 & 55.0 & 67 & 15 & 39.0 & 9 & -- \\
\hline GS38 & $01-26-91$ & 18 & 14 & 5.5 & 67 & 11 & 54.6 & 15 & -- \\
\hline \multicolumn{5}{|c|}{ Sediment cores } & & & & & -- \\
\hline $\mathrm{VCO}$ & $12-14-90$ & 18 & 14 & 25.2 & 67 & 11 & 16.8 & 6 & $160 \mathrm{~m}$ from outfall \\
\hline VCC & $01-26-91$ & 18 & 13 & 53.4 & 67 & 11 & 44.2 & 10 & Coral channel sands \\
\hline VCA & $01-26-91$ & 18 & 15 & 34.8 & 67 & 11 & 38.2 & 3 & $\begin{array}{l}\text { Río Grande de } \\
\text { Añasco delta }\end{array}$ \\
\hline VCY & $01-27-91$ & 18 & 12 & 34.6 & 67 & 9 & 50.6 & 5 & Río Yagüez delta \\
\hline
\end{tabular}


Table 3. Water-quality sampling locations, dates, water depths, and distance from outfall

[Puerto Rico Coordinate system (Equivalent to the local implementation of the North American Datum of 1927). Locations for onshore sites were determined from the topographic quadrangle. Remarks indicate the intended sampling site: IMZ, initial mixing zone; BND, boundary of the initial mixing zone; FMZ, at the boundary of the final mixing zone; FAR, beyond the final mixing zone where effect from the outfall may be reasonably expected; and CTL, the control stations off Rincón. Abbreviations: Repl, replicate; NA, not applicable; --, no remarks]

\begin{tabular}{|c|c|c|c|c|c|c|c|c|c|c|}
\hline \multirow{2}{*}{ Station } & \multirow{2}{*}{$\begin{array}{l}\text { Date of } \\
\text { sampling }\end{array}$} & \multicolumn{3}{|c|}{ Latitude } & \multicolumn{3}{|c|}{ Longitude } & \multirow{2}{*}{$\begin{array}{c}\text { Water } \\
\text { depth } \\
\text { (m) }\end{array}$} & \multirow{2}{*}{ Remarks } & \multirow{2}{*}{$\begin{array}{l}\text { Distance } \\
\text { to outfall } \\
(\mathrm{m})\end{array}$} \\
\hline & & Degrees & Minutes & Seconds & Degrees & Minutes & Seconds & & & \\
\hline EFFL & $01-29-91$ & 18 & 15 & 5.7 & 67 & 9 & 22.5 & NA & -- & NA \\
\hline INFL & 01-29-91 & 18 & 15 & 5.7 & 67 & 9 & 22.5 & NA & -- & NA \\
\hline QW-An1 & 01-29-91 & 18 & 15 & 58.7 & 67 & 8 & 3.7 & NA & -- & NA \\
\hline $\begin{array}{l}\text { QW-An1 } \\
\text { (Repl) }\end{array}$ & 01-29-91 & 18 & 15 & 58.7 & 67 & 8 & 3.7 & NA & -- & NA \\
\hline QW-An2 & $01-31-91$ & 18 & 16 & 28.6 & 67 & 9 & 42.7 & NA & -- & NA \\
\hline QW-Ya1 & 01-28-91 & 18 & 12 & 30.4 & 67 & 8 & 43.8 & NA & -- & NA \\
\hline QW-1 & 01-29-91 & 18 & 14 & 11.7 & 67 & 11 & 11.8 & 11 & FAR & 570 \\
\hline QW-2 & 01-29-91 & 18 & 14 & 20.7 & 67 & 11 & 17.8 & 12 & FMZ & 240 \\
\hline QW-3 & 01-30-91 & 18 & 14 & 27.4 & 67 & 11 & 21.5 & 11 & BND & 10 \\
\hline QW-4 & 01-30-91 & 18 & 14 & 27.8 & 67 & 11 & 21.8 & 11 & IMZ & 0 \\
\hline QW-5 & 01-30-91 & 18 & 14 & 34.4 & 67 & 11 & 25.4 & 10 & IMZ & 0 \\
\hline QW-5 (Repl) & 01-30-91 & 18 & 14 & 34.4 & 67 & 11 & 25.4 & 10 & $\mathrm{IMZ}$ & 0 \\
\hline QW-6 & 01-30-91 & 18 & 14 & 34.9 & 67 & 11 & 25.7 & 10 & BND & 10 \\
\hline QW-7 & 01-29-91 & 18 & 14 & 45.0 & 67 & 11 & 32.9 & 11 & FMZ & 390 \\
\hline QW-8 & 01-29-91 & 18 & 14 & 55.4 & 67 & 11 & 42.2 & 11 & FAR & 800 \\
\hline QW-9 & 01-28-91 & 18 & 18 & 35.1 & 67 & 14 & 48.9 & 14 & CTL & 9,500 \\
\hline QW-10 & $01-28-91$ & 18 & 19 & 37.4 & 67 & 15 & 19.5 & 10 & CTL & 11,500 \\
\hline
\end{tabular}

\section{Habitats in the Bahía de Añasco}

Despite shallow depths in the Bahía de Añasco, high turbidity makes mapping of the sea floor from the surface an unreasonable proposition. A detailed and contemporary map of the sea floor was needed to describe the spatial distribution of bottom habitats in the bay and to develop a representative sampling program. High-frequency sidescan sonar was selected as the geophysical technique most appropriate to the level of detail desired for the present study, and for use in comparisons by future monitoring studies. The system produces an image of backscattered energy from the ocean floor. Fine-grained sediments (silts and clays), the habitat for macrobenthic infaunal communities, return only minimal energy back to the sonar transducer, resulting in light areas (less ink placed on a white background) in the sidescan-sonar image. Coarse-grained sediments (sands and gravel), rocky bottoms, and coral communities, return more energy, and so appear as darker areas in the image. Gases discharging from the organic-rich, fine-grained sediments, also reflect energy, and appear as dark blotches in some areas in the interior of the bay. The imagery was used to map the spatial distribution of soft-bottom habitats that support communities of infauna and hard-bottom habitats capable of supporting coral communities, thereby providing a basis for subsequent sampling programs. In addition, the image was inspected for evidence of accumulation of sediment deposited from the outfall itself. Finegrained sediments settled out around the outfall should be detectable as a shadow if they settle in an area 
previously covered by coarse-grained deposits. Highresolution seismic-reflection profiles $(3.5 \mathrm{kHz}$ and UNIBOOM) were also collected along with the sidescan-sonar traverses, and provided data of the thickness of accumulated sediments and the expression of the underlying substrate.

Approximately $10 \mathrm{~km}^{2}$ of the Bahía de Añasco, containing the diffuser array, and adjacent areas, potentially subject to its influence, were successfully mapped. The survey lines were oriented with an azimuth of $330^{\circ} \mathrm{N}$, parallel to the coastline. The outfall trench, the bay floor, and the coral reefs are prominent features of the sidescan-sonar mosaic.

The bottom was mapped by traversing the study area with a sonar fish towed behind the research vessel. A detailed description of the theory, instrumentation, and processing of the sidescan-sonar data is given by Danforth and others (1991). Precise positioning was indispensable in the assembly of the images generated along each track.

Marine navigation during sidescan-sonar imaging as well as other phases of the field work depended upon range-range navigation using the MINIRANGER Falcon microwave transponder system. The master unit on board the ship would interrogate the two shore-based transponders once every ten seconds and then update the position. Navigation fixes were printed on paper and recorded digitally. The error associated with the ship's position is estimated to be not greater than $5 \mathrm{~m}$. Because the sonar fish was not navigated independently, the total possible error associated with the mosaic was the sum of $5 \mathrm{~m}$ from the MINIRANGER and the 10 to $20 \mathrm{~m}$ length of the cable towing the fish.

The mosaic was constructed by piecing together the series of parallel track lines. The first mock-up of the sidescan-sonar image was completed on December 13, two days after recording the last sonar data. The image was used immediately as a base map (fig. 6) (Schwab and others, 1991). Sampling of bottom sediments for the ground truthing and for macrobenthic infauna was conducted with a Shipek grab sampler on December 15-16, 1990.

\section{Biota}

The diversity and abundance of macrobenthic infauna, fish, and corals were measured. Where possible, surveys of the biota were conducted at the locations of previously studied stations. The locations for the survey stations are presented in figures 7 and 2 .

The presence or absence of a balanced indigenous population living in the upper layers of the sediment column can be used as an indicator of pollution stress. The EPA (1984) notes that certain opportunistic species are more resistant to pollution than others, and as a result are expected to exist in higher numbers in polluted sediment than in unpolluted sediment. A decrease in diversity is expected to accompany the proliferation in numbers of the more pollution-tolerant species. The macrobenthic infauna populations at stations B1 through B6, and B8, were measured in January and May of 1985 (Metcalf and Eddy, 1987a). This study represents the third visit to these stations.

Measurements of community structure included identification of individuals to the lowest taxa and calculations of species diversity for macrobenthic infauna, sessile benthos, and fish. In addition, indices of species richness, evenness, and dominance, were calculated for the macrobenthic infauna.

The Shannon-Weaver (or Shannon-Weiner) diversity index $\left(H^{\prime}\right)$ (Shannon and Weaver, 1949) measures the degree of uncertainty of predicting the correct species of an individual picked at random from a community. The index can be written as

$$
H^{\prime}=\sum_{i=1}^{S} p_{i}\left(-\ln p_{i}\right)
$$

where

$$
\begin{gathered}
S=\text { total number of species, and } \\
p_{i}=\frac{n_{i}}{N} \quad \begin{array}{l}
\text { the proportion of the number of } \\
\text { individuals of a given species }\left(n_{i}\right) \text { to the } \\
\text { total number of individuals }(N) .
\end{array}
\end{gathered}
$$




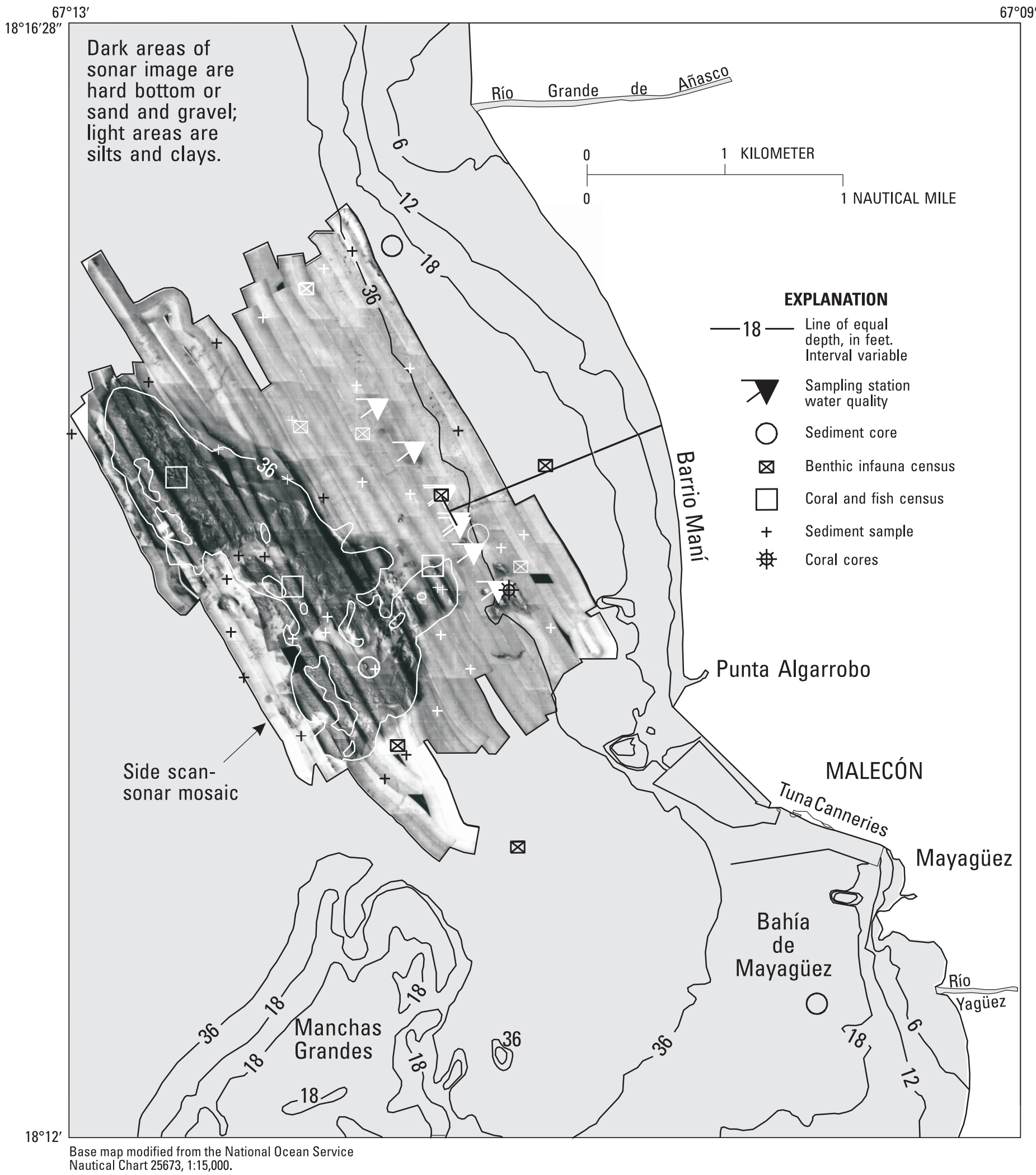

Figure 6. Locations of sampling stations, superimposed on a sidescan-sonar mosaic, Bahía de Añasco and the Bahía de Mayagüez, Puerto Rico. Additional sampling was completed north of the study area at water-quality sites QW-9 and $\mathrm{QW}-10$, and southwest of the study area at biological sites M0-3 and M0-4, and at sediment sites GS-36 and GS-37 (see figure 2).

18 Assessment of the Habitats, Biota, Sediments, and Water Quality Near the Discharge of Primary-Treated Effluent from the Mayagüez Regional Wastewater Treatment Plant, Bahía de Añasco, Puerto Rico 


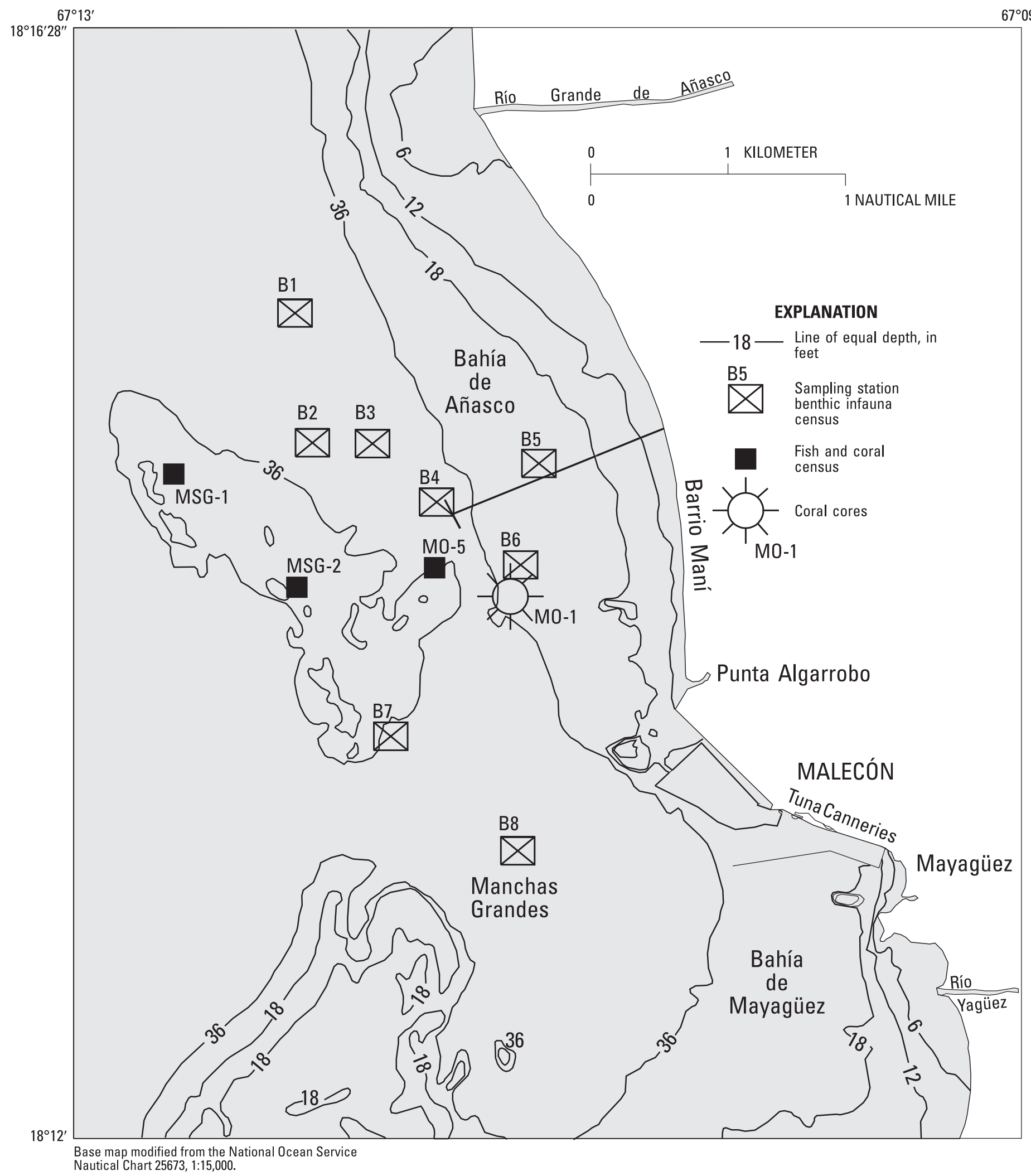

Figure 7. Sampling sites for macrobenthic infauna, coral and fish census, for and coral coring the Bahía de Añasco and the Bahía de Mayagüez, Puerto Rico. Additional sites for fish and coral census and coral coring are located near Escollo Negro (fig. 2). 
The Shannon-Weaver diversity index was selected as the most appropriate measure of diversity, because of its independence from sample size (Bowman and others, 1970), and because its proportionality approach reflects community structure (McErlean and others, 1973; Kimmel, 1978). The index varies from a value of 0 for communities with only a single species to high values for communities having many species, each with similar numbers of individuals.

Note that the diversity index will change with the base of the logarithm used. All diversity index values in this report were calculated using natural logarithms. Results of macrobenthic infauna are sometimes reported using base 2 logarithms $\left(\log _{2}\right)$, whereas diversity of sessile bethos is sometimes reported using common logarithms $\left(\log _{10}\right)$. Where this was found to be the case, the values from previous studies were converted to equivalent diversity indices using natural logarithms. The linear conversion factors are included in the preface of this report.

Margalef's index of species richness $(S R)$ is an indicator of the number of species present. The calculated $S R$ of a collection increases monotonically as the total number of individuals $(N)$ examined increases. A species-area curve can be constructed by plotting $S R$, or species density as it is sometimes referred to, versus number of individuals. The curve increases rapidly at first and eventually levels off once the majority of the most common species present in the area have been included in the sampled population. The curve is commonly used to develop an appropriate sampling program that will ensure an adequate level of characterization for the community of interest. SR is calculated as

$$
S R=(N-1) /(\ln (S)),
$$

where

$$
\begin{aligned}
& N=\text { total number of individuals, and } \\
& S=\text { total number of species. }
\end{aligned}
$$

The species evenness $\left(J^{\prime}\right)$, or equitability, is a measure of the homogeneity of the community. It is the ratio of the measured diversity $\left(H^{\prime}\right)$, to the theoretical maximum level of diversity for a community, $\ln (S)$. The maximum diversity is attained when all of the individuals are equally divided among all of the species. $J^{\prime}$ is calculated as

$$
J^{\prime}=\frac{H^{\prime}}{\ln (S)},
$$

where

$$
\begin{aligned}
& \begin{array}{l}
H^{\prime}= \\
\quad \text { Shannon-Weaver diversity index calculated } \\
\text { using natural logarithms, and }
\end{array} \\
& S=\text { total number of species. }
\end{aligned}
$$

Simpson's dominance index $\left(S I^{\prime}\right)$, varies inversely with species diversity. It is sensitive to the abundance of one or two of the most common species and can be regarded as a measure of "dominance concentration" (Ourso, 1997). If contaminants from the outfall effluent deposited in the sampling area resulted in an increase of the dominance of a few pollutant-tolerant species, this index may be expected to increase. $\left(S I^{\prime}\right)$ is calculated as

$$
S I^{\prime}=\sum_{i=1}^{S} p_{i}^{2}
$$

where

$$
\begin{gathered}
S=\text { total number of species, and } \\
p_{i}=\frac{n_{i}}{N} \begin{array}{l}
\text { the proportion of the number of } \\
\text { individuals of a given species }\left(n_{i}\right) \text { to } \\
\text { the total number of individuals }(N) .
\end{array}
\end{gathered}
$$

If the outfall is having a negative impact on the biota of the Bahía de Añasco, it should be reflected in shifts with time in some or all of these indices for stations closest to the outfall. Therefore, statistical analysis of the macrobenthic infauna observed at stations B1 to B8 and the census data collected for sessile benthos observed in December 1990 at stations MSG-1, MSG-2, MO-5, and MO-4 was carried out.

Diversity measured for infaunal communities at stations B1 to B8, collected in December 1990, were compared between stations to determine if they were significantly different. Additional testing was completed to compare diversity measured at stations B1 to B6 and B8 in December 1990 with the diversity 
measured at the same stations in January 1985 (station B7 was not sampled in 1985).

The null hypothesis that the diversities measured for two populations are equal was evaluated using a t-test (Hutchinson, 1970; as quoted in Zar, 1974).

$$
t=\frac{H_{1}^{\prime}-H_{2}^{\prime}}{s_{H_{1}^{\prime}-H_{2}^{\prime}}},
$$

where $H^{\prime}$ is the diversity described above and

$$
s_{H_{1-H_{2}}^{\prime}}=\sqrt{s_{H_{1}^{\prime}}^{2}+s_{H_{2}^{\prime}}^{2}} \text {. }
$$

The variance of $H^{\prime}$ may be approximated by

$$
s_{H^{\prime}}^{2}=\frac{\sum_{i=1}^{S} p_{i}\left(\ln p_{i}\right)^{2}-\left(\sum_{i=1}^{S} p_{i} \ln p_{i}\right)^{2}}{100} .
$$

The degrees of freedom $(v)$ associated with the preceding $t$ are approximated by

$$
v=\frac{\left(s_{H_{1}^{\prime}}^{2}+s_{H_{2}^{\prime}}^{2}\right)^{2}}{\frac{\left(s_{H_{1}^{\prime}}^{2}\right)^{2}}{n_{1}}+\frac{\left(s_{H_{2}}{ }^{2}\right)^{2}}{n_{2}}} .
$$

Since diversity can be equal for two communities composed of completely different taxa, the percentage similarity (PS) (Bray and Curtis, 1957; as quoted in Gauch, 1982) was calculated to compare community compositions observed at stations B1 to B8 in December 1990. The PS between samples $j$ and $k$ is

$$
P S_{j k}=\frac{200 \sum_{i=1}^{S} \min \left(n_{i j}, n_{i k}\right)}{\sum_{i=1}^{S}\left(n_{i j}+n_{i k}\right)}
$$

where $S$ is the total number of species in common, min is the minimum of the two values, and $n_{i j}$ and $n_{i k}$ are the abundances of species $i$ in samples $j$ and $k$, respectively. To arrive at a distance measure, percentage dissimilarity, for comparing sample pairs, the similarity has to be subtracted from the similarity among replicate samples, the internal association. Because overestimation of the internal association is less problematic than underestimation (Gauch, 1982), the value of 100 is often suitable if one cannot supply an empirical estimate of the replicate. Therefore, dissimilarity values used to place sampling stations on a common ordination axis presented later were calculated as 100 - PS. Stations with dissimilar taxa were identified and used as poles for showing community structure on both one-dimensional and two-dimensional plots using polar ordination techniques (Bray and Curtis, 1957). Finally, values of diversity and percent opportunistic species were plotted against distance from shore and distance from the outfall to ascertain if community structure varied along an environmental gradient.

Sessile benthos are less susceptible to transient or seasonal variations than populations of macrobenthic infauna or fishes. The analyses on the sessile benthos data consisted of one-way analysis of variance (ANOVA) and a Duncan's Multiple Range Test (MRT), to document significant changes in community structure. Sessile benthos at stations MSG-1 and MSG-2 were surveyed in January and May of 1985 (PRASA, 1985). Stations close to the originally identified coordinates for the 1985 stations were revisited during this study. The censuses of the sessile benthos for stations MSG-1, MSG-2, for 1985 and 1990, were subjected to a Duncan's Multiple Range Test to determine if significant changes in benthic populations had occurred in the interim.

\section{Macrobenthic Infauna}

Five replicate samples were collected at each of the eight stations B1 through B8. Samples were collected on December 15, 1990. A total of 0.2 square meter $\left(\mathrm{m}^{2}\right)$ was sampled using a Shipeck sampler at each station (five replicate sites of $0.04 \mathrm{~m}^{2}$ at each station). Upon recovery, the samples were anesthetized with 35 percent magnesium chloride and stained with rose bengal dye. Upon reaching shore, the samples were placed in a 10 percent formaldehyde buffer to preserve the specimens before these were transferred to 70 percent alcohol, 48 hours later. Specimens that were retained on a 0.5 millimeter $(\mathrm{mm})$ sieve were then identified to the lowest taxonomic species. 


\section{Coral and Fish Surveys}

Coral and fish communities were surveyed at four stations from December 13 through December 18, 1990. The survey stations are located in figures 2 and 7. Of the four stations selected for diversity studies of corals and fish, two stations were located as close as possible to stations MSG-1 and MSG-2, reported in previous studies (Metcalf \& Eddy, Inc., 1987). Two new stations were established: MO-5, identified in the sidescan-sonar image as being the closest reef community to the outfall; and MO-4, a control site in the Escollo Negro, presumably outside of the area influenced by pollutants discharged into the Bahía de Mayagüez. All transects within and between stations were set at similar depths, to reduce variability associated with depth. The stations MSG-1 and MSG-2 (Metcalf \& Eddy, Inc., 1985) were relocated from the positions recorded in the previous study. Rudimentary navigational techniques employed during the original surveys (Metcalf \& Eddy, 1985) could have resulted in a positioning error of a few hundred meters. The locations of MSG-1 and MSG-2, listed by PRASA (1985), corresponded to sandy areas; the nearest hard-bottom areas, observed in the sidescan-sonar mosaic, were occupied for the surveys. All present surveys were conducted at similar depths to ensure comparability.

Corals are an important natural resource of limited geographic distribution. The distribution of soft and hard corals is determined by the type of substrate available, the light levels, wave energy, suspended and settleable sediments, and physical and chemical characteristics of the water column. Fish are usually abundant in reef areas, because of the diverse habitats and food supplies.

Station localities were selected on the basis of similar prior studies (Center for Energy and Environment Research, 1985), conducted before the sewage treatment plant was built, with the intention of making before-and-after comparisons of the zoobenthos. Five line transects were surveyed to determine the relative abundance of benthic organisms at stations MSG-1 and MSG-2. Results were compared with observations made in 1985, when four line transects were surveyed at each of these stations. Because of the limited hard-bottom area at station MO-5, near the outfall, only two line transects were surveyed there. At station MO-4 in the Escollo Negro, oscillatory surges, resulting from the arrival of North Atlantic swells, made it difficult for the divers to maintain their position over the transect line. For this reason, observations of only two line transects at this station were possible before darkness set in and the expedition had to return to port.

Line transects were randomly located at each station and a 10-m metric tape stretched taught between two stakes driven into the substrate. The linear cover of sessile benthos under the tape was recorded, while fish were observed by traversing above the tape from end to end at a rate of approximately one meter per minute.

Topographic relief was estimated by hand contouring the substrate along the 10-m line transects with a $15-\mathrm{m}$ plastic-link chain carried to the bottom by the diver. The chain was previously marked at a distance of $10 \mathrm{~m}$. At the end of each $10-\mathrm{m}$ transect line, the total length of the chain in excess of the $10-\mathrm{m}$ mark on the chain was recorded as the substrate-relief index. A flat substrate would have a relief index of 0 , and the index would increase with increasing substrate relief.

The main targets for the sessile benthos study were the non-branching zoobenthos (mainly encrusting, massive and platy corals), which were described to the lowest possible taxonomic category. Notes on the phytobenthos were also included, although taxonomic ranking was generally higher (for example, generally up to genus). All erect soft corals (for example, gorgonians or octocorals) whose branches overlapped the metric tape were also counted, but their linear cover was not determined. Therefore, the relative abundance of non-branching zoobenthos is quantified in terms of linear cover per transect, whereas that of branching zoobenthos is quantified in terms of numbers per transect.

Photographs of the selected sessile benthos, and the position along the tape of each organism was also noted in case future studies on spatial patterns are deemed necessary. The photographs and positional data are available in the District office. In addition, the mean cover of non-branching zoobenthos was utilized to compare relative colony size of measured portions among stations. Non-cryptic, motile benthos one meter to each side of the transect were also individually counted. 
To summarize, the following were quantified: total number of species per station for corals, gorgonians, and other abundant sessile benthos; total linear cover per transect, and mean cover per station, for corals and other benthos; total number of gorgonian colonies passing through the vertical plane that included the survey line; and observable motile benthos. In addition, qualitative observations of the general site characteristics were recorded. These include mean depth, visually conspicuous biota, uncommon biota (outside of the transect lines), bottom topography, and general site appearance.

Quantitative data on fish abundance and species composition were obtained by enumeration of species and individuals along transects covering a surface area of $30 \mathrm{~m}^{2}$ (3-m wide $\times 10$-m long). Only diurnal, demersal, non-cryptic fish species were quantified. Fish abundance was reported as number of individuals per transect. The data can be normalized to individuals per $\mathrm{m}^{2}$ by dividing the number of individuals ( $\mathrm{n}$ ) by the total surface area surveyed $\left(30 \mathrm{~m}^{2}\right)$. All data were recorded underwater on plastic paper. Fish identifications follow Randall's (1983) guidelines.

\section{Coral Cores}

Numerous environmental proxies are available within the aragonitic structures built by corals. Four commonly used proxies were examined in this study: annual growth bands, fluorescence, lattice-bound stable isotopes, and trace metals.

The yearly addition of recognizable growth increments in the hermatypic coral Montastrea annularis (Dodge and Thomson, 1974) has been used extensively as the basis of interpretation of historical environment experienced during the life-span of a reef. Variations in extension rate provide indications of the relative rate of coral growth, which varies as a function of the environment's favorability for coral health (Goreau and MacFarlane, 1990).

Variations in fluorescence of the yearly growth bands has been related to river discharges. The intensity of fluorescence observed in annual bands deposited by corals sampled off New Guinea (Scoffin and others, 1989) and Australia (Isdale, 1984; Susic and others, 1991) was correlated with large discharges from the nearest rivers. The fluorescence is derived from humic substances contained in the riverine water masses.

Ratios of stable isotopes of carbon and oxygen can be used as proxies of sea temperature, light levels, salinity, and other factors (Fairbanks and Dodge, 1979). Emiliani and others (1978) found that, for deep-dwelling solitary corals lacking zooxanthellae, Bathypsammia tintinnabulum, the values for carbon and oxygen isotopes display a strong inverse relation. They found the relationship to be present, but much weaker, for shallow-water corals, Montastrea annularis, with active zooxanthellae. Carbon and oxygen isotopes are incorporated into coralline skeletons in disequilibria with the surrounding seawater (Swart, 1983). Ratios of carbon and oxygen isotopes incorporated into coralline skeletons are affected mainly by temperature and salinity ("kinetic effect"), whereas enrichment of carbon isotopes is also affected by a variety of physiologic factors reflecting such environmental effects as insolation, water turbidity, and specific coral stressors ("metabolic effect") (McConnaughey, 1989a). When the kinetic effect is dominant, relative depletions and enrichments of carbon and oxygen isotopes will correlate well (McConnaughey, 1989b). The warm waters resulting from the strong El Niño event of 1982-83 were accurately recorded by isotopic variations in corals growing in the eastern Pacific around the Isla de Caño, Costa Rica (Carriquiry and others, 1988).

The use of coral chemistry is particularly suited to assessing possible outfall effects in that the changes in aqueous metal concentrations are preserved in the lattice. Trace metal substitution for calcium in the aragonitic lattice can provide a proxy of the concentration of that metal in solution during that segment's growth. Concentration of barium and cadmium, which are enriched in deep oceanic waters, increase in coralline skeletons during periods of intense upwelling in the equatorial Pacific (Lea and others, 1989). Taken together, the various coral proxies offer the possibility of preserving a record of the water quality in the vicinity of the coral sampled.

Ten coral cores from heads of Montastrea annularis were collected during this study. Six of these were recovered from colonies on a rocky 
substrate $610 \mathrm{~m}$ southeast of the outfall, identified in the sidescan-sonar image (figs. 6, 7). The remaining four were collected in the Escollo Negro to serve as control samples (fig. 2). Corals were cored with a hydraulic rotary drill attached to a 1-m long stainless steel barrel with a tungsten carbide cutter head (inside diameter equal to 5.35 centimeter $(\mathrm{cm})$ ). Concrete plugs were placed into the voids left by the core extraction to avoid degradation of the colony by boring organisms and algae.

Processing of coral cores was undertaken at the USGS Coastal Research Division office in St.

Petersburg, Florida. All coral samples were cut into slabs 4-mm in thickness using a water-cooled diamond saw dedicated for coral sectioning. Individual slabs were X-rayed to reveal annual banding (Buddemeier and Kinzie, 1976). To reveal possible relations with river discharge, the coral slabs were exposed to UV radiation and the resultant fluorescence observed. $\mathrm{X}$-ray and slab fluorescence images were digitized for subsequent data analysis.

\section{X-radiography and Fluorescence of Coral Cores}

Coral cores were processed to document annual accretional rates and to select samples to be analyzed for trace metals and stable isotopes. Slabs were subsequently exposed to X-rays generated at $50 \mathrm{~mA}$ and $38 \mathrm{kV}$ for 2 seconds. The distance to the table top from the X-ray source was $122 \mathrm{~cm}$. Four of the ten coral cores $(\mathrm{C} 1, \mathrm{C} 2, \mathrm{C} 7$, and $\mathrm{C} 9)$ were selected for additional analysis, because the $\mathrm{X}$-radiographs indicated that the slabs were successfully cut parallel to the growth axis. Samples representing annual accretions for the most recent 7 years were cut from sections of $\mathrm{C} 1$ and $\mathrm{C} 2$ (near the outfall diffusers) and $\mathrm{C} 7$ and $\mathrm{C} 9$ (control site), using a high-rpm diamond bit blade in a Dremel Tool. Splits of selected samples were collected to estimate analytical precision. Couplets of adjacent coral mass that accumulated during the same years were also sampled in each of the cores, in order to evaluate intra-year compositional variation within the coral colony. In core $\mathrm{C} 2$, in addition to the 7-year annual sampling, seventeen 3-year composite samples were collected along the length of the recovered coral core. The composite samples were extracted and analyzed for trace metals and stable isotopes. Together, they represent approximately 51 years of coral growth (1938-89).

The fluorescence of the coral lattices was observed under ultraviolet (UV) light. The distance from the UV source to the table top was kept constant. A high-resolution CCD with a constant gain was used to record the fluorescence induced by the UV light for each sample.

\section{Analysis of Carbon and Oxygen Isotopes in Annual Coral Bands}

Stable isotope analyses for oxygen and carbon of the aragonite coral samples were supervised by Dr. K.C. Lohmann, at the University of Michigan's Department of Geology stable-isotope laboratory. Carbonate samples weighing between 10 micrograms $(\mu \mathrm{g})$ and 1 milligram $(\mathrm{mg})$ were placed in stainless steel boats. Samples were roasted at $200^{\circ} \mathrm{C}$ in vacuo for one hour to remove volatile contaminants while preventing conversion of the aragonite to calcite. Samples were then placed in individual borosilicate reaction vessels and reacted at $72^{\circ} \pm 2^{\circ} \mathrm{C}$ with three drops of anhydrous phosphoric acid for 8 minutes in a Finnigan "Kiel" extraction system coupled directly to the inlet of a Finnigan MAT 251 triple-collector isotope-ratio mass spectrometer. Isotopic enrichments are corrected for acid fractionation and oxygen-17 contribution, by calibration to a best fit-regression line defined by two NBS standards, NBS 18 and NBS 19. Data are reported in $\delta$ (del) notation, units are \%o (per mil) relative to Peedee belemnite (PDB), an international standard isotopic composition of carbon dioxide that is prepared from belemnites collected from the Peedee Formation, an Upper Cretaceous unit found in South Carolina, United States.

$$
\delta(\% o)=\left[\left(\mathrm{R}_{\text {sample }} / \mathrm{R}_{\text {standard }}\right)-1\right] \times 1000 ;
$$

where

$$
\begin{aligned}
& \mathrm{R}=\mathrm{C}^{13} / \mathrm{C}^{12} \text { or } \\
& \mathrm{R}=\mathrm{O}^{18} / \mathrm{O}^{16} .
\end{aligned}
$$

The precision of the data is monitored through daily analysis of a variety of powdered carbonate standards. At least six standards are reacted and analyzed daily, bracketing the sample suite at the 
beginning, middle, and end of the day's run. Measured precision is maintained at better than $0.1 \%$ or both carbon and oxygen isotope compositions.

Replicate samples of the same annual band (assigned a suffix of A/B) and of the coarse (suffix C) fraction of the crushed aragonite from the coral bands were run in order to estimate interannual variability and potential partitioning problems between the coarse and fine fractions. The results, including the average values and relative percent difference for each replicate analysis, are presented in table 4.

\section{Trace Elements in Annual Coral Bands}

Trace element analyses were conducted with the assistance of Dr. Glen Shen at the University of Washington's School of Oceanography. Individual subsamples - representing both individual years and three-year composites - were subjected to a series of cleaning procedures prior to digestion and analysis of the sample. In order to measure the low concentrations of metals present in the aragonitic coral lattice, a coprecipitation step was employed to concentrate all the metals into a precipitated bead, which was digested in concentrated acid and analyzed. The complete cleaning and wet-chemistry method is detailed in Shen and Boyle (1988).

Metals were analyzed on a graphite-furnace atomic-absorption spectrometer. Consistency standards were carried through the sample preparation procedure in order to assess the efficiency of the cobalt coprecipitation of these metals.

For all metals except zinc, metal concentrations in the corals were expressed as a ratio of metal concentration to calcium concentration. Calcium concentrations were measured using flame atomic absorption. The absorption/concentration plots for the standard zinc solutions were non-linear. Blanks were subtracted from zinc absorbance data, but these data were not converted to concentrations and are reported in units of absorbance. Zinc was excluded from the discussion sections but the results are presented with the rest of the lattice-bound metals data in appendix C. Cadmium concentrations were adjusted to compensate for the incomplete coprecipitation. Manganese recoveries were very near 100 percent in the concentration range of the samples, hence no correction was applied. Coprecipitation efficiency of other metals was unmeasured and was assumed to be 100 percent. Two coral samples on which Shen has performed multiple analyses (GTS) were similarly carried through the sample preparation and analysis procedures as a test of sampling and analytical accuracy. Extrapolation of the absorbance values measured for $\mathrm{Cr}$ and $\mathrm{Ni}$ using the assumption of a 100 percent coprecipitation efficiency resulted in negative values for the GTS samples. The negative values for $\mathrm{Cr}$ and Ni measured for the GTS sample are therefore listed as non-detects. No negative values were calculated for any of the coral samples from stations MO-1 or MO-3, so no corrections were applied to $\mathrm{Cr}$ or Ni. The analyses run for the GTS samples and for other replicate samples are used to estimate variability and precision (table 5).

Means and standard deviations were calculated for the normalized lattice-bound trace metals. The ratios of the abundance of the metals to the abundance of calcium in the corals were compared to that observed in average seawater. The composition used for average seawater is presented in table 6 (Nozaki, 1997). Comparisons were made with average seawater because many of the trace metals are present in the receiving waters at concentrations below the minimum reporting limit for the methods used in this study. The specific analytical methods are presented later in this report, in the water-quality section.

To elucidate processes affecting the incorporation of the trace metals into corals, a principal component analysis of the trace-metal data was carried out.

\section{Sediments}

Waters in the Bahía de Añasco are almost always cloudy; sometimes from sediments and debris discharged from the rivers, and other times from fines being resuspended from the bottom by storm swells. The majority of the suspended sediments are claysized particles and organic material. The fine particles settle slowly, interacting with the surrounding water for longer periods of time than the silts and sands that quickly settle to the bottom. 
Table 4. Variability in stable-isotope ratios measured in different parts of the same annual band, and that measured in fine and coarse fractions of coral core samples of annual growth bands deposited by colonies of Montastrea annularis growing at station $\mathrm{MO}-1$ (cores $\mathrm{C} 1$ and $\mathrm{C} 2$ ) and station $\mathrm{MO}-3$ (cores $\mathrm{C} 7$ and $\mathrm{C} 9$ )

[The sample ID C7-2A_C indicates that the sample came from core 7 - second (2) sample (1989) - one of two intra-annual samples (A/B) and that it was a coarse fraction (C). Except for the five coarse samples indicated here, all isotopic analyses of corals were run on the fine fraction. Abbreviations: $\delta^{13} \mathrm{C}$, del carbon-13; $\delta^{18} \mathrm{O}$, del oxygen-18; \%o, parts per mil; PDB, Peedee belemnite; RPD, relative percent difference]

\begin{tabular}{|c|c|c|c|}
\hline \multirow{2}{*}{ Sample ID } & \multirow{2}{*}{ Year } & $\delta^{13} \mathrm{C}$ & \multirow{2}{*}{$\frac{\delta^{18} 0}{\% \text { relative to PDB }}$} \\
\hline & & $\%$ relative to $\mathrm{PDB}$ & \\
\hline \multicolumn{4}{|l|}{ Interannual variability } \\
\hline C1-7A & 1984 & -4.47 & -5.99 \\
\hline C1-7B & 1984 & -3.63 & -4.13 \\
\hline Average & & -4.05 & -5.06 \\
\hline RPD & & 20.74 & 36.76 \\
\hline C7-2A & 1989 & -2.17 & -4.99 \\
\hline C7-2B & 1989 & -1.52 & -4.69 \\
\hline Average & & -1.84 & -4.84 \\
\hline RPD & & 35.23 & 6.20 \\
\hline C7-2A_C & 1989 & -0.76 & -4.61 \\
\hline C7-2B_C & 1989 & -0.86 & -3.53 \\
\hline Average & & -0.81 & -4.07 \\
\hline RPD & & 12.35 & 26.54 \\
\hline C9-7A & 1984 & -1.81 & -6.98 \\
\hline C9-7B & 1984 & -0.02 & -3.01 \\
\hline Average & & -0.92 & -5.00 \\
\hline RPD & & 195.63 & 79.48 \\
\hline \multicolumn{4}{|l|}{ Coarse/Fine variability } \\
\hline C7-1 & 1990 & -0.79 & -4.01 \\
\hline C7-1_C & 1990 & -0.61 & -4.5 \\
\hline Average & & -0.70 & -4.26 \\
\hline RPD & & 25.71 & 11.52 \\
\hline C7-2A & 1989 & -2.17 & -4.99 \\
\hline C7-2A_C & 1989 & -0.76 & -4.61 \\
\hline Average & & -1.46 & -4.80 \\
\hline RPD & & 96.25 & 7.92 \\
\hline C7-2B & 1989 & -1.52 & -4.69 \\
\hline C7-2B_C & 1989 & -0.86 & -3.53 \\
\hline Average & & -1.19 & -4.11 \\
\hline RPD & & 55.46 & 28.22 \\
\hline C7-3 & 1988 & -1.06 & -4.43 \\
\hline C7-3_C & 1988 & -0.33 & -4.30 \\
\hline Average & & -0.70 & -4.36 \\
\hline RPD & & 105.04 & 2.98 \\
\hline C7-4 & 1987 & -1.62 & -5.52 \\
\hline C7-4_C & 1987 & -2.66 & -7.29 \\
\hline Average & & -2.14 & -6.40 \\
\hline RPD & & 48.60 & 27.63 \\
\hline
\end{tabular}


Table 5. Trace metals measured in a laboratory standard (GTS), sample replicates, and intra-annual replicates from samples of annual growth bands deposited by colonies of Montastrea annularis growing at station $\mathrm{MO}-1$ (cores $\mathrm{C} 1$ and $\mathrm{C} 2$ ) and station $\mathrm{MO}-3$ (cores $\mathrm{C} 7$ and $\mathrm{C} 9$ )

[Cadmium was the only metal corrected for recovery. An assumption of 100 percent coprecipitation efficiency for the other metals resulted in negative values being calculated for $\mathrm{Cr} / \mathrm{Ca}(-14.7$ and -34.4$)$ and for $\mathrm{Ni} / \mathrm{Ca}(-0.1$ and -0.8$)$ for the GTS laboratory standard. These values are reported as non-detects. Abbreviations: $\mathrm{Ca}$, calcium; $\mathrm{Cd}$, cadmium; $\mathrm{Cr}$, chromium; Fe, iron; $\mathrm{Mn}$, manganese; $\mathrm{Ni}$, nickel; $\mathrm{Pb}$, lead; $\mathrm{nmol} / \mathrm{mol}$, nanomole per mole; $\mu \mathrm{mol} / \mathrm{mol}$, micromole per mole; ND, not detected; --, not calculated; RPD, relative percent difference]

\begin{tabular}{|c|c|c|c|c|c|c|c|c|}
\hline Core & Year & $\begin{array}{c}\mathrm{Cd} / \mathrm{Ca} \\
\mathrm{nmol} / \mathrm{mol}\end{array}$ & $\begin{array}{c}\mathrm{Cr} / \mathrm{Ca} \\
\mathrm{nmol} / \mathrm{mol}\end{array}$ & $\begin{array}{c}\mathrm{Cu} / \mathrm{Ca} \\
\mathrm{nmol} / \mathrm{mol}\end{array}$ & $\begin{array}{c}\mathrm{Fe} / \mathrm{Ca} \\
\mathrm{nmol} / \mathrm{mol}\end{array}$ & $\begin{array}{c}\mathrm{Mn} / \mathrm{Ca} \\
\mathrm{nmol} / \mathrm{mol}\end{array}$ & $\begin{array}{c}\mathrm{Ni} / \mathrm{Ca} \\
\mu \mathrm{mol} / \mathrm{mol}\end{array}$ & $\begin{array}{c}\mathrm{Pb} / \mathrm{Ca} \\
\mathrm{nmol} / \mathrm{mol}\end{array}$ \\
\hline \multicolumn{9}{|c|}{ Laboratory replicates } \\
\hline GTS & -- & 49.8 & ND & 324.6 & 2493.5 & 222.1 & ND & 12.9 \\
\hline GTS & -- & 50.8 & $\mathrm{ND}$ & 558.5 & 2260.4 & 185.1 & ND & 13.5 \\
\hline Average & & 50.3 & -- & 441.6 & 2376.9 & 203.6 & -- & 13.2 \\
\hline RPD & & 2.0 & -- & 53.0 & 9.8 & 18.2 & -- & 4.8 \\
\hline $\mathrm{C} 2$ & 1984 & 28.6 & 78.1 & 78.1 & 1937.3 & 424.1 & 0.6 & 21.5 \\
\hline $\mathrm{C} 2$ & 1984 & 15.7 & 80.4 & 521.7 & 476.8 & 1273.9 & 1.4 & 40.6 \\
\hline Average & & 22.2 & 79.3 & 299.9 & 1207.1 & 849.0 & 1.0 & 31.0 \\
\hline RPD & & 58.4 & 2.8 & 147.9 & 121.0 & 100.1 & 75.1 & 61.5 \\
\hline $\mathrm{C} 2$ & 1950 & 24.0 & 65.2 & 372.1 & 169.9 & 639.1 & 7.5 & 19.4 \\
\hline $\mathrm{C} 2$ & 1950 & 6.2 & 48.6 & 197.9 & 223.8 & 547.0 & 0.4 & 12.4 \\
\hline Average & & 15.1 & 56.9 & 285.0 & 196.8 & 593.0 & 4.0 & 15.9 \\
\hline RPD & & 117.9 & 29.1 & 61.1 & 27.4 & 15.5 & 179.6 & 44.0 \\
\hline C9 & 1989 & 32.2 & 11.6 & 87.4 & 2186.6 & 475.9 & 0.7 & 9.8 \\
\hline C9 & 1989 & 18.4 & 165.4 & 699.7 & 896.0 & 378.4 & 1.3 & 26.1 \\
\hline Average & & 25.3 & 88.5 & 393.6 & 1541.3 & 427.1 & 1.0 & 18.0 \\
\hline RPD & & 54.4 & 173.8 & 155.6 & 83.7 & 22.8 & 56.4 & 91.0 \\
\hline \multicolumn{9}{|c|}{ Intra-annual replicates } \\
\hline $\mathrm{C} 7$ & 1989 & 17.6 & 88.7 & 365.8 & 100.2 & 417.9 & 1.1 & 16.1 \\
\hline $\mathrm{C} 7$ & 1989 & 15.1 & 76.5 & 169.8 & 125.4 & 364.4 & 0.4 & 7.3 \\
\hline Average & & 16.4 & 82.6 & 267.8 & 112.8 & 391.1 & 0.7 & 11.7 \\
\hline RPD & & 15.5 & 14.8 & 73.2 & 22.3 & 13.7 & 106.3 & 74.7 \\
\hline C9 & 1984 & 16.2 & 58.2 & 210.3 & 119.3 & 288.4 & 0.8 & 19.2 \\
\hline $\mathrm{C} 9$ & 1984 & 9.2 & 69.6 & 186.8 & 252.7 & 295.0 & 0.8 & 59.5 \\
\hline Average & & 12.7 & 63.9 & 198.5 & 186.0 & 291.7 & 0.8 & 39.4 \\
\hline RPD & & 55.6 & 17.9 & 11.9 & 71.7 & 2.3 & 3.0 & 102.3 \\
\hline $\mathrm{C} 2$ & 1989 & 2.9 & 55.7 & 208.6 & 188.0 & 671.1 & 0.5 & 11.4 \\
\hline $\mathrm{C} 2$ & 1989 & 2.6 & 45.0 & 268.9 & 293.3 & 522.4 & 0.5 & 67.4 \\
\hline Average & & 2.7 & 50.3 & 238.7 & 240.6 & 596.7 & 0.5 & 39.4 \\
\hline RPD & & 10.2 & 21.3 & 25.3 & 43.7 & 24.9 & 17.2 & 142.1 \\
\hline $\mathrm{C} 1$ & 1984 & 8.7 & 50.0 & 309.4 & 452.4 & 608.4 & 0.5 & 9.7 \\
\hline $\mathrm{C} 1$ & 1984 & 0.0 & 217.9 & 325.4 & 1402.1 & 904.9 & 1.0 & 10.6 \\
\hline Average & & 4.4 & 133.9 & 317.4 & 927.3 & 756.6 & 0.7 & 10.1 \\
\hline RPD & & 200.0 & 125.4 & 5.0 & 102.4 & 39.2 & 70.4 & 9.0 \\
\hline
\end{tabular}


Table 6. Average abundances of selected elements in seawater

[Concentrations are in nanograms per kilogram (ng/kg)]

\begin{tabular}{cc}
\hline Trace metal & Concentration $^{1}$ \\
\hline $\mathrm{Ca}$ & $412 \times 10^{6}$ \\
$\mathrm{Cd}$ & 70 \\
$\mathrm{Cr}$ & 212 \\
$\mathrm{Cu}$ & 150 \\
$\mathrm{Fe}$ & 30 \\
$\mathrm{Mn}$ & 20 \\
$\mathrm{Ni}$ & 480 \\
$\mathrm{~Pb}$ & 2.7 \\
\hline
\end{tabular}

${ }^{1}$ Values from Nozaki (1997).

Clay-sized particles and organic material offer good substrates for the adsorption of metals, pesticides, and other hydrophobic molecules (Horowitz, 1985). By looking at the distribution of certain sediment characteristics throughout the surface sediments of the bay, and at the characteristics of the different sediment layers in the cores, the relative importance of the various sediment sources, and the general circulation patterns that distribute the sediments on the insular shelf, can be discerned.

Sediment cores were used to characterize changes in the sediments and contaminants introduced into the Bahía de Añasco over the past decades. The surface sediments around an outfall may contain contaminants discharged by an outfall on an irregular basis. Sediment cores were recovered from the deltas of the Río Grande de Añasco and the Río Yagüez, from a station near the outfall, and from a station in a large sand channel in the Manchas Interiores. The average sedimentation rate since 1964 was estimated by examining downcore variations in the cesium-137 concentrations.

\section{Bottom-Sediment Sampling}

During December 15-16, 1990, collection of bottom sediments was attempted at 33 stations
(GS1-GS33) using a Shipek grab sampler. The Shipek failed to return a sample from hard-bottom areas after three attempts at two of these stations (GS9 and GS17). Five additional surface samples (GS34 to GS38) were collected by hand during SCUBA-diving operations conducted during other parts of the study. Selected splits were analyzed for detailed grain size (31 sites), percent calcium carbonate ( 35 sites +3 field replicates), mineralogy (13 sites), trace metal and total organic carbon (13 sites) (fig. 8).

\section{Bottom-Sediment Cores and Sedimentation Rates}

Four sediment cores were recovered. A 66-cm core was collected on December 15, 1990, from near the outfall (VCO), whereas a 258 -cm core from the Río Grande de Añasco delta (VCA); a 220-cm core from the Río Yagüez delta (VCY); and a 110-cm core from a large sand channel in the Manchas Interiores (VCC) were collected January 26-27, 1991 (fig. 9). A 3 -in.-diameter aluminum tube was inserted vertically into the sediments by divers in the soft sediments at stations VCO, VCA, and VCY. A hydraulically operated jack hammer was used to facilitate coring of the coarse carbonate sands at station VCC. Once maximum penetration of the core barrel was attained (the full length of the tube or rejection), the jackhammer was removed. A diver then cut off the upper end of the tube with a tube cutter, inserted a rubber stopper, and secured a vinyl cap with a hose clamp to provide a hermetic seal. The core was then lifted using a block and tackle arrangement between inflated air bags on the surface and a lifting collar clamped onto the core. The bottom end was capped by a diver once the core was lifted clear of the sediment. On board the survey vessel, each core was sectioned into smaller cylinders using a tube cutter. The samples in each cylinder were then extruded onto a clean plastic trough, maintaining the stratigraphic order. The cylindrical samples were then split open using a plastic spatula or teflon blade. The cores were then photographed and described, and subsamples were collected for analysis of texture, mineralogy, total organic carbon, trace metals, and cesium-137. 


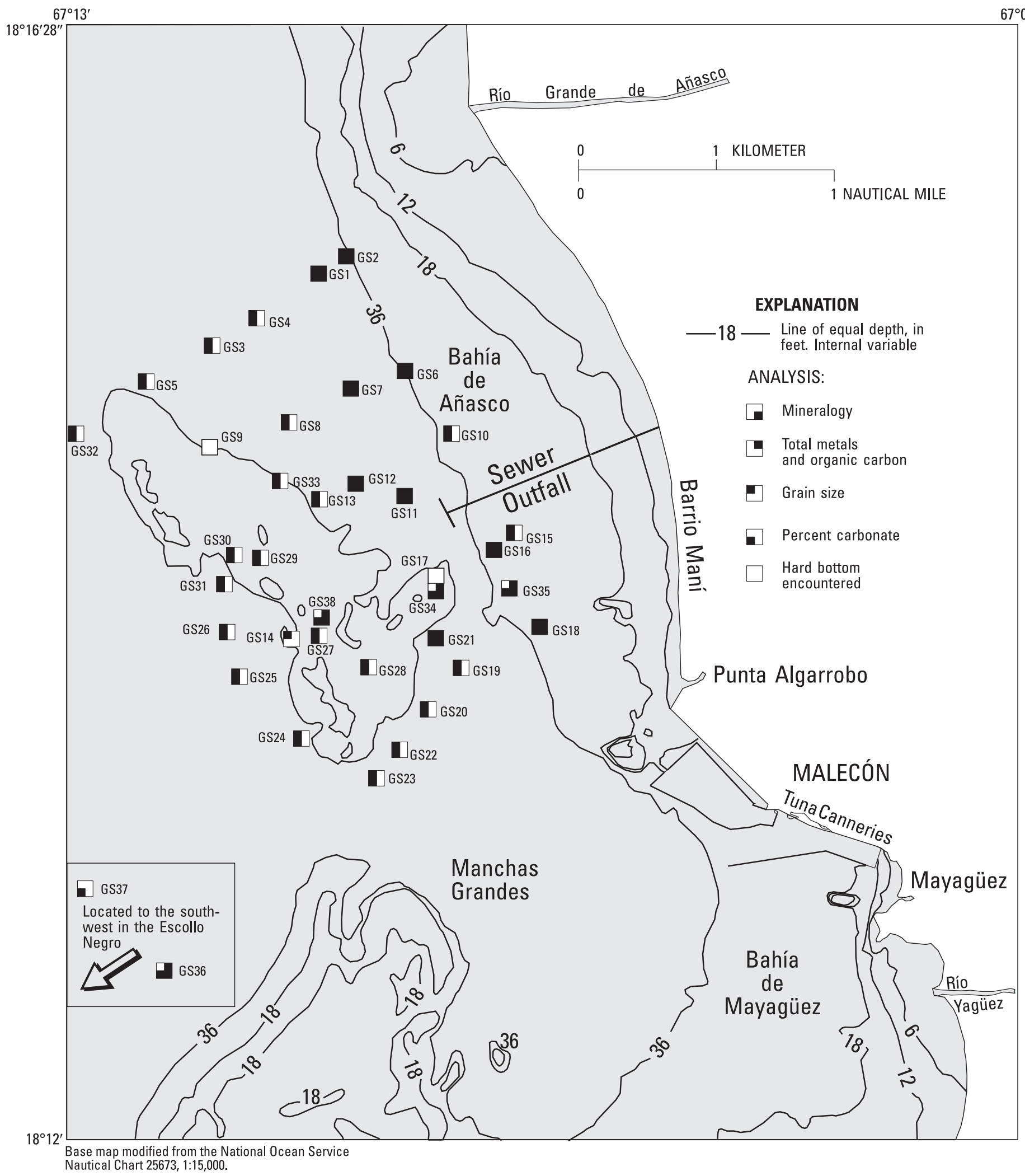

Figure 8. Locations of 38 bottom-sediment stations with descriptions of laboratory analyses performed on samples collected from the Bahía de Añasco and the Bahía de Mayagüez, Puerto Rico. Sediments were sampled at two additional sites, GS-36 and GS-37, in the Escollo Negro reef complex, approximately 10 kilometers to th e southwest of the study area (fig. 2). 


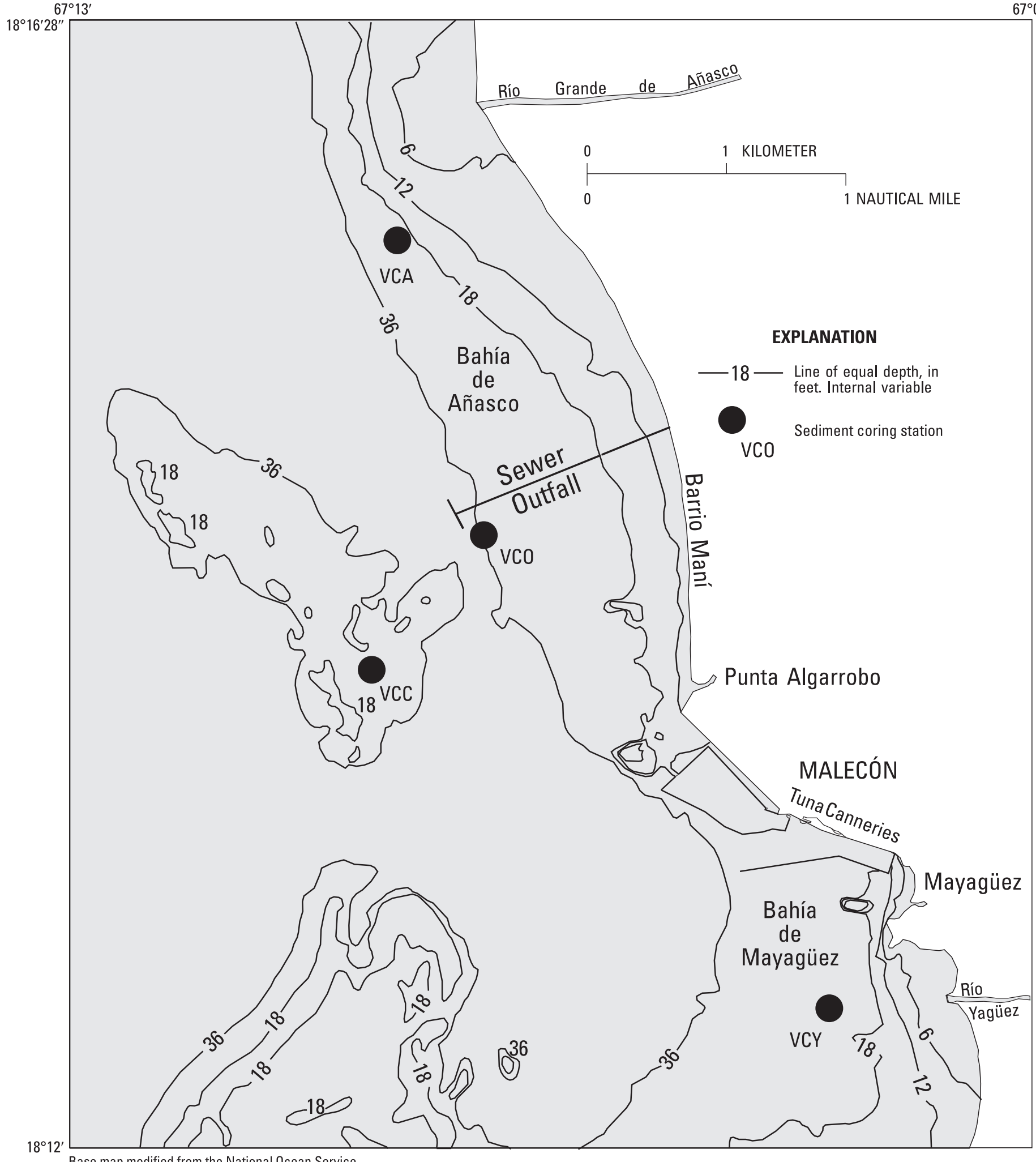

Base map modified from the National Ocean Service Nautical Chart 25673, 1:15,000.

Figure 9. Locations of sediment coring stations: VCA, at the Río Grande de Añasco delta; VCO, 160 meters southeast of the outfall; VCC, in a sand channel in the Manchas Interiores; and VCY, at the Río Yagüez delta, Puerto Rico. 
Texture

The sediment texture or grain-size distribution, of sediment samples GS1 through GS33, was analyzed by Larry Poppe at the USGS Sediment Laboratory, in Woods Hole, Massachusetts. Moist samples from the field were wet-sieved through a $62.5-\mu \mathrm{m}$ sieve, to separate the sand and gravel from silts and clays. Floating material, organic flock, and whole shells were removed from the sand and gravel fraction before processing with a stack of sieves, as described by Folk (1980). The silt and clay fraction was analyzed using a Coulter counter, as described by Poppe and others (1985). The salinity of the interstitial waters of the bottom sediments, needed to adjust the results of the Coulter counter analysis, was assumed to be 25 parts per thousand (ppt). For core samples analyzed for cesium-137, grain size was determined for three size classes, percent sand and gravel, silt, and clay.

\section{Carbonate}

Percent carbonate was determined by titration (Carver, 1971) for 40 samples, 35 from bottom samples, and five from core samples (top and bottom of core VCO, and three samples from core VCC). Samples were ground and dried at $110^{\circ} \mathrm{C}$ for 24 hours, and placed in a desiccator to cool. Approximately 1-gram (g) samples were carefully weighed to the nearest $\mathrm{mg}$, then dissolved in $50 \mathrm{ml}$ of a standardized hydrochloric $(\mathrm{HCl})$ acid solution $(0.5 \mathrm{~N})$ and heated at $90{ }^{\circ} \mathrm{C}$ for 20 minutes. If the measured $\mathrm{pH}$ of the solution was greater than 2, another $50 \mathrm{ml}$ of $\mathrm{HCl}$ was added and the process was repeated. When the $\mathrm{pH}$ remained less than 2 after heating, distilled water was added and the solution was back-titrated with a previously standardized $\mathrm{NaOH}$ solution $(0.25 \mathrm{~N})$ to pH 7, stirring constantly. The results were calculated as follows (assuming that all the carbonate occurs as calcium carbonate):

$$
\begin{aligned}
& \text { percent } \mathrm{CaCO}_{3}=100 \times 0.05 \times\left[\left(\mathrm{ml}_{\mathrm{HCl}} \times \mathrm{N}_{\mathrm{HCl}}\right)-\right. \\
& \left.\left(\mathrm{ml}_{\mathrm{NaOH}} \times \mathrm{N}_{\mathrm{NaOH}}\right)\right] / \mathrm{wt}_{\text {initial. }}
\end{aligned}
$$

\section{Clay Mineralogy}

The clay mineralogy of the sediments deposited in the Bahía de Añasco and the Bahía de Mayagüez was determined to better understand the elemental compositions observed in the sediments. A sample with high concentrations of calcium carbonate could consist of calcite, indicating an inorganic precipitate or deposits of calcareous algae, or it could consist of aragonite, a carbonate pseudomorph that is precipitated predominantly by corals. Similarly, a sample containing high concentrations of iron could contain minerals such as goethite, indicating deposition in an oxygen-rich environment, or the sample could contain pyrite, an iron sulphide indicative of reducing conditions. Goethite and glauconite are present in various abundances in the Cabo Rojo carbonate platform (Seiglie, 1971b). Clay minerals are major constituents of the sediments deposited in the Bahía de Añasco and the Bahía de Mayaguiez. Clay minerals generally refer to phyllosilicates, such as illite and kaolinite that naturally break down into small-diameter $(2 \mu \mathrm{m}$ or less) particles. However, samples often contain largersized clay minerals, such as mica and chlorite, in addition to many "non-clay" minerals, such as quartz, feldspar, amphiboles, and carbonates.

Twenty-three samples, nine from core samples, 13 from bottom-grab samples, and one of suspended sediments filtered from the Río Grande de Añasco, were processed by John Neil at the USGS Laboratory in Sacramento, California. The fine fraction (less than $62-\mu \mathrm{m}$ diameter) was used almost exclusively, as it contains more of the terrigenous grains that were of primary interest to this study.

The samples were prepared for X-ray diffraction analysis by washing through U.S. Standard No. 230 stainless-steel sieve screen. The silt/clay fractions were dried at $95^{\circ} \mathrm{C}$ and were packed into a frontloading, $30 \mathrm{~mm} \times 30 \mathrm{~mm}$ plexiglass sample holder. The actual sample volume was $26 \mathrm{~mm} \times 26 \mathrm{~mm} \times 1$ $\mathrm{mm}$. A glass slide was used to press the sample into the holder and smooth the sample surface.

Three samples from core VCC, collected from the sand channel in the Manchas Interiores, had a significant amount of coarse and fine carbonates that 
obscured the peaks presented by the terrigenous fraction. The sample from this core received additional treatments, including digestion by sodium acetate/ acetic acid buffer ( $\mathrm{pH}$ of 5) and digestion by weak and strong hydrochloric acid, to better discern changes in the terrestrial sediments deposited there, and to identify diagenetic processes.

All X-ray diffraction data were collected on a Scintag Pad V Automated Diffraction System that was equipped with scintillation detector and a graphite monochromator. The radius of the goniometer was set at $220 \mathrm{~mm}$, and the sample holder was in the horizontal configuration. The divergent slits were $2 \mathrm{~mm}$ and $4 \mathrm{~mm}$, and the receiving slits were $0.3 \mathrm{~mm}$ and $0.4 \mathrm{~mm}$. $\mathrm{Cu} \mathrm{K} \mathrm{K}_{\alpha}$ radiation $(\lambda=1.54091)$ was produced by a $\mathrm{Cu} \mathrm{X}$-ray tube running with an accelerating voltage of $45 \mathrm{kV}$ and a current of $40 \mathrm{~mA}$. The scan rate was $0.5^{\circ} / \mathrm{min}$, and the step size was $0.02^{\circ}$. Calibration of the instrument was checked by measuring the principal peak (101) of quartz at $26.652^{\circ}(2 \theta)$. If the position of the principal peak was in error by more than $0.002^{\circ}(2 \theta)$, the goniometer position counter was reset. The product of a sample run was a diffractograph for that sample. The diffractographs were processed using signalprocessing software, to provide a list of significant peaks and intensities. Minerals were then identified by comparing the processed data with peak/intensity patterns cataloged for known minerals.

\section{Trace Elements}

Fifty-three samples were analyzed for 16 trace elements (Fe, Mn, Al, Ti, Cu, Zn, Cd, Pb, Ni, Co, Cr, $\mathrm{As}, \mathrm{Ag}, \mathrm{Sb}, \mathrm{Se}$, and $\mathrm{Hg}$ ), total organic matter, and total organic carbon. These included nine samples from core VCO, 13 from core VCA, 11 from core VCY, 6 from core VCC, 13 from selected grab samples, and 1 from a sample backflushed from a filter paper containing suspended sediments from the Río Grande de Añasco. Samples were stored in new ziplock bags and transported to the laboratory of Dr. Art Horowitz, in Doraville, Georgia. Each sample was homogenized by stirring with acid-rinsed glass rod and then sieved through a $2,000-\mu \mathrm{m}$ plastic screen. The samples were freeze-dried, then ground to less than 100 mesh in a ball mill for subsequent bulk chemical analysis.
Chemical analyses were performed by Dr. Horowitz following the procedures of Horowitz and Elrick (1985), and Elrick and Horowitz (1985, 1987). For all chemical elements other than $\mathrm{As}, \mathrm{Sb}, \mathrm{Se}$, and $\mathrm{Hg}$, 500-mg samples were digested with a combination of hydrofluoric, perchloric, and nitric acids in Teflon beakers, at $200{ }^{\circ} \mathrm{C}$ taken to dryness, and the resulting salts solubilized with $50 \mathrm{~mL}$ of 2 percent hydrochloric acid. Determinations were done by flame atomicabsorption spectrophotometry (AAS) using mixed-salt standards. As, Sb, and Se determinations used the same digestion procedure, but final solutions were made up in 50 percent $\mathrm{HCl}$. The Se was determined directly in the digestate; As and Sb were determined after additional reduction with Potassium Iodide (KI), and heating. Quantitation of all three was performed by hydride generation AAS. Hg was determined by using a 500-mg aliquot digested with LeFort aqua regia at $100{ }^{\circ} \mathrm{C}$, followed by a cold-vapor AAS quantitation technique. Precision (usually better than \pm 10 percent) and bias were monitored by replicate analyses of selected samples and the concomitant digestion and analysis of NBS sediment, and USGS rock standards, and are similar to those reported previously (Elrick and Horowitz, 1985, 1987; Horowitz and Elrick, 1985). Total organic carbon (TOC) was determined, usually in duplicate, on sample aliquots pretreated with 10 percent $\mathrm{HCl}$, using a Leco Carbon Analyzer. Loss on ignition (LOI) was used as a measure of the total organic matter in the samples, and was determined by the ignition of preweighed samples and their subsequent reweighing after 1 hour at $550{ }^{\circ} \mathrm{C}$ in a muffle furnace (Fishman and Friedman, 1989). Other organic matter (OOM) was determined by subtracting TOC from LOI.

\section{Multivariate Analysis of Sediment Chemistry}

The results of the trace element and organic material analysis were subjected to extended Q-mode factor analysis (Miesch, 1976a, 1976b) to elucidate the provenance of sediments deposited in the study area. A cursory review of the sediment chemistry revealed that the sediments deposited in the Bahía de Mayagüez were elevated in concentrations of nickel, cobalt, and chromium, the origin of which is laterite deposits that weather and wash into the Río Yagüez and the Río 
Guanajibo, which transport their sediment loads to the Bahía de Mayagüez. Two outlier samples were eliminated from the dataset, the suspended-sediment sample from the Río Grande de Añasco, and the carbonate sands sampled from the Escollo Negro (GS36). Both of these samples were geochemically distinct and showed up as isolated extreme samples, accounting for a large amount of the variance on their own, but only containing weak correlations with the remainder of the data set. By eliminating them from the database, a more robust mixing model for sediments in the study area could be constructed. The simplified mixing model consists of three endmembers, one typical of sediments deposited in the Río Grande de Añasco delta, one typical of sediments deposited in the Río Yagüez delta, and a third typical of carbonate sediments formed and deposited in the Manchas Interiores-Manchas Exteriores coral reef complex. Loss on ignition was eliminated as a variable as it is the sum of the TOC and OOM. The total weight percent of elemental composition accounted for by the observed variables in the data set varied from approximately 30 percent, for samples consisting predominantly of terrigenous sediments, to less than 10 percent, for those samples consisting mostly of carbonate skeletal material. Major elements missing to obtain an adequate compositional accounting of the terrigenous samples include silica, magnesium, and oxygen, whereas calcium and oxygen would make up most of the missing mass for the carbonate-rich samples. Percent calcium carbonate was determined for a subset of the dataset, but its use as a variable was discarded because some of the core samples were not analyzed for this variable, and it could not be expected to be a variable independent of the OOM. To force a closed solution that would provide a mixing model of the three sediment endmembers, TOC, OOM, and the trace element data, were converted to weight percents and proportioned such that the sum of all observed variables accounted for 100 percent of each sample, as described in Miesch (1976a). The transformed data were entered into the EQMODE and EQCOMP routines of STATPAC (Miesch, 1976b) to determine endmember compositions and mixing proportions of the endmembers for all samples. The vectors describing the endmembers were obliquely rotated in data space such that each of the three endmembers is 100 percent of a given factor, and 0 percent of the other two.

\section{Water Quality}

The quantity and quality of water, sediments, nutrients, and contaminants discharged from the Río Grande de Añasco, the Río Yagüez, and the outfall, have the potential to affect the evolution and health of the coral reef communities of the Bahía de Añasco. The water quality from both rivers, the effluent, and the receiving waters, were sampled from January 28 to 31, 1991.

The sampling stations included the influent, effluent, the Río Añasco, the Río Yagüez, two stations in the initial mixing zone (IMZ), two stations at the boundary of the IMZ, two stations at the boundary of the final mixing zone (FMZ), and two stations beyond the location of the FMZ (farfield), where discharge effects might reasonably be expected, and at two control stations (figs. 2, 10, 11). The delineation of the mixing zone was defined by Environmental Science and Engineering, Inc. (1986). While on site, it was observed that the outfall diffuser has been modified so that only the last two ports on each end are discharging. This was probably done to increase the exit velocities and improve mixing. Discharge, temperature, $\mathrm{pH}$, and alkalinity, were measured at the rivers and the waste-treatment plant. Marine sampling stations also included vertical profiles of temperature, dissolved oxygen, light transmission, specific conductance, and chlorophyll 'a' concentration. Laboratories set up on board and onshore measured nonconservative properties, bacteria levels, BOD, settleable solids, oil and grease.

The influent and effluent were sampled on the grounds of the MRWTP with flow-regulated, refrigerated automatic samplers. The initial stock of effluent used for the bioassays was collected along with the samples sent for pollutant analysis. 


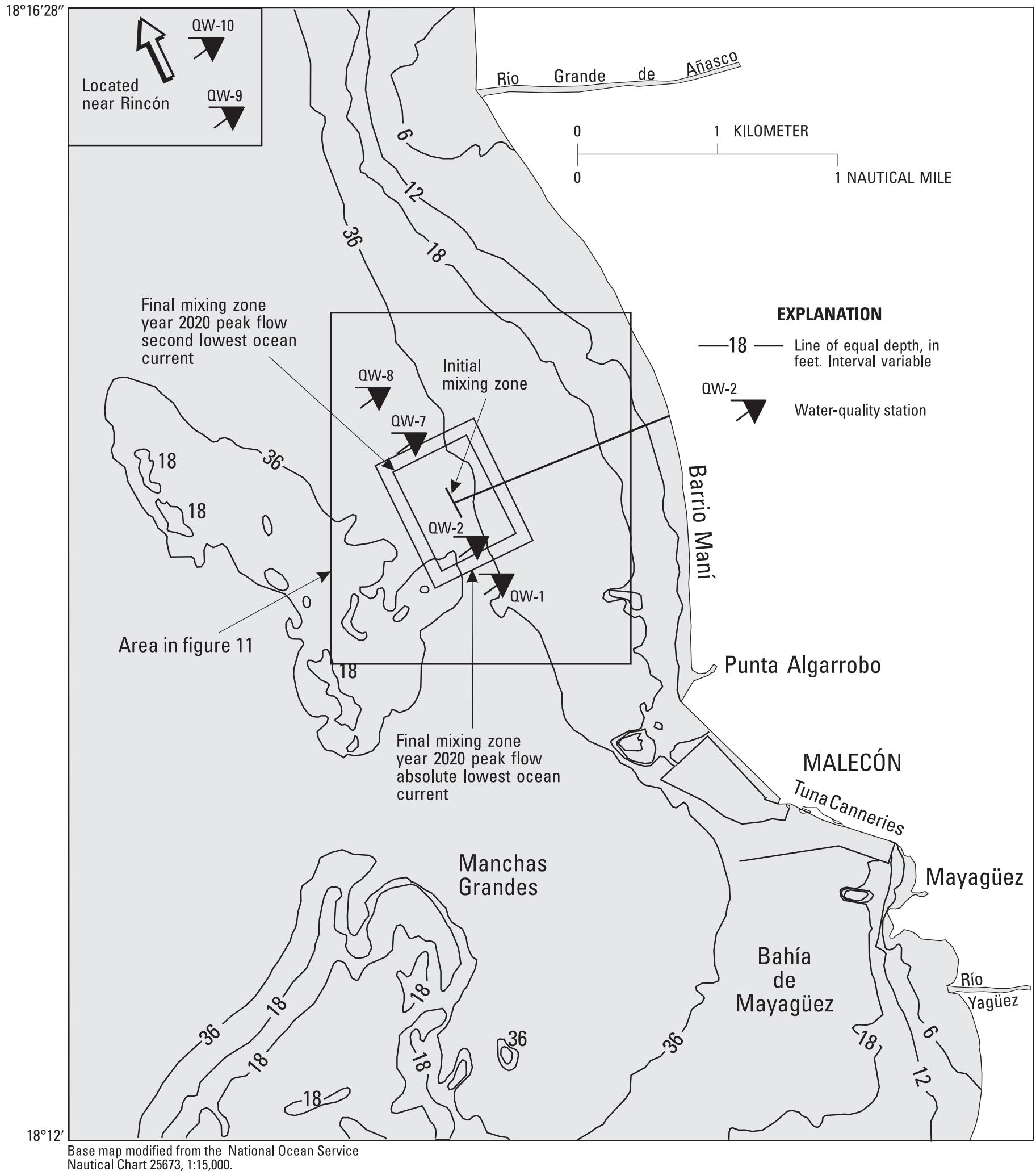

Figure 10. Water-quality stations at the boundary of the final mixing zone, $0 \mathrm{~W}-2$ and $\mathrm{QW}-7$, and in the far field, $0 \mathrm{~W}-1$ and $\mathrm{QW}-8$, Bahía de Añasco, Puerto Rico. Water-quality control stations, $0 \mathrm{~W}-9$ and $\mathrm{OW}-10$, are located approximately 10 kilometers to the northwest, near the town of Rincón (fig. 2). Water-quality stations in the initial mixing zone, QW-3, $\mathrm{QW}-4,0 \mathrm{~W}-5$, and $\mathrm{QW}-6$ are located in the immediate vicinity of the outfall diffusers (fig. 11).

34 Assessment of the Habitats, Biota, Sediments, and Water Quality Near the Discharge of Primary-Treated Effluent from the Mayagüez Regional Wastewater Treatment Plant, Bahía de Añasco, Puerto Rico 


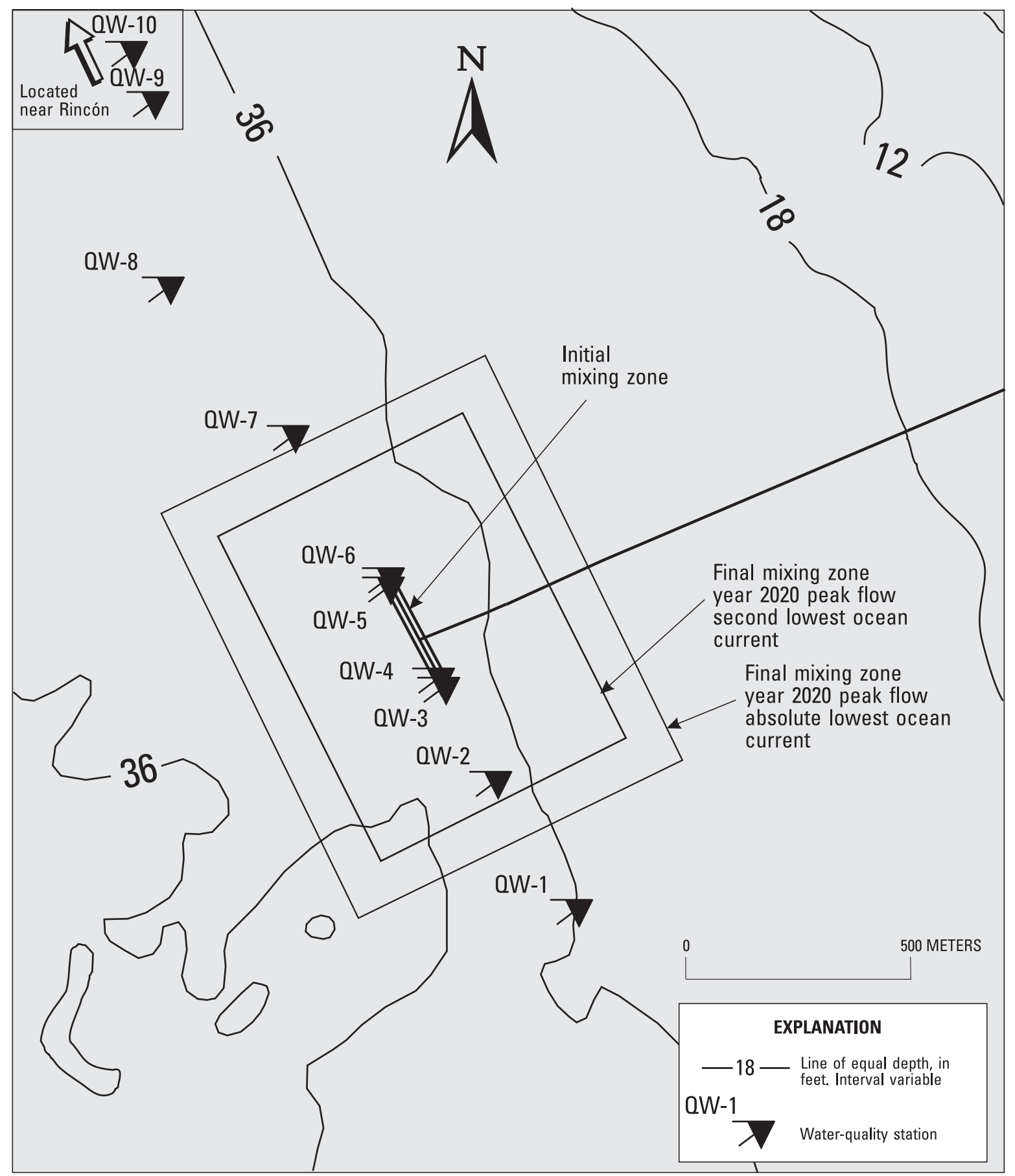

Base map modified from the National Ocean Service

Nautical Chart 25673, 1:15,000.

Figure 11. Enlargement of figure 10, detailing the initial and final mixing zones and locations of water-quality sampling stations, QW-1 to QW-8, Bahía de Añasco, Puerto Rico. Water-quality control stations, QW-9 and QW-10, are located approximately 10 kilometers to the northwest near the town of Rincón (fig. 2). 
Water-quality sampling techniques followed standard USGS and EPA procedures. At the offshore stations, the RV Jean A was navigated to the sampling station and a buoy was set. The research vessel was then anchored several hundred meters downcurrent of the buoy so as to avoid contamination from the antifouling paint. The sampling crew then boarded a rubber raft and motored to the buoy. After anchoring, a peristaltic pump was used to retrieve a composite sample through a 50-ft teflon hose from 10, 50 and 90 percent of the water depth. Composites were collected in a stainless steel and a plastic bucket. Even though a sealed weight was attached to the end of the hose, currents could move the sampling hose off vertical. In $35 \mathrm{ft}$ of water the operator might release $40 \mathrm{ft}$ of teflon hose before it hit bottom. The hose was purged before recovering a sample from a new depth. VOC samples were collected and stored on ice immediately after the sample had been composited. The chlorophyll ' $a$ ' samples were collected from mid-depth. Oil and grease samples were taken from the surface and immediately stored on ice. Depth profiles of temperature, $\mathrm{pH}$, conductivity, and light extinction, were also determined.

Phytoplankton blooms are common where nutrients mix with ocean waters. Chlorophyll 'a' has long been used as a phytoplankton biomass indicator, and was measured at all water-quality stations. Water samples were collected and analyzed by Fernando Gilbes, a graduate student studying phytoplankton fluctuations in the Bahía de Añasco. Three replicate $1.5 \mathrm{~mL}$ samples were placed in test tubes and $8.5 \mathrm{~mL}$ of 100 percent acetone was added to each (Phinney and Yentsch, 1985). Samples were placed in the dark for 24 hours at a temperature of 2 to $5{ }^{\circ} \mathrm{C}$. After this time, the fluorescence was measured using a Turner Model 111 Fluorometer. Measurements of fluorescence before and after acidification were recorded. The fluorescence values were converted to values of chlorophyll ' $a$ ' in milligrams per cubic meter, using a regression equation that was calibrated using chlorophyll 'a' from Anacystis nidulans algae. Measurements of light were taken in place at 2, 4, 6, 8, and $10 \mathrm{~m}$ depth, using a photometer. These measurements were used to calculate the extinction coefficient $(\mathrm{k})$ in the water column.
Biological assays were conducted on three test species, Mysidopsis bahia (mysid shrimp), Cyprinodon variegatus (sheepshead minnow), and Champia parvula (red macro algae), in accordance with the EPA methodology specified for conducting marine acute and chronic tests (Webber and others, 1988). The bioassays were run with static renewal of effluent collected between January 29 and February 8, 1991.

\section{SUMMARY OF RESULTS}

The following is a synopsis of the results obtained as part of the sampling of the biota, water quality, and bottom sediments, in the vicinity of the ocean outfall of the Mayagüez Regional Wastewater Treatment Plant. During the initial site reconnaissance and sampling expedition, carried out from December 7-17, 1990, a sidescan-sonar mosaic of the floor of the Bahía de Añasco was created, bottom sediments were sampled for characterization of infauna, texture, and chemistry, a sediment core was recovered from a station near the outfall, and fish and sessile benthos were censused. During the second expedition, from January 25-30, 1991, sediment cores were recovered from three more stations, and water quality was sampled in the vicinity of the outfall and at the control stations near Rincón.

All field data and analytical results are given in the appendices of the report as follows:

Appendix A. Macrobenthic infauna identified at stations B1 through B8, December 15, 1990, in the Bahía de Añasco and the Bahía de Mayagüez, Puerto Rico.

Appendix B. Biological census data for fish and sessile benthos at stations MSG-1, MSG-2, MO-5, and MO-4, December 13-17, 1990, in the Bahía de Añasco and the Escollo Negro reef complex, Puerto Rico.

Appendix C. Elemental and isotopic composition of annual coral bands of Montastrea annularis, sampled from cores $\mathrm{C} 1$ and $\mathrm{C} 2$, recovered at station $\mathrm{MO}-1$ near the outfall, December 14, 1990, and cores C7 and C9, sampled at station MO-3 in the Escollo Negro, Puerto Rico, December 17, 1990. 
Appendix D. Texture, elemental composition, percent carbonate, cesium-137 activity, and clay mineralogy for bottom sediments and core samples collected from December 15, 1990, through January 27, 1991, in the Bahía de Añasco and the Escollo Negro, Puerto Rico.

Appendix E. General water quality with depth and general water quality, bacteria, volatile organic compounds, semivolatile organic compounds, pesticides, PCB's, herbicides, total metals and trace elements, general inorganics, and radiochemistry by sample at 10 waterquality sampling site in the Bahía de Añasco and near Rincón, Puerto Rico, at two sites sampled in the Río Grande de Añasco and the Río Yagüez, and at the influent and effluent of the Mayagüez Regional Watewater Treatment Plant, January 25-30, 1991.

Because of the limited scope of sampling during this study, associated data sets compiled during past and ongoing studies by the USGS in cooperation with agencies of the Commonwealth of Puerto Rico were accessed and evaluated to identify historical trends in changing water quality in the estuary system.

\section{Associated Data Sets}

Water-quality data for samples collected at stations in the upland drainage basins for the years 1970 through 1997 were retrieved from the National Water-Data Storage and Retrieval System (WATSTORE). Direct access to the WATSTORE data base may be obtained by signing a Memorandum of Agreement with the USGS, available through the USGS National Water Data Exchange office in Reston, Virginia. In addition, data can be provided in various machine-readable formats, such as magnetic tape, floppy disk, or compact disk. Yearly WaterResources Data Reports for Puerto Rico and the U.S. Virgin Islands are published by the USGS and distributed to libraries and to Federal and Commonwealth agencies. The most recent report presents the data for water year 1998 (Díaz and others, 1999).
The WATSTORE database is populated with data collected by USGS personnel in support of a wide range of missions. Data from five stations within the basins draining into the Bahía de Añasco and the Bahía de Mayagüez (fig. 1) have been collected as part of the USGS-Commonwealth of Puerto Rico waterquality monitoring network or the National Stream Quality Accounting Network (NASQAN), both of which were established to provide data to describe areal variability and detection of changes or trends in water-quality characteristics over broad geographical areas.

\section{Habitats and Sedimentation Patterns Observed in Sidescan-Sonar Mosaic and Seismic Reflection Profiles}

The progradation of the Río Grande de Añasco delta into the bay precluded mapping as far inshore as originally planned; the $10-\mathrm{m}$ contour shown on the nautical chart, based on data collected at the turn of the century, has shifted approximately $300 \mathrm{~m}$ to the west. Approximately $3,000,000 \mathrm{~m}^{3}$ of silt and clay deposited on the delta during the period 1903-95 (Grove, 1998). In the sidescan-sonar mosaic, the outfall trench can be clearly identified, along with the muddy floor of the bay, and a hard bottom area with the potential for reef development (fig. 6). The calibration with actual bottom samples enabled the classification of the seafloor into hard bottom, mud, and sand (Schwab and others, 1991). Near the south leg of the diffuser pipe, a halo of coarse sediments is located east of a small area of hard bottom. No noticeable deposition of fines from the outfall is observed in this area. Fines deposited from the outfall could be expected to appear as a darker shade in the bright returns in the halo of coarse sediments deposited around the top of a now nearly extinct patch reef. The same cannot be determined for the area to the north of the outfall, because the image does not allow for the distinction between outfall sediment and fine-grained river sediment deposited there.

Macrobenthic infauna in the immediate area of the outfall was sampled at station B4. The January 1985 survey of infauna found 106 taxa there in comparison with only 22 taxa found in 
December 1990. The sediments for station B4 in 1985 were described as rubble, suggesting that the area sampled was probably from the coarse-sediment area near the south leg of the diffuser, approximately $200 \mathrm{~m}$ to the southeast from its indicated position near the north leg of the diffuser. The coarse-sediment area should be a heterogeneous habitat, with associated increased diversity, in comparison with the homogeneous fine sediments in the area sampled as station B4 in December 1990.

Seismic reflection profiles revealed that the rocky outcrops to the northwest and southeast of the diffuser are the tops of reef structures buried by sediment. This interpretation was supported by the high-relief indurated structures revealed in highfrequency seismic reflection data and by the inability to penetrate the sediments to a depth greater than about $1 \mathrm{~m}$ during coring near the outfall. Observations by SCUBA-divers at one of the outcrops verified that the substrate matrix consisted of the skeletal remains of hermatypic corals. The seismic profiles collected are stored at the data library in Woods Hole, Massachusetts. A copy is available for examination at the USGS office in Guaynabo, Puerto Rico.

\section{Biota}

Temporal changes in the community structure of macrobenthic infauna, sessile benthos, and fishes, were observed between the surveys of biota carried out in 1985 and 1995. The observed changes appear to be well within the range of expected natural variability and responses to shifting environmental gradients.

\section{Macrobenthic Infauna}

A variety of biological and physical factors can contribute to changes in the community structure of infauna. This section discusses the temporal and spatial changes in the community structure observed from 1985 to 1990 in the Bahía de Añasco and the Bahía de Mayagüez. The following conclusions were reached:

- There is a strong seasonal variability in the infaunal community.
- Diversity and percentage of opportunistic organisms decrease with distance from shore.

- The two station-pairs with the greatest dissimilarity of taxa were B2-B5 and B4-B7. The first pair present a depth/grain size gradient, whereas the second pair presents what could be a bottom-energy gradient favoring conveyor-belt feeders.

Basic community statistics are reported to describe the infaunal community, how species richness and diversity changed from 1985 to 1990 , and to document any evidence of changes in the community structure in response to the discharge from the outfall. Marked natural seasonal and spatial variations of the soft-bottom communities were observed in previous studies of infaunal communities in the area, and during the current study. Patchy distributions and intense seasonal variations are common for infaunal communities in the tropics (Calderón-Aguilera, 1992; Plate and Husemann, 1991). The 200 taxa, with an average of 2,235 organisms $/ \mathrm{m}^{2}$, found in January $1985^{1}$, increased to 295 taxa, with an average of 6,883 organisms $/ \mathrm{m}^{2}$, found in the May 1985 survey (Metcalf \& Eddy, 1987a). The December 1990 survey, yielded 56 taxa with an average of $472 \mathrm{organisms} / \mathrm{m}^{2}$. A VanVeen sampler was used in $1985\left(0.1 \mathrm{~m}^{2} /\right.$ replicate $)$, whereas a Shipeck grab sampler $\left(0.04 \mathrm{~m}^{2} /\right.$ replicate $)$ was used in 1990. The overall number of taxa is not directly comparable because of the different sampling areas, but the density of individuals can be compared, as the number of individuals at each station in the 1990 survey was multiplied by 2.5 to correct for the difference in surface area sampled. As discussed in the following sections, the effect of dissimilar sample sizes on the calculation of community statistics and the interpretation of temporal and spatial variability appears to be minor. The data collected in 1990 are sufficient in quantity and quality to derive meaningful conclusions on the structure of the sampled communities, and the differences between previous sampling expeditions.

\footnotetext{
${ }^{1}$ Re-examination of the unedited data from January 1985 found only 156 taxa with an average of $1,303 \mathrm{organisms} / \mathrm{m}^{2}$. These are the values used for subsequent plots and t-test comparisons.
} 
The number of taxa increased at all stations from January to May 1985, except for station B4, where the number of taxa increased but diversity decreased. The anomaly at station B4 was likely the result of sampling a different substrate, as discussed in the previous section. The presence of a heterogenous substrate at the station sampled as B4 in January 1985 is further supported by the observation that just two replicates at the station $\left(0.2 \mathrm{~m}^{2}\right.$ total area) contained 85 different species, more than the total number of taxa contained at the eight stations (40 replicates) sampled in December 1990.

The significant seasonal change between the January and May sampling was recognized as typical of coastal tropical communities. The species-area curves for January 1985 and December 1990 (fig. 12) show two things: (1) the number of taxa at each station was significantly less in December 1990 than it was in January 1985, and (2) the sampling effort in December 1990 , while covering only 40 percent of the area sampled at each station in January 1985, appears to have been sufficient to identify the majority of the species at each station, as revealed by the decreasing slope of the species-area curve.

Diversity $\left(\mathrm{H}^{\prime}\right)$ is a measure of the uncertainty in being able to correctly predict the species of an individual selected at random from the population. The measure is less subject to the effect of sample size and provides a better estimate of the heterogeneity of the infaunal community than simply the number of taxa. For example, the species-area curves for 1985 and 1990 (fig. 12) for station B2 are more similar than the corresponding curves for station B6. However, using the t-test $(\alpha-0.05)$ explained earlier in the methods section, it was found that the diversity was significantly different for four out of seven stations (station B7 was not surveyed in January 1985) surveyed in January 1985 and December 1990 (table 7). The diversities measured at stations B2 and B5 in 1985 were significantly different than those measure at the same stations in 1990 (fig. 13). At station B2 in 1985, the most common species, Scoloplos texana, accounted for only 25 percent of the individuals, and 10 species each accounted for more than 2 percent of the individuals. In December 1990, Sipuncula accounted for 59 percent of the individuals, and only five species accounted for more than 2 percent of the individuals. On the contrary, even though the number of taxa identified at station B6 in 1985 was much greater than the number identified at the station in 1990, the overall distribution of species and abundances were similar, resulting in insignificant differences in the calculated diversity values. In general, although the four stations that showed significant changes in the diversity were located near the outfall, the changes were not accompanied by increases in taxa identified as opportunistic and pollution-tolerant species.

Table 7. Differences in the diversity of macrobenthic infauna measured at stations B1 to B6 and B8, January 1985 and December 1990

[A two-tailed t-test (Hutcheson, 1970) at $\alpha-0.05$ was used to determine whether to reject the null hypothesis that the diversity measured at the same site in 1985 and 1990 was the same.]

\begin{tabular}{cccccc}
\hline Site & $\begin{array}{c}\text { Theoretical } \\
\text { variance } \\
S_{H_{1}^{\prime}-H_{2}}\end{array}$ & $t$ statistic & $\begin{array}{c}\text { Degrees of } \\
\text { freedom } \\
\mathrm{v}\end{array}$ & $t_{0.05, \mathrm{v}}$ & $\begin{array}{c}\text { Diversity } \\
\text { different? }\end{array}$ \\
\hline B1 & 0.18 & -0.96 & 198 & 1.97 & No \\
B2 & 0.20 & -4.17 & 183 & 1.97 & Yes \\
B3 & 0.18 & -3.46 & 196 & 1.97 & Yes \\
B4 & 0.18 & -7.85 & 197 & 1.97 & Yes \\
B5 & 0.14 & -4.86 & 192 & 1.97 & Yes \\
B6 & 0.17 & -1.53 & 175 & 1.97 & No \\
B8 & 0.17 & 0.72 & 185 & 1.97 & No \\
\hline
\end{tabular}



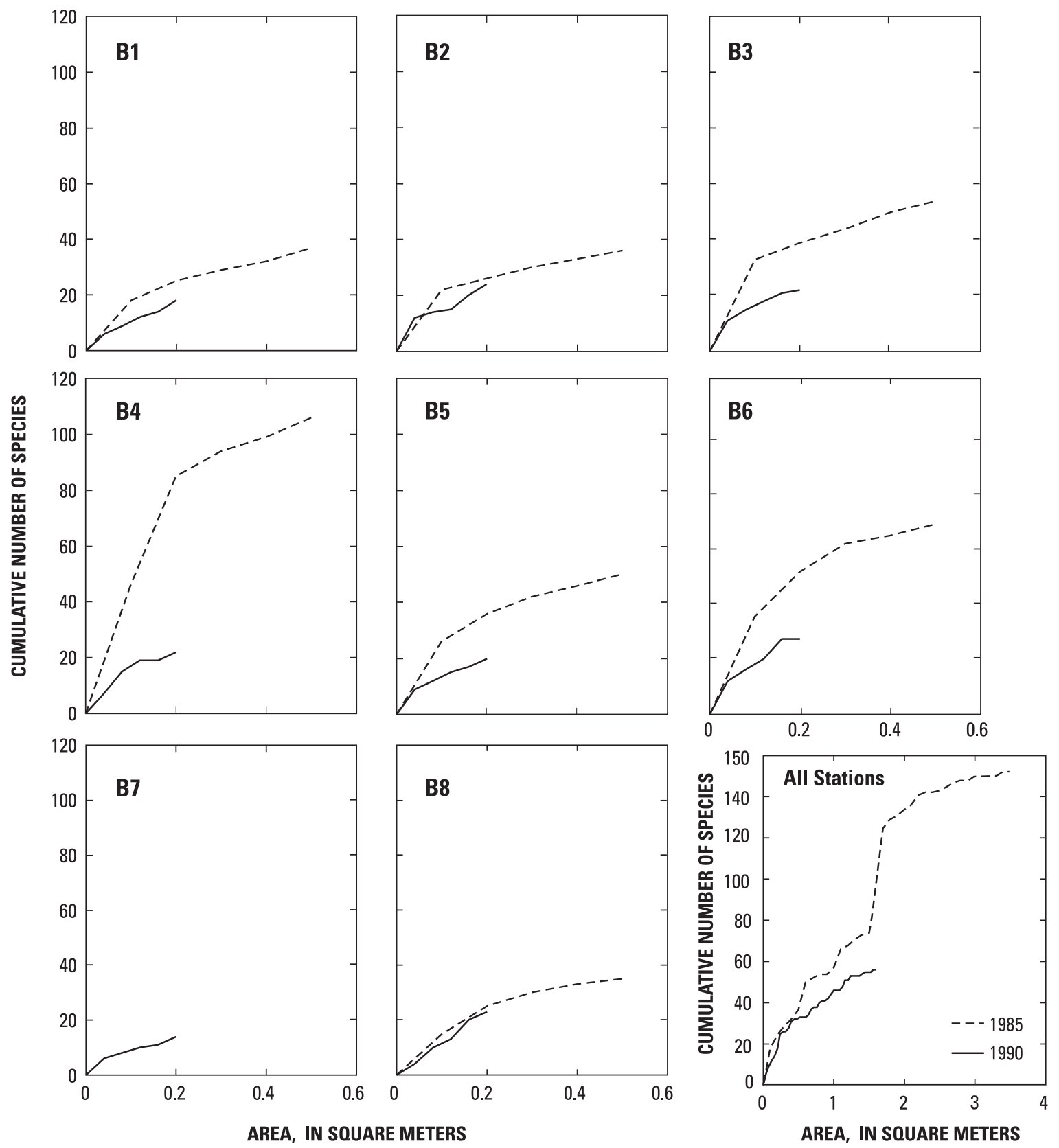

Figure 12. Species-area curves for macrobenthic infauna measured in January 1985 and December 1990 at stations B1 to B8, Bahía de Añasco and the Bahía de Mayagüez, Puerto Rico (station B7 was not sampled in 1985). In general, sampling was sufficient to collect most species present at each station for each sampling expedition, as indicated by the flattening-out of the species-area curves. For each station, five replicates were collected. The Van Veen used in 1985, sampled $0.1 \mathrm{~m}^{2}$ for each replicate. The Shipeck used in 1990, sampled $0.04 \mathrm{~m}^{2}$ for each replicate. In 1985, station B4 was identified as containing rubble, a substrate not present in the area of site B4 as identified in the sidescan-sonar imagery collected in 1990 as part of this study. 

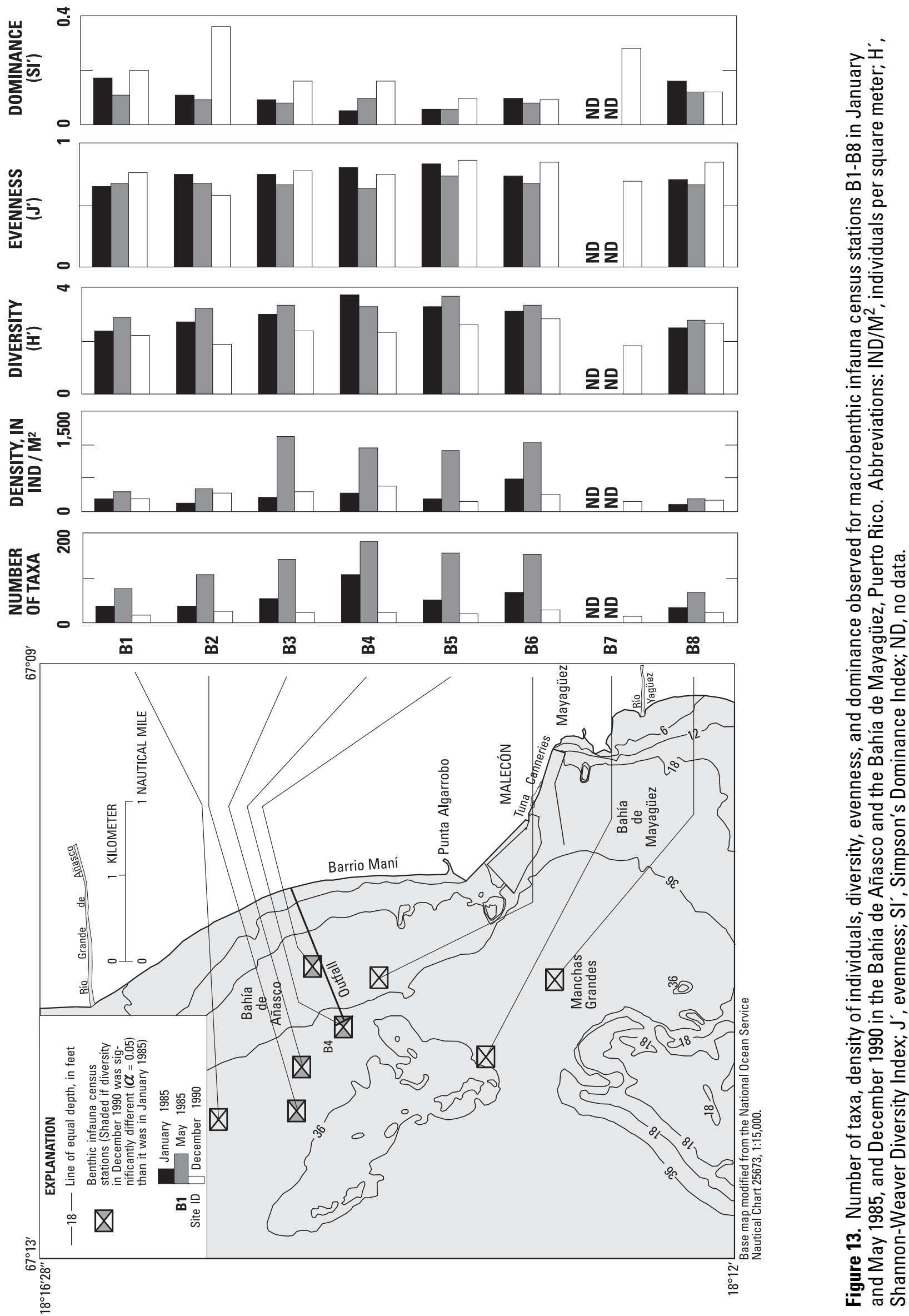
Opportunistic and pollution-tolerant taxa identified by Pearson and Rosenberg (1978) did not appear enriched at any station. Six taxa were represented, all of them annelids: Neanthes sp. A, three species of Prionospio, Mediomastus sp. A, and Capitellidae sp. A (table 8). The percentage of opportunistic species was markedly less than in the January 1985 survey, when the percentages ranged from 5.3 percent at station B3 to 22.8 percent at station B5.

To further understand the heterogeneity of the community structure in the Bahía de Añasco and the Bahía de Mayaguiez, the differences in diversity was examined as well as the similarity of fauna common to pairs of stations. For the 28 combinations of paired stations, the two-tailed t-test was used to determine if observed differences in diversity were significant at the $\alpha-0.05$ level. The Bray-Curtis similarity values were calculated to determine the degree that the compositions were similar for pairs of stations. Of the 28 comparisons made, 17 showed significant differences in diversity and 12 showed similarity values less than 50 percent (fig. 14).

The predominant pattern in both the diversity and similarity values appears to be related to an onshore-offshore gradient. Ordination of stations and species along the B2-B5 axis reveals a gradient from deeper, muddier stations, with lower diversity (predominance of Sipuncula), to shallower, more sandy stations, with higher diversity (more Scoloplos, Amphiodia, and total opportunistic species) (fig. 15). The gradient in station diversity (which correlated also with percent opportunistic species) with distance offshore is not present if the same values are plotted with distance from the outfall (fig. 16).

A secondary gradient in the community structure may reflect a combination of the grain size and the amount of organic carbon in the sediment (fig. 17). Excluding stations $B 2$ and $B 5$ from selection for a secondary polar ordination axis, the most dissimilar of the remaining stations were B4 and B7. Similarity values shown in figure 14 were converted to Percent Dissimilarity by subtracting from 100 (this assumes an internal association of 100 percent for replicates). The two-dimensional ordination graphs plotted with the species abundances indicates an increase in the percentage of the bamboo worm Maldane from B7 (1.8 percent) to $\mathrm{B} 4$ (13.2 percent). Maldane is a conveyor belt feeder that often indicates low organic carbon content in the sediments (Gallagher and Keay, 1998).

Table 8. Percent of benthic infauna represented by various opportunistic taxa at stations B1 to B8, December 1990

\begin{tabular}{ccccccc}
\hline Site & $\begin{array}{c}\text { Neanthes } \\
\text { sp. } A\end{array}$ & $\begin{array}{c}\text { Prionospio } \\
\text { sp. } A\end{array}$ & $\begin{array}{c}\text { Prionospio } \\
\text { sp. } C\end{array}$ & $\begin{array}{c}\text { Prionospio } \\
\text { sp. } B\end{array}$ & $\begin{array}{c}\text { Mediomastus } \\
s p . A\end{array}$ & $\begin{array}{c}\text { Capitellidae } \\
s p . A\end{array}$ \\
\hline B1 & 5.0 & 2.5 & 0.0 & 0.0 & 0.0 & 0.0 \\
B2 & 5.4 & 0.9 & 1.8 & 0.0 & 0.9 & 0.0 \\
B3 & 2.5 & 0.0 & 1.6 & 2.5 & 0.0 & 0.0 \\
B4 & 1.3 & 3.9 & 2.0 & 0.0 & 0.0 & 0.0 \\
B5 & 1.6 & 0.0 & 9.5 & 1.6 & 0.0 & 1.6 \\
B6 & 1.9 & 3.8 & 0.0 & 3.8 & 1.0 & 0.0 \\
B8 & 2.9 & 4.4 & 2.9 & 1.5 & 1.5 & 0.0 \\
\hline
\end{tabular}




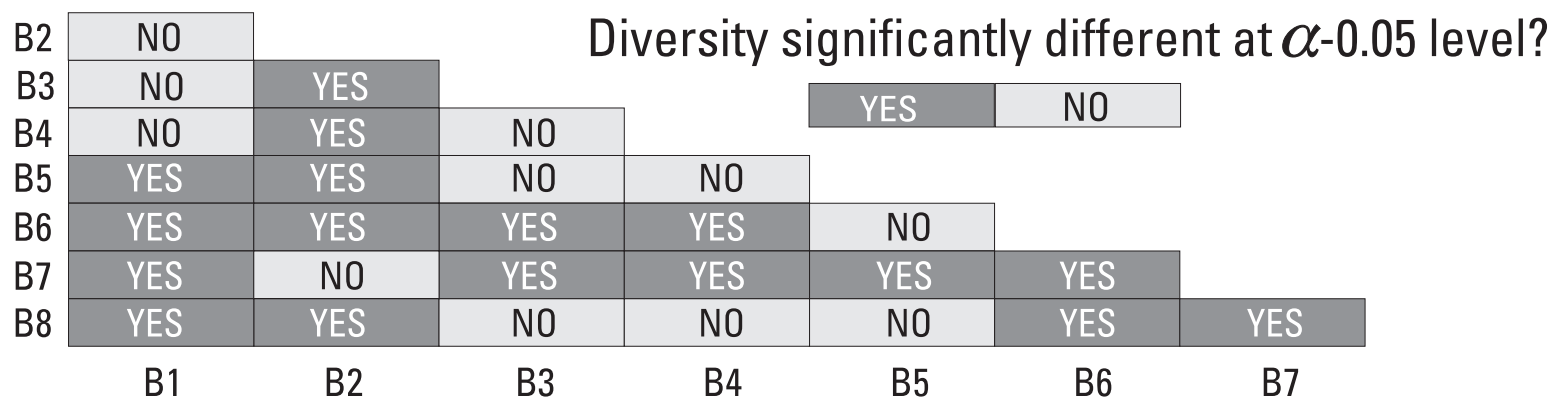

\begin{tabular}{|c|c|c|c|c|c|c|c|c|}
\hline B2 & 59.4 & \multicolumn{6}{|c|}{ Bray-Curtis similarity values } & \\
\hline B3 & 62.4 & 63.2 & & & & $\stackrel{D}{0}$ & 60 & \\
\hline B4 & 51.7 & 58.3 & 66.4 & & & $\stackrel{\bar{c}}{\overline{0}}$ & 50 & \\
\hline B5 & 47.6 & 34.3 & 43.2 & 40.9 & & 造 $=\frac{=}{5}$ & $\overline{5} 40$ & \\
\hline B6 & 48.9 & 40.7 & 55.8 & 57.8 & 46.7 & & 30 & \\
\hline B7 & 65.2 & 50.3 & 52.0 & 45.4 & 42.4 & 69.2 & & \\
\hline 8 & 55.4 & 46.7 & 53.7 & 48.2 & 47.3 & 58.1 & & 60.2 \\
\hline & B1 & B2 & B3 & B4 & B5 & B6 & & B7 \\
\hline
\end{tabular}

Figure 14. Matrices of interstation comparisons of diversity and similarity for macrobenthic infauna identified for stations B1-B8, December 1990, in the Bahía de Añasco and the Bahía de Mayagüez, Puerto Rico. The upper matrix indicates whether the diversity measured at the stations were significantly different, using a two-tailed t-test at the 0.05 alpha level. The lower matrix lists the Bray-Curtis similarity values that indicate the percentage similarity of taxa found at each station. The backgrounds behind the t-test results and similarity values are shaded darker for stations that are statistically different or less similar.

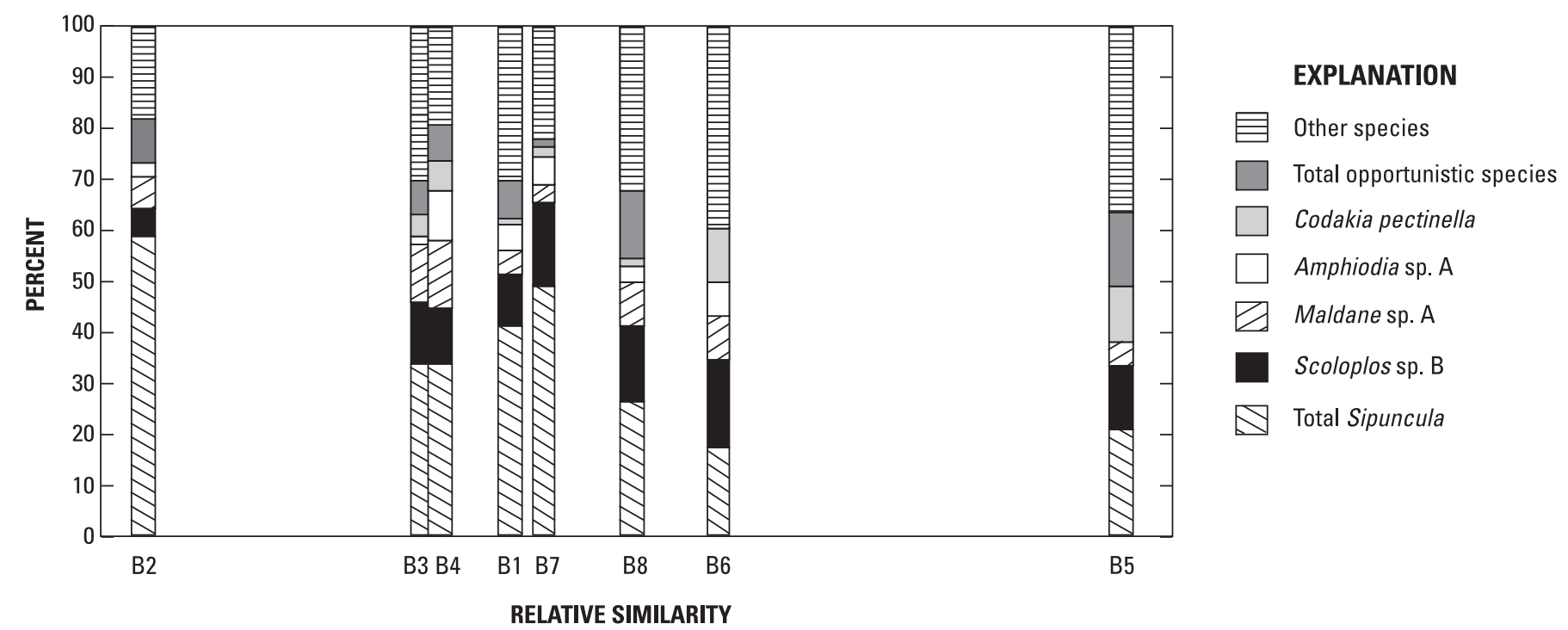

Figure 15. Ordination graph with percentages of the five most common macrobenthic infauna species, total opportunistic species, and other species identified in samples collected at stations B1-B8, December 1990, in the Bahía de Añasco and the Bahía de Mayagüez, Puerto Rico. The order and spacing of the stations along the horizontal axis were determined by using ordination techniques (Bray and Curtis, 1957) as explained in Gauch (1982). The horizontal axis is a measure of dissimilarity of species compositions between stations, so that stations that are closer together are more similar in composition. In general, the stations show gradients in community structure. 

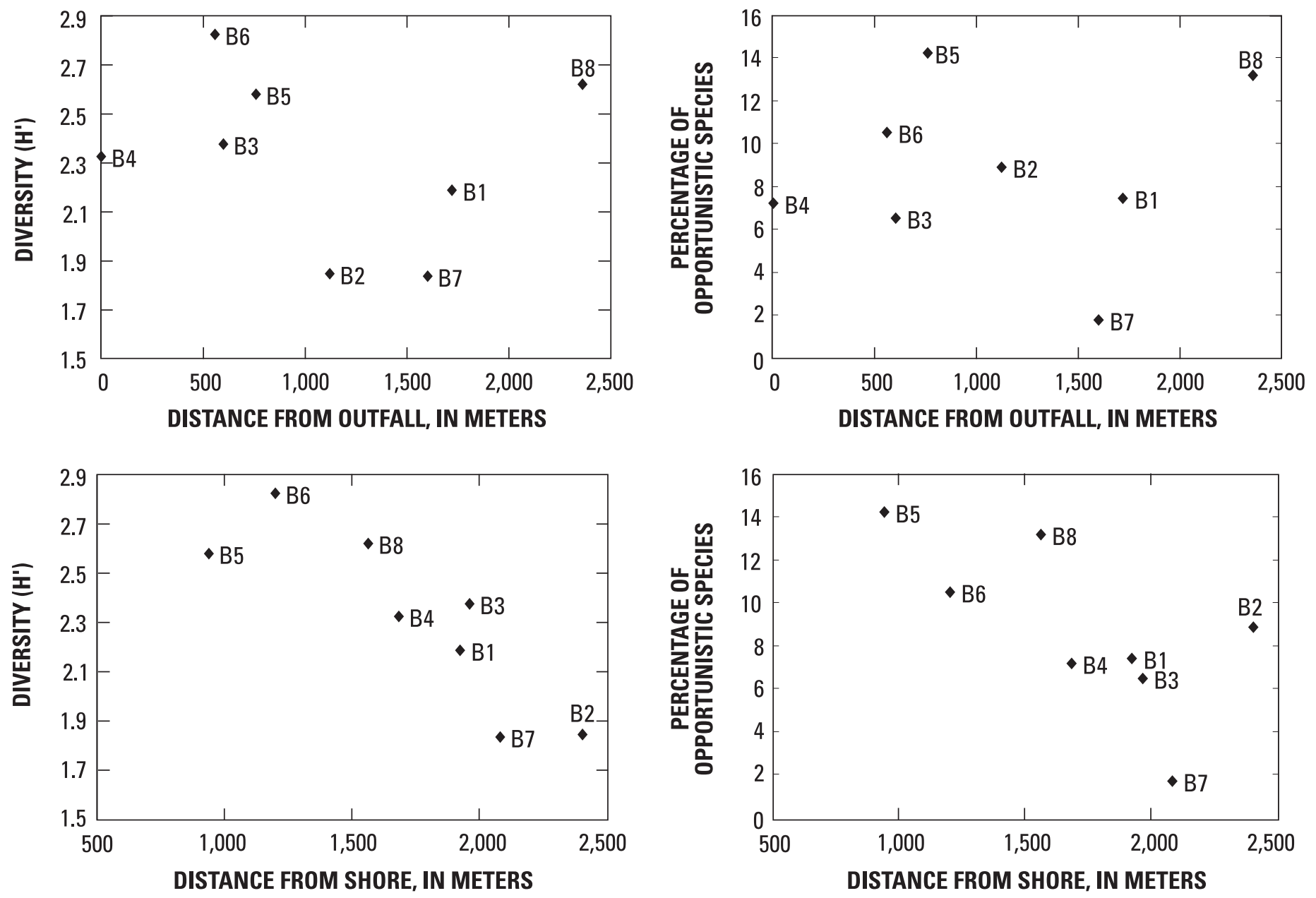

Figure 16. Diversity and percentage of opportunistic species versus distance from the outfall and distance from shore, stations B1 to B8, in the Bahía de Añasco and the Bahía de Mayagüez, Puerto Rico.

\section{Fish and Coral Surveys}

The populations of fishes and sessile benthos vary from station to station in response to local environmental conditions. The community structure of the sessile benthos and icthyofauna was observed from December 13-17, 1991, at three stations in the Bahía de Añasco, MSG-1, MSG-2, and MO-5, and at the control station in the Escollo Negro, MO-4 (figs. 2, 7). Detailed observations by transect for each station are presented in appendix B. Water depths at all stations were between 8 and $9 \mathrm{~m}$. However, substrate relief (table 9) and environmental conditions varied at each station. Station MSG-1, in the Manchas Exteriores, located approximately $3.3 \mathrm{~km}$ southwest of the Río Grande de Añasco river mouth, had low substrate relief, and was subject to significant wave energy arriving from the northwest. Station MSG-2, in the Manchas Interiores, located $1.2 \mathrm{~km}$ to the west of the ocean outfall, had high substrate relief, and was subject to moderate wave energy. Station MO-5, located 350 $\mathrm{m}$ southwest of the outfall, had high relief and low wave energy. Station MO-4, located in the Escollo Negro on the extensive Cabo Rojo carbonate platform, more than $8 \mathrm{~km}$ to the west of the Río Guanajibo river mouth, had intermediate relief and was subject to intense wave energy arriving from the deep waters of the North Atlantic through Mona Passage. 

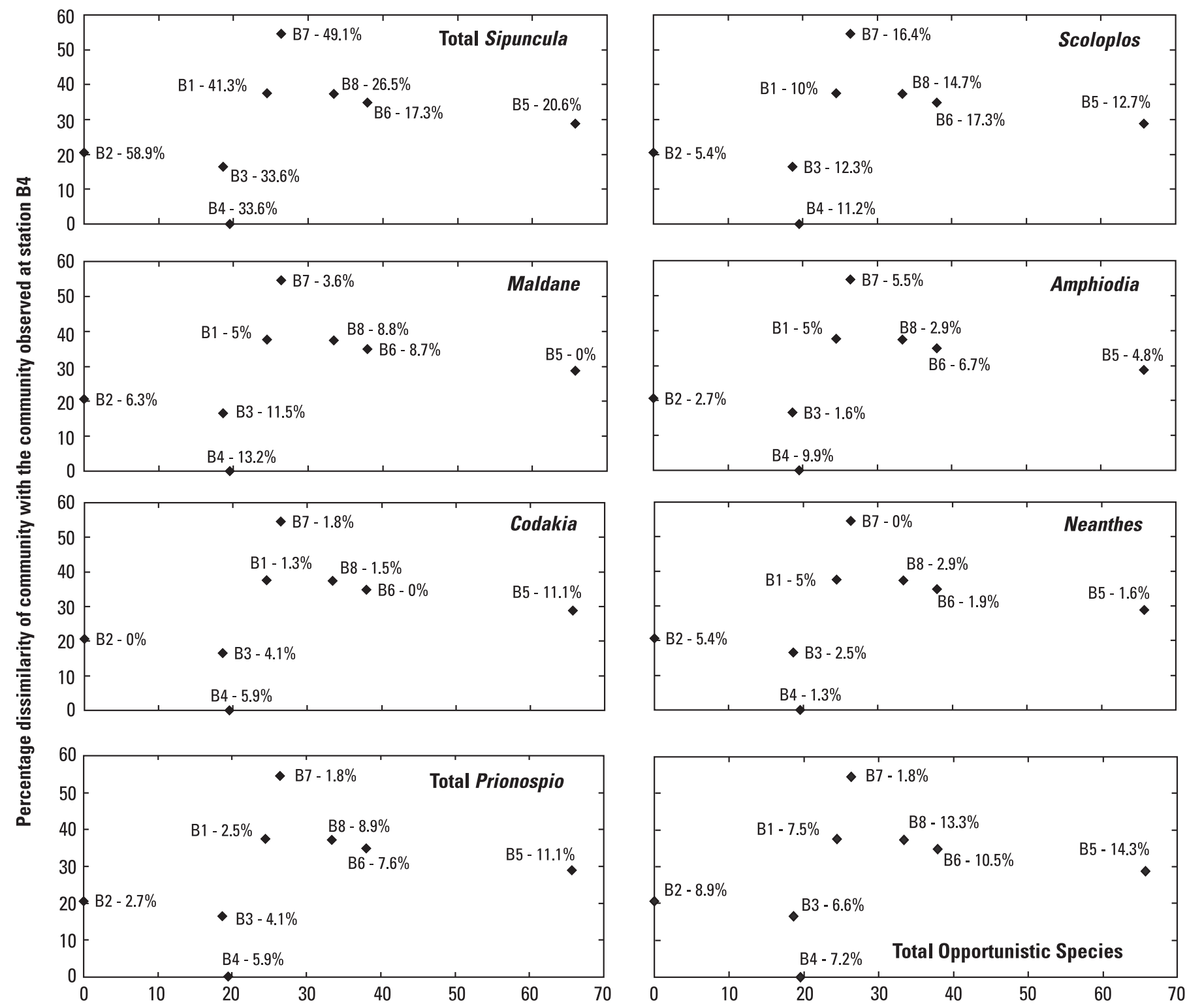

Percentage dissimilarity of community with the community observed at station B2

Figure 17. Two-dimensional ordination showing the abundance of major taxa and opportunistic species for macrobenthic infauna survey stations B1 to B8, sampled December 1990 in the Bahía de Añasco and the Bahía de Mayagüez, Puerto Rico. At each sample point, the stations and the percentage of a given taxa are given. The coordinates for the points were calculated by using polar ordination techniques (Bray and Curtis, 1957), by using the independent sample pairs with the greatest dissimilarity. Stations B2 and B5 are the poles for the abscissa and B4 and $\mathrm{B} 7$ are the poles for the ordinate. Stations that plot close together share more common taxa than stations that plot farther apart. 
Table 9. Substrate relief index measured at biological census stations

[The relief index is the length of chain in excess of 10 meters required to trace the substrate surface for a horizontal distance of 10 meters. Standard deviation in parentheses.]

\begin{tabular}{ccccc}
\hline & MSG-1 & MSG-2 & M0-5 & M0-4 \\
\hline Relief index & $1.3(0.2)$ & $2.3(0.3)$ & $2.8(0.6)$ & $1.2(0.6)$ \\
\hline
\end{tabular}

The circumstances under which data on fishes and sessile benthos at the Escollo Negro station were collected impede comparison with the other stations. In particular, rough seas and heavy surge prevented the observer from staying over the transect line while observing fishes or observing sessile benthos below the metric tape. The resulting high parallax did not permit precise location and measurement. Quantification of gorgonian taxa was less affected as their densities were readily noted regardless of the position of the observer. Temporal variations of fishes and sessile benthos at stations MSG-1 and MSG-2 were documented by comparing observations made in this study with those made in 1985 (Center for Energy and Environment Research, 1985).

Limited numbers of motile benthos were observed at the four stations. This precludes inferences being made about the effect of the sewage outfall on these organisms. Nevertheless, the observations of these organisms presented in appendix B, represent a record for future comparisons.

\section{MSG-1 (Manchas Exteriores: 18¹4'39.3" N. 67 12'32.5" W., depth 8-9 m)}

A total surface area of $150 \mathrm{~m}^{2}$ was surveyed (five transects) in the Manchas Exteriores. The depth at which the surveys were made ranged between 8 and $9 \mathrm{~m}$. Topographic relief ranged between 0.9 and $1.5 \mathrm{~m}$ (mean $\pm 1.3 \mathrm{~m}$ ).

\section{Fishes}

A total of 24 species were identified in the transects at this station. The number of species per transect ranged between 8 and 15 (mean: $12 \pm 3$ S.D.). Values of the Shannon-Weaver diversity index ranged between 1.66 and 2.50 (mean: 2.14). Mean fish abundance was $36.2 \mathrm{ind} /$ transect.

The taxonomic distribution and abundance of fishes present at MSG-1 are presented in appendix B. Two species represented 39 percent of the total fish abundance. They were the bluehead wrasse, Thalassoma bifasciatum (7.2 ind/transect), and the bicolor damselfish, Stegastes partitus $(6.8$ ind/Transect). The bluehead wrasse was found in only three of the five transects, its abundance variance to mean ratio was 8.2 , suggesting an aggregated or 'patchy' distribution pattern. This type of distribution is quite typical of the bluehead wrasse, and is related to the occurrence of relatively high numbers of females in guilds dominated by one male. Together with the yellowhead wrasse, Halichoeres garnoti, wrasses were the numerically dominant family of fishes found at this station. Wrasses are small carnivores that forage for benthic invertebrates in the reef. The bicolor damselfish was present in all five transects surveyed, and was distributed more evenly (variance to mean ratio $=0.7$ ) between and also within transects. This species is highly territorial and defends its microhabitat in the reef. The yellow damselfish, Stegastes planifrons, was present in four of the transects surveyed, showing some degree of niche overlap with the bicolor damselfish.

Damselfishes represented the numerically dominant family of herbivorous fishes. Parrotfishes and doctorfishes (Acanthuridae), together with damselfishes, comprise the assemblage of herbivores at MSG-1. Commercially important fish species identified in the transects included the coney (Cephalopholis fulva), red hind (Epinephelus guttatus), French grunt (Haemulon flavolineatum), and the spotted goatfish (Pseudupeneus maculatus). 


\section{Sessile Benthos}

Station MSG-1 was characterized by a relatively high abundance and diversity of soft corals. The most commonly observed gorgonian was Pseudopterogorgia americana. Coral cover and diversity are quite high, with Montastrea cavernosa as the dominant species. Many scleractinian colonies, however, exhibit partial death and/or boring by sponges. Also the abundance of the major Caribbean reef builder, Montastrea annularis, is low in comparison to station MSG-2. Poriferans are abundant. The bottom is of a generally low relief, and substrate that is uncovered with sessile fauna is profusely covered by red filamentous algae with fleshy brown algae in scattered patches.

\section{MSG-2 (Manchas Interiores: 18 $14^{\prime} 13.0^{\prime \prime} \mathrm{N}$., 67²' $3.3^{\prime \prime}$ W., depth 7-8 m)}

A total surface area of $150 \mathrm{~m}^{2}$ was surveyed (five transects) in the Manchas Interiores. The depth at which the surveys were made ranged between 8 and 9 $\mathrm{m}$. Topographic relief ranged between 1.9 and $2.7 \mathrm{~m}$ $($ mean $=2.3 \mathrm{~m})$.

\section{Fishes}

In total, 34 species were identified. The number of species per transect ranged between 16 and 19 (mean: $18 \pm 1$ S.D). Values of the Shannon-Weaver diversity index varied between 2.46 and 2.80 (mean: 2.64). The average abundance of fishes was 39.8 ind/transect.

Damselfishes dominated the numerical abundance of fishes at MSG-2, representing, with four species, 29 percent of the total individuals. The bicolor damselfish, Stegastes partitus, was the most abundant (4.8 ind/transect) followed by the yellow damselfish, Stegastes planifrons (3.8 ind/transect). The yellow damselfish was present in all five transects, while the bicolor Damselfish was present in four. Another damselfish species, the blue chromis, Chromis cyanea, was also common at this station (2.2 ind/transect). Unlike the more demersal and herbivorous Stegastes spp. aforementioned, the blue chromis occupies parcels of the water column just above the reef and feeds upon reef zooplankton.
Six parrotfish species (Sparisoma spp. and Scarus spp.) accounted for 24 percent of the total individuals at this station. Together with two other species of doctorfishes (Acanthurus spp.), herbivores represented more than half of the total fishes surveyed. Wrasses, which were the numerically dominant fish family at MSG-1, ranked third in abundance at MSG-2. The bluehead wrasse, Thalassoma bifasciatum, and the yellowhead wrasse, Halichoeres garnoti, had a combined abundance of 4.4 ind/transect. Groupers and hamlets, included in the Serranidae, presented five species and a cumulative abundance of $3.2 \mathrm{ind} /$ transect. These included three species of hamlets (Hypoplectrus spp.), the coney, Cephalopholis fulva, and the graysby, C. cruentatus. Serranids, together with the wrasses, grunts, snappers, lizardfishes, and barracudas, represented the carnivorous trophic component at the Manchas Interiores station.

García (1990) noted the occurrence of very high activity of pelagic fishes at this station. Top predators, such as the tarpon (Megalops atlantica) were reported feeding upon large schools of sardines (Clupeidae). It is uncertain if sardines, as planktivores, are directly associated with food resources in the reef.

\section{Sessile Benthos}

The benthic community is dominated visually by gorgonians, which are of a large mean size, highly abundant, and diverse. P. americana and species of Eunicea are the predominant gorgonians. Poriferans are an important component of the benthos with abundant Anthosigmella varians, an encrusting species. M. annularis is common in comparison with the limited abundance observed at the stations in the Manchas Interiores-Manchas Exteriores coral reef complex. Colony height of this species is also greater on the average. The abundance of the more sedimenttolerant M. cavernosa (Hubbard, 1972) is less than that of MSG-1. Corals, in general, appear to be healthier (for example, with less necrotic tissue and less bioeroded) than in other stations. Bottom vertical relief is medium, and the substrate consists of red crustose algae overlain by a thin film of fine sediment. Fleshy algae are rare. 


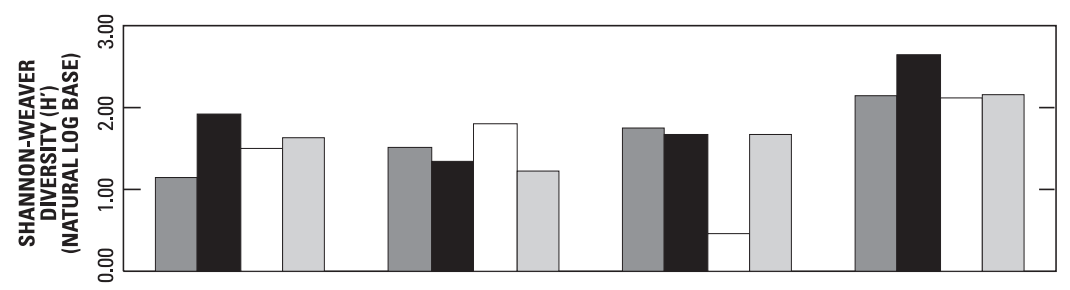

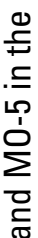

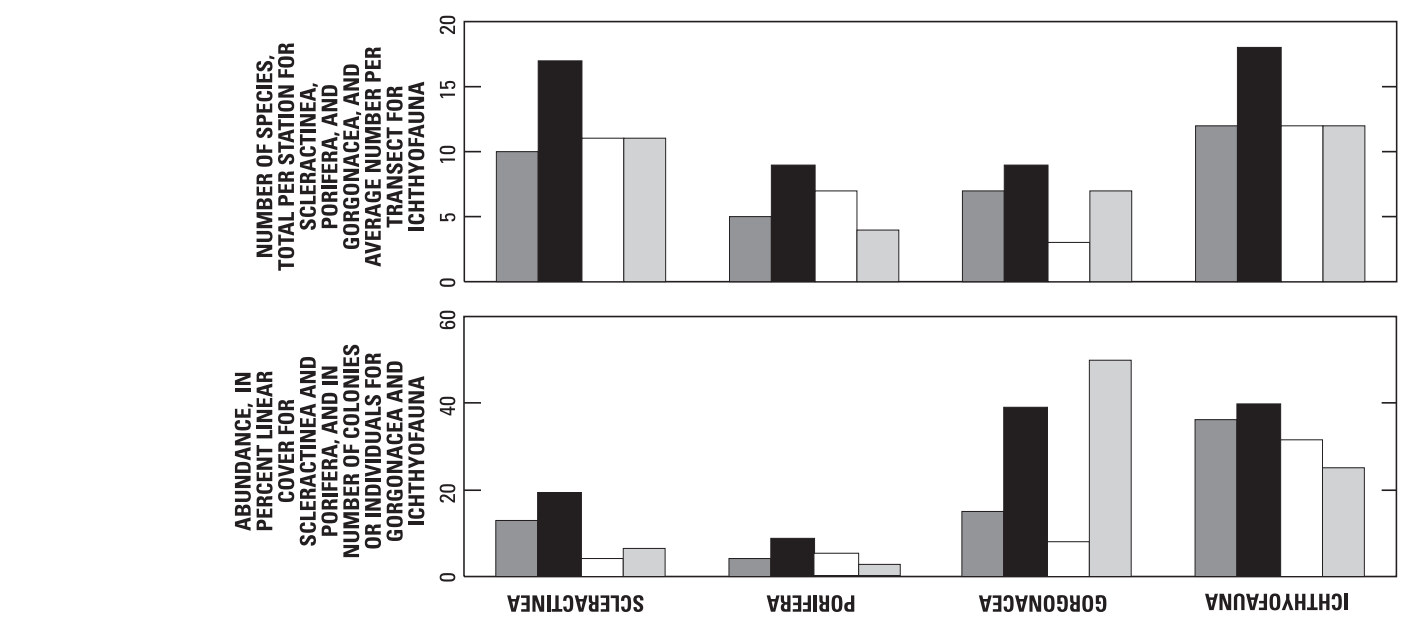

个

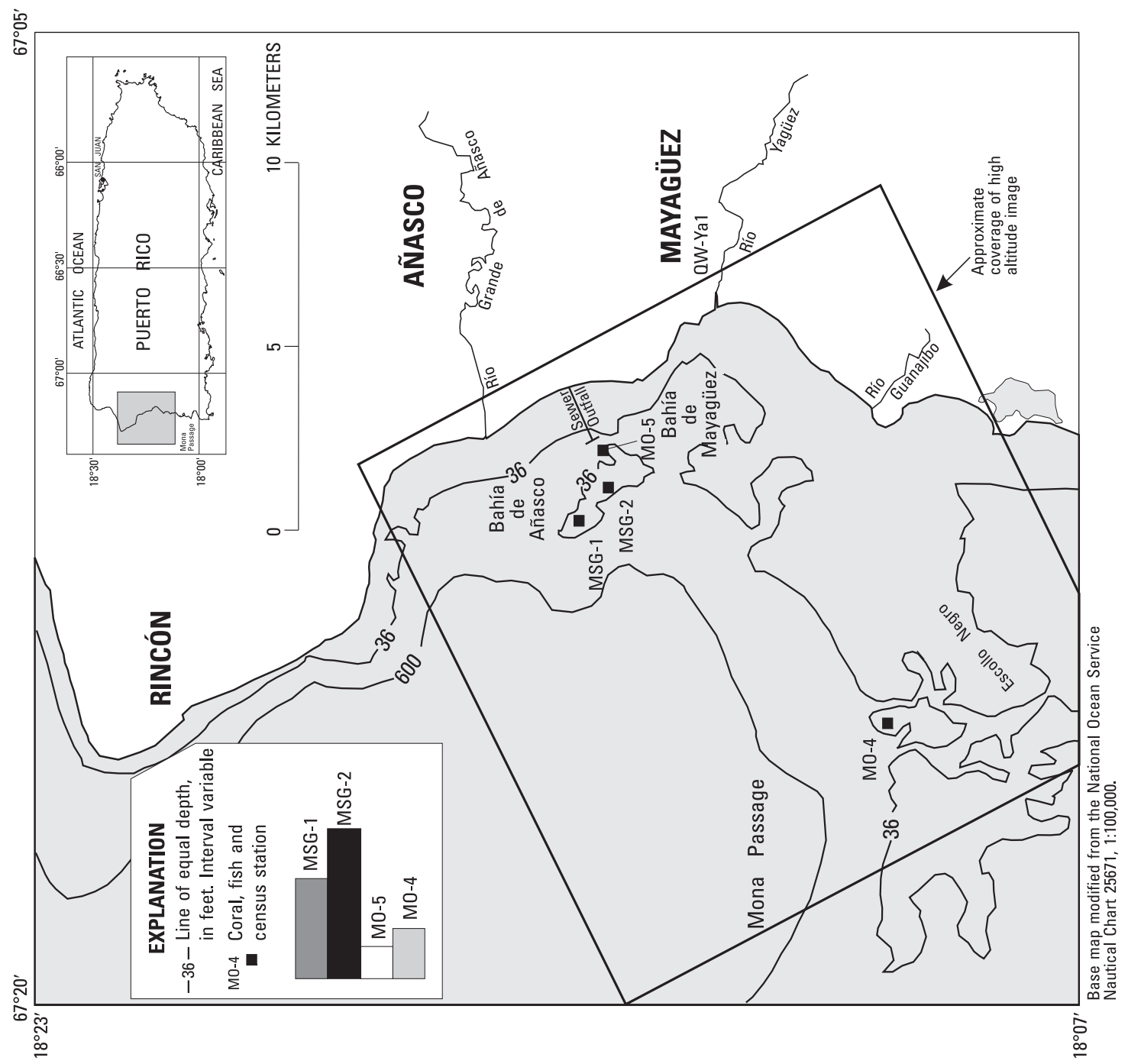




\section{MO-5 (350 $\mathrm{m}$ west of outfall: $18^{\circ} 14^{\prime} 18^{\prime \prime} \mathrm{N}$.. 67'11'28.2" W., depth 8-10 m)}

This station is a submerged outcrop to the southsouthwest of the outfall. The water was appreciably more turbid than at the other two stations in the Manchas Interiores-Manchas Exteriores coral reef complex, at least during the December 1990 survey. A total surface area of $90 \mathrm{~m}^{2}$ was surveyed (three transects) at station MO-5. The depth at which the surveys were made ranged between 8 and $9 \mathrm{~m}$. Topographic relief ranged between 2.2 and $3.4 \mathrm{~m}$ $($ mean $=2.8 \mathrm{~m})$.

\section{Fishes}

A total of 20 species were identified at this station. The number of species per transect ranged between 9 and 15 (mean: $12 \pm 3$ S.D.). Values of the Shannon-Weaver diversity index varied between 1.88 and 2.47 (mean: 2.12). The average abundance of fishes was $31.5 \mathrm{ind} /$ transect.

Two species of damselfishes dominated the numerical abundance of fishes, representing 34 percent of total individuals. The dusky damselfish, Stegastes fuscus, was the most abundant species (6.7 ind/transect), and was present in all three transects. This damselfish species was only found at MO-5, while the bicolor damselfish ( $S$. partitus), which was the most abundant damselfish at stations MSG-1 and MSG-2, was not found at MO-5. The yellow damselfish (S. Planifrons) was the other damselfish present (4.0 ind/transect). The bluehead wrasse, Thalassoma bifasciatum, and the yellowhead wrasse, Halichoeres garnoti, had a combined abundance of 5.3 ind/transect, second to damselfishes in numerical abundance. The sharpnose puffer, Canthigaster rostrata, and the coney, Cephalopholis fulva, were the other two fishes present at all three transects surveyed.

Pelagic fishes were very abundant at this station but were not quantified in the transect survey. Schools of red-ear sardine (Harengula humeralis) and threadherring (Opisthonema oglinum) were being predated upon by smaller schools of cero and king mackrel (Scomberomorus regalis and S. cavalla, respectively).

\section{Sessile Benthos}

Gorgonians are not abundant but are the most conspicuous fauna. There are many species of scleractinians, but their cover is low, and most colonies are partially dead and/or exhibit necrotic tissue. The substrate is covered by a thick (1-2 mm) sediment film trapped in the filaments of red algal carpet, with green fleshy and/or brown algae in many places. Biotic elements of deeper waters are common, possibly due to the predominantly high mean water turbidity. These include the scleractinian Agaricia lamarcki and the antipatharian Stichopathes sp. Arborescent, colonial hydrozoans are common. In general, the area is heavily silted and living coral cover is quite low. Relief is quite high in relation to other stations (table 9), and it is evident that its origin is scleractinian related. Upon scraping silted surfaces, one can observe the underlying coral calices below the sediment film.

\section{M0-4 (Escollo Negro: 189'55" N., 67'15'39" W. depth 8-9 m)}

This station was surveyed under unfavorable conditions which precluded adequate assessment of general characteristics. A total surface area of $60 \mathrm{~m}^{2}$ was surveyed in two transects at station MO-4. The depth at which the surveys were made ranged between 8 and $9 \mathrm{~m}$. Topographic relief ranged between 0.7 and $1.8 \mathrm{~m}($ mean $=1.2 \mathrm{~m})$. A total of 16 species was identified at this station. The two values for number of species observed per transect were 9 and 14 (mean: 12 \pm 4 S.D.). Shannon-Weaver diversity index values corresponding to the two transects surveyed were 2.00 and 2.32. The average abundance of fishes was $25 \mathrm{ind} /$ transect.

Nine out of the 16 fish species recorded at this station were present in only one of the transects surveyed. Also, most of these species refer back to only one individual. Therefore, the quantitative information has very limited statistical significance, and the reader is advised to evaluate with caution the data from this station. Only four fishes presented more than one individual at the two transects. It seems that the bicolor damselfish (Stegastes partitus) is one of the numerically dominant fishes in this reef. In 
addition to the bicolor damselfish, the yellowhead wrasse (Halichoeres garnoti), and the striped and redband parrotfishes (Scarus iserti and Sparisoma aurofrenatum), appear to be common here, as they are all typical of shallow water coral reef environments in Puerto Rico. Additional observations are critically needed to characterize the community of fishes at this reef.

\section{Sessile Benthos}

In general, the area has low to medium relief substrate and high gorgonian abundance. This taxa predominates visually. Scleractinians are abundant and diverse, although generally small. Sponges are a minor component of the community.

\section{Species Diversity and Abundance Patterns}

Whereas the station nearest the outfall, MO-5, is noteworthy for the limited abundance of scleractinians, poriferans, and gorgonians, the community of scleractinians and poriferans present is as diverse as at the other stations (fig. 18). The communities established at station MO-5 are deeper water communities.

\section{Fishes}

Fish abundance and diversity were highest at station MSG-2, located in Manchas Interiores, 1,200 $\mathrm{m}$ west of the outfall. This station also had the most diverse coral community. The correlation between fish diversity and bottom relief increases if the station closest to the outfall, MO-5, is withdrawn from the data set. The habitats at station MO-5, as discussed previously, are affected by sediments and nutrients discharged from west coast rivers. Diversity and mean number of species per transect were roughly equal at the three stations, MSG-1, MO-5, and MO-4, the control site. Mean fish abundance per transect was lowest at station MO-4. This site was affected by swells arriving from the north when visited. The surge caused by the swells made surveying difficult, both due to the inability of the observer to remain stationary in the water column and to the turbidity resulting from the resuspended sediments. The sites presenting leastto-greatest mean fish abundance, in order of increasing abundance, were MO-4, MO-5, MSG-1, and finally
MSG-2. In conclusion, the fish communities near the outfall, station MO-5, were similar to those at three of the four survey stations. In general, it could be observed that fish populations reflected natural variations in food and habitat availability.

A scatter diagram of abundance and diversity values plotted against substrate relief for all stations is presented in figure 19. Fish abundance and species diversity values varied independently from substrate relief at MSG-1 (abundance, $\mathrm{r}^{2}=0.01$; diversity $r^{2}=0.23$ ). Substrate relief was relatively constant at MSG-1. Only one of the five transects measured was different from the others in substrate relief within the precision limits of the method ( 10 percent). Therefore, the variability of fish abundance and diversity between transects may reflect a scale of variation that could be expected to occur naturally or at a constant substrate relief.

Patterns of fish abundance and diversity were also statistically independent of substrate relief at MSG-2. Although four out of five diversity values increased as substrate relief increased (suggesting a positive association), the suggestion of direct relationship is contradicted by a single observation in which the highest diversity value corresponded to the transect of lowest relief. As was the case with MSG-1, variation in substrate relief between transects at MSG-2 was relatively low. Therefore, the variability of fish abundance and diversity at MSG-2 may be reflecting a scale of natural variation inherent to a given substrate relief.

A trend of increasing fish abundance and diversity with substrate relief emerged from the two observations at station MO-4. Substrate relief varied more than two-fold between the two transects surveyed. The limited number of observations, however, constrains further analysis of fish diversity and abundance patterns at this station. Observations at station MO-5 were limited to three, again resulting in high uncertainty in the analysis of fish abundance and diversity patterns. Figure 20 shows that two out of the three values obtained fall at the extreme lower right of the scatter diagram. The trend of the three points from station MO-5 suggests a pattern of lower fish abundance and diversity with increasing substrate relief. 

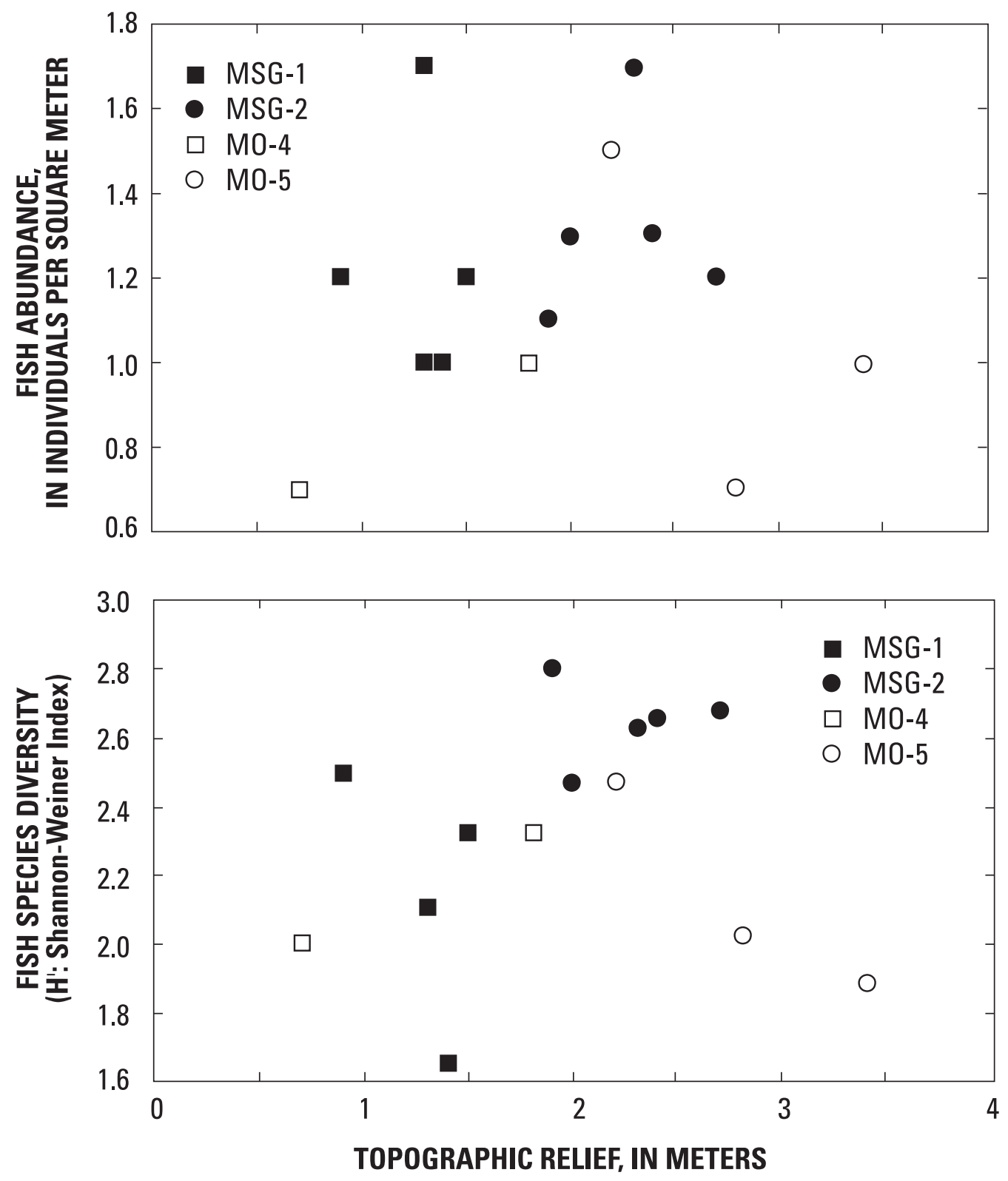

Figure 19. Fish abundance and diversity versus relief for stations MSG-1, MSG-2, and M0-5 in the Manchas InterioresManchas Exteriores, and for station M0-4 in the Escollo Negro, Puerto Rico, December 1990. 

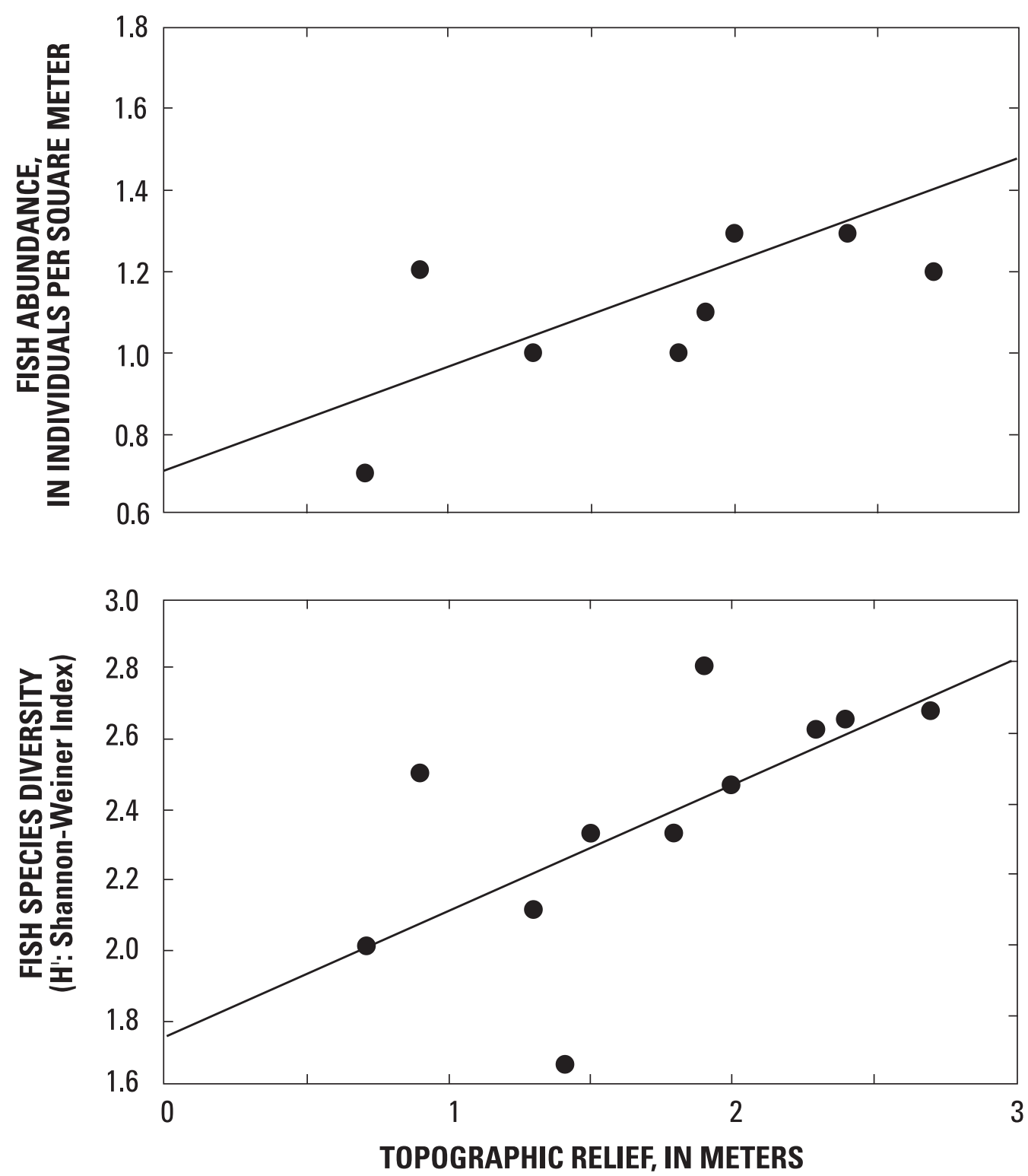

Figure 20. Relation of fish abundance and diversity versus relief for composite plots of data from stations MSG-1 and MSG-2 in the Manchas Interiores-Manchas Exteriores coral reef complex, and for station M0-4 in the Escollo Negro, Puerto Rico, December 1990. 
A preliminary hypothesis was developed from the descriptive information available: fish abundance and diversity increase as a function of substrate relief in unpolluted shallow reefs. Due to the relatively large differences in substrate relief between stations, it was possible to examine the potential influence of substrate relief on fish abundance and diversity. Exclusion of the data set for station MO-5 resulted in a positive significant $(\mathrm{p}<0.05$; d.f. $=10)$ correlation between fish abundance and substrate relief $\left(\mathrm{r}^{2}=0.41\right)$, and between species diversity ( $H^{\prime}$ values) and substrate relief $\left(r^{2}=0.42\right)$. Linear fits to the preliminary models that correlate fish abundance and diversity with substrate relief are presented in figure 20. Inclusion of the MO-5 data set virtually nullified the apparent relationship between substrate relief and fish abundance and diversity.

\section{Sessile Benthos}

The total number of species (scleractinians, poriferans, and gorgonians), mean and total benthic cover per station (scleractinians and poriferans), and total number of colonies per station (gorgonians), were highest for station MSG-2 (Manchas Interiores), intermediate at station MSG-1 (Manchas Exteriores), and lowest at Station MO-5. However, in spite of being at a similar depth, the sessile benthos observed at station MO-5 are not readily comparable with the other stations. Shallow-water communities were common at all other stations, and even form the substrate at station MO-5, where a deeper-water community has now become established. The diversity of scleractinians at MO-5, exceeds that observed at station MSG-1, and is comparable to that observed at the control site MO-4 in the Escollo Negro.

The diversity of porifera (sponges) at station MO-5 was the highest of all of the stations. Poriferans are second only to scleractinians in abundance in many tropical habitats (Reiswig, 1973). Sponges appear to be vulnerable to shifts in community structure in response to regional warm-water episodes (Vicente and Smith, 1990; Vicente, 1989). Poriferans feed primarily on particulate organic material. Their diversity and abundance at station MO-5 are further evidence that hard-bottom communities in the inner parts of the Bahía de Añasco have adapted to high levels of siltation and particulate organic material. Although sponges may provide additional nutrients needed to maintain high levels of reef productivity (Corredor and others, 1988), they may also be aggressive when competing with corals for limited substrate (Vicente, 1985, 1978).

Gorgonacea were low in abundance and diversity at MO-5, although the abundance of encrusting gorgonacea Erythropodium caribaeorum and Briaerum asbestinum were similar to that observed at station MSG-2. Gorgonian density at the Escollo Negro station MO-4 was above that of MSG-2.

Mean cover and density observed during this survey were compared among stations and with mean cover and density observed in the previous survey (Metcalf \& Eddy, 1985) to determine if there were gross differences between the two studies (fig. 21). Scleractinian cover was significantly higher at MSG-2 than at the other stations (table 10). Gorgonian density was higher at MO-4 than at MSG-2 and at MSG-1. Gorgonian density at MO-5 was significantly less than the other three stations. Sponge cover was not significantly different among stations.

Scleractinian cover at MSG-1 and MSG-2 does not differ significantly between the current survey and the 1985 survey (tables 11, 12). Gorgonian density at MSG-2 was higher in the 1990 survey than the 1985 survey. The reverse was observed at MSG-1. Differences in sponge cover from 1985 to 1990 were insignificant at both sites.

Coral abundance and diversity were greatest at station MSG-2 and lowest near the outfall. Considering a transect starting at Punta Algarrobo, near the probable major point source of nutrients, continuing to station MO-3, $350 \mathrm{~m}$ from the outfall, and finishing at station MSG-2, about 1,200 m west of the outfall, a clear trend of improving coral condition is seen (see fig. 6 for general locations). The corals at the patch reef off Punta Algarrobo, at the north end of the Bahía de Mayaguiez were once healthy (Evermann, 1900). By 1980, the reef was heavily silted over, with only two coral species, Porities asteroides and Montastrea cavernosa, together with Millepora alcicornis, occupying less than 2 percent of the reef (Morelock and others, 1983). Moving to the west, station MSG-2 has the most diverse and populated coral community studied, including that of the control site MO-4. If the transect is continued north to station MSG-1, about 1,900 m from the outfall, conditions of the corals worsen as the distance to the Río Grande de Añasco decreases. 

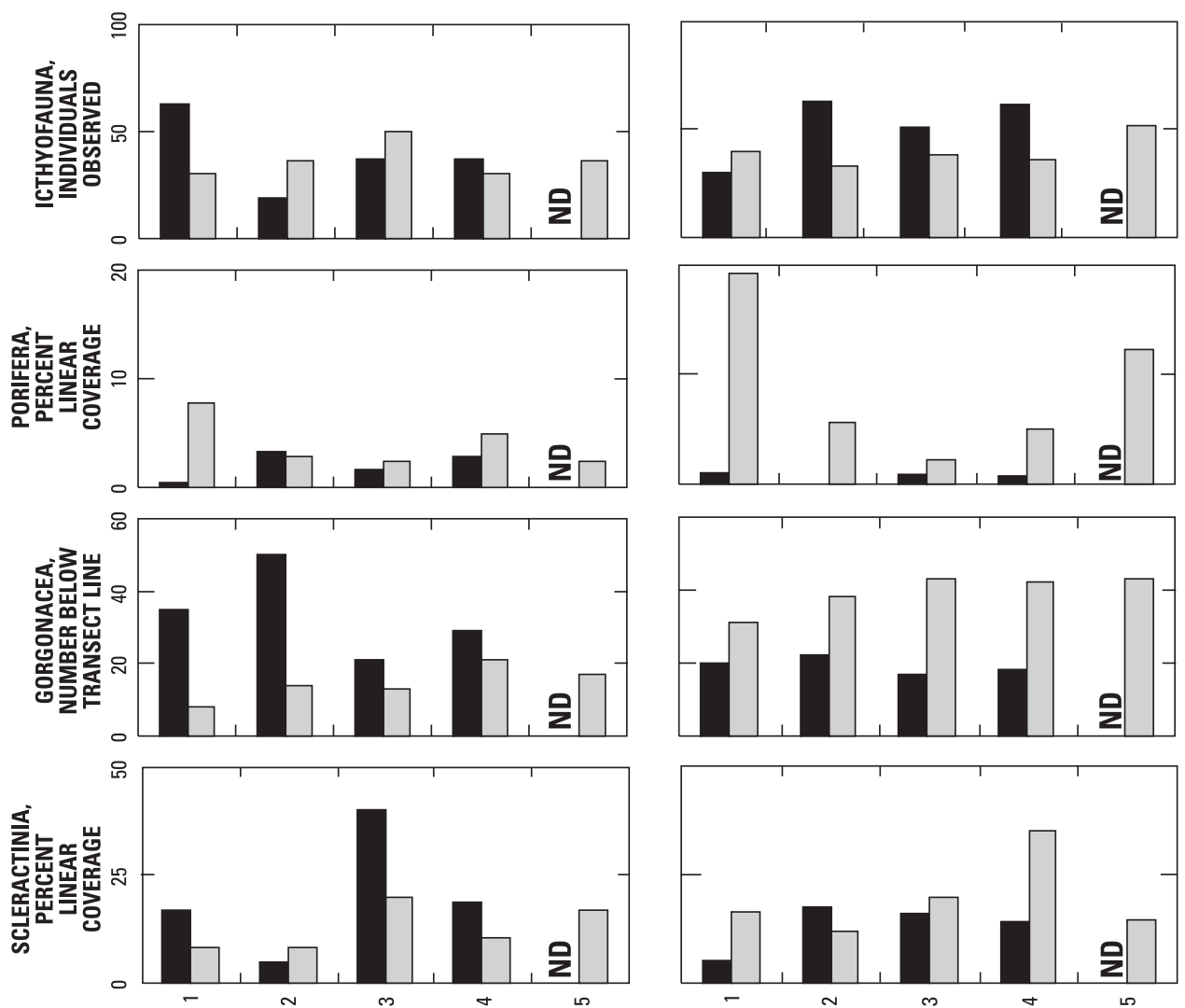

l-פSW ‘y

z-פSW ‘y

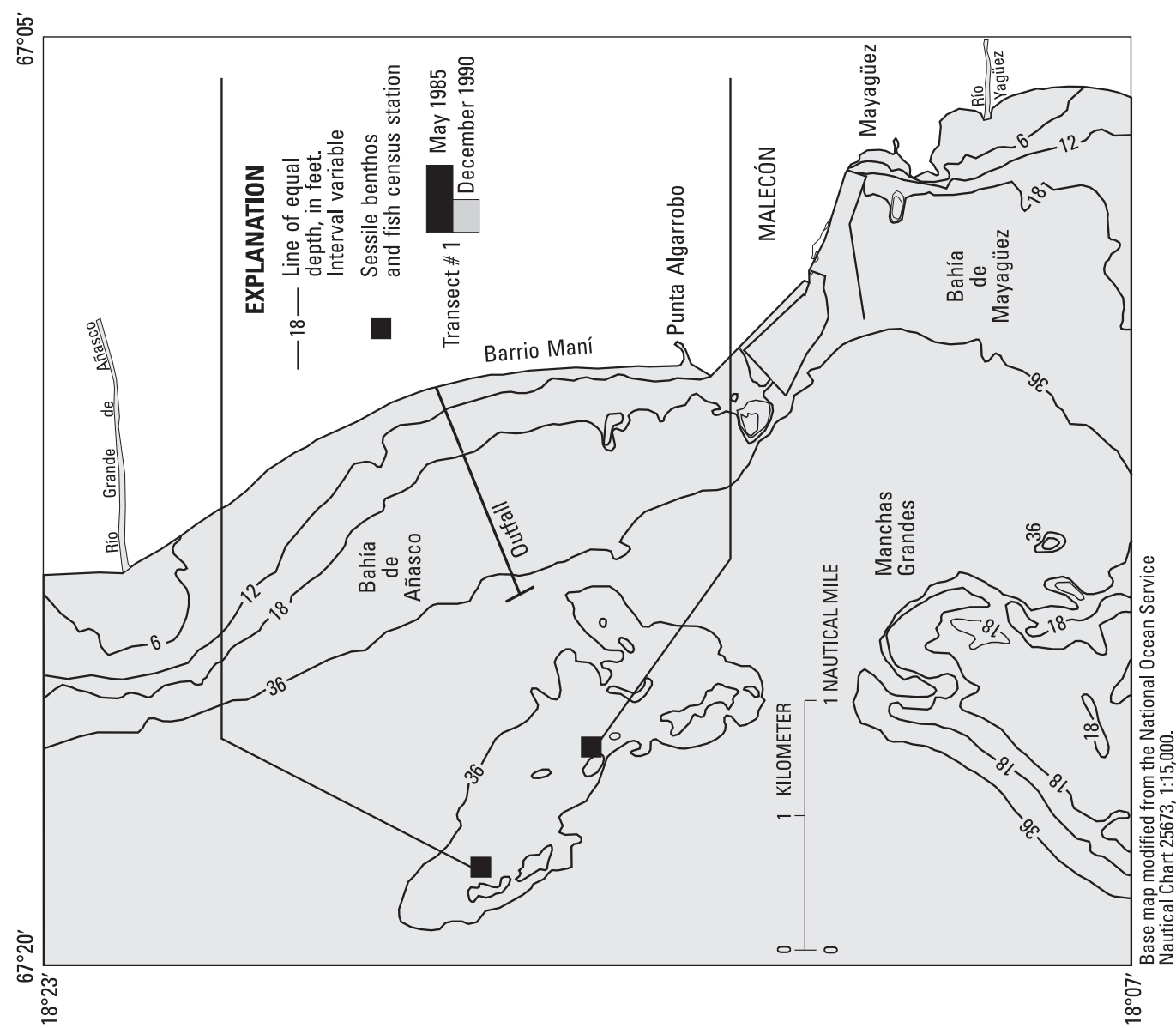

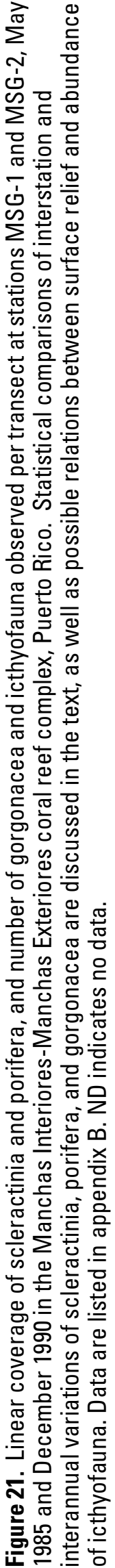

54 Assessment of the Habitats, Biota, Sediments, and Water Quality Near the Discharge of Primary-Treated Effluent from the Mayagüez Regional Wastewater Treatment Plant, Bahía de Añasco, Puerto Rico 
Table 10. Differences in cover (scleractinians and sponges) and density (gorgonians) among stations in this study

[One way ANOVA ( $\mathrm{p}=$ probability; $\mathrm{F}=\mathrm{F}$ ratio; $\mathrm{df}=$ degrees of freedom) and multiple range test $(\mathrm{MRT})$ based on 95 percent confidence interval. Data are detailed in appendix B.]

\begin{tabular}{lcccl}
\hline & $\mathrm{p}$ & $\mathrm{F}$ & $\mathrm{df}$ & \multicolumn{1}{c}{ MRT } \\
\hline Scleractinia & 0.07 & 3.11 & 13 & MSG2>rest \\
Porifera & 0.36 & 1.19 & 13 & non-significant \\
Gorgonacea & $<0.0001$ & 32.06 & 13 & MO-4> MSG-2> \\
& & & & MSG-1>>MO-5 \\
\hline
\end{tabular}

Table 11. Differences in cover (scleractinians and sponges) and density (gorgonians) at station MSG-1 for the 1985 and 1990 surveys

[One way ANOVA ( $\mathrm{p}=$ probability; $\mathrm{F}=\mathrm{F}$ ratio; $\mathrm{df}=$ degrees of freedom) and multiple range test (MRT) based on 95 percent confidence intervals. The data collected in this study (detailed in appendix B) were compared with the observations made in the same vicinity before the outfall became operational (PRASA, 1985).]

\begin{tabular}{lcccc}
\hline & $\mathrm{p}$ & $\mathrm{F}$ & $\mathrm{df}$ & $\mathrm{MRT}$ \\
\hline Scleractinia & 0.32 & 1.1 & 8 & non-significant \\
Gorgonacea & 0.01 & 10.4 & 8 & $1985>1990$ \\
Porifera & 0.17 & 2.3 & 8 & non-significant \\
\hline
\end{tabular}

Table 12. Differences in cover (scleractinians and sponges) and density (gorgonians) at station MSG-2 for the 1985 and 1990 surveys

[One way ANOVA ( $\mathrm{p}=$ probability; $\mathrm{F}=\mathrm{F}$ ratio; $\mathrm{df}=$ degrees of freedom) and multiple range test (MRT) based on 95 percent confidence intervals. The data collected in this study (detailed in appendix B) were compared with the observations made in the same vicinity before the outfall became operational (PRASA, 1985).]

\begin{tabular}{llccc}
\hline & $\mathrm{p}$ & $\mathrm{F}$ & $\mathrm{df}$ & $\mathrm{MRT}$ \\
\hline Scleractinia & 0.26 & 1.44 & 8 & non-significant \\
Gorgonacea & 0.0002 & 52.6 & 8 & $1990>1985$ \\
Porifera & 0.051 & 5.5 & 8 & non-significant \\
\hline
\end{tabular}




\section{Interannual Variations in Coral Extension Rates and Skeletal Chemistry}

Interannual variations in coral extensional rates and skeletal chemistry have been shown to be useful proxies for a variety of oceanographic and hydrologic events (Hudson and others, 1976). Hermatypic corals derive energy from the precipitation of calcium carbonate, which is deposited as an aragonitic skeleton that also serves as a protective habitat. This ability to extend the substrate upon which they live upward, toward the light that energizes the symbiotic zooxanthellae, gives them a unique advantage in areas where sea level is rising. Many species of corals will deposit aragonite at differing rates throughout the year, in response to ambient conditions and vital processes, thus forming annual high-density/low-density couplets similar to tree rings (Hudson and others, 1976). Corals generally deposit their high-density bands during late summer, when water temperatures are warmest (Hudson and others, 1976; Winter and others, 1991), although the exact timing varies in response to reproduction, temperature, and food supply (Wellington and Glynn, 1983; Goenaga, 1988). Variations in the concentrations of lattice-bound cadmium and manganese comprise paleo-upwelling indicators that display great sensitivity in the eastern Pacific Ocean (Shen and Sanford, 1989). Shen and Sanford also documented that variations in barium trapped in the aragonitic lattice of reef-building corals growing in Barbados and Tobago reflect variations of discharges of the Río Orinoco and Amazon, that drain large parts of South America. The increase of lead in surface waters of the North Atlantic in response to late 19th century- and 20th century-industrialization, and subsequent reductions in lead concentrations following the mid 1970's, resulted in variations in lattice-bound lead concentrations in corals growing at North Rock, Bermuda (Shen and Boyle, 1988).

Enhanced fluorescence of annual bands precipitated by corals has been related to the discharge events in other regions (Scoffin and other, 1989; Isdale, 1984; Susic and others, 1991). Humic acids discharged with flood waters can be incorporated into the aragonitic coral lattice, resulting in greater fluorescence of annual bands during years of greater runoff. Analyses of fluorescence displayed by the skeletons of four corals growing off the west coast of Puerto Rico indicated that fluorescence is not a useful proxy for flooding of the rivers discharging to the area. Significant fluorescence was observed only in coral core $\mathrm{C}$, the fastest growing of the four cores (fig. 22). Fluorescence in the other cores was faint and did not correlate consistently with annual banding. Contamination of the slab surfaces by cutting oil is discounted, as the rock saw used to cut the slabs used non-recycled tap water. To provide additional comparisons, coral cores from the Parguera area in southern Puerto Rico were retrieved from the archives at the USGS Coastal Processes office in St. Petersburg, Florida.

Fluorescence of the coral cores from the Parguera area was much more intense than that of any of the coral cores sampled from the Bahía de Añasco or Escollo Negro. Whereas surface runoff clearly affects the reefs off the west coast to a greater extent than the reefs of the south coast, the reefs off the south coast are bathed in waters receiving humic and fulvic acids exported from the mangrove communities prevalent there. Water sampled from channels in the mangroves in southern Florida fluoresces intensely when exposed to ultraviolet light (Bob Halley, personal commun., 1990).

\section{Extensional Rates}

Average extensional rates, as measured by distance between high-density bands, varied from 4.3 $\mathrm{mm} / \mathrm{yr}$ in core $\mathrm{C} 2$, growing at station MO- $1,610 \mathrm{~m}$ from the outfall, to $10.5 \mathrm{~mm} / \mathrm{yr}$ in core $\mathrm{C} 9$, growing at station MO-3, at Escollo Negro. The X-radiographs of the corals show that the growth rates of three of the four colonies sampled at the two stations were stunted coincident with a bleaching event experienced throughout the Caribbean in 1987-88 (fig. 23). Coral core $\mathrm{C} 7$, the fastest growing core, was an exception; it actually grew faster in 1988 . However, as seen in figure 24, core C7 did show an extended period of high-density deposition during the same period. The three coral cores that slowed growth during the bleaching event recovered; during 1989-90 they began growing at rates equal to or greater than before the event occurred (fig. 24). 
Station MO-1 (610 $\mathrm{m}$ from the outfall)

C1

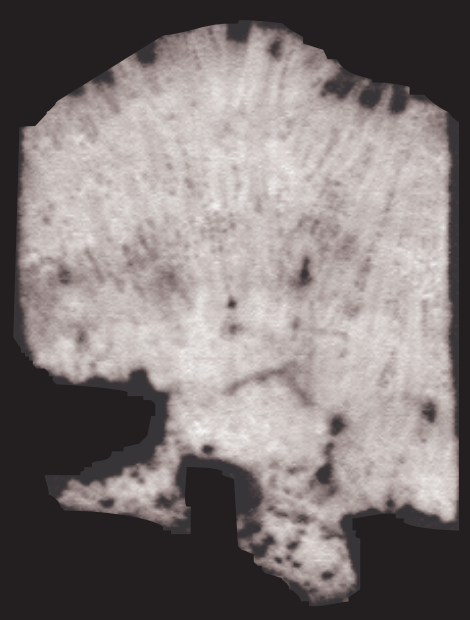

C2

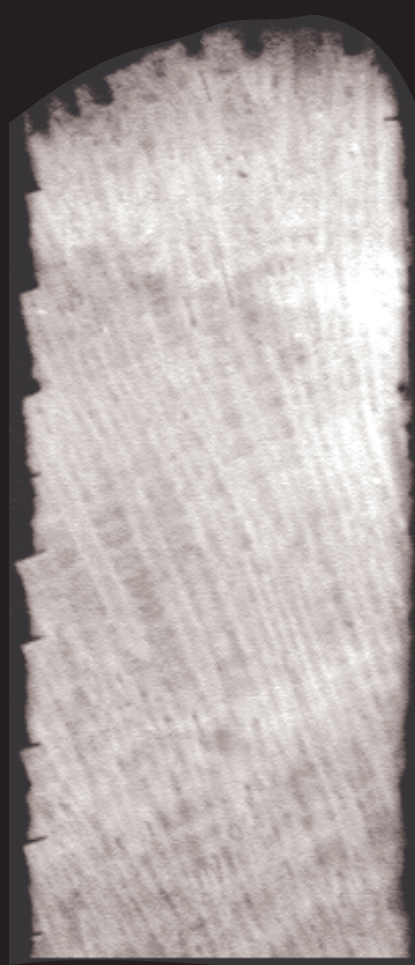

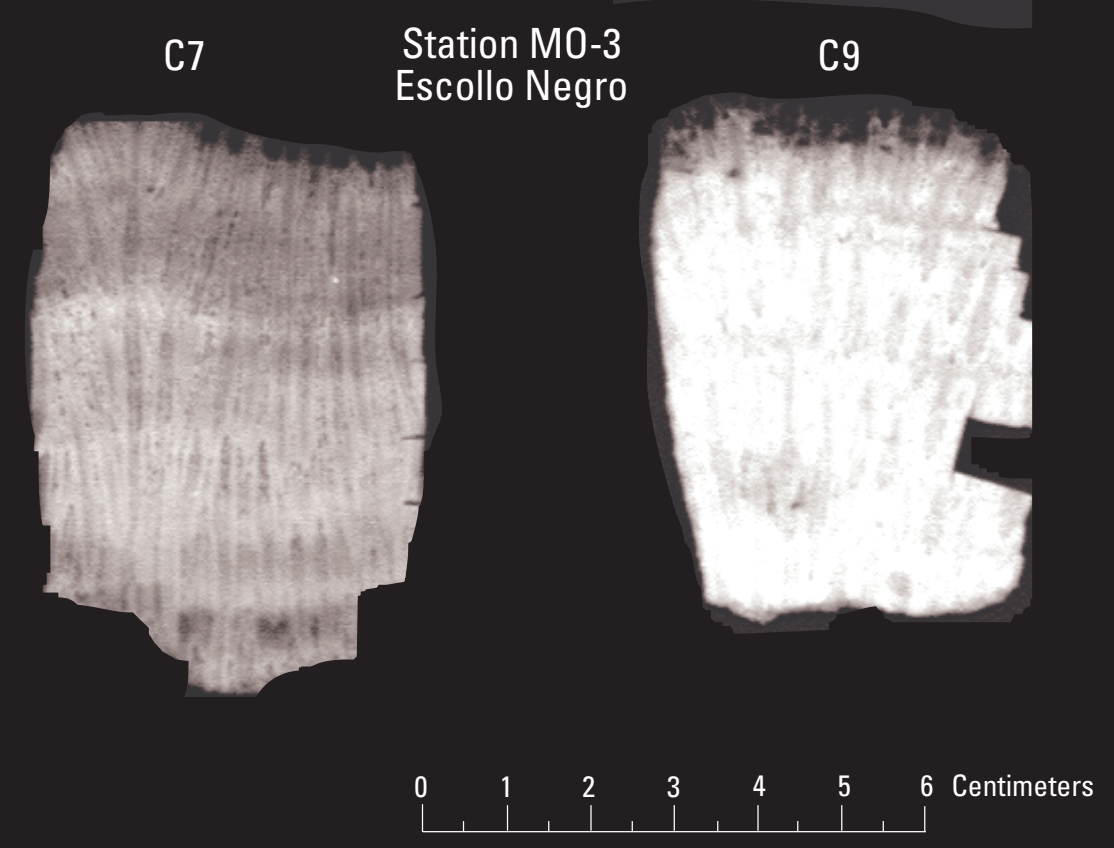

Figure 22. Fluorescence for four samples of Montastrea annularis at station M0-1,610 meters southeast of the outfall, and at station M0-3 in the Escollo Negro, Puerto Rico. These images of C2, C7, and C9 were recorded after samples were cut from the slabs. The voids and cut marks are seen on the margins of the coral slabs. Scale and incident UV light intensities were constant for all samples. 


\section{Station M0-1 (610 $\mathrm{m}$ from the outfall)}
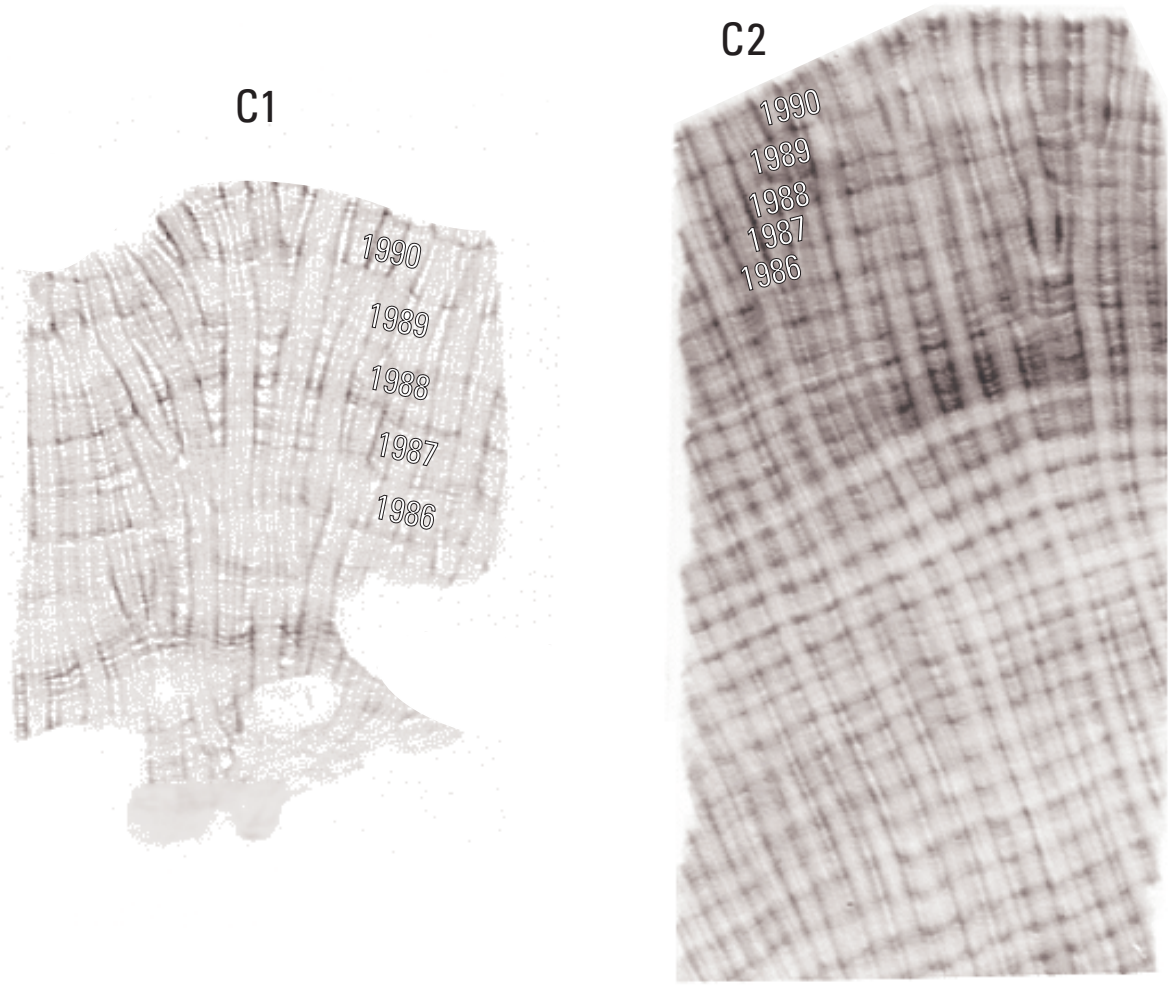

\section{Station MO-3 - Escollo Negro}
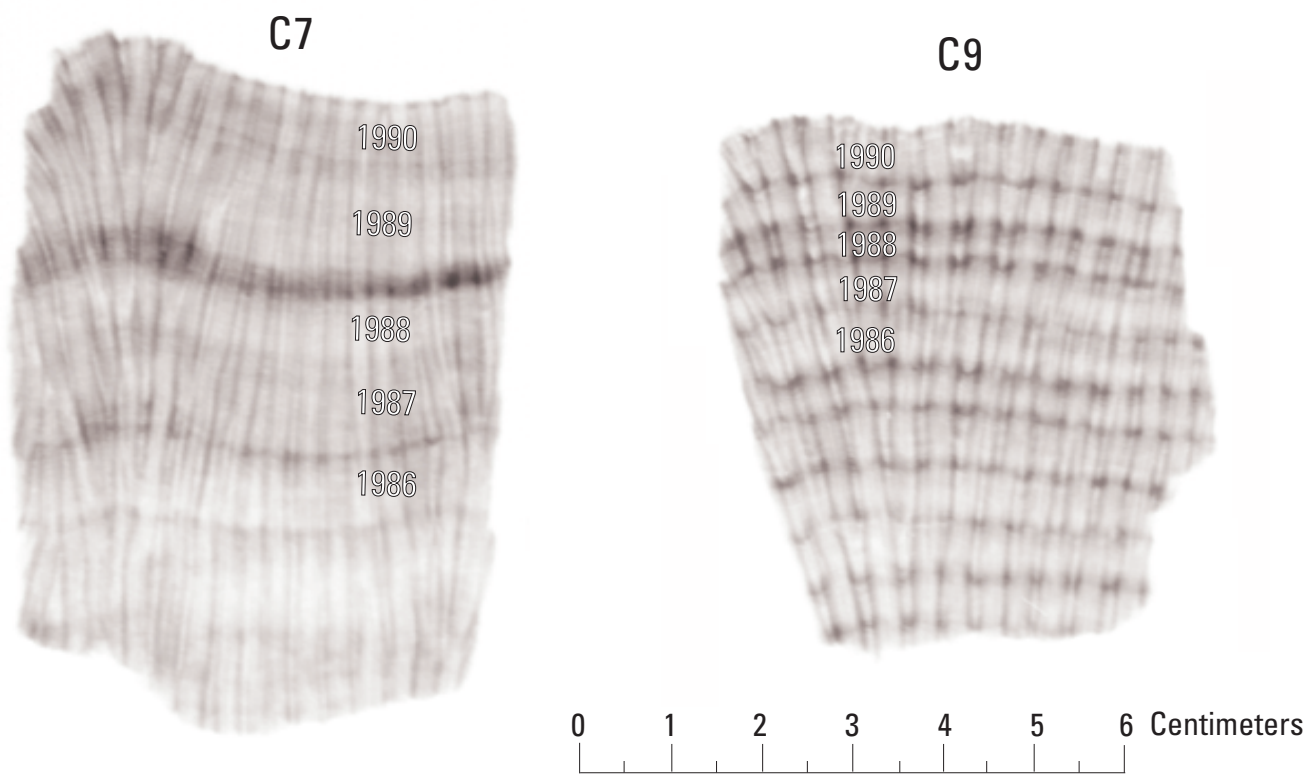

Figure 23. X-radiographs of four samples of Montastrea annularis cored at station M0-1, 610 meters southeast of the outfall, and at station M0-3 in the Escollo Negro, Puerto Rico. In these positives of the X-radiographs, high-density bands appear darker than the low-density bands. Note that the annual banding indicates that the extensional rates of these corals have not significantly decreased since 1987.

58 Assessment of the Habitats, Biota, Sediments, and Water Quality Near the Discharge of Primary-Treated Effluent from the Mayagüez Regional Wastewater Treatment Plant, Bahía de Añasco, Puerto Rico 


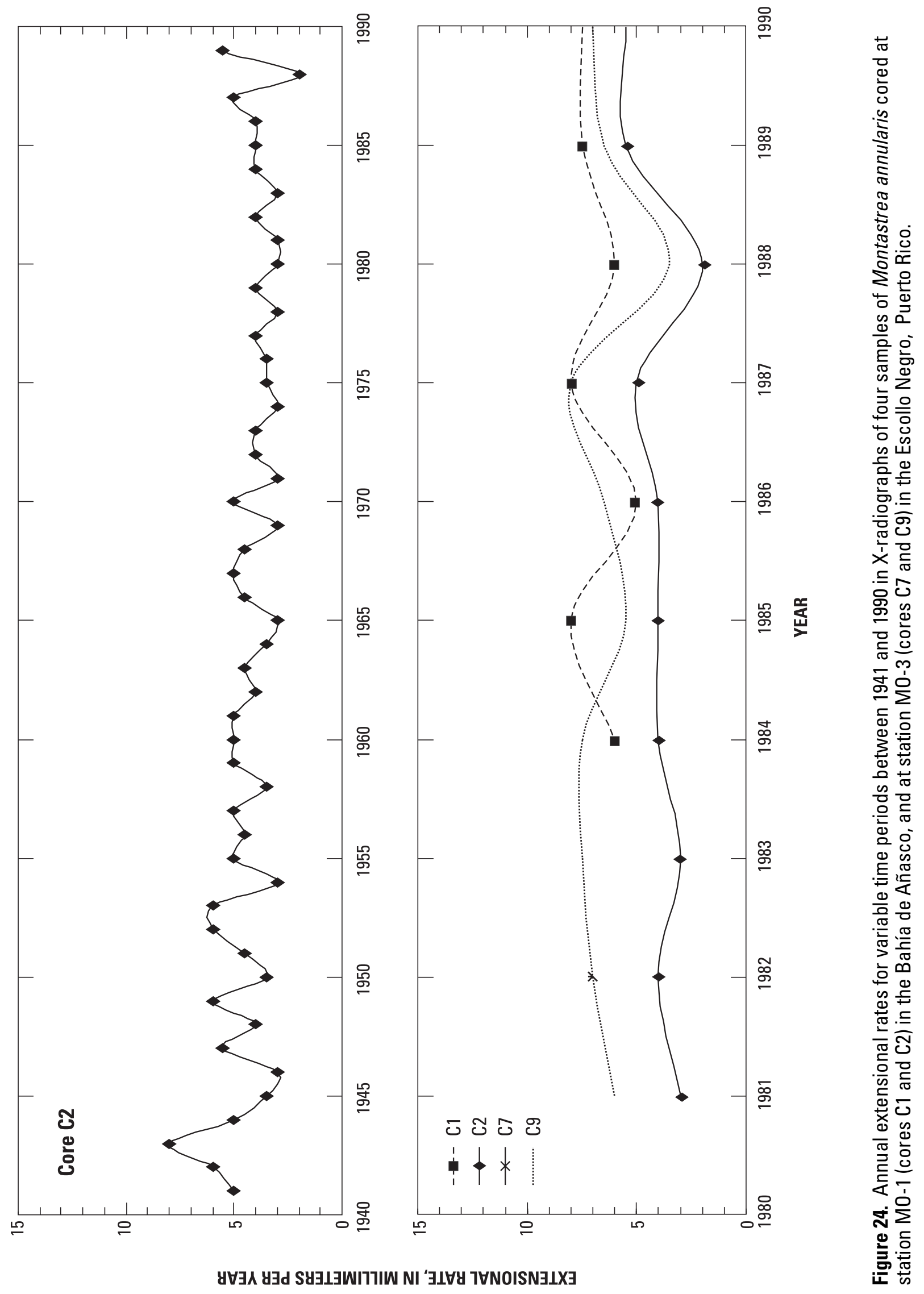




\section{Chemistry of the Coral Lattice}

The chemistry of the aragonite lattice deposited by coral communities varies in response to ambient environmental conditions such as water temperature and light, in addition to vital metabolic processes such as growth and reproduction. Correlations of ratios for carbon and oxygen isotopes measured during this study vary through time, from site to site, and from colony to colony (fig. 25). Values of $\delta^{18} \mathrm{O}$ varied from -6.88 to -4.01 . Values for $\delta^{13} \mathrm{C}$ varied from -4.05 to -0.09. The average $\delta^{18} \mathrm{O}$ value for the 1984-90 period for core $\mathrm{C} 7$, the fastest growing coral colony $(10.5 \mathrm{~mm} / \mathrm{yr})$, was -4.6 , whereas the average value for core $\mathrm{C} 9$, an adjacent slower growing community (6.5 $\mathrm{mm} / \mathrm{yr}$ ), was -5.18 . Even though the average values are different for communities growing at the same site, the relative changes in isotopic ratios are generally similar. Goenaga (1988) showed that high-density bands do not necessarily form at the same time of the year for all communities in a given area. Values of $\delta^{18} \mathrm{O}$ measured in annual bands deposited from 1964 through 1982 at Enrique Reef in southwestern Puerto Rico varied between -4.96 and -4.08 , whereas values for $\delta^{13} \mathrm{C}$ varied from -2.4 to 0.60 (Winter and others, 1991). For the period measured from 1984-90, variations of carbon isotopes in the cores from Escollo Negro correlated with oxygen isotopes better than similarly paired carbon/oxygen measurements for the cores from the Bahía de Añasco. Paired $\delta^{18} \mathrm{O} / \delta^{13} \mathrm{C}$ values for samples from cores C7 and C9 (1984-90), had correlation coefficients of 0.69 and 0.91 , respectively. Cores $\mathrm{C} 1$ and $\mathrm{C} 2$ had a correlation coefficient of 0.40 (1984-90). This indicates that the corals growing in the Escollo Negro respond more linearly to changes in light, temperature, and salinity, than those growing at the station sampled in the Bahía de Añasco. McConnaughey (1989) may describe the reefs of Escollo Negro as being more subject to "kinetic" isotope effects (physical properties of the water and climate) than the reefs growing in the Bahía de Añasco, that apparently are more subject to "vital" isotope effects (metabolic effects of respiration, photosynthesis, and reproduction).

The isotopic ratios measured in the 3-year composites for the period 1938-89, sampled from core C2 in the Bahía de Añasco, reveal that the "kinetic" isotope effect or strength of correlation between carbon and oxygen isotopes has varied greatly in the Bahía de Añasco through the years (fig. 26). In general, the correlations were good except for two periods, 1950-53 and 1962-65. This could be a result of changing circulation or changing water quality. Winter and others (1991) did not find statistically significant correlations between the carbon and oxygen isotopes measured in annual bands deposited by Montastrea annularis living at Enrique Reef, off southwestern Puerto Rico, for the period 1964-82. However, they noted that correlations between the isotopes and sea surface temperature improved considerably after 1969 . They attributed the change in trends to changes in the interannual variability of the North Atlantic circulation.

Whereas isotope values do not correlate well with observed extensional rates in core $\mathrm{C} 2$ for the period 1938-90 (fig. 27), there is evidence that warm waters associated with strong El Niño years are recorded faithfully. During years when "kinetic" effects are dominant, isotopic minima should occur in years of higher temperatures and clearer waters (McConnoughey, 1989). The four minima (excluding the outermost year) observed in the average annual $\delta^{18} \mathrm{O}$ and $\delta^{13} \mathrm{C}$ values for the long-term $\mathrm{C} 2$ core coincide with the years 1941, 1959, 1968, and 1982. The two most significant of these minima were centered at years 1941 and 1982, corresponding to two of the strongest El Niño years of this century (1940 and 1982). During El Niño years, there is a transfer of warm sea surface temperatures from the eastern equatorial Pacific to the western equatorial Atlantic, which is very distinct up to $10^{\circ}$ latitude and is observable at the latitude of Puerto Rico (Kawamura, 1994). Malmgren and others (1998) verified that El Niño events are strongly related to increased sea and air temperature in Puerto Rico, whereas interannual precipitation is related more strongly to the North Atlantic Oscillation.

Lattice-bound trace-metal concentrations varied between stations and also with time, although the analyses were problematic. Because the duplicate analyses had low precision (table 5), interannual variations of specific trace metals throughout the coral skeleton are considered only as qualitative. 

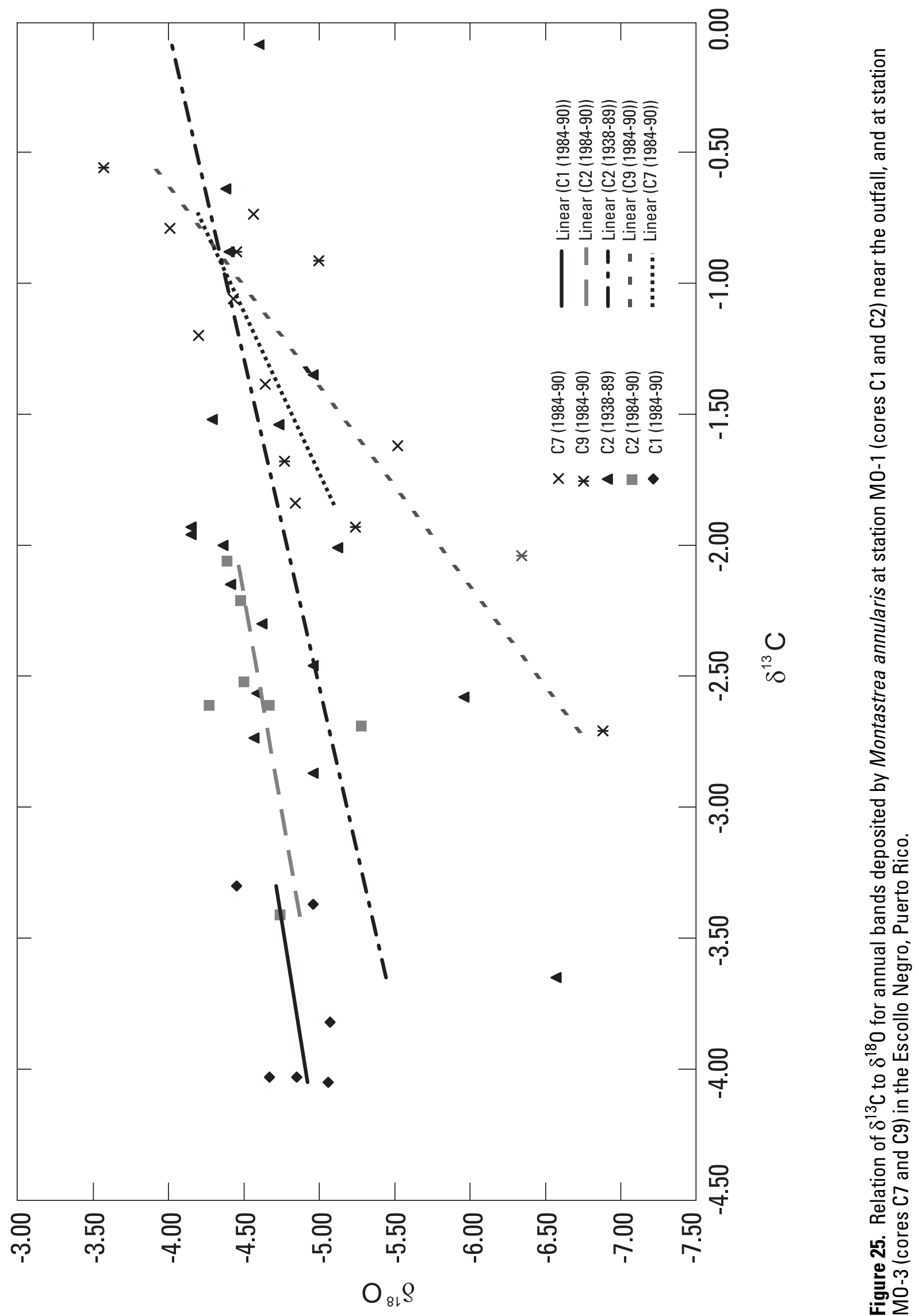

Summary of Results $\quad 61$ 


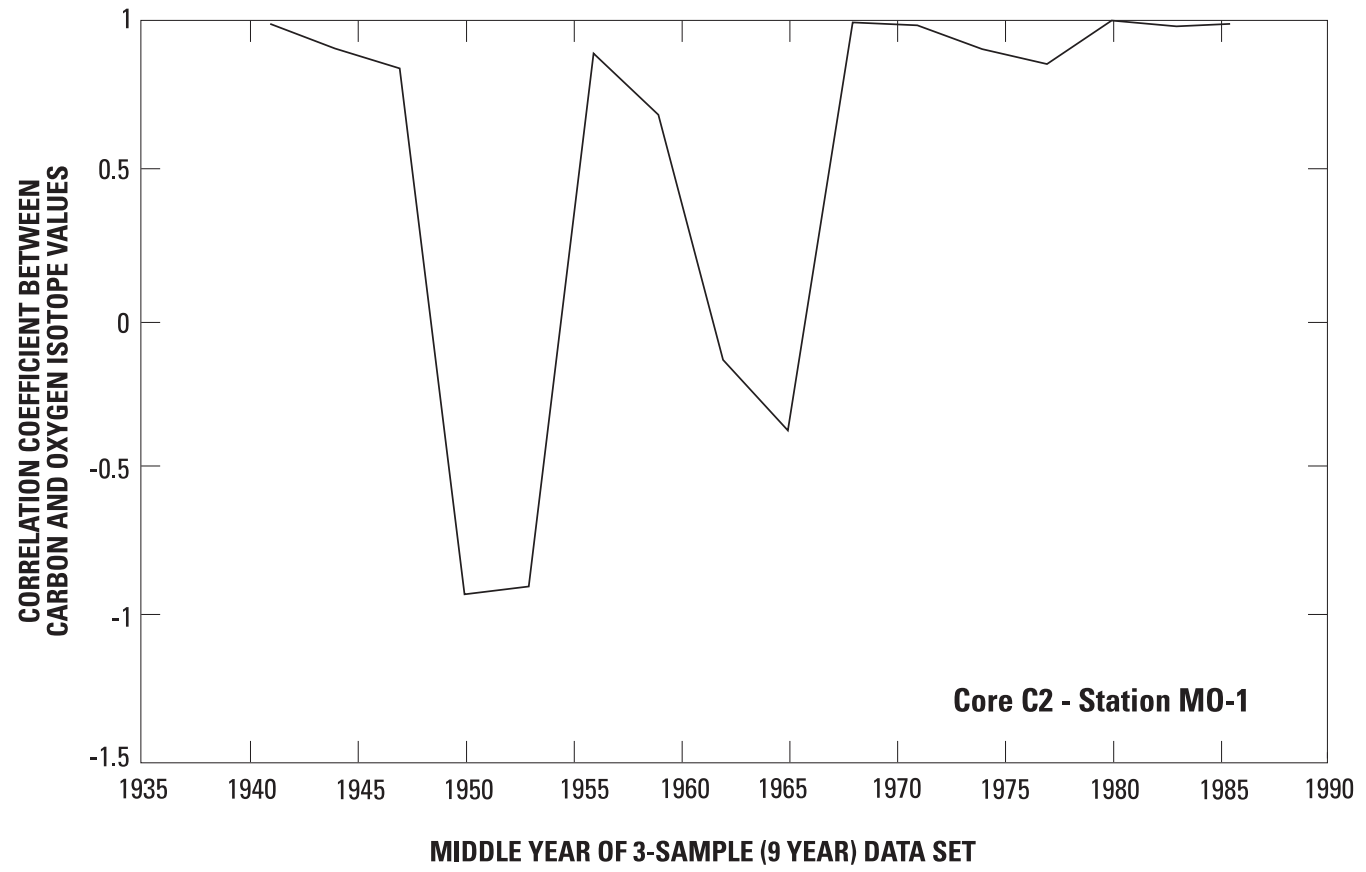

Figure 26. Three-period (9-year) moving average of correlation coefficients between carbon and oxygen values for the period 1941-86, measured in the lattice of coral core C2, growing at station M0-5 near the outfall in the Bahía de Añasco, Puerto Rico. The dataset includes isotope values measured for the period 1938-89.

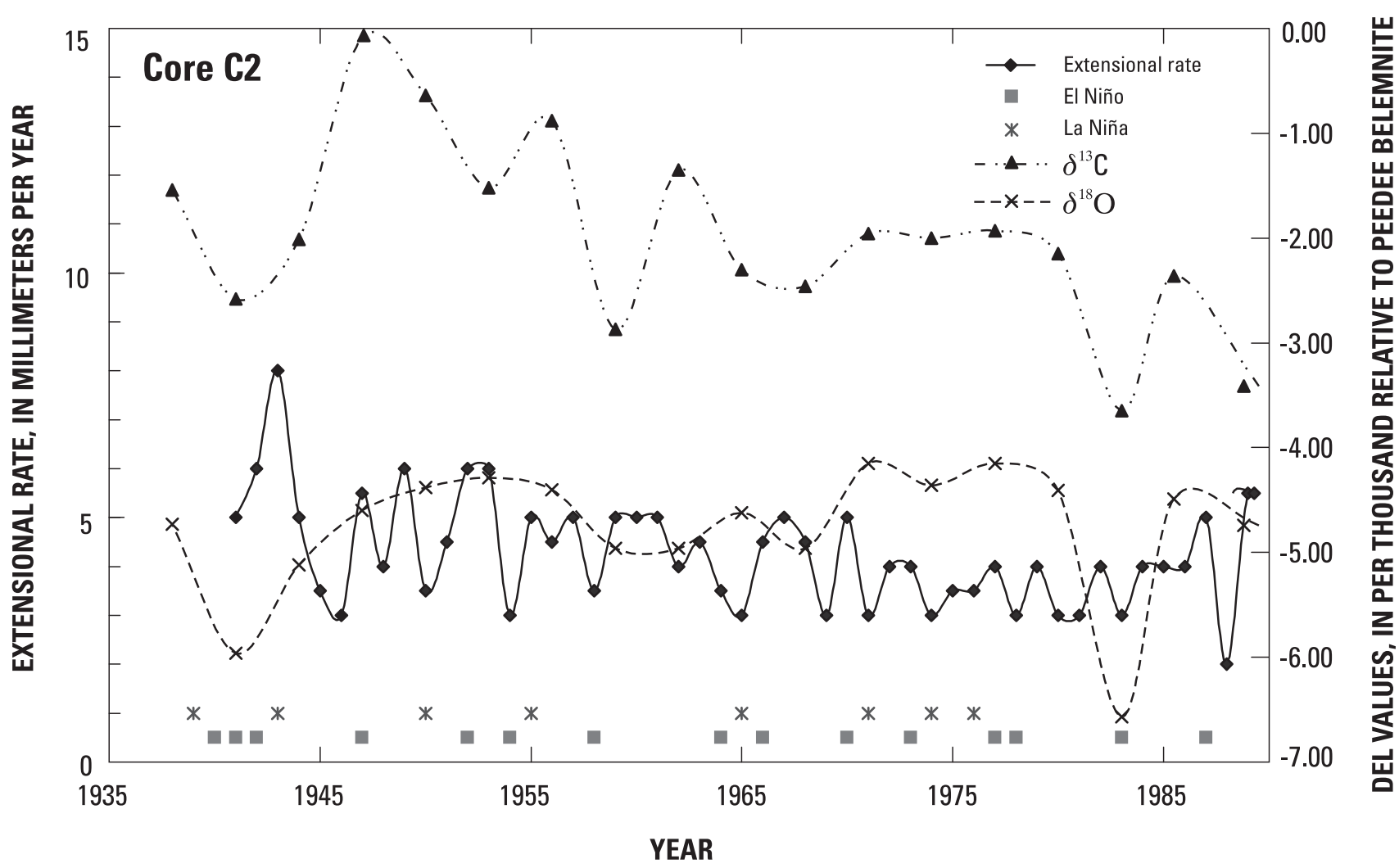

Figure 27. Extensional rates and $\delta^{13} \mathrm{C}$ to $\delta^{18} \mathrm{O}$ values for the period $1938-90$ measured in core $\mathrm{C} 2$, growing at station M0-5 near the outfall in the Bahía de Añasco, Puerto Rico.

62 Assessment of the Habitats, Biota, Sediments, and Water Quality Near the Discharge of Primary-Treated Effluent from the Mayagüez Regional Wastewater Treatment Plant, Bahía de Añasco, Puerto Rico 
Duplicate samples were run in a separate analytical run after the primary samples run. The time-series samples were run sequentially and bracketed by runs of standard solutions, so there is some confidence that the observed temporal changes in trace-element concentrations in the coral lattices are indicative of changing water quality through time. Additional confidence may be derived from the differences observed between the average trace-metal concentrations among all stations, and also in the differences in the average concentrations between station MO-1 near the outfall and station MO-3 in the Escollo Negro. In order of decreasing concentration, lattice-bound trace metals detected were nickel, manganese, copper and iron (similar concentrations), zinc, chromium, and lead (table 13 and appendix C).

The enrichment relative to seawater of latticebound manganese in corals sampled in the Bahía de Añasco is significantly greater than those measured in corals sampled in the Escollo Negro, whereas the enrichment of cadmium in the corals sampled in the Escollo Negro is significantly greater than that observed in the corals sampled in the Bahía de Añasco (fig. 28). Average seawater concentrations were used for comparison, because trace-metal concentrations measured for the receiving waters during this study were often below the minimum reporting limit. The manganese is apparently an indicator of proximity to the discharge of the Río Grande de Añasco. Cadmium is more concentrated in deeper ocean water and its variations in coralline lattices have been related to upwelling intensity in the area in which the corals are growing. The rotation of the earth results in net surface-water movements 90 degrees to the right of the prevailing winds in the northern hemisphere, a phenomenon known as Ekman transport. Ekman transport produced by the easterly trade winds blowing over the deep waters west of Mayagüez should move surface water to the north in the area of the Escollo Negro. Escollo Negro lies on the northern margin of the extensive carbonate platform that lies off of southwest Puerto Rico. Water depths that are commonly less than $10 \mathrm{~m}$ on the platform increase to over $200 \mathrm{~m}$ within a few $\mathrm{km}$ to the north. Therefore, in terms of the intermediate ocean depths that Ekman transport operates, the platform may be considered subaerial, effectively an east-west oriented shoreline. The deeper waters to the north of the platform could be expected to upwell along the shelf break as the surface waters are transported to the north. Overall, the chromium, copper, nickel, and lead values measured in the lattice of the corals growing in the Escollo Negro exceeded those measured for the Bahía de Añasco corals. This suggests that a significant amount of the dissolved metals discharged from the Río Yagüez and the Río Guanajibo may travel westward into the waters bathing the Escollo Negro.

Variations in manganese/calcium and cadmium/calcium ratios measured for the period 1938-90 in the lattice of core C2 suggest that the effect of the Río Grande de Añasco is increasing in the area of the outfall and that periodic upwelling of deep water may affect the interior portions of the Bahía de Añasco (fig. 29).

Table 13. Mean concentrations of lattice-bound trace metals measured in corals growing at station $\mathrm{MO}-1$ (C1 and C2) near the ocean outfall, and at station M0-3 (C7 and C9) in the Escollo Negro reef complex

[Units are nanomoles per mole of calcium, except for nickel, which is in micromoles per mole of calcium. Standard deviations are listed in parentheses.]

\begin{tabular}{lccclcll}
\hline \multicolumn{1}{c}{ Core } & \multicolumn{1}{c}{$\mathrm{Cd} / \mathrm{Ca}$} & \multicolumn{1}{c}{$\mathrm{Cr} / \mathrm{Ca}$} & \multicolumn{1}{c}{$\mathrm{Cu} / \mathrm{Ca}$} & \multicolumn{1}{c}{$\mathrm{Fe} / \mathrm{Ca}$} & $\mathrm{Mn} / \mathrm{Ca}$ & $\mathrm{Ni} / \mathrm{Ca}$ & \multicolumn{1}{c}{$\mathrm{Pb} / \mathrm{Ca}$} \\
\hline C1 (1984-90) $(\mathrm{n}=7)$ & $4.6(2.3)$ & $59.8(26)$ & $250.2(81.2)$ & $386.2(463)$ & $823.7(116.3)$ & $0.5(0.2)$ & $12.4(3.7)$ \\
C2 (1984-90) $(\mathrm{n}=7)$ & $7.5(4.8)$ & $65.5(12.8)$ & $376.6(140.8)$ & $447.4(287.5)$ & $901.3(248.1)$ & $0.9(0.5)$ & $29.5(18.4)$ \\
C2 (1943-89) $(\mathrm{n}=16)$ & $8.4(5.1)$ & $63.7(16.4)$ & $266.9(151.2)$ & $341(340.1)$ & $637.4(121.2)$ & $0.6(0.3)$ & $18(8.8)$ \\
C7 (1985-90) $(\mathrm{n}=6)$ & $34.1(25.2)$ & $71.8(11.7)$ & $606.9(706.1)$ & $287.2(312.3)$ & $342.5(51.3)$ & $0.9(0.1)$ & $19.9(7.1)$ \\
C9 (1984-90) $(\mathrm{n}=7)$ & $19.3(8.3)$ & $73.4(42.2)$ & $414(204.5)$ & $665.1(561.5)$ & $308.1(94.3)$ & $1.6(0.4)$ & $26.4(5)$ \\
\hline
\end{tabular}




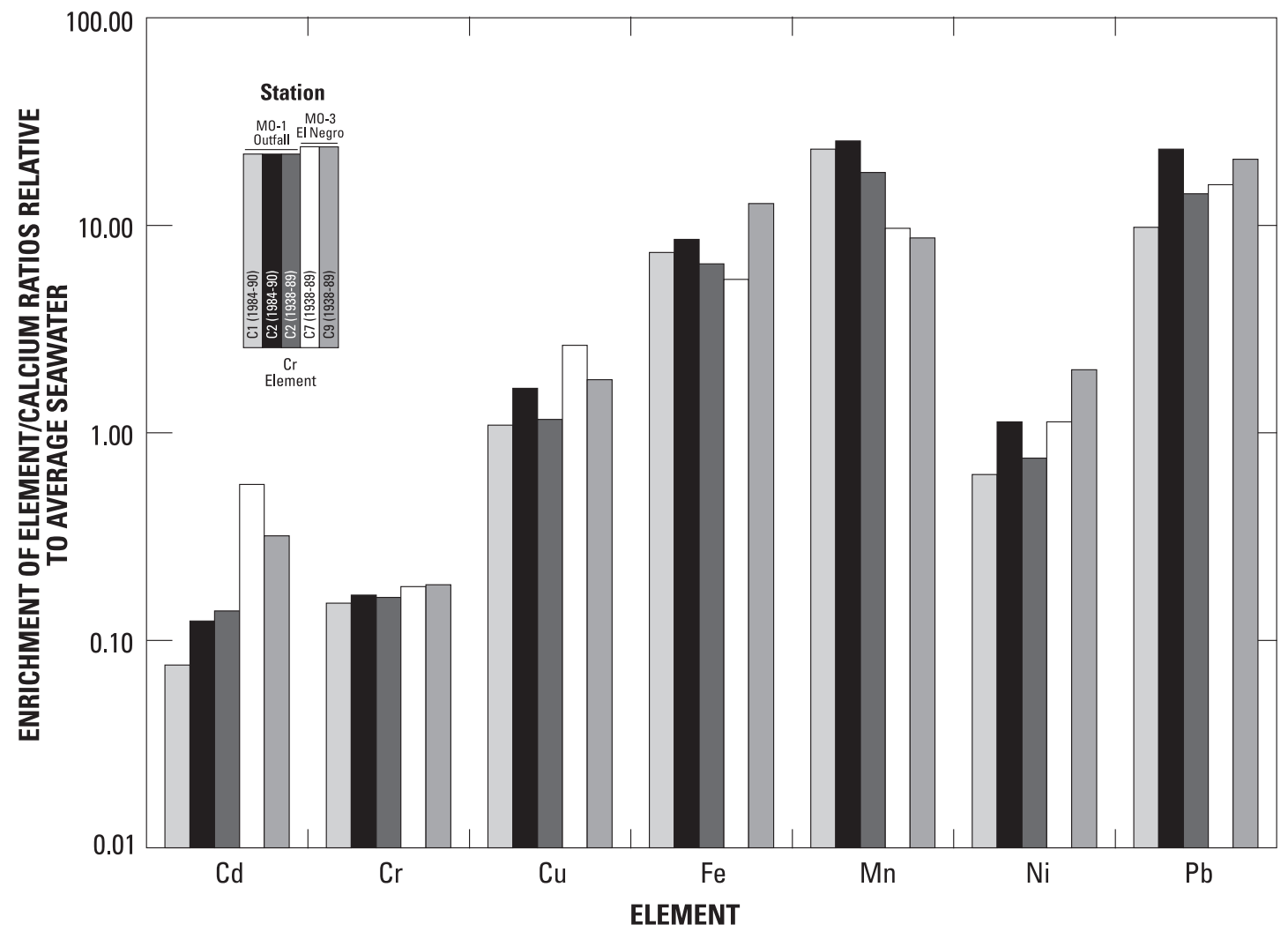

Figure 28. Average enrichment of coral lattice-bound elements relative to average concentrations in seawater for coral cores $\mathrm{C} 1$ and $\mathrm{C} 2$, growing at station $\mathrm{M} 0-1$ near the outfall, and cores $\mathrm{C} 7$ and $\mathrm{C} 9$, growing at station $\mathrm{M} 0-3$ in the Escollo Negro, Puerto Rico.

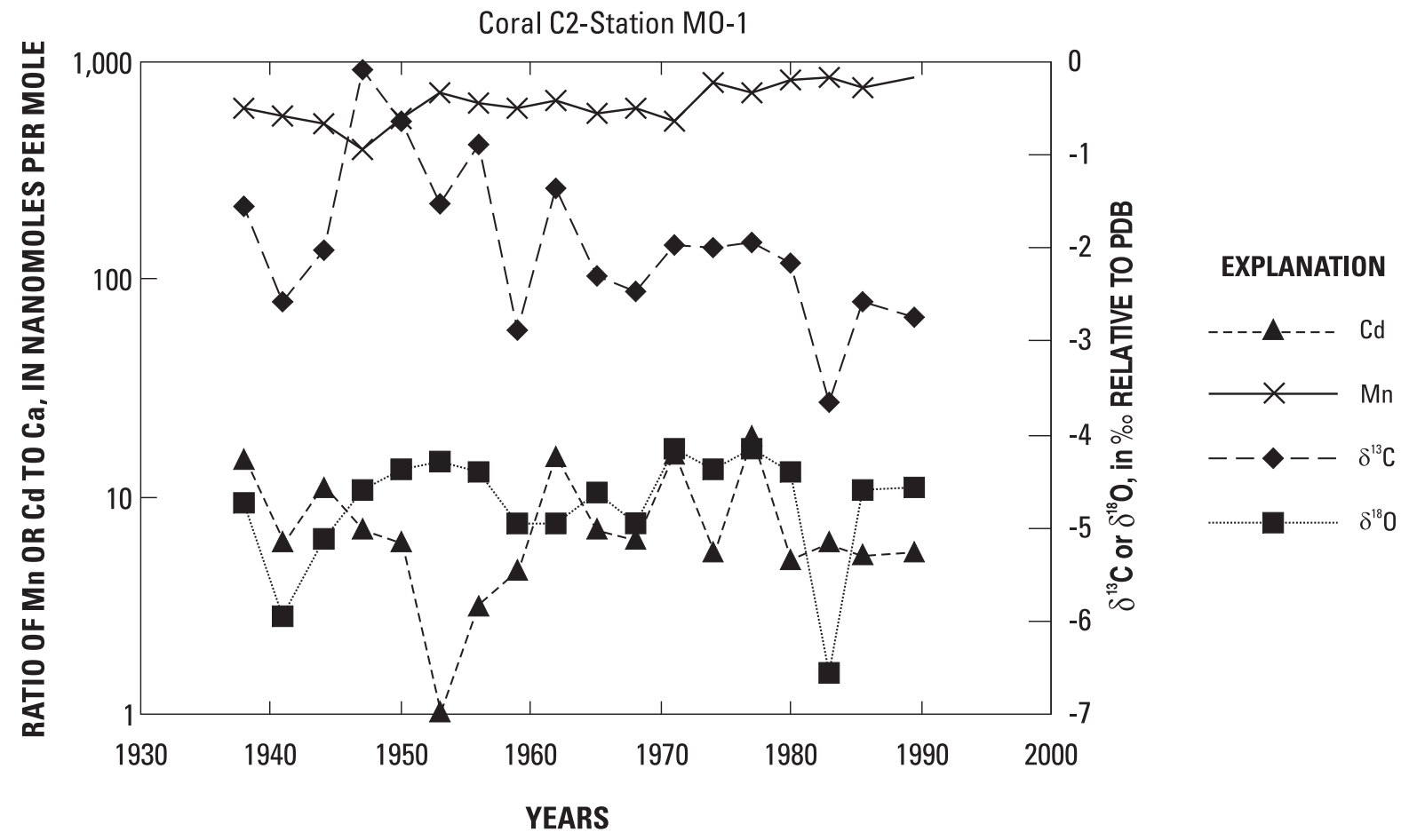

Figure 29. Manganese/calcium and cadmium/calcium ratios, and $\delta^{18} 0$ to $\delta^{13} \mathrm{C}$ values for the period 1938-90 measured in core $\mathrm{C} 2$, growing at station M0-1 in the Bahía de Añasco, Puerto Rico.

64 Assessment of the Habitats, Biota, Sediments, and Water Quality Near the Discharge of Primary-Treated Effluent from the Mayagüez Regional Wastewater Treatment Plant, Bahía de Añasco, Puerto Rico 
To evaluate whether groups of lattice-bound metals are responding similarly to environmental conditions, such as river discharge and ocean circulation patterns (upwelling or downwelling), a principal component analysis was completed using the $8 \mathrm{metal} / \mathrm{calcium}$ ratios measured in 41 samples obtained from the corals at stations MO- 1 and MO-3. The largest factor could account only for 38 percent of the variance; increasing the number of factors to three helped only slightly, accounting for 68 percent of the variance. Therefore, the data for the 28 samples analyzed from station MO-1 were analyzed separately from the 13 samples for station MO-3. This eliminates the variance, due to differences between stations, and is reasonable in light of their distinct environments.

Using the separated data sets, three factors could account for 78 percent of variance observed at station MO-1 and for 74 percent at station MO-3. The factors appear to be associated with river discharge and ocean currents. For convenience, they are named river (factor 1), oceanic (factor 2 at MO-1 and factor 3 at MO-3), and calm (factor 3 at MO- 1 and factor 2 at MO-3). The river factor is likely associated with periods of intense runoff, whereas the oceanic and calm factors are likely associated with changes in surface water chemistry resulting from shifts in local and regional oceanic circulation patterns. The river factor accounted for 49 percent of the variance at MO-1 and 37 percent of the variance at MO-3. The oceanic factor accounted for 17 percent of the variance at MO-1 and 16 percent of the variance at MO-3. The calm factor accounted for 12 percent of the variance at MO- 1 and 21 percent of the variance at MO-3. The elements, communalities, and loadings for the three factors are presented in table 14 . The three factors poorly fit (as determined by the communalities) the observations of chromium and lead at MO-1, and copper and iron at station MO-3. To highlight groups within the decreasingly important factors (shaded in table 14), significant elements are here described as those with scores greater than 0.6 for the river factor, greater than 0.5 for oceanic or calm factor (whichever was the second most significant factor), and greater than 0.4 for the calm or oceanic factor (whichever was the third most significant factor). Thus defined, the significant elements in the river factor are copper, manganese, nickel, lead, and zinc, for station MO-1, and iron, nickel, lead, and zinc, for station MO-3. All the river-factor metals are positively correlated. The oceanic factor consists of cadmium inversely correlated with chromium and manganese at both stations MO-1 and MO-3. Increasing cadmium concentrations coincident with decreasing manganese and chromium concentrations could be expected during oceanic processes such as upwelling, which may produce a diffuse flow of cadmium-rich deep water toward the shelf, effectively displacing manganese-rich coastal waters either

Table 14. Factor loadings and communalities for river, oceanic, and calm factors, derived from a principal- component analysis of lattice-bound trace-metal/calcium ratios measured in coral cores $\mathrm{C} 1$ and $\mathrm{C} 2$ (station $\mathrm{M} 0-1$ near the outfall), and cores $\mathrm{C} 7$ and $\mathrm{C} 9$ (station M0-3 in the Escollo Negro reef complex)

[Factors for each site are listed from left to right in order of decreasing significance in explaining the variability observed at that site. Shaded values identify the significant constituents as described in the text. Abbreviations: comm, communality; prop, proportion of variation accounted for by this factor; --, not applicable]

\begin{tabular}{|c|c|c|c|c|c|c|c|c|}
\hline \multirow{2}{*}{ Metal } & \multicolumn{4}{|c|}{ Station MO-1 } & \multicolumn{4}{|c|}{ Station MO-3 } \\
\hline & River & Oceanic & Calm & Comm & River & Calm & Oceanic & Comm \\
\hline $\mathrm{Cd}$ & 0.56 & 0.72 & -0.04 & 0.83 & -0.07 & 0.67 & -0.62 & 0.84 \\
\hline $\mathrm{Cr}$ & 0.51 & -0.52 & -0.43 & 0.72 & -0.22 & 0.37 & 0.75 & 0.75 \\
\hline $\mathrm{Cu}$ & 0.84 & 0.20 & -0.18 & 0.78 & -0.15 & 0.53 & -0.12 & 0.32 \\
\hline $\mathrm{Fe}$ & 0.57 & -0.06 & -0.67 & 0.78 & 0.66 & 0.43 & 0.11 & 0.63 \\
\hline $\mathrm{Mn}$ & 0.61 & -0.51 & 0.39 & 0.78 & -0.45 & 0.61 & 0.41 & 0.74 \\
\hline $\mathrm{Ni}$ & 0.93 & -0.01 & 0.12 & 0.88 & 0.91 & -0.19 & 0.14 & 0.89 \\
\hline $\mathrm{Pb}$ & 0.71 & -0.33 & 0.30 & 0.70 & 0.75 & 0.45 & -0.18 & 0.80 \\
\hline $\mathrm{Zn}$ & 0.77 & 0.36 & 0.27 & 0.80 & 0.92 & 0.04 & 0.25 & 0.91 \\
\hline Prop & 0.49 & 0.17 & 0.12 & -- & 0.37 & 0.21 & 0.16 & -- \\
\hline
\end{tabular}


against the shore or to a shallow surface lens, or during downwelling, when shifts in cadmium versus manganese and chromium may reverse. The calm factor consists of chromium and iron at station MO-1, and cadmium, manganese, and copper, at station MO-3. During periods when river discharge is low and a distinct oceanic influence is not present, variations in trace metals in the surface waters will reflect those present in the regional water masses, modified by metals diffused upward from the surrounding sediments. Iron and manganese oxyhydroxides are constituents of natural aquatic systems, and are thought to play a predominant role in the cycling of toxic trace elements in both marine and freshwater sediments (Belzile and others, 1989).

Plotting the factor scores (relative magnitude of each factor in a given sample) with time showed that the mineral assemblages are dissimilar for the two cores growing at different rates at each station (fig. 30). At station MO-3, the oceanic factor reached a minimum in 1987. Negative values for the oceanic factor at station MO-3 would correspond to increasing cadmium and decreasing manganese and chromium, effectively an upwelling event. The greatest river score observed was for the 3-year composite of aragonite deposited in coral core C2 during 1976-79, immediately following the September 1975 flood, the largest on record for the Río Grande de Añasco (Johnson and Quiñones-Aponte, 1982). The river factor in the two cores at MO-3 show mirrored trends, perhaps reflecting that faster growing corals add considerable mass during clear-water periods. This is supported by the observation that the calm factor is more dominant in the two fastest growing cores, $\mathrm{C} 1$ and $\mathrm{C} 7$, than it is in the two slower growing corals, $\mathrm{C} 2$ and C9. Again, the validity of these arguments can only be verified by additional laboratory analyses of the coral-core slabs, to obtain records with finer temporal resolution, and relate the observed variations with oceanographic observations.

\section{Sediments}

Sediments sampled in the Bahía de Añasco and the Bahía de Mayagüez were analyzed for texture, percent carbonate, trace elements, and clay mineralogy. In addition, core samples were analyzed for the radioisotope cesium-137 to estimate sedimentation rates. The results were used to elucidate the varying roles of terrigenous and carbonate sediment production, and to clarify how currents and waves are distributing the sediments throughout the study area. Specific results are presented in appendix D.

\section{Texture and Carbonate Content of Bottom Sediments}

The texture of the sediments was similar to that sampled and described by Morelock and others (1983), with groups of sand and gravel, silty sand, and silty clay. Coarser sediments (fig. 31) with higher carbonate content (fig. 32), were sampled in the Manchas Interiores-Manchas Exteriores coral reef complex. The reefal material was dominated by coral fragments, calcareous algae grains, and mollusc fragments. A significant portion of the carbonate grains were darkened. Swift (1967) also found significant darkened carbonate grains in the Bahía de Añasco, as well as terrigenous grains originating from the Río Grande de Añasco, the Río Guanajibo, and local carbonate production.

\section{Texture and Cesium-137 Analytical Results for Discrete Depth Intervals of Core Samples}

The concentration of cesium-137 was measured for four sediment cores (appendix D). The minimum reporting limit for the cesium-137 was 1 milliBecquerel per gram $(\mathrm{mBq} / \mathrm{g})$. The outfall site (station VCO) apparently has a low sedimentation rate, as significant cesium-137 concentrations were only measured in the most recently deposited sample $(0-15 \mathrm{~cm})$. The percent carbonate as determined by wet chemistry was approximately 35 percent, significantly higher than samples recovered in finer sediments nearby that had 10 to 15 percent calcium carbonate. The sidescan-sonar mosaic shows that the southern leg of the outfall is located near a recently buried patch reef. The cesium activity in the sediment core collected from the sand channel in the Manchas Interiores (VCC) was so diluted with carbonate grains that no significant concentrations of cesium-137 were measured. Therefore, no sedimentation rate was calculated for station VCC. The sedimentation rate for the Río Grande de Añasco (station VCA) was calculated to be 3.46 centimeter per year $(\mathrm{cm} / \mathrm{yr})$, while that for the Río Yagüez (station VCY) was 2.3 $\mathrm{cm} / \mathrm{yr}$. 

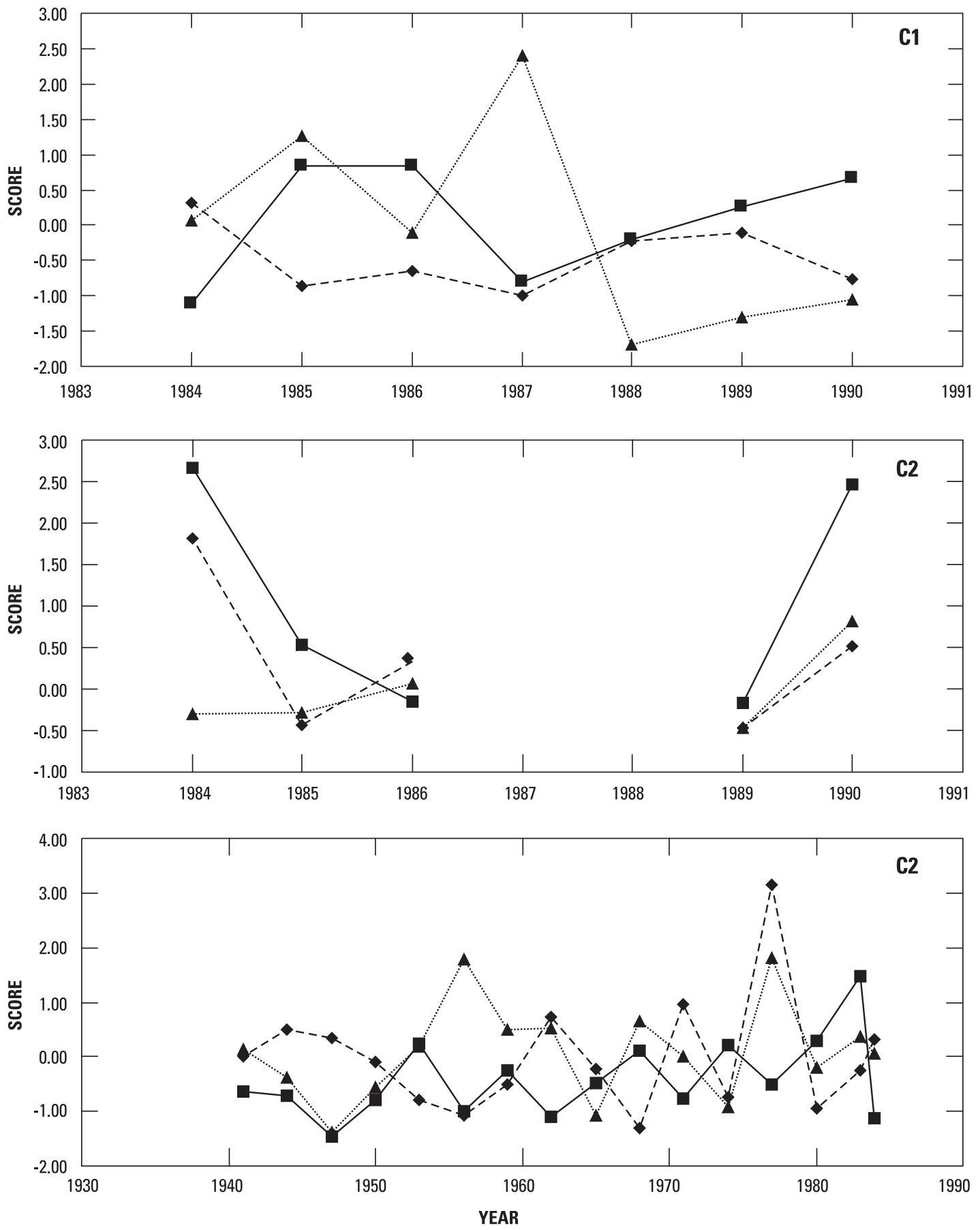

EXPLANATION

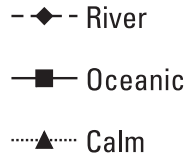

Figure 30. Time series of scores for river, oceanic, and calm factors for the period 1985-90, calculated from trace metals measured in cores $\mathrm{C} 1$ and $\mathrm{C} 2$, growing at station $\mathrm{MO}-1$ near the outfall, and in cores $\mathrm{C} 7$ and $\mathrm{C}$, growing at station $\mathrm{MO}-3$ in the Escollo Negro, Puerto Rico. 

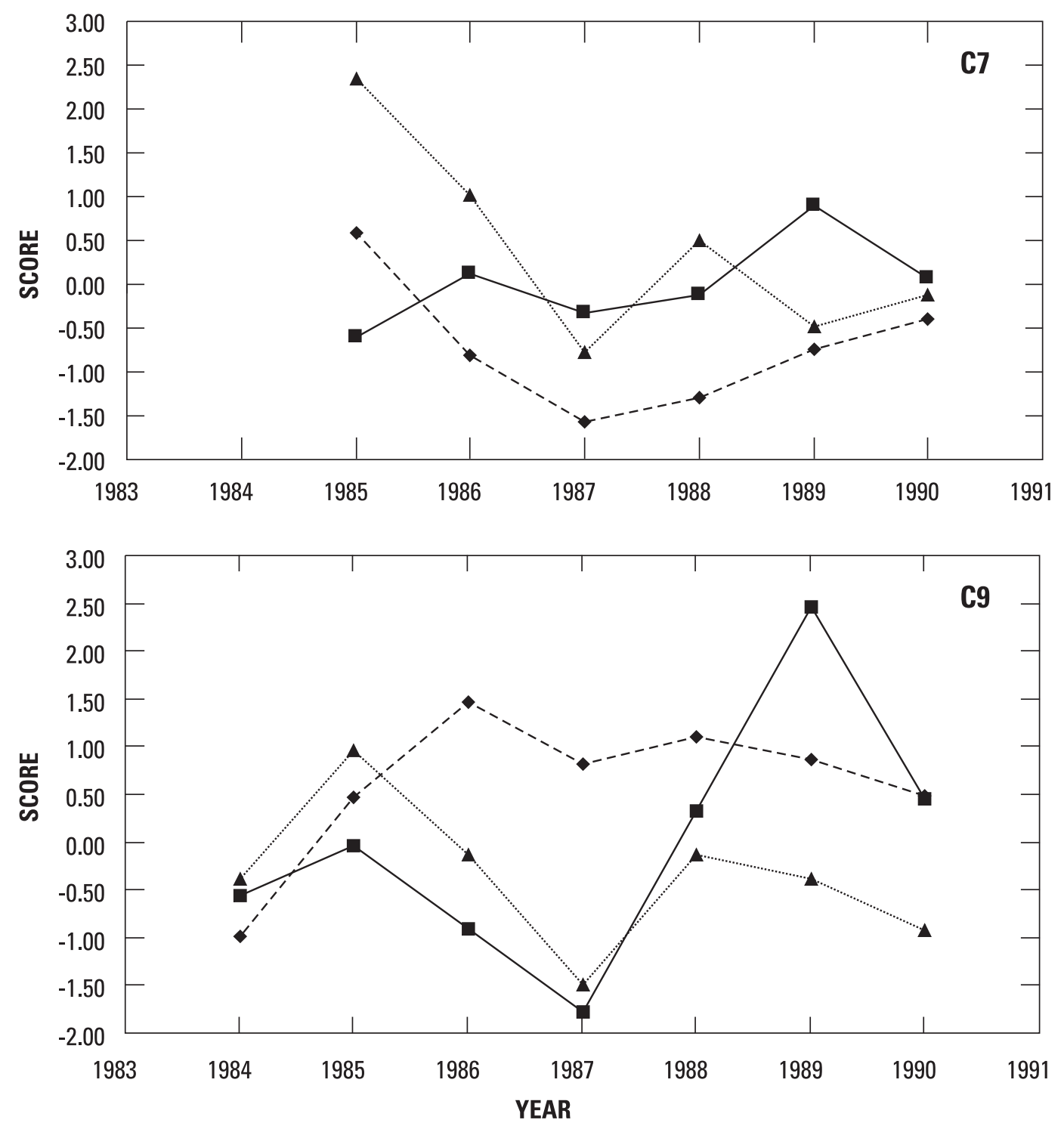

EXPLANATION

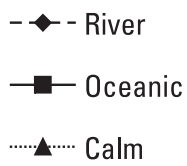

Figure 30. Time series of scores for river, oceanic, and calm factors for the period 1985-90, calculated from trace metals measured in cores $\mathrm{C} 1$ and $\mathrm{C} 2$, growing at station $\mathrm{MO}-1$ near the outfall, and in cores $\mathrm{C} 7$ and $\mathrm{C}$, growing at station $\mathrm{MO}-3$ in the Escollo Negro, Puerto Rico-Continued. 


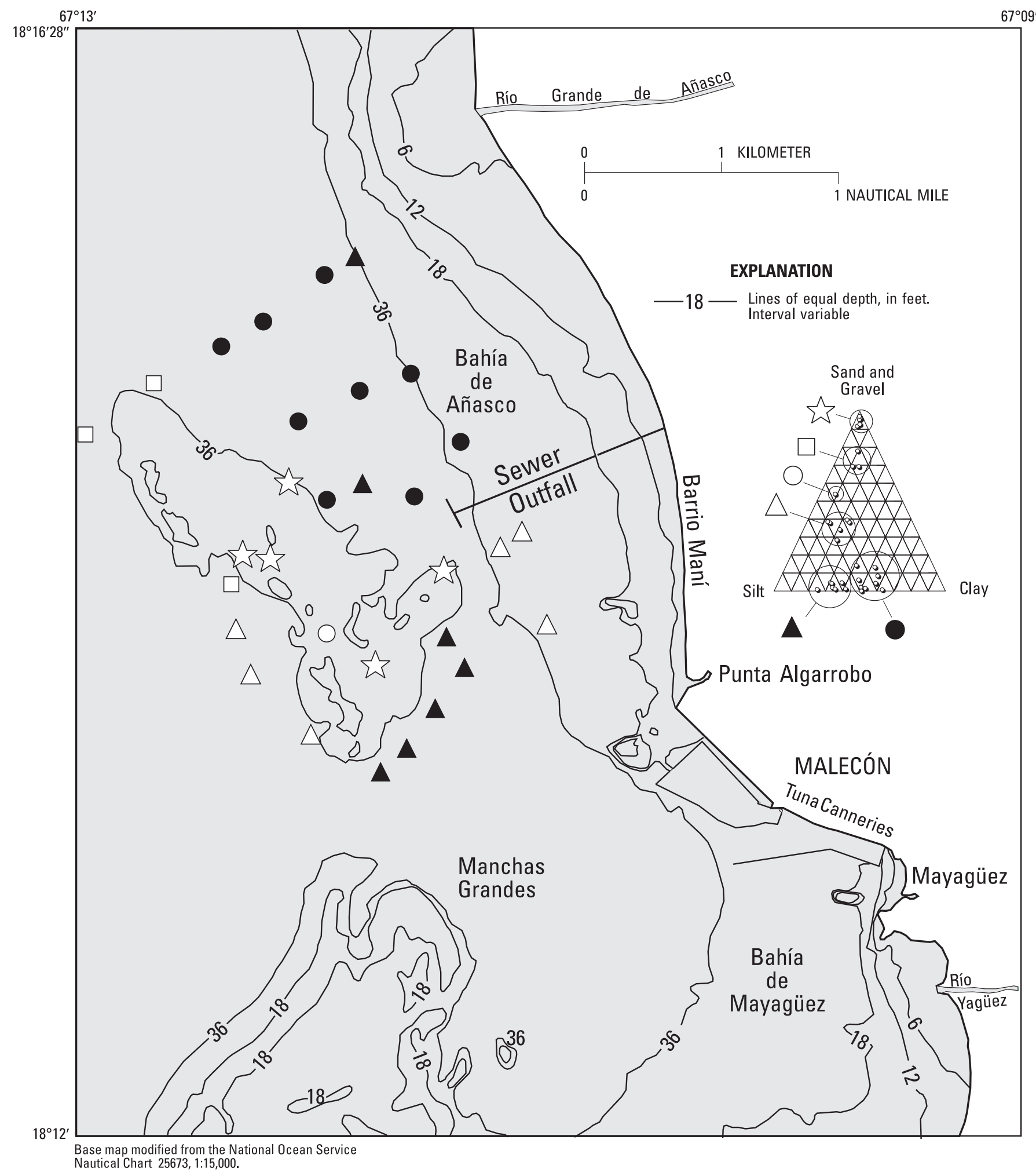

Figure 31. Texture of sediment samples from 31 stations in the Bahía de Añasco and the Bahía de Mayagüez, Puerto Rico. The ternary diagram indicates the relative percentages of sand and gravel, silt, and clay. Depths measured near the delta of the Río Grande de Añasco during this study were shallower than those indicated by the depths shown from the dated navigation chart used as the base map. 


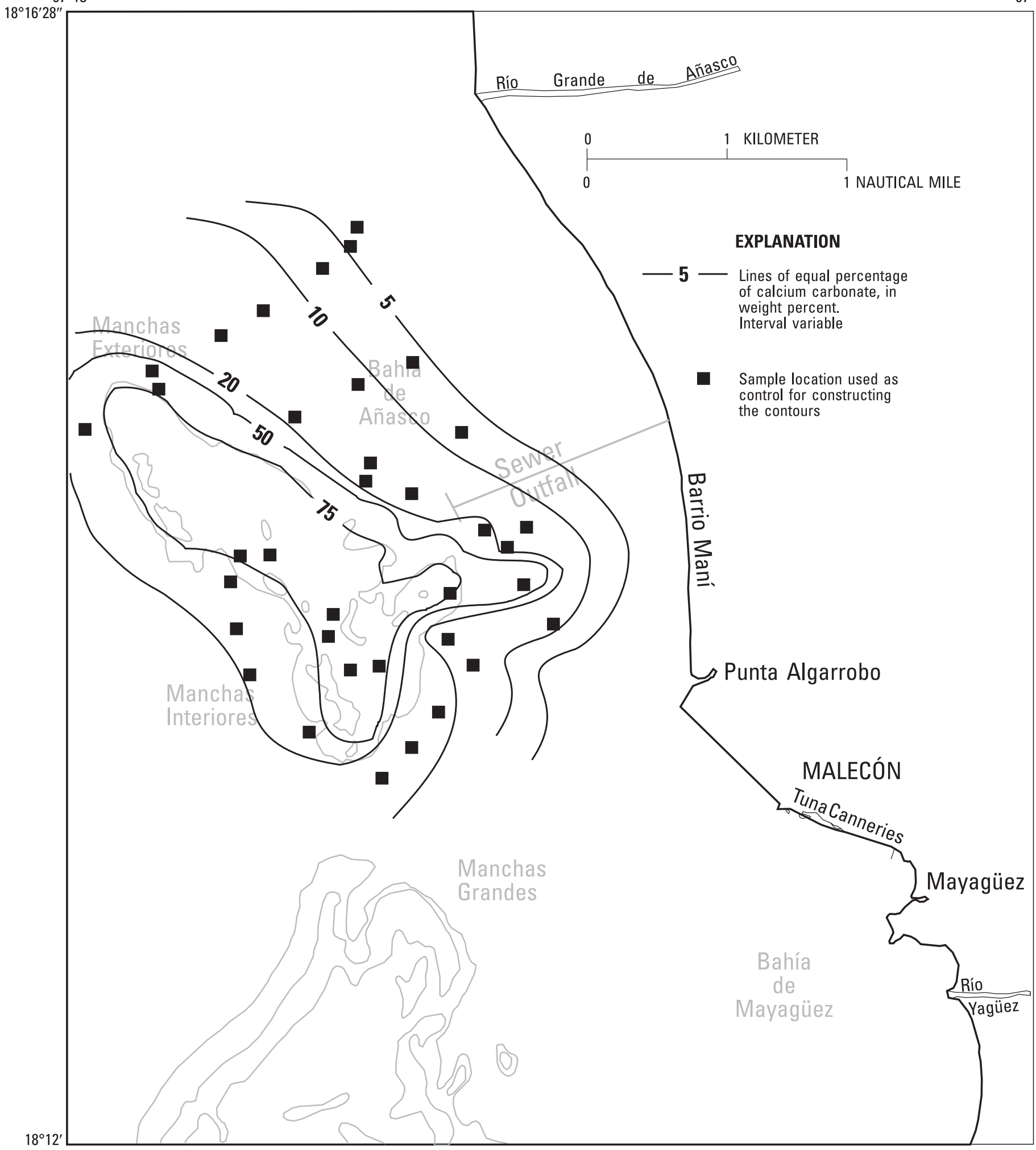

Base map modified from the National Ocean Service Nautical Chart 25673, 1:15,000.

Figure 32. Percentage calcium carbonate measured in sediments sampled in the Bahía de Añasco and the Bahía de Mayagüez, Puerto Rico. Unlabeled bathymetric lines are shown in gray. 


\section{Clay Mineralogy}

The mineralogy of sediments deposited in the Bahía de Añasco (appendix D) reflect the sources in the uplands watersheds, carbonate production, and diagenesis of the marine sediments. Pirie (1967) identified the major clay types illite, chlorite, kaolinite and montmorillonite. The target of Pirie's work was specifically the terrigenous grains. Therefore, he used aggressive digestion techniques that eliminated or obscured the presence of aragonite muds and diagenetic fabrics that were documented during the current study. The presence of kutnahorite and glauconite in the sediments of the Bahía de Añasco and the Manchas Interiores-Manchas Exteriores coral reef complex suggest that terrigenous sediments, organic material, carbonate grains and bacteria have commonly mixed together during the evolution of the Puerto Rico insular shelf. Glauconite is a green micaceous mineral that can be found filling voids of carbonate grains sampled from almost any area off western Puerto Rico (Schneidermann and others, 1976), and has been observed in the tests of foraminifers sampled from the submerged reef immediately west of Manchas Exteriores (Seiglie, 1968). It forms under moderately reducing conditions through the mediation, in some cases at least, of sulfate-reducing bacteria (Deer and others, 1977). The presence of reducing conditions and the presence of reduced sulfur is confirmed by the identification of pyrite, $\mathrm{FeS}_{2}$, in the sediments. Glauconite was not identified as a separate phase in the diffractographs of the samples obtained during the current study; its presence was likely included within the smectite group which shares similar crystallographic properties. Aragonite, manganese-magnesium carbonates, and calcite, were common components of almost all of the sediments sampled away from the mouth of the Río Grande de Añasco. A particularly strong pattern for a manganese carbonate was present in sample GS18 and the mineral kutnahorite, $\mathrm{CaMn}\left(\mathrm{CO}_{3}\right)_{2}$, was identified. Kutnahorite resembles dolomite, $\mathrm{CaMn}\left(\mathrm{CO}_{3}\right)_{2}$, in $\mathrm{X}$-ray diffractographs, and forms a solid solution between rhodochrosite, $\mathrm{MnCO}_{3}$, and calcite, $\mathrm{CaCO}_{3}$. Its formation is bacterially-mediated, and it has been observed in electron microscopy to form as rims on calcite grains in laminated lake sediments (Lora R. Stevens, University of Minnesota, oral commun., 1997). Bacterially-mediated diagenesis of the carbonate grains in the Bahía de Añasco has apparently produced an impure carbonate population within the sediments that is geochemically distinct from carbonates accumulating west of Puerto Rico in areas far removed from the effect of the rivers.

\section{Provenance of Sediments}

Organic material and trace metals contained in core samples and surface grab samples were analyzed by Dr. Art Horowitz at the USGS Sediment Quality laboratory in Doraville, Georgia. The results are presented in appendix D. Significant temporal and spatial variability in the sediment constituents are present. Concentrations of nickel and chromium deposited in the Bahía de Mayagüez are about 10 times greater than those deposited in the Río Grande de Añasco delta. The concentrations of nickel and chromium in the sediments in the core collected in front of the Río Yagüez (core VCY) varied from 310 to $450 \mathrm{mg} / \mathrm{kg}$ and from 299 to $548 \mathrm{mg} / \mathrm{kg}$, respectively. These values exceed the Probable Effects Level (PEL) (42.8 mg/kg for nickel and $160 \mathrm{mg} / \mathrm{kg}$ for chromium) used in the sediment-quality guidelines developed for Florida (Florida Department of Environmental Protection, 1994). The sources of these sediments are naturally occurring metal-rich laterite deposits southeast of Mayagüez. The mercury concentration of $1.49 \mathrm{mg} / \mathrm{kg}$ measured in one sample (core VCO; 5-10 cm) also exceeds the PEL of 0.696 $\mathrm{mg} / \mathrm{kg}$ established for mercury.

Lead concentrations measured in core VCO, near the outfall, have increased from $5 \mathrm{mg} / \mathrm{kg}$ in the oldest strata to $11 \mathrm{mg} / \mathrm{kg}$ in the most recently deposited sediments. However, even these concentrations are still below those measured for the Río Yagüez core site (station VCY), where lead concentrations varied from 11 to $27 \mathrm{mg} / \mathrm{kg}$. All are well below the PEL for lead, established at $112 \mathrm{mg} / \mathrm{kg}$. As with chromium, cobalt, and nickel, lead concentrations in the rocks draining into the Bahía de Mayagüez are elevated in comparison to those draining into the Bahía de Añasco.

To more clearly understand the sources and fates of sediments in the Bahía de Añasco, a provenance analysis was carried out. The results of the provenance study helped to define the sampled sediments as mixtures of distinct sources, each consisting of a suite of associated elements. 
To study the provenance of the sediments, an endmember mixing model was developed using a dataset of trace element concentrations measured for 51 sediment samples collected in the Bahía de Añasco. The mixing model was developed using extended Q-mode factor analysis that calculated constituent concentrations of "idealized" mathematical endmembers that closely matched the concentrations measured in "observed" endmembers included in the dataset. Sediment sampling was largely confined to the Bahía de Añasco and the reef area, so the dataset excluded the results of a sediment sample collected in the Escollo Negro (GS36). The geochemistry of the carbonate sample collected in the Escollo Negro was significantly different from the diagenetically-altered carbonates of the Bahía de Añasco, and its inclusion reduced the overall fit of a 3 -endmember model tentatively used to describe all of the sediments sampled. The overall fit of the model is described by the communalities, defined as the percentage of variance in the data that can be accounted for by the 3-endmember model.

The endmembers were readily attributed to three sources: sediments discharged by the Río Grande de Añasco, sediments produced by carbonate-fixing organisms within the bay, and sediments discharged by the Río Yagüez/Guanajibo. The three idealized endmembers and their associated observed samples were Añasco (core VCA: 120-140 cm), carbonates (core VCC: $60-110 \mathrm{~cm}$ ), and Yagüez (core VCY: 40-60 cm) (fig. 33).

For this dataset, communalities averaged 96 percent, with a standard deviation of 5 percent. The worst fit was for a downcore sample near the outfall that had an anomalous mercury value of over 1 part per million, whereas no other sample exceeded 0.5 part per million. The communality using the three endmembers for that sample was 71 percent. In general, the 3-endmember model described the mixing of fine terrigenous sediments in the Bahía de Añasco and the Bahía de Mayagüez with communalities exceeding 98 percent. Communalities for carbonate samples varied between 81 percent and 100 percent (table 15).

Results from the provenance study show that sediments discharged from the Río Grande de Añasco and sediments resuspended from the interior of the bay are not transported to the western portion of the
Manchas Interiores, where the healthiest coral communities were documented. Samples collected from the sand channels in that area contain negligible amounts of the Añasco endmember (fig. 34).

The nickel and cobalt-rich sediments typical of the Río Yaguiez and the Río Guanajibo, identified as the Yagüez endmember, are dispersed to the northwest, both to the west and east of the Manchas Interiores (fig. 35).

The percentages of specific endmember contributions at each of the core stations has changed through time. The sedimentation rates calculated for the stations VCA $(3.46 \mathrm{~cm} / \mathrm{yr})$ and VCY $(2.3 \mathrm{~cm} / \mathrm{yr})$ were used to convert the sample depths to approximate age of deposition. The percentage of the Añasco endmember in core VCY (Río Yagüez delta) apparently decreased from the beginning of the century until reaching a minimum in 1975 , and increased since then. This correlates well with decreasing sediment yields throughout the century, as previously cultivated lands were allowed to go fallow, and the Río Grande de Añasco caused a major flood in 1975. The percentage of the Yagüez endmember in the sediments deposited in the sand channels in the western part of the Manchas Interiores is apparently increasing. The percentage of the Yaguiez endmember increased toward the surface of core VCC. The Añasco endmember also increased in core VCC from the base at $110 \mathrm{~cm}$ to a maximum in the sediments sampled at between 15 and $20 \mathrm{~cm}$, and decreased in the more recently deposited sediments (fig. 36).

\section{Water Quality}

The Río Grande de Añasco, the Río Yagüez, and the Río Guanajibo, affect the water quality of the receiving waters, including the Bahía de Añasco and the Bahía de Mayagüez. The Río Grande de Añasco has the largest discharge of the three rivers and is the principal source of sediments deposited in the Bahía de Añasco. Criteria for dissolved oxygen are often not met in the coastal waters near the tuna canneries (fig. 5) (Natural Resources Conservation Service, 1998). Concentrations of total zinc, boron, iron, lead, manganese, and fecal coliform in the Bahía de Mayagüez also have exceeded coastal water-quality criteria (Natural Resources Conservation Service, 1998). 


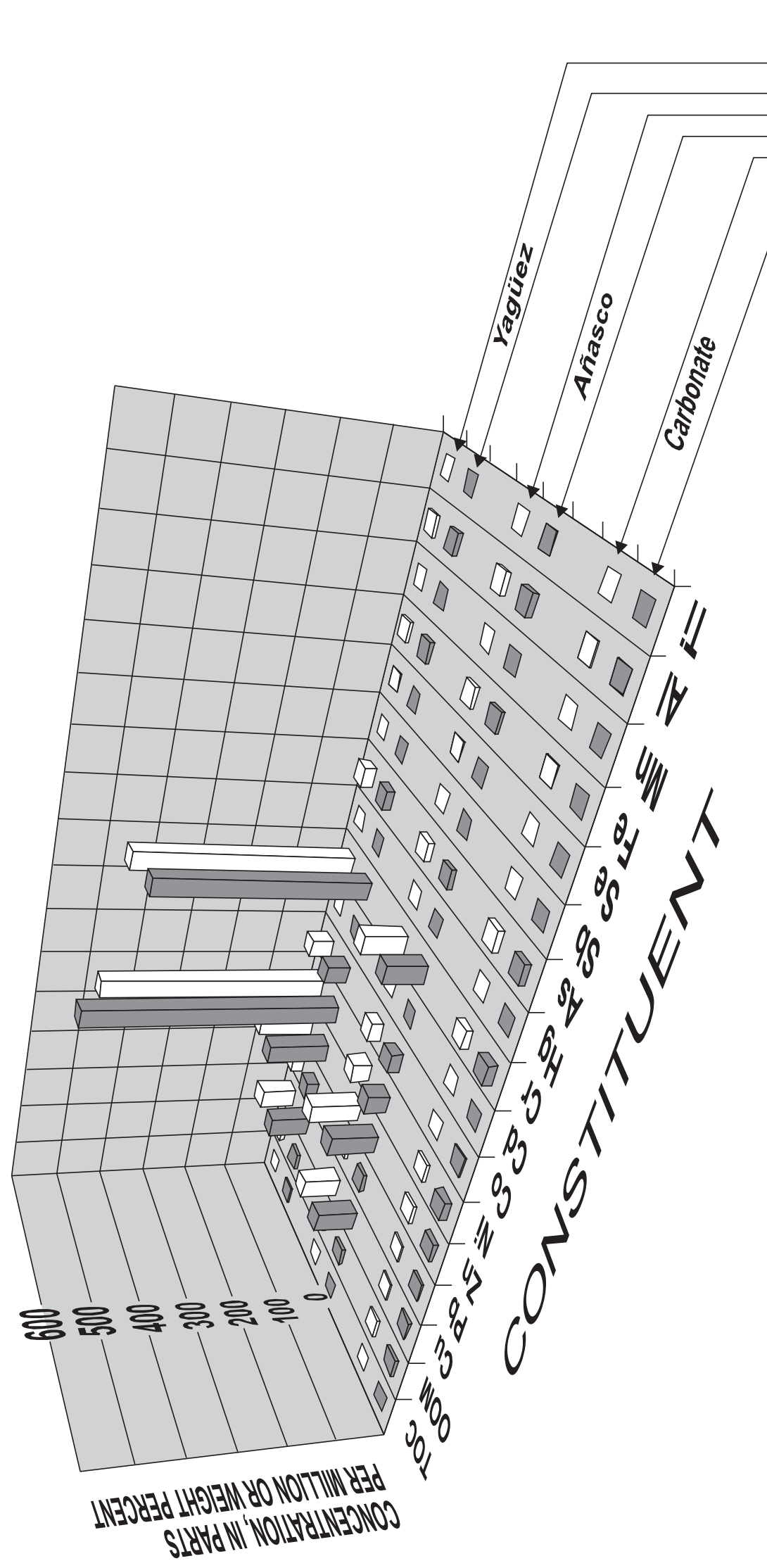

응

为

宅兽

응 등

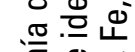

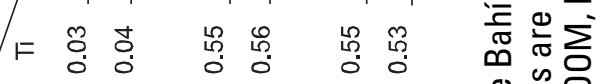

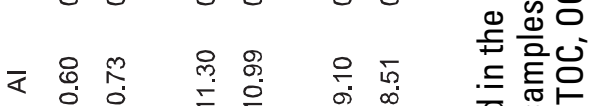

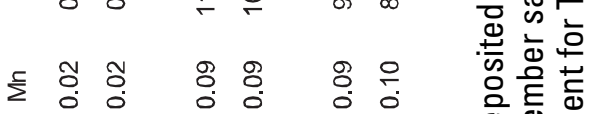

응 है

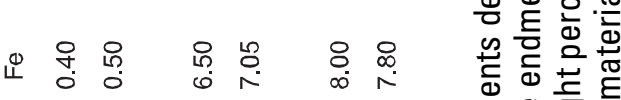

๙

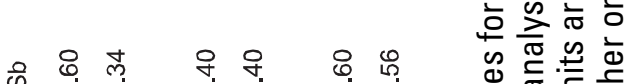

\begin{tabular}{llllll}
0 & 0 & 0 & 0 & 0 \\
0 & 0 & 0 & 0 \\
\hline
\end{tabular}

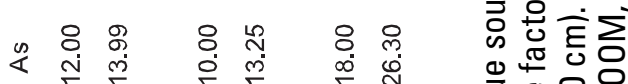

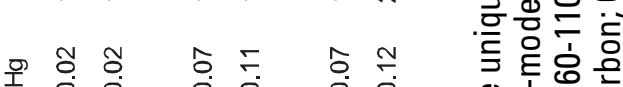

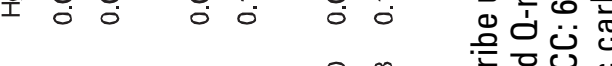

广

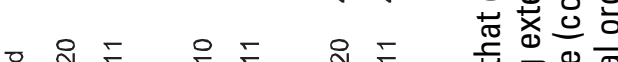

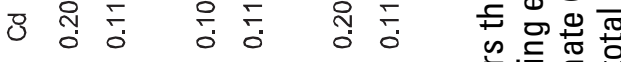

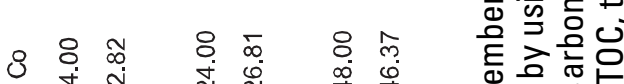

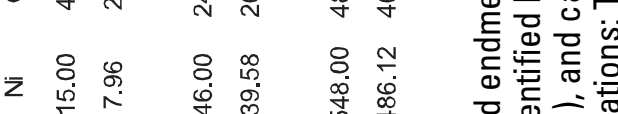

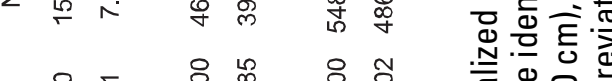

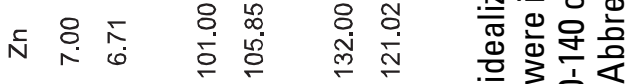

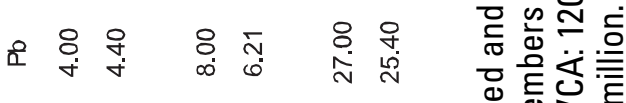

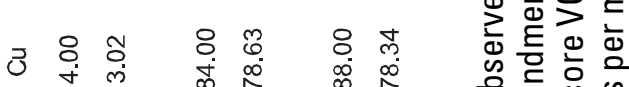

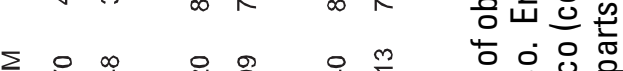

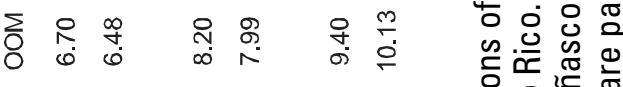

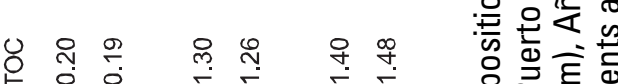

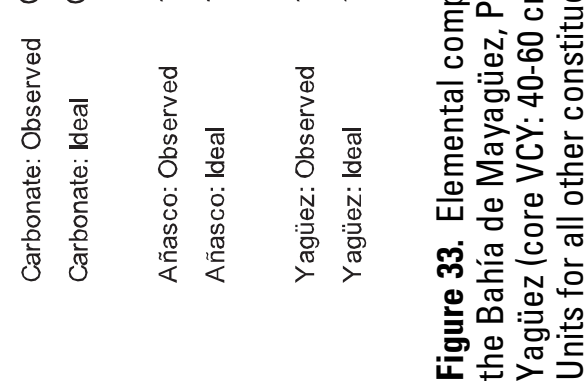


Table 15. Communalities explaining percent of variability measured in geochemical composition of sediment samples that can be accounted for as a mixture of the three idealized endmember compositions detailed in figure 33

[Intervals are depth below the sediment/water interface, in centimeters. The 12 bottom sediment sites in the GS series are assigned a sampling depth of 10 centimeters, the average depth of the Shipeck sampling bucket. Abbreviations: comm, communality]

\begin{tabular}{|c|c|c|c|c|c|c|c|}
\hline \multirow{2}{*}{ Site } & \multicolumn{2}{|c|}{ Sampled interval } & \multirow{2}{*}{ Comm } & \multirow{2}{*}{ Site } & \multicolumn{2}{|c|}{ Sampled interval } & \multirow{2}{*}{ Comm } \\
\hline & Top & Bottom & & & Top & Bottom & \\
\hline $\mathrm{VCA}$ & 0 & 20 & 0.98 & VCC & 10 & 15 & 0.98 \\
\hline VCA & 20 & 40 & 0.98 & $\mathrm{VCC}$ & 15 & 20 & 0.91 \\
\hline VCA & 40 & 60 & 0.98 & $\mathrm{VCC}$ & 20 & 60 & 0.90 \\
\hline VCA & 60 & 80 & 0.99 & VCC & 60 & 110 & 0.90 \\
\hline VCA & 80 & 100 & 0.98 & $\mathrm{VCO}$ & 0.0 & 5.1 & 0.96 \\
\hline VCA & 100 & 120 & 0.99 & $\mathrm{VCO}$ & 5.1 & 10.2 & 0.71 \\
\hline VCA & 120 & 140 & 0.99 & $\mathrm{VCO}$ & 10.2 & 15.2 & 0.97 \\
\hline VCA & 140 & 160 & 0.95 & $\mathrm{VCO}$ & 15.2 & 20.3 & 0.97 \\
\hline VCA & 160 & 180 & 0.99 & $\mathrm{VCO}$ & 25.4 & 30.5 & 0.97 \\
\hline VCA & 180 & 200 & 0.99 & $\mathrm{VCO}$ & 30.5 & 35.6 & 0.95 \\
\hline VCA & 200 & 220 & 0.97 & $\mathrm{VCO}$ & 35.6 & 45.7 & 0.93 \\
\hline VCA & 220 & 240 & 0.98 & $\mathrm{VCO}$ & 45.7 & 50.8 & 0.95 \\
\hline VCA & 240 & 258 & 0.98 & $\mathrm{VCO}$ & 61.0 & 63.5 & 0.92 \\
\hline VCY & 0 & 20 & 0.99 & GS1 & 0.0 & 5.0 & 0.97 \\
\hline VCY & 20 & 40 & 0.99 & GS2 & 0 & 10 & 0.97 \\
\hline VCY & 40 & 60 & 0.99 & GS6 & 0 & 10 & 0.97 \\
\hline VCY & 60 & 80 & 0.99 & GS7 & 0 & 10 & 0.97 \\
\hline VCY & 80 & 100 & 0.99 & GS11 & 0 & 10 & 0.99 \\
\hline VCY & 100 & 120 & 0.99 & GS12 & 0 & 10 & 0.97 \\
\hline VCY & 120 & 140 & 0.99 & GS16 & 0 & 10 & 0.92 \\
\hline VCY & 140 & 160 & 0.99 & GS18 & 0 & 10 & 0.92 \\
\hline VCY & 160 & 180 & 0.99 & GS21 & 0 & 10 & 0.97 \\
\hline VCY & 180 & 200 & 0.98 & GS34 & 0 & 10 & 0.81 \\
\hline VCY & 200 & 220 & 0.97 & GS35 & 0 & 10 & 0.85 \\
\hline $\mathrm{VCC}$ & 0 & 5 & 0.90 & GS38 & 0 & 10 & 0.96 \\
\hline VCC & 5 & 10 & 0.92 & & & & \\
\hline
\end{tabular}




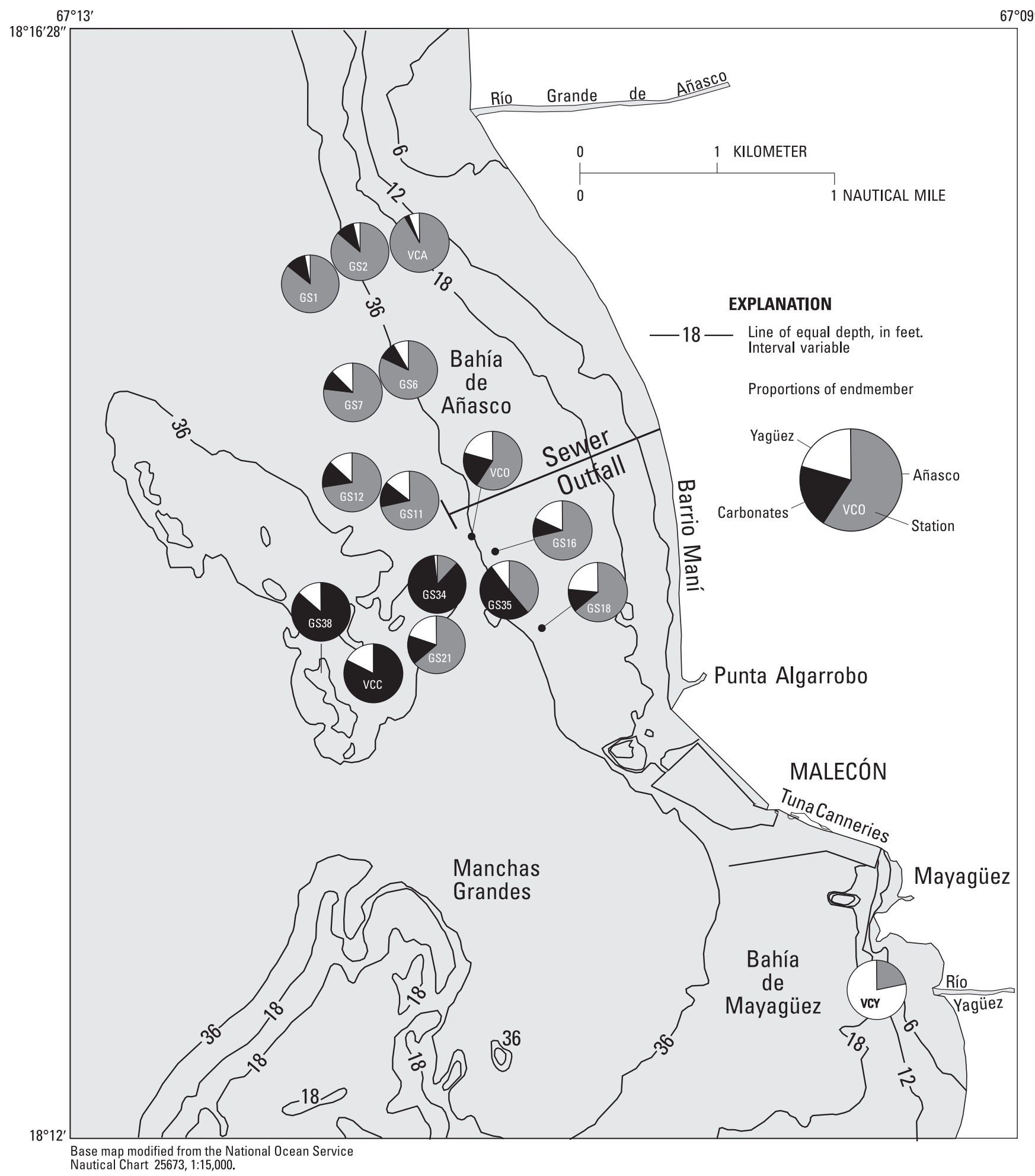

Figure 34. Relative percentages of source material for bottom sediments sampled from 16 stations in the Bahía de Añasco and in and around the Manchas Interiores-Manchas Exteriores coral reef complex, Puerto Rico. The pie charts indicate the relative percentages contributed from idealized endmember sources identified with extended Q-mode factor analysis as typical of the Río Grande de Añasco, the Río Yagüez (includes sediment from the Río Guanajibo), and carbonate grains produced by local benthos (fig. 33). Pie charts are centered over the sample location unless otherwise indicated. Depths measured near the delta of the Río Grande de Añasco during this study were shallower that those indicated by the depths shown from the dated navigation chart used as the base map. 

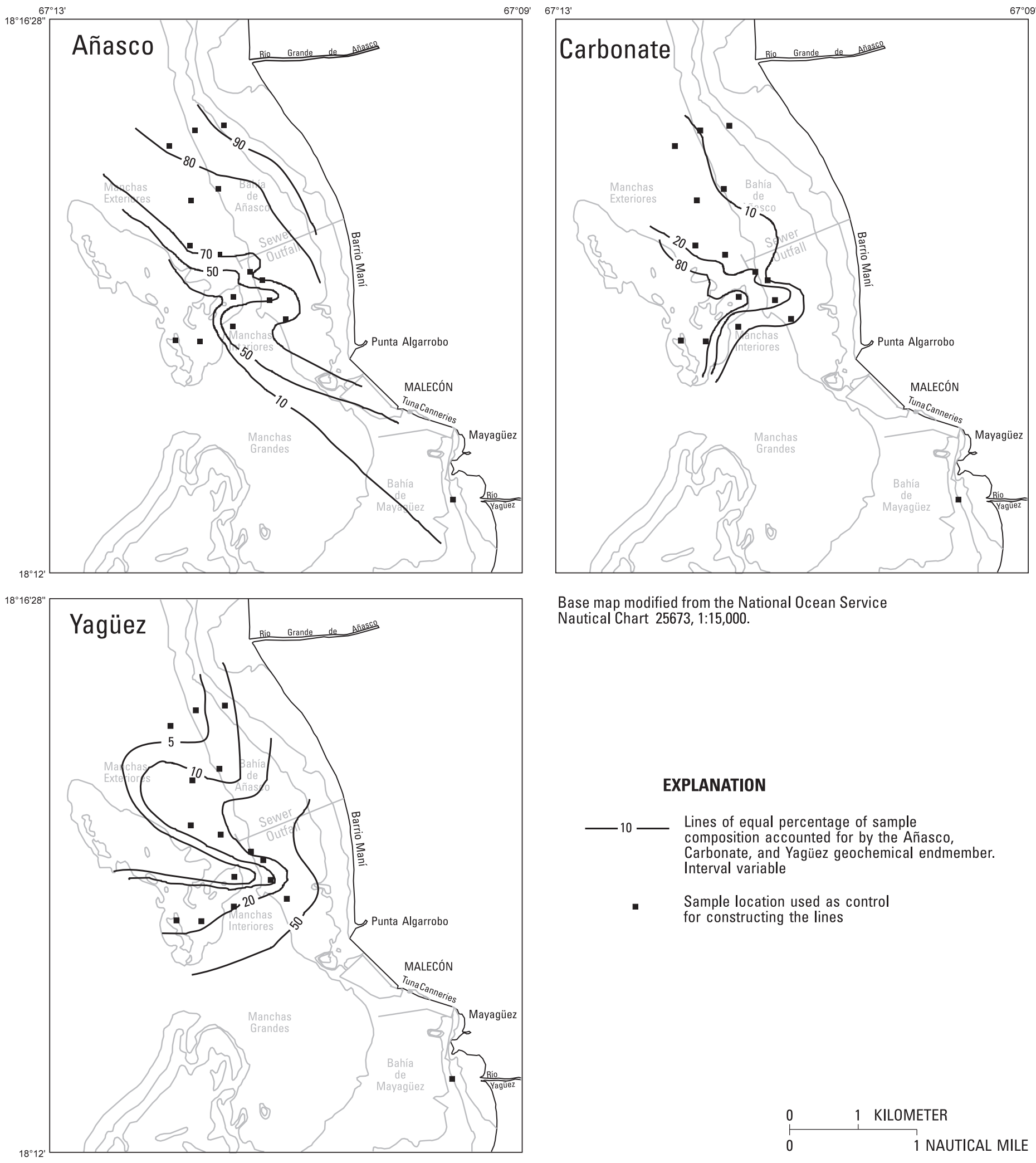

Base map modified from the National Ocean Service Nautical Chart 25673, 1:15,000.
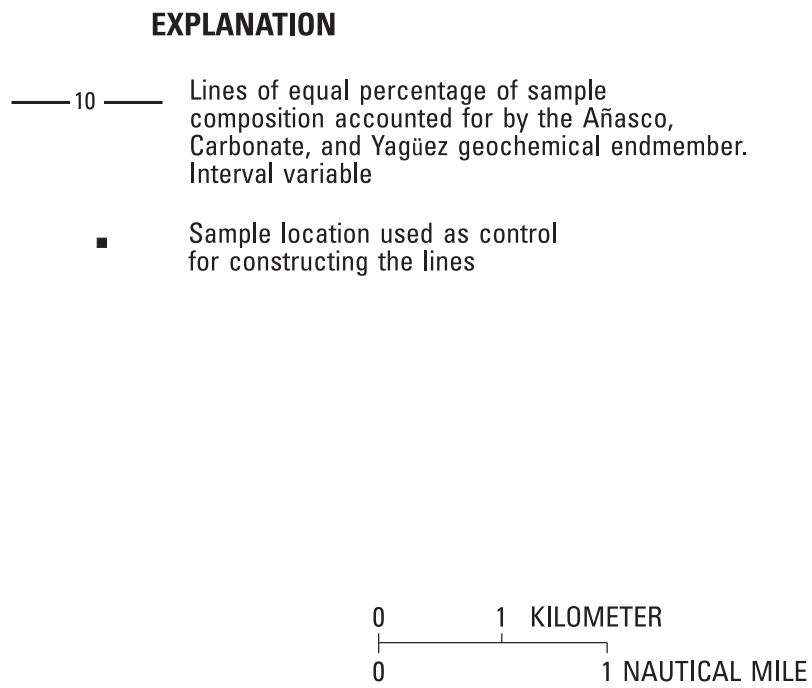

Figure 35. Percentage of sediment composition accounted for by the geochemical endmembers representing sediment sources identified as Añasco, carbonate, and Yagüez, using extended Q-mode factor analysis. Results of the factor analysis are listed in appendix D-7.

76 Assessment of the Habitats, Biota, Sediments, and Water Quality Near the Discharge of Primary-Treated Effluent from the Mayagüez Regional Wastewater Treatment Plant, Bahía de Añasco, Puerto Rico 


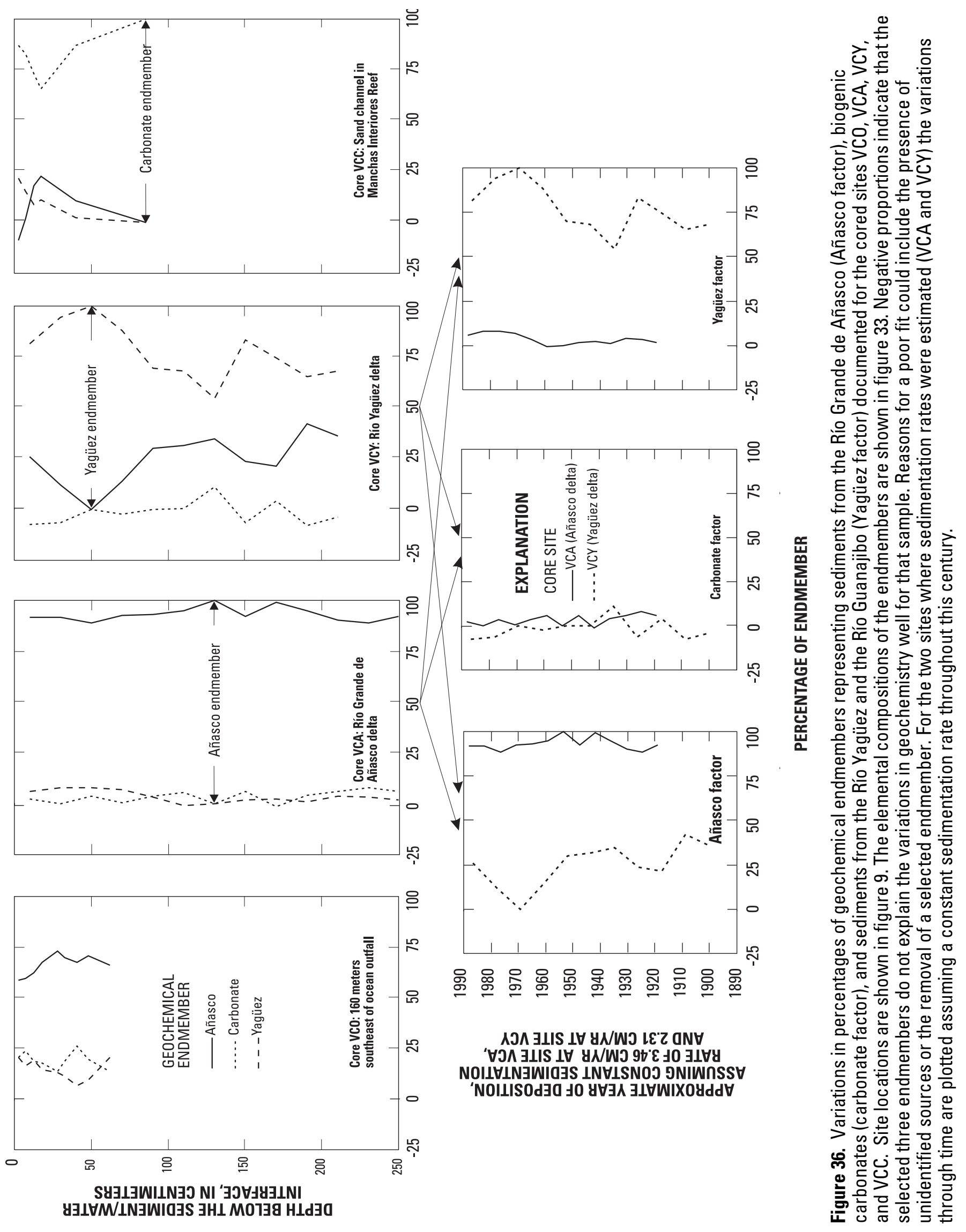

Summary of Results $\quad 77$ 


\section{Historical Water Quality of the Río Grande de Añasco, the Río Yagüez, and the Río Guanajibo}

Several local wastewater plants discharge into the drainage system of the Río Guanajibo, resulting in higher overall contaminant loadings for that river in comparison with the Río Grande de Añasco (Natural Resources Conservation Service, 1998). Wet and dry years for the Río Grande de Añasco and the Río Guanajibo covary (fig. 37). Data collected at the stream gage and water-quality site on the Río Rosario (USGS station number 50136400) show that, in general, sediment loads discharged from the uplands also correlate with average discharge. The greatest daily load of sediment, 74,700 tons, passed the Río Rosario station on October 7, 1985, the day of the tragic landslides that occurred in the Mameyes sector of Ponce.

Specific conductivity is higher and dissolved oxygen concentrations are lower in the Río Guanajibo than they are in the Río Grande de Añasco (fig. 38).
The Río Guanajibo drainage basin contains more municipal wastewater treatment plants, has lower average slopes, and has more ground water storage than the Río Grande de Añasco. The Río Guanajibo has an extensive alluvial valley underlain by 50 to 150 feet of clay, sand, and gravel, deposited on limestone in the southern part of the watershed, and deposited directly on andesite and basalt in the northern part of the watershed (Colón-Dieppa and Quiñones-Márquez, 1985).

\section{Receiving Water Quality, January 1991}

Vertical profiles of the marine water quality in the area of the ocean outfall showed that the waters are well mixed and oxygen saturated. A summary of all analyses for priority pollutants, pesticides, herbicides, metals, general inorganics, and radionuclides, done at Rocky Mountain Analytical Laboratory (RMAL) are presented in table 16 (page 91). Detailed results are presented in appendix E.

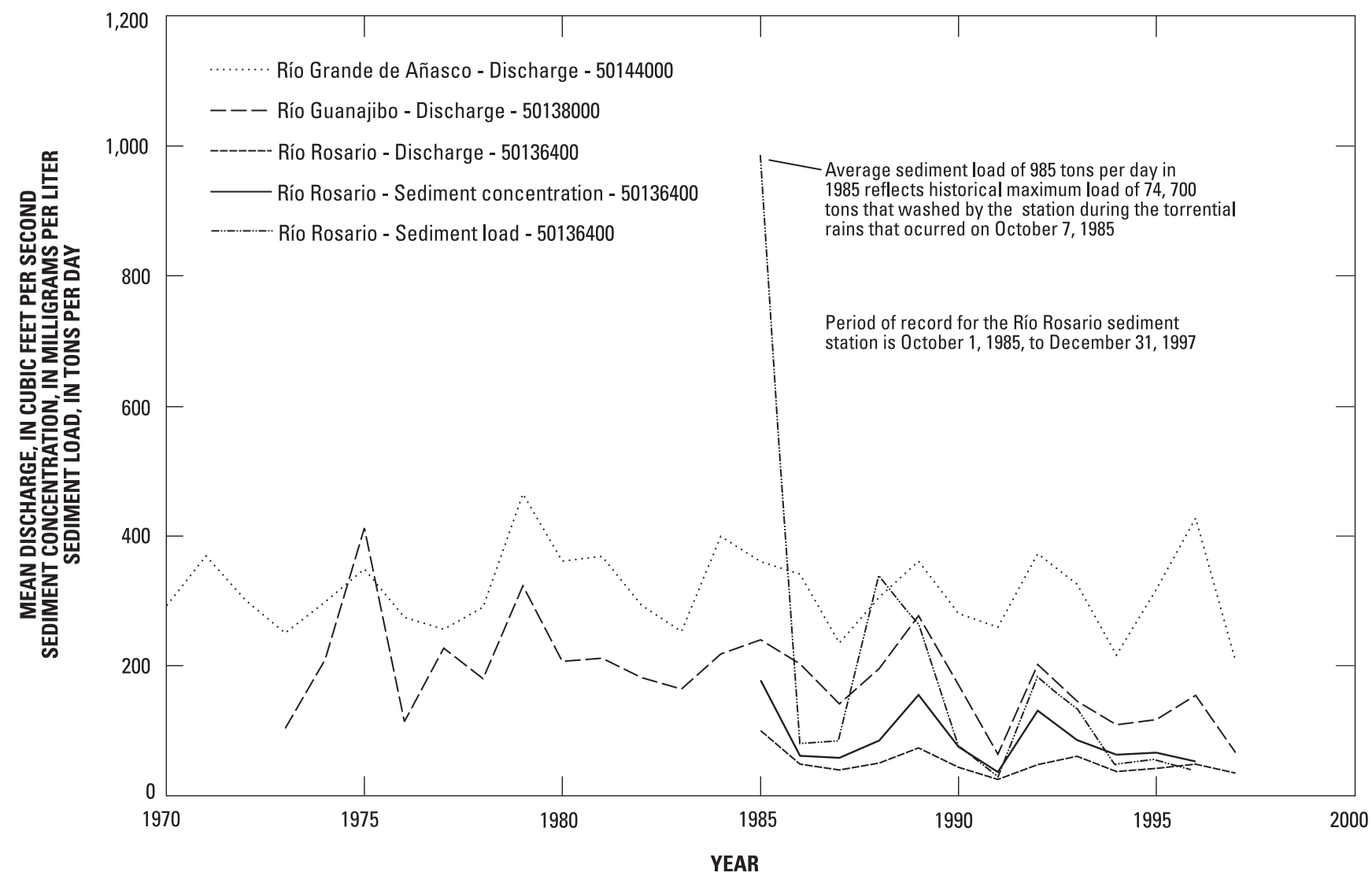

Figure 37. Yearly mean discharges for Río Grande de Añasco, the Río Guanajibo, and the Río Rosario, and sediment concentrations and loads measured at the Río Rosario station.

78 Assessment of the Habitats, Biota, Sediments, and Water Quality Near the Discharge of Primary-Treated Effluent from the Mayagüez Regional Wastewater Treatment Plant, Bahía de Añasco, Puerto Rico 

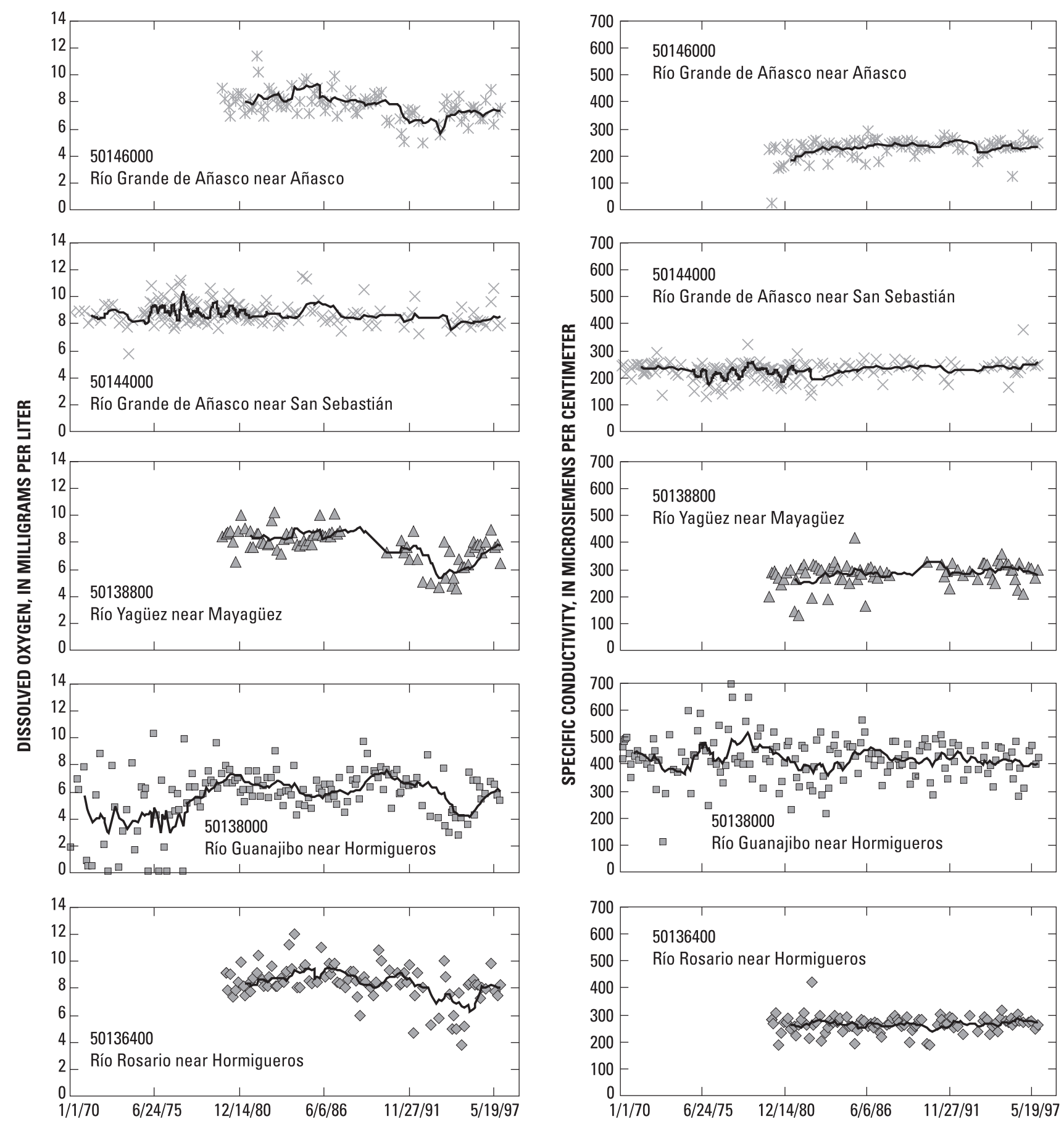

DATE

Figure 38. Specific-conductivity values and dissolved-oxygen concentrations measured at five west coast water-quality monitoring sites for the period 1970-97. The solid line is a 5-point moving average of the individual results. 
Flow-weighted composites of the effluent were collected daily over a period of eight days in a refrigerated sampler and sent by overnight courier to Envirosystems Inc., in New Hampshire. The results of the chronic and acute bioassays are presented in appendix E.

Synthetic organic compounds and trace metals were analyzed in marine water, as well as influent and effluent wastewater and fresh water from the Río Grande de Añasco and the Río Yagüez. Results of the water-quality sampling verify that the outfall is effectively dispersing the effluent within the prescribed mixing zone. The data are briefly summarized below.

\section{Dissolved Nutrients, Chlorophyll, and Bacteria in the Surface Waters}

Ammonia concentrations of $20.6 \mathrm{mg} / \mathrm{L}$ were measured in the effluent waste stream at the plant. The highest value measured in the zone of initial dilution, inside of the plume, was $0.68 \mathrm{mg} / \mathrm{L}$. Ammonia was not detected at the boundary of the initial mixing zone or at any other marine sampling station. Ammonia was not detected above the minimum reporting limit of $0.1 \mathrm{mg} / \mathrm{L}$ in the Río Yagüez, and had a concentration of $0.25 \mathrm{mg} / \mathrm{L}$ in the Río Grande de Añasco.

Neither nitrate nor nitrite was detected $(<0.1 \mathrm{mg} / \mathrm{L})$ in the influent, effluent, or in marine samples. Concentrations in the rivers were 0.28 (Río Grande de Añasco) and $0.46 \mathrm{mg} / \mathrm{L}$ (Río Yagüez).

Orthophosphate concentrations in the wastewater were 4.4 and $5.3 \mathrm{mg} / \mathrm{L}$ for the influent and effluent, respectively. This constituent was not found in the Río Grande de Añasco and was measured at a concentration of $0.068 \mathrm{mg} / \mathrm{L}$ in the Río Yagüez. Orthophosphate was not detected above the minimum reporting limit of $0.05 \mathrm{mg} / \mathrm{L}$ in any of the marine samples.

Total phosphorus concentration was 7.9 and $6.1 \mathrm{mg} / \mathrm{L}$, as phosphorus, in influent and effluent, respectively. Phosphorus was non-detectable $(<0.05$ $\mathrm{mg} / \mathrm{L}$ ) in river water, and was found at a concentration of $2.7 \mathrm{mg} / \mathrm{L}$ in one marine sample collected in the far mixing zone (QW-7), between the outfall and the Río
Grande de Añasco. No phosphorus was measured at any other marine station.

Total Kjeldahl nitrogen was detected in the influent and effluent and at the control marine station. At a detection limit of $5.0 \mathrm{mg} / \mathrm{L}$, total Kjeldahl nitrogen was not found in any of the remaining saltwater stations. It was not detected at a limit of $0.5 \mathrm{mg} / \mathrm{L}$ in river waters.

Both chlorophyll ' $a$ ' and the light extinction coefficient (LEC) are listed in table 16 and in appendix E. At station QW-5, in the northernmost plume in the initial mixing zone (IMZ), chlorophyll 'a' measured $0.0879 \mathrm{mg} / \mathrm{m}^{3}$ at 10:40 a.m. By 3:00 p.m., station QW-4, the other IMZ site, was sampled, and chlorophyll 'a' measured $0.1771 \mathrm{mg} / \mathrm{m}^{3}$. The effluent $\left(1.32 \mathrm{mg} / \mathrm{m}^{3}\right)$ and the Río Yagüez $\left(1.64 \mathrm{mg} / \mathrm{m}^{3}\right)$ had the highest levels. Significant diurnal variations occur in phytoplankton populations. Chlorophyll 'a' increased throughout the day for the receiving waters measured on January 29. The lowest concentration for the day $\left(0.096 \mathrm{mg} / \mathrm{m}^{3}\right)$ was measured at QW-8 at 9:30 a.m. Station QW-7 was sampled at 10:45 a.m., and measured $0.098 \mathrm{mg} / \mathrm{m}^{3}$. The next site, QW-1, was sampled at 12:40 p.m., and chlorophyll 'a' measured $0.1098 \mathrm{mg} / \mathrm{m}^{3}$. The last station of the day, QW-2, was sampled at 5:46 p.m. and measured $0.154 \mathrm{mg} / \mathrm{m}^{3}$. The concentrations of chlorophyll ' $a$ ' measured for all of the receiving water stations ranged from $0.05 \mathrm{mg} / \mathrm{m}^{3}$ at the control stations QW-9 and QW-10, to $0.18 \mathrm{mg} / \mathrm{m}^{3}$ at the IMZ boundary station QW-3. These values are still far below those measured in the Río Grande de Añasco $\left(0.53 \mathrm{mg} / \mathrm{m}^{3}\right)$, the effluent $\left(0.61 \mathrm{mg} / \mathrm{m}^{3}\right)$, and the Río Yaguiez $\left(1.64 \mathrm{mg} / \mathrm{m}^{3}\right)$. The potential for the development of significant algal blooms is not suggested by the data collected during this study.

\section{Trace Elements}

The majority of the regulated trace elements were detected in the wastewater samples and/or river water samples. Cadmium was detected in both rivers but not in the wastewater. Trace elements that were detected in marine water samples include: chromium, boron, selenium, and lead. Selenium and lead were detected at one of the control stations and not at any other location, suggesting that these trace-metal 'hits', 
which coincided with the only total Kjeldahl nitrogen marine water detection, are not related to outfall activity. Boron is present at uniform concentrations in marine samples at approximately 50 times the concentration found in waste water. This results from boron's natural occurrence as a marine water constituent. Chromium was detected in each of the mixing zones sampled, and its presence is expected in areas influenced by the runoff from the Río Yagüez and the Río Guanajibo, which drain laterite deposits formed on the serpentinite. No reduction in concentration was observed for chromium. All chromium concentrations were beneath applicable limits.

\section{Organic Compounds in the Surface Waters}

The following volatile organic compounds were detected in either the influent or the effluent: carbon tetrachloride, chloroform, ethylbenzene, and toluene. For all but carbon tetrachloride, the concentrations of the effluent sampled from the waste stream on the grounds of the MRWTP met the stricter standards for the receiving waters. The concentration of carbon tetrachloride measured in the effluent $(8.7 \mu \mathrm{g} / \mathrm{L})$ exceeded the strictest EPA marine criterion $(4.5 \mu \mathrm{g} / \mathrm{L}$, for waters harvested for organisms) by a factor of 2 ; concentrations of the compound were below the detection limit for all other stations, including those sampled within the outfall plume. Volatile organic compounds were not detected in either the river waters or in the set of marine water samples. None of the regulated semivolatiles were detected in any of the samples collected. No organochlorine pesticides or PCB's were detected in any of the samples collected. No organophosphorus pesticides were detected in any of the samples collected. No chlorinated herbicides were detected in any of the samples collected.

\section{SUMMARY}

The discharge of anthropogenic contaminants from previous sewage outfalls in the Bahía de Mayagüez and from industries discharging to coastal waters has resulted in clear and documented degradation of water quality in the Bahía de
Mayagüez. The degraded water quality was linked to shifts in the populations of foraminifers in the northern parts of the Bahía de Mayagüez and the near extinction of corals growing at Arrecife Algarrobo in the northern part of the bay. To relieve the obvious acute and chronic stresses produced by the previous outfalls and other industrial discharges around the perimeter of the Bahía de Mayagüez, the present discharge site in the Bahía de Añasco was located and identified as an area with good mixing capabilities.

The U.S. Geological Survey and the Puerto Rico Aqueduct and Sewer Authority carried out a study in 1990-91, to determine if primary-treated wastewater, discharged through the Mayagüez Regional

Wastewater Treatment Plant ocean outfall since 1987, had resulted in adverse impacts on the natural resources in the Bahía de Añasco. It was found that the physical environment and biota in the Bahía de Añasco, including the area around the outfall, continue to evolve in response to sediments and nutrients discharged from the rivers and upwelled from deep waters. Data collected during the study did not implicate the outfall as a stressor.

The diffuser is located at a depth of $11 \mathrm{~m}$, about 1,700 $\mathrm{m}$ offshore. The immediate area around the outfall is characterized by muddy sediments deposited on an irregular bedrock surface. A high-resolution sidescan-sonar image clearly defined the outfall's position relative to the coral reefs and unconsolidated sediments deposited in the bay. The seismic reflection lines also reveal reeflike structures buried underneath the fine sediments deposited between the shelf-edge reefs and shore. Diverse communities of organisms were found living both in the soft sediments and on the hard bottom.

Balanced indigenous populations were documented in the soft-bottom communities at eight stations in the bay, including a station in the initial mixing zone of the outfall. No enrichment of pollution-tolerant species with time was observed. Community diversity was found to covary with the percentage of pollution-tolerant species, and both decreased with distance from shore. It must be noted, however, that one of the stations downcurrent from the outfall, station B2, showed a significant increase in dominance by peanut worms (sipunculans). 
Sipunculans make up a relatively small phylum of organisms that are adept in living in a wide array of shallow-water marine habitats, and have not been identified as opportunistic species tolerant of pollutants. Some burrow into sand or mud, while others bore into shells or test. The possibility exists that since the area around the outfall has good dispersion and strong currents, wastewater-related impacts may not appear around the outfall at all, but rather appear in lower energy areas downcurrent where sediments and contaminants may accumulate.

Hard-bottom communities in the bay have adapted to the discharge of sediments and nutrients from the rivers and the presence of upwelled nutrients from deeper waters to the west. The community of sessile benthos observed at station MO-5, located 350 $\mathrm{m}$ from the outfall, included species adapted to growing in deeper waters, such as the scleractinian Agaricia lamarcki and the antipatharian Stichopathes $s p$. The coverage and abundance was low at the station, but the measured diversity was similar to that observed at other stations. This was the first visit to the site and, therefore, no comparison could be made with pre-outfall conditions. At two stations in the reefs west of the outfall, previously surveyed in 1985 , no significant changes in the hard-bottom communities were found.

The taxonomic composition of fishes in the Manchas Interiores-Manchas Exteriores coral reef complex in the Bahía de Añasco is typical of shallow coral reef ecosystems. In general, fish abundance and diversity increased with substrate relief. Contrary to this trend, low abundance and diversity of fishes were found at station MO-5, a high-relief habitat surveyed near the outfall. The high-relief substrate is one of several relict patch reefs located in the interior portions of the Bahía de Añasco. Subbottom profiling of the interior of the bay verified that these structures were patch reefs that succeed in keeping pace with the rising sea level, but eventually succumbed to the significant loads of sediment discharged from the Río Grande de Añasco over the last few millennia.

The mineralogy of sediments deposited in the Bahía de Añasco reflect the sources in the uplands watersheds, carbonate production, and diagenesis of the marine sediments. Around the outfall the sediments consist mostly of terrigenous grains discharged by the Río Grande de Añasco with roughly similar secondary proportions from the Río Yagüez/ Río Guanajibo and skeletal carbonate grains. Bacterial mediation in the diagenesis of carbonate grains is suggested by the dark staining of carbonate grains and the identification of the calcian-manganese carbonate, kutnahorite, in X-ray diffractographs. The sediment provenance study also revealed that one of the reasons that sessile benthos at station MSG-2 are so abundant and diverse is that the area is hydrodynamically sheltered from discharge from the Río Grande de Añasco. Trace-metal concentrations in the coralline skeletons from the interior of the Bahía de Añasco suggest that deep waters to the west of the coral complex commonly upwell to the east to replace surface waters blown away from shore by the winds. The deep waters to the west, therefore, commonly pass up and through the coral reef complex to the east.

Water quality measured at and near the outfall diffuser at the end of January met all applicable criteria established for marine waters by the United States Environmental Protection Agency and the Puerto Rico Environmental Quality Board. Nutrients present in the effluent fell below detection limits at the boundary of the initial mixing zone.

The stressed condition of corals in the Bahía de Añasco could be attributed to the sediments and nutrients discharged from the Río Grande de Añasco, the Río Yagüez, the Río Guanajibo, industrial sources discharging directly into the Bahía de Mayagüez, or the discharge from the ocean outfall. Nutrient-rich discharges into the Bahía de Mayagüez are commonly trapped close to shore, where they flow northward until mixing with water masses from the Río Grande de Añasco, before travelling offshore into the Bahía de Añasco. This transport pattern has resulted in the rapid demise of coral communities at Punta Algarrobo and at other small reefs nearby, and may account for the higher percentages of opportunistic infaunal species documented for stations closest to shore. The abundance and diversity of coral communities are greater at stations near the outfall than they are at Punto Algarrobo, and greater still at station MSG-2, in the Manchas Interiores to the west. The net transport 
of effluent by the currents in the area of the outfall is to the northwest, an area floored by muds and populated by balanced indigenous species of macrobenthic infauna. Nonetheless, the existing data collected in this report and by previous studies do not implicate the outfall as being responsible for any recent changes in the coral community, the macrobenthic infauna, fish populations, or deposited sediments.

\section{SELECTED REFERENCES}

Bakus, G.J., 1966, Some relationships of fishes to benthic organisms in coral reefs: Nature, v. 210, p. $280-284$.

Banner, A.H., 1974, Kaneohe Bay, Hawaii: urban pollution and a coral reef ecosystem, in Proceedings of the Second International Coral Reef Symposium, A.M. Cameron and others, eds.: Great Barrier Reef Commission, Brisbane, v. 2 , p. $685-701$.

Belzile, Nelson, De Vitre, R.R., and Tessier, André, 1989, In situ collection of diagenetic iron and manganese oxyhydroxides from natural sediments: Nature, v. 340, p. 376.

Best, B.R., Bailey, R.D., Marsh, J.A., and Matlock, C.B., 1982, Effect of chlorine on some coral reef phytoplankters and invertebrate larvae, in Proceedings Fourth International Coral Reef Symposium, Gómez and others, eds.: University Philippines, Manila, v. 1, p. 169-172.

Bowman, K.O., Hutcheson, K., Odum, E.P., and Shenton, L.R., 1970, Comments on the distribution of indices of diversity, in International Symposium on Statistical Ecology, v. 3: Pennsylvania State University Press, State College, Penn.

Bray, J.R., and Curtis, J.T., 1957, An ordination of the upland forest communities of southern Wisconsin: Ecological Monographs, v. 27, p. 325-349.

Buddemeier, R.W., and Kinzie, R.A., III, 1976, Coral growth: Oceanography and Marine Biology: An Annual Review, v. 14, p. 183-225.
Burk, C.A., ed., 1964, A study of serpentinite; the AMSOC core hole near Mayagüez, Puerto Rico: The AMSOC Committee of the Division of Earth Sciences, National Academy of Sciences, National Research Committee, Publication No. $1188,175 \mathrm{p}$.

Calderón-Aguilera, L.E., 1992, Analysis of the benthic infauna from Bahía de Quintin, Baja California, with emphasis on its use in impact assessment studied: Ciencias Marinas, v. 18, no. 4, p. 27-46.

Campbell, D.G, 1977, Bahamian chlorine bleach fishing: a survey, in D.L. Taylor, ed., Proceedings Third International Coral Reef Symposium: University Miami, p. 593-596.

Carriquiry, J.R., Risk, M.J., and Schwarcz, H.P., 1988, Timing and temperature record from stable isotopes of the 1982-1983 El Niño warming event in eastern Pacific corals: The Society of Economic Paleontologists and Mineralogists, Research Letters, Palaios, v. 3, p. 359-364.

Carver, R.E., ed., 1971, Procedures in sedimentary petrology: Wiley-Interscience, New York, p. 593-594.

Center for Energy and Environment Research, 1983, Mixing zone determination for effluent discharges of the ocean outfall of the Mayagüez Regional Wastewater Treatment Plant: Prepared by the Center for Energy and Environment Research for the Puerto Rico Aqueduct and Sewer Authority.

Center for Energy and Environment Research, 1985, Marine survey in the vicinity of the Mayagüez PRASA submarine outfall: Regional Wastewater Treatment Plant: Prepared by the Center for Energy and Environment Research, University of Puerto Rico, Marine Ecology Division for Metcalf \& Eddy, Inc., Woburn, Mass. 45 p.

Colón-Dieppa, Eloy, and Quiñones-Márquez, Ferdinand, 1985, A reconnaissance of the water resources of the central Guanajibo valley, Puerto Rico: U.S. Geological Survey Water- Resources Investigations Report 82-4050, 47 p.

Corredor, J.E., Wilkenson, C.R., Vicente, V.P., Morell, J.M., and Otero, Ernesto, 1988, Nitrate release by Caribbean sponges: Limnology Oceanography, v. 33 , no. 1 , p. 114-120. 
Cox, D.P., and Briggs, R.P., 1973, Metallogenic map of Puerto Rico: U.S. Geological Survey Miscellaneous Geologic Investigations Map I-721, 6. p., 1 sheet, scale 1:240,000.

Danforth, W.W., O'Brien, T.F., and Schwab, W.C., 1991, U.S.G.S. image processing system: near real-time mosaicing of high-resolution sidescansonar data: Sea Technology, January 1991, p. 54-59.

Deer, W.A., Howie, R.A., and Zussman, J., 1977, An introduction to the rock forming minerals: Longman Group Limited, London, England, p. 207.

Department of Public Works, 1971, Data analysis of the first survey of the Mayagüez disposal site area "H": Area of Natural Resources, Oceanographic Program, 28 p.

Department of Public Works, 1974, Oceanographic baseline data for the formulation of marine waste disposal alternatives for Puerto Rico: Area of Natural Resources of the Department of Public Works, prepared for the Environmental Quality Board.

Díaz, P.L., Aquino, Zaida, Figueroa-Alamo, Carlos, Vachier, R.J., and Sánchez, A.V., 1999, Water Resources Data, Puerto Rico and the U.S. Virgin Islands, Water Year 1998: U.S. Geological Survey Water-Data Report, p. 629.

Dillon, W.P., and Oldale, R.N., 1978, Late Quaternary sea-level curve: Reinterpretation based on glaciotectonic influence: Geology, v. 6, p. 56-60.

Dodge, R.E., and Thomson, John, 1974, The natural radiochemical and growth records in contemporary hermatypic corals from the Atlantic and Caribbean, Earth and Planetary Science Letters, v. 23, no.3, p. 313-322.

Elrick, K., and Horowitz, A., 1985, Analysis of rocks and sediments for arsenic, antimony, and selenium, by wet digestion and hydride generation atomic absorption: Varian Instruments at Work, AA-56, 5 p.

Elrick, K., and Horowitz, A., 1987, Analysis of rocks and sediments for mercury by wet digestion and flameless cold vapor atomic absorption: Varian Instruments at Work, AA-72, $5 \mathrm{p}$.
Emiliani, Cesare, Hudson, J.H., Shinn, E.A., George, R.Y., and Lidz, Barbara, 1978, Oxygen and carbon isotopic growth record in a reef coral from the Florida Keys and a deep-sea coral from Blake Plateau: Science, v. 202, p. 627-629.

Environmental Science and Engineering, Inc, 1986, Final mixing zone application for Mayagüez regional outfall: Prepared for Puerto Rico Aqueduct and Sewer Authority.

Evans, C.W., Maragos, J.E., and Holthus, P.F., 1986, Coral reef population biology, in P.L. Jokiel and others, eds.: Hawaii Institute of Marine Biology Technical Report No. 37, University of Hawaii, Honolulu, p. 76-90.

Evermann, B.W., 1900, General report on the investigations in Porto Rico of the United States Fish Commission Steamer Fish Hawk in 1899: U.S. Commission of Fish and Fisheries, Washington, D.C., p. 19-20.

Fairbanks, R.G., and Dodge, R.E., 1979, Annual periodicity of the ${ }^{18} \mathrm{O} /{ }^{16} \mathrm{O}$ and ${ }^{13} \mathrm{C} /{ }^{12} \mathrm{C}$ ratios in the coral Montastrea annularis: Geochimica et Cosmochimica Acta, v. 43, p. 1009-1020.

Fishman, M.J., and Friedman, L.C., 1989, Methods for determination of inorganic substances in water and fluvial sediments: Techniques of WaterResources Investigations of the U.S. Geological Survey, Chapter A1, Book 5, Laboratory Analysis, Method I-5753-85, p. 451.

Florida Department of Environmental Protection, 1994, Approach to the assessment of sediment quality in Florida coastal water, v. 1, Development and evaluation of sediment quality assessment guidelines: Prepared for Florida Department of Environmental Protection, Office of Water Policy, Tallahassee, Florida, by MacDonald Environmental Sciences Ltd., Ladysmith, British Columbia, 101 p.

Folk, R.L., 1980, Petrology of sedimentary rocks: Hemphill Publshing Company, Austin, Texas, $182 \mathrm{p}$.

Gallagher, E.D., and Keay, K.E., 1998, Organismsediment-contaminant interactions in Boston harbor: p. 89-132, in K.D. Stolzenbach and E.E. Adams, eds,: Contaminated Sediments in Boston Harbor: MIT Sea Grant Press, Cambridge, Mass., p. $89-132$ 
García, J.R., 1990a, General characterization of the marine community at Manchas Interiores Reef in Añasco Bay: Report prepared for ENSR Consulting and Engineering Co., May 1990, 16 p.

García, J.R., 1990b, Survey of marine communities along potential transect sites for intake and discharge pipes of the proposed Cogentrix Power Plant off Punta Algarrobo in Añasco Bay: August 1990, $18 \mathrm{p}$.

García, J.R., Goenaga, Carlos, and Vicente, V.P., 1985, Survey of marine communities associated with coral reefs off Añasco Bay: Report prepared for Metcalf and Eddy, Inc., June 1985, 22 p.

Gauch, H.G., Jr., 1982, Multivariate analysis in community ecology: Cambridge University Press, New York, New York, p. 109-135.

Gelabert, P.A., and Singh, N.C., 1992, Strategy for the control of land-based sources of marine pollution in the wider Caribbean region: Chemistry and Ecology, v. 7, p. 117-121.

Gierbolini, R.E., 1975, Soil survey of Mayagüez area of western Puerto Rico: U.S. Department of Agriculture, Soil Conservation Service, in cooperation with the University of Puerto Rico, College of Agricultural Science, 296 p.

Goenaga, Carlos, 1988, The distribution and growth of Montastrea annularis (Ellis and Solaner) in Puerto Rican Inshore Platform reefs: Department of Marine Sciences, University of Puerto Rico, Mayagüez Campus, March 1988, Ph.D. dissertation, $186 \mathrm{p}$.

Goenaga, Carlos, 1991, The state of coral reefs in the Wider Caribbean: Interciencia, v. 15, no. 6, p. 12-20.

Goenaga, Carlos, and Canals, Miguel, 1990, Islandwide coral bleaching in Puerto Rico: 1990, Caribbean Journal of Science, v. 26, no. 3-4, p. 171-175.

Goenaga, Carlos, and Cintrón, Gilberto, 1979, Inventory of the Puerto Rican coral reefs: Report submitted to the Coastal Zone Management Program of the Department of Natural Resources, Commonwealth of Puerto Rico.
Goenaga, Carlos, Vicente, V.P., and Armstrong, R.A., 1989, Bleaching induced mortalities in reef corals from La Parguera, Puerto Rico: a precursor of change in the community structure of coral reefs?: Caribbean Journal of Science, v. 25, no. 1-2, p. 59-65.

Goreau, T.J., and MacFarlane, A.H., 1990, Reduced growth rate of Montastrea annularis following the 1987-1988 coral bleaching event: Coral Reefs, v. 8 , p. 211-215.

Grove, K.A., 1998, Nearshore sediment transport and shoreline change at Añasco Bay, Puerto Rico: University of Puerto Rico, Mayagüez Campus, Ph.D. dissertation, $141 \mathrm{p}$.

Guzmán, R.M., and Associates, 1974, Oceanographic considerations for wastewater disposal at Mayagüez, Puerto Rico: Prepared for the Puerto Rico Aqueduct and Sewer Authority.

Hallock, P., 1988, The role of nutrient availability in bioerosion: consequences to carbonate buildups: Palaeogeography Palaeoclimatology Palaeoecology, v. 63, no. 1-3, p. 275-291.

Hatcher, B.G., Johannes, R.E., and Robertson, A.I., 1989, Review of research relevant to the conservation of shallow tropical marine ecosystems: Oceanography and Marine Biology: An Annual Review, v. 27, p. 337-414.

Highsmith, R.C., 1981, Coral bioerosion: damage relative to skeletal density: American Naturalist, v. 117 , no. 2 , p. 193-198.

Horowitz, A.J., 1985, A primer on trace metalsediment chemistry: U.S. Geological Survey Water-Supply Paper 2277, 67 p.

Horowitz, A.J., and Elrick, K., 1985, Multielement analysis of rocks and sediments by wet digestion and atomic absorption spectroscopy: Varian Instruments at Work, AA-47, 7 p.

Hubbard, Julia A.E.B., and Pocock, Y.P.,1972, Sediment rejection by scleractinian corals: a key to paleo-environmental reconstruction: Geologische Rundschau, v. 61, no. 2, p. 598-626.

Hudson, J.H., Shinn, E.A., Halley, R.B., and Lidz, Barbara, 1976, Sclerochronology: A tool for interpreting past environments: Geology, v. 4, p. $361-364$. 
Hutchinson, G.E., 1970, The influence of the environment: in Cloud Preston, ed, Adventures in Earth History, W.H. Freeman \& Co., San Francisco, Cal., p. 756-760.

Isdale, Peter, 1984, Fluorescent bands in massive corals record centuries of coastal rainfall: Nature, v. 310 , p. $578-579$.

Johannes, R.E., 1975, Pollution and degradation of coral reef communities, in Ferguson-Wood, E.J., and Johannes, R.E., eds., Tropical Marine Pollution: Elsevier Oceanography Series 12, Elsevier, N.Y., p. 13-51.

Johnson, K.C., and Quiñones-Aponte, Vicente, 1982, Flood of September 16, 1975, in the Añasco area, Puerto Rico: U.S. Geological Survey Open-File Report 81-345, 1 pl.

Kawamura, R., 1994, A rotated EOF analysis of global sea surface temperature variability with interannual and interdecadal scales: Journal of Physical Oceanography, v. 24, p. 707-716.

Kinsey, D.W., and Davies, P.J., 1979, Effects of elevated nitrogen and phosphorous on coral reef growth: Limnology Oceanography, v. 24, no. 5, p. 935-940.

Kimmel, J., 1978, Fish studies in Guayanilla Bay: Annual Report CEER, University of Puerto Rico, Mayagüez. $30 \mathrm{p}$.

Kolehmainen, S.E., 1973, Siltation experiments on corals "in situ": Final Report Mission 8, PRINUL, San German, Puerto Rico, 20 p.

Lea, D.W., Shen, G.T., and Boyle, E.A., 1989, Coralline barium records temporal variability in equatorial Pacific upwelling: Nature, v. 340 , no. 6232 , p. $373-376$.

Loya, Y., 1976, Effects of water turbidity and sedimentation on the community structure of Puerto Rico corals: Bulletin of Marine Sciences, v. 26, p. $450-466$.

Luckhurst, B.E., and Luckhurst, K., 1978, Analysis of the influence of substrate variables on coral reef fish communities: Marine Biology, v. 49, p. 317-323.

Macintyre, I.G., 1972, Submerged reefs of eastern Caribbean: The American Association of Petroleum Geologists Bulletin, v. 56, no. 4, p. $720-738$.
Malmgren, B.A., Winter, Amos, and Chen, Deliang, 1998, El Niño-Southern Oscillation and North Atlantic Oscillation Control of Climate in Puerto Rico: Journal of Climate, v. 11, p. 2713-2717.

Marszalek, D.S., 1981, Impact of dredging on a subtropical reef community, southeast Florida: Fourth International Coral Reef Symposium, Manila v. 1, p. 147-153.

Marszalek, D.S., 1987, Sewage and eutrophication, in Salvat, B., ed., Human impacts on coral reefs: facts and recommendations: Antenne MuseumEPHE, Tahiti, p. 77-90.

Mattson, P.H., 1960, Geology of the Mayagüez area, Puerto Rico: Bulletin of the Geological Society of America, v. 71, p. 319-362.

McConnaughey, T., 1989a, 13-C and 18-O isotopic disequilibrium in biological carbonates: I. Patterns: Geochimica et Cosmochimica Acta, v. 53, p. 151-162.

McConnaughey, T., 1989b, 13-C and 18-O isotopic disequilibrium in biological carbonates: II. In vitro simulation of kinetic isotope effects: Geochimica et Cosmochimica Acta, v. 53, p. 163-171.

McErlean, A.J., O'Connor, S.G., Mihursky, J.A., and Gibson, C.I., 1973, Abundance, diversity and seasonal patterns of estuarine fish populations: Estuarine and Coastal Marine Science, v. 1, p. 19-36.

Metcalf \& Eddy, Inc., 1985a, Application for a waiver of secondary treatment for the Mayagüez regional wastewater treatment plant: Prepared for the Puerto Rico Aqueduct and Sewer Authority, February 1985.

Metcalf \& Eddy, Inc., 1985b, Application for a waiver of secondary treatment for the Mayagüez Regional Wastewater Treatment Plant: Supplement, Prepared for PRASA, June 1985.

Metcalf \& Eddy, Inc., 1985c, Marine survey in the vicinity of the Mayaguiez outfall: Prepared by the Center for Energy and Environment Research, University of Puerto Rico, Mayagüez.

Metcalf \& Eddy, Inc., 1987a, Application for a Waiver of Secondary Treatment for the Mayagüez Regional Wastewater Treatment Plant: Information Supplement, Prepared for the Puerto Rico Aqueduct and Sewer Authority, April 1987. 
Metcalf \& Eddy, Inc., 1987b, Mayagüez regional wastewater treatment plant: 301(h) Waiver Application, Information Supplement, April 1987.

Miesch, A.T., 1976a, Q-mode factor analysis of geochemical and petrologic data matrices with constant row-sums: U.S. Geological Survey Professional Paper 574-G, 47 p.

Miesch, A.T., 1976b, Interactive computer programs for petrologic modeling with extended Q-mode factor analysis: Computers \& Geosciences, v. 2, no. 4, p. 439-492.

Morelock, Jack, 1987, Beach sand budget for western Puerto Rico: Proceedings of Coastal Sediment 1987, WW Div./ASCE, New Orleans, LA, May 12-14, 1987, p. 1,333-1,345.

Morelock, Jack, Grove, Kurt, and Hernández, M.L., 1983, Oceanography and patterns of shelf sediments Mayaguiez, Puerto Rico: Journal of Sedimentary Petrology, v. 53, no. 2, p. 371-381.

Muchmore, D., and Eepel, D., 1973, The effects of chlorination of wastewater on fertilization in some marine invertebrates: Marine Biology, v. 19 , p. 93-95.

Muscatine, L., and Porter, J.W., 1977, Reef corals: mutualistic symbioses adapted to nutrient-poor environments: BioScience, v. 27, p. 7, p. 454-460.

Natural Resources Conservation Service, 1998, Mayagüez Bay watershed nonpoint assessment report, [Draft]: U.S. Department of Agriculture report prepared for the Puerto Rico Aqueduct and Sewer Authority as part of the Federal Court Order EPA-CWA-II-91-05, 63 p.

Nozaki, Yoshiyuki, 1997, A fresh look at element distribution in the North Pacific: posted on the American Geophysical Union's EOS Electronic Supplements, site accepted on November 3, 1998 at URL http://www.agu.org/eos_elec/ 97025e.html/

Ourso, R.T., 1997, Professor, Southwest Texas State University Species Diversity: accessed March 27, 1998 at URL http://sunfish.aquabio.swt.edu/ ecology/notes/spdiversity/spdiversity.html/

Pastorok, R.A., and Bilyard, G.R., 1985a, Effects of sewage pollution on coral reef communities: Marine Environmental Research, v. 6, p. 83-98.
Pastorok, R.A., and Bilyard, G.R., 1985b, Effects of sewage pollution on coral reef communities: Marine Ecology Progress Series 21, p. 175-189.

Pearson, R.G., 1981, Recovery and recolonization of coral reefs: Marine Ecology Progress Series 4, p. $105-122$.

Pearson, T.H., and Rosenberg, R., 1978, Macrobenthic succession in relation to organic enrichment and pollution of the marine environment: Oceanography and Marine Biology: An Annual Review, v. 16, p. 229-311.

Phinney, D.A., and Yentsch, C.S., 1985, A novel phytoplankton chlorophyll technique: toward automated analysis: Journal of Plankton Research, v. 7, no. 5, p. 663-642.

Pirie, R.G., 1967, Clay mineralogy of Bahía de Añasco, western Puerto Rico: Puerto Rico Nuclear Center Marine Biology Program, Progress Summary Report no. 5, p. 147-165.

Plate, S., and Husemann, E., 1991, An alternative mode of larval development in Scoloplos armiger (O.F. Mueller, 1776) (Polychaeta, Orbiniidae): Helgolander Meeresuntersuchungen, v. 45, no. 4, p. 487-492.

Poppe, L.J., Eliason, A.H., and Frederick, J.J., 1985, APSAS-An automated particle size analysis system: U.S. Geological Survey Circular 963, $77 \mathrm{p}$.

Puerto Rico Aqueduct and Sewer Authority, 1963, Report of the sanitary survey of Mayagüez Bay, 1963: Prepared by the Sanitary Engineering Section of the Puerto Rico Aqueduct and Sewer Authority under contract with the Department of Health of the Commonwealth of Puerto Rico, 8 p.

Puerto Rico Aqueduct and Sewer Authority, 1979, Application for modification of the requirements of secondary treatment for the Mayagüez Regional Wastewater Treatment facility: Submitted to the U.S. Environmental Protection Agency, September 12, 1979.

Puerto Rico Aqueduct and Sewer Authority, 1985, Application for a waiver of secondary treatment for Mayagüez Regional Wastewater Treatment Plant: Submitted to the U.S. Environmental Protection Agency.

Randall, J.E., 1983, Caribbean reef fishes: T.F.H. Publications, Inc., Edgewood Cliffs, N.J., 350 p. 
Reiswig, H.M., 1973, Population dynamics of three Jamaican Demospongiae: Bulletin of Marine Science, v. 23, p. 231-249.

Risk, M.J., 1972, Fish diversity on a coral reef in the Virgin Islands: Atoll Research Bulletin, v. 153, p. 1-6.

Roberts, C.M., and Ormond, R.F.G., 1987, Habitat complexity and coral reef fish diversity and abundance on Red Sea fringing reefs: Marine Ecology Progress Series 41, p. 1-8.

Russo, A.R., 1982, Temporal changes in fish community structure near a marine sewer outfall: Journal of Marine Environmental Research, v. 6, p. 83-98.

Sammarco, P.W., 1980, Diadema and its relationship to coral spat mortality: grazing, competition and biological disturbance: Journal of Experimental Biology and Ecology, v. 45, p. 245-272.

Schneidermann, N., Pilkey, O.H., and Saunders, C., 1976, Sedimentation on the Puerto Rico Insular Shelf: Journal of Sedimentary Petrology, v. 46, no. 1, p. 167-173.

Schwab, W.C., Webb, R.M.T., Danforth, W.W., O’Brien, T.F., and Irwin, B.J., 1991, Highresolution sidescan-sonar imagery of the Manchas Interiores-Manchas Exteriores coral reef complex, Mayagüez, Puerto Rico: U.S. Geological Survey Open-File Report 91-436, $13 \mathrm{p}$.

Scoffin, T.P., Tudhope, A.W., and Brown, B.E., 1989, Fluorescent and skeletal density banding in Porites lutea from Paua New Guinea and Indonesia: Coral Reefs, v. 7, p. 169-178.

Seiglie, G.A., 1968, Foraminiferal assemblages as indicators of high organic carbon content in sediments and of polluted waters: American Association of Petroleum Geologists Bulletin, v. 52 , no. 11 , p. 2231-2241.

Seiglie, G.A., 1971a, A preliminary note on the relationships between foraminifers and pollution in two Puerto Rican bays: Caribbean Journal of Science, v. 11, no. 1-2, p. 93-98.

Seiglie, G.A., 1971b, Distribution of foraminifers in the Cabo Rojo platform and their paleoecological significance: Revista Española de Micropaleontología, v. 3, no. 1, p. 5-33.
Shannon, C.E., and Weaver, W., 1949, The mathematical theory of communication: University of Illinois Press, Urbana, Illinois.

Shen, G.T., and Boyle, E.A., 1988, Determination of lead, cadmium and other trace metals in annuallybanded corals: Chemical Geology, v. 67, p. 47-62.

Shen, G.T., and Sanford, C.L., 1989, Trace element indicators of climate variability in reef-building corals: [preprint] Global Ecological Consequences of the 1982-83 El Niño-Southern Oscillation, Elsevier Oceanography Series, 29 p.

Smith, R.M., and Abruña, F., 1955, Soil and water conservation research in Puerto Rico, 1938 to 1947: University of Puerto Rico Agricultural Experiment Station Bulletin 124, 51 p.

Smith, S.V., Kimmerer, W.J., Laws, E.A., Brock, R.E., and Walsh, T.W., 1981, Kaneohe Bay sewage diversion experiment: perspective of ecosystem responses to nutritional perturbation: Pacific Science, v. 35, p. 279-397.

Susic, Michael, Boto, Kevin, and Isdale, Peter, 1991, Fluorescent humic acid bands in coral skeletons originate from terrestrial runoff: Marine Chemistry, v. 33, p. 91-104.

Swart, P.K., 1983, Carbon and oxygen isotope fractionation in scleractinian corals: A review: Earth-Science Reviews, v. 19, p. 51-80.

Swift, D.J.P., 1967, Sediment dispersal patterns and trace element distribution, coastal western Puerto Rico: Puerto Rico Nuclear Center Marine Biology Program, Progress Summary Report no. 5, p. 121-146.

Taylor, D.L., 1981, Evolutionary impact of intracellular symbiosis: Berichte der Deutschen Botanischen Gesellschaft, v. 94, 583-590.

Tetra Tech, Inc., 1985, Technical review of the Mayagüez regional wastewater treatment plant (Puerto Rico) Section 301(h) Application for Modification of Secondary Treatment Requirements for Discharge into Marine Waters: Prepared for U.S. Environmental Protection Agency, December 1985, 142 p.

Tomascik, T., and Sander, F., 1985, Effects of eutrophication on reef building corals. 1. Growth rate of the reef building coral Montastrea annularis: Marine Biology, v. 87, p. 143-155. 
U.S. Environmental Protection Agency, 1984, Report on the Implementation of Section 301(h): Office of Water Programs Operations, Office of Water, U.S. Environmental Protection Agency, Washington, D.C., 79 p.

U.S. Environmental Protection Agency, 1985, Technical support document for water qualitybased toxics control: Office of Water Program Operations, Office of Water, Washington, D.C., September 1985.

U.S. Environmental Protection Agency, 1986, Analysis for the Section 301(h) Secondary Treatment Waiver Application for the Mayagüez Wastewater Treatment Plant, NPDES No. PR 0023795, Puerto Rico: Decision document prepared by the U.S. Environmental Protection Agency, Region II 301(h) Review Team, June 1986.

Velazco-Domínguez, A.T., Webb, R.M., Cintrón, G., and Martínez, R.F., 1985, Sedimentation and Puerto Rican coral reefs: Technical report prepared for the Coastal Zone Management Program, Task 3.7, by the Division of Marine Resources, Area of Scientific Resources, Department of Natural Resources, Commonwealth of Puerto Rico, 112 p.

Vicente, V.P., 1978, An ecological evaluation of the West Indian Demosponge Anthosigmella varians (Hadromerida: Spirastrellidae): Bulletin of Marine Science, v. 28, no. 4, p. 771-777.

Vicente, V.P., 1985, Overgrowth activity by the encrusting sponge Chondrilla nucula on a coral reef in Puerto Rico: in New Perspectives in Sponge Biology, contributions to the Third International Conference on the Biology of Sponges, convened by Hartman, W.D., and Rützler, Klaus, eds., at Woods Hole, MA, 17-23 November 1985: Smithsonian Institution Press, Washington, D.C., p. 436-442.

Vicente, V.P., 1989, Regional commercial sponge extinctions in the West Indies: Are recent climatic changes responsible?: Marine Ecology, v. 10, no. 2, p. 179-191.
Vicente, V.P., and Goenaga, Carlos, 1984, Mass mortalities of the sea urchin Diadema antillarum (Philippi) in Puerto Rico: Center for Energy and Environmental Research (CEER-M-195).

Vicente, V.P., and Smith, K.P., 1990, Nuevos registros de esponjas comerciales (spongia) en Puerto Rico: Decimosexto Simposio de Recursos Naturales, Departamento de Recursos Naturales, 13-14 de septiembre de 1990, p. 173-176.

Wade, B.A., Antonio, L., and Mahon, R., 1972, Increasing organic pollution in Kingston Harbour, Jamaica: Marine Pollution Bulletin, v. 3, p. 106-110.

Walker, D.I., and Ormond, R.F.G., 1982, Coral deaths from sewage and phosphate pollution at Aqaba, Red Sea: Marine Pollution Bulletin, v. 13, p. 21-25.

Webber, C.I., Horning, W.B., II, Klemm, D.J., Neiheisel, T.I., Lewis, P.A., Robinson, E.L., Menkedick, J., and Kessler, F., 1988, Short-term methods for estimating the chronic toxicity of effluents and receiving waters to marine and estuarine organisms: Environmental Monitoring and Support Laboratory, Office of Research and Development, U.S. Environmental Protection Agency, Cincinnati, Ohio, Document EPA/600/4$87 / 028$.

Wellington, G.M., and Glynn, P.W., 1983, Environmental influences on skeletal banding in Eastern Pacific (Panama) corals: Coral Reefs, v. 1, p. 215-222.

Williams, E.H., Goenaga, Carlos, and Vicente, V.P., 1987, Mass bleaching in Atlantic coral reefs: Science, v. 238, p. 877-878.

Winter, Amos, Goenaga, Carlos, and Maul, G.A., 1991, Carbon and oxygen isotope time series from an 18-year Caribbean reef coral: Journal of Geophysical Research, v. 96(C9), p. 16, 673-16, 678.

Zar, J.H., 1974, Biostatistical analysis: Prentice Hall, Inc., Englewood Cliffs, N.J., p. 115-117. 
90 Assessment of the Habitats, Biota, Sediments, and Water Quality Near the Discharge of Primary-Treated Effluent from the Mayagüez Regional Wastewater Treatment Plant, Bahía de Añasco, Puerto Rico 


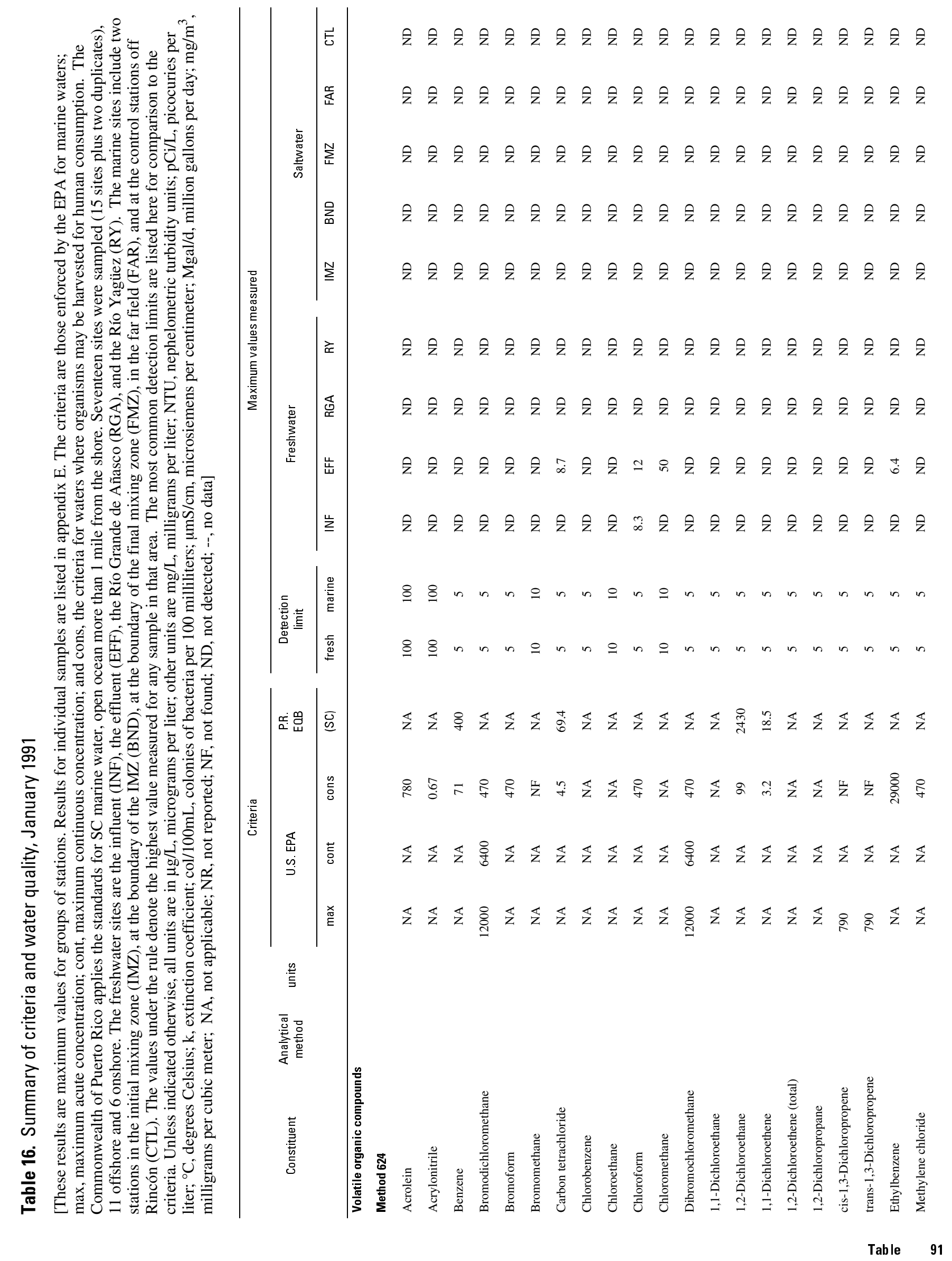




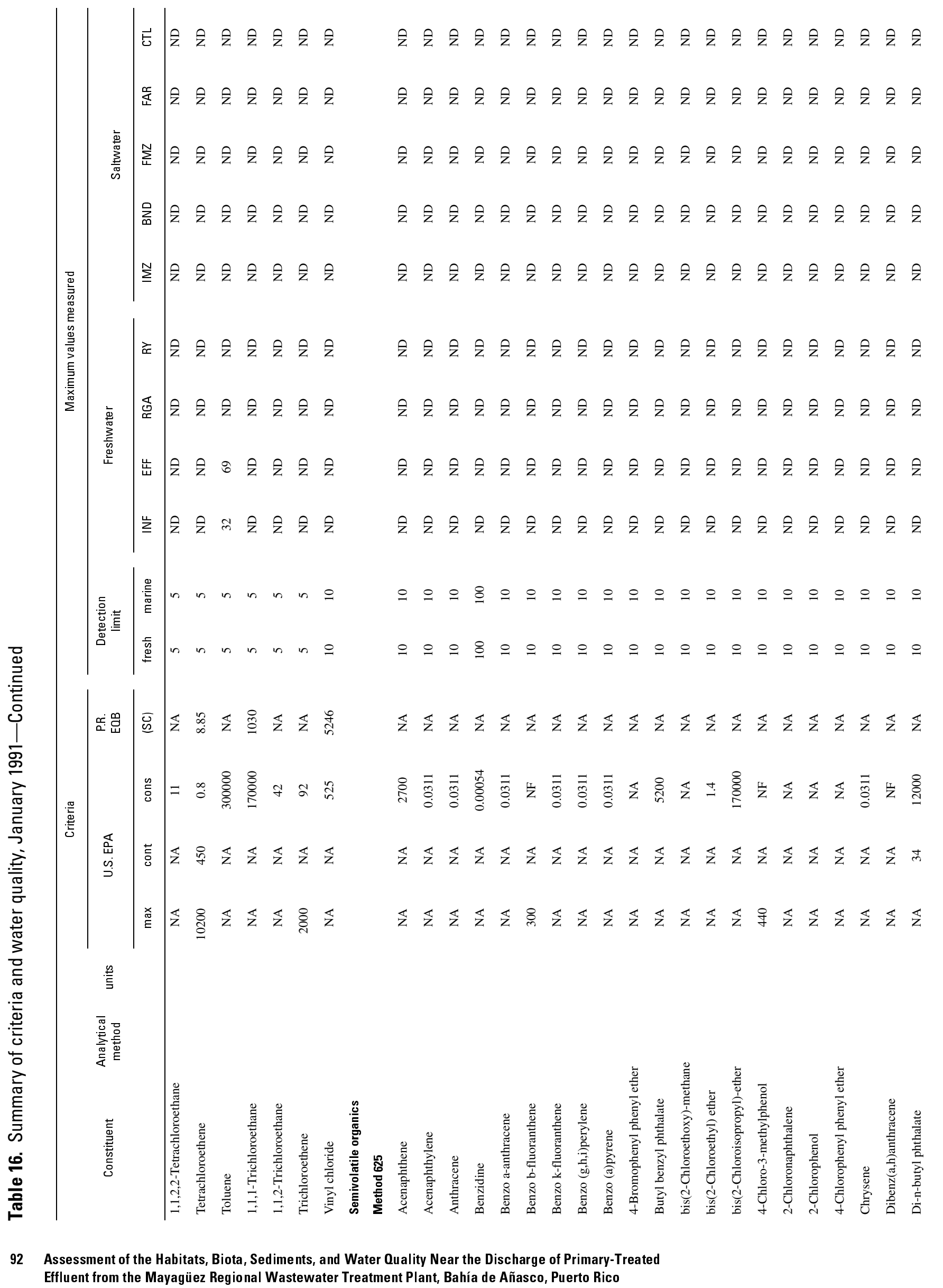




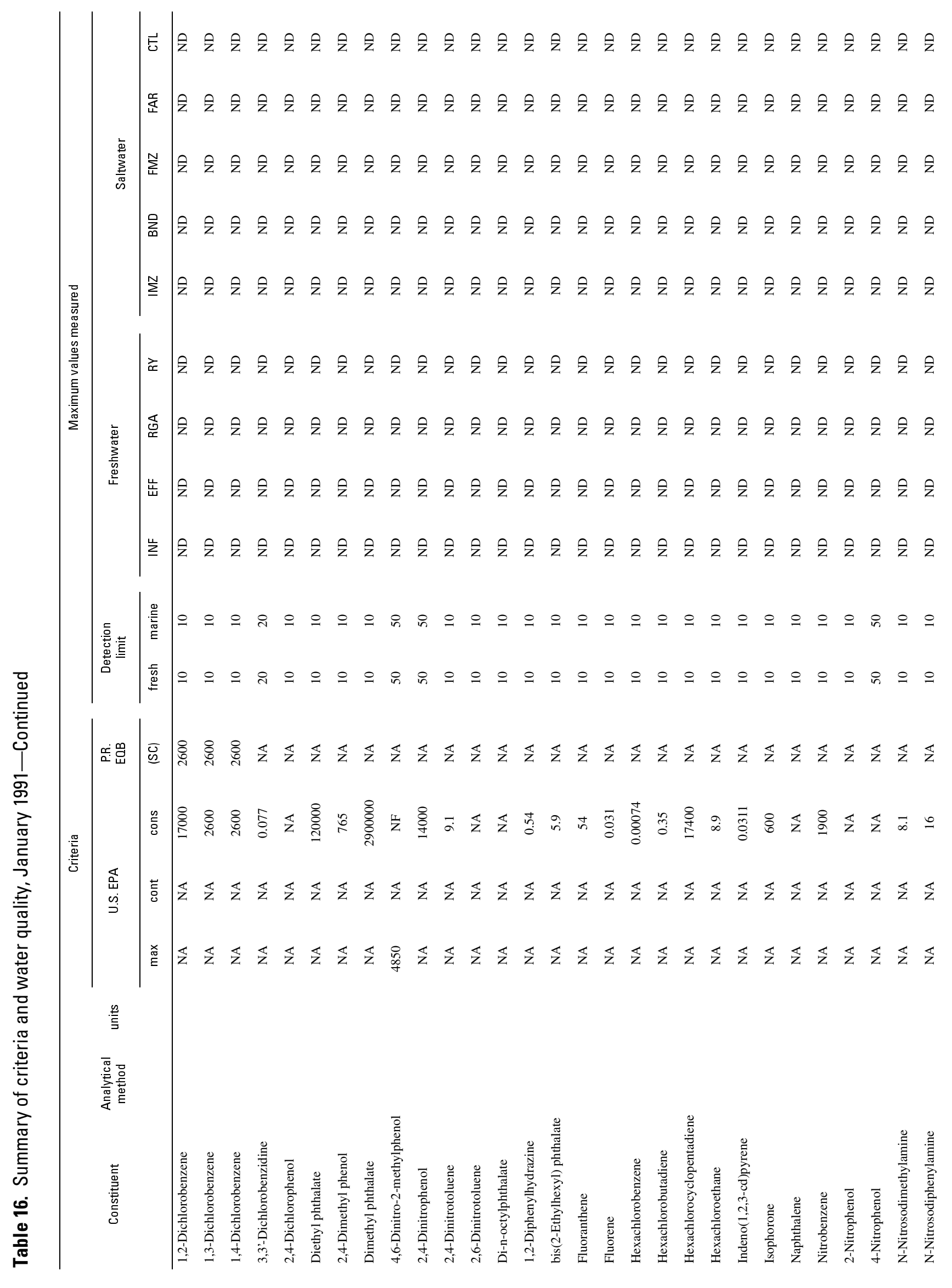




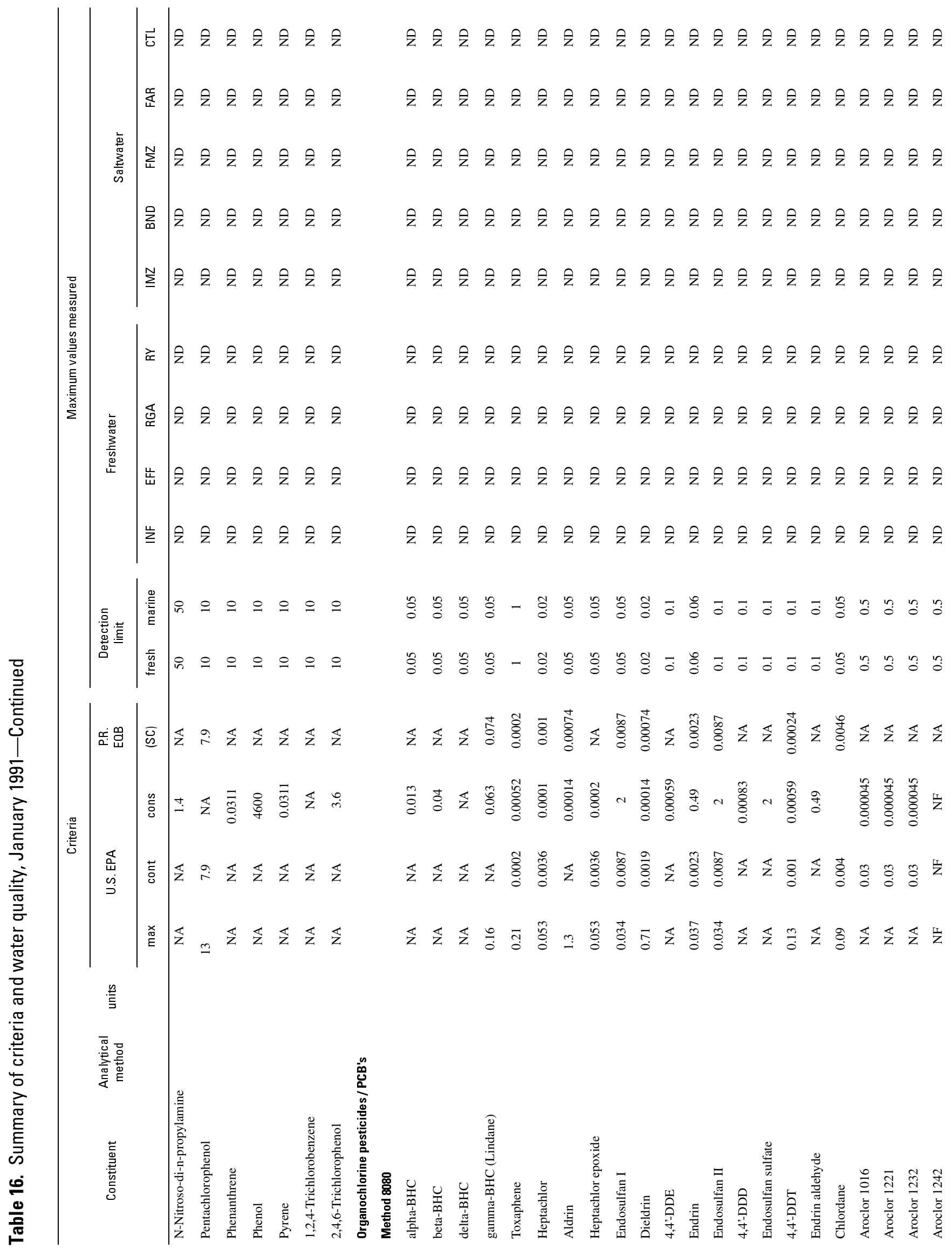

94 Assessment of the Habitats, Biota, Sediments, and Water Quality Near the Discharge of Primary-Treated Effluent from the Mayagüez Regional Wastewater Treatment Plant, Bahía de Añasco, Puerto Rico 


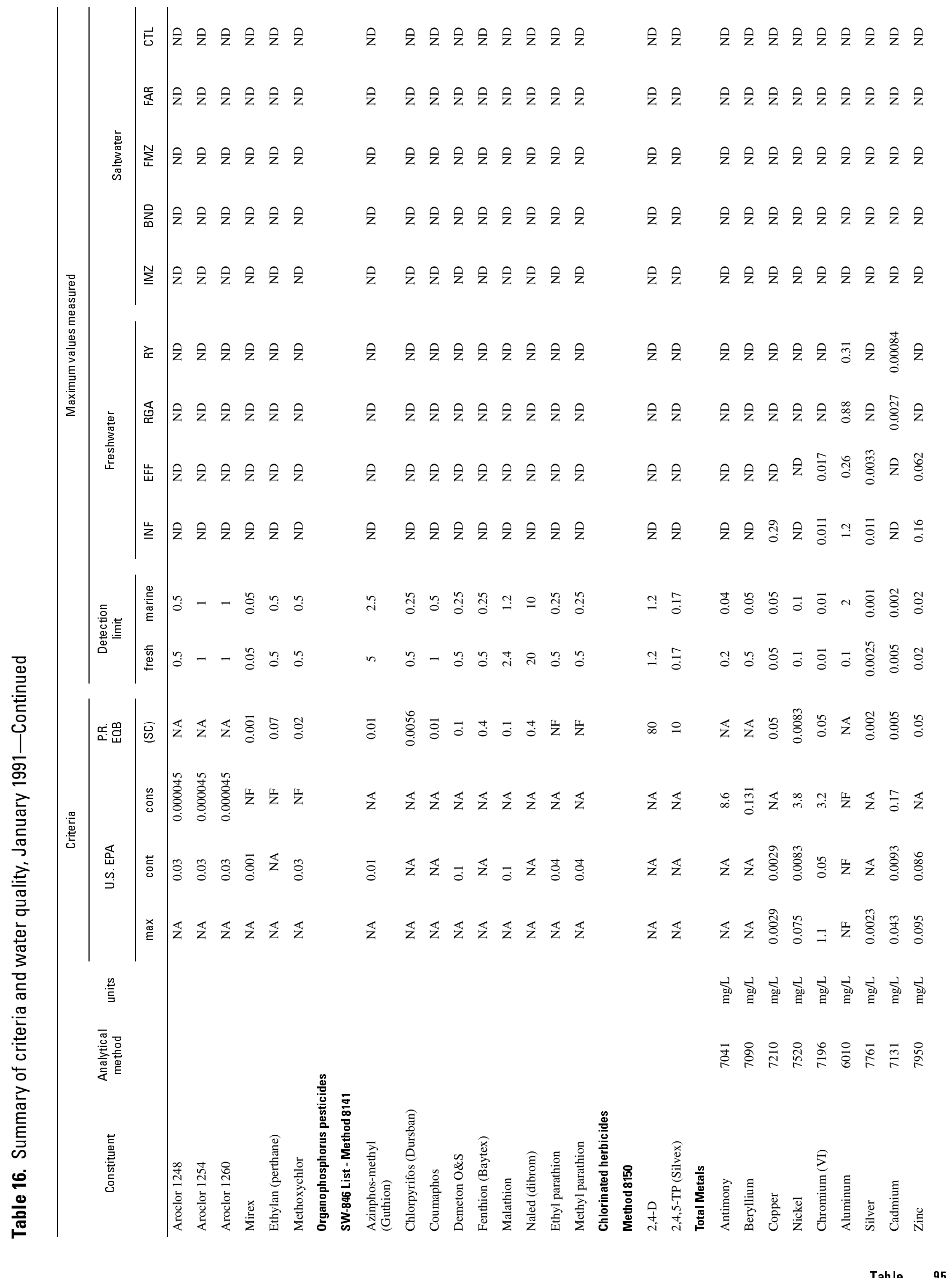




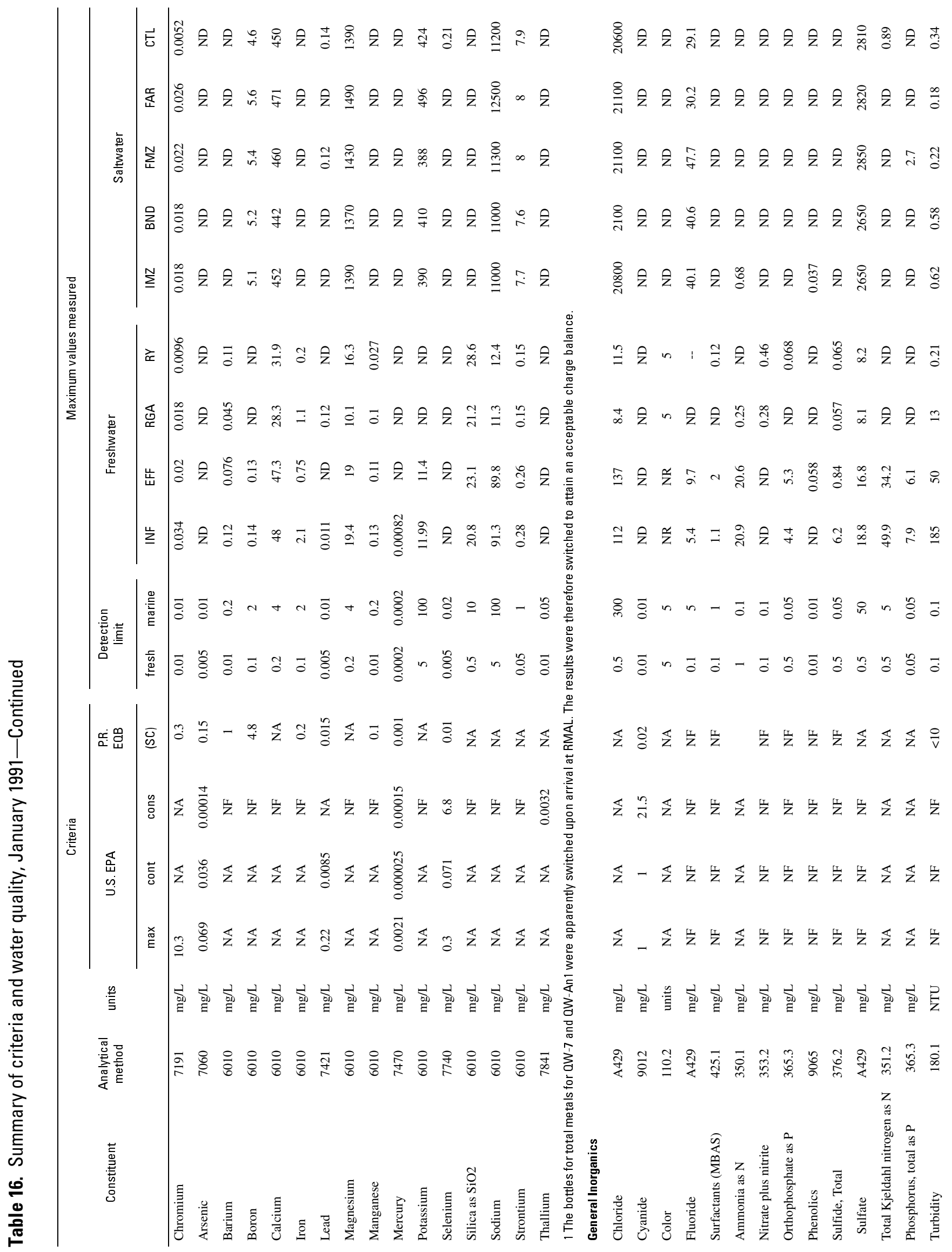

96 Assessment of the Habitats, Biota, Sediments, and Water Quality Near the Discharge of Primary-Treated Effluent from the Mayagüez Regional Wastewater Treatment Plant, Bahía de Añasco, Puerto Rico 


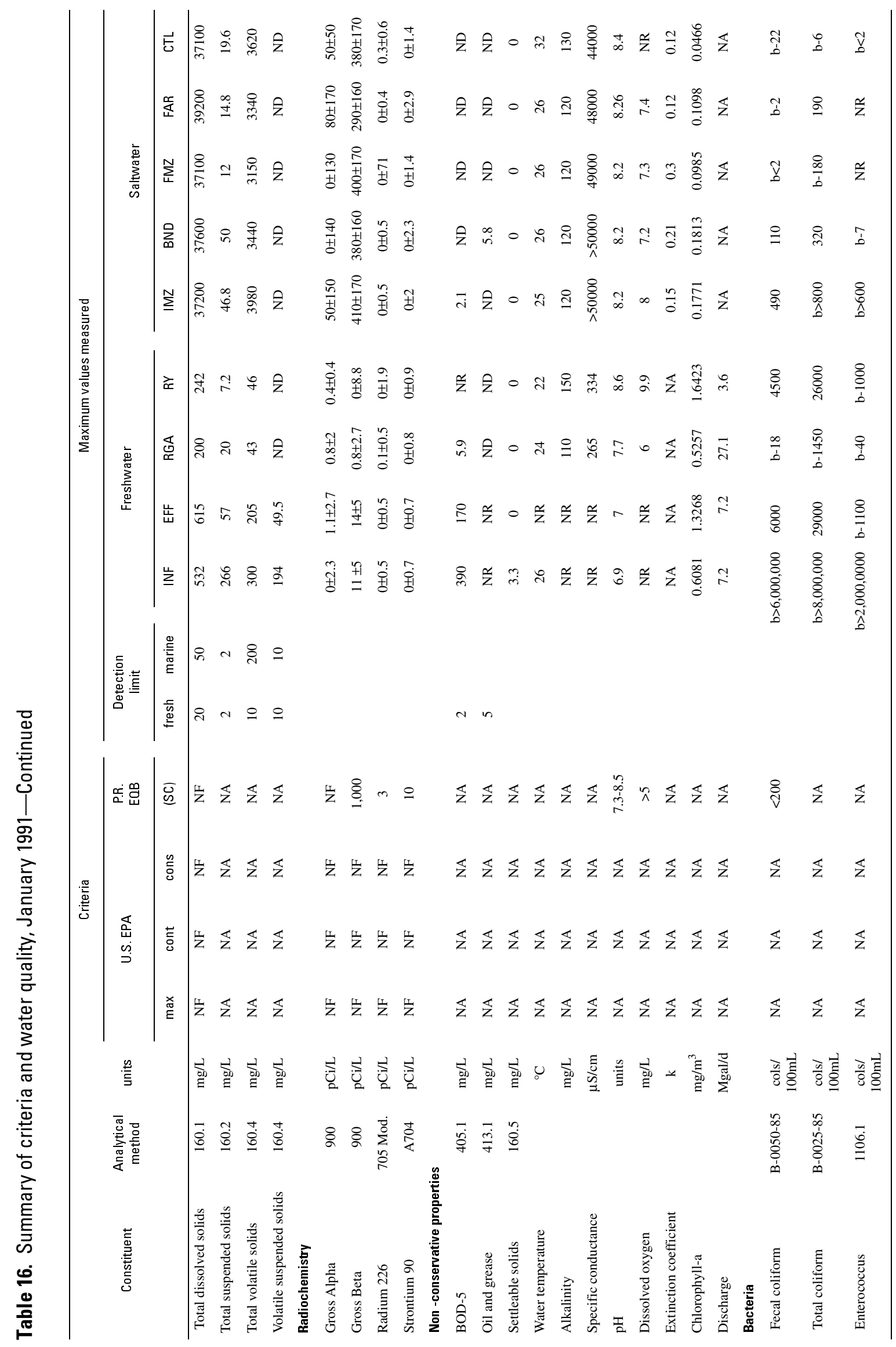


98 Assessment of the Habitats, Biota, Sediments, and Water Quality Near the Discharge of Primary-Treated Effluent from the Mayagüez Regional Wastewater Treatment Plant, Bahía de Añasco, Puerto Rico 


\section{APPENDIXES}


100 Assessment of the Habitats, Biota, Sediments, and Water Quality Near the Discharge of Primary-Treated Effluent from the Mayagüez Regional Wastewater Treatment Plant, Bahía de Añasco, Puerto Rico 
Appendix A. Macrobenthic infauna identified at stations B1 through B8, December 15, 1990, in the Bahía de Añasco and the Bahía de Mayagüez, Puerto Rico.

Appendix A-1. Summary of macrobenthic infauna observed in the Bahía de Añasco and the Bahía de Mayagüez, December 15, 1990.

\begin{tabular}{lcccccc}
\hline Site & $\begin{array}{c}\text { Number of } \\
\text { individuals }\end{array}$ & $\begin{array}{c}\text { Number of } \\
\text { species }\end{array}$ & $\begin{array}{c}\text { Shannon's } \\
\text { diversity } \\
\text { index }\end{array}$ & $\begin{array}{c}\text { Species } \\
\text { richness }\end{array}$ & $\begin{array}{c}\text { Species } \\
\text { evenness }\end{array}$ & $\begin{array}{c}\text { Simpson's } \\
\text { dominance } \\
\text { index }\end{array}$ \\
\hline B1 & 80 & 18 & 2.18 & 3.88 & 0.76 & 0.20 \\
B2 & 112 & 24 & 1.84 & 4.87 & 0.58 & 0.36 \\
B3 & 122 & 22 & 2.38 & 4.37 & 0.77 & 0.16 \\
B4 & 152 & 22 & 2.33 & 4.18 & 0.75 & 0.16 \\
B5 & 63 & 20 & 2.58 & 4.59 & 0.86 & 0.10 \\
B6 & 104 & 27 & 2.82 & 5.6 & 0.85 & 0.09 \\
B7 & 55 & 14 & 1.83 & 3.24 & 0.69 & 0.28 \\
B8 & 68 & 23 & 2.62 & 5.21 & 0.84 & 0.12 \\
B1-B8 & 756 & 56 & 2.70 & 8.30 & 0.67 & 0.15 \\
\hline
\end{tabular}

Appendix A-2. Summary of statistics describing macrobenthic infauna communities observed from sampling carried out in January and May 1985 and December 1990.

[--, indicates no data]

\begin{tabular}{|c|c|c|c|c|c|c|c|c|}
\hline Survey date & B1 & B2 & B3 & B4 & B5 & B6 & B7 & B8 \\
\hline \multicolumn{9}{|c|}{ Number of taxa } \\
\hline Jan-85 & 38 & 36 & 54 & 106 & 50 & 68 & -- & 35 \\
\hline May-85 & 75 & 108 & 142 & 179 & 156 & 151 & -- & 67 \\
\hline Dec-90 & 18 & 24 & 22 & 22 & 20 & 27 & 14 & 23 \\
\hline \multicolumn{9}{|c|}{ Density, in individuals per $0.1 \mathrm{~m}^{2}$} \\
\hline Jan-85 & 192 & 124 & 202 & 267 & 190 & 476 & -- & 106 \\
\hline May-85 & 286 & 344.6 & 1112 & 941 & 911.8 & 1042.8 & -- & 179.6 \\
\hline Dec-90 & 200 & 280 & 305 & 380 & 157.5 & 260 & 137.5 & 170 \\
\hline \multicolumn{9}{|c|}{ Shannon-Weaver's Diversity ( $H^{\prime}$, using natural logarithms) } \\
\hline Jan-85 & 2.36 & 2.70 & 2.99 & 3.71 & 3.24 & 3.09 & -- & 2.49 \\
\hline May-85 & 2.87 & 3.19 & 3.30 & 3.25 & 3.64 & 3.33 & -- & 2.78 \\
\hline Dec-90 & 2.18 & 1.84 & 2.38 & 2.33 & 2.58 & 2.82 & 1.83 & 2.62 \\
\hline \multicolumn{9}{|c|}{ Evenness $(J)$} \\
\hline Jan-85 & 0.65 & 0.75 & 0.75 & 0.80 & 0.83 & 0.73 & -- & 0.70 \\
\hline May-85 & 0.67 & 0.68 & 0.66 & 0.63 & 0.73 & 0.67 & -- & 0.66 \\
\hline Dec-90 & 0.76 & 0.58 & 0.77 & 0.75 & 0.86 & 0.85 & 0.69 & 0.84 \\
\hline \multicolumn{9}{|c|}{ Simpson's Dominance Index ( $S I$ ) } \\
\hline Jan-85 & 0.17 & 0.11 & 0.09 & 0.05 & 0.06 & 0.10 & -- & 0.16 \\
\hline May-85 & 0.11 & 0.09 & 0.08 & 0.1 & 0.06 & 0.08 & -- & 0.12 \\
\hline Dec-90 & 0.20 & 0.36 & 0.16 & 0.16 & 0.10 & 0.09 & 0.28 & 0.12 \\
\hline
\end{tabular}


Appendix A. Macrobenthic infauna identified at stations B1 through B8, December 15, 1990, in the Bahía de Añasco and the Bahía de Mayagüez, Puerto Rico-Continued.

Appendix A-3. Percentages of taxa of macrobenthic infauna identified at all sampled stations (B1-B8) in the Bahía de Añasco and the Bahía de Mayagüez, December 15, 1990. A surface area of $0.04 \mathrm{~m}^{2}$ was sampled using a Shipeck grab sampler. Species are those retained on a $0.50-\mathrm{mm}$ sieve .

[Phylum enclosed in parentheses. An, Annelida; Ar, Arthropoda; E, Echinodermata; M, Mollusca; R, Nemertia; S, Sipuncula]

\begin{tabular}{|c|c|c|c|}
\hline Taxa & Count & Percent & $\begin{array}{c}\text { Cumulative } \\
\text { percent }\end{array}$ \\
\hline Sipuncula $(S)$ & 267 & 35.32 & 35.32 \\
\hline Scoloplos sp. B (An) & 91 & 12.04 & 47.35 \\
\hline Maldane sp. A (An) & 62 & 8.20 & 55.56 \\
\hline Amphiodia sp. A (E) & 39 & 5.16 & 60.71 \\
\hline Codakia pectinella $(M)$ & 24 & 3.17 & 63.89 \\
\hline Maldanidae A (An) & 20 & 2.65 & 66.53 \\
\hline Magelona sp. A (An) & 19 & 2.51 & 69.05 \\
\hline Neanthes sp. A (An) & 19 & 2.51 & 71.56 \\
\hline Scoloplos sp. A (An) & 18 & 2.38 & 73.94 \\
\hline Prionospio sp. A (An) & 17 & 2.25 & 76.19 \\
\hline Callianassidae A (Ar) & 16 & 2.12 & 78.31 \\
\hline Cirrophorus sp. A (An) & 15 & 1.98 & 80.29 \\
\hline Prionospio sp. $C(A n)$ & 15 & 1.98 & 82.28 \\
\hline Nephtyidae A (An) & 12 & 1.59 & 83.86 \\
\hline Marphysa sp. A (An) & 11 & 1.46 & 85.32 \\
\hline Myrthea pristiphora $(M)$ & 9 & 1.19 & 86.51 \\
\hline Prionospio sp. B (An) & 9 & 1.19 & 87.70 \\
\hline Diplodonta punctata $(M)$ & 7 & 0.93 & 88.62 \\
\hline Nemertea $(R)$ & 6 & 0.79 & 89.42 \\
\hline Eunice sp. A (An) & 6 & 0.79 & 90.21 \\
\hline Oligochaeta (An) & 6 & 0.79 & 91.01 \\
\hline Aphroditidae A (An) & 5 & 0.66 & 91.67 \\
\hline Leiolambrus nitidus (Ar) & 4 & 0.53 & 92.20 \\
\hline Xanthidae A (Ar) & 4 & 0.53 & 92.72 \\
\hline Oliva caribaeensis (M) & 4 & 0.53 & 93.25 \\
\hline Tellina sp. A $(M)$ & 4 & 0.53 & 93.78 \\
\hline Pilumnus sp. A (Ar) & 3 & 0.40 & 94.18 \\
\hline Corbula caribaea (M) & 3 & 0.40 & 94.58 \\
\hline Mediomastus sp. A (An) & 3 & 0.40 & 94.97 \\
\hline Paradoneis sp. A (An) & 3 & 0.40 & 95.37 \\
\hline Poecilochaetus sp. A (An) & 3 & 0.40 & 95.77 \\
\hline Alpheidae A (Ar) & 2 & 0.26 & 96.03 \\
\hline Axiopsis sp. A (Ar) & 2 & 0.26 & 96.30 \\
\hline Mitrella nitens $(M)$ & 2 & 0.26 & 96.56 \\
\hline Scaphopoda (M) & 2 & 0.26 & 96.83 \\
\hline
\end{tabular}


Appendix A. Macrobenthic infauna identified at stations B1 through B8, December 15, 1990, in the Bahía de Añasco and the Bahía de Mayagüez, Puerto Rico-Continued.

Appendix A-3. Percentages of taxa of macrobenthic infauna identified at all sampled stations (B1-B8) in the Bahía de Añasco and the Bahía de Mayagüez, December 15, 1990. A surface area of $0.04 \mathrm{~m}^{2}$ was sampled using a Shipeck grab sampler. Species are those retained on a $0.50-\mathrm{mm}$ sieve--Continued.

[Phylum enclosed in parentheses. An, Annelida; Ar, Arthropoda; E, Echinodermata; M, Mollusca; R, Nemertia; S, Sipuncula]

\begin{tabular}{|c|c|c|c|}
\hline Taxa & Count & Percent & $\begin{array}{c}\text { Cumulative } \\
\text { percent }\end{array}$ \\
\hline Aphroditidae B (Polynoinae) (An) & 2 & 0.26 & 97.09 \\
\hline Glycera sp. A (An) & 2 & 0.26 & 97.35 \\
\hline Nereidae A (An) & 2 & 0.26 & 97.62 \\
\hline Chasmocarcinus cylindricus (Ar) & 1 & 0.13 & 97.75 \\
\hline Gonoplacidae A (Ar) & 1 & 0.13 & 97.88 \\
\hline Pygnigonida A (Ar) & 1 & 0.13 & 98.02 \\
\hline Amphiuridae A (E) & 1 & 0.13 & 98.15 \\
\hline Holothuroidea A (E) & 1 & 0.13 & 98.28 \\
\hline Corbula contracta $(M)$ & 1 & 0.13 & 98.41 \\
\hline Gouldia sp. A (M) & 1 & 0.13 & 98.54 \\
\hline Phacoides muricatus (M) & 1 & 0.13 & 98.68 \\
\hline Trigoniocardia antillarum $(M)$ & 1 & 0.13 & 98.81 \\
\hline Aphroditidae C (An) & 1 & 0.13 & 98.94 \\
\hline Aphroditidae D (Sigalioninae) (An) & 1 & 0.13 & 99.07 \\
\hline Capitellidae A (An) & 1 & 0.13 & 99.21 \\
\hline Chloeia sp. A (An) & 1 & 0.13 & 99.34 \\
\hline Ophelia sp. A (An) & 1 & 0.13 & 99.47 \\
\hline Scoloplos sp. C (An) & 1 & 0.13 & 99.60 \\
\hline Palmyridae A (An) & 1 & 0.13 & 99.74 \\
\hline Phyllodocidae A (An) & 1 & 0.13 & 99.87 \\
\hline Sigambra sp. A (An) & 1 & 0.13 & 100.00 \\
\hline Total & 756 & 100.00 & \\
\hline
\end{tabular}


Appendix A. Macrobenthic infauna identified at stations B1 through B8, December 15, 1990, in the Bahía de Añasco and the Bahía de Mayagüez, Puerto Rico-Continued.

Appendix A-4. Percentages of taxa of macrobenthic infauna identified at station B1 in the Bahía de Añasco, December 15, 1990. A surface area of $0.04 \mathrm{~m}^{2}$ was sampled using a Shipeck grab sampler. Taxa are those retained on a $0.50-\mathrm{mm}$ sieve.

[Phylum enclosed in parentheses. An, Annelida; Ar, Arthropoda; E, Echinodermata; M, Mollusca; R, Nemertia; S, Sipuncula]

\begin{tabular}{|c|c|c|c|}
\hline Taxa & Count & Percent & $\begin{array}{c}\text { Cumulative } \\
\text { percent }\end{array}$ \\
\hline Sipuncula $(S)$ & 33 & 41.25 & 41.25 \\
\hline Scoloplos sp. B (An) & 8 & 10 & 51.25 \\
\hline Magelona sp. A (An) & 6 & 7.5 & 58.75 \\
\hline Myrthea pristiphora $(M)$ & 5 & 6.25 & 65 \\
\hline Amphiodia sp. A (E) & 4 & 5 & 70 \\
\hline Neanthes sp. A (An) & 4 & 5 & 75 \\
\hline Maldane sp. A (An) & 4 & 5 & 80 \\
\hline Cirrophorus sp. A (An) & 4 & 5 & 85 \\
\hline Nemertea $(R)$ & 2 & 2.5 & 87.5 \\
\hline Prionospio sp. A (An) & 2 & 2.5 & 90 \\
\hline Codakia pectinella $(M)$ & 1 & 1.25 & 91.25 \\
\hline Scaphopoda $(M)$ & 1 & 1.25 & 92.5 \\
\hline Gonoplacidae A (Ar) & 1 & 1.25 & 93.75 \\
\hline Pilumnus sp. A (Ar) & 1 & 1.25 & 95 \\
\hline Nephtyidae A (An) & 1 & 1.25 & 96.25 \\
\hline Marphysa sp. A (An) & 1 & 1.25 & 97.5 \\
\hline Ophelia sp. A (An) & 1 & 1.25 & 98.75 \\
\hline Scoloplos sp. A (An) & 1 & 1.25 & 100 \\
\hline Total & 80 & 100.00 & \\
\hline
\end{tabular}


Appendix A. Macrobenthic infauna identified at stations B1 through B8, December 15, 1990, in the Bahía de Añasco and the Bahía de Mayagüez, Puerto Rico-Continued.

Appendix A-5. Percentages of taxa of macrobenthic infauna identified at station B2 in the Bahía de Añasco, December 15, 1990. A surface area of $0.04 \mathrm{~m}^{2}$ was sampled using a Shipeck grab sampler. Taxa are those retained on a $0.50-\mathrm{mm}$ sieve.

[Phylum enclosed in parentheses. An, Annelida; Ar, Arthropoda; E, Echinodermata; M, Mollusca; R, Nemertia; S, Sipuncula]

\begin{tabular}{|c|c|c|c|}
\hline Taxa & Count & Percent & $\begin{array}{c}\text { Cumulative } \\
\text { percent }\end{array}$ \\
\hline Sipuncula $(S)$ & 66 & 58.93 & 58.93 \\
\hline Maldane sp. A (An) & 7 & 6.25 & 65.18 \\
\hline Scoloplos sp. B (An) & 6 & 5.36 & 70.54 \\
\hline Neanthes sp. A (An) & 6 & 5.36 & 75.89 \\
\hline Amphiodia sp. A (E) & 3 & 2.68 & 78.57 \\
\hline Axiopsis sp. A (Ar) & 2 & 1.79 & 80.36 \\
\hline Prionospio sp. $C(A n)$ & 2 & 1.79 & 82.14 \\
\hline Paradoneis sp. A (An) & 2 & 1.79 & 83.93 \\
\hline Magelona sp. A (An) & 2 & 1.79 & 85.71 \\
\hline Eunice sp. A (An) & 2 & 1.79 & 87.50 \\
\hline Oliva caribaeensis $(M)$ & 1 & 0.89 & 88.39 \\
\hline Pilumnus sp. A (Ar) & 1 & 0.89 & 89.29 \\
\hline Leionambrus nitidus (Ar) & 1 & 0.89 & 90.18 \\
\hline Callianassidae A (Ar) & 1 & 0.89 & 91.07 \\
\hline Amphiuridae A (E) & 1 & 0.89 & 91.96 \\
\hline Oligochaeta (An) & 1 & 0.89 & 92.86 \\
\hline Glycera sp. A (An) & 1 & 0.89 & 93.75 \\
\hline Scoloplos sp. C (An) & 1 & 0.89 & 94.64 \\
\hline Prionospio sp. A (An) & 1 & 0.89 & 95.54 \\
\hline Mediomastus sp. A (An) & 1 & 0.89 & 96.43 \\
\hline Marphysa sp. A (An) & 1 & 0.89 & 97.32 \\
\hline Cirrophorus sp. A (An) & 1 & 0.89 & 98.21 \\
\hline Scoloplos sp. A (An) & 1 & 0.89 & 100.00 \\
\hline Aphroditidae B (An) & 1 & 0.89 & 100.00 \\
\hline Total & 112 & 100 & \\
\hline
\end{tabular}


Appendix A. Macrobenthic infauna identified at stations B1 through B8, December 15, 1990, in the Bahía de Añasco and the Bahía de Mayagüez, Puerto Rico-Continued.

Appendix A-6. Percentages of taxa of macrobenthic infauna identified at station B3 in the Bahía de Añasco, December 15, 1990. A surface area of $0.04 \mathrm{~m}^{2}$ was sampled using a Shipeck grab sampler. Taxa are those retained on a $0.50-\mathrm{mm}$ sieve.

[Phylum enclosed in parentheses. An, Annelida; Ar, Arthropoda; E, Echinodermata; M, Mollusca; R, Nemertia; S, Sipuncula]

\begin{tabular}{|c|c|c|c|}
\hline Taxa & Count & Percent & $\begin{array}{c}\text { Cumulative } \\
\text { percent }\end{array}$ \\
\hline Sipuncula $(S)$ & 41 & 33.61 & 33.61 \\
\hline Scoloplos sp. B (An) & 15 & 12.30 & 45.90 \\
\hline Maldane sp. A (An) & 14 & 11.48 & 57.38 \\
\hline Maldanidae A (An) & 9 & 7.38 & 64.75 \\
\hline Callianassidae A (Ar) & 6 & 4.92 & 69.67 \\
\hline Codakia pectinella $(M)$ & 5 & 4.10 & 73.77 \\
\hline Magelona sp. A (An) & 5 & 4.10 & 77.87 \\
\hline Marphysa sp. A (An) & 4 & 3.28 & 81.15 \\
\hline Neanthes sp. A (An) & 3 & 2.46 & 83.61 \\
\hline Prionospio sp. $B(A n)$ & 3 & 2.46 & 86.07 \\
\hline Cirrophorus sp. A (An) & 3 & 2.46 & 88.52 \\
\hline Amphiodia sp. A (E) & 2 & 1.64 & 90.16 \\
\hline Prionospio sp. $C(A n)$ & 2 & 1.64 & 91.80 \\
\hline Eunice sp. A (An) & 2 & 1.64 & 93.44 \\
\hline Oliva caribaeensis $(M)$ & 1 & 0.82 & 94.26 \\
\hline Scaphopoda A (M) & 1 & 0.82 & 95.08 \\
\hline Leiolambrus nitidus (Ar) & 1 & 0.82 & 95.90 \\
\hline Oligochaeta $(A n)$ & 1 & 0.82 & 96.72 \\
\hline Glycera sp. A (An) & 1 & 0.82 & 97.54 \\
\hline Nephtyidae A (An) & 1 & 0.82 & 98.36 \\
\hline Paradoneis sp. A (An) & 1 & 0.82 & 99.18 \\
\hline Scoloplos sp. A (An) & 1 & 0.82 & 100.00 \\
\hline Total & 122 & 100 & \\
\hline
\end{tabular}


Appendix A. Macrobenthic infauna identified at stations B1 through B8, December 15, 1990, in the Bahía de Añasco and the Bahía de Mayagüez, Puerto Rico-Continued.

Appendix A-7. Percentages of taxa of macrobenthic infauna identified at station B4 in the Bahía de Añasco, December 15, 1990. A surface area of $0.04 \mathrm{~m}^{2}$ was sampled using a Shipeck grab sampler. Taxa are those retained on a $0.50-\mathrm{mm}$ sieve.

[Phylum enclosed in parentheses. An, Annelida; Ar, Arthropoda; E, Echinodermata; M, Mollusca; R, Nemertia; S, Sipuncula]

\begin{tabular}{|c|c|c|c|}
\hline Taxa & Count & Percent & $\begin{array}{c}\text { Cumulative } \\
\text { Percent }\end{array}$ \\
\hline Sipuncula $(S)$ & 51 & 33.55 & 33.55 \\
\hline Maldane sp. A (An) & 20 & 13.16 & 46.71 \\
\hline Scoloplos sp. B (An) & 17 & 11.18 & 57.89 \\
\hline Amphiodia sp. A (E) & 15 & 9.87 & 67.76 \\
\hline Codakia pectinella $(M)$ & 9 & 5.92 & 73.68 \\
\hline Scoloplos sp. A (An) & 6 & 3.95 & 77.63 \\
\hline Prionospio sp. A (An) & 6 & 3.95 & 81.58 \\
\hline Callianassidae a $(A r)$ & 3 & 1.97 & 83.55 \\
\hline Aphroditidae A (An) & 3 & 1.97 & 85.53 \\
\hline Prionospio sp. $C(A n)$ & 3 & 1.97 & 87.50 \\
\hline Diplodonta punctata $(M)$ & 2 & 1.32 & 88.82 \\
\hline Xanthidae A (Ar) & 2 & 1.32 & 90.13 \\
\hline Nemertea $(R)$ & 2 & 1.32 & 91.45 \\
\hline Maldanidae A (An) & 2 & 1.32 & 92.76 \\
\hline Neanthes sp. A (An) & 2 & 1.32 & 94.08 \\
\hline Nephtyidae A (An) & 2 & 1.32 & 95.39 \\
\hline Magelona sp. A (An) & 2 & 1.32 & 96.71 \\
\hline Mitrella nitens $(M)$ & 1 & 0.66 & 97.37 \\
\hline Gouldia sp. A (M) & 1 & 0.66 & 98.03 \\
\hline Corbula contracta $(M)$ & 1 & 0.66 & 98.68 \\
\hline Oligochaeta (An) & 1 & 0.66 & 99.34 \\
\hline Aphroditidae C (An) & 1 & 0.66 & 100.00 \\
\hline Total & 152 & 100 & \\
\hline
\end{tabular}


Appendix A. Macrobenthic infauna identified at stations B1 through B8, December 15, 1990, in the Bahía de Añasco and the Bahía de Mayagüez, Puerto Rico-Continued.

Appendix A-8. Percentages of taxa of macrobenthic infauna identified at station B5 in the Bahía de Añasco, December 15, 1990. A surface area of $0.04 \mathrm{~m}^{2}$ was sampled using a Shipeck grab sampler. Taxa are those retained on a $0.50-\mathrm{mm}$ sieve.

[Phylum enclosed in parentheses. An, Annelida; Ar, Arthropoda; E, Echinodermata; M, Mollusca; R, Nemertia; S, Sipuncula]

\begin{tabular}{|c|c|c|c|}
\hline Taxa & Count & Percent & $\begin{array}{c}\text { Cumulative } \\
\text { percent }\end{array}$ \\
\hline Sipuncula $(S)$ & 13 & 20.63 & 20.63 \\
\hline Scoloplos sp. B (An) & 8 & 12.70 & 33.33 \\
\hline Codakia pectinella $(M)$ & 7 & 11.11 & 44.44 \\
\hline Prionospio sp. C (An) & 6 & 9.52 & 53.97 \\
\hline Cirrophorus sp. A (An) & 6 & 9.52 & 63.49 \\
\hline Scoloplos sp. A (An) & 4 & 6.35 & 69.84 \\
\hline Amphiodia sp. A (E) & 3 & 4.76 & 74.60 \\
\hline Magelona sp. A (An) & 3 & 4.76 & 79.37 \\
\hline Tellina sp. $A(M)$ & 2 & 3.17 & 82.54 \\
\hline Corbula caribaea $(M)$ & 1 & 1.59 & 84.13 \\
\hline Diplodonta punctata $(M)$ & 1 & 1.59 & 85.71 \\
\hline Phacoides muricatus (M) & 1 & 1.59 & 87.30 \\
\hline Alpheidae A (Ar) & 1 & 1.59 & 88.89 \\
\hline Aphroditidae A (An) & 1 & 1.59 & 90.48 \\
\hline Prionospio sp. $B(A n)$ & 1 & 1.59 & 92.06 \\
\hline Poecilochaetus sp. A (An) & 1 & 1.59 & 93.65 \\
\hline Neanthes sp. A (An) & 1 & 1.59 & 95.24 \\
\hline Aphroditidae B (Polynoinae) (An) & 1 & 1.59 & 96.83 \\
\hline Capitellidae sp. A (An) & 1 & 1.59 & 98.41 \\
\hline Maldanidae A (An) & 1 & 1.59 & 100.00 \\
\hline Total & 63 & 100.00 & \\
\hline
\end{tabular}


Appendix A. Macrobenthic infauna identified at stations B1 through B8, December 15, 1990, in the Bahía de Añasco and the Bahía de Mayagüez, Puerto Rico-Continued.

Appendix A-9. Percentages of taxa of macrobenthic infauna identified at station B6 in the Bahía de Añasco, December 15, 1990. A surface area of $0.04 \mathrm{~m}^{2}$ was sampled using a Shipeck grab sampler. Taxa are those retained on a $0.50-\mathrm{mm}$ sieve.

[Phylum enclosed in parentheses. An, Annelida; Ar, Arthropoda; E, Echinodermata; M, Mollusca; R, Nemertia; S, Sipuncula]

\begin{tabular}{|c|c|c|c|}
\hline Taxa & Count & Percent & $\begin{array}{c}\text { Cumulative } \\
\text { percent }\end{array}$ \\
\hline Sipuncula $(S)$ & 18 & 17.31 & 17.31 \\
\hline Scoloplos sp. B (An) & 18 & 17.31 & 34.62 \\
\hline Maldane sp. A (An) & 9 & 8.65 & 43.27 \\
\hline Amphiodia sp. A (E) & 7 & 6.73 & 50.00 \\
\hline Nephtyidae A (An) & 6 & 5.77 & 55.77 \\
\hline Marphysa sp. A (An) & 5 & 4.81 & 60.58 \\
\hline Scoloplos sp. A (An) & 5 & 4.81 & 65.38 \\
\hline Prionospio sp. A (An) & 4 & 3.85 & 69.23 \\
\hline Prionospio sp. $B(A n)$ & 4 & 3.85 & 73.08 \\
\hline Diplodonta punctata $(M)$ & 3 & 2.88 & 75.96 \\
\hline Maldanidae A (An) & 3 & 2.88 & 78.85 \\
\hline Corbula caribaea $(M)$ & 2 & 1.92 & 80.77 \\
\hline Tellina sp. A $(M)$ & 2 & 1.92 & 82.69 \\
\hline Callianassidae A (Ar) & 2 & 1.92 & 84.62 \\
\hline Nemertea $(R)$ & 2 & 1.92 & 86.54 \\
\hline Poecilochaetus sp. A (An) & 2 & 1.92 & 88.46 \\
\hline Nereidae A (An) & 2 & 1.92 & 90.38 \\
\hline Trioniocardia antillarum $(M)$ & 1 & 0.96 & 91.35 \\
\hline Pygnigonida A (Ar) & 1 & 0.96 & 92.31 \\
\hline Holothuroidea A (E) & 1 & 0.96 & 93.27 \\
\hline Eunice sp. A (An) & 1 & 0.96 & 94.23 \\
\hline Cirrophorus sp. A (An) & 1 & 0.96 & 95.19 \\
\hline Magelona sp. A (An) & 1 & 0.96 & 96.15 \\
\hline Aphroditidae & 1 & 0.96 & 97.12 \\
\hline Mediomastus sp. A (An) & 1 & 0.96 & 98.08 \\
\hline Neanthes sp. A (An) & 1 & 0.96 & 99.04 \\
\hline Palmyridae A (An) & 1 & 0.96 & 100.00 \\
\hline Total & 104 & 100.00 & \\
\hline
\end{tabular}


Appendix A. Macrobenthic infauna identified at stations B1 through B8, December 15, 1990, in the Bahía de Añasco and the Bahía de Mayagüez, Puerto Rico-Continued.

Appendix A-10. Percentages of taxa of macrobenthic infauna identified at station B7 in the Bahía de Añasco, December 15, 1990. A surface area of $0.04 \mathrm{~m}^{2}$ was sampled using a Shipeck grab sampler. Taxa are those retained on a $0.50-\mathrm{mm}$ sieve.

[Phylum enclosed in parentheses. An, Annelida; Ar, Arthropoda; E, Echinodermata; M, Mollusca; R, Nemertia; S, Sipuncula]

\begin{tabular}{|c|c|c|c|}
\hline Taxa & Count & Percent & $\begin{array}{c}\text { Cumulative } \\
\text { percent }\end{array}$ \\
\hline Sipuncula $(S)$ & 27 & 49.09 & 49.09 \\
\hline Scoloplos sp. B (An) & 9 & 16.36 & 65.45 \\
\hline Callianassidae A (Ar) & 3 & 5.45 & 70.91 \\
\hline Amphiodia sp. A (E) & 3 & 5.45 & 76.36 \\
\hline Myrthea pristiphora $(M)$ & 2 & 3.64 & 80.00 \\
\hline Leiolambrus nitidus (Ar) & 2 & 3.64 & 83.64 \\
\hline Maldane sp. A (An) & 2 & 3.64 & 87.27 \\
\hline Codakia pectinella $(M)$ & 1 & 1.82 & 89.09 \\
\hline Chasmocarcinus cylindricus (Ar) & 1 & 1.82 & 90.91 \\
\hline Xanthidae A (Ar) & 1 & 1.82 & 92.73 \\
\hline Phyllodocidae A (An) & 1 & 1.82 & 94.55 \\
\hline Eunice sp. $A(A n)$ & 1 & 1.82 & 96.36 \\
\hline Prionospio sp. A (An) & 1 & 1.82 & 98.18 \\
\hline Chloeia sp. A (An) & 1 & 1.82 & 100.00 \\
\hline Total & 55 & 100.00 & \\
\hline
\end{tabular}


Appendix A. Macrobenthic infauna identified at stations B1 through B8, December 15, 1990, in the Bahía de Añasco and the Bahía de Mayagüez, Puerto Rico-Continued.

Appendix A-11. Percentages of taxa of macrobenthic infauna identified at station B8 in the Bahía de Añasco Mayagüez, December 15, 1990. A surface area of $0.04 \mathrm{~m}^{2}$ was sampled using a Shipeck grab sampler. Taxa are those retained on a $0.50-\mathrm{mm}$ sieve.

[Phylum enclosed in parentheses. An, Annelida; Ar, Arthropoda; E, Echinodermata; M, Mollusca; R, Nemertia; S, sipuncula]

\begin{tabular}{|c|c|c|c|}
\hline Taxa & Count & Percent & $\begin{array}{c}\text { Cumulative } \\
\text { percent }\end{array}$ \\
\hline Sipuncula $(S)$ & 18 & 26.47 & 26.47 \\
\hline Scoloplos sp. B (An) & 10 & 14.71 & 41.18 \\
\hline Maldane sp. A (An) & 6 & 8.82 & 50.00 \\
\hline Maldanidae A (An) & 5 & 7.35 & 57.35 \\
\hline Oligochaeta $(A n)$ & 3 & 4.41 & 61.76 \\
\hline Prionospio sp. A (An) & 3 & 4.41 & 66.18 \\
\hline Myrthea pristiphora $(M)$ & 2 & 2.94 & 69.12 \\
\hline Oliva caribaeensis $(M)$ & 2 & 2.94 & 72.06 \\
\hline Amphiodia sp. A (E) & 2 & 2.94 & 75.00 \\
\hline Neanthes sp. A (An) & 2 & 2.94 & 80.88 \\
\hline Nephtyidae A (An) & 2 & 2.94 & 83.82 \\
\hline Prionospio sp. $C(A n)$ & 2 & 1.47 & 98.53 \\
\hline Prionospio sp. $B(A n)$ & 1 & 2.94 & 77.94 \\
\hline Codakia pectinella $(M)$ & 1 & 1.47 & 85.29 \\
\hline Diplodonta punctata $(M)$ & 1 & 1.47 & 86.76 \\
\hline Mitrella nitens $(M)$ & 1 & 1.47 & 88.24 \\
\hline Pilumnus sp. A (Ar) & 1 & 1.47 & 89.71 \\
\hline Alpheidae A (Ar) & 1 & 1.47 & 91.18 \\
\hline Xanthidae A (Ar) & 1 & 1.47 & 92.65 \\
\hline Callianassidae A (Ar) & 1 & 1.47 & 94.12 \\
\hline Aphroditidae D (Sigalioninae) (An) & 1 & 1.47 & 95.59 \\
\hline Mediomastus sp. A (An) & 1 & 1.47 & 97.06 \\
\hline Sigambra sp. A (An) & 1 & 1.47 & 100.00 \\
\hline Total & 68 & 100.00 & \\
\hline
\end{tabular}


Appendix A. Macrobenthic infauna identified at stations B1 through B8, December 15, 1990, in the Bahía de Añasco and the Bahía de Mayagüez, Puerto Rico-Continued.

Appendix A-12. Number of individuals identified by taxa in each of five replicate samples of taxa of macrobenthic infauna identified at station B1 in the Bahía de Añasco, December 15, 1990. A surface area of $0.04 \mathrm{~m}^{2}$ was sampled using a Shipeck grab sampler. Taxa are those retained on a $0.50-\mathrm{mm}$ sieve.

[Phylum enclosed in parentheses. Rep, replicate; Avg, average; An, Annelida; Ar, Arthropoda; E, Echinodermata; M, Mollusca; R, Nemertia; S, Sipuncula]

\begin{tabular}{|c|c|c|c|c|c|c|c|}
\hline Taxa & $\operatorname{Rep} A$ & $\operatorname{Rep} B$ & $\operatorname{Rep} C$ & $\operatorname{Rep} D$ & $\operatorname{Rep} E$ & Total & Avg \\
\hline Sipuncula (S) & 5 & 8 & 9 & 6 & 5 & 33 & 6.6 \\
\hline Scoloplos sp. B (An) & 0 & 0 & 0 & 0 & 8 & 8 & 1.6 \\
\hline Magelona sp. A (An) & 1 & 1 & 0 & 2 & 2 & 6 & 1.2 \\
\hline Myrthea pristiphora $(M)$ & 3 & 0 & 0 & 1 & 1 & 5 & 1 \\
\hline Amphiodia sp. A (E) & 0 & 1 & 1 & 1 & 1 & 4 & 0.8 \\
\hline Neanthes sp. A (An) & 2 & 1 & 0 & 1 & 0 & 4 & 0.8 \\
\hline Maldane sp. A (An) & 0 & 2 & 1 & 0 & 1 & 4 & 0.8 \\
\hline Cirrophorus sp. A (An) & 0 & 0 & 0 & 0 & 4 & 4 & 0.8 \\
\hline Nemertea $(R)$ & 1 & 0 & 0 & 0 & 1 & 2 & 0.4 \\
\hline Prionospio sp. A (An) & 1 & 1 & 0 & 0 & 0 & 2 & 0.4 \\
\hline Codakia pectinella $(M)$ & 0 & 0 & 0 & 1 & 0 & 1 & 0.2 \\
\hline Scaphopoda (M) & 0 & 1 & 0 & 0 & 0 & 1 & 0.2 \\
\hline Gonoplacidae A (Ar) & 0 & 0 & 0 & 0 & 1 & 1 & 0.2 \\
\hline Pilumnus sp. A (Ar) & 0 & 0 & 1 & 0 & 0 & 1 & 0.2 \\
\hline Nephtyidae A (An) & 0 & 0 & 1 & 0 & 0 & 1 & 0.2 \\
\hline Marphysa sp. A (An) & 0 & 0 & 1 & 0 & 0 & 1 & 0.2 \\
\hline Ophelia sp. A (An) & 0 & 0 & 0 & 1 & 0 & 1 & 0.2 \\
\hline Scoloplos sp. A (An) & 0 & 0 & 0 & 0 & 1 & 1 & 0.2 \\
\hline Total & 13 & 15 & 14 & 13 & 25 & 80 & 16 \\
\hline
\end{tabular}


Appendix A. Macrobenthic infauna identified at stations B1 through B8, December 15, 1990, in the Bahía de Añasco and the Bahía de Mayagüez, Puerto Rico-Continued.

Appendix A-13. Number of individuals identified by taxa in each of five replicate samples of taxa of macrobenthic infauna identified at station B2 in the Bahía de Añasco, December 15, 1990. A surface area of $0.04 \mathrm{~m}^{2}$ was sampled using a Shipeck grab sampler. Taxa are those retained on a $0.50-\mathrm{mm}$ sieve.

[Phylum enclosed in parentheses. Rep, replicate; Avg, average; An, Annelida; Ar, Arthropoda; E, Echinodermata; M, Mollusca; R, Nemertia; S, Sipuncula]

\begin{tabular}{|c|c|c|c|c|c|c|c|}
\hline Taxa & $\operatorname{Rep} A$ & $\operatorname{Rep} B$ & Rep C & $\operatorname{Rep} D$ & $\operatorname{Rep} E$ & Total & Avg \\
\hline Sipuncula $(S)$ & 11 & 9 & 17 & 13 & 16 & 66 & 13.2 \\
\hline Maldane sp. A (An) & 1 & 1 & 0 & 2 & 3 & 7 & 1.4 \\
\hline Scoloplos sp. B (An) & 0 & 3 & 1 & 2 & 0 & 6 & 1.2 \\
\hline Neanthes sp. A (An) & 1 & 0 & 5 & 0 & 0 & 6 & 1.2 \\
\hline Amphiodia sp. A (E) & 1 & 1 & 0 & 1 & 0 & 3 & 0.6 \\
\hline Axiopsis sp. A (Ar) & 0 & 1 & 0 & 1 & 0 & 2 & 0.4 \\
\hline Prionospio sp. $C(A n)$ & 1 & 0 & 0 & 1 & 0 & 2 & 0.4 \\
\hline Paradoneis sp. A (An) & 1 & 0 & 0 & 0 & 1 & 2 & 0.4 \\
\hline Magelona sp. A (An) & 0 & 0 & 0 & 1 & 1 & 2 & 0.4 \\
\hline Eunice sp. A (An) & 0 & 0 & 0 & 1 & 1 & 2 & 0.4 \\
\hline Oliva caribaeensis $(M)$ & 1 & 0 & 0 & 0 & 0 & 1 & 0.2 \\
\hline Pilumnus sp. A (Ar) & 0 & 0 & 0 & 1 & 0 & 1 & 0.2 \\
\hline Leionambrus nitidus (Ar) & 0 & 0 & 0 & 1 & 0 & 1 & 0.2 \\
\hline Callianassidae A (Ar) & 0 & 0 & 0 & 0 & 1 & 1 & 0.2 \\
\hline Amphiuridae A (E) & 1 & 0 & 0 & 0 & 0 & 1 & 0.2 \\
\hline Oligochaeta (An) & 0 & 0 & 0 & 0 & 1 & 1 & 0.2 \\
\hline Glycera sp. A (An) & 1 & 0 & 0 & 0 & 0 & 1 & 0.2 \\
\hline Scoloplos sp. $C(A n)$ & 1 & 0 & 0 & 0 & 0 & 1 & 0.2 \\
\hline Prionospio sp. A (An) & 1 & 0 & 0 & 0 & 0 & 1 & 0.2 \\
\hline Mediomastus sp. A (An) & 1 & 0 & 0 & 0 & 0 & 1 & 0.2 \\
\hline Marphysa sp. A (An) & 0 & 0 & 1 & 0 & 0 & 1 & 0.2 \\
\hline Cirrophorus sp. A (An) & 0 & 0 & 0 & 1 & 0 & 1 & 0.2 \\
\hline Scoloplos sp. A & 0 & 0 & 0 & 0 & 1 & 1 & 0.2 \\
\hline Aphroditidae B (An) & 0 & 0 & 0 & 0 & 1 & 1 & 0.2 \\
\hline Total & 22 & 15 & 24 & 25 & 26 & 112 & 22.4 \\
\hline
\end{tabular}


Appendix A. Macrobenthic infauna identified at stations B1 through B8, December 15, 1990, in the Bahía de Añasco and the Bahía de Mayagüez, Puerto Rico-Continued.

Appendix A-14. Number of individuals identified by taxa in each of five replicate samples of taxa of macrobenthic infauna identified at station B3 in the Bahía de Añasco, December 15, 1990. A surface area of $0.04 \mathrm{~m}^{2}$ was sampled using a Shipeck grab sampler. Taxa are those retained on a $0.50-\mathrm{mm}$ sieve.

[Phylum enclosed in parentheses. Rep, replicate; Avg, average; An, Annelida; Ar, Arthropoda; E, Echinodermata; M, Mollusca; R, Nemertia; S, Sipuncula]

\begin{tabular}{|c|c|c|c|c|c|c|c|}
\hline Taxa & Rep A & $\operatorname{Rep~B}$ & Rep C & Rep D & Rep E & Total & Avg \\
\hline Sipuncula (S) & 7 & 16 & 6 & 3 & 9 & 41 & 8.2 \\
\hline Scoloplos sp. B (An) & 2 & 7 & 0 & 4 & 2 & 15 & 3 \\
\hline Maldane sp. A (An) & 5 & 7 & 1 & 0 & 1 & 14 & 2.8 \\
\hline Maldanidae A (An) & 0 & 0 & 5 & 4 & 0 & 9 & 1.8 \\
\hline Callianassidae A (Ar) & 1 & 1 & 1 & 2 & 1 & 6 & 1.2 \\
\hline Codakia pectinella $(M)$ & 2 & 0 & 0 & 3 & 0 & 5 & 1 \\
\hline Magelona sp. A (An) & 1 & 1 & 1 & 1 & 1 & 5 & 1 \\
\hline Marphysa sp. A (An) & 0 & 0 & 1 & 1 & 2 & 4 & 0.8 \\
\hline Neanthes sp. A (An) & 1 & 0 & 0 & 1 & 1 & 3 & 0.6 \\
\hline Prionospio sp. B (An) & 1 & 2 & 0 & 0 & 0 & 3 & 0.6 \\
\hline Cirrophorus sp. A (An) & 0 & 3 & 0 & 0 & 0 & 3 & 0.6 \\
\hline Amphiodia sp. A (E) & 0 & 1 & 0 & 0 & 1 & 2 & 0.4 \\
\hline Prionospio sp. $C(A n)$ & 2 & 0 & 0 & 0 & 0 & 2 & 0.4 \\
\hline Eunice sp. A (An) & 0 & 2 & 0 & 0 & 0 & 2 & 0.4 \\
\hline Oliva caribaeensis $(M)$ & 0 & 0 & 0 & 0 & 1 & 1 & 0.2 \\
\hline Scaphopoda A (M) & 1 & 0 & 0 & 0 & 0 & 1 & 0.2 \\
\hline Leiolambrus nitidus (Ar) & 0 & 1 & 0 & 0 & 0 & 1 & 0.2 \\
\hline Oligochaeta (An) & 1 & 0 & 0 & 0 & 0 & 1 & 0.2 \\
\hline Glycera sp. A (An) & 0 & 0 & 1 & 0 & 0 & 1 & 0.2 \\
\hline Nephtyidae A (An) & 0 & 0 & 0 & 1 & 0 & 1 & 0.2 \\
\hline Paradoneis sp. A (An) & 0 & 0 & 0 & 1 & 0 & 1 & 0.2 \\
\hline Scoloplos sp. A (An) & 0 & 0 & 0 & 1 & 0 & 1 & 0.2 \\
\hline Total & 24 & 41 & 16 & 22 & 19 & 122 & 24.4 \\
\hline
\end{tabular}


Appendix A. Macrobenthic infauna identified at stations B1 through B8, December 15, 1990, in the Bahía de Añasco and the Bahía de Mayagüez, Puerto Rico-Continued.

Appendix A-15. Number of individuals identified by taxa in each of five replicate samples of taxa of macrobenthic infauna identified at station B4 in the Bahía de Añasco, December 15, 1990. A surface area of $0.04 \mathrm{~m}^{2}$ was sampled using a Shipeck grab sampler. Taxa are those retained on a $0.50-\mathrm{mm}$ sieve.

[Phylum enclosed in parentheses. Rep, replicate; Avg, average; An, Annelida; Ar, Arthropoda; E, Echinodermata; M, Mollusca; R, Nemertia; S, Sipuncula]

\begin{tabular}{|c|c|c|c|c|c|c|c|}
\hline Taxa & $\operatorname{Rep} \mathrm{A}$ & Rep B & Rep C & $\operatorname{Rep} D$ & Rep E & Total & Avg \\
\hline Sipuncula (S) & 8 & 9 & 5 & 12 & 17 & 51 & 10.2 \\
\hline Maldane sp. A (An) & 0 & 14 & 2 & 2 & 2 & 20 & 4 \\
\hline Scoloplos sp. B (An) & 3 & 3 & 1 & 5 & 5 & 17 & 3.4 \\
\hline Amphiodia sp. A (E) & 4 & 1 & 4 & 1 & 5 & 15 & 3 \\
\hline Codakia pectinella $(M)$ & 1 & 7 & 0 & 1 & 0 & 9 & 1.8 \\
\hline Scoloplos sp. A (An) & 4 & 0 & 0 & 2 & 0 & 6 & 1.2 \\
\hline Prionospio sp. A (An) & 0 & 0 & 4 & 1 & 1 & 6 & 1.2 \\
\hline Callianassidae a $(A r)$ & 0 & 0 & 2 & 0 & 1 & 3 & 0.6 \\
\hline Aphroditidae A (An) & 0 & 1 & 1 & 1 & 0 & 3 & 0.6 \\
\hline Prionospio sp. $C(A n)$ & 0 & 1 & 0 & 2 & 0 & 3 & 0.6 \\
\hline Diplodonta punctata $(M)$ & 0 & 1 & 0 & 0 & 1 & 2 & 0.4 \\
\hline Xanthidae A (Ar) & 0 & 0 & 1 & 0 & 1 & 2 & 0.4 \\
\hline Nemertea $(R)$ & 0 & 0 & 0 & 0 & 2 & 2 & 0.4 \\
\hline Maldanidae A (An) & 0 & 1 & 0 & 0 & 1 & 2 & 0.4 \\
\hline Neanthes sp. A (An) & 0 & 1 & 1 & 0 & 0 & 2 & 0.4 \\
\hline Nephtyidae A (An) & 0 & 1 & 0 & 1 & 0 & 2 & 0.4 \\
\hline Magelona sp. A (An) & 0 & 0 & 1 & 0 & 1 & 2 & 0.4 \\
\hline Mitrella nitens $(M)$ & 0 & 0 & 0 & 0 & 1 & 1 & 0.2 \\
\hline Gouldia sp. A (M) & 0 & 0 & 0 & 0 & 1 & 1 & 0.2 \\
\hline Corbula contracta $(M)$ & 0 & 1 & 0 & 0 & 0 & 1 & 0.2 \\
\hline Oligochaeta (An) & 1 & 0 & 0 & 0 & 0 & 1 & 0.2 \\
\hline Aphroditidae C (An) & 1 & 0 & 0 & 0 & 0 & 1 & 0.2 \\
\hline Total & 22 & 41 & 22 & 28 & 39 & 152 & 30.4 \\
\hline
\end{tabular}


Appendix A. Macrobenthic infauna identified at stations B1 through B8, December 15, 1990, in the Bahía de Añasco and the Bahía de Mayagüez, Puerto Rico-Continued.

Appendix A-16. Number of individuals identified by taxa in each of five replicate samples of taxa of macrobenthic infauna identified at station B5 in the Bahía de Añasco, December 15, 1990. A surface area of $0.04 \mathrm{~m}^{2}$ was sampled using a Shipeck grab sampler. Taxa are those retained on a $0.50-\mathrm{mm}$ sieve.

[Phylum enclosed in parentheses. Rep, replicate; Avg, average; An, Annelida; Ar, Arthropoda; E, Echinodermata; M, Mollusca; R, Nemertia; S, Sipuncula]

\begin{tabular}{|c|c|c|c|c|c|c|c|}
\hline Taxa & $\operatorname{Rep} A$ & Rep B & Rep C & $\operatorname{Rep} D$ & $\operatorname{Rep} E$ & Total & Avg \\
\hline Sipuncula $(S)$ & 2 & 4 & 1 & 2 & 4 & 13 & 2.6 \\
\hline Scoloplos sp. B (An) & 1 & 2 & 1 & 1 & 3 & 8 & 1.6 \\
\hline Codakia pectinella (M) & 0 & 1 & 0 & 1 & 5 & 7 & 1.4 \\
\hline Prionospio sp. $C(A n)$ & 1 & 1 & 2 & 1 & 1 & 6 & 1.2 \\
\hline Cirrophorus sp. A (An) & 0 & 0 & 1 & 1 & 4 & 6 & 1.2 \\
\hline Scoloplos sp. A (An) & 1 & 0 & 3 & 0 & 0 & 4 & 0.8 \\
\hline Amphiodia sp. A (E) & 2 & 0 & 0 & 1 & 0 & 3 & 0.6 \\
\hline Magelona sp. A (An) & 0 & 0 & 1 & 1 & 1 & 3 & 0.6 \\
\hline Tellina sp. A $(M)$ & 0 & 0 & 0 & 0 & 2 & 2 & 0.4 \\
\hline Corbula caribaea $(M)$ & 0 & 0 & 0 & 1 & 0 & 1 & 0.2 \\
\hline Diplodonta punctata (M) & 1 & 0 & 0 & 0 & 0 & 1 & 0.2 \\
\hline Phacoides muricatus (M) & 0 & 0 & 0 & 0 & 1 & 1 & 0.2 \\
\hline Alpheidae A (Ar) & 1 & 0 & 0 & 0 & 0 & 1 & 0.2 \\
\hline Aphroditidae A (An) & 1 & 0 & 0 & 0 & 0 & 1 & 0.2 \\
\hline Prionospio sp. B (An) & 1 & 0 & 0 & 0 & 0 & 1 & 0.2 \\
\hline Poecilochaetus sp. A (An) & 0 & 0 & 1 & 0 & 0 & 1 & 0.2 \\
\hline Neanthes sp. A (An) & 0 & 1 & 0 & 0 & 0 & 1 & 0.2 \\
\hline Aphroditidae B (Polynoinae) (An) & 0 & 1 & 0 & 0 & 0 & 1 & 0.2 \\
\hline Capitellidae sp. A (An) & 0 & 0 & 0 & 1 & 0 & 1 & 0.2 \\
\hline Maldanidae A (An) & 0 & 0 & 0 & 0 & 1 & 1 & 0.2 \\
\hline Total & 11 & 10 & 10 & 10 & 22 & 63 & 12.6 \\
\hline
\end{tabular}


Appendix A. Macrobenthic infauna identified at stations B1 through B8, December 15, 1990, in the Bahía de Añasco and the Bahía de Mayagüez, Puerto Rico-Continued.

Appendix A-17. Number of individuals identified by taxa in each of five replicate samples of taxa of macrobenthic infauna identified at station B6 in the Bahía de Añasco, December 15, 1990. A surface area of $0.04 \mathrm{~m}^{2}$ was sampled using a Shipeck grab sampler. Taxa are those retained on a $0.50-\mathrm{mm}$ sieve.

Phylum enclosed in parentheses. Abbreviations: Rep, replicate; Avg, average; An, Annelida; Ar, Arthropoda; E, Echinodermata; M, Mollusca;

$R$, Nemertia; S, Sipuncula]

\begin{tabular}{|c|c|c|c|c|c|c|c|}
\hline Taxa & $\operatorname{Rep} A$ & $\operatorname{Rep} B$ & $\operatorname{Rep} C$ & $\operatorname{Rep} D$ & $\operatorname{Rep} \mathrm{E}$ & Total & Avg \\
\hline Sipuncula $(S)$ & 9 & 3 & 0 & 1 & 5 & 18 & 3.6 \\
\hline Scoloplos sp. B (An) & 3 & 5 & 2 & 6 & 2 & 18 & 3.6 \\
\hline Maldane sp. A (An) & 2 & & 3 & 2 & 2 & 9 & 1.8 \\
\hline Amphiodia sp. A (E) & 2 & 2 & 1 & 0 & 2 & 7 & 1.4 \\
\hline Nephtyidae A (An) & 3 & 2 & 0 & 0 & 1 & 6 & 1.2 \\
\hline Marphysa sp. A (An) & 0 & 1 & 0 & 0 & 3 & 4 & 0.8 \\
\hline Scoloplos sp. A (An) & 0 & 2 & 3 & 0 & 0 & 5 & 1 \\
\hline Prionospio sp. A (An) & 0 & 1 & 1 & 0 & 2 & 4 & 0.8 \\
\hline Prionospio sp. B (An) & 1 & 2 & 1 & 0 & 0 & 4 & 0.8 \\
\hline Diplodonta punctata (M) & 3 & 0 & 0 & 0 & 0 & 3 & 0.6 \\
\hline Maldanidae A (An) & 2 & 1 & 0 & 0 & 0 & 3 & 0.6 \\
\hline Corbula caribaea $(M)$ & 0 & 0 & 0 & 1 & 1 & 2 & 0.4 \\
\hline Tellina sp. A $(M)$ & 0 & 0 & 0 & 1 & 1 & 2 & 0.4 \\
\hline Callianassidae A (Ar) & 0 & 0 & 2 & 0 & 0 & 2 & 0.4 \\
\hline Nemertea $(R)$ & 1 & 1 & 0 & 0 & 0 & 2 & 0.4 \\
\hline Poecilochaetus sp. A (An) & 1 & 0 & 0 & 0 & 1 & 2 & 0.4 \\
\hline Nereidae A (An) & 0 & 0 & 1 & 0 & 1 & 2 & 0.4 \\
\hline Trioniocardia antillarum (M) & 0 & 0 & 0 & 1 & 0 & 1 & 0.2 \\
\hline Pygnigonida A (Ar) & 0 & 0 & 0 & 1 & 0 & 1 & 0.2 \\
\hline Holothuroidea A (E) & 0 & 0 & 1 & 0 & 0 & 1 & 0.2 \\
\hline Eunice sp. A (An) & 1 & 0 & 0 & 0 & 0 & 1 & 0.2 \\
\hline Cirrophorus sp. A (An) & 1 & 0 & 0 & 0 & 0 & 1 & 0.2 \\
\hline Magelona sp. A (An) & 0 & 1 & 0 & 0 & 0 & 1 & 0.2 \\
\hline Aphroditidae A (An) & 0 & 0 & 0 & 1 & 0 & 1 & 0.2 \\
\hline Mediomastus sp. A (An) & 0 & 0 & 1 & 0 & 0 & 1 & 0.2 \\
\hline Neanthes sp. A (An) & 0 & 0 & 0 & 1 & 1 & 2 & 0.4 \\
\hline Palmyridae A (An) & 0 & 0 & 0 & 1 & 0 & 1 & 0.2 \\
\hline Total & 29 & 21 & 16 & 16 & 22 & 104 & 20.8 \\
\hline
\end{tabular}


Appendix A. Macrobenthic infauna identified at stations B1 through B8, December 15, 1990, in the Bahía de Añasco and the Bahía de Mayagüez, Puerto Rico-Continued.

Appendix A-18. Number of individuals identified by taxa in each of five replicate samples of taxa of macrobenthic infauna identified at station B7 in the Bahía de Añasco, December 15, 1990. A surface area of $0.04 \mathrm{~m}^{2}$ was sampled using a Shipeck grab sampler. Taxa are those retained on a $0.50-\mathrm{mm}$ sieve.

[Phylum enclosed in parentheses. Rep, replicate; Avg, average; An, Annelida; Ar, Arthropoda; E, Echinodermata; M, Mollusca; R, Nemertia; S, Sipuncula]

\begin{tabular}{|c|c|c|c|c|c|c|c|}
\hline Taxa & Rep A & Rep B & Rep C & $\operatorname{Rep} D$ & Rep E & Total & Avg \\
\hline Sipuncula $(S)$ & 8 & 5 & 3 & 11 & 0 & 27 & 5.4 \\
\hline Scoloplos sp. B (An) & 0 & 0 & 0 & 8 & 1 & 9 & 1.8 \\
\hline Callianassidae A (Ar) & 0 & 0 & 2 & 0 & 1 & 3 & 0.6 \\
\hline Amphiodia sp. A (E) & 1 & 1 & 0 & 0 & 1 & 3 & 0.6 \\
\hline Myrthea pristiphora (M) & 0 & 0 & 1 & 0 & 1 & 2 & 0.4 \\
\hline Leiolambrus nitidus (Ar) & 0 & 2 & 0 & 0 & 0 & 2 & 0.4 \\
\hline Maldane sp. A (An) & 1 & 0 & 1 & 0 & 0 & 2 & 0.4 \\
\hline Codakia pectinella $(M)$ & 1 & 0 & 0 & 0 & 0 & 1 & 0.2 \\
\hline Chasmocarcinus cylindricus (Ar) & 1 & 0 & 0 & 0 & 0 & 1 & 0.2 \\
\hline Xanthidae A (Ar) & 0 & 1 & 0 & 0 & 0 & 1 & 0.2 \\
\hline Phyllodocidae A (An) & 1 & 0 & 0 & 0 & 0 & 1 & 0.2 \\
\hline Eunice sp. A (An) & 0 & 0 & 0 & 0 & 1 & 1 & 0.2 \\
\hline Prionospio sp. A (An) & 0 & 0 & 0 & 0 & 1 & 1 & 0.2 \\
\hline Chloeia sp. A (An) & 0 & 0 & 0 & 0 & 1 & 1 & 0.2 \\
\hline Total & 13 & 9 & 7 & 19 & 7 & 55 & 11 \\
\hline
\end{tabular}


Appendix A. Macrobenthic infauna identified at stations B1 through B8, December 15, 1990, in the Bahía de Añasco and the Bahía de Mayagüez, Puerto Rico-Continued.

Appendix A-19. Number of individuals identified by taxa in each of five replicate samples of taxa of macrobenthic infauna identified at station B8 in the Bahía de Mayagüez, December 15, 1990. A surface area of $0.04 \mathrm{~m}^{2}$ was sampled using a Shipeck grab sampler. Taxa are those retained on a $0.50-\mathrm{mm}$ sieve.

[Phylum enclosed in parentheses. Rep, replicate; Avg, average; An, Annelida; Ar, Arthropoda; E, Echinodermata; M, Mollusca; R, Nemertia; S, Sipuncula]

\begin{tabular}{|c|c|c|c|c|c|c|c|}
\hline Taxa & Rep A & $\operatorname{Rep~B}$ & Rep C & Rep D & Rep E & Total & Avg \\
\hline Sipuncula $(S)$ & 3 & 4 & 4 & 4 & 3 & 18 & 3.6 \\
\hline Scoloplos sp. B (An) & 1 & 1 & 0 & 3 & 5 & 10 & 2 \\
\hline Maldane sp. A (An) & 0 & 4 & 1 & 0 & 1 & 6 & 1.2 \\
\hline Maldanidae A (An) & 0 & 0 & 1 & 2 & 2 & 5 & 1 \\
\hline Oligochaeta (An) & 0 & 0 & 0 & 3 & 0 & 3 & 0.6 \\
\hline Prionospio sp. A (An) & 0 & 0 & 0 & 0 & 3 & 3 & 0.6 \\
\hline Myrthea pristiphora $(M)$ & 0 & 1 & 0 & 1 & 0 & 2 & 0.4 \\
\hline Oliva caribaeensis $(M)$ & 0 & 2 & 0 & 0 & 0 & 2 & 0.4 \\
\hline Amphiodia sp. A (E) & 1 & 0 & 1 & 0 & 0 & 2 & 0.4 \\
\hline Neanthes sp. A (An) & 0 & 0 & 0 & 1 & 1 & 2 & 0.4 \\
\hline Nephtyidae A (An) & 0 & 0 & 0 & 2 & 0 & 2 & 0.4 \\
\hline Prionospio sp. $C(A n)$ & 0 & 0 & 0 & 1 & 1 & 2 & 0.4 \\
\hline Prionospio sp. B (An) & 0 & 0 & 0 & 1 & 0 & 1 & 0.2 \\
\hline Codakia pectinella $(M)$ & 0 & 0 & 0 & 1 & 0 & 1 & 0.2 \\
\hline Diplodonta punctata (M) & 0 & 1 & 0 & 0 & 0 & 1 & 0.2 \\
\hline Mitrella nitens $(M)$ & 0 & 1 & 0 & 0 & 0 & 1 & 0.2 \\
\hline Pilumnus sp. A (Ar) & 0 & 0 & 0 & 0 & 1 & 1 & 0.2 \\
\hline Alpheidae A (Ar) & 0 & 0 & 0 & 0 & 1 & 1 & 0.2 \\
\hline Xanthidae A (Ar) & 0 & 0 & 1 & 0 & 0 & 1 & 0.2 \\
\hline Callianassidae A (Ar) & 0 & 1 & 0 & 0 & 0 & 1 & 0.2 \\
\hline Aphroditidae D (Sigalioninae) (An) & 1 & 0 & 0 & 0 & 0 & 1 & 0.2 \\
\hline Mediomastus sp. A (An) & 0 & 0 & 1 & 0 & 0 & 1 & 0.2 \\
\hline Sigambra sp. A (An) & 0 & 0 & 0 & 1 & 0 & 1 & 0.2 \\
\hline Total & 6 & 15 & 9 & 20 & 18 & 68 & 13.6 \\
\hline
\end{tabular}


120 Assessment of the Habitats, Biota, Sediments, and Water Quality Near the Discharge of Primary-Treated Effluent from the Mayagüez Regional Wastewater Treatment Plant, Bahía de Añasco, Puerto Rico 
Appendix B. Biological census data for fish and sessile benthos at stations MSG-1, MSG-2, M0-5, and M0-4, December 13-17, 1990, in the Bahía de Añasco and at the Escollo Negro reef complex, Puerto Rico.

Appendix B-1. Summary of ichthyofaunal communities.

[Standard deviation in parentheses. Complete list of species is included in appendix B.]

\begin{tabular}{lccccc}
\hline Site & $\begin{array}{c}\text { Total surface area } \\
\text { surveyed }\left(\mathrm{m}^{2}\right)\end{array}$ & $\begin{array}{c}\text { Total number of } \\
\text { species }\end{array}$ & $\begin{array}{c}\text { Mean number of } \\
\text { species per } \\
\text { transect }\end{array}$ & $\begin{array}{c}\text { Shannon- } \\
\text { Weaver diversity } \\
\text { index }\end{array}$ & $\begin{array}{c}\text { Mean fish } \\
\text { abundance per } \\
\text { transect }\end{array}$ \\
\hline MSG-1 & 150 & 24 & $12(3)$ & 2.14 & 36.2 \\
MSG-2 & 150 & 34 & $18(1)$ & 2.64 & 39.8 \\
MO-5 & 90 & 20 & $12(3)$ & 2.12 & 31.5 \\
MO-4 & 60 & 16 & $12(4)$ & 2.16 & 25 \\
\hline
\end{tabular}

Appendix B-2. Station transect statistics on fish abundance, diversity and substrate relief for station M0-5.

[H', Shannon-Weaver diversity index (natural log base); No., number; Sub, substrate; Ind/tra, individuals per transect]

\begin{tabular}{|c|c|c|c|c|}
\hline \multirow{2}{*}{ Transect } & \multirow{2}{*}{$H^{\prime}$} & Abundance & \multirow{2}{*}{ No. species } & \multirow{2}{*}{$\frac{\text { Sub relief }}{\text { (meters) }}$} \\
\hline & & (Ind/tra) & & \\
\hline 1 & 1.88 & 29 & 9 & 3.4 \\
\hline 2 & 2.47 & 44 & 15 & 2.2 \\
\hline 3 & 2.02 & 22 & 11 & 2.8 \\
\hline Mean & 2.12 & 32 & 12 & 2.8 \\
\hline
\end{tabular}

Appendix B-3. Station transect statistics on fish abundance, diversity and substrate relief for station MSG-1.

[H', Shannon-Weaver diversity index (natural log base); No., number; Sub, substrate; Ind/tra, individuals per transect]

\begin{tabular}{ccccc}
\hline \multirow{2}{*}{ Transect } & $H^{\prime}$ & Abundance & No. species & Sub relief \\
\cline { 3 - 4 } \cline { 5 - 5 } & & (Ind/tra) & & (meters) \\
\hline 1 & 1.66 & 30 & 8 & 1.4 \\
2 & 2.32 & 36 & 13 & 1.5 \\
3 & 2.10 & 50 & 13 & 1.3 \\
4 & 2.10 & 30 & 10 & 1.3 \\
5 & 2.50 & 36 & 15 & 0.9 \\
Mean & 2.14 & 36 & 12 & 1.3 \\
\hline
\end{tabular}


Appendix B. Biological census data for fish and sessile benthos at stations MSG-1, MSG-2, M0-5, and M0-4, December 13-17, 1990, in the Bahía de Añasco and at the Escollo Negro reef complex, Puerto Rico-Continued.

Appendix B-4. Station transect statistics on fish abundance, diversity and substrate relief for station MSG-2.

[H', Shannon-Weaver diversity index (natural log base); No, number; Sub, substrate; Ind/tra, individuals per transect]

\begin{tabular}{ccccc}
\hline \multirow{2}{*}{ Transect } & $H^{\prime}$ & Abundance & & Sub relief \\
\cline { 3 - 3 } \cline { 5 - 5 } & & (Ind/tra) & & (meters) \\
\hline 1 & 2.46 & 40 & 16 & 2.0 \\
2 & 2.80 & 33 & 19 & 1.9 \\
3 & 2.65 & 38 & 18 & 2.4 \\
4 & 2.67 & 36 & 18 & 2.7 \\
5 & 2.62 & 52 & 19 & 2.3 \\
Mean & 2.64 & 40 & 28 & 2.3 \\
\hline
\end{tabular}

Appendix B-5. Station transect statistics on fish abundance, diversity and substrate relief for station M0-4.

[H', Shannon-Weaver diversity index (natural log base); No., number; Sub, substrate; Ind/tra, individuals per transect]

\begin{tabular}{ccccc}
\hline \multirow{2}{*}{ Transect } & $H^{\prime}$ & Abundance & & Sub relief \\
\cline { 3 - 3 } \cline { 5 - 5 } & & (Ind/tra) & & (meters) \\
\hline 1 & 2.32 & 30 & 14 & 1.8 \\
2 & 2.00 & 20 & 9 & 0.7 \\
Mean & 2.16 & 25 & 12 & 1.2 \\
\hline
\end{tabular}


Appendix B. Biological census data for fish and sessile benthos at stations MSG-1, MSG-2, M0-5, and M0-4, December 13-17, 1990, in the Bahía de Añasco and at the Escollo Negro reef complex, Puerto Rico-Continued.

Appendix B-6. Summary of coral diversity studies conducted from December13-18, 1990.

[cm, centimeter; Por, Porifera; Scler, Scleractinia; Gorg, Gorgonacea. Standard deviation in parentheses. H', Shannon-Weaver diversity uses natural logarithms. Complete list of taxa are listed in appendix B]

\begin{tabular}{|c|c|c|c|c|c|c|c|c|c|c|c|c|}
\hline \multirow{3}{*}{ Site } & \multirow{2}{*}{\multicolumn{3}{|c|}{$\begin{array}{c}\text { Total number of } \\
\text { species per transect }\end{array}$}} & \multirow{2}{*}{\multicolumn{2}{|c|}{$\begin{array}{l}\text { Mean percent linear } \\
\text { cover per transect }\end{array}$}} & \multirow{2}{*}{\multicolumn{2}{|c|}{$\begin{array}{l}\text { Total cover } \\
\text { per station } \\
\text { (cm) }\end{array}$}} & \multicolumn{2}{|c|}{ Gorgonian colonies } & \multicolumn{3}{|c|}{ Diversity $\left(H^{\prime}\right)$} \\
\hline & & & & & & & & \multirow{2}{*}{$\begin{array}{c}\text { Mean } \\
\text { number per } \\
\text { transect } \\
\text { per station }\end{array}$} & \multirow{2}{*}{$\begin{array}{l}\text { Total } \\
\text { number } \\
\text { per } \\
\text { station }\end{array}$} & \multirow{2}{*}{ Scler } & \multirow{2}{*}{ Por } & \multirow{2}{*}{ Gorg } \\
\hline & Scler & Por & Gorg & Scler & Por & Scler & Por & & & & & \\
\hline MSG-1 & 10 & 5 & 7 & $128.4(7.7)$ & $40.6(20.9)$ & 642 & 203 & $15(4)$ & 73 & 1.15 & 1.51 & 1.74 \\
\hline MSG -2 & 17 & 9 & 9 & $195.2(81.3)$ & $88.8(61.8)$ & 976 & 444 & $39(5)$ & 197 & 1.92 & 1.34 & 1.68 \\
\hline MO-5 & 11 & 7 & 3 & $41.0(3.0)$ & $51(30.0)$ & 82 & 102 & $8(3)$ & 16 & 1.50 & 1.80 & 0.46 \\
\hline MO-4 & 11 & 4 & 7 & $65.5(45.5)$ & $27(5.0)$ & 131 & 54 & $50(8)$ & 100 & 1.63 & 1.22 & 1.67 \\
\hline
\end{tabular}

Appendix B-7. Summary of results from censuses of sessile benthos and fishes conducted in 1985 and 1990.

[Units are percent linear coverage under the transect survey line for scleractinia and porifera, number passing through the vertical plane that includes the survey tape for gorgonians, and total number of individuals per transect for the fishes. The survey transect line was 30 feet in 1985 and 10 meters in 1990. .]

\begin{tabular}{|c|c|c|c|c|c|c|c|c|}
\hline \multirow{2}{*}{$\begin{array}{c}\text { Site/ } \\
\text { Transect }\end{array}$} & \multicolumn{2}{|c|}{ SCLERACTINIA } & \multicolumn{2}{|c|}{ GORGONACEA } & \multicolumn{2}{|c|}{ PORIFERA } & \multicolumn{2}{|c|}{ FISHES } \\
\hline & 1985 & 1990 & 1985 & 1990 & 1985 & 1990 & 1985 & 1990 \\
\hline \multicolumn{9}{|c|}{ Site MSG-1 } \\
\hline 1 & 16.8 & 8.4 & 35 & 8 & 0.5 & 7.8 & 63 & 30 \\
\hline 2 & 5.0 & 8.3 & 50 & 14 & 3.3 & 2.8 & 19 & 36 \\
\hline 3 & 40.3 & 20.1 & 21 & 13 & 1.6 & 2.4 & 37 & 50 \\
\hline 4 & 18.8 & 10.6 & 29 & 21 & 2.9 & 4.9 & 37 & 30 \\
\hline 5 & & 16.8 & & 17 & & 2.4 & & 36 \\
\hline \multicolumn{9}{|c|}{ Site MSG-2 } \\
\hline 1 & 5.4 & 16.5 & 20 & 31 & 1.0 & 19.3 & 30 & 40 \\
\hline 2 & 17.6 & 11.8 & 22 & 38 & 0.0 & 5.6 & 63 & 33 \\
\hline 3 & 16.0 & 19.9 & 17 & 43 & 0.9 & 2.2 & & \\
\hline 4 & 14.1 & 34.9 & 18 & 42 & 0.7 & 5.0 & 63 & 30 \\
\hline 5 & & 14.5 & & 43 & & 12.3 & 19 & 36 \\
\hline
\end{tabular}


Appendix B. Biological census data for fish and sessile benthos at stations MSG-1, MSG-2, M0-5, and M0-4, December 13-17, 1990, in the Bahía de Añasco and at the Escollo Negro reef complex, Puerto Rico-Continued.

Appendix B-8. Taxonomic composition and abundance of fishes surveyed at station MSG-1 in the Manchas Exteriores coral reef in the Bahía de Añasco, Puerto Rico.

[TR, transect; Std. Dev., standard deviation]

\begin{tabular}{|c|c|c|c|c|c|c|c|c|}
\hline \multirow{2}{*}{ Species } & \multirow{2}{*}{ Common name } & \multicolumn{7}{|c|}{ Individuals per transect } \\
\hline & & TR-1 & TR-2 & TR-3 & TR-4 & TR-5 & Mean & Std. Dev. \\
\hline Thalassoma bifasciatum & Bluehead Wrasse & 10 & 8 & 18 & 0 & 0 & 7.2 & 7.6 \\
\hline Stegastes partitus & Bicolor Damselfish & 9 & 4 & 6 & 6 & 9 & 6.8 & 2.2 \\
\hline Serranus tigrinus & Harlequin Bass & 2 & 2 & 3 & 5 & 3 & 3.0 & 1.2 \\
\hline Scarus iserti & Striped Parrotfish & 5 & 5 & 2 & 0 & 0 & 2.4 & 2.5 \\
\hline Stegastes planifrons & Yellow Damselfish & 0 & 1 & 5 & 3 & 3 & 2.4 & 1.9 \\
\hline Halichoeres garnoti & Yellowhead Wrasse & 0 & 3 & 3 & 4 & 2 & 2.4 & 1.5 \\
\hline Sparisoma aurofrenatum & Redband Parrotfish & 1 & 4 & 1 & 2 & 3 & 2.2 & 1.3 \\
\hline Acanthurus bahianus & Ocean Surgeon & 1 & 2 & 0 & 5 & 0 & 1.6 & 2.1 \\
\hline Myripristis jacobus & Blackbar Soldierfish & 0 & 0 & 5 & 1 & 2 & 1.6 & 2.1 \\
\hline Cephalopholis fulva & Coney & 1 & 0 & 2 & 2 & 2 & 1.4 & 0.9 \\
\hline Chromis cyanea & Blue Chromis & 0 & 0 & 2 & 1 & 4 & 1.4 & 1.7 \\
\hline Canthigaster rostrata & Sharpnose Puffer & 1 & 2 & 1 & 0 & 1 & 1.0 & 0.7 \\
\hline Haemulon flavolineatum & French Grunt & 0 & 1 & 1 & 0 & 0 & 0.4 & 0.5 \\
\hline Chaetodon capistratus & Four-eye Butterflyfish & 0 & 0 & 0 & 0 & 2 & 0.4 & 0.9 \\
\hline Hypoplectrus chlorurus & Yellowtail Hamlet & 0 & 1 & 0 & 0 & 0 & 0.2 & 0.4 \\
\hline Pseudupeneus maculatus & Spotted Goatfish & 0 & 1 & 0 & 0 & 0 & 0.2 & 0.4 \\
\hline Stegastes variabilis & Cocoa Damselfish & 0 & 1 & 0 & 0 & 0 & 0.2 & 0.4 \\
\hline Bodianus rufus & Spanish Hogfish & 0 & 0 & 1 & 0 & 0 & 0.2 & 0.4 \\
\hline Sparisoma radians & Bucktooth Parrotfish & 0 & 0 & 0 & 1 & 0 & 0.2 & 0.4 \\
\hline Holocentrus rufus & Squirrelfish & 0 & 0 & 0 & 0 & 1 & 0.2 & 0.4 \\
\hline Halichoeres maculipinna & Clown Wrasse & 0 & 0 & 0 & 0 & 1 & 0.2 & 0.4 \\
\hline Epinephelus guttatus & Red Hind & 0 & 0 & 0 & 0 & 1 & 0.2 & 0.4 \\
\hline Hypoplectrus puella & Barred Hamlet & 0 & 0 & 0 & 0 & 1 & 0.2 & 0.4 \\
\hline Sparisoma viride & Stoplight Parrotfish & 0 & 0 & 0 & 0 & 1 & 0.2 & 0.4 \\
\hline
\end{tabular}


Appendix B. Biological census data for fish and sessile benthos at stations MSG-1, MSG-2, M0-5, and M0-4, December 13-17, 1990, in the Bahía de Añasco and at the Escollo Negro reef complex, Puerto Rico-Continued.

Appendix B-9. Taxonomic composition and abundance of fishes surveyed at station MSG-2 in the Manchas Interiores coral reef in the Bahía de Añasco, Puerto Rico.

[TR, transect; Std. Dev., standard deviation]

\begin{tabular}{|c|c|c|c|c|c|c|c|c|}
\hline \multirow{2}{*}{ Species } & \multirow{2}{*}{ Common name } & \multicolumn{7}{|c|}{ Individuals per transect } \\
\hline & & TR-1 & TR-2 & TR-3 & TR-4 & TR-5 & Mean & Std. Dev. \\
\hline Stegastes partitus & Bicolor Damselfish & 8 & 4 & 3 & 0 & 9 & 4.8 & 3.7 \\
\hline Stegastes planifrons & Yellow Damselfish & 7 & 1 & 2 & 6 & 3 & 3.8 & 2.6 \\
\hline Thalassoma bifasciatum & Bluehead Wrasse & 0 & 0 & 7 & 1 & 10 & 3.6 & 4.6 \\
\hline Scarus iserti & Striped Parrotfish & 3 & 2 & 4 & 3 & 3 & 3.0 & 0.7 \\
\hline Sparisoma radians & Bucktooth Parrotfish & 4 & 4 & 0 & 1 & 2 & 2.2 & 1.8 \\
\hline Chromis cyanea & Blue Chromis & 3 & 3 & 0 & 2 & 3 & 2.2 & 1.3 \\
\hline Sparisoma aurofrenatum & Redband Parrotfish & 1 & 2 & 3 & 2 & 2 & 2.0 & 0.7 \\
\hline Chaetodon capistratus & Four-eye Butterflyfish & 3 & 2 & 1 & 0 & 4 & 2.0 & 1.6 \\
\hline Cephalopholis fulva & Coney & 1 & 1 & 4 & 3 & 1 & 2.0 & 1.4 \\
\hline Scarus vetula & Queen Parrotfish & 1 & 0 & 0 & 5 & 1 & 1.4 & 2.1 \\
\hline Canthigaster rostrata & Sharpnose Puffer & 1 & 0 & 3 & 2 & 1 & 1.4 & 1.1 \\
\hline Serranus tigrinus & Harlequin Bass & 0 & 1 & 1 & 3 & 0 & 1.0 & 1.2 \\
\hline Halichoeres garnoti & Yellowhead Wrasse & 0 & 0 & 1 & 1 & 2 & 0.8 & 0.8 \\
\hline Ocyurus chrysurus & Yellowtail Snapper & 0 & 0 & 0 & 0 & 4 & 0.8 & 1.8 \\
\hline Sparisoma viride & Stoplight Parrotfish & 1 & 1 & 0 & 0 & 2 & 0.8 & 0.8 \\
\hline Scarus taeniopterus & Princess Parrotfish & 0 & 3 & 0 & 1 & 0 & 0.8 & 1.3 \\
\hline Hypoplectrus unicolor & Butter Hamlet & 1 & 1 & 1 & 0 & 0 & 0.6 & 0.5 \\
\hline Aulostomus maculatus & Trumpetfish & 0 & 2 & 0 & 0 & 1 & 0.6 & 0.9 \\
\hline Acanthurus bahianus & Ocean Surgeon & 1 & 1 & 0 & 0 & 1 & 0.6 & 0.5 \\
\hline Myripristis jacobus & Blackbar Soldierfish & 0 & 1 & 1 & 1 & 0 & 0.6 & 0.5 \\
\hline Anisotremus virginicus & Porkfish & 0 & 0 & 1 & 1 & 1 & 0.6 & 0.5 \\
\hline Pseudupeneus maculatus & Spotted Goatfish & 0 & 0 & 1 & 1 & 1 & 0.6 & 0.5 \\
\hline Stegastes variabilis & Cocoa Damselfish & 3 & 0 & 0 & 0 & 0 & 0.6 & 1.3 \\
\hline Holacanthus tricolor & Rock Beauty & 1 & 0 & 1 & 0 & 0 & 0.4 & 0.5 \\
\hline Haemulon flavolineatum & French Grunt & 0 & 0 & 2 & 0 & 0 & 0.4 & 0.9 \\
\hline Chaetodon aculeatus & Longsnout Butterflyfish & 0 & 0 & 1 & 1 & 0 & 0.4 & 0.5 \\
\hline Acanthurus chirurgus & Doctorfish & 0 & 1 & 0 & 1 & 0 & 0.4 & 0.5 \\
\hline Cephalopholis cruentatum & Graysby & 1 & 0 & 0 & 0 & 0 & 0.2 & 0.4 \\
\hline Sphoeroides greeleyi & Caribbean Puffer & 0 & 1 & 0 & 0 & 0 & 0.2 & 0.4 \\
\hline Hypoplectrus puella & Barred Hamlet & 0 & 1 & 0 & 0 & 0 & 0.2 & 0.4 \\
\hline Synodus intermedius & Sand Diver & 0 & 1 & 0 & 0 & 0 & 0.2 & 0.4 \\
\hline Odontoscion dentex & Reef Croaker & 0 & 0 & 1 & 0 & 0 & 0.2 & 0.4 \\
\hline Sphyraena barracuda & Great Barracuda & 0 & 0 & 0 & 1 & 0 & 0.2 & 0.4 \\
\hline Hypoplectrus nigricans & Black Hamlet & 0 & 0 & 0 & 0 & 1 & 0.2 & 0.4 \\
\hline
\end{tabular}


Appendix B. Biological census data for fish and sessile benthos at stations MSG-1, MSG-2, M0-5, and M0-4, December 13-17, 1990, in the Bahía de Añasco and at the Escollo Negro reef complex, Puerto Rico-Continued.

Appendix B-10. Taxonomic composition and abundance of fishes surveyed at station M0-5 in the Bahía de Añasco, Puerto Rico.

[TR, transect; Std. Dev., standard deviation]

\begin{tabular}{llccccc}
\hline \multicolumn{1}{c}{ Species } & \multicolumn{1}{c}{ Common name } & \multicolumn{3}{c}{ Individuals per transect } \\
\cline { 3 - 6 } & & TR-1 & TR-2 & TR-3 & Mean & Std. Dev. \\
\hline Stegastes fuscus & Dusky Damselfish & 6 & 6 & 8 & 6.7 & 1.2 \\
Thalassoma bifasciatum & Bluehead Wrasse & 7 & 8 & 0 & 5.0 & 4.4 \\
Canthigaster rostrata & Sharpnose Puffer & 5 & 4 & 4 & 4.3 & 0.6 \\
Stegastes planifrons & Yellow Damselfish & 6 & 5 & 1 & 4.0 & 2.6 \\
Pomacanthus arcuatus & Gray Angelfish & 0 & 5 & 2 & 2.3 & 2.5 \\
Cephalopholis fulva & Coney & 1 & 2 & 1 & 1.3 & 0.6 \\
Myripristis jacobus & Blackbar Soldierfish & 0 & 3 & 0 & 1.0 & 1.7 \\
Cephalopholis cruentatum & Graysby & 1 & 2 & 0 & 1.0 & 1.0 \\
Haemulon flavolineatum & French Grunt & 0 & 2 & 1 & 1.0 & 1.0 \\
Haemulon macrostomum & Spanish Grunt & 0 & 1 & 1 & 0.7 & 0.6 \\
Chaetodon capistratus & Four-eye Butterflyfish & 0 & 2 & 0 & 0.7 & 1.2 \\
Anisotremus virginicus & Porkfish & 0 & 1 & 1 & 0.7 & 0.6 \\
Hypoplectrus nigricans & Black Hamlet & 1 & 1 & 0 & 0.7 & 0.6 \\
Odontoscion dentex & Reef Croaker & 1 & 0 & 0 & 0.3 & 0.6 \\
Anisotremus surinamensis & Black Margate & 0 & 1 & 0 & 0.3 & 0.6 \\
Haemulon aurolineatum & Tomtate & 1 & 0 & 0 & 0.3 & 0.6 \\
Halichoeres garnoti & Yellowhead Wrasse & 0 & 1 & 0 & 0.3 & 0.6 \\
Aulostomus maculatus & Trumpetfish & 0 & 0 & 1 & 0.3 & 0.6 \\
Serranus tigrinus & Harlequin Bass & 0 & 0 & 1 & 0.3 & 0.6 \\
Amblycirrhitus pinos & Redspotted Hawkfish & 0 & 0 & 1 & 0.3 & 0.6 \\
\hline
\end{tabular}


Appendix B. Biological census data for fish and sessile benthos at stations MSG-1, MSG-2, M0-5, and M0-4, December 13-17, 1990, in the Bahía de Añasco and at the Escollo Negro reef complex, Puerto Rico-Continued.

Appendix B-11. Taxonomic composition and abundance of fishes surveyed at station M0-4 in the Escollo Negro reef complex west of Mayagüez, Puerto Rico.

[TR, transect; Std. Dev., standard deviation]

\begin{tabular}{llcccc}
\hline \multirow{2}{*}{ Species } & \multicolumn{1}{c}{ Common name } & \multicolumn{4}{c}{ Individuals per transect } \\
\cline { 3 - 6 } & & TR-1 & TR-2 & Mean & Std. Dev. \\
\hline Stegates partitus & Bilocolor Damselfish & 9.0 & 3.0 & 6.0 & 4.2 \\
Halichoeres garnoti & Yellowhead Wrasse & 3.0 & 4.0 & 3.5 & 0.7 \\
Scarus iserti & Striped Parrotfish & 3.0 & 4.0 & 3.5 & 0.7 \\
Sparisoma aurofrenatum & Redband Parrotfish & 3.0 & 3.0 & 3.0 & 0.0 \\
Acanthurus bahianus & Ocean Surgeon & 1.0 & 2.0 & 1.5 & 0.7 \\
Chaetodon capistratus & Foureye Butterflyfish & 2.0 & 0.0 & 1.0 & 1.4 \\
Scarus taeniopterus & Princess Parrotfish & 2.0 & 0.0 & 1.0 & 1.4 \\
Sparisoma radians & Bucktooth Parrotfish & 1.0 & 1.0 & 1.0 & 0.0 \\
Pseudupeneus maculatus & Spotted Goatfish & 1.0 & 1.0 & 1.0 & 0.0 \\
Canthigaster rostrata & Sharpnose Puffer & 1.0 & 0.0 & 0.5 & 0.7 \\
Cephalopholis fulva & Coney & 1.0 & 0.0 & 0.5 & 0.7 \\
Carangoides ruber & Bar Jack & 1.0 & 0.0 & 0.5 & 0.7 \\
Acanthurus coeruleus & Blue Tang & 1.0 & 0.0 & 0.5 & 0.7 \\
Thalassoma bifasciatum & Bluehead Wrasse & 1.0 & 0.0 & 0.5 & 0.7 \\
Halichoeres radiatus & Pudding Wife & 0.0 & 1.0 & 0.5 & 0.7 \\
Aulostomus maculatus & Trumpetfish & 0.0 & 1.0 & 0.5 & 0.7 \\
\hline
\end{tabular}


Appendix B. Biological census data for fish and sessile benthos at stations MSG-1, MSG-2, M0-5, and M0-4, December 13-17, 1990, in the Bahía de Añasco and at the Escollo Negro reef complex, Puerto Rico-Continued.

Appendix B-12. Sessile benthos observed at site MSG-1.

[The numbers represent the total coverage in centimeters for all species except branching or erect gorgonians, for which the number represents the number that pass through the vertical plane that includes the survey tape.]

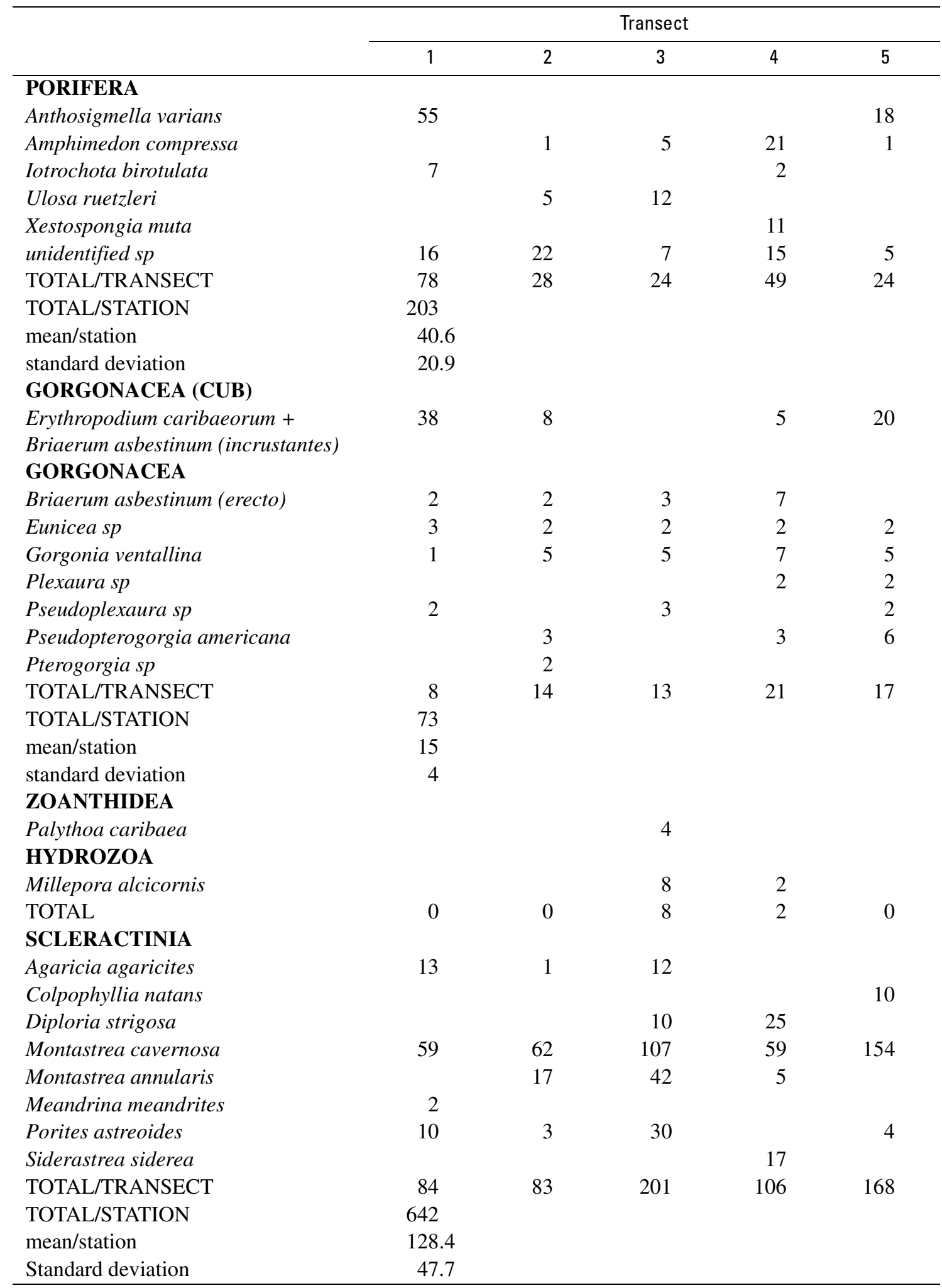

128 Assessment of the Habitats, Biota, Sediments, and Water Quality Near the Discharge of Primary-Treated Effluent from the Mayagüez Regional Wastewater Treatment Plant, Bahía de Añasco, Puerto Rico 
Appendix B. Biological census data for fish and sessile benthos at stations MSG-1, MSG-2, M0-5, and M0-4, December 13-17, 1990, in the Bahía de Añasco and at the Escollo Negro reef complex, Puerto Rico-Continued.

Appendix B-13. Sessile benthos observed at station MSG-2 .

[The numbers represent the total coverage in centimeters for all species except branching or erect gorgonians, for which the number represents the number of individuals that pass through the vertical plane that includes the survey tape.]

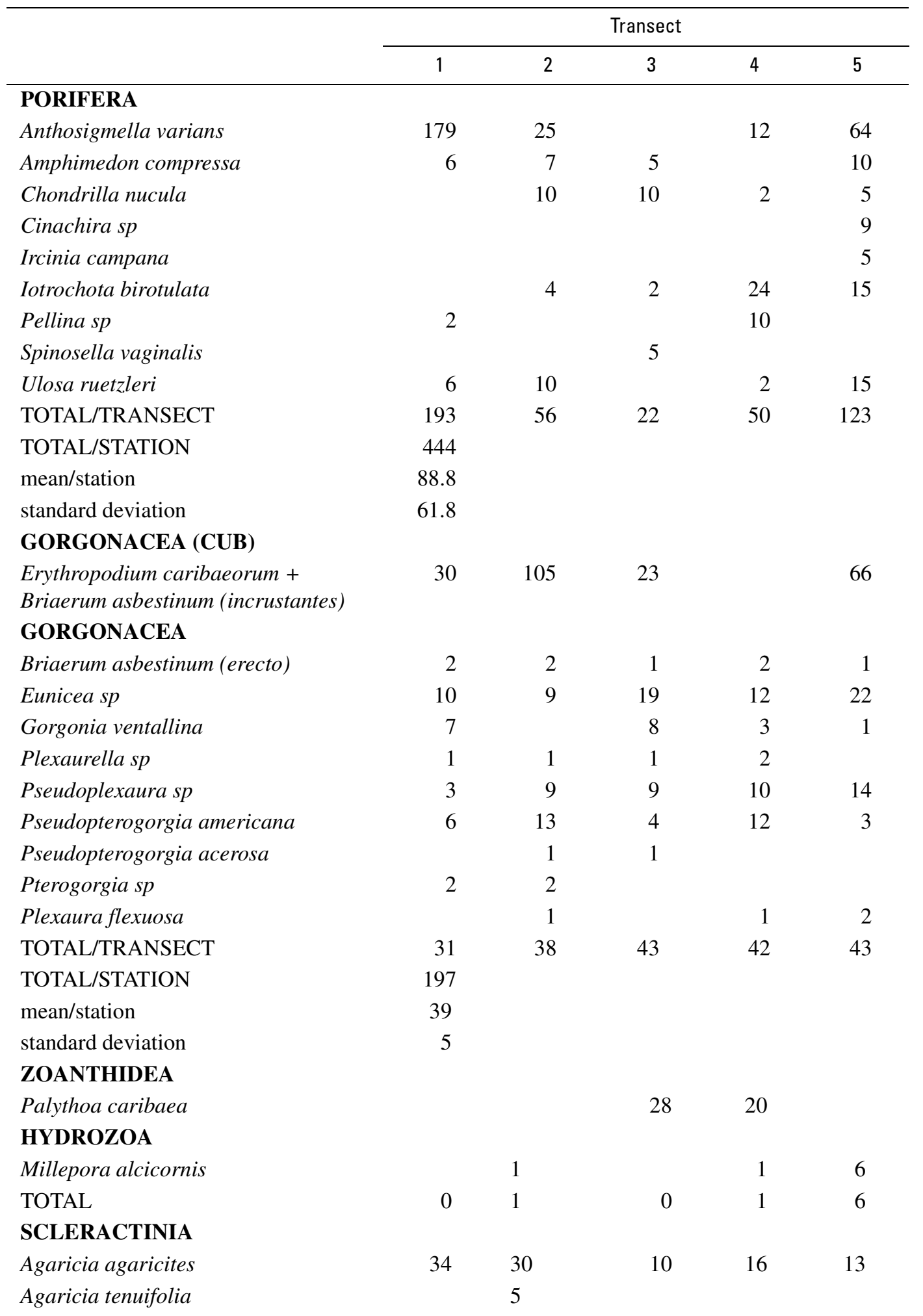


Appendix B. Biological census data for fish and sessile benthos at stations MSG-1, MSG-2, M0-5, and M0-4, December 13-17, 1990, in the Bahía de Añasco and at the Escollo Negro reef complex, Puerto Rico-Continued.

Appendix B-13. Sessile benthos observed at station MSG-2 --Continued.

[The numbers represent the total coverage in centimeters for all species except branching or erect gorgonians, for which the number represents the number of individuals that pass through the vertical plane that includes the survey tape.]

\begin{tabular}{lrrrrr}
\hline & \multicolumn{5}{c}{ Transect } \\
\cline { 2 - 6 } & 1 & 2 & 3 & 4 & 5 \\
\hline $\begin{array}{l}\text { Colpophyllia natans } \\
\text { Diploria strigosa }\end{array}$ & & & 69 & 6 \\
Leptoseris cucullata & & & & 2 & 5 \\
Montastrea cavernosa & 38 & 25 & 19 & 75 & 20 \\
Montastrea annularis & 4 & 20 & 73 & 23 & 30 \\
Meandrina meandrites & & & 20 & & 5 \\
Porites porites & 23 & & & 2 & 5 \\
Porites astreoides & 66 & 36 & 77 & 89 & 61 \\
Siderastrea siderea & & 2 & & 55 & \\
Stephanocoenia michelini & 165 & 118 & 199 & 349 & 145 \\
TOTAL/TRANSECT & 976 & & & & \\
TOTAL/STATION & 195.2 & & & & \\
mean/station & 81.3 & & & & \\
Standard deviation & & & & & \\
\hline
\end{tabular}


Appendix B. Biological census data for fish and sessile benthos at stations MSG-1, MSG-2, M0-5, and M0-4, December 13-17, 1990, in the Bahía de Añasco and at the Escollo Negro reef complex, Puerto Rico-Continued.

Appendix B-14. Sessile benthos observed at stations M0-5 and M0-4 .

[The numbers represent the total coverage in centimeters for all species except branching or erect gorgonians, for which the number represents the number that pass through the vertical plane that includes the survey tape.]

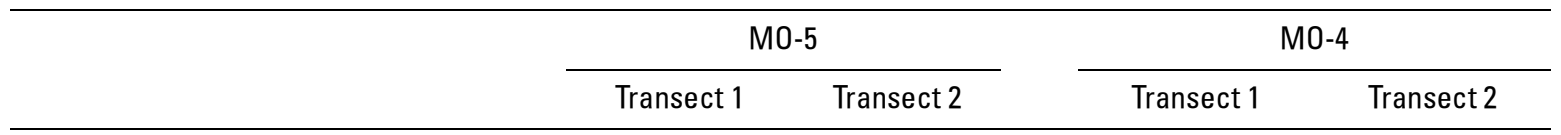

\section{PORIFERA}

Anthosigmella varians

Amphimedon compressa

Aplysina lacunosa

Cliona aprica

Chondrilla nucula

Desmapsama anchorata

Iotrochota birotulata

Spinosella vaginalis

Ulosa ruetzleri

unidentified $s p$

TOTAL/TRANSECT

TOTAL/STATION

mean/station

Standard deviation

\section{GORGONACEA (CUB)}

Erythropodium caribaeorum +

Briaerum asbestinum (incrustantes)

\section{GORGONACEA}

Eunicea sp

Gorgonia ventallina

Plexaurella $s p$

Pseudoplexaura sp

Pseudopterogorgia americana

Pterogorgia sp

Plexaura flexuosa

TOTAL/TRANSECT

TOTAL/STATION

mean/station

Standard deviation

ZOANTHIDEA

Palythoa caribaea

\section{HYDROZOA}

Millepora complanata

Millepora alcicornis

TOTAL

\section{SCLERACTINIA}

Acropora cervicornis

Agaricia agaricites

20

101

16

3
11

7

17

8

2

22

20

5

21

81

32

54

27

5.0

7

2

10

19

13

7

6

1 1

115

5

12

21

54

58

42

11

100

50

8

20

2

22

(1)

(1)

1
4

8

8

10

8

18

2

0

10

10

29 
Appendix B. Biological census data for fish and sessile benthos at stations MSG-1, MSG-2, M0-5, and M0-4, December 13-17, 1990, in the Bahía de Añasco and at the Escollo Negro reef complex, Puerto Rico-Continued.

Appendix B-14. Sessile benthos observed at stations M0-5 and M0-4 --Continued.

[The numbers represent the total coverage in centimeters for all species except branching or erect gorgonians, for which the number represents the number that pass through the vertical plane that includes the survey tape.]

\begin{tabular}{|c|c|c|c|c|}
\hline & \multicolumn{2}{|c|}{ MO-5 } & \multicolumn{2}{|c|}{$\mathrm{MO}-4$} \\
\hline & Transect 1 & Transect 2 & Transect 1 & Transect 2 \\
\hline Diploria labyrinthiformes & & & 20 & \\
\hline Diploria strigosa & & & 37 & 15 \\
\hline Dichocoenia stokesi & & & 5 & \\
\hline Madracis mirabilis & 8 & & & \\
\hline Montastrea cavernosa & & 16 & & \\
\hline Montastrea annularis & & & 10 & \\
\hline Porites astreoides & & 18 & & \\
\hline Siderastrea siderea & 30 & & & \\
\hline Stephanocoenia michelini & & & & 5 \\
\hline TOTAL/TRANSECT & 38 & 44 & 111 & 20 \\
\hline TOTAL/STATION & 82 & & 131 & \\
\hline mean/station & 41 & & 65.5 & \\
\hline Standard deviation & 3.0 & & 45.5 & \\
\hline
\end{tabular}


Appendix B. Biological census data for fish and sessile benthos at stations MSG-1, MSG-2, M0-5, and M0-4, December 13-17, 1990, in the Bahía de Añasco and at the Escollo Negro reef complex, Puerto Rico-Continued.

Appendix B-15. List of motile and associated benthos observed at stations MSG-1, MSG-2, M0-5, and M0-4.

$[\mathrm{T}$, transect]

$\begin{array}{lllll}\text { T1 } & \text { T2 } & \text { T3 } & \text { T4 } & \text { T5 }\end{array}$

\section{Station MSG-1}

Cnidaria

Lebrunia danae

Polychaeta

Sabellastarte magnifica

Mollusca

Cyphoma gibbosum

\section{Station MSG-2}

\section{Cnidaria}

Palythoa caribbaeorum (patch)

unidentified actiniarian

Polychaeta

Spirobranchus giganteus

1

Sabellastarte magnifica

Mollusca

Cyphoma gibbosum

Crustacea

Mysidium sp. (patch)

Tunicata

Clavelina oblonga

unidentified tunicate

1

2

\section{Station MO-5}

\section{Polychaeta}

Sabellastarte magnifica

1

1

\section{Station MO-4}

Polychaeta

Sabellastarte magnifica

\section{Mollusca}

Cyphoma gibbosum

\section{Tunicata}

Clavelina oblonga 
134 Assessment of the Habitats, Biota, Sediments, and Water Quality Near the Discharge of Primary-Treated Effluent from the Mayagüez Regional Wastewater Treatment Plant, Bahía de Añasco, Puerto Rico 
Appendix C. Elemental and isotopic composition of annual coral bands of Montastrea annularis sampled from cores C1 and C2, recovered at site M0-1 near the outfall, December 14, 1990, and cores C7 and C9, sampled at site M0-3 in the Escollo Negro, Puerto Rico, December 17, 1990.

Appendix C-1. Stable isotopes and trace metals measured in the annual bands deposited by colonies of Montastrea annularis at station $\mathrm{MO}-1$ (cores $\mathrm{C} 1$ and $\mathrm{C} 2$ ), 610 meters from the outfall, and at station $\mathrm{M} 0-3$ (cores $\mathrm{C} 7$ and $\mathrm{C} 9$ ), at $\mathrm{El}$ Negro reef, more than $11 \mathrm{~km}$ to the southwest .

[Units: PDB, per dem belemnite; $\mathrm{nmol} / \mathrm{mol}$, nanomole per mole; $\mu \mathrm{mol} / \mathrm{mol}$, micromole per mole. Abbreviations: $\delta^{13} \mathrm{C}$, delta Carbon 13; $\delta^{18} \mathrm{O}$, delta Oxygen 18; Ca, Calcium; Cd, cadmium; Cr, chromium; Fe, iron; Mn, manganese; Ni, nickel; Pb, lead; rel, relative; $\%$, parts per mil; Std. Dev., standard deviation; --, indicates no data]

\begin{tabular}{|c|c|c|c|c|c|c|c|c|c|c|}
\hline $\begin{array}{c}\text { Year of } \\
\text { band }\end{array}$ & $\begin{array}{c}\delta^{13} \mathrm{C} \\
\text { (\% rel } \\
\text { to } \\
\text { PDB) }\end{array}$ & $\begin{array}{c}\delta^{18} 0 \\
(\% \text { rel } \\
\text { to } \\
\text { PDB) }\end{array}$ & $\begin{array}{c}\mathrm{Cd} / \mathrm{Ca} \\
\mathrm{nmol} / \\
\mathrm{mol}\end{array}$ & $\begin{array}{c}\mathrm{Cr} / \mathrm{Ca} \\
\mathrm{nmol} / \\
\mathrm{mol}\end{array}$ & $\begin{array}{c}\mathrm{Cu} / \mathrm{Ca} \\
\mathrm{nmol} / \\
\mathrm{mol}\end{array}$ & $\begin{array}{c}\mathrm{Fe} / \mathrm{Ca} \\
\mathrm{nmol} / \\
\mathrm{mol}\end{array}$ & $\begin{array}{c}\mathrm{Mn} / \mathrm{Ca} \\
\mathrm{nmol} / \\
\mathrm{mol}\end{array}$ & $\begin{array}{c}\mathrm{Ni} / \mathrm{Ca} \\
\mu \mathrm{mol} / \\
\mathrm{mol}\end{array}$ & $\begin{array}{c}\mathrm{Pb} / \mathrm{Ca} \\
\mathrm{nmol} / \\
\mathrm{mol}\end{array}$ & $\begin{array}{c}\mathrm{Zn} / \mathrm{Ca} \\
\mu \mathrm{mol} / \\
\mathrm{mol}\end{array}$ \\
\hline \multicolumn{11}{|c|}{ Core C1 - Site MO-1 (1984-1990) } \\
\hline 1990 & -3.82 & -5.07 & 3.4 & 47 & 131 & 138 & 875 & 0.6 & 17.1 & 0.1 \\
\hline 1989 & -- & -- & 5.1 & 37 & 358 & 16 & 880 & 0.3 & 13.4 & 0.1 \\
\hline 1988 & -3.37 & -4.96 & 4.3 & 31 & 169 & 2 & 751 & 0.3 & 7.9 & 0.1 \\
\hline 1987 & -4.03 & -4.85 & 2.9 & 80 & 259 & 1346 & 803 & 0.3 & 9.1 & 0.1 \\
\hline 1986 & -4.03 & -4.67 & 3.9 & 71 & 221 & 292 & 963 & 0.8 & 12.9 & 0.1 \\
\hline 1985 & -3.30 & -4.45 & 3.0 & 104 & 305 & 458 & 887 & 0.8 & 17.1 & 0.1 \\
\hline 1984 & -4.05 & -5.06 & 9.7 & 50 & 309 & 452 & 608 & 0.5 & 9.7 & 0.0 \\
\hline $\mathrm{n}$ & 6 & 6 & 7 & 7 & 7 & 7 & 7 & 7 & 7 & 7 \\
\hline Average & -3.77 & -4.84 & 4.6 & 59.8 & 250.3 & 386.3 & 823.8 & 0.50 & 12.5 & 0.07 \\
\hline Std. Dev. & 0.35 & 0.24 & 2.4 & 26.1 & 81.3 & 463.0 & 116.3 & 0.22 & 3.7 & 0.02 \\
\hline \multicolumn{11}{|c|}{ Core C2 - Site MO-1 (1984-1990) } \\
\hline 1990 & -3.41 & -4.74 & 8.0 & 73 & 492 & 848 & 1032 & 1.6 & 56.3 & 0.1 \\
\hline 1989 & -2.06 & -4.39 & 3.2 & 56 & 209 & 188 & 671 & 0.5 & 11.4 & 0.1 \\
\hline 1988 & -2.61 & -4.27 & -- & -- & -- & -- & -- & -- & -- & -- \\
\hline 1987 & -2.21 & -4.48 & -- & -- & -- & -- & -- & -- & -- & -- \\
\hline 1986 & -2.52 & -4.50 & 6.8 & 49 & 410 & 572 & 756 & 0.5 & 20.6 & 0.1 \\
\hline 1985 & -2.61 & -4.67 & 4.1 & 69 & 251 & 153 & 773 & 0.7 & 18.7 & 0.1 \\
\hline 1984 & -2.69 & -5.28 & 15.4 & 80 & 522 & 477 & 1274 & 1.4 & 40.6 & 0.2 \\
\hline $\mathrm{n}$ & 7 & 7 & 5 & 5 & 5 & 5 & 5 & 5 & 5 & 5 \\
\hline Average & -2.59 & -4.62 & 7.5 & 65.6 & 376.6 & 447.5 & 901.4 & 0.95 & 29.5 & 0.10 \\
\hline Std. Dev. & 0.43 & 0.33 & 4.8 & 12.9 & 140.8 & 287.6 & 248.1 & 0.52 & 18.5 & 0.05 \\
\hline
\end{tabular}

Core C2 - Site MO-1 (1938-1990) * Values for 1989.5 is average of 1989-90, and 1985.5 is average of 1985-86 from annual samples above.

$\begin{array}{lrrrrrrrrrl}1989.5 & -2.74 & -4.57 & 5.6 & 65 & 350 & 518 & 852 & 1.1 & 33.8 & 0.1 \\ 1985.5 & -2.57 & -4.59 & 5.5 & 59 & 331 & 362 & 765 & 0.6 & 19.7 & 0.1 \\ 1983 & -3.65 & -6.57 & 6.3 & 74 & 285 & 543 & 846 & 1.0 & 44.1 & 0.1 \\ 1980 & -2.15 & -4.41 & 5.1 & 67 & 174 & 212 & 823 & 0.4 & 18.4 & 0.0 \\ 1977 & -1.93 & -4.15 & 19.3 & 80 & 691 & 1232 & 717 & 1.5 & 19.6 & 0.2 \\ 1974 & -2.00 & -4.36 & 5.6 & 49 & 90 & 176 & 797 & 0.4 & 19.1 & 0.1 \\ 1971 & -1.96 & -4.15 & 15.7 & 74 & 237 & 219 & 540 & 0.9 & 15.6 & 0.1 \\ 1968 & -2.46 & -4.96 & 6.3 & 92 & 147 & 153 & 615 & 0.5 & 29.4 & 0.0 \\ 1965 & -2.30 & -4.62 & 7.1 & 50 & 126 & 0 & 586 & 0.4 & 14.1 & 0.1 \\ 1962 & -1.35 & -4.96 & 15.2 & 55 & 344 & 696 & 671 & 0.4 & 18.5 & 0.0\end{array}$


Appendix C. Elemental and isotopic composition of annual coral bands of Montastrea annularis sampled from cores C1 and C2, recovered at site M0-1 near the outfall, December 14, 1990, and cores C7 and C9, sampled at site M0-3 in the Escollo Negro, Puerto Rico, December 17, 1990-Continued.

Appendix C-1. Stable isotopes and trace metals measured in the annual bands deposited by colonies of Montastrea annularis at station $\mathrm{M0}-1$ (cores $\mathrm{C} 1$ and $\mathrm{C2}$ ), 610 meters from the outfall, and at station $\mathrm{M0}-3$ (cores $\mathrm{C} 7$ and $\mathrm{C} 9$ ), at $\mathrm{El}$ Negro reef, more than $11 \mathrm{~km}$ to the southwest--Continued.

[Units: PDB, per dem belemnite; $\mathrm{nmol} / \mathrm{mol}$, nanomole per mole; $\mu \mathrm{mol} / \mathrm{mol}$, micromole per mole. Abbreviations: $\delta^{13} \mathrm{C}$, delta Carbon 13; $\delta^{18} \mathrm{O}$, delta Oxygen 18; Ca, Calcium; $\mathrm{Cd}$, cadmium; $\mathrm{Cr}$, chromium; $\mathrm{Fe}$, iron; Mn, manganese; $\mathrm{Ni}$, nickel; $\mathrm{Pb}$, lead; rel, relative; $\%$, parts per mil; Std. Dev., standard deviation; --, indicates no data]

\begin{tabular}{|c|c|c|c|c|c|c|c|c|c|c|}
\hline $\begin{array}{c}\text { Year of } \\
\text { band }\end{array}$ & $\begin{array}{c}\delta^{13} \mathrm{C} \\
\text { (\%o rel } \\
\text { to } \\
\text { PDB) }\end{array}$ & $\begin{array}{c}\delta^{18} 0 \\
\text { (\%) rel } \\
\text { to } \\
\text { PDB) }\end{array}$ & $\begin{array}{c}\mathrm{Cd} / \mathrm{Ca} \\
\mathrm{nmol} / \\
\mathrm{mol}\end{array}$ & $\begin{array}{c}\mathrm{Cr} / \mathrm{Ca} \\
\mathrm{nmol} / \\
\mathrm{mol}\end{array}$ & $\begin{array}{c}\mathrm{Cu} / \mathrm{Ca} \\
\mathrm{nmol} / \\
\mathrm{mol}\end{array}$ & $\begin{array}{c}\mathrm{Fe} / \mathrm{Ca} \\
\mathrm{nmol} / \\
\mathrm{mol}\end{array}$ & $\begin{array}{c}\mathrm{Mn} / \mathrm{Ca} \\
\mathrm{nmol} / \\
\mathrm{mol}\end{array}$ & $\begin{array}{c}\mathrm{Ni} / \mathrm{Ca} \\
\mu \mathrm{mol} / \\
\mathrm{mol}\end{array}$ & $\begin{array}{c}\mathrm{Pb} / \mathrm{Ca} \\
\mathrm{nmol} / \\
\mathrm{mol}\end{array}$ & $\begin{array}{c}\mathrm{Zn} / \mathrm{Ca} \\
\mu \mathrm{mol} / \\
\mathrm{mol}\end{array}$ \\
\hline 1959 & -2.87 & -4.96 & 4.6 & 75 & 429 & 146 & 605 & 0.5 & 20.5 & 0.0 \\
\hline 1956 & -0.88 & -4.40 & 3.1 & 70 & 273 & 954 & 649 & 0.4 & 11.7 & 0.0 \\
\hline 1953 & -1.52 & -4.29 & 1.0 & 75 & 304 & 148 & 720 & 0.7 & 11.5 & 0.1 \\
\hline 1950 & -0.64 & -4.38 & 6.2 & 49 & 198 & 224 & 547 & 0.4 & 12.4 & 0.1 \\
\hline 1947 & -0.09 & -4.60 & 7.1 & 28 & 82 & 162 & 393 & 0.4 & 6.7 & 0.1 \\
\hline 1944 & -2.01 & -5.12 & 11.0 & 65 & 223 & 146 & 519 & 0.6 & 15.9 & 0.1 \\
\hline 1941 & -2.58 & -5.96 & 6.3 & 73 & 287 & 200 & 556 & 0.6 & 10.1 & 0.1 \\
\hline 1938 & -1.54 & -4.73 & 15.0 & 44 & 382 & 245 & 615 & 0.7 & 21.4 & 0.1 \\
\hline $\mathrm{n}$ & 18 & 18 & 18 & 18 & 18 & 18 & 18 & 18 & 18 & 18 \\
\hline Average & -1.96 & -4.77 & 8.1 & 63.5 & 275.1 & 352.1 & 656.4 & 0.64 & 19.0 & 0.07 \\
\hline Std. Dev. & 0.86 & 0.62 & 5.0 & 15.5 & 144.1 & 322.2 & 127.4 & 0.31 & 9.1 & 0.04 \\
\hline \multicolumn{11}{|c|}{ Core C7 - Site MO-3 (1984-1990) } \\
\hline 1990 & -0.79 & -4.01 & 16.7 & 62 & 261 & 573 & 357 & 1.0 & 23.2 & 0.1 \\
\hline 1989 & -1.84 & -4.84 & 19.7 & 89 & 366 & 100 & 418 & 1.1 & 16.1 & 0.1 \\
\hline 1988 & -1.06 & -4.43 & 42.0 & 68 & 294 & 219 & 357 & 0.8 & 15.7 & 0.0 \\
\hline 1987 & -1.62 & -5.52 & 17.3 & 82 & 82 & 0 & 268 & 0.9 & 13.9 & 0.0 \\
\hline 1986 & -1.20 & -4.20 & 27.6 & 58 & 2000 & 62 & 352 & 1.0 & 17.8 & 0.1 \\
\hline 1985 & -1.39 & -4.64 & 81.8 & 71 & 639 & 770 & 304 & 1.2 & 33.0 & 0.1 \\
\hline 1984 & -0.74 & -4.56 & -- & -- & -- & -- & -- & -- & -- & -- \\
\hline $\mathrm{n}$ & 7 & 7 & 6 & 6 & 6 & 6 & 6 & 6 & 6 & 6 \\
\hline Average & -1.23 & -4.60 & 34.2 & 71.8 & 607.0 & 287.3 & 342.5 & 1.00 & 20.0 & 0.07 \\
\hline Std. Dev. & 0.41 & 0.49 & 25.2 & 11.7 & 706.2 & 312.4 & 51.4 & 0.15 & 7.1 & 0.03 \\
\hline \multicolumn{11}{|c|}{ Core C9 - Site MO-3 (1984-1990) } \\
\hline 1990 & -2.71 & -6.88 & 12.9 & 77 & 273 & 486 & 364 & 1.7 & 21.6 & 0.1 \\
\hline 1989 & -1.93 & -5.24 & 18.4 & 165 & 700 & 896 & 378 & 1.3 & 26.1 & 0.1 \\
\hline 1988 & -0.88 & -4.45 & 19.6 & 65 & 501 & 922 & 377 & 1.9 & 28.7 & 0.1 \\
\hline 1987 & -2.04 & -6.34 & 8.5 & 50 & 188 & 53 & 137 & 2.3 & 28.2 & 0.2 \\
\hline 1986 & -1.68 & -4.77 & 22.7 & 39 & 391 & 1684 & 233 & 1.8 & 26.5 & 0.2 \\
\hline 1985 & -0.56 & -3.57 & 35.1 & 61 & 635 & 495 & 380 & 1.4 & 34.9 & 0.1 \\
\hline 1984 & -0.92 & -5.00 & 18.1 & 58 & 210 & 119 & 288 & 0.8 & 19.2 & 0.1 \\
\hline $\mathrm{n}$ & 7 & 7 & 7 & 7 & 7 & 7 & 7 & 7 & 7 & 7 \\
\hline Average & -1.53 & -5.18 & 19.3 & 73.5 & 414.0 & 665.1 & 308.1 & 1.62 & 26.5 & 0.13 \\
\hline Std. Dev. & 0.77 & 1.12 & 8.4 & 42.3 & 204.5 & 561.6 & 94.4 & 0.49 & 5.1 & 0.03 \\
\hline
\end{tabular}


Appendix D. Texture, elemental composition, percent carbonate, cesium-137 activity, and clay mineralogy for bottom sediments and core samples collected from December 15, 1990, through January 27, 1991, in the Bahía de Añasco and in the Escollo Negro, Puerto Rico.

Appendix D-1. Size breaks and verbal descriptions for surficial sediment samples GS1 to GS33.

\begin{tabular}{|c|c|c|c|c|c|}
\hline Site & $\begin{array}{c}\text { Gravel } \\
\text { percent }\end{array}$ & $\begin{array}{c}\text { Sand } \\
\text { percent }\end{array}$ & $\begin{array}{c}\text { Silt } \\
\text { percent }\end{array}$ & $\begin{array}{c}\text { Clay } \\
\text { percent }\end{array}$ & $\begin{array}{c}\text { Verbal } \\
\text { description }\end{array}$ \\
\hline GS1 & 0 & 0.11 & 49.06 & 50.84 & Silty Clay \\
\hline GS2 & 0 & 0.93 & 74.42 & 24.65 & Clayey Silt \\
\hline GS3 & 0 & 8.45 & 35.25 & 56.3 & Silty Clay \\
\hline GS4 & 0.13 & 0.62 & 36.52 & 62.73 & Silty Clay \\
\hline GS5 & 1.93 & 76 & 12.31 & 9.76 & Sand \\
\hline GS6 & 0.77 & 0.8 & 46.03 & 52.4 & Silty Clay \\
\hline GS7 & 1.6 & 2.8 & 38.48 & 57.12 & Silty Clay \\
\hline GS8 & 0.22 & 13.04 & 34.55 & 52.19 & Silty Clay \\
\hline GS9 & & & & & Hard Bottom \\
\hline GS10 & 0.74 & 5.51 & 47.51 & 46.25 & Clayey Silt \\
\hline GS11 & 0.42 & 13.89 & 44.91 & 40.77 & Clayey Silt \\
\hline GS12 & 0.04 & 4.6 & 58.14 & 37.22 & Clayey Silt \\
\hline GS13 & 0 & 2.15 & 48.24 & 49.6 & Silty Clay \\
\hline GS14 & & & & & Hard Bottom \\
\hline GS15 & 1.62 & 32.62 & 44.57 & 21.19 & Sandy Silty Clay \\
\hline GS16 & 2.34 & 35.97 & 37.08 & 24.61 & Sandy Silty Clay \\
\hline GS17 & 49.64 & 46.29 & 1.57 & 2.51 & Gravel $>10$ percent \\
\hline GS18 & 0.44 & 27.97 & 49.16 & 22.43 & Sandy Silty Clay \\
\hline GS19 & 3.63 & 0.97 & 64.94 & 30.46 & Clayey Silt \\
\hline GS20 & 0.38 & 1.55 & 65.06 & 33.01 & Clayey Silt \\
\hline GS21 & 0.11 & 1.12 & 57.76 & 41.01 & Clayey Silt \\
\hline GS22 & 0.06 & 1.09 & 63.88 & 34.97 & Clayey Silt \\
\hline GS23 & 0.6 & 3.71 & 64.2 & 31.49 & Clayey Silt \\
\hline GS24 & 0.37 & 37.64 & 48.51 & 13.47 & Sandy Silt \\
\hline GS25 & 0.79 & 37.74 & 49.46 & 12.02 & Sandy Silt \\
\hline GS26 & 1.9 & 37.65 & 37.65 & 22.79 & Sandy Silty Clay \\
\hline GS27 & 2.21 & 51.74 & 37.43 & 8.63 & Silty Sand \\
\hline GS28 & 11.72 & 83.59 & 2.55 & 2.15 & Gravel $>10$ percent \\
\hline GS29 & 2.99 & 88.71 & 5.61 & 2.69 & Sand \\
\hline GS30 & 5.57 & 87.2 & 3.55 & 3.69 & Sand \\
\hline GS31 & 1.08 & 68.32 & 19.56 & 11.04 & Silty Sand \\
\hline GS32 & 10.52 & 58.73 & 15.98 & 14.77 & Gravel $>10$ percent \\
\hline GS33 & 10.34 & 86.8 & 1.59 & 1.28 & Gravel $>10$ percent \\
\hline
\end{tabular}


Appendix D. Texture, elemental composition, percent carbonate, cesium-137 activity, and clay mineralogy for bottom sediments and core samples collected from December 15, 1990, through January 27, 1991, in the Bahía de Añasco and in the Escollo Negro, Puerto Rico-Continued.

Appendix D-2. Inclusive graphics statistics for surficial sediment samples GS1 to GS33.

[Units are phi, the negative logarithm (base 2) of the size in millimeters.]

\begin{tabular}{|c|c|c|c|c|c|c|}
\hline Site & Median & Mean & $\begin{array}{l}\text { Standard } \\
\text { deviation }\end{array}$ & Skewness & Kurtosis & Description \\
\hline GS1 & 8.05 & 7.97 & 1.63 & -0.08 & 0.76 & Poorly sorted, nearly-symmetrical, platykurtic \\
\hline GS2 & 6.02 & 6.63 & 1.76 & 0.49 & 0.84 & Poorly sorted, strongly fine-skewed, platykurtic \\
\hline GS3 & 8.33 & 8.02 & 2.06 & -0.5 & 1.1 & Very poorly sorted, strongly coarse-skewed, mesokurtic \\
\hline GS4 & 8.58 & 8.3 & 1.64 & -0.31 & 0.89 & Poorly sorted, strongly coarse-skewed, platykurtic \\
\hline GS5 & 2.2 & 2.92 & 2.66 & 0.49 & 1.87 & Very poorly sorted, strongly fine-skewed, very leptokurtic \\
\hline GS6 & 8.15 & 7.88 & 1.79 & -0.2 & 0.72 & Poorly sorted, coarse-skewed, platykurtic \\
\hline GS7 & 8.34 & 8.1 & 1.78 & -0.33 & 0.94 & Poorly sorted, strongly coarse-skewed, mesokurtic \\
\hline GS8 & 8.12 & 7.76 & 2.25 & -0.49 & 1.09 & Very poorly sorted, strongly coarse-skewed, mesokurtic \\
\hline GS9 & & & & & & Hard Bottom \\
\hline GS10 & 7.71 & 7.41 & 2.15 & -0.22 & 0.75 & Very poorly sorted, coarse-skewed, platykurtic \\
\hline GS11 & 7.14 & 6.94 & 2.41 & -0.14 & 0.74 & Very poorly sorted, coarse-skewed, platykurtic \\
\hline GS12 & 7.31 & 7.41 & 1.82 & 0 & 0.94 & Poorly sorted, nearly-symmetrical, mesokurtic \\
\hline GS13 & 7.98 & 7.82 & 1.75 & -0.16 & 0.76 & Poorly sorted, coarse-skewed, platykurtic \\
\hline GS14 & & & & & & Hard Bottom \\
\hline GS15 & 5.03 & 5.69 & 2.43 & 0.37 & 0.8 & Very poorly sorted, strongly fine-skewed, platykurtic \\
\hline GS16 & 4.83 & 5.68 & 2.63 & 0.39 & 0.75 & Very poorly sorted, strongly fine-skewed, platykurtic \\
\hline GS17 & -0.95 & -1.23 & 2.68 & -0.08 & 0.61 & Very poorly sorted, nearly-symmetrical, very platykurtic \\
\hline GS18 & 4.93 & 5.71 & 2.36 & 0.46 & 0.75 & Very poorly sorted, strongly fine-skewed, platykurtic \\
\hline GS19 & 9.09 & 7.82 & 1.76 & -0.98 & 0.95 & Poorly sorted, strongly coarse-skewed, mesokurtic \\
\hline GS20 & 7.14 & 7.2 & 1.69 & 0.07 & 0.84 & Poorly sorted, nearly-symmetrical, platykurtic \\
\hline GS21 & 7.56 & 7.57 & 1.62 & 0.01 & 0.82 & Poorly sorted, nearly-symmetrical, platykurtic \\
\hline GS22 & 6.93 & 7.01 & 1.99 & 0.07 & 0.73 & Poorly sorted, nearly-symmetrical, platykurtic \\
\hline GS23 & 6.58 & 6.77 & 2.03 & 0.15 & 0.71 & Very poorly sorted, fine-skewed, platykurtic \\
\hline GS24 & 4.39 & 4.9 & 2.32 & 0.35 & 1.69 & Very poorly sorted, strongly fine-skewed, very leptokurtic \\
\hline GS25 & 4.51 & 4.87 & 2.27 & 0.27 & 1.31 & Very poorly sorted, fine-skewed, leptokurtic \\
\hline GS26 & 4.98 & 5.52 & 2.83 & 0.23 & 0.8 & Very poorly sorted, fine-skewed, platykurtic \\
\hline GS27 & 3.85 & 3.88 & 1.95 & 0.19 & 1.73 & Poorly sorted, fine-skewed, very leptokurtic \\
\hline GS28 & 0.49 & 0.5 & 1.44 & 0.15 & 1.27 & Poorly sorted, fine-skewed, leptokurtic \\
\hline GS29 & 2.34 & 2.16 & 1.55 & -0.07 & 1.4 & Poorly sorted, nearly-symmetrical, leptokurtic \\
\hline GS30 & 1.18 & 1.28 & 19.62 & 0.54 & 27.15 & $\begin{array}{l}\text { Extremely poorly sorted, strongly fine-skewed, extremely } \\
\text { leptokurtic }\end{array}$ \\
\hline GS31 & 3.36 & 3.75 & 2.82 & 0.26 & 1.2 & Very poorly sorted, fine-skewness, leptokurtic \\
\hline GS32 & 2.07 & 3.11 & 3.78 & 0.37 & 0.88 & Very poorly sorted, strongly fine-skewed, platykurtic \\
\hline GS33 & 1.28 & 1.03 & 1.3 & -0.45 & 1.36 & Poorly sorted, strongly coarse-skewed, leptokurtic \\
\hline
\end{tabular}


Appendix D. Texture, elemental composition, percent carbonate, cesium-137 activity, and clay mineralogy for bottom sediments and core samples collected from December 15, 1990, through January 27, 1991, in the Bahía de Añasco and in the Escollo Negro, Puerto Rico-Continued.

Appendix D-3. Cesium-137 concentrations, dry bulk density, and grain size of sediment core layers for cores VCA, VCC, VCY, VCO, with derived sedimentation rates for sites VCA and VCY .

[Units: $\mathrm{mBq} / \mathrm{g}$, milliBecquerels per gram; $\mu \mathrm{m}$, microns; $\mathrm{cm} / \mathrm{yr}$, centimeters per year. Dry bulk density is the weight of dry sediments per wet volume. The sedimentation rate was calculated by dividing the estimated depth of the maximum activity of cesium-137 by the number of years since 1964, in this case 26 years.]

\begin{tabular}{|c|c|c|c|c|c|c|c|c|}
\hline \multirow[b]{2}{*}{ Core } & \multicolumn{2}{|c|}{ Interval (cm) } & \multirow[b]{2}{*}{$\begin{array}{l}\text { Cesium-137 } \\
(\mathrm{mBq} / \mathrm{g})\end{array}$} & \multirow[b]{2}{*}{$\begin{array}{c}\text { Dry bulk } \\
\text { density } \\
\left(\mathrm{gm} / \mathrm{cm}^{3}\right)\end{array}$} & \multicolumn{3}{|c|}{ Grain size } & \multirow[b]{2}{*}{$\begin{array}{l}\text { Sedimentation } \\
\text { rate }(\mathrm{cm} / \mathrm{yr})\end{array}$} \\
\hline & $\begin{array}{l}\text { Inte } \\
\text { Top }\end{array}$ & $\begin{array}{l}\text { al }(\mathrm{cm}) \\
\text { Bottom }\end{array}$ & & & $\begin{array}{c}\text { Sand } \\
(>62 \mu \mathrm{m}) \\
\text { percent }\end{array}$ & $\begin{array}{c}\text { Silt } \\
\text { percent }\end{array}$ & $\begin{array}{c}\text { Clay } \\
(<2 \mu \mathrm{m}) \\
\text { percent }\end{array}$ & \\
\hline \multirow[t]{13}{*}{ VCA } & 0 & 20 & 2.44 & 0.75 & 12 & 46 & 42 & 3.46 \\
\hline & 20 & 40 & 2.02 & 0.87 & 11 & 56 & 33 & \\
\hline & 40 & 60 & 3.23 & 0.84 & 5 & 66 & 29 & \\
\hline & 60 & 80 & 5.78 & 0.9 & 10 & 49 & 41 & \\
\hline & 80 & 100 & 7.92 & 0.91 & 4 & 51 & 45 & \\
\hline & 100 & 120 & 2.28 & 0.79 & 2 & 50 & 48 & \\
\hline & 120 & 140 & $<1$ & 0.75 & 2 & 51 & 47 & \\
\hline & 140 & 160 & $<1$ & 0.79 & 3 & 67 & 30 & \\
\hline & 160 & 180 & 1.95 & 0.87 & 10 & 50 & 40 & \\
\hline & 180 & 200 & $<1$ & 0.79 & 3 & 46 & 51 & \\
\hline & 200 & 220 & $<1$ & 0.86 & 2 & 41 & 57 & \\
\hline & 220 & 240 & $<1$ & 0.85 & 5 & 43 & 52 & \\
\hline & 240 & 258 & $<1$ & 0.74 & 3 & 53 & 44 & \\
\hline \multirow[t]{11}{*}{ VCC } & 0 & 10 & $<1$ & 1.07 & 80 & 7 & 13 & \\
\hline & 10 & 20 & $<1$ & 1.13 & 72 & 8 & 20 & \\
\hline & 20 & 30 & $<1$ & 1.05 & 62 & 13 & 25 & \\
\hline & 30 & 40 & $<1$ & 1.34 & 82 & 6 & 12 & \\
\hline & 40 & 50 & $<1$ & 1.09 & 80 & 8 & 12 & \\
\hline & 50 & 60 & $<1$ & 1.27 & 79 & 7 & 14 & \\
\hline & 60 & 70 & $<1$ & 1.26 & 81 & 6 & 13 & \\
\hline & 70 & 80 & $<1$ & 1.15 & 86 & 5 & 9 & \\
\hline & 80 & 90 & $<1$ & 1.32 & 88 & 4 & 8 & \\
\hline & 90 & 100 & $<1$ & 1.39 & 92 & 3 & 5 & \\
\hline & 100 & 110 & $<1$ & 1.22 & 89 & 5 & 6 & \\
\hline \multirow[t]{11}{*}{ VCY } & 0 & 20 & 2.62 & 0.49 & 2 & 44 & 54 & 2.3 \\
\hline & 20 & 40 & 4.74 & 0.53 & 1 & 42 & 57 & \\
\hline & 40 & 60 & 5.94 & 0.59 & 1 & 47 & 52 & \\
\hline & 60 & 80 & 5.98 & 0.56 & 2 & 39 & 59 & \\
\hline & 80 & 100 & $<1$ & 0.59 & 2 & 35 & 63 & \\
\hline & 100 & 120 & $<1$ & 0.56 & 4 & 37 & 59 & \\
\hline & 120 & 140 & $<1$ & 0.63 & 1 & 25 & 74 & \\
\hline & 140 & 160 & $<1$ & 0.64 & 2 & 36 & 62 & \\
\hline & 160 & 180 & $<1$ & 0.69 & 1 & 39 & 60 & \\
\hline & 180 & 200 & $<1$ & 0.62 & 1 & 29 & 70 & \\
\hline & 200 & 220 & $<1$ & 0.76 & 3 & 48 & 49 & \\
\hline \multirow[t]{4}{*}{ VCO } & 0 & 15 & 2.53 & 0.64 & 43 & 28 & 29 & \\
\hline & 15 & 30 & $<1$ & 0.87 & 26 & 35 & 39 & \\
\hline & 30 & 45 & $<1$ & 0.91 & 22 & 38 & 40 & \\
\hline & 45 & 60 & $<1$ & 1.18 & 23 & 38 & 39 & \\
\hline
\end{tabular}


Appendix D. Texture, elemental composition, percent carbonate, cesium-137 activity, and clay mineralogy for bottom sediments and core samples collected from December 15, 1990, through January 27, 1991, in the Bahía de Añasco and in the Escollo Negro, Puerto Rico-Continued.

Appendix D-4. Total organic carbon and total metals measured in the cores recovered from the outfall site (VCO), the Río Grande de Añasco delta (VCA), the Río Yagüez delta (VCY), and from the channel of carbonate sands in the Manchas Interiores (VCC).

[Units: wt.\%, weight percent; ppm, parts per million; Abbreviations: cm, centimeter; TOC, Total Organic Carbon; LOI, Loss on Ignition; OOM, Other Organic Material (LOI-TOC)]

\begin{tabular}{|c|c|c|c|c|c|c|c|c|c|c|c|c|c|c|c|c|c|c|c|c|}
\hline \multicolumn{2}{|c|}{ Interval $(\mathrm{cm})$} & \multirow{2}{*}{$\begin{array}{c}\text { TOC } \\
\text { wt. \% }\end{array}$} & \multirow{2}{*}{$\begin{array}{c}\text { LOI } \\
\text { wt. } \%\end{array}$} & \multirow{2}{*}{$\begin{array}{l}\text { OOM } \\
\text { wt. } \%\end{array}$} & \multirow{2}{*}{$\begin{array}{c}\mathrm{Ag} \\
\mathrm{ppm}\end{array}$} & \multirow{2}{*}{$\underset{\mathrm{ppm}}{\mathrm{Cu}}$} & \multirow{2}{*}{$\begin{array}{c}\mathrm{Pb} \\
\mathrm{ppm}\end{array}$} & \multirow{2}{*}{$\underset{\mathrm{ppm}}{\mathrm{Zn}}$} & \multirow{2}{*}{$\underset{\mathrm{ppm}}{\mathrm{Ni}}$} & \multirow{2}{*}{$\begin{array}{c}\text { Co } \\
\mathrm{ppm}\end{array}$} & \multirow{2}{*}{$\underset{\mathrm{ppm}}{\mathrm{Cd}}$} & \multirow{2}{*}{$\underset{\mathrm{ppm}}{\mathrm{Cr}}$} & \multirow{2}{*}{$\underset{\mathrm{ppm}}{\mathrm{Hg}}$} & \multirow{2}{*}{$\begin{array}{c}\text { As } \\
\mathrm{ppm}\end{array}$} & \multirow{2}{*}{$\underset{\mathrm{ppm}}{\mathrm{Sb}}$} & \multirow{2}{*}{$\begin{array}{c}\mathrm{Se} \\
\mathrm{ppm}\end{array}$} & $\mathrm{Fe}$ & $n$ & 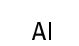 & Ti \\
\hline Top & Bottom & & & & & & & & & & & & & & & & wt. $\%$ & wt.\% & wt.\% & $w+\%$ \\
\hline Core V & & & & & & & & & & & & & & & & & & & & \\
\hline 0 & 5.08 & 0.9 & 10.2 & 9.3 & 0.7 & 43 & 11 & 85 & 73 & 24 & $<0.1$ & 111 & 0.06 & 26 & 0.5 & 0.2 & 5.5 & 0.08 & 6.7 & 0.37 \\
\hline 5.08 & 10.16 & 0.7 & 11.5 & 10.8 & $<0.2$ & 41 & 8 & 72 & 75 & 23 & 0.1 & 109 & 1.49 & 23 & 0.4 & 0.2 & 4.9 & 0.07 & 6.3 & 0.34 \\
\hline 10.16 & 15.24 & 0.8 & 8.9 & 8.1 & $<0.2$ & 39 & 8 & 72 & 70 & 22 & $<0.1$ & 104 & 0.04 & 25 & 0.3 & 0.2 & 5.1 & 0.07 & 6.1 & 0.33 \\
\hline 15.24 & 20.32 & 0.8 & 9.8 & 9 & $<0.2$ & 45 & 7 & 75 & 84 & 23 & $<0.1$ & 122 & 0.05 & 21 & 0.4 & 0.3 & 5.5 & 0.08 & 7.2 & 0.39 \\
\hline 25.4 & 30.48 & 0.9 & 9 & 8.1 & 0.4 & 41 & 5 & 71 & 77 & 21 & 0.1 & 117 & 0.02 & 23 & 0.4 & 0.2 & 5.3 & 0.07 & 6.8 & 0.39 \\
\hline 30.48 & 35.56 & 0.9 & 8.6 & 7.7 & $<0.2$ & 35 & 4 & 61 & 61 & 19 & $<0.1$ & 100 & 0.04 & 24 & 0.4 & 0.2 & 4.7 & 0.07 & 5.8 & 0.32 \\
\hline 35.56 & 45.72 & 0.7 & 12.2 & 11.5 & $<0.2$ & 43 & 5 & 70 & 77 & 22 & 0.1 & 123 & 0.09 & 24 & 0.6 & 0.3 & 5.1 & 0.07 & 7.5 & 0.4 \\
\hline 45.72 & 50.8 & 0.7 & 8.7 & 8 & $<0.2$ & 43 & 5 & 71 & 73 & 21 & $<0.1$ & 115 & 0.05 & 24 & 0.5 & 0.3 & 5.4 & 0.07 & 7.2 & 0.38 \\
\hline 60.96 & 63.5 & 0.6 & 8.2 & 7.6 & $<0.2$ & 38 & 5 & 74 & 92 & 23 & $<0.1$ & 148 & 0.04 & 29 & 0.3 & 0.2 & 5.5 & 0.07 & 6.7 & 0.38 \\
\hline Core V & & & & & & & & & & & & & & & & & & & & \\
\hline 0 & 20 & 0.9 & 8.7 & 7.8 & $<0.2$ & 75 & 9 & 104 & 49 & 28 & $<0.1$ & 91 & 0.07 & 9 & 0.5 & 0.2 & 6.6 & 0.09 & 10.2 & 0.54 \\
\hline 20 & 40 & 0.9 & 8.2 & 7.3 & $<0.2$ & 77 & 10 & 105 & 49 & 29 & $<0.1$ & 90 & 0.07 & 9 & 0.4 & 0.2 & 6.7 & 0.09 & 10.3 & 0.54 \\
\hline 40 & 60 & 1.1 & 8.7 & 7.6 & $<0.2$ & 86 & 11 & 108 & 63 & 28 & 0.2 & 101 & 0.06 & 9 & 0.6 & 0.2 & 6.8 & 0.09 & 11.1 & 0.56 \\
\hline 60 & 80 & 1 & 8 & 7 & $<0.2$ & 78 & 10 & 104 & 48 & 27 & 0.1 & 89 & 0.06 & 10 & 0.4 & 0.2 & 6.7 & 0.09 & 10.4 & 0.55 \\
\hline 80 & 100 & 1.4 & 9.5 & 8.1 & $<0.2$ & 86 & 9 & 102 & 46 & 25 & 0.1 & 85 & 0.06 & 10 & 0.5 & 0.3 & 6.6 & 0.08 & 10.6 & 0.55 \\
\hline 100 & 120 & 1.3 & 9.7 & 8.4 & $<0.2$ & 88 & 8 & 104 & 47 & 25 & 0.2 & 82 & 0.07 & 9 & 0.4 & 0.3 & 6.6 & 0.09 & 11.4 & 0.55 \\
\hline 120 & 140 & 1.3 & 9.5 & 8.2 & $<0.2$ & 84 & 8 & 101 & 46 & 24 & 0.1 & 83 & 0.07 & 10 & 0.4 & 0.2 & 6.5 & 0.09 & 11.3 & 0.55 \\
\hline 140 & 160 & 1.8 & 10.4 & 8.6 & $<0.2$ & 85 & 8 & 101 & 51 & 25 & 0.2 & 80 & 0.07 & 12 & 0.4 & 0.3 & 6.6 & 0.1 & 11 & 0.55 \\
\hline 160 & 180 & 1.1 & 8.5 & 7.4 & $<0.2$ & 80 & 7 & 101 & 55 & 27 & 0.2 & 96 & 0.05 & 8 & 0.3 & 0.2 & 6.5 & 0.09 & 11.2 & 0.55 \\
\hline 180 & 200 & 1.4 & 9.9 & 8.5 & $<0.2$ & 82 & 7 & 100 & 55 & 25 & 0.2 & 90 & 0.06 & 13 & 0.4 & 0.2 & 6.6 & 0.1 & 10.8 & 0.55 \\
\hline 200 & 220 & 1.6 & 10 & 8.4 & $<0.2$ & 82 & 8 & 100 & 54 & 25 & 0.1 & 92 & 0.07 & 12 & 0.6 & 0.3 & 6.4 & 0.09 & 10.5 & 0.55 \\
\hline 220 & 240 & 1.5 & 9.7 & 8.2 & $<0.2$ & 81 & 8 & 98 & 54 & 24 & 0.1 & 94 & 0.06 & 14 & 0.4 & 0.4 & 6.4 & 0.09 & 10.4 & 0.55 \\
\hline 240 & 258 & 1.4 & 9.6 & 8.2 & $<0.2$ & 88 & 8 & 102 & 57 & 24 & 0.1 & 92 & 0.06 & 12 & 0.4 & 0.4 & 6.5 & 0.09 & 10.9 & 0.57 \\
\hline Core V & & & & & & & & & & & & & & & & & & & & \\
\hline 0 & 20 & 1.5 & 8.5 & 7 & 0.3 & 85 & 19 & 124 & 392 & 40 & 0.1 & 395 & 0.17 & 18 & 0.5 & 0.3 & 7.3 & 0.09 & 9 & 0.53 \\
\hline 20 & 40 & 1.5 & 10.8 & 9.3 & 0.3 & 87 & 24 & 129 & 471 & 44 & 0.1 & 410 & 0.15 & 17 & 0.4 & 0.3 & 7.6 & 0.09 & 9 & 0.54 \\
\hline 40 & 60 & 1.4 & 10.8 & 9.4 & 0.3 & 88 & 27 & 132 & 548 & 48 & 0.2 & 450 & 0.07 & 18 & 0.6 & 0.4 & 8 & 0.09 & 9.1 & 0.55 \\
\hline 60 & 80 & 1.5 & 10.8 & 9.3 & 0.3 & 85 & 24 & 131 & 449 & 43 & 0.1 & 400 & 0.07 & 20 & 0.6 & 0.3 & 7.5 & 0.09 & 9.1 & 0.54 \\
\hline 80 & 100 & 1.5 & 9.6 & 8.1 & 0.2 & 83 & 22 & 126 & 325 & 37 & 0.1 & 350 & 0.08 & 19 & 0.5 & 0.3 & 7.2 & 0.1 & 9 & 0.52 \\
\hline 100 & 120 & 1.4 & 8.1 & 6.7 & $<0.2$ & 80 & 19 & 107 & 336 & 37 & 0.1 & 340 & 0.07 & 23 & 0.6 & 0.3 & 7.1 & 0.1 & 9.2 & 0.5 \\
\hline 120 & 140 & 1.3 & 12.5 & 11.2 & 0.2 & 68 & 14 & 94 & 302 & 35 & 0.1 & 310 & 0.06 & 26 & 0.7 & 0.3 & 6.7 & 0.1 & 8.6 & 0.49 \\
\hline 140 & 160 & 1.4 & 10.5 & 9.1 & $<0.2$ & 84 & 17 & 110 & 405 & 44 & 0.1 & 410 & 0.12 & 14 & 0.5 & 0.3 & 7.2 & 0.1 & 8.8 & 0.53 \\
\hline 160 & 180 & 1.5 & 10.7 & 9.2 & $<0.2$ & 79 & 26 & 109 & 331 & 39 & $<0.1$ & 350 & 0.12 & 18 & 0.5 & 0.3 & 7.1 & 0.1 & 9.1 & 0.52 \\
\hline 180 & 200 & 1.3 & 9.8 & 8.5 & $<0.2$ & 77 & 12 & 90 & 315 & 39 & $<0.1$ & 330 & 0.08 & 20 & 0.4 & 0.2 & 7 & 0.09 & 9 & 0.53 \\
\hline 200 & 220 & 1.4 & 9.6 & 8.2 & $<0.2$ & 61 & 11 & 84 & 299 & 36 & $<0.1$ & 330 & 0.06 & 26 & 0.4 & 0.2 & 6.6 & 0.09 & 8 & 0.48 \\
\hline Core & & & & & & & & & & & & & & & & & & & & \\
\hline 0 & 5 & 0.3 & 7.1 & 6.8 & $<0.2$ & 7 & 9 & 12 & 21 & 4 & $<0.1$ & 25 & 0.02 & 14 & 0.4 & 0.2 & 0.8 & 0.02 & 1.1 & 0.06 \\
\hline 5 & 10 & 0.3 & 8.8 & 8.4 & $<0.2$ & 11 & 8 & 17 & 33 & 6 & $<0.1$ & 39 & 0.01 & 16 & 0.4 & 0.3 & 1.2 & 0.02 & 1.8 & 0.09 \\
\hline 10 & 15 & 0.4 & 8.8 & 8.4 & $<0.2$ & 13 & 6 & 19 & 38 & 6 & $<0.1$ & 47 & 0.01 & 18 & 0.5 & 0.3 & 1.4 & 0.03 & 2.1 & 0.11 \\
\hline 15 & 20 & 0.5 & 6.9 & 6.4 & $<0.2$ & 12 & 5 & 18 & 36 & 6 & $<0.1$ & 43 & 0.01 & 19 & 0.4 & 0.3 & 1.3 & 0.03 & 2 & 0.1 \\
\hline 20 & 60 & 0.3 & 9.9 & 9.6 & $<0.2$ & 11 & 5 & 17 & 32 & 7 & 0.2 & 41 & 0.03 & 16 & 0.5 & 0.3 & 1.1 & 0.02 & 1.8 & 0.1 \\
\hline 60 & 110 & 0.2 & 6.9 & 6.7 & $<0.2$ & 4 & 4 & 7 & 15 & 4 & 0.2 & 17 & 0.02 & 12 & 0.6 & 0.3 & 0.4 & 0.02 & 0.6 & 0.03 \\
\hline
\end{tabular}


Appendix D. Texture, elemental composition, percent carbonate, cesium-137 activity, and clay mineralogy for bottom sediments and core samples collected from December 15, 1990, through January 27, 1991, in the Bahía de Añasco and in the Escollo Negro, Puerto Rico-Continued.

Appendix D-5. Total organic carbon and total metals measured in selected surface sediments in addition to those measured in a suspendedsediment sample collected from Río Grande de Añasco water quality site QW-An1.

[Units: wt.\%, weight percent; ppm, parts per million. Abbreviations: TOC, Total Organic Carbon; LOI, Loss on Ignition; OOM, Other Organic Material (LOI-TOC); ,-- no data]

\begin{tabular}{|c|c|c|c|c|c|c|c|c|c|c|c|c|c|c|c|c|c|c|c|}
\hline $\begin{array}{c}\text { Sample } \\
\text { Identific } \\
\text { ation }\end{array}$ & $\begin{array}{l}\text { TOC } \\
\text { wt. } \%\end{array}$ & $\begin{array}{c}\text { LOI } \\
\text { wt. } \%\end{array}$ & $\begin{array}{l}\text { 00M } \\
\text { wt.\% }\end{array}$ & $\begin{array}{c}\mathrm{Ag} \\
\mathrm{ppm}\end{array}$ & $\begin{array}{c}\mathrm{Cu} \\
\mathrm{ppm}\end{array}$ & $\begin{array}{c}\mathrm{Pb} \\
\mathrm{ppm}\end{array}$ & $\begin{array}{c}\mathrm{Zn} \\
\mathrm{ppm}\end{array}$ & $\begin{array}{c}\mathrm{Ni} \\
\mathrm{ppm}\end{array}$ & $\begin{array}{c}\text { Co } \\
\mathrm{ppm}\end{array}$ & $\begin{array}{c}\mathrm{Cd} \\
\mathrm{ppm}\end{array}$ & $\begin{array}{c}\mathrm{Cr} \\
\mathrm{ppm}\end{array}$ & $\underset{\mathrm{ppm}}{\mathrm{Hg}}$ & $\begin{array}{c}\text { As } \\
\mathrm{ppm}\end{array}$ & $\begin{array}{c}\mathrm{Sb} \\
\mathrm{ppm}\end{array}$ & $\begin{array}{c}\text { Se } \\
\mathrm{ppm}\end{array}$ & $\begin{array}{c}\mathrm{Fe} \\
\mathrm{wt.} \%\end{array}$ & $\begin{array}{c}\mathrm{Mn} \\
\text { wt. } \%\end{array}$ & $\underset{\text { wt. } \%}{\mathrm{Al}}$ & $\begin{array}{c}\mathrm{Ti} \\
\text { wt. } \%\end{array}$ \\
\hline GS1 & 1.4 & 11.8 & 10.4 & $<0.2$ & 89 & 11 & 103 & 66 & 25 & 0.1 & 92 & 0.09 & 14 & 0.6 & 0.4 & 6.3 & 0.08 & 11.7 & 0.55 \\
\hline GS2 & 1.5 & 11 & 9.5 & $<0.2$ & 88 & 11 & 101 & 56 & 25 & 0.1 & 81 & 0.08 & 11 & 0.6 & 0.4 & 6.7 & 0.09 & 11.1 & 0.53 \\
\hline GS6 & 1.5 & 10.9 & 9.4 & $<0.2$ & 84 & 11 & 103 & 77 & 25 & $<0.1$ & 103 & 0.09 & 14 & 0.5 & 0.4 & 6.3 & 0.08 & 10.7 & 0.53 \\
\hline GS7 & 1.5 & 10.5 & 9 & $<0.2$ & 79 & 12 & 101 & 89 & 25 & 0.1 & 120 & 0.09 & 17 & 0.6 & 0.4 & 6.5 & 0.08 & 10.6 & 0.51 \\
\hline GS11 & 1.2 & 12 & 10.8 & $<0.2$ & 67 & 11 & 99 & 87 & 28 & 0.1 & 121 & 0.07 & 20 & 0.6 & 0.3 & 6.5 & 0.08 & 9.3 & 0.48 \\
\hline GS12 & 1.5 & 12.9 & 11.4 & $<0.2$ & 72 & 10 & 95 & 84 & 25 & 0.1 & 112 & 0.08 & 18 & 0.5 & 0.3 & 6.1 & 0.08 & 8.3 & 0.47 \\
\hline GS16 & 0.7 & 9.7 & 9 & $<0.2$ & 52 & 10 & 104 & 91 & 32 & 0.1 & 125 & 0.06 & 27 & 0.5 & 0.2 & 7.1 & 0.09 & 8.7 & 0.5 \\
\hline GS18 & 0.7 & 9.5 & 8.8 & $<0.2$ & 51 & 10 & 107 & 109 & 33 & 0.2 & 167 & 0.06 & 26 & 0.6 & 0.2 & 7.2 & 0.09 & 8.3 & 0.51 \\
\hline GS21 & 1.3 & 13.7 & 12.4 & $<0.2$ & 70 & 12 & 97 & 130 & 26 & 0.2 & 159 & 0.08 & 15 & 0.6 & 0.3 & 6 & 0.07 & 9.4 & 0.47 \\
\hline GS34 & 0.2 & 6.1 & 5.9 & $<0.2$ & 3 & 3 & 9 & 12 & 4 & 0.1 & 17 & 0.02 & 22 & 0.3 & 0.2 & 0.7 & 0.03 & 0.7 & 0.03 \\
\hline GS35 & 0.7 & 14.8 & 14.1 & $<0.2$ & 28 & 8 & 45 & 69 & 13 & 0.2 & 86 & 0.06 & 7 & 0.2 & 0.3 & 2.7 & 0.06 & 3.9 & 0.23 \\
\hline GS36 & 0.1 & 3.3 & 3.2 & $<0.2$ & 1 & 5 & 2 & 5 & 2 & 0.1 & 6 & 0.01 & 4.1 & 0.1 & 0.1 & 0.1 & 1 & 0.1 & 0.01 \\
\hline GS38 & 0.2 & 6.4 & 6.2 & $<0.2$ & 7 & 6 & 10 & 18 & 4 & $<0.1$ & 24 & 0.03 & 14 & 0.2 & 0.2 & 0.7 & 0.02 & 1 & 0.05 \\
\hline $\begin{array}{l}\text { Añasco } \\
\text { Susp } \\
\text { Seds }\end{array}$ & -- & -- & -- & 19.5 & 90 & 30 & 120 & 40 & 20 & 2.5 & 40 & 1 & 3.3 & 0.6 & 0.3 & 4.3 & 0.07 & 7.3 & 0.35 \\
\hline
\end{tabular}


Appendix D. Texture, elemental composition, percent carbonate, cesium-137 activity, and clay mineralogy for bottom sediments and core samples collected from December 15, 1990, through January 27, 1991, in the Bahía de Añasco and in the Escollo Negro, Puerto Rico-Continued.

Appendix D-6. Mineral phases identified in selected sediments from cores, the suspended sediments of the Río Grande de Añasco, and the surface samples, using X-ray diffraction .

\begin{tabular}{|c|c|c|c|c|c|c|c|c|c|}
\hline \multirow[b]{2}{*}{ Site } & \multicolumn{2}{|c|}{ Depth interval units } & \multirow{2}{*}{$\begin{array}{c}\text { Size } \\
\text { fraction } \\
(\mathrm{mm})\end{array}$} & \multirow{2}{*}{$\begin{array}{l}\text { Type and strength } \\
\text { of acid used to } \\
\text { dissolve the } \\
\text { carbonates }\end{array}$} & \multirow[b]{2}{*}{ Principal phase } & \multirow[b]{2}{*}{ Major phases } & \multirow[b]{2}{*}{ Minor phases } & \multirow[b]{2}{*}{ Clay mine ralogy } & \multirow[b]{2}{*}{ Other phases } \\
\hline & Top & Bottom & & & & & & & \\
\hline \multicolumn{10}{|c|}{ Sediment cores } \\
\hline \multirow[t]{11}{*}{$\mathrm{VCO}$} & 0 & 10.16 & $<.062$ & & quartz & albite & 7A clay & kaolinite & brookite \\
\hline & & & & & & & $\begin{array}{l}10 \mathrm{~A} \text { clay } \\
\text { aragonite } \\
\text { (Mn, } \mathrm{Mg} \text { ) calcite } \\
\text { calcite }\end{array}$ & kaolinite-smectite & \\
\hline & 0 & 10.16 & $<.062$ & Na acet.@pH5 & quartz & albite & 7A clay & kaolinite & \\
\hline & & & & & & & & $\begin{array}{l}\text { kaolinite-smectite } \\
\text { halloysite }\end{array}$ & \\
\hline & 10.16 & 35.56 & $<.062$ & & quartz & aragonite & calcite & kaolinite & pyrite \\
\hline & & & & & & $\begin{array}{l}(\mathrm{Mn}, \mathrm{Mg}) \text { calcite } \\
\text { albite }\end{array}$ & 7A clay & & \\
\hline & 35.56 & 63.5 & $<.062$ & & quartz & $\begin{array}{l}\text { (Mn, } \mathrm{Mg} \text { ) calcite } \\
\text { albite }\end{array}$ & $\begin{array}{l}\text { aragonite } \\
\text { calcite }\end{array}$ & kaolinite-smectite & pyrite \\
\hline & & & & & & & 7A clay & & \\
\hline & 35.56 & 63.5 & $<.062$ & Na acet.@pH5 & quartz & albite & 7A clay & kaolinite & \\
\hline & & & & & & & brookite & kaolinite-smectite & \\
\hline & & & & & & & pyrite & halloysite & \\
\hline \multirow[t]{4}{*}{$\mathrm{VCA}$} & 0 & 5 & $<.062$ & & quartz & albite & & kaolinite & aragonite \\
\hline & & & & & & 7A clay & & kaolinite-smectite & pyrite \\
\hline & 240 & 258 & $<.062$ & & quartz & albite & 7A clay & kaolinite & \\
\hline & & & & & & & & kaolinite-smectite & \\
\hline Añasco & NA & NA & $<.062$ & & quartz & & & kaolinite & 10A illite \\
\hline Susp Sed & & & & & 7A clay & & & kaolinite-smectite & \\
\hline \multirow[t]{4}{*}{ VCY } & 0 & 20 & $<.062$ & & quartz & 7A clay & albite & $\begin{array}{l}\text { kaolinite } \\
\text { kaolinite-smectite } \\
\text { halloysite }\end{array}$ & $\begin{array}{l}\text { calcite } \\
\text { aragonite } \\
(\mathrm{Mn}, \mathrm{Mg}) \text { calcite }\end{array}$ \\
\hline & 200 & 220 & $<.062$ & & quartz & albite & & kaolinite & aragonite \\
\hline & & & & & & 7A clay & & kaolinite-smectite & calcite \\
\hline & & & & & & (Mn, $\mathrm{Mg}$ ) calcite & & & \\
\hline \multirow[t]{10}{*}{$\mathrm{VCC}$} & 0 & 60 & $<.062$ & & quartz & aragonite & & kaolinite-smectite & (Mn, Mg) calcite \\
\hline & & & & & & calcite & & & \\
\hline & & & & & & 7A clay & & & \\
\hline & 0 & 60 & $>.062$ & Na acet.@pH5 & $(\mathrm{Mn}, \mathrm{Mg}$ ) calcite & aragonite & calcite & & \\
\hline & & & $>.062$ & Na acet.@pH5 & $(\mathrm{Mn}, \mathrm{Mg}$ ) calcite & aragonite & calcite & & \\
\hline & & & & & & & (Mn, Mg) calcite & & \\
\hline & 0 & 60 & $>.062$ & cold dilute $\mathrm{HCl}$ & $(\mathrm{Mn}, \mathrm{Mg})$ calcite & aragonite & & & quartz \\
\hline & & & & & & & & & calcite \\
\hline & 0 & 60 & $>.062$ & hot $\mathrm{HCl} @ 6 \mathrm{M}$ & quartz & albite & & present & 7A clay \\
\hline & 60 & 110 & $<.062$ & & (Mn, Mg) calcite & $\begin{array}{l}\text { pyrite } \\
\text { quartz }\end{array}$ & $(\mathrm{Mn}, \mathrm{Mg}$ ) calcite & & albite \\
\hline
\end{tabular}


Appendix D. Texture, elemental composition, percent carbonate, cesium-137 activity, and clay mineralogy for bottom sediments and core samples collected from December 15, 1990, through January 27, 1991, in the Bahía de Añasco and in the Escollo Negro, Puerto Rico-Continued.

Appendix D-6. Mineral phases identified in selected sediments from cores, the suspended sediments of the Río Grande de Añasco, and the surface samples, using X-ray diffraction--Continued.

\begin{tabular}{|c|c|c|c|c|c|c|c|c|c|}
\hline \multirow[b]{2}{*}{ Site } & \multicolumn{2}{|c|}{ Depth interval units } & \multirow{2}{*}{$\begin{array}{l}\text { Size } \\
\text { fraction } \\
(\mathrm{mm})\end{array}$} & \multirow{2}{*}{$\begin{array}{l}\text { Type and strength } \\
\text { of acid used to } \\
\text { dissolve the } \\
\text { carbonates }\end{array}$} & \multirow[b]{2}{*}{ Principal phase } & \multirow[b]{2}{*}{ Major phases } & \multirow[b]{2}{*}{ Minor phases } & \multirow[b]{2}{*}{ Clay mineralogy } & \multirow[b]{2}{*}{ Other phases } \\
\hline & Top & Bottom & & & & & & & \\
\hline & & & & & & $\begin{array}{l}\text { aragonite } \\
\text { calcite }\end{array}$ & & & \\
\hline & 60 & 110 & $<.062$ & Na acet.@pH5 & quartz & $\begin{array}{l}\text { albite } \\
\text { 7A clay }\end{array}$ & pyrite & $\begin{array}{l}\text { kaolinite } \\
\text { kaolinite-smectite }\end{array}$ & brookite \\
\hline \multicolumn{10}{|c|}{ Surface samples } \\
\hline GS1 & NA & NA & $<.062$ & & quartz & $\begin{array}{l}\text { 7A clay } \\
\text { 10A clay }\end{array}$ & $\begin{array}{l}\text { albite } \\
\text { calcite } \\
\text { brookite }\end{array}$ & $\begin{array}{l}\text { kaolinite } \\
\text { kaolinite-smectite }\end{array}$ & pyrite \\
\hline GS2 & NA & NA & $<.062$ & & quartz & & $\begin{array}{l}\text { albite } \\
\text { 7A clay }\end{array}$ & $\begin{array}{l}\text { kaolinite } \\
\text { kaolinite-smectite }\end{array}$ & $\begin{array}{l}\text { aragonite } \\
\text { calcite }\end{array}$ \\
\hline GS6 & NA & NA & $<.062$ & & quartz & $\begin{array}{l}\text { 7A clay } \\
10 \text { A clay }\end{array}$ & albite & $\begin{array}{l}\text { kaolinite } \\
\text { kaolinite-smectite }\end{array}$ & $\begin{array}{l}\text { calcite } \\
\text { brookite } \\
\text { pyrite }\end{array}$ \\
\hline GS7 & NA & NA & $<.062$ & & quartz & $\begin{array}{l}\text { 7A clay } \\
\text { albite }\end{array}$ & calcite & $\begin{array}{l}\text { kaolinite } \\
\text { kaolinite-smectite }\end{array}$ & aragonite \\
\hline GS11 & NA & NA & $<.062$ & & quartz & $\begin{array}{l}\text { 7A clay } \\
\text { albite }\end{array}$ & & $\begin{array}{l}\text { kaolinite } \\
\text { kaolinite-smectite }\end{array}$ & $\begin{array}{l}\text { calcite } \\
\text { aragonite } \\
(\mathrm{Mn}, \mathrm{Mg}) \text { calcite }\end{array}$ \\
\hline GS12 & NA & NA & $<.062$ & & quartz & albite & $\begin{array}{l}\text { 7A clay } \\
\text { 10A clay }\end{array}$ & $\begin{array}{l}\text { kaolinite } \\
\text { kaolinite-smectite }\end{array}$ & $\begin{array}{l}\text { calcite } \\
\text { aragonite } \\
(\mathrm{Mn}, \mathrm{Mg}) \text { calcite }\end{array}$ \\
\hline GS16 & NA & NA & $<.062$ & & $\begin{array}{l}\text { albite } \\
\text { quartz }\end{array}$ & 7A clay & & $\begin{array}{l}\text { kaolinite } \\
\text { kaolinite-smectite }\end{array}$ & $\begin{array}{l}\text { aragonite } \\
\text { calcite }\end{array}$ \\
\hline GS18 & NA & NA & $<.062$ & & quartz & albite & $\begin{array}{l}\text { 7A clay } \\
\text { calcian kutno- } \\
\text { horite }\end{array}$ & $\begin{array}{l}\text { kaolinite } \\
\text { kaolinite-smectite }\end{array}$ & $\begin{array}{l}\text { calcite } \\
\text { aragonite }\end{array}$ \\
\hline GS21 & NA & NA & $<.062$ & & quartz & 7A clay & & $\begin{array}{l}\text { kaolinite } \\
\text { kaolinite-smectite }\end{array}$ & $\begin{array}{l}\text { albite } \\
\text { aragonite } \\
\text { calcite }\end{array}$ \\
\hline GS34 & NA & NA & $<.062$ & & $\begin{array}{l}\text { quartz } \\
\text { 7A clay }\end{array}$ & aragonite & & kaolinite-smectite & (Mn, Mg) calcite \\
\hline GS35 & NA & NA & $<.062$ & & quartz & & & kaolinite-smectite & $\begin{array}{l}\text { aragonite } \\
\text { calcite } \\
\text { albite } \\
7 \text { A clay }\end{array}$ \\
\hline GS36 & NA & NA & $<.062$ & & quartz & $\begin{array}{l}\text { aragonite } \\
\text { calcite }\end{array}$ & & & \\
\hline GS38 & NA & NA & $<.062$ & & $\begin{array}{l}\text { quartz } \\
\text { aragonite } \\
(\mathrm{Mn}, \mathrm{Mg}) \text { calcite }\end{array}$ & $\begin{array}{l}\text { albite } \\
\text { calcite } \\
\text { 7A clay }\end{array}$ & & $\begin{array}{l}\text { kaolinite } \\
\text { kaolinite-smectite }\end{array}$ & \\
\hline
\end{tabular}


Appendix D. Texture, elemental composition, percent carbonate, cesium-137 activity, and clay mineralogy for bottom sediments and core samples collected from December 15, 1990, through January 27, 1991, in the Bahía de Añasco and in the Escollo Negro, Puerto Rico-Continued.

Appendix D-7. Composition of surficial sediment samples as percentages of three geochemical endmember sources identified as typical of the Río Grande de Añasco, carbonates, and the Rio Yagüez.

[Also included are the uppermost samples from the four sediment-core sites. The endmember compositions are described in the text. Three of the surficial sediment samples were indicated to have a negative percentage of a certain endmember, indicating either a removal of elements typical of that endmember or the presence of another endmember not well described by the three presented here. To facilitate plotting pie charts and drawing component contours in the report, the negative percentages present in those three samples were set equal to zero and the other two factors decreased by one-half of the cancelled value. The resultant values are listed below with the original values in parenthesis.]

\begin{tabular}{cccc}
\hline ID & Añasco & Carbonate & Yagüez \\
\hline GS1 & 85.9 & 10.9 & 3.2 \\
GS2 & 86.2 & 10.2 & 3.6 \\
GS6 & 81.8 & 9.9 & 8.3 \\
GS7 & 76.5 & 11.0 & 12.4 \\
GS11 & 71.5 & 14.2 & 14.3 \\
GS12 & 72.6 & 14.5 & 12.9 \\
GS16 & 71.2 & 10.6 & 18.2 \\
GS18 & 63.7 & 12.6 & 23.7 \\
GS21 & 63.6 & 16.5 & 20.0 \\
GS34 & 11.8 & 86.6 & 1.6 \\
GS35 & 38.9 & 51.0 & 10.2 \\
GS-38 & $0(-1)$ & $86.5(87)$ & $13.5(14)$ \\
VCO & 58.8 & 20.4 & 20.7 \\
VCC & $0(-9)$ & $82.5(87)$ & $17.5(22)$ \\
VCA & 91.7 & 2.5 & 5.9 \\
VCY & $22.1(26)$ & $0(-7)$ & $77.9(82)$ \\
\hline
\end{tabular}


Appendix D. Texture, elemental composition, percent carbonate, cesium-137 activity, and clay mineralogy for bottom sediments and core samples collected from December 15, 1990, through January 27, 1991, in the Bahía de Añasco and in the Escollo Negro, Puerto Rico-Continued.

Appendix D-8. Percent calcium carbonate in selected surface-sediment samples, the core VCO, and the core VCC.

[Values in parenthesis indicate the relative percent difference (RPD) for samples where laboratory replicates were analyzed. $\mathrm{cm}$, centimeter]

\begin{tabular}{|c|c|c|c|c|c|c|c|}
\hline \multirow{2}{*}{\multicolumn{4}{|c|}{ Surface samples }} & \multicolumn{4}{|c|}{ Sediment cores } \\
\hline & & & & \multicolumn{4}{|c|}{ Interval $(\mathrm{cm})$} \\
\hline Site & $\% \mathrm{CaCO}_{3}$ & Site & $\% \mathrm{CaCO}_{3}$ & Site & Top & Bottom & $\% \mathrm{CaCO}_{3}$ \\
\hline GS1 & 5.3 & GS20 & 30.3 & $\mathrm{VCO}$ & 0 & 5.08 & 34.2 \\
\hline GS2 & 4.7 & GS21 & 16.6 & & 50.8 & 63.5 & 34.2 \\
\hline GS2 & $5.5(15.7)$ & GS22 & 31.9 & & & & \\
\hline GS3 & 15.2 & GS23 & 35.2 & VCC & 0 & 20 & 84.6 \\
\hline GS4 & 14.6 & GS24 & 68.3 & & 20 & 60 & 78.3 \\
\hline GS5 & 76.8 & GS25 & 58.9 & & 60 & 110 & 89.7 \\
\hline GS5 & $76.4(0.5)$ & GS26 & 65.4 & & & & \\
\hline GS6 & 6.8 & GS27 & 75.6 & & & & \\
\hline GS7 & 10.8 & GS28 & 91.5 & & & & \\
\hline GS8 & 19.5 & GS29 & 85.7 & & & & \\
\hline GS10 & 9.7 & GS30 & 87.7 & & & & \\
\hline GS11 & 12.0 & GS31 & 74.8 & & & & \\
\hline GS12 & 15.5 & GS32 & 71.2 & & & & \\
\hline GS12 & $13.4(14.5)$ & GS33 & 93.7 & & & & \\
\hline GS13 & 17.1 & GS34 & 90.3 & & & & \\
\hline GS15 & 13.7 & GS35 & 61.5 & & & & \\
\hline GS16 & 12.9 & GS36 & 95.7 & & & & \\
\hline GS18 & 11.3 & GS37 & 96.3 & & & & \\
\hline GS19 & 19.6 & GS38 & 87.3 & & & & \\
\hline
\end{tabular}


146 Assessment of the Habitats, Biota, Sediments, and Water Quality Near the Discharge of Primary-Treated Effluent from the Mayagüez Regional Wastewater Treatment Plant, Bahía de Añasco, Puerto Rico 
Appendix E. General water quality with depth and general water quality, bacteria, volatile organic compounds, semivolatile organic compounds, pesticides, PCB's, herbicides, total metals and trace elements, general inorganics, and radiochemistry by sample at 10 water-quality sampling sites in the Bahía de Añasco and near Rincón, Puerto Rico, at two sites sampled in the Río Grande de Añasco and the Río Yagüez, and at the influent and effluent of the Mayagüez Regional Wastewater Treatment Plant, January 25-30, 1991.

Appendix E-1. Summary of the results of acute and chronic exposure bioassays conducted during January 1991.

[Analysis of effluent water quality is given in appendixes E-2 through E-7. Concentrations are expressed as nominal values; actual values are 78 percent of nominal. This variation is due to adjustment of effluent salinity by addition of natural seawater brine. Units: LC-50, median lethal concentration. NA, not applicable. Concentrations are percent effluent of the total effluent dilution water-effluent mix.]

\begin{tabular}{|c|c|c|c|c|c|c|c|}
\hline \multirow[b]{2}{*}{ Species } & \multicolumn{3}{|c|}{ Acute toxicity evaluation } & \multicolumn{4}{|c|}{ Chronic toxicity evaluation } \\
\hline & $\begin{array}{c}\text { Exposure } \\
\text { (hours) }\end{array}$ & $\begin{array}{c}\text { LC-50 } \\
\text { (percent) }\end{array}$ & $\begin{array}{c}\text { No observed } \\
\text { acute effect } \\
\text { level } \\
\text { (percent) }\end{array}$ & $\begin{array}{c}\text { Exposure } \\
\text { (days) }\end{array}$ & $\begin{array}{l}\text { No observed } \\
\text { effect } \\
\text { concentration } \\
\text { (percent) }\end{array}$ & $\begin{array}{c}\text { Lowest } \\
\text { observed effect } \\
\text { concentration } \\
\text { (percent) }\end{array}$ & $\begin{array}{c}\text { Chronic } \\
\text { value } \\
\text { (percent) }\end{array}$ \\
\hline Mysidopsis bahia & 96 & 8.3 & 1 & 7 & 15 & 25 & 19.4 \\
\hline Cyprinodon variegatus & 96 & 43.3 & 10 & 7 & 1 & 10 & 3.2 \\
\hline Champia parvula & $48 / 168$ & NA & 1 & 7 & 5 & 10 & 7.1 \\
\hline
\end{tabular}


Appendix E. General water quality with depth and general water quality, bacteria, volatile organic compounds, semivolatile organic compounds, pesticides, PCB's, herbicides, total metals and trace elements, general inorganics, and radiochemistry by sample at 10 water-quality sampling sites in the Bahía de Añasco and near Rincón, Puerto Rico, at two sites sampled in the Río Grande de Añasco and the Río Yagüez, and at the influent and effluent of the Mayagüez Regional Wastewater Treatment Plant, January 25-30, 1991-Continued

Appendix E-2. Volatile organic compounds measured in the Mayagüez Regional Wastewater Treatment Plant, January 29, 1991.

[Method 624. Samples to be analyzed for volatile compounds cannot be composited. Therefore, four samples each of the influent and effluent were individually collected throughout the day. Units are micrograms per liter. Abbreviations: WWTP, Wastewater Treatment Plant; Rep. Limit, Reporting Limit; ND, not detected. Values for surrogates represent percent recovery.]

\begin{tabular}{|c|c|c|c|c|c|c|c|c|c|c|}
\hline \multirow{2}{*}{ Constituent } & \multicolumn{5}{|c|}{ Influent } & \multicolumn{5}{|c|}{ Effluent } \\
\hline & $\begin{array}{c}\text { WWTP } \\
1\end{array}$ & $\begin{array}{c}\text { WWTP } \\
2\end{array}$ & $\begin{array}{c}\text { WWTP } \\
3\end{array}$ & $\begin{array}{c}\text { WWTP } \\
4\end{array}$ & $\begin{array}{l}\text { Rep. } \\
\text { Limit }\end{array}$ & WWTP 5 & $\begin{array}{c}\text { WWTP } \\
6\end{array}$ & WWTP 7 & $\begin{array}{c}\text { WWTP } \\
8\end{array}$ & $\begin{array}{l}\text { Rep. } \\
\text { Limit }\end{array}$ \\
\hline Acrolein & ND & ND & ND & ND & 100 & ND & ND & ND & ND & 100 \\
\hline Acrylonitrile & ND & ND & ND & ND & 100 & ND & ND & ND & ND & 100 \\
\hline Benzene & ND & ND & ND & ND & 5 & ND & ND & ND & ND & 5 \\
\hline Bromodichloromethane & ND & ND & ND & ND & 5 & ND & ND & ND & ND & 5 \\
\hline Bromoform & ND & ND & ND & ND & 5 & ND & ND & ND & ND & 5 \\
\hline Bromomethane & ND & ND & ND & ND & 10 & ND & ND & ND & ND & 10 \\
\hline Carbon tetrachloride & ND & ND & ND & ND & 5 & ND & ND & ND & 8.7 & 5 \\
\hline Chlorobenzene & ND & ND & ND & ND & 5 & ND & ND & ND & ND & 5 \\
\hline Chloroethane & ND & ND & ND & ND & 10 & ND & ND & ND & ND & 10 \\
\hline Chloroform & ND & 8.3 & 6.5 & ND & 5 & 9.7 & 7.7 & 9.6 & 12 & 5 \\
\hline Chloromethane & ND & ND & ND & ND & 10 & 36 & 23 & 30 & 50 & 10 \\
\hline Dibromochloromethane & ND & ND & ND & ND & 5 & ND & ND & ND & ND & 5 \\
\hline 1,1-Dichloroethane & ND & ND & ND & ND & 5 & ND & ND & ND & ND & 5 \\
\hline 1,2-Dichloroethane & ND & ND & ND & ND & 5 & ND & ND & ND & ND & 5 \\
\hline 1,1-Dichloroethene & ND & ND & ND & ND & 5 & ND & ND & ND & ND & 5 \\
\hline 1,2-Dichloroethene (total) & ND & ND & ND & ND & 5 & ND & ND & ND & ND & 5 \\
\hline 1,2-Dichloropropane & ND & ND & ND & ND & 5 & ND & ND & ND & ND & 5 \\
\hline cis-1,3-Dichloropropene & ND & ND & ND & ND & 5 & ND & ND & ND & ND & 5 \\
\hline trans-1,3-Dichloropropene & ND & ND & ND & ND & 5 & ND & ND & ND & ND & 5 \\
\hline Ethylbenzene & ND & ND & ND & ND & 5 & ND & 6.4 & ND & ND & 5 \\
\hline Methylene chloride & ND & ND & ND & ND & 5 & ND & ND & ND & ND & 5 \\
\hline 1,1,2,2-Tetrachloroethane & ND & ND & ND & ND & 5 & ND & ND & ND & ND & 5 \\
\hline Tetrachloroethene & ND & ND & ND & ND & 5 & ND & ND & ND & ND & 5 \\
\hline Toluene & 13 & 32 & 28 & 13 & 5 & ND & 62 & 69 & 13 & 5 \\
\hline 1,1,1-Trichloroethane & ND & ND & ND & ND & 5 & ND & ND & ND & ND & 5 \\
\hline 1,1,2-Trichloroethane & ND & ND & ND & ND & 5 & ND & ND & ND & ND & 5 \\
\hline Trichloroethene & ND & ND & ND & ND & 5 & ND & ND & ND & ND & 5 \\
\hline Vinyl chloride & ND & ND & ND & ND & 10 & ND & ND & ND & ND & 10 \\
\hline Surrogate & & & & & $\operatorname{Rec}$ & & & & & \\
\hline Toluene-d 8 & 99 & 102 & 104 & 96 & & 102 & 102 & 103 & 104 & \\
\hline 4-Bromofluorobenzene & 100 & 105 & 105 & 106 & & 104 & 106 & 103 & 101 & \\
\hline 1,2-Dichloroethane-d4 & 98 & 95 & 98 & 92 & & 90 & 99 & 97 & 98 & \\
\hline
\end{tabular}


Appendix E. General water quality with depth and general water quality, bacteria, volatile organic compounds, semivolatile organic compounds, pesticides, PCB's, herbicides, total metals and trace elements, general inorganics, and radiochemistry by sample at 10 water-quality sampling sites in the Bahía de Añasco and near Rincón, Puerto Rico, at two sites sampled in the Río Grande de Añasco and the Río Yagüez, and at the influent and effluent of the Mayagüez Regional Wastewater Treatment Plant, January 25-30, 1991-Continued

Appendix E-3. Semivolatile organic compounds measured in the Mayagüez Regional Wastewater Treatment Plant, January $29,1991$.

[Method 625. Units are micrograms per liter; ND, not detected; conc., concentration; Rep. Limit, Reporting Limit; conf. level, confidence level. Values for surrogates represent percent recovery. All tentatively identified compounds were found in the base neutral acids. Confidence levels for the tentatively identified compounds: 1- tentative; 2-confident; and 3-confirmed.]

\begin{tabular}{|c|c|c|c|c|}
\hline \multirow[b]{2}{*}{ Constituent } & \multicolumn{2}{|c|}{ Influent } & \multicolumn{2}{|c|}{ Effluent } \\
\hline & conc. & $\begin{array}{l}\text { Rep. } \\
\text { Limit }\end{array}$ & conc. & $\begin{array}{l}\text { Rep. } \\
\text { Limit }\end{array}$ \\
\hline Acenaphthene & ND & 40 & ND & 20 \\
\hline Acenaphthylene & ND & 40 & ND & 20 \\
\hline Anthracene & ND & 40 & ND & 20 \\
\hline Benzidine & ND & 400 & ND & 200 \\
\hline Benzo a-anthracene & ND & 40 & ND & 20 \\
\hline Benzo $b$ fluoranthene & ND & 40 & ND & 20 \\
\hline Benzo k fluoranthene & ND & 40 & ND & 20 \\
\hline Benzo $(g, h, i)$ perylene & ND & 40 & ND & 20 \\
\hline Benzo (a)pyrene & ND & 40 & ND & 20 \\
\hline 4-Bromophenyl phenyl ether & $\mathrm{ND}$ & 40 & ND & 20 \\
\hline Butyl benzyl phthalate & ND & 40 & ND & 20 \\
\hline bis(2-Chloroethoxy)-methane & ND & 40 & ND & 20 \\
\hline bis(2-Chloroethyl) ether & ND & 40 & ND & 20 \\
\hline bis(2-Chloroisopropyl)-ether & ND & 40 & ND & 20 \\
\hline 4-Chloro-3-methylphenol & $\mathrm{ND}$ & 40 & ND & 20 \\
\hline 2-Chloronaphthalene & ND & 40 & ND & 20 \\
\hline 2-Chlorophenol & ND & 40 & ND & 20 \\
\hline 4-Chlorophenyl phenyl ether & ND & 40 & ND & 20 \\
\hline Chrysene & ND & 40 & ND & 20 \\
\hline Dibenz(a,h)anthracene & ND & 40 & ND & 20 \\
\hline Di-n-butyl phthalate & ND & 40 & ND & 20 \\
\hline 1,2-Dichlorobenzene & ND & 40 & ND & 20 \\
\hline 1,3-Dichlorobenzene & ND & 40 & ND & 20 \\
\hline 1,4-Dichlorobenzene & $\mathrm{ND}$ & 40 & ND & 20 \\
\hline 3,3'-Dichlorobenzidine & ND & 80 & ND & 40 \\
\hline 2,4-Dichlorophenol & ND & 40 & ND & 20 \\
\hline Diethyl phthalate & ND & 40 & ND & 20 \\
\hline 2,4-DimethylPhenol & ND & 40 & ND & 20 \\
\hline Dimethyl phthalate & ND & 40 & ND & 20 \\
\hline 4,6-Dinitro-2-methylphenol & ND & 200 & ND & 100 \\
\hline 2,4-Dinitrophenol & $\mathrm{ND}$ & 200 & ND & 100 \\
\hline
\end{tabular}


Appendix E. General water quality with depth and general water quality, bacteria, volatile organic compounds, semivolatile organic compounds, pesticides, PCB's, herbicides, total metals and trace elements, general inorganics, and radiochemistry by sample at 10 water-quality sampling sites in the Bahía de Añasco and near Rincón, Puerto Rico, at two sites sampled in the Río Grande de Añasco and the Río Yagüez, and at the influent and effluent of the Mayagüez Regional Wastewater Treatment Plant, January 25-30, 1991--Continued

Appendix E-3. Semivolatile organic compounds measured in the Mayagüez Regional Wastewater Treatment Plant, January 29, 1991-Continued.

[Method 625. Units are micrograms per liter; ND, not detected; conc., concentration; Rep. Limit, Reporting Limit; conf. level, confidence level. Values for surrogates represent percent recovery. All tentatively identified compounds were found in the base neutral acids. Confidence levels for the tentatively identified compounds: 1- tentative; 2-confident; and 3-confirmed.]

\begin{tabular}{|c|c|c|c|c|}
\hline \multirow[b]{2}{*}{ Constituent } & \multicolumn{2}{|c|}{ Influent } & \multicolumn{2}{|c|}{ Effluent } \\
\hline & conc. & $\begin{array}{l}\text { Rep. } \\
\text { Limit }\end{array}$ & conc. & $\begin{array}{l}\text { Rep. } \\
\text { Limit }\end{array}$ \\
\hline 2,4-Dinitrotoluene & ND & 40 & ND & 20 \\
\hline 2,6-Dinitrotoluene & ND & 40 & ND & 20 \\
\hline Di-n-octylphthalate & ND & 40 & ND & 20 \\
\hline 1,2-Diphenylhydrazine & ND & 40 & ND & 20 \\
\hline bis(2-Ethylhexyl)phthalate & ND & 40 & ND & 20 \\
\hline Fluoranthene & ND & 40 & ND & 20 \\
\hline Fluorene & ND & 40 & ND & 20 \\
\hline Hexachlorobenzene & ND & 40 & ND & 20 \\
\hline Hexachlorobutadiene & ND & 40 & ND & 20 \\
\hline Hexachlorocyclopentadiene & ND & 40 & ND & 20 \\
\hline Hexachloroethane & ND & 40 & ND & 20 \\
\hline Indeno(1,2,3-cd)pyrene & ND & 40 & ND & 20 \\
\hline Isophorone & ND & 40 & ND & 20 \\
\hline Naphthalene & ND & 40 & ND & 20 \\
\hline Nitrobenzene & ND & 40 & ND & 20 \\
\hline 2-Nitrophenol & ND & 40 & ND & 20 \\
\hline 4-Nitrophenol & ND & 200 & ND & 100 \\
\hline N-Nitrosodimethylamine & ND & 40 & ND & 20 \\
\hline N-Nitrosodiphenylamine & ND & 40 & ND & 20 \\
\hline N-Nitroso-di-n-Propylamine & ND & 40 & ND & 20 \\
\hline Pentachlorophenol & ND & 200 & ND & 100 \\
\hline Phenanthrene & ND & 40 & ND & 20 \\
\hline Phenol & ND & 40 & ND & 20 \\
\hline Pyrene & ND & 40 & ND & 20 \\
\hline 1,2,4-Trichlorobenzene & ND & 40 & ND & 20 \\
\hline 2,4,6-Trichlorophenol & ND & 40 & ND & 20 \\
\hline Surrogate & & & & \\
\hline Nitrobenzene-d5 & 70 & & 66 & \\
\hline 2-Fluorobiphenyl & 54 & & 68 & \\
\hline Terphenyl-dl4 & 14 & & 35 & \\
\hline
\end{tabular}

150 Assessment of the Habitats, Biota, Sediments, and Water Quality Near the Discharge of Primary-Treated Effluent from the Mayagüez Regional Wastewater Treatment Plant, Bahía de Añasco, Puerto Rico 
Appendix E. General water quality with depth and general water quality, bacteria, volatile organic compounds, semivolatile organic compounds, pesticides, PCB's, herbicides, total metals and trace elements, general inorganics, and radiochemistry by sample at 10 water-quality sampling sites in the Bahía de Añasco and near Rincón, Puerto Rico, at two sites sampled in the Río Grande de Añasco and the Río Yagüez, and at the influent and effluent of the Mayagüez Regional Wastewater Treatment Plant, January 25-30, 1991—Continued

Appendix E-3. Semivolatile organic compounds measured in the Mayagüez Regional Wastewater Treatment Plant, January 29, 1991-Continued.

[Method 625. Units are micrograms per liter; ND, not detected; conc., concentration; Rep. Limit, Reporting Limit; conf. level, confidence level. Values for surrogates represent percent recovery. All tentatively identified compounds were found in the base neutral acids. Confidence levels for the tentatively identified compounds: 1- tentative; 2-confident; and 3-confirmed.]

\begin{tabular}{|c|c|c|c|c|}
\hline \multirow[b]{2}{*}{ Constituent } & \multicolumn{2}{|c|}{ Influent } & \multicolumn{2}{|c|}{ Effluent } \\
\hline & conc. & $\begin{array}{l}\text { Rep. } \\
\text { Limit }\end{array}$ & conc. & $\begin{array}{l}\text { Rep. } \\
\text { Limit }\end{array}$ \\
\hline Surrogate & & & & \\
\hline Phenol-d5 & 80 & & 75 & \\
\hline 2-Fluorophenol & 75 & & 74 & \\
\hline 2,4,6-Tribromophenol & 67 & & 68 & \\
\hline
\end{tabular}

Tentatively identified compounds

\begin{tabular}{|c|c|c|c|c|c|}
\hline \multicolumn{3}{|c|}{ Influent } & \multicolumn{2}{|l|}{ Effluent } & \multirow[b]{2}{*}{ conc. } \\
\hline Constituent & conf. level & conc. & Constituent & conf. level & \\
\hline Cyclohexane,Methyl- & 2 & 100 & 1-Butanol,3-Methyl- & 1 & 89 \\
\hline Propanoic Acid & 2 & 180 & Propanoic Acid & 2 & 150 \\
\hline Propanoic Acid,2-Methyl- & 2 & 120 & Propanoic Acid,2-Methyl- & 2 & 76 \\
\hline Butanoic Acid & 2 & 170 & Butanoic Acid,3-Methyl- & 1 & 69 \\
\hline Butanoic Acid,3-Methyl- & 2 & 300 & Butanoic Acid,-Methyl & 1 & 88 \\
\hline Butanoic Acid,2-Methyl & 2 & 100 & 2,4-Pentanediol,2-Methyl & 2 & 63 \\
\hline Pentanoic Acid & 2 & 150 & Hexanoic Acid & 2 & 66 \\
\hline Hexanoic Acid,Anhydride & 1 & 210 & Benzeneethanol & 2 & 75 \\
\hline Benzeneethanol & 2 & 79 & $\begin{array}{l}\text { Benzoic Acid,Ammonium } \\
\text { Salt }\end{array}$ & 1 & 170 \\
\hline $\begin{array}{l}\text { 3-Cyclohexene-1-Methanol,. } \\
\text {.Alpha.,.Alpha.,4-Trimethyl- }\end{array}$ & 1 & 140 & $\begin{array}{l}\text { 3-Cyclohexene-1-Metha- } \\
\text { nol,.Alpha.,.Alpha., } \\
\text { 4-Trimethyl- }\end{array}$ & 1 & 87 \\
\hline Benzeneacetic Acid & 2 & 200 & Benzeneacetic Acid & 2 & 140 \\
\hline Dodecanoic Acid & 1 & 120 & Dodecanoic Acid & 1 & 86 \\
\hline Tetradecanoic Acid & 1 & 280 & 9-Hexadecenoic Acid & 1 & 64 \\
\hline 9-Hexadecenoic Acid & 1 & 75 & Hexadecanoic Acid & 1 & 410 \\
\hline Hexadecanoic Acid & 1 & 1300 & Oxygenated Hydrocarbon & & 370 \\
\hline 9-Hexadecenoic Acid & 1 & 910 & Octadecanoic Acid & 1 & 170 \\
\hline Oxygenated Hydrocarbon & 2 & 82 & Cholestan-3-OL & 1 & 83 \\
\hline Octadecanoic Acid & 1 & 230 & Cholest-5-EN-3-OL & 1 & 47 \\
\hline Cholestan-3-OL & 1 & 130 & & & \\
\hline Cholest-5-EN-3-OL & 1 & 78 & & & \\
\hline
\end{tabular}


Appendix E. General water quality with depth and general water quality, bacteria, volatile organic compounds, semivolatile organic compounds, pesticides, PCB's, herbicides, total metals and trace elements, general inorganics, and radiochemistry by sample at ten water-quality sampling sites in the Bahía de Añasco and near Rincón, Puerto Rico, at two sites sampled in the Río Grande de Añasco and the Río Yagüez, and at the influent and effluent of the Mayagüez Regional Wastewater Treatment Plant, January 25-30, 1991—Continued

Appendix E-4. Concentrations of pesticides, PCB's, and herbicides, Mayagüez Regional Wastewater Treatment Plant, January 29, 1991 .

[Units are micrograms per liter; ND, not detected; conc., concentration; Rep. Limit, Reporting Limit. Values for surrogates represent percent recovery. Sporadic hits reported as ND unless verified in 2nd-column test.]

\begin{tabular}{|c|c|c|c|c|}
\hline \multirow{2}{*}{ Constituent } & \multicolumn{2}{|c|}{$\begin{array}{c}\text { Influent } \\
\text { Site } 18\end{array}$} & \multicolumn{2}{|c|}{$\begin{array}{l}\text { Effluent } \\
\text { Site } 11\end{array}$} \\
\hline & conc. & Rep. Limit & conc. & Rep. Limit \\
\hline \multicolumn{5}{|c|}{ Organochlorine Pesticides/PCB's } \\
\hline \multicolumn{5}{|l|}{ Method 8080} \\
\hline alpha-BHC & ND & 0.1 & ND & 0.1 \\
\hline beta-BHC & ND & 0.1 & ND & 0.1 \\
\hline delta-BHC & ND & 0.1 & ND & 0.1 \\
\hline gamma-BHC (Lindane) & ND & 0.1 & ND & 0.1 \\
\hline Toxaphene & ND & 2 & ND & 2 \\
\hline Heptachlor & ND & 0.04 & ND & 0.04 \\
\hline Aldrin & ND & 0.04 & ND & 0.04 \\
\hline Heptachlor epoxide & ND & 0.1 & ND & 0.1 \\
\hline Endosulfan I & ND & 10 & ND & 10 \\
\hline Dieldrin & ND & 0.04 & ND & 0.04 \\
\hline 4,4'-DDE & ND & 0.12 & ND & 0.12 \\
\hline Endrin & ND & 0.12 & ND & 0.12 \\
\hline Endosulfan II & ND & 0.2 & ND & 0.2 \\
\hline 4,4'-DDD & ND & 0.2 & ND & 0.2 \\
\hline Endosulfan sulfate & ND & 0.2 & ND & 0.2 \\
\hline 4,4'-DDT & ND & 0.2 & ND & 0.2 \\
\hline Endrin aldehyde & ND & 0.2 & ND & 0.2 \\
\hline Chlordane & ND & 0.1 & ND & 0.1 \\
\hline Aroclor 1016 & ND & 1 & ND & 1 \\
\hline Aroclor 1221 & ND & 1 & ND & 1 \\
\hline Aroclor 1232 & ND & 1 & ND & 1 \\
\hline Aroclor 1242 & ND & 1 & ND & 1 \\
\hline Aroclor 1248 & ND & 1 & ND & 1 \\
\hline Aroclor 1254 & ND & 2 & ND & 2 \\
\hline Aroclor 1260 & ND & 2 & ND & 2 \\
\hline Mirex & ND & 0.1 & ND & 0.1 \\
\hline Ethylan (Perthane) & ND & 1 & ND & 1 \\
\hline
\end{tabular}


Appendix E. General water quality with depth and general water quality, bacteria, volatile organic compounds, semivolatile organic compounds, pesticides, PCB's, herbicides, total metals and trace elements, general inorganics, and radiochemistry by sample at 10 water-quality sampling sites in the Bahía de Añasco and near Rincón, Puerto Rico, at two sites sampled in the Río Grande de Añasco and the Río Yagüez, and at the influent and effluent of the Mayagüez Regional Wastewater Treatment Plant, January 25-30, 1991-Continued

Appendix E-4. Concentrations of pesticides, PCB's, and herbicides, Mayagüez Regional Wastewater Treatment Plant, January 29, 1991--Continued.

[Units are micrograms per liter; ND, not detected; conc., concentration; Rep. Limit, Reporting Limit. Values for surrogates represent percent recovery. Sporadic hits reported as ND unless verified in 2nd-column test.]

\begin{tabular}{|c|c|c|c|c|}
\hline \multirow{2}{*}{ Constituent } & \multicolumn{2}{|c|}{$\begin{array}{l}\text { Influent } \\
\text { Site } 18\end{array}$} & \multicolumn{2}{|c|}{$\begin{array}{l}\text { Effluent } \\
\text { Site } 11\end{array}$} \\
\hline & conc. & Rep. Limit & conc. & Rep. Limit \\
\hline Methoxychlor & ND & 1 & ND & 1 \\
\hline Surrogate & \multicolumn{3}{|c|}{ Recovery } & \\
\hline Dibutyl chlorendate & 98 & & 120 & \\
\hline
\end{tabular}

\section{Organophosphorus Pesticides}

SW-846 List

Method 8141

\begin{tabular}{|c|c|c|c|c|}
\hline Azinphos-methyl (Guthion) & ND & 5 & ND & 5 \\
\hline Chlorpyrifos (Dursban) & ND & 0.5 & ND & 0.5 \\
\hline Coumaphos & ND & 1 & ND & 1 \\
\hline Demeton O\&S & ND & 0.5 & ND & 0.5 \\
\hline Fenthion (Baytex) & ND & 0.5 & ND & 0.5 \\
\hline Malathion & ND & 2.4 & ND & 2.4 \\
\hline Naled (Dibrom) & ND & 20 & ND & 20 \\
\hline Ethyl parathion & ND & 0.5 & ND & 0.5 \\
\hline Methyl parathion & ND & 0.5 & ND & 0.5 \\
\hline \multicolumn{5}{|l|}{ Chlorinated Herbicides } \\
\hline \multicolumn{5}{|l|}{ Method 8150} \\
\hline $2,4-\mathrm{D}$ & ND & 1.2 & ND & 1.2 \\
\hline 2,4,5-TP (Silvex) & ND & 0.17 & ND & 0.17 \\
\hline Surrogate & \multicolumn{3}{|c|}{ Recovery } & \\
\hline DCAA & 113 & & 76 & \\
\hline
\end{tabular}


Appendix E. General water quality with depth and general water quality, bacteria, volatile organic compounds, semivolatile organic compounds, pesticides, PCB's, herbicides, total metals and trace elements, general inorganics, and radiochemistry by sample at ten water-quality sampling sites in the Bahía de Añasco and near Rincón, Puerto Rico, at two sites sampled in the Río Grande de Añasco and the Río Yagüez, and at the influent and effluent of the Mayagüez Regional Wastewater Treatment Plant, January 25-30, 1991—Continued

Appendix E-5. Concentrations of total metals, Mayagüez Regional Wastewater Treatment Plant, January 29, 1991.

[Units are milligrams per liter; Abbreviation: conc., concentration; Rep. Limit, Reporting Limit; ND, not detected.]

\begin{tabular}{|c|c|c|c|c|c|}
\hline \multirow{2}{*}{ Constituent } & \multirow{2}{*}{$\begin{array}{l}\text { Analytical } \\
\text { Method }\end{array}$} & \multicolumn{2}{|c|}{ Influent } & \multicolumn{2}{|c|}{ Effluent } \\
\hline & & Conc. & Rep. Limit & Conc. & Rep. Limit \\
\hline Antimony & 7041 & ND & 0.2 & ND & 0.01 \\
\hline Beryllium & 7090 & ND & 0.5 & ND & 0.05 \\
\hline Copper & 7210 & 0.29 & 0.05 & ND & 0.05 \\
\hline Nickel & 7520 & ND & 0.1 & ND & 0.1 \\
\hline Chromium (VI) & 7196 & 0.011 & 0.01 & 0.017 & 0.01 \\
\hline Aluminum & 6010 & 1.2 & 0.1 & 0.26 & 0.1 \\
\hline Silver & 7761 & 0.011 & 0.0025 & 0.0033 & 0.001 \\
\hline Cadmium & 7131 & ND & 0.005 & ND & 0.005 \\
\hline Zinc & 7950 & 0.16 & 0.02 & 0.062 & 0.02 \\
\hline Chromium & 7191 & 0.034 & 0.01 & 0.02 & 0.006 \\
\hline Arsenic & 7060 & ND & 0.005 & ND & 0.005 \\
\hline Barium & 6010 & 0.12 & 0.01 & 0.076 & 0.01 \\
\hline Boron & 6010 & 0.14 & 0.1 & 0.13 & 0.1 \\
\hline Calcium & 6010 & 48 & 0.2 & 47.3 & 0.2 \\
\hline Iron & 6010 & 2.1 & 0.1 & 0.75 & 0.1 \\
\hline Lead & 7421 & 0.011 & 0.005 & ND & 0.005 \\
\hline Magnesium & 6010 & 19.4 & 0.2 & 19 & 0.2 \\
\hline Manganese & 6010 & 0.13 & 0.01 & 0.11 & 0.01 \\
\hline Mercury & 7470 & 0.00082 & 0.0002 & ND & 0.0002 \\
\hline Potassium & 6010 & 11.99 & 5 & 11.4 & 5 \\
\hline Selenium & 7740 & ND & 0.005 & ND & 0.005 \\
\hline Silica as $\mathrm{SiO}_{2}$ & 6010 & 20.8 & 0.5 & 23.1 & 0.5 \\
\hline Sodium & 6010 & 91.3 & 5 & 89.8 & 5 \\
\hline Strontium & 6010 & 0.28 & 0.05 & 0.26 & 0.05 \\
\hline Thallium & 7841 & ND & 0.01 & ND & 0.01 \\
\hline
\end{tabular}


Appendix E. General water quality with depth and general water quality, bacteria, volatile organic compounds, semivolatile organic compounds, pesticides, PCB's, herbicides, total metals and trace elements, general inorganics, and radiochemistry by sample at ten water-quality sampling sites in the Bahía de Añasco and near Rincón, Puerto Rico, at two sites sampled in the Río Grande de Añasco and the Río Yagüez, and at the influent and effluent of the Mayagüez Regional Wastewater Treatment Plant, January 25-30, 1991—Continued

Appendix E-6. General inorganics and radiochemistry, Mayagüez Regional Wastewater Treatment Plant, January 29, 1991.

[Units are in mg/L, milligrams per liter. Abbreviations: conc., concentration; Rep. Limit, Reporting Limit; NTU, nephelometric turbidity units; pCi/L, picocuries per liter; ND, not detected.]

\begin{tabular}{|c|c|c|c|c|c|c|}
\hline \multirow{2}{*}{ Constituent } & \multirow{2}{*}{$\begin{array}{c}\text { Analytical } \\
\text { method }\end{array}$} & \multirow[b]{2}{*}{ units } & \multicolumn{2}{|c|}{ Influent } & \multicolumn{2}{|c|}{ Effluent } \\
\hline & & & conc. & Rep. Limit & conc. & Rep. Limit \\
\hline \multicolumn{7}{|l|}{ General Inorganics } \\
\hline Chloride & A 429 & $\mathrm{mg} / \mathrm{L}$ & 112 & 3 & 137 & 3 \\
\hline Cyanide & 9012 & $\mathrm{mg} / \mathrm{L}$ & ND & 0.01 & ND & 0.01 \\
\hline Color & 110.2 & units & NR & & - & - \\
\hline Fluoride & A429 & $\mathrm{mg} / \mathrm{L}$ & 5.4 & 0.1 & 9.7 & 0.1 \\
\hline Surfactants (MBAS) & 425.1 & $\mathrm{mg} / \mathrm{L}$ & 1.1 & 0.1 & 2 & 0.2 \\
\hline Ammonia as $\mathrm{N}$ & 350.1 & $\mathrm{mg} / \mathrm{L}$ & 20.9 & 1 & 20.6 & 1 \\
\hline Nitrate plus Nitrite & 353.2 & $\mathrm{mg} / \mathrm{L}$ & ND & 0.1 & ND & 0.1 \\
\hline Orthophosphate as $\mathrm{P}$ & 365.3 & $\mathrm{mg} / \mathrm{L}$ & 4.4 & 0.5 & 5.3 & 0.5 \\
\hline Phenolics & 9065 & $\mathrm{mg} / \mathrm{L}$ & ND & 0.01 & 0.058 & 0.01 \\
\hline Sulfide, Total & 376.2 & $\mathrm{mg} / \mathrm{L}$ & 6.2 & 0.5 & 0.84 & 0.25 \\
\hline Sulfate & A 429 & $\mathrm{mg} / \mathrm{L}$ & 18.8 & 0.5 & 16.8 & 0.5 \\
\hline Total Kjeldahl Nitrogen as $\mathrm{N}$ & 351.2 & $\mathrm{mg} / \mathrm{L}$ & 49.9 & 5 & 34.2 & 5 \\
\hline Phosphorus, Total as $\mathrm{P}$ & 365.3 & $\mathrm{mg} / \mathrm{L}$ & 7.9 & 1 & 6.1 & 0.5 \\
\hline Turbidity & 180.1 & NTU & 185 & 0.5 & 50 & 0.1 \\
\hline Total Dissolved Solids & 160.1 & $\mathrm{mg} / \mathrm{L}$ & 532 & 20 & 615 & 50 \\
\hline Total Suspended Solids & 160.2 & $\mathrm{mg} / \mathrm{L}$ & 266 & 10 & 57 & 2.5 \\
\hline Total Volatile Solids & 160.4 & $\mathrm{mg} / \mathrm{L}$ & 300 & 10 & 205 & 10 \\
\hline Volatile Suspended Solids & 160.4 & $\mathrm{mg} / \mathrm{L}$ & 194 & 50 & 49.5 & 12.5 \\
\hline \multicolumn{7}{|l|}{ Radiochemistry } \\
\hline & & & & $(+/-)$ & & $(+/-)$ \\
\hline Gross Alpha & 900 & $\mathrm{pCi} / \mathrm{L}$ & 0 & 2.3 & 1.1 & 2.7 \\
\hline Gross Beta & 900 & $\mathrm{pCi} / \mathrm{L}$ & 11 & 5 & 14 & 5 \\
\hline Radium 226 & 705 Mod. & $\mathrm{pCi} / \mathrm{L}$ & 0 & 0.5 & 0 & 0.5 \\
\hline Strontium 90 & A704 & $\mathrm{pCi} / \mathrm{L}$ & 0 & 0.7 & 0 & 0.7 \\
\hline
\end{tabular}


Appendix E. General water quality with depth and general water quality, bacteria, volatile organic compounds, semivolatile organic compounds, pesticides, PCB's, herbicides, total metals and trace elements, general inorganics, and radiochemistry by sample at ten water-quality sampling sites in the Bahía de Añasco and near Rincón, Puerto Rico, at two sites sampled in the Río Grande de Añasco and the Río Yagüez, and at the influent and effluent of the Mayagüez Regional Wastewater Treatment Plant, January 25-30, 1991-Continued

Appendix E-7. General water quality, Mayagüez Regional Wastewater Treatment Plant, January 29, 1991.

[Units and abbreviations are $\mathrm{mg} / \mathrm{L}$, milligrams per liter; ${ }^{\circ} \mathrm{C}$, degrees Celsius; $\mathrm{k}$, extinction coefficient; dil/count, dilution (per $100 \mathrm{ml}$ ) and number of bacteria colonies counted using the filter membrane method; col/100ml, colonies of bacteria per 100 milliliters; TNTC, too numerous to count; $\mu \mathrm{S} / \mathrm{cm}$, microsiemens per centimeter; $\mathrm{mg} / \mathrm{m}^{3}$, milligram per cubic meter; Mgal/d, million gallons per day; NA, not applicable; NR, not reported]

\begin{tabular}{|c|c|c|c|c|c|}
\hline Constituent & units & & Influent & & ient \\
\hline BOD-5 & $\mathrm{mg} / \mathrm{L}$ & & 390 & & 170 \\
\hline Oil and Grease & $\mathrm{mg} / \mathrm{L}$ & & NR & & NR \\
\hline Settleable Solids & $\mathrm{mg} / \mathrm{L}$ & & 3.3 & & 0 \\
\hline Water Temperature & ${ }^{\circ} \mathrm{C}$ & & 26 & & NR \\
\hline Alkalinity & $\mathrm{mg} / \mathrm{L}$ & & NR & & NR \\
\hline Spec. Cond. & $\mu \mathrm{S} / \mathrm{cm}$ & & NR & & NR \\
\hline $\mathrm{pH}$ & units & & 6.9 & & 7 \\
\hline Dissolved Oxygen & $\mathrm{mg} / \mathrm{L}$ & & NR & & NR \\
\hline Extinction Coefficient & $\mathrm{k}$ & & NA & & NA \\
\hline Chlorophyll-a & $\mathrm{mg} / \mathrm{m}^{3}$ & & 0.6081 & & 1.3268 \\
\hline Discharge & $\mathrm{Mgal} / \mathrm{d}$ & & 7.2 & & 7.2 \\
\hline Bacteria & & vol. filt. & count & vol. filt. & count \\
\hline Fecal Coli(dil/count) & & 0.1 & TNTC & 1 & 60 \\
\hline Fecal Coli(dil/count) & & 0.01 & TNTC & 0.1 & 18 \\
\hline \multirow[t]{2}{*}{ Fecal Coli(dil/count) } & & 0.001 & TNTC & 0.01 & 0 \\
\hline & cols $/ 100 \mathrm{~mL}$ & & $b>6000000$ & & 6000 \\
\hline Total Coli(dil/count) & & 0.1 & TNTC & 1 & TNTC \\
\hline Total Coli(dil/count) & & 0.01 & TNTC & 0.1 & 29 \\
\hline \multirow[t]{2}{*}{ Total Coli(dil/count) } & & 0.001 & TNTC & 0.01 & 2 \\
\hline & cols $/ 100 \mathrm{~mL}$ & & $b>8000000$ & & 29000 \\
\hline Enterococcus(dil/count) & & 1 & TNTC & 1 & 11 \\
\hline Enterococcus(dil/count) & & 0.01 & TNTC & 0.1 & 0 \\
\hline \multirow[t]{2}{*}{ Enterococcus(dil/count) } & & 0.001 & 204 & 0.01 & 0 \\
\hline & cols $/ 100 \mathrm{~mL}$ & & $b>20000000$ & & b-1100 \\
\hline
\end{tabular}


Appendix E. General water quality with depth and general water quality, bacteria, volatile organic compounds, semivolatile organic compounds, pesticides, PCB's, herbicides, total metals and trace elements, general inorganics, and radiochemistry by sample at ten water-quality sampling sites in the Bahía de Añasco and near Rincón, Puerto Rico, at two sites sampled in the Río Grande de Añasco and the Río Yagüez, and at the influent and effluent of the Mayagüez Regional Wastewater Treatment Plant, January 25-30, 1991-Continued

Appendix E-8. Volatile organic compounds, Río Grande de Añasco and Río Yagüez.

[Method 624. Units are micrograms per liter. Abbreviations: Repl., replicate sample; Rep. Limit, Reporting limit; ND, not detected. Values for surrogates represent percent recovery. Sample dates: QW-Ya1, 1/28/91; QW-An1, 1/29/91; QW-An2, 1/31/91.]

\begin{tabular}{|c|c|c|c|c|c|c|c|c|}
\hline \multirow[b]{2}{*}{ Constituent } & \multicolumn{2}{|c|}{ QW-An1 } & \multicolumn{2}{|c|}{ QW-An1 (Repl.) } & \multicolumn{2}{|c|}{ oW-An2 } & \multicolumn{2}{|c|}{ QW-Ya1 } \\
\hline & conc. & $\begin{array}{l}\text { Rep. } \\
\text { Limit }\end{array}$ & conc. & $\begin{array}{l}\text { Rep. } \\
\text { Limit }\end{array}$ & conc. & $\begin{array}{l}\text { Rep. } \\
\text { Limit }\end{array}$ & conc. & $\begin{array}{l}\text { Rep. } \\
\text { Limit }\end{array}$ \\
\hline Acrolein & ND & 100 & ND & 100 & ND & 100 & ND & 100 \\
\hline Acrylonitrile & ND & 100 & ND & 100 & ND & 100 & ND & 100 \\
\hline Benzene & ND & 5 & ND & 5 & ND & 5 & ND & 5 \\
\hline Bromodichloromethane & ND & 5 & ND & 5 & ND & 5 & ND & 5 \\
\hline Bromoform & ND & 5 & ND & 5 & ND & 5 & ND & 5 \\
\hline Bromomethane & ND & 10 & ND & 10 & ND & 10 & ND & 10 \\
\hline Carbon tetrachloride & ND & 5 & ND & 5 & ND & 5 & ND & 5 \\
\hline Chlorobenzene & ND & 5 & ND & 5 & ND & 5 & ND & 5 \\
\hline Chloroethane & ND & 10 & ND & 10 & ND & 10 & ND & 10 \\
\hline Chloroform & ND & 5 & ND & 5 & ND & 5 & ND & 5 \\
\hline Chloromethane & ND & 10 & ND & 10 & ND & 10 & ND & 10 \\
\hline Dibromochloromethane & ND & 5 & ND & 5 & ND & 5 & ND & 5 \\
\hline 1,1-Dichloroethane & ND & 5 & ND & 5 & ND & 5 & ND & 5 \\
\hline 1,2-Dichloroethane & ND & 5 & ND & 5 & ND & 5 & ND & 5 \\
\hline 1,1-Dichloroethene & ND & 5 & ND & 5 & ND & 5 & ND & 5 \\
\hline 1,2-Dichloroethene (total) & ND & 5 & ND & 5 & ND & 5 & ND & 5 \\
\hline 1,2-Dichloropropane & ND & 5 & ND & 5 & ND & 5 & ND & 5 \\
\hline cis-1,3-Dichloropropene & ND & 5 & ND & 5 & ND & 5 & $\mathrm{ND}$ & 5 \\
\hline trans-1,3-Dichloropropene & ND & 5 & ND & 5 & ND & 5 & ND & 5 \\
\hline Ethylbenzene & ND & 5 & ND & 5 & ND & 5 & ND & 5 \\
\hline Methylene chloride & ND & 5 & ND & 5 & ND & 5 & ND & 5 \\
\hline 1,1,2,2-Tetrachloroethane & ND & 5 & ND & 5 & ND & 5 & ND & 5 \\
\hline Tetrachloroethene & ND & 5 & ND & 5 & ND & 5 & $\mathrm{ND}$ & 5 \\
\hline Toluene & ND & 5 & ND & 5 & ND & 5 & ND & 5 \\
\hline 1,1,1-Trichloroethane & ND & 5 & ND & 5 & ND & 5 & ND & 5 \\
\hline 1,1,2-Trichloroethane & ND & 5 & ND & 5 & ND & 5 & ND & 5 \\
\hline Trichloroethene & ND & 5 & ND & 5 & ND & 5 & ND & 5 \\
\hline Vinyl chloride & ND & 10 & ND & 10 & ND & 10 & $\mathrm{ND}$ & 10 \\
\hline Surrogate & & & & & & & & \\
\hline Toluene-d8 & 100 & & 102 & & 101 & & 101 & \\
\hline 4-Bromofluorobenzene & 99 & & 104 & & 93 & & 101 & \\
\hline 1,2-Dichloroethane-d4 & 103 & & 90 & & 108 & & 103 & \\
\hline
\end{tabular}


Appendix E. General water quality with depth and general water quality, bacteria, volatile organic compounds, semivolatile organic compounds, pesticides, PCB's, herbicides, total metals and trace elements, general inorganics, and radiochemistry by sample at ten water-quality sampling sites in the Bahía de Añasco and near Rincón, Puerto Rico, at two sites sampled in the Río Grande de Añasco and the Río Yagüez, and at the influent and effluent of the Mayagüez Regional Wastewater Treatment Plant, January 25-30, 1991—Continued

Appendix E-9. Semivolatile organic compounds, Río Grande de Añasco and Río Yagüez .

[Method 625. Units are micrograms per liter. Abbreviations: Repl., replicate; Rep. Limit, reporting limit; ND, not detected; conc., concentration; conf. level, confidence level. Values for surrogates represent percent recovery. All tentatively identified compounds were found in the base neutral acids. Confidence levels for the tentatively identified compounds: 1- tentative; 2-confident; and 3-confirmed. Sampling dates: QW-Ya1, 1/28/91; QW-An1, 1/29/91; QW-An2, $1 / 31 / 91$.

\begin{tabular}{|c|c|c|c|c|c|c|c|c|}
\hline \multirow[b]{2}{*}{ Constituent } & \multicolumn{2}{|c|}{ QW-An1 } & \multicolumn{2}{|c|}{ QW-An1 (Repl.) } & \multicolumn{2}{|c|}{ QW-An2 } & \multicolumn{2}{|c|}{ oW-Ya1 } \\
\hline & conc. & $\begin{array}{l}\text { Rep. } \\
\text { Limit }\end{array}$ & conc. & Rep. Limit & conc. & $\begin{array}{l}\text { Rep. } \\
\text { Limit }\end{array}$ & conc. & $\begin{array}{l}\text { Rep. } \\
\text { Limit }\end{array}$ \\
\hline Acenaphthene & ND & 10 & ND & 10 & ND & 10 & ND & 10 \\
\hline Acenaphthylene & ND & 10 & ND & 10 & ND & 10 & ND & 10 \\
\hline Anthracene & $\mathrm{ND}$ & 10 & ND & 10 & ND & 10 & ND & 10 \\
\hline Benzidine & $\mathrm{ND}$ & 100 & ND & 100 & ND & 100 & ND & 100 \\
\hline Benzo a-anthracene & ND & 10 & ND & 10 & ND & 10 & ND & 10 \\
\hline Benzo $b$ fluoranthene & $\mathrm{ND}$ & 10 & ND & 10 & ND & 10 & ND & 10 \\
\hline Benzo k fluoranthene & ND & 10 & ND & 10 & ND & 10 & ND & 10 \\
\hline Benzo (g,h,i)perylene & ND & 10 & ND & 10 & ND & 10 & ND & 10 \\
\hline Benzo (a)pyrene & ND & 10 & ND & 10 & ND & 10 & ND & 10 \\
\hline 4-Bromophenyl phenyl ether & ND & 10 & ND & 10 & ND & 10 & ND & 10 \\
\hline Butyl benzyl phthalate & ND & 10 & ND & 10 & ND & 10 & ND & 10 \\
\hline bis(2-Chloroethoxy)-methane & ND & 10 & ND & 10 & ND & 10 & ND & 10 \\
\hline bis(2-Chloroethyl) ether & ND & 10 & ND & 10 & ND & 10 & ND & 10 \\
\hline bis(2-Chloroisopropyl)-ether & ND & 10 & ND & 10 & ND & 10 & ND & 10 \\
\hline 4-Chloro-3-methylphenol & ND & 10 & ND & 10 & ND & 10 & ND & 10 \\
\hline 2-Chloronaphthalene & ND & 10 & ND & 10 & ND & 10 & ND & 10 \\
\hline 2-Chlorophenol & ND & 10 & ND & 10 & ND & 10 & ND & 10 \\
\hline 4-Chlorophenyl phenyl ether & ND & 10 & ND & 10 & ND & 10 & ND & 10 \\
\hline Chrysene & ND & 10 & ND & 10 & ND & 10 & ND & 10 \\
\hline $\operatorname{Dibenz}(\mathrm{a}, \mathrm{h})$ anthracene & ND & 10 & ND & 10 & ND & 10 & ND & 10 \\
\hline Di-n-butyl phthalate & ND & 10 & ND & 10 & ND & 10 & ND & 10 \\
\hline 1,2-Dichlorobenzene & ND & 10 & ND & 10 & ND & 10 & ND & 10 \\
\hline 1,3-Dichlorobenzene & ND & 10 & ND & 10 & ND & 10 & ND & 10 \\
\hline 1,4-Dichlorobenzene & ND & 10 & ND & 10 & ND & 10 & ND & 10 \\
\hline 3,3'-Dichlorobenzidine & ND & 20 & ND & 20 & ND & 20 & ND & 20 \\
\hline 2,4-Dichlorophenol & ND & 10 & ND & 10 & ND & 10 & ND & 10 \\
\hline Diethyl phthalate & ND & 10 & ND & 10 & ND & 10 & ND & 10 \\
\hline 2,4-DimethylPhenol & ND & 10 & ND & 10 & ND & 10 & ND & 10 \\
\hline
\end{tabular}


Appendix E. General water quality with depth and general water quality, bacteria, volatile organic compounds,

semivolatile organic compounds, pesticides, PCB's, herbicides, total metals and trace elements, general inorganics, and radiochemistry by sample at 10 water-quality sampling sites in the Bahía de Añasco and near Rincón, Puerto Rico, at two sites sampled in the Río Grande de Añasco and the Río Yagüez, and at the influent and effluent of the Mayagüez Regional Wastewater Treatment Plant, January 25-30, 1991-Continued

Appendix E-9. Semivolatile organic compounds, Río Grande de Añasco and Río Yagüez--Continued.

[Method 625. Units are micrograms per liter. Abbreviations: Repl., replicate; Rep. Limit, reporting limit; ND, not detected; conc., concentration; conf. level, confidence level. Values for surrogates represent percent recovery. All tentatively identified compounds were found in the base neutral acids. Confidence levels for the tentatively identified compounds: 1- tentative; 2-confident; and 3-confirmed. Sampling dates: QW-Ya1, 1/28/91; QW-An1, 1/29/91; QW-An2, 1/31/91.]

\begin{tabular}{|c|c|c|c|c|c|c|c|c|}
\hline \multirow[b]{2}{*}{ Constituent } & \multicolumn{2}{|c|}{ QW-An1 } & \multicolumn{2}{|c|}{ QW-An1 (Repl.) } & \multicolumn{2}{|c|}{ oW-An2 } & \multicolumn{2}{|c|}{ oW-Ya1 } \\
\hline & conc. & $\begin{array}{l}\text { Rep. } \\
\text { Limit }\end{array}$ & conc. & Rep. Limit & conc. & $\begin{array}{l}\text { Rep. } \\
\text { Limit }\end{array}$ & conc. & $\begin{array}{l}\text { Rep. } \\
\text { Limit }\end{array}$ \\
\hline Dimethyl phthalate & ND & 10 & ND & 10 & ND & 10 & ND & 10 \\
\hline 4,6-Dinitro-2-methylphenol & ND & 50 & ND & 50 & ND & 50 & ND & 50 \\
\hline 2,4-Dinitrophenol & ND & 50 & ND & 50 & ND & 50 & ND & 50 \\
\hline 2,4-Dinitrotoluene & ND & 10 & ND & 10 & ND & 10 & ND & 10 \\
\hline 2,6-Dinitrotoluene & $\mathrm{ND}$ & 10 & ND & 10 & ND & 10 & ND & 10 \\
\hline Di-n-octylphthalate & ND & 10 & ND & 10 & ND & 10 & ND & 10 \\
\hline 1,2-Diphenylhydrazine & ND & 10 & ND & 10 & ND & 10 & ND & 10 \\
\hline bis(2-Ethylhexyl)phthalate & $\mathrm{ND}$ & 10 & ND & 10 & ND & 10 & ND & 10 \\
\hline Fluoranthene & $\mathrm{ND}$ & 10 & ND & 10 & ND & 10 & ND & 10 \\
\hline Fluorene & ND & 10 & ND & 10 & ND & 10 & ND & 10 \\
\hline Hexachlorobenzene & ND & 10 & ND & 10 & ND & 10 & ND & 10 \\
\hline Hexachlorobutadiene & ND & 10 & ND & 10 & ND & 10 & ND & 10 \\
\hline Hexachlorocyclopentadiene & ND & 10 & ND & 10 & ND & 10 & ND & 10 \\
\hline Hexachloroethane & ND & 10 & ND & 10 & ND & 10 & ND & 10 \\
\hline Indeno(1,2,3-cd)pyrene & ND & 10 & ND & 10 & ND & 10 & ND & 10 \\
\hline Isophorone & ND & 10 & ND & 10 & ND & 10 & ND & 10 \\
\hline Naphthalene & ND & 10 & ND & 10 & ND & 10 & ND & 10 \\
\hline Nitrobenzene & ND & 10 & ND & 10 & ND & 10 & ND & 10 \\
\hline 2-Nitrophenol & ND & 10 & ND & 10 & ND & 10 & ND & 10 \\
\hline 4-Nitrophenol & ND & 50 & ND & 50 & ND & 50 & ND & 50 \\
\hline N-Nitrosodimethylamine & ND & 10 & ND & 10 & ND & 10 & ND & 10 \\
\hline N-Nitrosodiphenylamine & ND & 10 & ND & 10 & ND & 10 & ND & 10 \\
\hline N-Nitroso-di-n-Propylamine & ND & 10 & ND & 10 & ND & 10 & ND & 10 \\
\hline Pentachlorophenol & ND & 50 & ND & 50 & ND & 50 & ND & 50 \\
\hline Phenanthrene & ND & 10 & ND & 10 & ND & 10 & ND & 10 \\
\hline Phenol & ND & 10 & ND & 10 & ND & 10 & ND & 10 \\
\hline Pyrene & ND & 10 & ND & 10 & ND & 10 & ND & 10 \\
\hline 1,2,4-Trichlorobenzene & ND & 10 & ND & 10 & ND & 10 & ND & 10 \\
\hline
\end{tabular}


Appendix E. General water quality with depth and general water quality, bacteria, volatile organic compounds, semivolatile organic compounds, pesticides, PCB's, herbicides, total metals and trace elements, general inorganics, and radiochemistry by sample at 10 water-quality sampling sites in the Bahía de Añasco and near Rincón, Puerto Rico, at two sites sampled in the Río Grande de Añasco and the Río Yagüez, and at the influent and effluent of the Mayagüez Regional Wastewater Treatment Plant, January 25-30, 1991-Continued

Appendix E-9. Semivolatile organic compounds, Río Grande de Añasco and Río Yagüez--Continued.

[Method 625. Units are micrograms per liter. Abbreviations: Repl., replicate; Rep. Limit, reporting limit; ND, not detected; conc., concentration; conf. level, confidence level. Values for surrogates represent percent recovery. All tentatively identified compounds were found in the base neutral acids. Confidence levels for the tentatively identified compounds: 1- tentative; 2-confident; and 3-confirmed. Sampling dates: QW-Ya1, 1/28/91; QW-An1, 1/29/91; QW-An2, $1 / 31 / 91$.

\begin{tabular}{|c|c|c|c|c|c|c|c|c|}
\hline \multirow[b]{2}{*}{ Constituent } & \multicolumn{2}{|c|}{ QW-An1 } & \multicolumn{2}{|c|}{ QW-An1 (Repl.) } & \multicolumn{2}{|c|}{ QW-An2 } & \multicolumn{2}{|c|}{ QW-Ya1 } \\
\hline & conc. & $\begin{array}{l}\text { Rep. } \\
\text { Limit }\end{array}$ & conc. & Rep. Limit & conc. & $\begin{array}{l}\text { Rep. } \\
\text { Limit }\end{array}$ & conc. & $\begin{array}{l}\text { Rep. } \\
\text { Limit }\end{array}$ \\
\hline 2,4,6-Trichlorophenol & ND & 10 & ND & 10 & ND & 10 & ND & 10 \\
\hline Surrogate & \multicolumn{8}{|c|}{ Recovery } \\
\hline Nitrobenzene-d5 & 80 & & 91 & & 70 & & 84 & \\
\hline 2-Fluorobiphenyl & 73 & & 85 & & 64 & & 68 & \\
\hline Terphenyl-dl4 & 96 & & 118 & & 87 & & 74 & \\
\hline Phenol-d5 & 76 & & 85 & & 64 & & 81 & \\
\hline 2-Fluorophenol & 77 & & 86 & & 66 & & 76 & \\
\hline \multirow[t]{5}{*}{ 2,4,6-Tribromophenol } & 90 & & 108 & & 88 & & 84 & \\
\hline & \multicolumn{6}{|c|}{ Tentatively identified compounds } & & \\
\hline & Site & & Constit & & $\begin{array}{l}\text { conf. } \\
\text { level }\end{array}$ & conc. & & \\
\hline & QW-A & & Oxygena & Hydrocarbon & NR & 24 & & \\
\hline & QW-Y & & Cyclope & ne, Ethyl- & 2 & 12 & & \\
\hline
\end{tabular}


Appendix E. General water quality with depth and general water quality, bacteria, volatile organic compounds, semivolatile organic compounds, pesticides, PCB's, herbicides, total metals and trace elements, general inorganics, and radiochemistry by sample at ten water-quality sampling sites in the Bahía de Añasco and near Rincón, Puerto Rico, at two sites sampled in the Río Grande de Añasco and the Río Yagüez, and at the influent and effluent of the Mayagüez Regional Wastewater Treatment Plant, January 25-30, 1991—Continued

Appendix E-10. Concentrations of pesticides, PCB's, and herbicides, Río Grande de Añasco and Río Yagüez.

[Units are micrograms per liter; Repl., replicate; Rep. Limit, reporting limit; conc., concentration; ND, not detected. Values for surrogates represent percent recovery. Sporadic hits reported as ND unless verified in 2nd-column test. Sampling date: QW-Ya1, 1/28/91; QW-An1, 1/29/91; QW-An2, 1/31/91.]

\begin{tabular}{|c|c|c|c|c|c|c|c|c|}
\hline \multirow[b]{2}{*}{ Constituent } & \multicolumn{2}{|c|}{ OW-An1 } & \multicolumn{2}{|c|}{ OW-An1 (Repl.) } & \multicolumn{2}{|c|}{ QW-An2 } & \multicolumn{2}{|c|}{ QW-Ya1 } \\
\hline & conc. & $\begin{array}{l}\text { Rep. } \\
\text { Limit }\end{array}$ & conc. & $\begin{array}{l}\text { Rep. } \\
\text { Limit }\end{array}$ & conc. & $\begin{array}{l}\text { Rep. } \\
\text { Limit }\end{array}$ & conc. & $\begin{array}{l}\text { Rep. } \\
\text { Limit }\end{array}$ \\
\hline \multicolumn{9}{|c|}{ Organochlorine Pesticides/PCB's } \\
\hline \multicolumn{9}{|l|}{ Method 8080} \\
\hline alpha-BHC & ND & 0.05 & ND & 0.05 & ND & 0.05 & ND & 0.05 \\
\hline beta-BHC & ND & 0.05 & ND & 0.05 & ND & 0.05 & ND & 0.05 \\
\hline delta-BHC & ND & 0.05 & ND & 0.05 & ND & 0.05 & ND & 0.05 \\
\hline gamma-BHC (Lindane) & ND & 0.05 & ND & 1 & ND & 0.05 & ND & 0.05 \\
\hline Toxaphene & ND & 1 & ND & 0.05 & ND & 1 & ND & 1 \\
\hline Heptachlor & ND & 0.02 & ND & 0.02 & ND & 0.02 & ND & 0.02 \\
\hline Aldrin & ND & 0.05 & ND & 0.05 & ND & 0.05 & ND & 0.05 \\
\hline Heptachlor epoxide & ND & 0.05 & ND & 0.05 & ND & 0.05 & ND & 0.05 \\
\hline Endosulfan I & ND & 0.05 & ND & 0.05 & ND & 0.05 & ND & 0.05 \\
\hline Dieldrin & ND & 0.02 & ND & 0.02 & ND & 0.02 & ND & 0.02 \\
\hline 4,4'-DDE & ND & 0.1 & ND & 0.1 & ND & 0.1 & ND & 0.1 \\
\hline Endrin & ND & 0.06 & ND & 0.06 & ND & 0.06 & ND & 0.06 \\
\hline Endosulfan II & ND & 0.1 & ND & 0.1 & ND & 0.1 & ND & 0.1 \\
\hline 4,4'-DDD & ND & 0.1 & ND & 0.1 & ND & 0.1 & ND & 0.1 \\
\hline Endosulfan sulfate & ND & 0.1 & ND & 0.1 & ND & 0.1 & ND & 0.1 \\
\hline 4,4'-DDT & ND & 0.1 & ND & 0.1 & ND & 0.1 & ND & 0.1 \\
\hline Endrin aldehyde & ND & 0.1 & ND & 0.1 & ND & 0.1 & ND & 0.1 \\
\hline Chlordane & ND & 0.05 & ND & 0.05 & ND & 0.05 & ND & 0.05 \\
\hline Aroclor 1016 & ND & 0.5 & ND & 0.5 & ND & 0.5 & ND & 0.5 \\
\hline Aroclor 1221 & ND & 0.5 & ND & 0.5 & ND & 0.5 & ND & 0.5 \\
\hline Aroclor 1232 & ND & 0.5 & ND & 0.5 & ND & 0.5 & ND & 0.5 \\
\hline Aroclor 1242 & ND & 0.5 & ND & 0.5 & ND & 0.5 & ND & 0.5 \\
\hline Aroclor 1248 & ND & 0.5 & ND & 0.5 & ND & 0.5 & ND & 0.5 \\
\hline Aroclor 1254 & ND & 1 & ND & 1 & ND & 1 & ND & 1 \\
\hline Aroclor 1260 & ND & 1 & ND & 1 & ND & 1 & ND & 1 \\
\hline Mirex & ND & 0.05 & ND & 0.05 & ND & 0.05 & ND & 0.05 \\
\hline Ethylan (Perthane) & ND & 0.5 & ND & 0.5 & ND & 0.5 & ND & 0.5 \\
\hline
\end{tabular}


Appendix E. General water quality with depth and general water quality, bacteria, volatile organic compounds, semivolatile organic compounds, pesticides, PCB's, herbicides, total metals and trace elements, general inorganics, and radiochemistry by sample at 10 water-quality sampling sites in the Bahía de Añasco and near Rincón, Puerto Rico, at two sites sampled in the Río Grande de Añasco and the Río Yagüez, and at the influent and effluent of the Mayagüez Regional Wastewater Treatment Plant, January 25-30, 1991—Continued

Appendix E-10. Concentrations of pesticides, PCB's, and herbicides, Río Grande de Añasco and Río Yagüez--Continued.

[Units are micrograms per liter; Repl., replicate; Rep. Limit, reporting limit; conc., concentration; ND, not detected. Values for surrogates represent percent recovery. Sporadic hits reported as ND unless verified in 2nd-column test. Sampling date: QW-Ya1, 1/28/91; QW-An1, 1/29/91; QW-An2, 1/31/91.]

\begin{tabular}{|c|c|c|c|c|c|c|c|c|}
\hline \multirow[b]{2}{*}{ Constituent } & \multicolumn{2}{|c|}{ OW-An1 } & \multicolumn{2}{|c|}{ OW-An1 (Repl.) } & \multicolumn{2}{|c|}{ OW-An2 } & \multicolumn{2}{|c|}{ OW-Ya1 } \\
\hline & conc. & $\begin{array}{l}\text { Rep. } \\
\text { Limit }\end{array}$ & conc. & $\begin{array}{l}\text { Rep. } \\
\text { Limit }\end{array}$ & conc. & $\begin{array}{l}\text { Rep. } \\
\text { Limit }\end{array}$ & conc. & $\begin{array}{l}\text { Rep. } \\
\text { Limit }\end{array}$ \\
\hline Methoxychlor & ND & 0.5 & ND & 0.5 & ND & 0.5 & ND & 0.5 \\
\hline Surrogate & \multicolumn{8}{|c|}{ Recovery } \\
\hline Dibutyl chlorendate & 112 & & 107 & & 102 & & 103 & \\
\hline \multicolumn{9}{|c|}{ Organophosphorus Pesticides } \\
\hline \multicolumn{9}{|l|}{ SW-846 List } \\
\hline \multicolumn{9}{|l|}{ Method 8141} \\
\hline Azinphos-methyl (Guthion) & ND & 2.5 & ND & 2.5 & ND & 2.5 & ND & 2.5 \\
\hline Chlorpyrifos (Dursban) & ND & 0.25 & ND & 0.25 & ND & 0.25 & ND & 0.25 \\
\hline Coumaphos & ND & 0.5 & ND & 0.5 & ND & 0.5 & ND & 0.5 \\
\hline Demeton O\&S & ND & 0.25 & ND & 0.25 & ND & 0.25 & ND & 0.25 \\
\hline Fenthion (Baytex) & ND & 0.25 & ND & 0.25 & ND & 0.25 & ND & 0.25 \\
\hline Malathion & ND & 1.2 & ND & 1.2 & ND & 1.2 & ND & 1.2 \\
\hline Naled (Dibrom) & ND & 10 & ND & 10 & ND & 10 & ND & 10 \\
\hline Ethyl parathion & ND & 0.25 & ND & 0.25 & ND & 0.25 & ND & 0.25 \\
\hline Methyl parathion & ND & 0.25 & ND & 0.25 & ND & 0.25 & ND & 0.25 \\
\hline
\end{tabular}

\section{Chlorinated Herbicides}

\section{Method 8150}

\begin{tabular}{|c|c|c|c|c|c|c|c|c|}
\hline $2,4-\mathrm{D}$ & $\mathrm{ND}$ & 1.2 & ND & 1.2 & ND & 1.2 & ND & 1.2 \\
\hline 2,4,5-TP (Silvex) & ND & 0.17 & ND & 0.17 & ND & 0.17 & ND & 0.17 \\
\hline Surrogate & & & & Recove & & & & \\
\hline DCAA & 90 & & 110 & & 114 & & 112 & \\
\hline
\end{tabular}


Appendix E. General water quality with depth and general water quality, bacteria, volatile organic compounds, semivolatile organic compounds, pesticides, PCB's, herbicides, total metals and trace elements, general inorganics, and radiochemistry by sample at ten water-quality sampling sites in the Bahía de Añasco and near Rincón, Puerto Rico, at two sites sampled in the Río Grande de Añasco and the Río Yagüez, and at the influent and effluent of the Mayagüez Regional Wastewater Treatment Plant, January 25-30, 1991—Continued

Appendix E-11. Concentrations of total metals, Río Grande de Añasco and Río Yagüez.

[Units are milligrams per liter. Abbreviations, Repl., replicate; conc., concentration; Rep. Limit, reporting limit; NA, not applicable. Sampling dates: QW-Ya1, 1/28/91; QW-An1, 1/29/91; QW-An2, 1/31/91.]

\begin{tabular}{|c|c|c|c|c|c|c|c|c|c|}
\hline \multirow{2}{*}{ Constituent } & \multirow{2}{*}{$\begin{array}{l}\text { Analytical } \\
\text { method }\end{array}$} & \multicolumn{2}{|c|}{ QW-An1 } & \multicolumn{2}{|c|}{ OW-An1 (Repl.) } & \multicolumn{2}{|c|}{ oW-An2 } & \multicolumn{2}{|c|}{ QW-Ya1 } \\
\hline & & conc. & Rep. Limit & conc. & Rep. Limit & conc. & $\begin{array}{l}\text { Rep. } \\
\text { Limit }\end{array}$ & conc. & $\begin{array}{l}\text { Rep. } \\
\text { Limit }\end{array}$ \\
\hline Antimony & 7041 & ND & 0.02 & ND & 0.02 & ND & 0.02 & ND & 0.02 \\
\hline Beryllium & 7090 & ND & 0.05 & ND & 0.05 & ND & 0.05 & ND & 0.05 \\
\hline Copper & 7210 & ND & 0.05 & ND & 0.05 & ND & 0.05 & ND & 0.05 \\
\hline Nickel & 7520 & ND & 0.1 & ND & 0.1 & ND & 0.1 & ND & 0.1 \\
\hline Chromium (VI) & 7196 & ND & 0.01 & ND & 0.01 & ND & 0.01 & ND & 0.01 \\
\hline Aluminum & 6010 & 0.58 & 0.1 & 0.88 & 0.1 & 0.19 & 0.1 & 0.31 & 0.1 \\
\hline Silver & 7761 & ND & 0.0005 & ND & 0.0005 & ND & 0.001 & ND & 0.0005 \\
\hline Cadmium & 7131 & ND & 0.001 & 0.00053 & 0.0005 & 0.0027 & 0.0025 & 0.00084 & 0.0005 \\
\hline Zinc & 7950 & ND & 0.02 & ND & 0.02 & ND & 0.02 & ND & 0.02 \\
\hline Chromium & 7191 & 0.018 & 0.0061 & 0.017 & 0.01 & 0.016 & 0.01 & 0.0096 & 0.005 \\
\hline Arsenic & 7060 & ND & 0.01 & ND & 0.005 & ND & 0.005 & ND & 0.005 \\
\hline Barium & 6010 & 0.042 & 0.01 & 0.045 & 0.01 & 0.045 & 0.01 & 0.11 & 0.01 \\
\hline Boron & 6010 & ND & 0.1 & ND & 0.1 & ND & 0.1 & ND & 0.1 \\
\hline Calcium & 6010 & 25.8 & 0.2 & 26.1 & 0.2 & 28.3 & 0.2 & 31.9 & 0.2 \\
\hline Iron & 6010 & 0.83 & 0.1 & 1.1 & 0.1 & 0.44 & 0.1 & 0.2 & 0.1 \\
\hline Lead & 7421 & 0.12 & 0.025 & ND & 0.005 & ND & 0.01 & ND & 0.005 \\
\hline Magnesium & 6010 & 9.1 & 0.2 & 9.3 & 0.2 & 10.1 & 0.2 & 16.3 & 0.2 \\
\hline Manganese & 6010 & 0.096 & 0.01 & 0.099 & 0.01 & 0.1 & 0.01 & 0.027 & 0.01 \\
\hline Mercury & 7470 & ND & 0.0002 & ND & 0.0002 & ND & 0.0002 & ND & 0.0002 \\
\hline Potassium & 6010 & ND & 5 & ND & 5 & ND & 5 & ND & 5 \\
\hline Selenium & 7740 & ND & 0.02 & ND & 0.005 & ND & 0.005 & ND & 0.005 \\
\hline Silica as $\mathrm{SiO}_{2}$ & 6010 & 18.9 & 0.5 & 20.5 & 0.5 & 21.2 & 50 & 28.6 & 0.5 \\
\hline Sodium & 6010 & 11.1 & 5 & 9.6 & 5 & 11.3 & 5 & 12.4 & 5 \\
\hline Strontium & 6010 & 0.11 & 0.05 & 0.13 & 0.05 & 0.15 & 0.05 & 0.15 & 0.05 \\
\hline Thallium & 7841 & ND & 0.005 & ND & 0.01 & ND & 0.005 & ND & 0.01 \\
\hline
\end{tabular}


Appendix E. General water quality with depth and general water quality, bacteria, volatile organic compounds, semivolatile organic compounds, pesticides, PCB's, herbicides, total metals and trace elements, general inorganics, and radiochemistry by sample at ten water-quality sampling sites in the Bahía de Añasco and near Rincón, Puerto Rico, at two sites sampled in the Río Grande de Añasco and the Río Yagüez, and at the influent and effluent of the Mayagüez Regional Wastewater Treatment Plant, January 25-30, 1991—Continued

Appendix E-12. General inorganics and radiochemistry, Río Grande de Añasco and Río Yagüez.

[Repl., replicate; conc., concentration; Rep. Limit, reporting limit; mg/L, milligrams per liter; NTU, nephelometric turbidity units; pCi/L, picocuries per liter; ND, not detected. Sampling dates: QW-Ya1, 1/28/91; QW-An1, 1/29/91; QW-An2, 1/31/91.]

\begin{tabular}{|c|c|c|c|c|c|c|c|c|c|c|}
\hline \multirow[b]{2}{*}{ Constituent } & \multirow{2}{*}{$\begin{array}{l}\text { Analytical } \\
\text { Method }\end{array}$} & \multirow[b]{2}{*}{ units } & \multicolumn{2}{|c|}{ QW-An1 } & \multicolumn{2}{|c|}{ QW-An1 (Repl.) } & \multicolumn{2}{|c|}{ QW-An2 } & \multicolumn{2}{|c|}{ OW-Ya1 } \\
\hline & & & conc. & $\begin{array}{l}\text { Rep. } \\
\text { Limit }\end{array}$ & conc. & $\begin{array}{l}\text { Rep. } \\
\text { Limit }\end{array}$ & conc. & $\begin{array}{l}\text { Rep. } \\
\text { Limit }\end{array}$ & conc. & $\begin{array}{l}\text { Rep. } \\
\text { Limit }\end{array}$ \\
\hline \multicolumn{11}{|l|}{ General Inorganics } \\
\hline Chloride & A 429 & $\mathrm{mg} / \mathrm{L}$ & 7.6 & 0.5 & 7.9 & 0.5 & 8.4 & 0.5 & 11.5 & 0.5 \\
\hline Cyanide & 9012 & $\mathrm{mg} / \mathrm{L}$ & ND & 0.01 & ND & 0.01 & ND & 0.01 & ND & 0.01 \\
\hline Color & 110.2 & units & 5 & 5 & 5 & 5 & 5 & 5 & 5 & 5 \\
\hline Fluoride & A 429 & $\mathrm{mg} / \mathrm{L}$ & ND & 0.5 & ND & 5 & ND & 0.5 & & 0.5 \\
\hline Surfactants (MBAS) & 425.1 & $\mathrm{mg} / \mathrm{L}$ & ND & 0.1 & ND & 1 & ND & 0.1 & 0.12 & 0.1 \\
\hline Ammonia as $\mathrm{N}$ & 350.1 & $\mathrm{mg} / \mathrm{L}$ & ND & 0.1 & ND & 0.1 & 0.25 & 0.1 & ND & 0.1 \\
\hline Nitrate plus Nitrite & 353.2 & $\mathrm{mg} / \mathrm{L}$ & 0.27 & 0.1 & ND & 0.1 & 0.28 & 0.1 & 0.46 & 0.1 \\
\hline Orthophosphate as P & 365.3 & $\mathrm{mg} / \mathrm{L}$ & ND & 0.05 & 0.11 & 0.05 & ND & 0.5 & 0.068 & 0.05 \\
\hline Phenolics & 9065 & $\mathrm{mg} / \mathrm{L}$ & ND & 0.01 & ND & 0.01 & ND & 0.01 & ND & 0.01 \\
\hline Sulfide, Total & 376.2 & $\mathrm{mg} / \mathrm{L}$ & ND & 0.05 & 0.057 & 0.05 & 0.057 & 0.05 & 0.065 & 0.05 \\
\hline Sulfate & A 429 & $\mathrm{mg} / \mathrm{L}$ & 8.1 & 0.5 & 8.3 & 50 & 8.1 & 0.5 & 8.2 & 0.5 \\
\hline $\begin{array}{l}\text { Total Kjeldahl Nitrogen as } \\
\mathrm{N}\end{array}$ & 351.2 & $\mathrm{mg} / \mathrm{L}$ & ND & 0.5 & ND & 5 & ND & 0.5 & ND & 0.5 \\
\hline Phosphorus, as Total P & 365.3 & $\mathrm{mg} / \mathrm{L}$ & ND & 0.05 & ND & 0.05 & ND & 0.05 & ND & 0.05 \\
\hline Turbidity & 180.1 & NTU & 0.18 & 0.1 & 0.19 & 0.1 & 13 & 0.1 & 0.21 & 0.1 \\
\hline Total Dissolved Solids & 160.1 & $\mathrm{mg} / \mathrm{L}$ & 200 & 20 & 168 & 20 & 166 & 10 & 242 & 20 \\
\hline Total Suspended Solids & 160.2 & $\mathrm{mg} / \mathrm{L}$ & 12 & 2 & 12 & 2 & 20 & 2 & 7.2 & 2 \\
\hline Total Volatile Solids & 160.4 & $\mathrm{mg} / \mathrm{L}$ & 33 & 10 & 42 & 10 & 43 & 10 & 46 & 11 \\
\hline Volatile Suspended Solids & 160.4 & $\mathrm{mg} / \mathrm{L}$ & ND & 10 & ND & 10 & ND & 10 & ND & 10 \\
\hline \multicolumn{11}{|l|}{ Radiochemistry } \\
\hline & & & & $(+/-)$ & & $(+/-)$ & & $(+/-)$ & & $(+/-)$ \\
\hline Gross Alpha & 900 & $\mathrm{pCi} / \mathrm{L}$ & 0.8 & 2 & 0 & 1.6 & 0.5 & 2.3 & 0.4 & 0.4 \\
\hline Gross Beta & 900 & $\mathrm{pCi} / \mathrm{L}$ & 0 & 4.3 & 0.8 & 2.7 & 0 & 6.3 & 0 & 8.8 \\
\hline Radium 226 & 705 Mod. & $\mathrm{pCi} / \mathrm{L}$ & 0.1 & 0.5 & 0.1 & 0.5 & 0 & 0.5 & 0 & 1.9 \\
\hline Strontium 90 & A704 & $\mathrm{pCi} / \mathrm{L}$ & 0 & 0.8 & 0 & 0.8 & 1 & 0.8 & 0 & 0.9 \\
\hline
\end{tabular}


Appendix E. General water quality with depth and general water quality, bacteria, volatile organic compounds, semivolatile organic compounds, pesticides, PCB's, herbicides, total metals and trace elements, general inorganics, and radiochemistry by sample at ten water-quality sampling sites in the Bahía de Añasco and near Rincón, Puerto Rico, at two sites sampled in the Río Grande de Añasco and the Río Yagüez, and at the influent and effluent of the Mayagüez Regional Wastewater Treatment Plant, January 25-30, 1991-Continued

Appendix E-13. General water quality, Río Grande de Añasco and Río Yagüez.

[Repl., replicate; mg/L, milligrams per liter; ${ }^{\circ} \mathrm{C}$, degrees Celsius; $\mathrm{k}$, extinction coefficient; vol, volume of sample filtered; col/100ml, colonies of bacteria per 100 milliliters; TNTC, too numerous to count; $\mu \mathrm{S} / \mathrm{cm}$, microsiemens per centimeter; $\mathrm{mg} / \mathrm{m}^{3}$, milligram per cubic meter; Mgal/d, million gallons per day;

NA, not applicable; NR, not reported; ND, not detected; -- no data. Sampling dates: QW-Ya, 1/28/91; QW-An1, 1/29/91; QW-An2, 1/31/91.]

\begin{tabular}{|c|c|c|c|c|c|c|c|c|c|}
\hline \multirow{2}{*}{ Constituent } & \multirow{2}{*}{\multicolumn{2}{|c|}{ units }} & \multirow{2}{*}{$\begin{array}{l}\text { QW-An1 } \\
\text { Result }\end{array}$} & & \multirow{2}{*}{$\begin{array}{c}\begin{array}{c}\text { QW-An1 } \\
\text { (Repl.) }\end{array} \\
\text { Result }\end{array}$} & & \multicolumn{2}{|l|}{ QW-An2 } & \multirow{2}{*}{$\frac{\text { OW-Ya }}{\text { Result }}$} \\
\hline & & & & & & & Result & & \\
\hline BOD-5 & $\mathrm{mg} / \mathrm{L}$ & & ND & & 5.9 & & NR & & NR \\
\hline Oil and Grease & $\mathrm{mg} / \mathrm{L}$ & & ND & & ND & & 5.5 & & ND \\
\hline Settleable Solids & $\mathrm{mg} / \mathrm{L}$ & & 0 & & 0 & & NR & & 0 \\
\hline Water Temperature & ${ }^{\circ} \mathrm{C}$ & & 23.3 & & -- & & 24 & & 22 \\
\hline Alkalinity & $\mathrm{mg} / \mathrm{L}$ & & -- & & -- & & 110 & & 150 \\
\hline Spec.Cond. & $\mu \mathrm{S} / \mathrm{cm}$ & & 250 & & -- & & 265 & & 334 \\
\hline $\mathrm{pH}$ & units & & -- & & -- & & 7.8 & & 8.6 \\
\hline Dissolved Oxygen & $\mathrm{mg} / \mathrm{L}$ & & 8 & & -- & & 6 & & 9.9 \\
\hline Extinction Coefficient & $\mathrm{k}$ & & NA & & NA & & NA & & NA \\
\hline Chlorophyll-a & $\mathrm{mg} / \mathrm{m}^{3}$ & & 0.5257 & & -- & & -- & & 1.6423 \\
\hline Discharge & $\mathrm{Mgal} / \mathrm{d}$ & & 88.7 & & 88.7 & & 27.1 & & 3.6 \\
\hline Bacteria & & vol & count & vol & count & vol & count & vol & count \\
\hline Fecal Coli(vol/count) & & 10 & 1 & 10 & 2 & 10 & 3 & 10 & TNTC \\
\hline Fecal Coli(vol/count) & & 1 & 1 & 1 & 0 & 1 & 1 & 1 & 45 \\
\hline \multirow[t]{2}{*}{ Fecal Coli(vol/count) } & & 0.1 & 0 & 0.1 & 0 & 0.1 & 0 & 0.1 & 1 \\
\hline & $\mathrm{cols} / 100 \mathrm{ml}$ & & b-18 & & $b-20$ & & $b-36$ & & 4500 \\
\hline Total Coli(vol/count) & & 10 & TNTC & 10 & TNTC & 10 & 3 & 10 & TNTC \\
\hline Total Coli(vol/count) & & 1 & 12 & 1 & 14 & 1 & 1 & 1 & TNTC \\
\hline \multirow[t]{2}{*}{ Total Coli(vol/count) } & & 0.1 & 4 & 0.1 & 0 & 0.1 & 0 & 0.1 & 26 \\
\hline & $\mathrm{cols} / 100 \mathrm{ml}$ & & b-1450 & & b-1400 & & 350 & & 26000 \\
\hline Enterococcus(vol/count) & & 10 & 4 & 10 & 1 & 10 & 1 & 10 & TNTC \\
\hline Enterococcus(vol/count) & & 1 & 0 & 1 & 0 & 1 & 0 & 1 & 10 \\
\hline \multirow[t]{2}{*}{ Enterococcus(vol/count) } & & 0.1 & 0 & 0.1 & 0 & 0.1 & 0 & 0.1 & 1 \\
\hline & cols $/ 100 \mathrm{ml}$ & & $b-40$ & & $b-10$ & & $b-10$ & & b-1000 \\
\hline
\end{tabular}


Appendix E. General water quality with depth and general water quality, bacteria, volatile organic compounds, semivolatile organic compounds, pesticides, PCB's, herbicides, total metals and trace elements, general inorganics, and radiochemistry by sample at ten water-quality sampling sites in the Bahía de Añasco and near Rincón, Puerto Rico, at two sites sampled in the Río Grande de Añasco and the Río Yagüez, and at the influent and effluent of the Mayagüez Regional Wastewater Treatment Plant, January 25-30, 1991—Continued

Appendix E-14. Volatile organic compounds inside (QW-4, QW-5) and at the limit $(0 \mathrm{~W}-3, \mathrm{QW}-6)$ of the initial mixing zone, January 30 , 1991.

[Method 624. Units are micrograms per liter. Repl., replicate; conc., concentration; Rep. Limit, reporting limit; ND, not detected. Values for surrogates represent percent recovery.]

\begin{tabular}{|c|c|c|c|c|c|c|c|c|c|c|}
\hline \multirow[b]{2}{*}{ Constituent } & \multicolumn{2}{|c|}{ QW-3 } & \multicolumn{2}{|c|}{ oW-4 } & \multicolumn{2}{|c|}{ OW-5 } & \multicolumn{2}{|c|}{ OW-5 (Repl.) } & \multicolumn{2}{|c|}{ OW-6 } \\
\hline & conc. & $\begin{array}{l}\text { Rep. } \\
\text { Limit }\end{array}$ & conc. & $\begin{array}{l}\text { Rep. } \\
\text { Limit }\end{array}$ & conc. & $\begin{array}{l}\text { Rep. } \\
\text { Limit }\end{array}$ & conc. & $\begin{array}{l}\text { Rep. } \\
\text { Limit }\end{array}$ & conc. & $\begin{array}{l}\text { Rep. } \\
\text { Limit }\end{array}$ \\
\hline Acrolein & ND & 100 & ND & 100 & ND & 100 & ND & 100 & ND & 100 \\
\hline Acrylonitrile & ND & 100 & ND & 100 & ND & 100 & ND & 100 & ND & 100 \\
\hline Benzene & ND & 5 & ND & 5 & ND & 5 & ND & 5 & ND & 5 \\
\hline Bromodichloromethane & ND & 5 & ND & 5 & ND & 5 & ND & 5 & ND & 5 \\
\hline Bromoform & ND & 5 & ND & 5 & ND & 5 & ND & 5 & ND & 5 \\
\hline Bromomethane & ND & 10 & ND & 10 & ND & 10 & ND & 10 & ND & 10 \\
\hline Carbon tetrachloride & ND & 5 & ND & 5 & ND & 5 & ND & 5 & ND & 5 \\
\hline Chlorobenzene & ND & 5 & ND & 5 & ND & 5 & ND & 5 & ND & 5 \\
\hline Chloroethane & $\mathrm{ND}$ & 10 & ND & 10 & ND & 10 & ND & 10 & ND & 10 \\
\hline Chloroform & ND & 5 & ND & 5 & ND & 5 & ND & 5 & ND & 5 \\
\hline Chloromethane & $\mathrm{ND}$ & 10 & ND & 10 & ND & 10 & ND & 10 & ND & 10 \\
\hline Dibromochloromethane & ND & 5 & ND & 5 & ND & 5 & ND & 5 & ND & 5 \\
\hline 1,1-Dichloroethane & ND & 5 & ND & 5 & ND & 5 & ND & 5 & ND & 5 \\
\hline 1,2-Dichloroethane & ND & 5 & ND & 5 & ND & 5 & ND & 5 & ND & 5 \\
\hline 1,1-Dichloroethene & ND & 5 & ND & 5 & ND & 5 & ND & 5 & ND & 5 \\
\hline 1,2-Dichloroethene (total) & ND & 5 & ND & 5 & ND & 5 & ND & 5 & ND & 5 \\
\hline 1,2-Dichloropropane & ND & 5 & ND & 5 & ND & 5 & ND & 5 & ND & 5 \\
\hline cis-1,3-Dichloropropene & ND & 5 & ND & 5 & ND & 5 & ND & 5 & ND & 5 \\
\hline trans-1,3-Dichloropropene & ND & 5 & ND & 5 & ND & 5 & ND & 5 & ND & 5 \\
\hline Ethylbenzene & ND & 5 & ND & 5 & ND & 5 & ND & 5 & ND & 5 \\
\hline Methylene chloride & ND & 5 & ND & 5 & ND & 5 & ND & 5 & ND & 5 \\
\hline 1,1,2,2-Tetrachloroethane & $\mathrm{ND}$ & 5 & ND & 5 & ND & 5 & ND & 5 & ND & 5 \\
\hline Tetrachloroethene & ND & 5 & ND & 5 & ND & 5 & ND & 5 & ND & 5 \\
\hline Toluene & ND & 5 & ND & 5 & ND & 5 & ND & 5 & ND & 5 \\
\hline 1,1,1-Trichloroethane & ND & 5 & ND & 5 & ND & 5 & ND & 5 & ND & 5 \\
\hline 1,1,2-Trichloroethane & ND & 5 & ND & 5 & ND & 5 & ND & 5 & ND & 5 \\
\hline Trichloroethene & $\mathrm{ND}$ & 5 & ND & 5 & ND & 5 & ND & 5 & ND & 5 \\
\hline Vinyl chloride & ND & 10 & ND & 10 & ND & 10 & ND & 10 & ND & 10 \\
\hline Surrogate & & & & & Recc & ery & & & & \\
\hline Toluene-d8 & 103 & & 105 & & 105 & & 105 & & 108 & \\
\hline 4-Bromofluorobenzene & 98 & & 100 & & 100 & & 99 & & 98 & \\
\hline 1,2-Dichloroethane-d4 & 103 & & 101 & & 103 & & 100 & & 103 & \\
\hline
\end{tabular}


Appendix E. General water quality with depth and general water quality, bacteria, volatile organic compounds, semivolatile organic compounds, pesticides, PCB's, herbicides, total metals and trace elements, general inorganics, and radiochemistry by sample at ten water-quality sampling sites in the Bahía de Añasco and near Rincón, Puerto Rico, at two sites sampled in the Río Grande de Añasco and the Río Yagüez, and at the influent and effluent of the Mayagüez Regional Wastewater Treatment Plant, January 25-30, 1991-Continued

Appendix E-15. Semivolatile organic compounds inside (QW-4, QW-5) and at the limit (QW-3, QW-6) of the initial mixing zone, January 30,1991.

[Method 625. Units are micrograms per liter. Repl., replicate; conc., concentration; Rep. Limit, reporting limit; ND, not detected; conf. level, confidence level. Values for surrogates represent percent recovery. All tentatively identified compounds were found in the base neutral acids. Confidence levels for the tentatively identified compounds: 1- tentative; 2-confident; and 3-confirmed.]

\begin{tabular}{|c|c|c|c|c|c|c|c|c|c|c|}
\hline \multirow[b]{2}{*}{ Constituent } & \multicolumn{2}{|c|}{ QW-3 } & \multicolumn{2}{|c|}{ QW-4 } & \multicolumn{2}{|c|}{ QW-5 } & \multicolumn{2}{|c|}{ OW-5 (Repl.) } & \multicolumn{2}{|c|}{ OW-6 } \\
\hline & conc. & $\begin{array}{l}\text { Rep. } \\
\text { Limit }\end{array}$ & conc. & $\begin{array}{l}\text { Rep. } \\
\text { Limit }\end{array}$ & conc. & $\begin{array}{l}\text { Rep. } \\
\text { Limit }\end{array}$ & conc. & $\begin{array}{l}\text { Rep. } \\
\text { Limit }\end{array}$ & conc. & $\begin{array}{l}\text { Rep. } \\
\text { Limit }\end{array}$ \\
\hline Acenaphthene & ND & 10 & ND & 10 & $\mathrm{ND}$ & 10 & $\mathrm{ND}$ & 10 & ND & 10 \\
\hline Acenaphthylene & ND & 10 & ND & 10 & ND & 10 & ND & 10 & ND & 10 \\
\hline Anthracene & ND & 10 & ND & 10 & ND & 10 & $\mathrm{ND}$ & 10 & $\mathrm{ND}$ & 100 \\
\hline Benzidine & ND & 100 & ND & 100 & ND & 100 & ND & 100 & ND & 10 \\
\hline Benzo a-anthracene & ND & 10 & ND & 10 & ND & 10 & ND & 10 & ND & 10 \\
\hline Benzo $b$ fluoranthene & ND & 10 & ND & 10 & ND & 10 & $\mathrm{ND}$ & 10 & ND & 10 \\
\hline Benzo k fluoranthene & ND & 10 & ND & 10 & ND & 10 & ND & 10 & ND & 10 \\
\hline Benzo (g,h,i)perylene & ND & 10 & ND & 10 & ND & 10 & ND & 10 & ND & 10 \\
\hline Benzo (a)pyrene & ND & 10 & ND & 10 & ND & 10 & ND & 10 & ND & 10 \\
\hline 4-Bromophenyl phenyl ether & ND & 10 & ND & 10 & ND & 10 & ND & 10 & ND & 10 \\
\hline Butyl benzyl phthalate & ND & 10 & ND & 10 & ND & 10 & ND & 10 & ND & 10 \\
\hline bis(2-Chloroethoxy)-methane & ND & 10 & ND & 10 & ND & 10 & ND & 10 & ND & 10 \\
\hline bis(2-Chloroethyl) ether & ND & 10 & ND & 10 & ND & 10 & ND & 10 & ND & 10 \\
\hline bis(2-Chloroisopropyl)-ether & ND & 10 & ND & 10 & ND & 10 & ND & 10 & ND & 10 \\
\hline 4-Chloro-3-methylphenol & ND & 10 & ND & 10 & ND & 10 & ND & 10 & ND & 10 \\
\hline 2-Chloronaphthalene & ND & 10 & ND & 10 & ND & 10 & ND & 10 & ND & 10 \\
\hline 2-Chlorophenol & ND & 10 & ND & 10 & ND & 10 & ND & 10 & ND & 10 \\
\hline 4-Chlorophenyl phenyl ether & ND & 10 & ND & 10 & ND & 10 & ND & 10 & ND & 10 \\
\hline Chrysene & ND & 10 & ND & 10 & ND & 10 & ND & 10 & ND & 10 \\
\hline $\operatorname{Dibenz}(\mathrm{a}, \mathrm{h})$ anthracene & ND & 10 & ND & 10 & ND & 10 & ND & 10 & ND & 10 \\
\hline Di-n-butyl phthalate & ND & 10 & ND & 10 & ND & 10 & ND & 10 & ND & 10 \\
\hline 1,2-Dichlorobenzene & ND & 10 & ND & 10 & ND & 10 & ND & 10 & ND & 10 \\
\hline 1,3-Dichlorobenzene & ND & 10 & ND & 10 & ND & 10 & ND & 10 & ND & 10 \\
\hline 1,4-Dichlorobenzene & ND & 10 & ND & 10 & ND & 10 & ND & 10 & ND & 10 \\
\hline 3,3'-Dichlorobenzidine & ND & 20 & ND & 20 & ND & 20 & ND & 20 & ND & 20 \\
\hline 2,4-Dichlorophenol & ND & 10 & ND & 10 & ND & 10 & ND & 10 & ND & 10 \\
\hline Diethyl phthalate & ND & 10 & ND & 10 & ND & 10 & ND & 10 & ND & 10 \\
\hline 2,4-DimethylPhenol & ND & 10 & ND & 10 & ND & 10 & ND & 10 & ND & 10 \\
\hline
\end{tabular}


Appendix E. General water quality with depth and general water quality, bacteria, volatile organic compounds, semivolatile organic compounds, pesticides, PCB's, herbicides, total metals and trace elements, general inorganics, and radiochemistry by sample at 10 water-quality sampling sites in the Bahía de Añasco and near Rincón, Puerto Rico, at two sites sampled in the Río Grande de Añasco and the Río Yagüez, and at the influent and effluent of the Mayagüez Regional Wastewater Treatment Plant, January 25-30, 1991--Continued

Appendix E-15. Semivolatile organic compounds inside (0W-4, QW-5) and at the limit (QW-3, QW-6) of the initial mixing zone, January 30,1991--Continued.

[Method 625. Units are micrograms per liter. Repl., replicate; conc., concentration; Rep. Limit, reporting limit; ND, not detected; conf. level, confidence level.

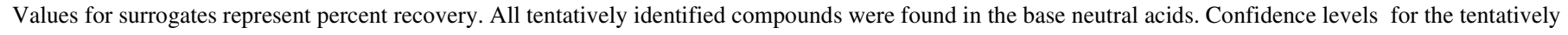
identified compounds: 1- tentative; 2-confident; and 3-confirmed.]

\begin{tabular}{|c|c|c|c|c|c|c|c|c|c|c|}
\hline \multirow[b]{2}{*}{ Constituent } & \multicolumn{2}{|c|}{ oW-3 } & \multicolumn{2}{|c|}{ QW-4 } & \multicolumn{2}{|c|}{ QW-5 } & \multicolumn{2}{|c|}{ QW-5 (Repl.) } & \multicolumn{2}{|c|}{ oW-6 } \\
\hline & conc. & $\begin{array}{l}\text { Rep. } \\
\text { Limit }\end{array}$ & conc. & $\begin{array}{l}\text { Rep. } \\
\text { Limit }\end{array}$ & conc. & $\begin{array}{l}\text { Rep. } \\
\text { Limit }\end{array}$ & conc. & $\begin{array}{l}\text { Rep. } \\
\text { Limit }\end{array}$ & conc. & $\begin{array}{l}\text { Rep. } \\
\text { Limit }\end{array}$ \\
\hline Dimethyl phthalate & ND & 10 & ND & 10 & ND & 10 & ND & 10 & ND & 10 \\
\hline 4,6-Dinitro-2-methylphenol & ND & 50 & ND & 50 & ND & 50 & ND & 50 & ND & 50 \\
\hline 2,4-Dinitrophenol & ND & 50 & ND & 50 & ND & 50 & ND & 50 & ND & 50 \\
\hline 2,4-Dinitrotoluene & ND & 10 & ND & 10 & ND & 10 & ND & 10 & ND & 10 \\
\hline 2,6-Dinitrotoluene & ND & 10 & ND & 10 & ND & 10 & ND & 10 & ND & 10 \\
\hline Di-n-octylphthalate & ND & 10 & ND & 10 & ND & 10 & ND & 10 & ND & 10 \\
\hline 1,2-Diphenylhydrazine & ND & 10 & ND & 10 & ND & 10 & ND & 10 & ND & 10 \\
\hline bis(2-Ethylhexyl)phthalate & ND & 10 & ND & 10 & ND & 10 & ND & 10 & ND & 10 \\
\hline Fluoranthene & ND & 10 & ND & 10 & ND & 10 & ND & 10 & ND & 10 \\
\hline Fluorene & ND & 10 & ND & 10 & ND & 10 & ND & 10 & ND & 10 \\
\hline Hexachlorobenzene & ND & 10 & ND & 10 & ND & 10 & ND & 10 & ND & 10 \\
\hline Hexachlorobutadiene & ND & 10 & ND & 10 & ND & 10 & ND & 10 & ND & 10 \\
\hline Hexachlorocyclopentadiene & ND & 10 & ND & 10 & ND & 10 & ND & 10 & ND & 10 \\
\hline Hexachloroethane & ND & 10 & ND & 10 & ND & 10 & ND & 10 & ND & 10 \\
\hline Indeno(1,2,3-cd)pyrene & ND & 10 & ND & 10 & ND & 10 & ND & 10 & ND & 10 \\
\hline Isophorone & ND & 10 & ND & 10 & ND & 10 & ND & 10 & ND & 10 \\
\hline Naphthalene & ND & 10 & ND & 10 & ND & 10 & ND & 10 & ND & 10 \\
\hline Nitrobenzene & ND & 10 & ND & 10 & ND & 10 & ND & 10 & ND & 10 \\
\hline 2-Nitrophenol & ND & 10 & ND & 10 & ND & 10 & ND & 10 & ND & 10 \\
\hline 4-Nitrophenol & ND & 50 & ND & 50 & ND & 50 & ND & 50 & ND & 10 \\
\hline N-Nitrosodimethylamine & ND & 10 & ND & 10 & ND & 10 & ND & 10 & ND & 10 \\
\hline N-Nitrosodiphenylamine & ND & 10 & ND & 10 & ND & 10 & ND & 10 & ND & 10 \\
\hline N-Nitroso-di-n-Propylamine & ND & 10 & ND & 10 & ND & 10 & ND & 10 & $\mathrm{ND}$ & 10 \\
\hline Pentachlorophenol & ND & 50 & ND & 50 & ND & 50 & ND & 50 & ND & 50 \\
\hline Phenanthrene & ND & 10 & ND & 10 & ND & 10 & ND & 10 & ND & 10 \\
\hline Phenol & ND & 10 & ND & 10 & ND & 10 & ND & 10 & $\mathrm{ND}$ & 10 \\
\hline Pyrene & ND & 10 & ND & 10 & ND & 10 & ND & 10 & $\mathrm{ND}$ & 10 \\
\hline 1,2,4-Trichlorobenzene & ND & 10 & ND & 10 & ND & 10 & ND & 10 & ND & 10 \\
\hline
\end{tabular}


Appendix E. General water quality with depth and general water quality, bacteria, volatile organic compounds, semivolatile organic compounds, pesticides, PCB's, herbicides, total metals and trace elements, general inorganics, and radiochemistry by sample at 10 water-quality sampling sites in the Bahía de Añasco and near Rincón, Puerto Rico, at two sites sampled in the Río Grande de Añasco and the Río Yagüez, and at the influent and effluent of the Mayagüez Regional Wastewater Treatment Plant, January 25-30, 1991--Continued

Appendix E-15. Semivolatile organic compounds inside (QW-4, QW-5) and at the limit (QW-3, QW-6) of the initial mixing zone, January 30,1991--Continued.

[Method 625. Units are micrograms per liter. Repl., replicate; conc., concentration; Rep. Limit, reporting limit; ND, not detected; conf. level, confidence level. Values for surrogates represent percent recovery. All tentatively identified compounds were found in the base neutral acids. Confidence levels for the tentatively identified compounds: 1- tentative; 2-confident; and 3-confirmed.]

\begin{tabular}{|c|c|c|c|c|c|c|c|c|c|c|}
\hline \multirow[b]{2}{*}{ Constituent } & \multicolumn{2}{|c|}{ oW-3 } & \multicolumn{2}{|c|}{ QW-4 } & \multicolumn{2}{|c|}{ QW-5 } & \multicolumn{2}{|c|}{ OW-5 (Repl.) } & \multicolumn{2}{|c|}{ QW-6 } \\
\hline & conc. & $\begin{array}{l}\text { Rep. } \\
\text { Limit }\end{array}$ & conc. & $\begin{array}{l}\text { Rep. } \\
\text { Limit }\end{array}$ & conc. & $\begin{array}{l}\text { Rep. } \\
\text { Limit }\end{array}$ & conc. & $\begin{array}{l}\text { Rep. } \\
\text { Limit }\end{array}$ & conc. & $\begin{array}{l}\text { Rep. } \\
\text { Limit }\end{array}$ \\
\hline 2,4,6-Trichlorophenol & ND & 10 & ND & 10 & $\mathrm{ND}$ & 10 & ND & 10 & ND & 10 \\
\hline Surrogate & \multicolumn{10}{|c|}{ Recovery } \\
\hline Nitrobenzene-d5 & 56 & & 61 & & 64 & & 59 & & 55 & \\
\hline 2-Fluorobiphenyl & 53 & & 63 & & 65 & & 59 & & 53 & \\
\hline Terphenyl-dl4 & 70 & & 79 & & 83 & & 76 & & 76 & \\
\hline Phenol-d5 & 56 & & 64 & & 58 & & 57 & & 42 & \\
\hline 2-Fluorophenol & 52 & & 62 & & 56 & & 54 & & 56 & \\
\hline 2,4,6-Tribromophenol & 66 & & 74 & & 76 & & 70 & & 68 & \\
\hline
\end{tabular}

\begin{tabular}{llcc}
\multicolumn{4}{c}{ Tentatively identified compounds } \\
\cline { 2 - 4 } Site & Constituent & conf. & conc. \\
\cline { 2 - 2 } & & level \\
\hline QW-4 & Oxygenated Hydrocarbon & 2 & 18 \\
QW-5 & Oxygenated Hydrocarbon & 2 & 23 \\
QW-5(Repl) & Cyclohexane,Methyl- & 2 & 11 \\
QW-6 & Cyclohexane,Methyl- & 2 & 12 \\
QW-6 & Cyclohexane,Methyl- & 2 & 10 \\
QW-6 & Cyclopentanol,2-Methyl- & 2 & 98 \\
& Furan,2,5-Diethyltetrahydro- & 1 & 21 \\
\hline
\end{tabular}


Appendix E. General water quality with depth and general water quality, bacteria, volatile organic compounds, semivolatile organic compounds, pesticides, PCB's, herbicides, total metals and trace elements, general inorganics, and radiochemistry by sample at ten water-quality sampling sites in the Bahía de Añasco and near Rincón, Puerto Rico, at two sites sampled in the Río Grande de Añasco and the Río Yagüez, and at the influent and effluent of the Mayagüez Regional Wastewater Treatment Plant, January 25-30, 1991—Continued

Appendix E-16. Concentrations of pesticides, PCB's, and herbicides, inside (0W-4, QW-5) and at the limit (QW-3, QW-6) of the initial mixing zone, January 30,1991 .

[Units are micrograms per liter. Repl., replicate; conc., concentration; Rep. Limit, reporting limit; ND, not detected. Values for surrogates represent percent recovery. Sporadic hits reported as ND unless verified in 2nd-column test.]

\begin{tabular}{|c|c|c|c|c|c|c|c|c|c|c|}
\hline \multirow[b]{2}{*}{ Constituent } & \multicolumn{2}{|c|}{ oW-3 } & \multicolumn{2}{|c|}{ QW-4 } & \multicolumn{2}{|c|}{ QW-5 } & \multicolumn{2}{|c|}{ OW-5 (Repl.) } & \multicolumn{2}{|c|}{ QW-6 } \\
\hline & conc. & $\begin{array}{l}\text { Rep. } \\
\text { Limit }\end{array}$ & conc. & $\begin{array}{l}\text { Rep. } \\
\text { Limit }\end{array}$ & conc. & $\begin{array}{l}\text { Rep. } \\
\text { Limit }\end{array}$ & conc. & $\begin{array}{l}\text { Rep. } \\
\text { Limit }\end{array}$ & conc. & $\begin{array}{l}\text { Rep. } \\
\text { Limit }\end{array}$ \\
\hline \multicolumn{11}{|c|}{ Organochlorine Pesticides/PCB's } \\
\hline \multicolumn{11}{|l|}{ Method 8080} \\
\hline alpha-BHC & $\mathrm{ND}$ & 0.05 & ND & 0.05 & ND & 0.05 & ND & 0.05 & ND & 0.05 \\
\hline beta-BHC & ND & 0.05 & ND & 0.05 & ND & 0.05 & ND & 0.05 & ND & 0.05 \\
\hline delta-BHC & ND & 0.05 & ND & 0.05 & ND & 0.05 & ND & 0.05 & ND & 0.05 \\
\hline gamma-BHC (Lindane) & ND & 0.05 & ND & 1 & ND & 0.05 & ND & 0.05 & ND & 0.05 \\
\hline Toxaphene & ND & 1 & ND & 0.05 & ND & 1 & ND & 0.05 & ND & 1 \\
\hline Heptachlor & ND & 0.02 & ND & 0.02 & ND & 0.02 & ND & 1 & ND & 0.02 \\
\hline Aldrin & ND & 0.05 & ND & 0.05 & ND & 0.05 & ND & 0.02 & ND & 0.05 \\
\hline Heptachlor epoxide & ND & 0.05 & ND & 0.05 & ND & 0.05 & ND & 0.05 & ND & 0.05 \\
\hline Endosulfan I & ND & 0.05 & ND & 0.05 & ND & 0.05 & ND & 0.05 & ND & 0.05 \\
\hline Dieldrin & ND & 0.02 & ND & 0.02 & ND & 0.02 & ND & 0.05 & ND & 0.02 \\
\hline 4,4'-DDE & ND & 0.1 & ND & 0.1 & ND & 0.1 & ND & 0.02 & ND & 0.1 \\
\hline Endrin & ND & 0.06 & ND & 0.06 & ND & 0.06 & ND & 0.1 & ND & 0.06 \\
\hline Endosulfan II & ND & 0.1 & ND & 0.1 & ND & 0.1 & ND & 0.06 & ND & 0.1 \\
\hline 4,4'-DDD & ND & 0.1 & ND & 0.1 & ND & 0.1 & ND & 0.1 & ND & 0.1 \\
\hline Endosulfan sulfate & ND & 0.1 & ND & 0.1 & ND & 0.1 & ND & 0.1 & ND & 0.1 \\
\hline 4,4'-DDT & ND & 0.1 & ND & 0.1 & ND & 0.1 & ND & 0.1 & ND & 0.1 \\
\hline Endrin aldehyde & ND & 0.1 & ND & 0.1 & ND & 0.1 & ND & 0.1 & ND & 0.1 \\
\hline Chlordane & ND & 0.05 & ND & 0.05 & ND & 0.05 & ND & 0.1 & ND & 0.05 \\
\hline Aroclor 1016 & ND & 0.5 & ND & 0.5 & ND & 0.5 & ND & 0.05 & ND & 0.5 \\
\hline Aroclor 1221 & ND & 0.5 & ND & 0.5 & ND & 0.5 & ND & 0.5 & ND & 0.5 \\
\hline Aroclor 1232 & ND & 0.5 & ND & 0.5 & ND & 0.5 & ND & 0.5 & ND & 0.5 \\
\hline Aroclor 1242 & ND & 0.5 & ND & 0.5 & ND & 0.5 & ND & 0.5 & ND & 0.5 \\
\hline Aroclor 1248 & ND & 0.5 & ND & 0.5 & ND & 0.5 & ND & 0.5 & ND & 0.5 \\
\hline Aroclor 1254 & ND & 1 & ND & 1 & ND & 1 & ND & 1 & ND & 1 \\
\hline Aroclor 1260 & ND & 1 & ND & 1 & ND & 1 & ND & 1 & ND & 1 \\
\hline Mirex & ND & 0.05 & ND & 0.05 & ND & 0.05 & ND & 0.05 & ND & 0.05 \\
\hline Ethylan (Perthane) & ND & 0.5 & ND & 0.5 & ND & 0.5 & ND & 0.5 & ND & 0.5 \\
\hline
\end{tabular}


Appendix E. General water quality with depth and general water quality, bacteria, volatile organic compounds, semivolatile organic compounds, pesticides, PCB's, herbicides, total metals and trace elements, general inorganics, and radiochemistry by sample at 10 water-quality sampling sites in the Bahía de Añasco and near Rincón, Puerto Rico, at two sites sampled in the Río Grande de Añasco and the Río Yagüez, and at the influent and effluent of the Mayagüez Regional Wastewater Treatment Plant, January 25-30, 1991—Continued

Appendix E-16. Concentrations of pesticides, PCB's, and herbicides, inside (QW-4, QW-5) and at the limit (QW-3, QW-6) of the initial mixing zone, January 30,1991--Continued.

[Units are micrograms per liter. Repl., replicate; conc., concentration; Rep. Limit, reporting limit; ND, not detected. Values for surrogates represent percent recovery. Sporadic hits reported as ND unless verified in 2nd-column test.]

\begin{tabular}{|c|c|c|c|c|c|c|c|c|c|c|}
\hline \multirow[b]{2}{*}{ Constituent } & \multicolumn{2}{|c|}{ QW-3 } & \multicolumn{2}{|c|}{ QW-4 } & \multicolumn{2}{|c|}{ QW-5 } & \multicolumn{2}{|c|}{ QW-5 (Repl.) } & \multicolumn{2}{|c|}{ QW-6 } \\
\hline & conc. & $\begin{array}{l}\text { Rep. } \\
\text { Limit }\end{array}$ & conc. & $\begin{array}{l}\text { Rep. } \\
\text { Limit }\end{array}$ & conc. & $\begin{array}{l}\text { Rep. } \\
\text { Limit }\end{array}$ & conc. & $\begin{array}{l}\text { Rep. } \\
\text { Limit }\end{array}$ & conc. & $\begin{array}{l}\text { Rep. } \\
\text { Limit }\end{array}$ \\
\hline Methoxychlor & ND & 0.5 & ND & 0.5 & ND & 0.5 & ND & 0.5 & ND & 0.5 \\
\hline Surrogate & \multicolumn{10}{|c|}{ Recovery } \\
\hline Dibutyl chlorendate & 119 & & 118 & & 116 & & 112 & & 118 & \\
\hline
\end{tabular}

\section{Organophosphorus Pesticides}

\section{SW-846 List}

\section{Method 8141}

\begin{tabular}{|c|c|c|c|c|c|c|c|c|c|c|}
\hline $\begin{array}{l}\text { Azinphos-methyl } \\
\text { (Guthion) }\end{array}$ & ND & 2.5 & ND & 2.5 & ND & 2.5 & ND & 2.5 & ND & 2.5 \\
\hline Chlorpyrifos (Dursban) & ND & 0.25 & ND & 0.25 & ND & 0.25 & ND & 0.25 & ND & 0.25 \\
\hline Coumaphos & ND & 0.5 & ND & 0.5 & ND & 0.5 & ND & 0.5 & ND & 0.5 \\
\hline Demeton O\&S & ND & 0.25 & ND & 0.25 & ND & 0.25 & ND & 0.25 & ND & 0.25 \\
\hline Fenthion (Baytex) & ND & 0.25 & ND & 0.25 & ND & 0.25 & ND & 0.25 & ND & 0.25 \\
\hline Malathion & ND & 1.2 & ND & 1.2 & ND & 1.2 & ND & 1.2 & ND & 1.2 \\
\hline Naled (Dibrom) & ND & 10 & ND & 10 & ND & 10 & ND & 10 & ND & 10 \\
\hline Ethyl parathion & ND & 0.25 & ND & 0.25 & ND & 0.25 & ND & 0.25 & ND & 0.25 \\
\hline Methyl parathion & ND & 0.25 & ND & 0.25 & ND & 0.25 & ND & 0.25 & ND & 0.25 \\
\hline Chlorinated Herbicide & & & & & & & & & & \\
\hline Method 8150 & & & & & & & & & & \\
\hline $2,4-\mathrm{D}$ & ND & 1.2 & ND & 1.2 & ND & 1.2 & ND & 1.2 & ND & 1.2 \\
\hline 2,4,5-TP (Silvex) & ND & 0.17 & ND & 0.17 & ND & 0.17 & ND & 0.17 & ND & 0.17 \\
\hline Surrogate & \multicolumn{10}{|c|}{ Recovery } \\
\hline DCAA & \multicolumn{2}{|l|}{113} & \multicolumn{2}{|l|}{123} & \multicolumn{2}{|l|}{117} & \multicolumn{2}{|l|}{102} & \multicolumn{2}{|l|}{115} \\
\hline
\end{tabular}


Appendix E. General water quality with depth and general water quality, bacteria, volatile organic compounds, semivolatile organic compounds, pesticides, PCB's, herbicides, total metals and trace elements, general inorganics, and radiochemistry by sample at ten water-quality sampling sites in the Bahía de Añasco and near Rincón, Puerto Rico, at two sites sampled in the Río Grande de Añasco and the Río Yagüez, and at the influent and effluent of the Mayagüez Regional Wastewater Treatment Plant, January 25-30, 1991—Continued

Appendix E-17. Concentrations of total metals inside ( $0 \mathrm{~W}-4,0 \mathrm{~W}-5)$ and at the limit $(0 \mathrm{~W}-3,0 \mathrm{~W}-6)$, of the initial mixing zone, January 30,1991.

[Units are milligrams per liter. Repl., replicate; Rep. Limit, reporting limit; ND, not detected.]

\begin{tabular}{|c|c|c|c|c|c|c|c|c|c|c|c|}
\hline \multirow[b]{2}{*}{ Constituent } & \multirow{2}{*}{$\begin{array}{l}\text { Analytical } \\
\text { method }\end{array}$} & \multicolumn{2}{|c|}{ oW-3 } & \multicolumn{2}{|c|}{ oW-4 } & \multicolumn{2}{|c|}{ oW-5 } & \multicolumn{2}{|c|}{ QW-5 (Repl.) } & \multicolumn{2}{|c|}{ oW- 6} \\
\hline & & Result & $\begin{array}{l}\text { Rep. } \\
\text { Limit }\end{array}$ & Result & $\begin{array}{l}\text { Rep. } \\
\text { Limit }\end{array}$ & Result & $\begin{array}{l}\text { Rep. } \\
\text { Limit }\end{array}$ & Result & $\begin{array}{l}\text { Rep. } \\
\text { Limit }\end{array}$ & Result & $\begin{array}{l}\text { Rep. } \\
\text { Limit }\end{array}$ \\
\hline Antimony & 7041 & ND & 0.02 & ND & 0.02 & ND & 0.04 & ND & 0.02 & ND & 0.04 \\
\hline Beryllium & 7090 & ND & 0.05 & ND & 0.05 & ND & 0.05 & ND & 0.05 & ND & 0.05 \\
\hline Copper & 7210 & ND & 0.05 & ND & 0.05 & ND & 0.05 & ND & 0.05 & ND & 0.05 \\
\hline Nickel & 7520 & ND & 0.1 & ND & 0.1 & ND & 0.1 & & 0.1 & ND & 0.1 \\
\hline Chromium (VI) & 7196 & ND & 0.01 & ND & 0.01 & ND & 0.01 & ND & 0.01 & ND & 0.01 \\
\hline Aluminum & 6010 & ND & 2 & ND & 2 & ND & 2 & ND & 2 & ND & 2 \\
\hline Silver & 7761 & ND & 0.0025 & ND & 0.0025 & ND & 0.001 & ND & 0.0025 & ND & 0.0005 \\
\hline Cadmium & 7131 & ND & 0.002 & ND & 0.001 & ND & 0.002 & ND & 0.001 & ND & 0.005 \\
\hline Zinc & 7950 & ND & 0.02 & ND & 0.02 & ND & 0.02 & ND & 0.02 & ND & 0.02 \\
\hline Chromium & 7191 & ND & 0.025 & 0.018 & 0.01 & ND & 0.01 & ND & 0.001 & 0.018 & 0.01 \\
\hline Arsenic & 7060 & ND & 0.01 & ND & 0.01 & ND & 0.01 & ND & 0.01 & ND & 0.01 \\
\hline Barium & 6010 & ND & 0.2 & ND & 0.2 & ND & 0.2 & ND & 0.2 & ND & 0.2 \\
\hline Boron & 6010 & 5.2 & 2 & 5.1 & 2 & 5.1 & 2 & 4 & 2 & 5.2 & 2 \\
\hline Calcium & 6010 & 441 & 4 & 437 & 4 & 452 & 4 & 407 & 4 & 442 & 4 \\
\hline Iron & 6010 & ND & 2 & ND & 2 & ND & 2 & ND & 2 & ND & 2 \\
\hline Lead & 7421 & ND & 0.01 & ND & 0.01 & ND & 0.01 & 0.046 & 0.025 & ND & 0.1 \\
\hline Magnesium & 6010 & 1370 & 4 & 1350 & 4 & 1390 & 4 & 1250 & 4 & 1370 & 4 \\
\hline Manganese & 6010 & ND & 0.2 & ND & 0.2 & ND & 0.2 & ND & 0.2 & ND & 0.2 \\
\hline Mercury & 7470 & ND & 0.0002 & ND & 0.0002 & ND & 0.0002 & ND & 0.0002 & ND & 0.0002 \\
\hline Potassium & 6010 & 410 & 100 & 378 & 100 & 390 & 100 & 326 & 100 & 385 & 100 \\
\hline Selenium & 7740 & ND & 0.02 & ND & 0.02 & ND & 0.02 & ND & 0.02 & ND & 0.02 \\
\hline Silica as $\mathrm{SiO} 2$ & 6010 & ND & 10 & ND & 10 & ND & 10 & ND & 10 & ND & 10 \\
\hline Sodium & 6010 & 11100 & 100 & 10800 & 100 & 11000 & 100 & 9780 & 100 & 11000 & 100 \\
\hline Strontium & 6010 & 7.4 & 1 & 7.5 & 1 & 7.7 & 1 & 6.9 & 1 & 7.6 & 1 \\
\hline Thallium & 7841 & ND & 0.05 & ND & 0.05 & ND & 0.02 & ND & 0.05 & ND & 0.02 \\
\hline
\end{tabular}


Appendix E. General water quality with depth and general water quality, bacteria, volatile organic compounds, semivolatile organic compounds, pesticides, PCB's, herbicides, total metals and trace elements, general inorganics, and radiochemistry by sample at ten water-quality sampling sites in the Bahía de Añasco and near Rincón, Puerto Rico, at two sites sampled in the Río Grande de Añasco and the Río Yagüez, and at the influent and effluent of the Mayagüez Regional Wastewater Treatment Plant, January 25-30, 1991-Continued

Appendix E-18. General inorganics and radiochemistry, inside $(0 \mathrm{~W}-4, \mathrm{QW}-5)$ and at the limit ( $0 \mathrm{~W}-3, \mathrm{QW}-6)$ of the initial mixing zone, January $30,1991$.

[Repl., replicate; Rep.Limit, reporting limit; NTU, nephelometric turbidity units; pCi/L, picocuries per liter; Mod. modified; ND, not detected.]

\begin{tabular}{|c|c|c|c|c|c|c|c|c|c|c|c|c|}
\hline \multirow[b]{2}{*}{ Constituent } & \multirow{2}{*}{$\begin{array}{l}\text { Analytical } \\
\text { method }\end{array}$} & \multirow[b]{2}{*}{ units } & \multicolumn{2}{|c|}{ QW-3 } & \multicolumn{2}{|c|}{ QW-4 } & \multicolumn{2}{|c|}{ QW-5 } & \multicolumn{2}{|c|}{ QW-5 } & \multicolumn{2}{|c|}{ QW-6 } \\
\hline & & & Result & $\begin{array}{l}\text { Rep. } \\
\text { Limit }\end{array}$ & Result & $\begin{array}{l}\text { Rep. } \\
\text { Limit }\end{array}$ & Result & $\begin{array}{l}\text { Rep. } \\
\text { Limit }\end{array}$ & Result & $\begin{array}{l}\text { Rep. } \\
\text { Limit }\end{array}$ & Result & $\begin{array}{l}\text { Rep. } \\
\text { Limit }\end{array}$ \\
\hline \multicolumn{13}{|l|}{ General Inorganics } \\
\hline Chloride & A429 & $\mathrm{mg} / \mathrm{L}$ & 20500 & 300 & 20100 & 300 & 20800 & 100 & 18800 & 300 & 21000 & 300 \\
\hline Cyanide & 9012 & $\mathrm{mg} / \mathrm{L}$ & ND & 0.01 & ND & 0.01 & ND & 0.01 & ND & 0.01 & ND & 0.01 \\
\hline Color & 110.2 & units & ND & 5 & ND & 5 & ND & 5 & $\mathrm{ND}$ & 5 & ND & 5 \\
\hline Fluoride & A429 & $\mathrm{mg} / \mathrm{L}$ & 39.3 & 5 & 40.1 & 5 & 39.2 & 5 & 39.3 & 5 & 40.6 & 5 \\
\hline Surfactants (MBAS) & 425.1 & $\mathrm{mg} / \mathrm{L}$ & ND & 1 & ND & 1 & ND & 1 & ND & 1 & ND & 1 \\
\hline Ammonia as $\mathrm{N}$ & 350.1 & $\mathrm{mg} / \mathrm{L}$ & ND & 0.1 & $\mathrm{ND}$ & 0.1 & 0.68 & 0.1 & 0.33 & 0.1 & ND & 0.1 \\
\hline Nitrate plus Nitrite & 353.2 & $\mathrm{mg} / \mathrm{L}$ & ND & 0.1 & ND & 0.1 & ND & 0.1 & ND & 0.1 & ND & 0.1 \\
\hline Orthophosphate as $\mathrm{P}$ & 365.3 & $\mathrm{mg} / \mathrm{L}$ & ND & 0.05 & ND & 0.05 & ND & 0.05 & ND & 0.05 & ND & 0.05 \\
\hline Phenolics & 9065 & $\mathrm{mg} / \mathrm{L}$ & ND & 0.01 & 0.016 & 0.01 & 0.037 & 0.01 & 0.014 & 0.01 & ND & 0.01 \\
\hline Sulfide, Total & 376.2 & $\mathrm{mg} / \mathrm{L}$ & ND & 0.05 & ND & 0.05 & ND & 0.05 & ND & 0.05 & ND & 0.05 \\
\hline Sulfate & A429 & $\mathrm{mg} / \mathrm{L}$ & 2650 & 50 & 2650 & 50 & 2620 & 50 & 2380 & 50 & 2640 & 50 \\
\hline Total Kjeldahl Nitrogen as $\mathrm{N}$ & 351.2 & $\mathrm{mg} / \mathrm{L}$ & ND & 5 & ND & 5 & ND & 5 & ND & 5 & ND & 5 \\
\hline Phosphorus, Total as $\mathrm{P}$ & 365.3 & $\mathrm{mg} / \mathrm{L}$ & ND & 0.05 & ND & 0.05 & ND & 0.05 & ND & 0.05 & ND & 0.05 \\
\hline Turbidity & 180.1 & NTU & 0.58 & 0.1 & 0.62 & 0.1 & 0.58 & 0.1 & 0.62 & 0.1 & 0.41 & 0.1 \\
\hline Total Dissolved Solids & 160.1 & $\mathrm{mg} / \mathrm{L}$ & 36900 & 50 & 33000 & 50 & 35800 & 10 & 37200 & 50 & 37600 & 50 \\
\hline Total Suspended Solids & 160.2 & $\mathrm{mg} / \mathrm{L}$ & 50 & 2 & 46.8 & 2 & 9.2 & 2 & 38.4 & 2 & 6 & 2 \\
\hline Total Volatile Solids & 160.4 & $\mathrm{mg} / \mathrm{L}$ & 3440 & 200 & 3920 & 200 & 2780 & 200 & 3980 & 200 & 3200 & 200 \\
\hline Volatile Suspended Solids & 160.4 & $\mathrm{mg} / \mathrm{L}$ & ND & 10 & ND & 10 & ND & 10 & ND & 10 & ND & 10 \\
\hline \multicolumn{13}{|l|}{ Radiochemistry } \\
\hline & & & & $(+/-)$ & & $(+/-)$ & & $(+/-)$ & & $(+/-)$ & & $(+/-)$ \\
\hline Gross Alpha & 900 & $\mathrm{pCi} / \mathrm{L}$ & 0 & 140 & 0 & 120 & 50 & 150 & 30 & 150 & 0 & 140 \\
\hline Gross Beta & 900 & $\mathrm{pCi} / \mathrm{L}$ & 380 & 160 & 410 & 170 & 290 & 160 & 270 & 150 & 290 & 160 \\
\hline Radium 226 & 705 Mod. & $\mathrm{pCi} / \mathrm{L}$ & 0 & 0.5 & 0 & 0.5 & 0 & 0.5 & 0 & 0.4 & 0 & 0.5 \\
\hline Strontium 90 & A704 & $\mathrm{pCi} / \mathrm{L}$ & 0 & 2.3 & 0 & 1.5 & 0 & 2 & 0 & 1.2 & 0 & 1 \\
\hline
\end{tabular}


Appendix E. General water quality with depth and general water quality, bacteria, volatile organic compounds, semivolatile organic compounds, pesticides, PCB's, herbicides, total metals and trace elements, general inorganics, and radiochemistry by sample at ten water-quality sampling sites in the Bahía de Añasco and near Rincón, Puerto Rico, at two sites sampled in the Río Grande de Añasco and the Río Yagüez, and at the influent and effluent of the Mayagüez Regional Wastewater Treatment Plant, January 25-30, 1991-Continued

Appendix E-19. General water quality inside (OW-4, QW-5) and at the limit (OW-3, QW-6) of the initial mixing zone, January 30,1991.

[Repl., replicate; Rep. Limit, reporting limit; mg/L, milligrams per liter; ${ }^{\circ} \mathrm{C}$, degrees Celsius; $\mu \mathrm{S} / \mathrm{cm}$, microsiemens per centimeter; $\mathrm{k}$, extinction coefficient; $\mathrm{vol} / \mathrm{count}$, volume of sample, in milliliters, filtered (diluted to $100 \mathrm{ml}$ ) and number of bacteria colonies counted using the filter membrane method; col/100ml, colonies of bacteria per 100 milliliters; TNTC, too numerous to count; $\mathrm{mg} / \mathrm{m}^{3}$, milligram per cubic meter; ND, not detected; --, no data.]

\begin{tabular}{|c|c|c|c|c|c|c|c|c|c|c|c|c|c|c|c|c|}
\hline \multirow[b]{2}{*}{ Constituent } & \multirow[b]{2}{*}{ units } & \multicolumn{3}{|c|}{ oW-3 } & \multicolumn{4}{|c|}{ QW-4 } & \multicolumn{2}{|c|}{ QW-5 } & \multicolumn{4}{|c|}{ OW-5 (Repl.) } & \multicolumn{2}{|c|}{ QW-6 } \\
\hline & & \multicolumn{2}{|c|}{ Result } & \multicolumn{2}{|c|}{$\begin{array}{l}\text { Rep. } \\
\text { Limit }\end{array}$} & Result & \multicolumn{2}{|l|}{$\begin{array}{l}\text { Rep. } \\
\text { Limit }\end{array}$} & Result & \multicolumn{2}{|l|}{$\begin{array}{l}\text { Rep. } \\
\text { Limit }\end{array}$} & Result & \multicolumn{2}{|l|}{$\begin{array}{l}\text { Rep. } \\
\text { Limit }\end{array}$} & Result & $\begin{array}{l}\text { Rep. } \\
\text { Limit }\end{array}$ \\
\hline BOD-5 & $\mathrm{mg} / \mathrm{L}$ & & ND & 2 & & 2.1 & 2 & & ND & 2 & & ND & 2 & & ND & 2 \\
\hline Oil and Grease & $\mathrm{mg} / \mathrm{L}$ & & 5.8 & 5 & & -- & -- & & ND & 5 & & ND & 5 & & ND & 5 \\
\hline Settleable Solids & $\mathrm{mg} / \mathrm{L}$ & & 0 & & & 0 & & & -- & & & -- & & & 0 & \\
\hline Water Temperature & ${ }^{\circ} \mathrm{C}$ & & 26.3 & & & 26 & & & 25 & & & 25.9 & & & 25.8 & \\
\hline Alkalinity & $\mathrm{mg} / \mathrm{L}$ & & 120 & & & 120 & & & 120 & & & 120 & & & 130 & \\
\hline Spec. Cond. & $\mu \mathrm{S} / \mathrm{cm}$ & & -- & & & -- & & & $>50000$ & & & $>50000$ & & & $>50000$ & \\
\hline $\mathrm{pH}$ & units & & 8.2 & & & 8.3 & & & 8.1 & & & 8.24 & & & 8.23 & \\
\hline Dissolved Oxygen & $\mathrm{mg} / \mathrm{L}$ & & 7.7 & & & 7.3 & & & 7.8 & & & 9.3 & & & 7.3 & \\
\hline Extinction Coefficient & $\mathrm{k}$ & & 0.21 & & & 0.15 & & & 0.15 & & & 0.15 & & & 0.12 & \\
\hline Chlorophyll-a & $\mathrm{mg} / \mathrm{m}^{3}$ & 0.18 & 813 & & & 0.1771 & & & 0.0872 & & & 0.0872 & & & 0.1005 & \\
\hline \multicolumn{17}{|l|}{ Bacteria } \\
\hline Fecal Coli(vol/count) & & 50 & 29 & & 50 & TNTC & & 50 & 85 & & 50 & 48 & & 50 & 43 & \\
\hline Fecal Coli(vol/count) & & 25 & 11 & & 25 & TNTC & & 25 & 53 & & 25 & 18 & & 25 & 41 & \\
\hline Fecal Coli(vol/count) & & 10 & 4 & & 10 & 49 & & 10 & 21 & & 10 & 6 & & 10 & 16 & \\
\hline & $\mathrm{s} / 100 \mathrm{ml}$ & & 58 & & & 490 & & & 210 & & & 96 & & & 110 & \\
\hline Total Coli(vol/count) & & & TNTC & & 50 & TNTC & & 50 & TNTC & & 50 & TNTC & & 50 & TNTC & \\
\hline Total Coli(vol/count) & & & TNTC & & 25 & TNTC & & 25 & TNTC & & 25 & 80 & & 25 & TNTC & \\
\hline Total Coli(vol/count) & & & 31 & & 10 & TNTC & & 10 & 80 & & 10 & 30 & & 10 & 32 & \\
\hline & $\mathrm{s} / 100 \mathrm{ml}$ & & 310 & & & $\mathrm{~b}>800$ & & & 800 & & & 310 & & & 320 & \\
\hline Enterococcus(dil/count) & & 50 & 1 & & 50 & TNTC & & 50 & 30 & & 50 & 43 & & 50 & 1 & \\
\hline Enterococcus(dil/count) & & 25 & 0 & & 25 & TNTC & & 25 & 4 & & 25 & 4 & & 25 & 4 & \\
\hline Enterococcus(dil/count) & & 10 & 0 & & 10 & TNTC & & 10 & 6 & & 10 & 2 & & 10 & 1 & \\
\hline & $\mathrm{s} / 100 \mathrm{ml}$ & & $\mathrm{b}-2$ & & & $b>600$ & & & 60 & & & 86 & & & $b-7$ & \\
\hline
\end{tabular}


Appendix E. General water quality with depth and general water quality, bacteria, volatile organic compounds, semivolatile organic compounds, pesticides, PCB's, herbicides, total metals and trace elements, general inorganics, and radiochemistry by sample at ten water-quality sampling sites in the Bahía de Añasco and near Rincón, Puerto Rico, at two sites sampled in the Río Grande de Añasco and the Río Yagüez, and at the influent and effluent of the Mayagüez Regional Wastewater Treatment Plant, January 25-30, 1991—Continued

Appendix E-20. Volatile organic compounds, final mixing zone limit (QW-2, QW-7) and far-field sites (QW-1, QW-8), January 29, 1991. [Method 624. Units are micrograms per liter. Rep. Limit, reporting limit; ND, not detected. Values for surrogates represent percent recovery.]

\begin{tabular}{|c|c|c|c|c|c|c|c|c|}
\hline \multirow[b]{2}{*}{ Constituent } & \multicolumn{2}{|c|}{ oW-1 } & \multicolumn{2}{|c|}{ oW-2 } & \multicolumn{2}{|c|}{ OW-7 } & \multicolumn{2}{|c|}{ QW-8 } \\
\hline & Result & $\begin{array}{l}\text { Rep. } \\
\text { Limit }\end{array}$ & Result & $\begin{array}{l}\text { Rep. } \\
\text { Limit }\end{array}$ & Result & $\begin{array}{l}\text { Rep. } \\
\text { Limit }\end{array}$ & Result & $\begin{array}{l}\text { Rep. } \\
\text { Limit }\end{array}$ \\
\hline Acrolein & ND & 100 & ND & 100 & ND & 100 & ND & 100 \\
\hline Acrylonitrile & ND & 100 & ND & 100 & ND & 100 & ND & 100 \\
\hline Benzene & ND & 5 & ND & 5 & ND & 5 & ND & 5 \\
\hline Bromodichloromethane & ND & 5 & ND & 5 & ND & 5 & ND & 5 \\
\hline Bromoform & ND & 5 & ND & 5 & ND & 5 & ND & 5 \\
\hline Bromomethane & ND & 10 & ND & 10 & ND & 10 & ND & 10 \\
\hline Carbon tetrachloride & ND & 5 & ND & 5 & ND & 5 & ND & 5 \\
\hline Chlorobenzene & ND & 5 & ND & 5 & ND & 5 & ND & 5 \\
\hline Chloroethane & ND & 10 & ND & 10 & ND & 10 & ND & 10 \\
\hline Chloroform & ND & 5 & ND & 5 & ND & 5 & ND & 5 \\
\hline Chloromethane & ND & 10 & ND & 10 & ND & 10 & ND & 10 \\
\hline Dibromochloromethane & ND & 5 & ND & 5 & ND & 5 & ND & 5 \\
\hline 1,1-Dichloroethane & ND & 5 & ND & 5 & ND & 5 & ND & 5 \\
\hline 1,2-Dichloroethane & ND & 5 & ND & 5 & ND & 5 & ND & 5 \\
\hline 1,1-Dichloroethene & ND & 5 & ND & 5 & ND & 5 & ND & 5 \\
\hline 1,2-Dichloroethene (total) & ND & 5 & ND & 5 & ND & 5 & ND & 5 \\
\hline 1,2-Dichloropropane & ND & 5 & ND & 5 & ND & 5 & ND & 5 \\
\hline cis-1,3-Dichloropropene & ND & 5 & ND & 5 & ND & 5 & ND & 5 \\
\hline trans-1,3-Dichloropropene & ND & 5 & ND & 5 & ND & 5 & ND & 5 \\
\hline Ethylbenzene & ND & 5 & ND & 5 & ND & 5 & ND & 5 \\
\hline Methylene chloride & ND & 5 & ND & 5 & ND & 5 & ND & 5 \\
\hline 1,1,2,2-Tetrachloroethane & ND & 5 & ND & 5 & ND & 5 & ND & 5 \\
\hline Tetrachloroethene & ND & 5 & ND & 5 & ND & 5 & ND & 5 \\
\hline Toluene & ND & 5 & ND & 5 & ND & 5 & ND & 5 \\
\hline 1,1,1-Trichloroethane & ND & 5 & ND & 5 & ND & 5 & ND & 5 \\
\hline 1,1,2-Trichloroethane & ND & 5 & ND & 5 & ND & 5 & ND & 5 \\
\hline Trichloroethene & ND & 5 & ND & 5 & ND & 5 & ND & 5 \\
\hline Vinyl chloride & ND & 10 & ND & 10 & ND & 10 & ND & 10 \\
\hline Surrogate & & & & Recor & & & & \\
\hline Toluene-d8 & 101 & & 99 & & 100 & & 102 & \\
\hline 4-Bromofluorobenzene & 101 & & 99 & & 100 & & 99 & \\
\hline 1,2-Dichloroethane-d4 & 95 & & 100 & & 102 & & 98 & \\
\hline
\end{tabular}


Appendix E. General water quality with depth and general water quality, bacteria, volatile organic compounds, semivolatile organic compounds, pesticides, PCB's, herbicides, total metals and trace elements, general inorganics, and radiochemistry by sample at ten water-quality sampling sites in the Bahía de Añasco and near Rincón, Puerto Rico, at two sites sampled in the Río Grande de Añasco and the Río Yagüez, and at the influent and effluent of the Mayagüez Regional Wastewater Treatment Plant, January 25-30, 1991—Continued

Appendix E-21. Semivolatile organic compounds at the final mixing zone limit (QW-2, QW-7) and at far-field sites (QW-1, QW-8), January 29, 1991.

[Method 625. Units are micrograms per liter; ND, not detected; NR, not reported; conf. level, confidence level. Values for surrogates represent percent recovery. All tentatively identified compounds were found in the base neutral acids. Confidence levels for the tentatively identified compounds: 1- tentative; 2-confident; and 3-confirmed.]

\begin{tabular}{|c|c|c|c|c|c|c|c|c|}
\hline \multirow[b]{2}{*}{ Constituent } & \multicolumn{2}{|c|}{ OW-1 } & \multicolumn{2}{|c|}{ oW-2 } & \multicolumn{2}{|c|}{ QW-7 } & \multicolumn{2}{|c|}{ QW-8 } \\
\hline & Result & $\begin{array}{l}\text { Rep. } \\
\text { Limit }\end{array}$ & Result & $\begin{array}{l}\text { Rep. } \\
\text { Limit }\end{array}$ & Result & $\begin{array}{l}\text { Rep. } \\
\text { Limit }\end{array}$ & Result & $\begin{array}{l}\text { Rep. } \\
\text { Limit }\end{array}$ \\
\hline Acenaphthene & ND & 10 & ND & 10 & ND & 10 & ND & 10 \\
\hline Acenaphthylene & ND & 10 & ND & 10 & ND & 10 & ND & 10 \\
\hline Anthracene & ND & 10 & ND & 10 & ND & 10 & ND & 10 \\
\hline Benzidine & ND & 100 & ND & 100 & ND & 100 & ND & 100 \\
\hline Benzo a-anthracene & ND & 10 & ND & 10 & ND & 10 & ND & 10 \\
\hline Benzo $b$ fluoranthene & ND & 10 & ND & 10 & ND & 10 & ND & 10 \\
\hline Benzo k fluoranthene & ND & 10 & ND & 10 & ND & 10 & ND & 10 \\
\hline Benzo $(\mathrm{g}, \mathrm{h}, \mathrm{i})$ perylene & ND & 10 & ND & 10 & ND & 10 & ND & 10 \\
\hline Benzo (a)pyrene & ND & 10 & ND & 10 & ND & 10 & ND & 10 \\
\hline 4-Bromophenyl phenyl ether & ND & 10 & ND & 10 & ND & 10 & ND & 10 \\
\hline Butyl benzyl phthalate & ND & 10 & ND & 10 & ND & 10 & ND & 10 \\
\hline bis(2-Chloroethoxy)-methane & ND & 10 & ND & 10 & ND & 10 & ND & 10 \\
\hline bis(2-Chloroethyl) ether & ND & 10 & ND & 10 & ND & 10 & ND & 10 \\
\hline bis(2-Chloroisopropyl)-ether & ND & 10 & ND & 10 & ND & 10 & ND & 10 \\
\hline 4-Chloro-3-methylphenol & ND & 10 & ND & 10 & ND & 10 & ND & 10 \\
\hline 2-Chloronaphthalene & ND & 10 & ND & 10 & ND & 10 & ND & 10 \\
\hline 2-Chlorophenol & ND & 10 & ND & 10 & ND & 10 & ND & 10 \\
\hline 4-Chlorophenyl phenyl ether & ND & 10 & ND & 10 & ND & 10 & ND & 10 \\
\hline Chrysene & ND & 10 & ND & 10 & ND & 10 & ND & 10 \\
\hline Dibenz(a,h)anthracene & ND & 10 & ND & 10 & ND & 10 & ND & 10 \\
\hline Di-n-butyl phthalate & ND & 10 & ND & 10 & ND & 10 & ND & 10 \\
\hline 1,2-Dichlorobenzene & ND & 10 & ND & 10 & ND & 10 & ND & 10 \\
\hline 1,3-Dichlorobenzene & ND & 10 & ND & 10 & ND & 10 & ND & 10 \\
\hline 1,4-Dichlorobenzene & ND & 10 & ND & 10 & ND & 10 & ND & 10 \\
\hline 3,3'-Dichlorobenzidine & ND & 20 & ND & 20 & ND & 20 & ND & 20 \\
\hline 2,4-Dichlorophenol & ND & 10 & ND & 10 & ND & 10 & ND & 10 \\
\hline Diethyl phthalate & ND & 10 & ND & 10 & ND & 10 & ND & 10 \\
\hline 2,4-DimethylPhenol & ND & 10 & ND & 10 & ND & 10 & ND & 10 \\
\hline Dimethyl phthalate & ND & 10 & ND & 10 & ND & 10 & ND & 10 \\
\hline
\end{tabular}


Appendix E. General water quality with depth and general water quality, bacteria, volatile organic compounds, semivolatile organic compounds, pesticides, PCB's, herbicides, total metals and trace elements, general inorganics, and radiochemistry by sample at 10 water-quality sampling sites in the Bahía de Añasco and near Rincón, Puerto Rico, at two sites sampled in the Río Grande de Añasco and the Río Yagüez, and at the influent and effluent of the Mayagüez Regional Wastewater Treatment Plant, January 25-30, 1991-Continued

Appendix E-21. Semivolatile organic compounds at the final mixing zone limit (QW-2, QW-7) and at far-field sites (QW-1, QW-8), January 29, 1991--Continued.

[Method 625. Units are micrograms per liter; ND, not detected; NR, not reported; conf. level, confidence level. Values for surrogates represent percent recovery. All tentatively identified compounds were found in the base neutral acids. Confidence levels for the tentatively identified compounds: 1- tentative; 2-confident; and 3-confirmed.]

\begin{tabular}{|c|c|c|c|c|c|c|c|c|}
\hline \multirow[b]{2}{*}{ Constituent } & \multicolumn{2}{|c|}{ oW-1 } & \multicolumn{2}{|c|}{ oW-2 } & \multicolumn{2}{|c|}{ oW-7 } & \multicolumn{2}{|c|}{ oW-8 } \\
\hline & Result & $\begin{array}{l}\text { Rep. } \\
\text { Limit }\end{array}$ & Result & $\begin{array}{l}\text { Rep. } \\
\text { Limit }\end{array}$ & Result & $\begin{array}{l}\text { Rep. } \\
\text { Limit }\end{array}$ & Result & $\begin{array}{l}\text { Rep. } \\
\text { Limit }\end{array}$ \\
\hline 4,6-Dinitro-2-methylphenol & ND & 50 & ND & 50 & ND & 50 & ND & 50 \\
\hline 2,4-Dinitrophenol & ND & 50 & ND & 50 & ND & 50 & ND & 50 \\
\hline 2,4-Dinitrotoluene & ND & 10 & ND & 10 & ND & 10 & ND & 10 \\
\hline 2,6-Dinitrotoluene & ND & 10 & ND & 10 & ND & 10 & ND & 10 \\
\hline Di-n-octylphthalate & ND & 10 & ND & 10 & ND & 10 & ND & 10 \\
\hline 1,2-Diphenylhydrazine & ND & 10 & ND & 10 & ND & 10 & ND & 10 \\
\hline bis(2-Ethylhexyl)phthalate & ND & 10 & ND & 10 & ND & 10 & ND & 10 \\
\hline Fluoranthene & ND & 10 & ND & 10 & ND & 10 & ND & 10 \\
\hline Fluorene & ND & 10 & ND & 10 & ND & 10 & ND & 10 \\
\hline Hexachlorobenzene & ND & 10 & ND & 10 & ND & 10 & ND & 10 \\
\hline Hexachlorobutadiene & ND & 10 & ND & 10 & ND & 10 & ND & 10 \\
\hline Hexachlorocyclopentadiene & ND & 10 & ND & 10 & ND & 10 & ND & 10 \\
\hline Hexachloroethane & ND & 10 & ND & 10 & ND & 10 & ND & 10 \\
\hline Indeno(1,2,3-cd)pyrene & ND & 10 & ND & 10 & ND & 10 & ND & 10 \\
\hline Isophorone & ND & 10 & ND & 10 & ND & 10 & ND & 10 \\
\hline Naphthalene & ND & 10 & ND & 10 & ND & 10 & ND & 10 \\
\hline Nitrobenzene & ND & 10 & ND & 10 & ND & 10 & ND & 10 \\
\hline 2-Nitrophenol & ND & 10 & ND & 10 & ND & 10 & ND & 10 \\
\hline 4-Nitrophenol & ND & 50 & ND & 50 & ND & 50 & ND & 50 \\
\hline N-Nitrosodimethylamine & ND & 10 & ND & 10 & ND & 10 & ND & 10 \\
\hline N-Nitrosodiphenylamine & ND & 10 & ND & 10 & ND & 10 & ND & 10 \\
\hline N-Nitroso-di-n-Propylamine & ND & 10 & ND & 10 & ND & 10 & ND & 10 \\
\hline Pentachlorophenol & ND & 50 & ND & 50 & ND & 50 & ND & 50 \\
\hline Phenanthrene & ND & 10 & ND & 10 & ND & 10 & ND & 10 \\
\hline Phenol & ND & 10 & ND & 10 & ND & 10 & ND & 10 \\
\hline Pyrene & ND & 10 & ND & 10 & ND & 10 & ND & 10 \\
\hline 1,2,4-Trichlorobenzene & ND & 10 & ND & 10 & ND & 10 & ND & 10 \\
\hline
\end{tabular}


Appendix E. General water quality with depth and general water quality, bacteria, volatile organic compounds, semivolatile organic compounds, pesticides, PCB's, herbicides, total metals and trace elements, general inorganics, and radiochemistry by sample at 10 water-quality sampling sites in the Bahía de Añasco and near Rincón, Puerto Rico, at two sites sampled in the Río Grande de Añasco and the Río Yagüez, and at the influent and effluent of the Mayagüez Regional Wastewater Treatment Plant, January 25-30, 1991-Continued

Appendix E-21. Semivolatile organic compounds at the final mixing zone limit (OW-2, $0 \mathrm{~W}-7)$ and at far-field sites (QW-1, QW-8), January 29, 1991--Continued.

[Method 625. Units are micrograms per liter; ND, not detected; NR, not reported; conf. level, confidence level. Values for surrogates represent percent recovery. All tentatively identified compounds were found in the base neutral acids. Confidence levels for the tentatively identified compounds: 1- tentative; 2-confident; and 3-confirmed.]

\begin{tabular}{|c|c|c|c|c|c|c|c|c|}
\hline \multirow[b]{2}{*}{ Constituent } & \multicolumn{2}{|c|}{ QW-1 } & \multicolumn{2}{|c|}{ oW-2 } & \multicolumn{2}{|c|}{ oW-7 } & \multicolumn{2}{|c|}{ QW-8 } \\
\hline & Result & $\begin{array}{l}\text { Rep. } \\
\text { Limit }\end{array}$ & Result & $\begin{array}{l}\text { Rep. } \\
\text { Limit }\end{array}$ & Result & $\begin{array}{l}\text { Rep. } \\
\text { Limit }\end{array}$ & Result & $\begin{array}{l}\text { Rep. } \\
\text { Limit }\end{array}$ \\
\hline 2,4,6-Trichlorophenol & ND & 10 & ND & 10 & ND & 10 & ND & 10 \\
\hline Surrogate & \multicolumn{8}{|c|}{ Recovery } \\
\hline Nitrobenzene-d5 & 57 & & 62 & & 53 & & 55 & \\
\hline 2-Fluorobiphenyl & 52 & & 59 & & 48 & & 53 & \\
\hline Terphenyl-dl4 & 88 & & 92 & & 91 & & 88 & \\
\hline Phenol-d5 & 54 & & 60 & & 50 & & 49 & \\
\hline 2-Fluorophenol & 52 & & 58 & & 47 & & 47 & \\
\hline \multirow[t]{5}{*}{ 2,4,6-Tribromophenol } & 80 & & 78 & & 64 & & & \\
\hline & \multicolumn{6}{|c|}{ Tentatively identified compounds } & & \\
\hline & Site & & Const & uent & $\begin{array}{l}\text { conf. } \\
\text { level }\end{array}$ & conc. & & \\
\hline & QW-2 & & $\begin{array}{l}\text { Oxygena } \\
\text { hydrocar }\end{array}$ & & NR & 13 & & \\
\hline & QW-7 & & $\begin{array}{l}\text { Oxygena } \\
\text { hydrocar }\end{array}$ & & NR & 11 & & \\
\hline
\end{tabular}


Appendix E. General water quality with depth and general water quality, bacteria, volatile organic compounds, semivolatile organic compounds, pesticides, PCB's, herbicides, total metals and trace elements, general inorganics, and radiochemistry by sample at ten water-quality sampling sites in the Bahía de Añasco and near Rincón, Puerto Rico, at two sites sampled in the Río Grande de Añasco and the Río Yagüez, and at the influent and effluent of the Mayagüez Regional Wastewater Treatment Plant, January 25-30, 1991—Continued

Appendix E-22. Concentrations of pesticides, PCB's, and herbicides at the final mixing zone limit (0W-2, QW-7) and at far-field sites (QW-1, QW-8), January 29, 1991.

[Units are micrograms per liter. Rep. Limit, reporting limit; ND, not detected. Values for surrogates represent percent recovery. Sporadic hits reported as ND unless verified in 2nd-column test.]

\begin{tabular}{|c|c|c|c|c|c|c|c|c|}
\hline \multirow[b]{2}{*}{ Constituent } & \multicolumn{2}{|c|}{ oW-1 } & \multicolumn{2}{|c|}{$\mathrm{QW}-2$} & \multicolumn{2}{|c|}{ oW-7 } & \multicolumn{2}{|c|}{ QW-8 } \\
\hline & Result & $\begin{array}{l}\text { Rep. } \\
\text { Limit }\end{array}$ & Result & $\begin{array}{l}\text { Rep. } \\
\text { Limit }\end{array}$ & Result & $\begin{array}{l}\text { Rep. } \\
\text { Limit }\end{array}$ & Result & $\begin{array}{l}\text { Rep. } \\
\text { Limit }\end{array}$ \\
\hline \multicolumn{9}{|c|}{ Organochlorine Pesticides/PCB's } \\
\hline \multicolumn{9}{|l|}{ Method 8080} \\
\hline alpha-BHC & ND & 0.05 & ND & 0.05 & ND & 0.05 & ND & 0.05 \\
\hline beta-BHC & ND & 0.05 & ND & 0.05 & ND & 0.05 & ND & 0.05 \\
\hline delta-BHC & ND & 0.05 & ND & 0.05 & ND & 0.05 & ND & 0.05 \\
\hline gamma-BHC (Lindane) & ND & 0.05 & ND & 0.05 & ND & 1 & ND & 0.05 \\
\hline Toxaphene & ND & 1 & ND & 1 & ND & 0.05 & ND & 1 \\
\hline Heptachlor & ND & 0.02 & ND & 0.02 & ND & 0.02 & ND & 0.02 \\
\hline Aldrin & ND & 0.05 & ND & 0.05 & ND & 0.05 & ND & 0.05 \\
\hline Heptachlor epoxide & ND & 0.05 & ND & 0.05 & ND & 0.05 & ND & 0.05 \\
\hline Endosulfan I & ND & 0.05 & ND & 0.05 & ND & 0.05 & ND & 0.05 \\
\hline Dieldrin & ND & 0.02 & ND & 0.02 & ND & 0.02 & ND & 0.02 \\
\hline 4,4'-DDE & ND & 0.1 & ND & 0.1 & ND & 0.1 & ND & 0.1 \\
\hline Endrin & ND & 0.06 & ND & 0.06 & ND & 0.06 & ND & 0.06 \\
\hline Endosulfan II & ND & 0.1 & ND & 0.1 & ND & 0.1 & ND & 0.1 \\
\hline 4,4'-DDD & ND & 0.1 & ND & 0.1 & ND & 0.1 & ND & 0.1 \\
\hline Endosulfan sulfate & ND & 0.1 & ND & 0.1 & ND & 0.1 & ND & 0.1 \\
\hline 4,4'-DDT & ND & 0.1 & ND & 0.1 & ND & 0.1 & ND & 0.1 \\
\hline Endrin aldehyde & ND & 0.1 & ND & 0.1 & ND & 0.1 & ND & 0.1 \\
\hline Chlordane & ND & 0.05 & ND & 0.05 & ND & 0.05 & ND & 0.05 \\
\hline Aroclor 1016 & ND & 0.5 & ND & 0.5 & ND & 0.5 & ND & 0.5 \\
\hline Aroclor 1221 & ND & 0.5 & ND & 0.5 & ND & 0.5 & ND & 0.5 \\
\hline Aroclor 1232 & ND & 0.5 & ND & 0.5 & ND & 0.5 & ND & 0.5 \\
\hline Aroclor 1242 & ND & 0.5 & ND & 0.5 & ND & 0.5 & ND & 0.5 \\
\hline Aroclor 1248 & ND & 0.5 & ND & 0.5 & ND & 0.5 & ND & 0.5 \\
\hline Aroclor 1254 & ND & 1 & ND & 1 & ND & 1 & ND & 1 \\
\hline Aroclor 1260 & ND & 1 & ND & 1 & ND & 1 & ND & 1 \\
\hline Mirex & ND & 0.05 & ND & 0.05 & ND & 0.05 & ND & 0.05 \\
\hline Ethylan (Perthane) & ND & 0.5 & ND & 0.5 & ND & 0.5 & ND & 0.5 \\
\hline
\end{tabular}


Appendix E. General water quality with depth and general water quality, bacteria, volatile organic compounds, semivolatile organic compounds, pesticides, PCB's, herbicides, total metals and trace elements, general inorganics, and radiochemistry by sample at 10 water-quality sampling sites in the Bahía de Añasco and near Rincón, Puerto Rico, at two sites sampled in the Río Grande de Añasco and the Río Yagüez, and at the influent and effluent of the Mayagüez Regional Wastewater Treatment Plant, January 25-30, 1991-Continued

Appendix E-22. Concentrations of pesticides, PCB's, and herbicides at the final mixing zone limit (QW-2, QW-7) and at far-field sites (OW-1, QW-8), January 29, 1991--Continued.

[Units are micrograms per liter. Rep. Limit, reporting limit; ND, not detected. Values for surrogates represent percent recovery. Sporadic hits reported as ND unless verified in 2nd-column test.]

\begin{tabular}{|c|c|c|c|c|c|c|c|c|}
\hline \multirow[b]{2}{*}{ Constituent } & \multicolumn{2}{|c|}{ oW-1 } & \multicolumn{2}{|c|}{$\mathrm{OW}-2$} & \multicolumn{2}{|c|}{ QW-7 } & \multicolumn{2}{|c|}{ QW-8 } \\
\hline & Result & $\begin{array}{l}\text { Rep. } \\
\text { Limit }\end{array}$ & Result & $\begin{array}{l}\text { Rep. } \\
\text { Limit }\end{array}$ & Result & $\begin{array}{l}\text { Rep. } \\
\text { Limit }\end{array}$ & Result & $\begin{array}{l}\text { Rep. } \\
\text { Limit }\end{array}$ \\
\hline Methoxychlor & ND & 0.5 & ND & 0.5 & ND & 0.5 & ND & 0.5 \\
\hline Surrogate & \multicolumn{8}{|c|}{ Recovery } \\
\hline Dibutyl chlorendate & 114 & & 119 & & 114 & & 116 & \\
\hline \multicolumn{9}{|l|}{ Organophosphorus Pesticides } \\
\hline \multicolumn{9}{|l|}{ SW-846 List } \\
\hline \multicolumn{9}{|l|}{ Method 8141} \\
\hline Azinphos-methyl (Guthion) & ND & 2.5 & ND & 2.5 & ND & 2.5 & ND & 2.5 \\
\hline Chlorpyrifos (Dursban) & ND & 0.25 & ND & 0.25 & ND & 0.25 & ND & 0.25 \\
\hline Coumaphos & ND & 0.5 & ND & 0.5 & ND & 0.5 & ND & 0.5 \\
\hline Demeton O\&S & ND & 0.25 & ND & 0.25 & ND & 0.25 & ND & 0.25 \\
\hline Fenthion (Baytex) & ND & 0.25 & ND & 0.25 & ND & 0.25 & ND & 0.25 \\
\hline Malathion & ND & 1.2 & ND & 1.2 & ND & 1.2 & ND & 1.2 \\
\hline Naled (Dibrom) & ND & 10 & ND & 10 & ND & 10 & ND & 10 \\
\hline Ethyl parathion & ND & 0.25 & ND & 0.25 & ND & 0.25 & ND & 0.25 \\
\hline Methyl parathion & ND & 0.25 & ND & 0.25 & ND & 0.25 & ND & 0.25 \\
\hline \multicolumn{9}{|l|}{ Chlorinated Herbicides } \\
\hline \multicolumn{9}{|l|}{ Method 8150} \\
\hline $2,4-\mathrm{D}$ & ND & 1.2 & ND & 1.2 & ND & 1.2 & ND & 1.2 \\
\hline 2,4,5-TP (Silvex) & ND & 0.17 & ND & 0.17 & ND & 0.17 & ND & 0.17 \\
\hline Surrogate & \multicolumn{8}{|c|}{ Recovery } \\
\hline DCAA & 93 & & 82 & & 104 & & 83 & \\
\hline
\end{tabular}


Appendix E. General water quality with depth and general water quality, bacteria, volatile organic compounds, semivolatile organic compounds, pesticides, PCB's, herbicides, total metals and trace elements, general inorganics, and radiochemistry by sample at ten water-quality sampling sites in the Bahía de Añasco and near Rincón, Puerto Rico, at two sites sampled in the Río Grande de Añasco and the Río Yagüez, and at the influent and effluent of the Mayagüez Regional Wastewater Treatment Plant, January 25-30, 1991—Continued

Appendix E-23. Concentrations of total metals at the final mixing zone limit (QW-2, QW-7) and at far-field sites (OW-1, QW-8), January 29, 1991.

[Units are milligrams per liter. Rep. Limit, reporting limit; ND, not detected.]

\begin{tabular}{|c|c|c|c|c|c|c|c|c|c|}
\hline \multirow[b]{2}{*}{ Constituent } & \multirow{2}{*}{$\begin{array}{c}\text { Analytical } \\
\text { method }\end{array}$} & \multicolumn{2}{|c|}{ oW-1 } & \multicolumn{2}{|c|}{ oW-2 } & \multicolumn{2}{|c|}{ QW-7 } & \multicolumn{2}{|c|}{ OW-8 } \\
\hline & & Result & $\begin{array}{l}\text { Rep. } \\
\text { Limit }\end{array}$ & Result & $\begin{array}{l}\text { Rep. } \\
\text { Limit }\end{array}$ & Result & $\begin{array}{l}\text { Rep. } \\
\text { Limit }\end{array}$ & Result & $\begin{array}{l}\text { Rep. } \\
\text { Limit }\end{array}$ \\
\hline Antimony & 7041 & ND & 0.02 & ND & 0.02 & ND & 0.02 & ND & 0.04 \\
\hline Beryllium & 7090 & ND & 0.05 & ND & 0.05 & ND & 0.05 & ND & 0.05 \\
\hline Copper & 7210 & ND & 0.05 & ND & 0.05 & ND & 0.05 & ND & 0.05 \\
\hline Nickel & 7520 & ND & 0.1 & ND & 0.1 & ND & 0.1 & ND & 0.1 \\
\hline Chromium (VI) & 7196 & ND & 0.01 & ND & 0.01 & ND & 0.01 & ND & 0.01 \\
\hline Aluminum & 6010 & ND & 2 & ND & 2 & ND & 2 & ND & 2 \\
\hline Silver & 7761 & ND & 0.0025 & ND & 0.0005 & ND & 0.0005 & ND & 0.0005 \\
\hline Cadmium & 7131 & ND & 0.0005 & ND & 0.002 & ND & 0.002 & ND & 0.001 \\
\hline Zinc & 7950 & ND & 0.02 & ND & 0.02 & ND & 0.02 & ND & 0.02 \\
\hline Chromium & 7191 & 0.026 & 0.01 & 0.019 & 0.01 & 0.022 & 0.022 & 0.017 & 0.01 \\
\hline Arsenic & 7060 & ND & 0.025 & ND & 0.01 & ND & 0.005 & ND & 0.01 \\
\hline Barium & 6010 & ND & 0.2 & ND & 0.2 & ND & 0.2 & ND & 0.2 \\
\hline Boron & 6010 & 5.6 & 2 & 5.4 & 2 & 5.3 & 2 & 5.1 & 2 \\
\hline Calcium & 6010 & 471 & 4 & 460 & 4 & 450 & 4 & 433 & 4 \\
\hline Iron & 6010 & ND & 2 & ND & 2 & ND & 2 & ND & 2 \\
\hline Lead & 7421 & ND & 0.2 & 0.12 & 0.025 & ND & 0.005 & ND & 0.05 \\
\hline Magnesium & 6010 & 1490 & 4 & 1430 & 4 & 1400 & 4 & 1350 & 4 \\
\hline Manganese & 6010 & ND & 0.2 & ND & 0.2 & ND & 0.2 & ND & 0.2 \\
\hline Mercury & 7470 & ND & 0.0002 & ND & 0.0002 & ND & 0.0002 & ND & 0.0002 \\
\hline Potassium & 6010 & 496 & 100 & 388 & 100 & 373 & 100 & 393 & 100 \\
\hline Selenium & 7740 & ND & 0.01 & ND & 0.02 & ND & 0.005 & ND & 0.02 \\
\hline Silica as $\mathrm{SiO}^{2}$ & 6010 & ND & 10 & ND & 10 & ND & 10 & ND & 10 \\
\hline Sodium & 6010 & 12500 & 100 & 11300 & 100 & 11000 & 100 & 10900 & 100 \\
\hline Strontium & 6010 & 8 & 1 & 8 & 1 & 7.9 & 1 & 7.4 & 1 \\
\hline Thallium & 7841 & ND & 0.01 & ND & 0.05 & ND & 0.005 & ND & 0.02 \\
\hline
\end{tabular}


Appendix E. General water quality with depth and general water quality, bacteria, volatile organic compounds, semivolatile organic compounds, pesticides, PCB's, herbicides, total metals and trace elements, general inorganics, and radiochemistry by sample at ten water-quality sampling sites in the Bahía de Añasco and near Rincón, Puerto Rico, at two sites sampled in the Río Grande de Añasco and the Río Yagüez, and at the influent and effluent of the Mayagüez Regional Wastewater Treatment Plant, January 25-30, 1991—Continued

Appendix E-24. General inorganics and radiochemistry at the final mixing zone limit (QW-2, QW-7) and at far-field sites (QW-1, QW-8), January 29, 1991.

[Units are milligrams per liter. Abbreviations: Rep. Limit, reporting limit; NTU, nephelometric turbidity units; pCi/L, picocuries per liter; ND, not detected; Mod. modified.]

\begin{tabular}{|c|c|c|c|c|c|c|c|c|c|c|}
\hline \multirow[b]{2}{*}{ Constituent } & \multirow[b]{2}{*}{$\begin{array}{l}\text { Analytical } \\
\text { method }\end{array}$} & \multirow[b]{2}{*}{ units } & \multicolumn{2}{|c|}{ oW-1 } & \multicolumn{2}{|c|}{$\mathrm{oW}-2$} & \multicolumn{2}{|c|}{ oW-7 } & \multicolumn{2}{|c|}{ QW-8 } \\
\hline & & & Result & $\begin{array}{l}\text { Rep. } \\
\text { Limit }\end{array}$ & Result & $\begin{array}{l}\text { Rep. } \\
\text { Limit }\end{array}$ & Result & $\begin{array}{l}\text { Rep. } \\
\text { Limit }\end{array}$ & Result & $\begin{array}{l}\text { Rep. } \\
\text { Limit }\end{array}$ \\
\hline \multicolumn{11}{|l|}{ General Inorganics } \\
\hline Chloride & A429 & $\mathrm{mg} / \mathrm{L}$ & 21100 & 250 & 21100 & 250 & 21100 & 250 & 20900 & 250 \\
\hline Cyanide & 9012 & $\mathrm{mg} / \mathrm{L}$ & ND & 0.01 & ND & 0.01 & ND & 0.01 & ND & 0.01 \\
\hline Color & 110.2 & units & ND & 5 & ND & 5 & ND & 5 & ND & 5 \\
\hline Fluoride & A429 & $\mathrm{mg} / \mathrm{L}$ & 26.6 & 5 & 30.8 & 5 & 47.7 & 5 & 30.2 & 5 \\
\hline Surfactants (MBAS) & 425.1 & $\mathrm{mg} / \mathrm{L}$ & ND & 1 & ND & 1 & ND & 1 & ND & 1 \\
\hline Ammonia as $\mathrm{N}$ & 350.1 & $\mathrm{mg} / \mathrm{L}$ & ND & 0.1 & ND & 0.1 & ND & 0.1 & ND & 0.1 \\
\hline Nitrate plus Nitrite & 353.2 & $\mathrm{mg} / \mathrm{L}$ & ND & 0.1 & ND & 0.1 & ND & 0.1 & ND & 0.1 \\
\hline Orthophosphate as P & 365.3 & $\mathrm{mg} / \mathrm{L}$ & ND & 0.05 & ND & 0.05 & ND & 0.05 & ND & 0.05 \\
\hline Phenolics & 9065 & $\mathrm{mg} / \mathrm{L}$ & ND & 0.01 & ND & 0.01 & ND & 0.01 & ND & 0.01 \\
\hline Sulfide, Total & 376.2 & $\mathrm{mg} / \mathrm{L}$ & ND & 0.05 & ND & 0.05 & ND & 0.05 & ND & 0.05 \\
\hline Sulfate & A429 & $\mathrm{mg} / \mathrm{L}$ & 2820 & 25 & 2850 & 25 & 2800 & 25 & 2810 & 25 \\
\hline Total Kjeldahl Nitrogen as $\mathrm{N}$ & 351.2 & $\mathrm{mg} / \mathrm{L}$ & ND & 5 & ND & 5 & ND & 5 & ND & 5 \\
\hline Phosphorus, Total as $\mathrm{P}$ & 365.3 & $\mathrm{mg} / \mathrm{L}$ & ND & 0.05 & ND & 0.05 & 2.7 & 0.5 & ND & 0.05 \\
\hline Turbidity & 180.1 & NTU & 0.15 & 0.1 & 0.22 & 0.1 & 0.15 & 0.1 & 0.18 & 0.1 \\
\hline Total Dissolved Solids & 160.1 & $\mathrm{mg} / \mathrm{L}$ & 39200 & 50 & 37100 & 50 & 35100 & 50 & 38600 & 50 \\
\hline Total Suspended Solids & 160.2 & $\mathrm{mg} / \mathrm{L}$ & 14.8 & 2 & 12 & 2 & 9.2 & 2 & 8 & 2 \\
\hline Total Volatile Solids & 160.4 & $\mathrm{mg} / \mathrm{L}$ & 2530 & 10 & 2890 & 10 & 3150 & 10 & 3340 & 200 \\
\hline Volatile Suspended Solids & 160.4 & $\mathrm{mg} / \mathrm{L}$ & ND & 10 & ND & 10 & ND & 10 & ND & 10 \\
\hline \multicolumn{11}{|l|}{ Radiochemistry } \\
\hline & & & & $(+/-)$ & & $(+/-)$ & & $(+/-)$ & & $(+/-)$ \\
\hline Gross Alpha & 900 & $\mathrm{pCi} / \mathrm{L}$ & 80 & 170 & 0 & 0.4 & 0 & 130 & 30 & 140 \\
\hline Gross Beta & 900 & $\mathrm{pCi} / \mathrm{L}$ & 250 & 160 & 380 & 160 & 400 & 170 & 290 & 160 \\
\hline Radium 226 & 705 Mod. & $\mathrm{pCi} / \mathrm{L}$ & 0 & 0.4 & 0 & 71 & 0 & 0.4 & 0 & 0.4 \\
\hline Strontium 90 & A704 & $\mathrm{pCi} / \mathrm{L}$ & 0 & 2.9 & 0 & 1.2 & 0 & 1.4 & 0 & 1.2 \\
\hline
\end{tabular}


Appendix E. General water quality with depth and general water quality, bacteria, volatile organic compounds, semivolatile organic compounds, pesticides, PCB's, herbicides, total metals and trace elements, general inorganics, and radiochemistry by sample at ten water-quality sampling sites in the Bahía de Añasco and near Rincón, Puerto Rico, at two sites sampled in the Río Grande de Añasco and the Río Yagüez, and at the influent and effluent of the Mayagüez Regional Wastewater Treatment Plant, January 25-30, 1991-Continued

Appendix E-25. General water quality at the final mixing zone limit (QW-2, QW-7) and at far-field sites (QW-1, QW-8), January 29, 1991.

[mg/L, milligrams per liter; ${ }^{\circ} \mathrm{C}$, degrees Celsius; $\mathrm{k}$, extinction coefficient; vol/count, volume of sample filtered (rest made up to $\left.100 \mathrm{ml}\right)$ and number of bacteria colonies counted using the filter membrane method; col/100ml, colonies of bacteria per 100 milliliters; TNTC, too numerous to count; $\mu$ S/cm, microsiemens per centimeter; $\mathrm{mg} / \mathrm{m}^{3}$, milligram per cubic meter; ND, not detected; --, no data.]

\begin{tabular}{|c|c|c|c|c|c|c|c|c|c|}
\hline \multirow[b]{2}{*}{ Constituent } & \multirow[b]{2}{*}{ units } & \multicolumn{2}{|c|}{ oW-1 } & \multicolumn{2}{|c|}{ oW-2 } & \multicolumn{2}{|c|}{ QW-7 } & \multicolumn{2}{|c|}{ QW-8 } \\
\hline & & Result & $\begin{array}{c}\text { Rep.L } \\
\text { imit }\end{array}$ & Result & $\begin{array}{l}\text { Rep. } \\
\text { Limit }\end{array}$ & Result & $\begin{array}{l}\text { Rep. } \\
\text { Limit }\end{array}$ & Result & $\begin{array}{l}\text { Rep. } \\
\text { Limit }\end{array}$ \\
\hline BOD-5 & $\mathrm{mg} / \mathrm{L}$ & ND & 2 & ND & 2 & ND & 2 & ND & 2 \\
\hline Oil and Grease & $\mathrm{mg} / \mathrm{L}$ & ND & 5 & ND & 5 & ND & 5 & ND & 5 \\
\hline Settleable Solids & $\mathrm{mg} / \mathrm{L}$ & 0 & & 0 & & 0 & & 0 & \\
\hline Water Temperature & ${ }^{\circ} \mathrm{C}$ & 26 & & 26 & & 26 & & 26 & \\
\hline Alkalinity & $\mathrm{mg} / \mathrm{L}$ & 120 & & 120 & & 120 & & 120 & \\
\hline Spec.Cond. & $\mu \mathrm{S} / \mathrm{cm}$ & 48000 & & 49500 & & 49500 & & 48000 & \\
\hline $\mathrm{pH}$ & units & 8.27 & & 8.26 & & 8.25 & & 8.26 & \\
\hline Dissolved Oxygen & $\mathrm{mg} / \mathrm{L}$ & 7.58 & & 7.9 & & 7.3 & & 7.3 & \\
\hline Extinction Coefficient & $\mathrm{k}$ & 0.12 & & 0.18 & & 0.3 & & 0.06 & \\
\hline Chlorophyll-a & $\mathrm{mg} / \mathrm{m}^{3}$ & 0.1098 & & 0.1539 & & 0.0985 & & 0.0958 & \\
\hline
\end{tabular}

Bacteria

\begin{tabular}{|c|c|c|c|c|c|c|c|c|}
\hline Fecal Coli(vol/count) & 50 & 1 & 50 & 0 & 50 & 0 & 50 & 1 \\
\hline Fecal Coli(vol/count) & 25 & 0 & 25 & 0 & 25 & 0 & 25 & 0 \\
\hline \multirow[t]{2}{*}{ Fecal Coli(vol/count) } & 10 & 0 & 10 & 0 & 10 & 0 & 10 & 0 \\
\hline & cols/100ml & $\mathrm{b}-2$ & & $\mathrm{~b}<2$ & & $\mathrm{~b}<2$ & & $b-2$ \\
\hline Total Coli(vol/count) & 50 & TNTC & 50 & TNTC & 50 & 40 & 50 & 42 \\
\hline Total Coli(vol/count) & 25 & 47 & 25 & TNTC & 25 & 12 & 25 & 23 \\
\hline \multirow[t]{2}{*}{ Total Coli(vol/count) } & 10 & 13 & 10 & 18 & 10 & 0 & 10 & 10 \\
\hline & cols/100ml & 190 & & b-180 & & 80 & & 87 \\
\hline \multicolumn{9}{|c|}{ Enterococcus(vol/count $)^{\mathrm{a}}$} \\
\hline \multicolumn{9}{|c|}{ Enterococcus(vol/count) } \\
\hline \multicolumn{9}{|c|}{ Enterococcus(vol/count) } \\
\hline & $\mathrm{col} / 100 \mathrm{ml}$ & -- & & -- & & -- & & -- \\
\hline
\end{tabular}

a. Enteroccoccus samples were read outside of the acceptable holding time. 
Appendix E. General water quality with depth and general water quality, bacteria, volatile organic compounds, semivolatile organic compounds, pesticides, PCB's, herbicides, total metals and trace elements, general inorganics, and radiochemistry by sample at ten water-quality sampling sites in the Bahía de Añasco and near Rincón, Puerto Rico, at two sites sampled in the Río Grande de Añasco and the Río Yagüez, and at the influent and effluent of the Mayagüez Regional Wastewater Treatment Plant, January 25-30, 1991—Continued

Appendix E-26. Volatile organic compounds at water-quality control sites QW-9 and QW-10 near Rincón, January 28, 1991.

[Method 624. Units are micrograms per liter. ND, not detected. Values for surrogates represent percent recovery.]

\begin{tabular}{|c|c|c|c|c|}
\hline \multirow{2}{*}{ Constituent } & \multicolumn{2}{|c|}{ OW-9 } & \multicolumn{2}{|c|}{ QW-10 } \\
\hline & Result & Rep. Limit & Result & Rep. Limit \\
\hline Acrolein & ND & 100 & ND & 100 \\
\hline Acrylonitrile & ND & 100 & ND & 100 \\
\hline Benzene & ND & 5 & ND & 5 \\
\hline Bromodichloromethane & ND & 5 & ND & 5 \\
\hline Bromoform & ND & 5 & ND & 5 \\
\hline Bromomethane & ND & 10 & ND & 10 \\
\hline Carbon tetrachloride & ND & 5 & ND & 5 \\
\hline Chlorobenzene & ND & 5 & ND & 5 \\
\hline Chloroethane & ND & 10 & ND & 10 \\
\hline Chloroform & ND & 5 & ND & 5 \\
\hline Chloromethane & ND & 10 & ND & 10 \\
\hline Dibromochloromethane & ND & 5 & ND & 5 \\
\hline 1,1-Dichloroethane & ND & 5 & ND & 5 \\
\hline 1,2-Dichloroethane & ND & 5 & ND & 5 \\
\hline 1,1-Dichloroethene & ND & 5 & ND & 5 \\
\hline 1,2-Dichloroethene (total) & ND & 5 & ND & 5 \\
\hline 1,2-Dichloropropane & ND & 5 & ND & 5 \\
\hline cis-1,3-Dichloropropene & ND & 5 & ND & 5 \\
\hline trans-1,3-Dichloropropene & ND & 5 & ND & 5 \\
\hline Ethylbenzene & ND & 5 & ND & 5 \\
\hline Methylene chloride & ND & 5 & ND & 5 \\
\hline 1,1,2,2-Tetrachloroethane & ND & 5 & ND & 5 \\
\hline Tetrachloroethene & ND & 5 & ND & 5 \\
\hline Toluene & ND & 5 & ND & 5 \\
\hline 1,1,1-Trichloroethane & ND & 5 & ND & 5 \\
\hline 1,1,2-Trichloroethane & ND & 5 & ND & 5 \\
\hline Trichloroethene & ND & 5 & ND & 5 \\
\hline Vinyl chloride & ND & 10 & ND & 10 \\
\hline Surrogate & & & & \\
\hline Toluene-d8 & 112 & & 111 & \\
\hline 4-Bromofluorobenzene & 104 & & 104 & \\
\hline 1,2-Dichloroethane-d4 & 104 & & 106 & \\
\hline
\end{tabular}


Appendix E. General water quality with depth and general water quality, bacteria, volatile organic compounds, semivolatile organic compounds, pesticides, PCB's, herbicides, total metals and trace elements, general inorganics, and radiochemistry by sample at ten water-quality sampling sites in the Bahía de Añasco and near Rincón, Puerto Rico, at two sites sampled in the Río Grande de Añasco and the Río Yagüez, and at the influent and effluent of the Mayagüez Regional Wastewater Treatment Plant, January 25-30, 1991—Continued

Appendix E-27. Semivolatile organic compounds at water-quality control sites QW-9 and QW-10, near Rincón, January 28, 1991 .

[Method 625. Units are micrograms per liter. Rep. Limit, reporting limit; NR, not reported; ND, not detected; conc., concentration; conf. level, confidence level. Values for surrogates represent percent recovery. All tentatively identified compounds were found in the base neutral acids. Confidence levels for the tentatively identified compounds: 1- tentative; 2-confident; and 3-confirmed.]

\begin{tabular}{|c|c|c|c|c|}
\hline \multirow{2}{*}{ Constituent } & \multicolumn{2}{|c|}{ OW-9 } & \multicolumn{2}{|c|}{ QW-10 } \\
\hline & Result & Rep. Limit & Result & Rep. Limit \\
\hline Acenaphthene & ND & 10 & ND & 10 \\
\hline Acenaphthylene & ND & 10 & ND & 10 \\
\hline Anthracene & ND & 10 & ND & 10 \\
\hline Benzidine & ND & 100 & ND & 100 \\
\hline Benzo a-anthracene & ND & 10 & ND & 10 \\
\hline Benzo $b$ fluoranthene & ND & 10 & ND & 10 \\
\hline Benzo k fluoranthene & ND & 10 & ND & 10 \\
\hline Benzo $(g, h, i)$ perylene & ND & 10 & ND & 10 \\
\hline Benzo (a)pyrene & ND & 10 & ND & 10 \\
\hline 4-Bromophenyl phenyl ether & ND & 10 & ND & 10 \\
\hline Butyl benzyl phthalate & ND & 10 & ND & 10 \\
\hline bis(2-Chloroethoxy)-methane & ND & 10 & ND & 10 \\
\hline bis(2-Chloroethyl) ether & ND & 10 & ND & 10 \\
\hline bis(2-Chloroisopropyl)-ether & ND & 10 & ND & 10 \\
\hline 4-Chloro-3-methylphenol & ND & 10 & ND & 10 \\
\hline 2-Chloronaphthalene & ND & 10 & ND & 10 \\
\hline 2-Chlorophenol & ND & 10 & ND & 10 \\
\hline 4-Chlorophenyl phenyl ether & ND & 10 & ND & 10 \\
\hline Chrysene & ND & 10 & ND & 10 \\
\hline Dibenz(a,h)anthracene & ND & 10 & ND & 10 \\
\hline Di-n-butyl phthalate & ND & 10 & ND & 10 \\
\hline 1,2-Dichlorobenzene & ND & 10 & ND & 10 \\
\hline 1,3-Dichlorobenzene & ND & 10 & ND & 10 \\
\hline 1,4-Dichlorobenzene & ND & 10 & ND & 10 \\
\hline 3,3'-Dichlorobenzidine & ND & 20 & ND & 20 \\
\hline 2,4-Dichlorophenol & ND & 10 & ND & 10 \\
\hline Diethyl phthalate & ND & 10 & ND & 10 \\
\hline 2,4-DimethylPhenol & ND & 10 & ND & 10 \\
\hline Dimethyl phthalate & ND & 10 & ND & 10 \\
\hline
\end{tabular}


Appendix E. General water quality with depth and general water quality, bacteria, volatile organic compounds, semivolatile organic compounds, pesticides, PCB's, herbicides, total metals and trace elements, general inorganics, and radiochemistry by sample at 10 water-quality sampling sites in the Bahía de Añasco and near Rincón, Puerto Rico, at two sites sampled in the Río Grande de Añasco and the Río Yagüez, and at the influent and effluent of the Mayagüez Regional Wastewater Treatment Plant, January 25-30, 1991-Continued

Appendix E-27. Semivolatile organic compounds at water-quality control sites QW-9 and QW-10, near Rincón, January 28, 1991-Continued.

[Method 625. Units are micrograms per liter. Rep. Limit, reporting limit; NR, not reported; ND, not detected; conc., concentration; conf. level, confidence level. Values for surrogates represent percent recovery. All tentatively identified compounds were found in the base neutral acids. Confidence levels for the tentatively identified compounds: 1- tentative; 2-confident; and 3-confirmed.]

\begin{tabular}{|c|c|c|c|c|}
\hline \multirow{2}{*}{ Constituent } & \multicolumn{2}{|c|}{ OW-9 } & \multicolumn{2}{|c|}{ QW-10 } \\
\hline & Result & Rep. Limit & Result & Rep. Limit \\
\hline 4,6-Dinitro-2-methylphenol & ND & 50 & ND & 50 \\
\hline 2,4-Dinitrophenol & ND & 50 & ND & 50 \\
\hline 2,4-Dinitrotoluene & ND & 10 & ND & 10 \\
\hline 2,6-Dinitrotoluene & ND & 10 & ND & 10 \\
\hline Di-n-octylphthalate & ND & 10 & ND & 10 \\
\hline 1,2-Diphenylhydrazine & ND & 10 & ND & 10 \\
\hline bis(2-Ethylhexyl)phthalate & ND & 10 & ND & 10 \\
\hline Fluoranthene & ND & 10 & ND & 10 \\
\hline Fluorene & ND & 10 & ND & 10 \\
\hline Hexachlorobenzene & ND & 10 & ND & 10 \\
\hline Hexachlorobutadiene & ND & 10 & ND & 10 \\
\hline Hexachlorocyclopentadiene & ND & 10 & ND & 10 \\
\hline Hexachloroethane & ND & 10 & ND & 10 \\
\hline Indeno(1,2,3-cd)pyrene & ND & 10 & ND & 10 \\
\hline Isophorone & ND & 10 & ND & 10 \\
\hline Naphthalene & ND & 10 & ND & 10 \\
\hline Nitrobenzene & ND & 10 & ND & 10 \\
\hline 2-Nitrophenol & ND & 10 & ND & 10 \\
\hline 4-Nitrophenol & ND & 50 & ND & 50 \\
\hline N-Nitrosodimethylamine & ND & 10 & ND & 10 \\
\hline N-Nitrosodiphenylamine & ND & 10 & ND & 10 \\
\hline N-Nitroso-di-n-Propylamine & ND & 50 & ND & 10 \\
\hline Pentachlorophenol & ND & 10 & ND & 50 \\
\hline Phenanthrene & ND & 10 & ND & 10 \\
\hline Phenol & ND & 10 & ND & 10 \\
\hline Pyrene & ND & 10 & ND & 10 \\
\hline 1,2,4-Trichlorobenzene & ND & 10 & ND & 10 \\
\hline 2,4,6-Trichlorophenol & ND & 10 & ND & 10 \\
\hline
\end{tabular}


Appendix E. General water quality with depth and general water quality, bacteria, volatile organic compounds, semivolatile organic compounds, pesticides, PCB's, herbicides, total metals and trace elements, general inorganics, and radiochemistry by sample at 10 water-quality sampling sites in the Bahía de Añasco and near Rincón, Puerto Rico, at two sites sampled in the Río Grande de Añasco and the Río Yagüez, and at the influent and effluent of the Mayagüez Regional Wastewater Treatment Plant, January 25-30, 1991-Continued

Appendix E-27. Semivolatile organic compounds at water-quality control sites QW-9 and QW-10, near Rincón, January 28, 1991-Continued.

[Method 625. Units are micrograms per liter. Rep. Limit, reporting limit; NR, not reported; ND, not detected; conc., concentration; conf. level, confidence level. Values for surrogates represent percent recovery. All tentatively identified compounds were found in the base neutral acids. Confidence levels for the tentatively identified compounds: 1- tentative; 2-confident; and 3-confirmed.]

\begin{tabular}{|c|c|c|c|c|}
\hline \multirow{2}{*}{ Constituent } & \multicolumn{2}{|r|}{ QW-9 } & \multicolumn{2}{|c|}{ QW-10 } \\
\hline & Result & Rep. Limit & Result & Rep. Limit \\
\hline \multicolumn{5}{|l|}{ Surrogate } \\
\hline & \multicolumn{4}{|c|}{ Recovery } \\
\hline Nitrobenzene-d5 & 65 & & 72 & \\
\hline 2-Fluorobiphenyl & 51 & & 58 & \\
\hline Terphenyl-dl4 & 73 & & 69 & \\
\hline Phenol-d5 & 64 & & 70 & \\
\hline 2-Fluorophenol & 59 & & 66 & \\
\hline \multirow[t]{6}{*}{ 2,4,6-Tribromophenol } & 77 & & 78 & \\
\hline & \multicolumn{4}{|c|}{ Tentatively Identified Compounds } \\
\hline & Site & Constituent & conf. level & conc. \\
\hline & QW-9 & Cyclopentane, Ethyl- & 2 & 18 \\
\hline & & Oxygenated Hydrocarbon & NR & 18 \\
\hline & QW-10 & Oxygenated Hydrocarbon & NR & 17 \\
\hline
\end{tabular}


Appendix E. General water quality with depth and general water quality, bacteria, volatile organic compounds, semivolatile organic compounds, pesticides, PCB's, herbicides, total metals and trace elements, general inorganics, and radiochemistry by sample at ten water-quality sampling sites in the Bahía de Añasco and near Rincón, Puerto Rico, at two sites sampled in the Río Grande de Añasco and the Río Yagüez, and at the influent and effluent of the Mayagüez Regional Wastewater Treatment Plant, January 25-30, 1991—Continued

Appendix E-28. Concentrations of pesticides, PCB's, and herbicides at water-quality control sites $\mathrm{QW}-9$ and $\mathrm{QW}-10$, near Rincón, January 28, 1991.

[Units are micrograms per liter. Rep. Limit, reporting limit; ND, not detected. Values for surrogates represent percent recovery. Sporadic hits reported as ND unless verified in 2nd-column test.]

\begin{tabular}{|c|c|c|c|c|}
\hline \multirow{2}{*}{ Constituent } & \multicolumn{2}{|c|}{ QW-9 } & \multicolumn{2}{|c|}{ QW-10 } \\
\hline & Result & Rep. Limit & Result & Rep. Limit \\
\hline \multicolumn{5}{|c|}{ Organochlorine Pesticides/PCB's } \\
\hline \multicolumn{5}{|l|}{ Method 8080} \\
\hline alpha-BHC & ND & 0.05 & ND & 0.05 \\
\hline beta-BHC & ND & 0.05 & ND & 0.05 \\
\hline delta-BHC & ND & 0.05 & ND & 0.05 \\
\hline gamma-BHC (Lindane) & ND & 0.05 & ND & 0.05 \\
\hline Toxaphene & ND & 1 & ND & 1 \\
\hline Heptachlor & ND & 0.02 & ND & 0.02 \\
\hline Aldrin & ND & 0.05 & ND & 0.05 \\
\hline Heptachlor epoxide & ND & 0.05 & ND & 0.05 \\
\hline Endosulfan I & ND & 0.05 & ND & 0.05 \\
\hline Dieldrin & ND & 0.02 & ND & 0.02 \\
\hline 4,4'-DDE & ND & 0.1 & ND & 0.1 \\
\hline Endrin & ND & 0.06 & ND & 0.06 \\
\hline Endosulfan II & ND & 0.1 & ND & 0.1 \\
\hline 4,4'-DDD & ND & 0.1 & ND & 0.1 \\
\hline Endosulfan sulfate & ND & 0.1 & ND & 0.1 \\
\hline 4,4'-DDT & ND & 0.1 & ND & 0.1 \\
\hline Endrin aldehyde & ND & 0.1 & ND & 0.1 \\
\hline Chlordane & ND & 0.05 & ND & 0.05 \\
\hline Aroclor 1016 & ND & 0.5 & ND & 0.5 \\
\hline Aroclor 1221 & ND & 0.5 & ND & 0.5 \\
\hline Aroclor 1232 & ND & 0.5 & ND & 0.5 \\
\hline Aroclor 1242 & ND & 0.5 & ND & 0.5 \\
\hline Aroclor 1248 & ND & 0.5 & ND & 0.5 \\
\hline Aroclor 1254 & ND & 1 & ND & 1 \\
\hline Aroclor 1260 & ND & 1 & ND & 1 \\
\hline Mirex & ND & 0.05 & ND & 0.05 \\
\hline Ethylan (Perthane) & ND & 0.5 & ND & 0.5 \\
\hline Methoxychlor & ND & 0.5 & ND & 0.5 \\
\hline Surrogate & & & & \\
\hline Dibutyl chlorendate & 110 & & 113 & \\
\hline
\end{tabular}


Appendix E. General water quality with depth and general water quality, bacteria, volatile organic compounds, semivolatile organic compounds, pesticides, PCB's, herbicides, total metals and trace elements, general inorganics, and radiochemistry by sample at ten water-quality sampling sites in the Bahía de Añasco and near Rincón, Puerto Rico, at two sites sampled in the Río Grande de Añasco and the Río Yagüez, and at the influent and effluent of the Mayagüez Regional Wastewater Treatment Plant, January 25-30, 1991—Continued

Appendix E-29. Concentrations of total metals at water-quality control sites QW-9 and QW-10 near Rincón, January 28, 1991.

[Units are milligrams per liter. Rep. Limit, reporting limit; ND, not detected.]

\begin{tabular}{|c|c|c|c|c|c|}
\hline \multirow{2}{*}{ Constituent } & \multirow{2}{*}{$\begin{array}{c}\text { Analytical } \\
\text { method }\end{array}$} & \multicolumn{2}{|c|}{ OW-9 } & \multicolumn{2}{|c|}{ QW-10 } \\
\hline & & Result & Rep. Limit & Result & Rep. Limit \\
\hline Antimony & 7041 & ND & 0.02 & ND & 0.02 \\
\hline Beryllium & 7090 & ND & 0.05 & ND & 0.05 \\
\hline Copper & 7210 & ND & 0.05 & ND & 0.05 \\
\hline Nickel & 7520 & ND & 0.1 & ND & 0.1 \\
\hline Chromium (VI) & 7196 & ND & 0.01 & ND & 0.01 \\
\hline Aluminum & 6010 & ND & 2 & ND & 2 \\
\hline Silver & 7761 & ND & 0.0005 & ND & 0.002 \\
\hline Cadmium & 7131 & ND & 0.001 & ND & 0.001 \\
\hline Zinc & 7950 & ND & 0.02 & ND & 0.02 \\
\hline Chromium & 7191 & 0.0052 & 0.005 & 0.005 & 0.005 \\
\hline Arsenic & 7060 & ND & 0.01 & ND & 0.01 \\
\hline Barium & 6010 & ND & 0.2 & ND & 0.2 \\
\hline Boron & 6010 & 4.6 & 2 & 4.6 & 2 \\
\hline Calcium & 6010 & 442 & 4 & 450 & 4 \\
\hline Iron & 6010 & ND & 2 & ND & 2 \\
\hline Lead & 7421 & 0.08 & 0.025 & 0.14 & 0.05 \\
\hline Magnesium & 6010 & 1370 & 4 & 1390 & 4 \\
\hline Manganese & 6010 & ND & 0.2 & ND & 0.2 \\
\hline Mercury & 7470 & ND & 0.0002 & ND & 0.0002 \\
\hline Potassium & 6010 & 414 & 100 & 424 & 100 \\
\hline Selenium & 7740 & 0.015 & 0.005 & 0.21 & 0.05 \\
\hline Silica as $\mathrm{SiO}_{2}$ & 6010 & ND & 10 & ND & 10 \\
\hline Sodium & 6010 & 11100 & 100 & 11200 & 100 \\
\hline Strontium & 6010 & 7.7 & 1 & 7.9 & 1 \\
\hline Thallium & 7841 & ND & 2 & ND & 0.5 \\
\hline
\end{tabular}


Appendix E. General water quality with depth and general water quality, bacteria, volatile organic compounds, semivolatile organic compounds, pesticides, PCB's, herbicides, total metals and trace elements, general inorganics, and radiochemistry by sample at ten water-quality sampling sites in the Bahía de Añasco and near Rincón, Puerto Rico, at two sites sampled in the Río Grande de Añasco and the Río Yagüez, and at the influent and effluent of the Mayagüez Regional Wastewater Treatment Plant, January 25-30, 1991—Continued

Appendix E-30. General inorganics and radiochemistry at water-quality control sites QW-9 and QW-10 near Rincón, January 28, 1991.

[Rep. Limit, reporting limit; mg/L, milligrams per liter; NTU, nephelometric turbidity units; pCi/L, picocuries per liter; ND, not detected.]

\begin{tabular}{|c|c|c|c|c|c|c|}
\hline \multirow{2}{*}{ Constituent } & \multirow{2}{*}{$\begin{array}{c}\text { Analytical } \\
\text { method }\end{array}$} & \multirow{2}{*}{ units } & \multicolumn{2}{|c|}{ QW-9 } & \multicolumn{2}{|c|}{ QW-10 } \\
\hline & & & Result & Rep.Limit & Result & Rep.Limit \\
\hline \multicolumn{7}{|l|}{ General Inorganics } \\
\hline Chloride & A429 & $\mathrm{mg} / \mathrm{L}$ & 20600 & 250 & 20800 & 250 \\
\hline Cyanide & 9012 & $\mathrm{mg} / \mathrm{L}$ & ND & 0.01 & ND & 0.01 \\
\hline Color & 110.2 & units & ND & 5 & ND & 5 \\
\hline Fluoride & A429 & $\mathrm{mg} / \mathrm{L}$ & 29.1 & 5 & 27.5 & 5 \\
\hline Surfactants (MBAS) & 425.1 & $\mathrm{mg} / \mathrm{L}$ & ND & 0.1 & ND & 0.1 \\
\hline Ammonia as $\mathrm{N}$ & 350.1 & $\mathrm{mg} / \mathrm{L}$ & ND & 0.1 & ND & 0.1 \\
\hline Nitrate plus Nitrite & 353.2 & $\mathrm{mg} / \mathrm{L}$ & ND & 0.1 & ND & 0.1 \\
\hline Orthophosphate as $\mathrm{P}$ & 365.3 & $\mathrm{mg} / \mathrm{L}$ & ND & 0.05 & ND & 0.05 \\
\hline Phenolics & 9065 & $\mathrm{mg} / \mathrm{L}$ & ND & 0.01 & ND & 0.01 \\
\hline Sulfide, Total & 376.2 & $\mathrm{mg} / \mathrm{L}$ & ND & 0.05 & ND & 0.05 \\
\hline Sulfate & A429 & $\mathrm{mg} / \mathrm{L}$ & 2800 & 25 & 2810 & 25 \\
\hline Total Kjeldahl Nitrogen as $\mathrm{N}$ & 351.2 & $\mathrm{mg} / \mathrm{L}$ & 0.89 & 0.5 & 0.86 & 0.5 \\
\hline Phosphorus, Total as P & 365.3 & $\mathrm{mg} / \mathrm{L}$ & ND & 0.05 & ND & 0.05 \\
\hline Turbidity & 180.1 & NTU & 0.3 & 0.1 & 0.34 & 0.1 \\
\hline Total Dissolved Solids & 160.1 & $\mathrm{mg} / \mathrm{L}$ & 37100 & 50 & 32600 & 50 \\
\hline Total Suspended Solids & 160.2 & $\mathrm{mg} / \mathrm{L}$ & 12.4 & 2 & 19.6 & 2 \\
\hline Total Volatile Solids & 160.4 & $\mathrm{mg} / \mathrm{L}$ & 2940 & 200 & 3620 & 200 \\
\hline Volatile Suspended Solids & 160.4 & $\mathrm{mg} / \mathrm{L}$ & ND & 10 & ND & 10 \\
\hline \multicolumn{7}{|l|}{ Radiochemistry } \\
\hline & & & & $(+/-)$ & & $(+/-)$ \\
\hline Gross Alpha & 900 & $\mathrm{pCi} / \mathrm{L}$ & 0 & 110 & 50 & 160 \\
\hline Gross Beta & 900 & $\mathrm{pCi} / \mathrm{L}$ & 380 & 170 & 280 & 150 \\
\hline Radium 226 & 705 Mod. & $\mathrm{pCi} / \mathrm{L}$ & 0.3 & 0.6 & 0.3 & 0.6 \\
\hline Strontium 90 & A704 & $\mathrm{pCi} / \mathrm{L}$ & 0 & 1 & 0 & 1.4 \\
\hline
\end{tabular}


Appendix E. General water quality with depth and general water quality, bacteria, volatile organic compounds, semivolatile organic compounds, pesticides, PCB's, herbicides, total metals and trace elements, general inorganics, and radiochemistry by sample at ten water-quality sampling sites in the Bahía de Añasco and near Rincón, Puerto Rico, at two sites sampled in the Río Grande de Añasco and the Río Yagüez, and at the influent and effluent of the Mayagüez Regional Wastewater Treatment Plant, January 25-30, 1991-Continued

Appendix E-31. General water quality at water-quality control sites QW-9 and QW-10 near Rincón, January 28, 1991.

[Rep. Limit, reporting limit; $\mathrm{mg} / \mathrm{L}$, milligrams per liter; ${ }^{\circ} \mathrm{C}$, degrees Celsius; $\mathrm{k}$, extinction coefficient; vol/count, volume of sample (rest made up to $100 \mathrm{ml}$ ) and number of bacteria colonies counted using the filter membrane method; col/100ml, colonies of bacteria per 100 milliliters; TNTC, too numerous to count; $\mu \mathrm{S} / \mathrm{cm}$, microsiemens per centimenter; $\mathrm{mg} / \mathrm{m}^{3}$, milligram per cubic meter; $\mathrm{ND}$, not detected; --, no data.]

\begin{tabular}{|c|c|c|c|c|c|c|c|}
\hline \multirow{2}{*}{ Constituent } & \multirow{2}{*}{ units } & & \multicolumn{2}{|c|}{ OW-9 } & & \multicolumn{2}{|c|}{ QW-10 } \\
\hline & & & Result & Rep. Limit & & Result & Rep. Limit \\
\hline BOD-5 & $\mathrm{mg} / \mathrm{L}$ & & ND & 2 & & ND & 2 \\
\hline Oil and Grease & $\mathrm{mg} / \mathrm{L}$ & & ND & 5 & & ND & 5 \\
\hline Settleable Solids & $\mathrm{mg} / \mathrm{L}$ & & 0 & & & 0 & \\
\hline Water Temp. & ${ }^{\circ} \mathrm{C}$ & & -- & & & -- & \\
\hline Alkalinity & $\mathrm{mg} / \mathrm{L}$ & & 120 & & & 130 & \\
\hline Spec.Cond. & $\mu \mathrm{S} / \mathrm{cm}$ & & 44000 & & & -- & \\
\hline $\mathrm{pH}$ & units & & 8.2 & & & 8.26 & \\
\hline Dissolved Oxygen & $\mathrm{mg} / \mathrm{L}$ & & -- & & & -- & \\
\hline Extinction Coefficient & $\mathrm{k}$ & & 0.12 & & & 0.29 & \\
\hline Chlorophyll-a & $\mathrm{mg} / \mathrm{m}^{3}$ & & 0.0466 & & & 0.0479 & \\
\hline \multicolumn{8}{|l|}{ Bacteria } \\
\hline Fecal Coli(dil/count) & & 50 & 10 & & 50 & 10 & \\
\hline Fecal Coli(vol/count) & & 25 & 7 & & 25 & 3 & \\
\hline \multirow[t]{2}{*}{ Fecal Coli(vol/count) } & & 10 & 2 & & 10 & 0 & \\
\hline & cols/100ml & & $b-22$ & & & $b-17$ & \\
\hline Total Coli(vol/count) & & 50 & 3 & & 50 & 3 & \\
\hline Total Coli(vol/count) & & 25 & 0 & & 25 & 0 & \\
\hline \multirow[t]{2}{*}{ Total Coli(vol/count) } & & 10 & 0 & & 10 & 0 & \\
\hline & cols/100ml & & $b-6$ & & & $b-6$ & \\
\hline Enterococcus(vol/count) & & 50 & 0 & & 50 & 0 & \\
\hline Enterococcus(vol/count) & & 25 & 0 & & 25 & 0 & \\
\hline \multirow[t]{2}{*}{ Enterococcus(vol/count) } & & 10 & 0 & & 10 & 0 & \\
\hline & cols/100ml & & $\mathrm{b}<1$ & & & $\mathrm{~b}<2$ & \\
\hline
\end{tabular}


Appendix E. General water quality with depth and general water quality, bacteria, volatile organic compounds, semivolatile organic compounds, pesticides, PCB's, herbicides, total metals and trace elements, general inorganics, and radiochemistry by sample at ten water-quality sampling sites in the Bahía de Añasco and near Rincón, Puerto Rico, at two sites sampled in the Río Grande de Añasco and the Río Yagüez, and at the influent and effluent of the Mayagüez Regional Wastewater Treatment Plant, January 25-30, 1991—Continued

Appendix E-32. Vertical profiles of physical and chemical properties measured inside the initial mixing zone (0W-4, OW-5), January $30,1991$.

[Repl., replicate; ${ }^{\circ} \mathrm{C}$, degrees Celsius; $\mathrm{m}$, meter; mg/L, milligrams per liter; $\mu \mathrm{S} / \mathrm{cm}$, microsiemens per centimeter at 25 degrees Celsius; --, data not available.]

\begin{tabular}{|c|c|c|c|c|c|c|c|c|c|c|c|c|}
\hline \multirow[b]{2}{*}{$\begin{array}{l}\text { Sampled } \\
\text { depth } \\
\text { (m) }\end{array}$} & \multicolumn{4}{|c|}{ oW-4 } & \multicolumn{4}{|c|}{ QW-5 } & \multicolumn{4}{|c|}{ QW-5 (Repl.) } \\
\hline & $\begin{array}{c}\text { Tempera- } \\
\text { ture } \\
\left({ }^{\circ} \mathrm{C}\right)\end{array}$ & $\begin{array}{c}\mathrm{pH} \\
\text { (units) }\end{array}$ & $\begin{array}{l}\text { Dissolved } \\
\text { oxygen } \\
(\mathrm{mg} / \mathrm{L})\end{array}$ & $\begin{array}{c}\text { Specific } \\
\text { conduct- } \\
\text { ance } \\
(\mu \mathrm{S} / \mathrm{cm})\end{array}$ & $\begin{array}{l}\text { Temper- } \\
\text { ature } \\
\left({ }^{\circ} \mathrm{C}\right)\end{array}$ & $\underset{\text { (units) }}{\mathrm{pH}}$ & $\begin{array}{l}\text { Dissolved } \\
\text { oxygen } \\
\text { (mg/L) }\end{array}$ & $\begin{array}{c}\text { Specific } \\
\text { conduct- } \\
\text { ance } \\
(\mu \mathrm{S} / \mathrm{cm})\end{array}$ & $\begin{array}{c}\text { Tem- } \\
\text { pera- } \\
\text { ture } \\
\left({ }^{\circ} \mathrm{C}\right)\end{array}$ & $\underset{\text { (units) }}{\mathrm{pH}}$ & $\begin{array}{l}\text { Dissolved } \\
\text { oxygen } \\
\text { (mg/L) }\end{array}$ & $\begin{array}{c}\text { Specific } \\
\text { conduct- } \\
\text { ance } \\
(\mu \mathrm{S} / \mathrm{cm})\end{array}$ \\
\hline 0.0 & 26.2 & 8.31 & 7.35 & -- & 25.9 & 8.2 & 7.94 & $>50000$ & 25.9 & 8.17 & 8.95 & 50000 \\
\hline 0.6 & 26.2 & & 7.36 & & 25.9 & & 7.86 & & 25.9 & & 9 & \\
\hline 1.2 & 26.2 & & 7.36 & & 25.9 & & 7.85 & & 25.9 & & 8.85 & \\
\hline 1.5 & & 8.31 & & -- & & 8.22 & & $>50000$ & & 8.25 & & $>50000$ \\
\hline 1.8 & 26.2 & & 7.4 & & 25.9 & & 7.85 & & 25.9 & & 9.05 & \\
\hline 2.4 & 26.3 & & 7.47 & & 25.9 & & 7.86 & & 25.9 & & 9.05 & \\
\hline 3.0 & 26.3 & 8.31 & 7.4 & -- & 25.9 & 8.26 & 7.85 & $>50000$ & 25.9 & 8.24 & 9.2 & $>50000$ \\
\hline 3.7 & 26.3 & & 7.45 & & 25.9 & & 7.95 & & 25.9 & & 9.2 & \\
\hline 4.3 & 26.3 & & 7.4 & & 25.9 & & 7.85 & & 25.9 & & 9.16 & \\
\hline 4.6 & & 8.32 & & -- & & 8.25 & & $>50000$ & & 8.27 & & $>50000$ \\
\hline 4.9 & 26.3 & & 7.4 & & 25.9 & & 7.86 & & 25.9 & & 9.25 & \\
\hline 5.5 & 26.2 & & 7.4 & & 25.9 & & 7.85 & & 25.8 & & 9.27 & \\
\hline 6.1 & 26.3 & 8.31 & 7.35 & -- & 25.9 & 8.23 & 7.98 & $>50000$ & 25.9 & 8.24 & 9.41 & 50000 \\
\hline 6.7 & 26.1 & & 7.25 & & 25.9 & & 7.84 & & 25.8 & & 9.35 & \\
\hline 7.3 & 26.1 & & 7.25 & & 25.8 & & 8.01 & & 25.9 & & 9.38 & \\
\hline 7.6 & & 8.31 & & -- & & 8.26 & & $>50000$ & & 8.27 & & $>50000$ \\
\hline 7.9 & 25.9 & & 7.18 & & 25.9 & & 7.99 & & 25.9 & & 9.34 & \\
\hline 8.5 & 25.9 & & 7.2 & & 25.9 & & 8.01 & & 25.9 & & 9.46 & \\
\hline 9.1 & 25.9 & 8.31 & 7.1 & -- & 25.9 & 8.28 & 8.19 & $>50000$ & 25.9 & 8.26 & 9.5 & $>50000$ \\
\hline 9.8 & 26.3 & & 7.26 & & 25.9 & & 8.45 & & 25.8 & & 9.47 & \\
\hline 10.4 & 26.3 & & 7.28 & & 25.9 & & 8.3 & & 25.9 & & 8.98 & \\
\hline 10.7 & & 8.31 & & -- & 25.9 & 8.27 & 8.68 & $>50000$ & 25.9 & 8.26 & 8.63 & $>50000$ \\
\hline 11.0 & 26.3 & & 7.2 & & & & & & & & & \\
\hline \multicolumn{13}{|l|}{11.6} \\
\hline 12.2 & & 8.33 & & -- & & 8.27 & & $>50000$ & & 8.28 & & $>50000$ \\
\hline
\end{tabular}


Appendix E. General water quality with depth and general water quality, bacteria, volatile organic compounds, semivolatile organic compounds, pesticides, PCB's, herbicides, total metals and trace elements, general inorganics, and radiochemistry by sample at ten water-quality sampling sites in the Bahía de Añasco and near Rincón, Puerto Rico, at two sites sampled in the Río Grande de Añasco and the Río Yagüez, and at the influent and effluent of the Mayagüez Regional Wastewater Treatment Plant, January 25-30, 1991—Continued

Appendix E-33. Vertical profiles of physical and chemical properties measured at the limit (QW-3 and QW-6) of the initial mixing zone, January 30,1991.

[Units: ${ }^{\circ} \mathrm{C}$, degrees Celsius; $\mathrm{mg} / \mathrm{L}$, milligrams per liter; $\mu \mathrm{S} / \mathrm{cm}$, microsiemens per centimeter at 25 degrees Celsius; --, data not available.]

\begin{tabular}{|c|c|c|c|c|c|c|c|c|}
\hline \multirow{2}{*}{$\begin{array}{l}\text { Sampled } \\
\text { depth } \\
\text { (m) }\end{array}$} & \multicolumn{4}{|c|}{$0 W-3$} & \multicolumn{4}{|c|}{ QW-6 } \\
\hline & $\begin{array}{c}\text { Temperature } \\
\left({ }^{\circ} \mathrm{C}\right)\end{array}$ & $\begin{array}{c}\mathrm{pH} \\
\text { (units) }\end{array}$ & $\begin{array}{l}\text { Dissolved } \\
\text { oxygen } \\
\text { (mg/L) }\end{array}$ & $\begin{array}{c}\text { Specific } \\
\text { conductance } \\
(\mu \mathrm{S} / \mathrm{cm})\end{array}$ & $\begin{array}{c}\text { Temperature } \\
\left({ }^{\circ} \mathrm{C}\right)\end{array}$ & $\begin{array}{c}\mathrm{pH} \\
\text { (units) }\end{array}$ & $\begin{array}{c}\text { Dissolved } \\
\text { oxygen } \\
(\mathrm{mg} / \mathrm{L})\end{array}$ & $\begin{array}{c}\text { Specific } \\
\text { conductance } \\
(\mu \mathrm{S} / \mathrm{cm})\end{array}$ \\
\hline 0.0 & 26.6 & 8.26 & 7.97 & -- & 25.7 & 8.23 & 7.5 & $>50000$ \\
\hline 0.6 & 26.6 & & 8.1 & & 25.7 & & 7.28 & \\
\hline 1.2 & 26.6 & & 8.16 & & 25.8 & & 7.24 & \\
\hline 1.5 & & 8.26 & & -- & & 8.27 & & $>50000$ \\
\hline 1.8 & 26.5 & & 8.1 & & 25.8 & & 7.22 & \\
\hline 2.4 & 26.5 & & 8.1 & & 25.8 & & 7.16 & \\
\hline 3.0 & 26.5 & 8.26 & 7.95 & -- & 25.8 & 8.28 & 7.2 & $>50000$ \\
\hline 3.7 & 26.4 & & 7.95 & & 25.8 & & 7.18 & \\
\hline 4.3 & 26.4 & & 7.93 & & 25.8 & & 7.26 & \\
\hline 4.6 & & 8.25 & & -- & & 8.26 & & $>50000$ \\
\hline 4.9 & 26.4 & & 7.83 & & 25.8 & & 7.21 & \\
\hline 5.5 & 26.4 & & 7.75 & & 25.8 & & 7.26 & \\
\hline 6.1 & 26.3 & 8.26 & 7.72 & -- & 25.8 & 8.28 & 7.2 & $>50000$ \\
\hline 6.7 & 26.3 & & 7.7 & & 25.8 & & 7.21 & \\
\hline 7.3 & 26.3 & & 7.72 & & 25.8 & & 7.19 & \\
\hline 7.6 & & 8.26 & & -- & & 8.27 & & $>50000$ \\
\hline 7.9 & 26.3 & & 7.6 & & 25.8 & & 7.23 & \\
\hline 8.5 & 26.2 & & 7.61 & & 25.8 & & 7.2 & \\
\hline 9.1 & 25.8 & 8.24 & 7.4 & -- & 25.8 & 8.26 & 7.25 & $>50000$ \\
\hline 9.8 & 25.9 & & 7.41 & & 25.8 & & 7.29 & \\
\hline 10.4 & 25.8 & & 7.4 & & 25.8 & & 7.23 & \\
\hline 10.7 & & 8.25 & & -- & & 8.28 & & $>50000$ \\
\hline 11.0 & 25.8 & & 7.4 & & 25.8 & & 7.2 & \\
\hline 11.6 & 25.9 & & 7.31 & & & & & \\
\hline 12.2 & & 8.23 & & -- & & 8.28 & & $>50000$ \\
\hline
\end{tabular}


Appendix E. General water quality with depth and general water quality, bacteria, volatile organic compounds, semivolatile organic compounds, pesticides, PCB's, herbicides, total metals and trace elements, general inorganics, and radiochemistry by sample at ten water-quality sampling sites in the Bahía de Añasco and near Rincón, Puerto Rico, at two sites sampled in the Río Grande de Añasco and the Río Yagüez, and at the influent and effluent of the Mayagüez Regional Wastewater Treatment Plant, January 25-30, 1991—Continued

Appendix E-34. Vertical profiles of physical and chemical properties measured at the limit of the final mixing zone (0W-2 and QW-7), January 29, 1991.

[Units: ${ }^{\circ} \mathrm{C}$, degrees Celsius; $\mathrm{m}$, meter; $\mathrm{mg} / \mathrm{L}$, milligrams per liter; $\mu \mathrm{S} / \mathrm{cm}$, microsiemens per centimeter at 25 degrees Celsius; --, data not available.]

\begin{tabular}{|c|c|c|c|c|c|c|c|c|}
\hline \multirow{2}{*}{$\begin{array}{l}\text { Sampled } \\
\text { Depth } \\
\text { (m) }\end{array}$} & \multicolumn{4}{|c|}{ aW-2 } & \multicolumn{4}{|c|}{ QW-7 } \\
\hline & $\begin{array}{c}\text { Temperature } \\
\left({ }^{\circ} \mathrm{C}\right)\end{array}$ & $\begin{array}{c}\mathrm{pH} \\
\text { (units) }\end{array}$ & $\begin{array}{l}\text { Dissolved } \\
\text { oxygen } \\
\text { (mg/L) }\end{array}$ & $\begin{array}{c}\text { Specific } \\
\text { conductance } \\
(\mu \mathrm{S} / \mathrm{cm})\end{array}$ & $\begin{array}{c}\text { Temperature } \\
\left({ }^{\circ} \mathrm{C}\right)\end{array}$ & $\underset{\text { (units) }}{\mathrm{pH}}$ & $\begin{array}{l}\text { Dissolved } \\
\text { oxygen } \\
\text { (mg/L) }\end{array}$ & $\begin{array}{c}\text { Specific } \\
\text { conductance } \\
(\mu \mathrm{S} / \mathrm{cm})\end{array}$ \\
\hline 0.0 & 26 & 8.25 & 7.88 & 49500 & 26.6 & 8.23 & 7.33 & 49500 \\
\hline 0.6 & 26 & & 7.86 & & 26.5 & & 7.21 & \\
\hline 1.2 & 26 & & 7.88 & & 26.2 & & 7.23 & \\
\hline 1.5 & & 8.25 & & 49500 & & 8.25 & & 50000 \\
\hline 1.8 & 26 & & 7.88 & & 26.1 & & 7.35 & \\
\hline 2.4 & 26 & & 7.88 & & 26.1 & & 7.46 & \\
\hline 3.0 & 26 & 8.26 & 7.82 & 49500 & 26 & 8.25 & 7.46 & 50000 \\
\hline 3.7 & 26 & & 7.8 & & 26 & & 7.46 & \\
\hline 4.3 & 26 & & 7.9 & & 25.9 & & 7.36 & \\
\hline 4.6 & & 8.26 & & 50000 & & 8.25 & & 49500 \\
\hline 4.9 & 26 & & 7.94 & & 25.9 & & 7.3 & \\
\hline 5.5 & 26 & & 7.9 & & 25.9 & & 7.34 & \\
\hline 6.1 & 26 & 8.26 & 7.87 & 49500 & 25.9 & 8.23 & 7.28 & 48500 \\
\hline 6.7 & 26 & & 7.83 & & 25.9 & & 7.31 & \\
\hline 7.3 & 26 & & 7.84 & & 25.9 & & 7.31 & \\
\hline 7.6 & & 8.26 & & 50000 & & 8.26 & & 49500 \\
\hline 7.9 & 25.9 & & 7.83 & & 25.9 & & 7.3 & \\
\hline 8.5 & 25.9 & & 7.87 & & 25.9 & & 7.37 & \\
\hline 9.1 & 25.9 & 8.26 & 7.87 & 50000 & 25.9 & 8.26 & 7.2 & 48500 \\
\hline 9.8 & 25.9 & & 7.9 & & 25.9 & & 7.26 & \\
\hline 10.4 & 25.9 & & 7.83 & & 25.9 & & 7.2 & \\
\hline 10.7 & & 8.26 & & 50000 & & 8.25 & & 49000 \\
\hline 11.0 & 25.9 & & 7.86 & & 25.9 & & 7.34 & \\
\hline 11.6 & -- & & -- & & -- & & -- & \\
\hline 12.2 & & 8.26 & & 50000 & & 8.25 & & 49500 \\
\hline
\end{tabular}


Appendix E. General water quality with depth and general water quality, bacteria, volatile organic compounds, semivolatile organic compounds, pesticides, PCB's, herbicides, total metals and trace elements, general inorganics, and radiochemistry by sample at ten water-quality sampling sites in the Bahía de Añasco and near Rincón, Puerto Rico, at two sites sampled in the Río Grande de Añasco and the Río Yagüez, and at the influent and effluent of the Mayagüez Regional Wastewater Treatment Plant, January 25-30, 1991--Continued

Appendix E-35. Vertical profiles of physical and chemical properties measured at the farfield stations $0 \mathrm{~W}-1$ and $0 \mathrm{~W}-8$, January 29, 1991.

[Units: ${ }^{\circ} \mathrm{C}$, degrees Celsius; $\mathrm{m}$, meters; $\mathrm{mg} / \mathrm{L}$, milligrams per liter; $\mu \mathrm{S} / \mathrm{cm}$, microsiemens per centimeter at 25 degrees Celsius; --, data not available.]

\begin{tabular}{|c|c|c|c|c|c|c|c|c|}
\hline \multirow{2}{*}{$\begin{array}{l}\text { Sampled } \\
\text { Depth } \\
\text { (m) }\end{array}$} & \multicolumn{4}{|c|}{ QW-1 } & \multicolumn{4}{|c|}{ QW-8 } \\
\hline & $\begin{array}{c}\text { Temperature } \\
\left({ }^{\circ} \mathrm{C}\right)\end{array}$ & $\begin{array}{c}\mathrm{pH} \\
\text { (units) }\end{array}$ & $\begin{array}{c}\text { Dissolved } \\
\text { oxygen } \\
\text { (mg/L) }\end{array}$ & $\begin{array}{c}\text { Specific } \\
\text { conductance } \\
(\mu \mathrm{S} / \mathrm{cm})\end{array}$ & $\begin{array}{c}\text { Temperature } \\
\left({ }^{\circ} \mathrm{C}\right)\end{array}$ & $\begin{array}{c}\mathrm{pH} \\
\text { (units) }\end{array}$ & $\begin{array}{l}\text { Dissolved } \\
\text { oxygen } \\
\text { (mg/L) }\end{array}$ & $\begin{array}{c}\text { Specific } \\
\text { conductance } \\
(\mu \mathrm{S} / \mathrm{cm})\end{array}$ \\
\hline 0.0 & 26.1 & 8.27 & 7.59 & 48000 & 25.6 & 8.26 & 7.45 & 48000 \\
\hline 0.6 & 26.1 & & 7.54 & & 25.7 & & 7.36 & \\
\hline 1.2 & 26.1 & & 7.53 & & 25.8 & & 7.4 & \\
\hline 1.5 & & 8.27 & & 48000 & & 8.24 & & 48000 \\
\hline 1.8 & 26.1 & & 7.57 & & 25.9 & & 7.4 & \\
\hline 2.4 & 26.1 & & 7.52 & & 25.9 & & 7.36 & \\
\hline 3.0 & 26.1 & 8.27 & 7.47 & 48500 & 25.9 & 8.26 & 7.34 & 49000 \\
\hline 3.7 & 26.1 & & 7.51 & & 25.8 & & 7.31 & \\
\hline 4.3 & 26 & & 7.5 & & 25.9 & & 7.32 & \\
\hline 4.6 & & 8.27 & & 47500 & & 8.26 & & 47500 \\
\hline 4.9 & 26 & & 7.54 & & 25.9 & & 7.24 & \\
\hline 5.5 & 26 & & 7.48 & & 25.9 & & 7.26 & \\
\hline 6.1 & 26 & 8.27 & 7.58 & 48000 & 25.9 & 8.26 & 7.29 & 48000 \\
\hline 6.7 & 26 & & 7.55 & & 26 & & 7.3 & \\
\hline 7.3 & 26 & & 7.52 & & 25.8 & & 7.29 & \\
\hline 7.6 & & 8.27 & & 48000 & & 8.26 & & 48000 \\
\hline 7.9 & 26 & & 7.5 & & 25.9 & & 7.3 & \\
\hline 8.5 & 26 & & 7.61 & & 25.9 & & 7.18 & \\
\hline 9.1 & 25.9 & 8.25 & 7.58 & 48500 & 26 & 8.26 & 7.19 & 48000 \\
\hline 9.8 & 25.9 & & 7.6 & & 25.9 & & 7.14 & \\
\hline 10.4 & 25.9 & & 7.54 & & 25.9 & & 7.15 & \\
\hline 10.7 & & 8.25 & & 47500 & & 8.26 & & 48000 \\
\hline 11.0 & 25.9 & & 7.57 & & 26 & & 6.98 & \\
\hline 11.6 & -- & & -- & & 26.1 & & 6.9 & \\
\hline 12.2 & & 8.25 & & 48000 & 26 & 8.26 & 6.86 & 49000 \\
\hline
\end{tabular}


Appendix E. General water quality with depth and general water quality, bacteria, volatile organic compounds, semivolatile organic compounds, pesticides, PCB's, herbicides, total metals and trace elements, general inorganics, and radiochemistry by sample at ten water-quality sampling sites in the Bahía de Añasco and near Rincón, Puerto Rico, at two sites sampled in the Río Grande de Añasco and the Río Yagüez, and at the influent and effluent of the Mayagüez Regional Wastewater Treatment Plant, January 25-30, 1991—Continued

Appendix E-36. Vertical profiles of physical and chemical properties measured at the control stations $0 \mathrm{~W}-9$ and $\mathrm{QW}-10$ near Rincón, January 28, 1991.

[Units: ${ }^{\circ} \mathrm{C}$, degrees Celsius; $\mathrm{m}$, meter; $\mathrm{mg} / \mathrm{L}$, milligrams per liter; $\mu \mathrm{S} / \mathrm{cm}$, microsiemens per centimeter at 25 degrees Celsius; --, data not available.]

\begin{tabular}{|c|c|c|c|c|c|c|c|c|}
\hline \multirow{2}{*}{$\begin{array}{l}\text { Sampled } \\
\text { Depth } \\
\text { (m) }\end{array}$} & \multicolumn{4}{|c|}{ QW-9 } & \multicolumn{4}{|c|}{$0 W-10$} \\
\hline & $\begin{array}{c}\text { Temperature } \\
\left({ }^{\circ} \mathrm{C}\right)\end{array}$ & $\begin{array}{c}\mathrm{pH} \\
\text { (units) }\end{array}$ & $\begin{array}{c}\text { Dissolved } \\
\text { oxygen } \\
\text { (mg/L) }\end{array}$ & $\begin{array}{c}\text { Specific } \\
\text { conductance } \\
(\mu \mathrm{S} / \mathrm{cm})\end{array}$ & $\begin{array}{c}\text { Temperature } \\
\left({ }^{\circ} \mathrm{C}\right)\end{array}$ & $\begin{array}{c}\mathrm{pH} \\
\text { (units) }\end{array}$ & $\begin{array}{c}\text { Dissolved } \\
\text { oxygen } \\
\text { (mg/L) }\end{array}$ & $\begin{array}{c}\text { Specific } \\
\text { conductance } \\
(\mu \mathrm{S} / \mathrm{cm})\end{array}$ \\
\hline 0.0 & -- & & -- & & -- & 8.27 & -- & -- \\
\hline 0.6 & -- & 8.37 & -- & -- & -- & & -- & \\
\hline 1.2 & -- & & -- & & -- & & -- & \\
\hline \multicolumn{9}{|l|}{1.5} \\
\hline 1.8 & -- & & -- & & -- & 8.28 & -- & -- \\
\hline 2.4 & -- & & -- & & -- & & -- & \\
\hline 3.0 & -- & & -- & & -- & & -- & \\
\hline 3.7 & -- & & -- & & -- & 8.27 & -- & -- \\
\hline 4.3 & -- & & -- & & -- & & -- & \\
\hline 4.6 & & 8.36 & & -- & & & & \\
\hline 4.9 & -- & & -- & & -- & & -- & \\
\hline 5.5 & -- & & -- & & -- & 8.28 & -- & -- \\
\hline 6.1 & -- & & -- & & -- & & -- & \\
\hline 6.7 & -- & & -- & & -- & & -- & \\
\hline 7.3 & -- & & -- & & -- & 8.28 & -- & -- \\
\hline \multicolumn{9}{|l|}{7.6} \\
\hline 7.9 & -- & & -- & & -- & & -- & \\
\hline 8.5 & -- & 8.33 & -- & -- & -- & & -- & \\
\hline 9.1 & -- & & -- & & -- & 8.27 & -- & -- \\
\hline 9.8 & -- & & -- & & -- & & -- & \\
\hline 10.4 & -- & & -- & & -- & & -- & \\
\hline 10.7 & & -- & & -- & & -- & & -- \\
\hline 11.0 & -- & & -- & & -- & & -- & \\
\hline 11.6 & -- & & -- & & -- & & -- & \\
\hline 12.2 & -- & & -- & & -- & & -- & \\
\hline
\end{tabular}


District Chief

Caribbean District

U.S. Geological Survey

Water Resources Division

GSA Center, Suite 400-15

651 Federal Drive

Guaynabo, Puerto Rico 00965-5703 